\title{
INSPECTION OF NUCLEAR POWER PLANT STRUCTURES - OVERVIEW OF METHODS AND RELATED APPLICATIONS
}

May 2009

D. J. Naus 
This report was prepared as an account of work sponsored by an agency of the United States Government. Neither the United States government nor any agency thereof, nor any of their employees, makes any warranty, express or implied, or assumes any legal liability or responsibility for any third party's use, or the results of such use, of any information, apparatus, product, or process disclosed in this publication, or represents that its use by such third party would not infringe privately owned rights. 


\title{
INSPECTION OF NUCLEAR POWER PLANT STRUCTURES - OVERVIEW OF METHODS AND RELATED APPLICATIONS
}

\author{
D. J. Naus
}

Materials Science and Technology Division Oak Ridge National Laboratory

Oak Ridge, TN 37831

May 2009

\author{
Prepared by \\ OAK RIDGE NATIONAL LABORATORY \\ P.O. Box 2008 \\ Oak Ridge, Tennessee 37831-6285 \\ managed by \\ UT-Battelle, LLC \\ for the \\ U.S. DEPARTMENT OF ENERGY \\ under contract DE-AC05-00OR22725
}




\section{CONTENTS}

PAGE

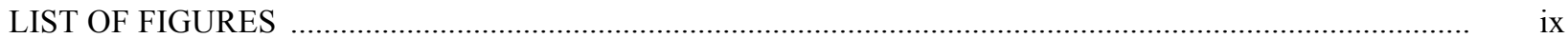

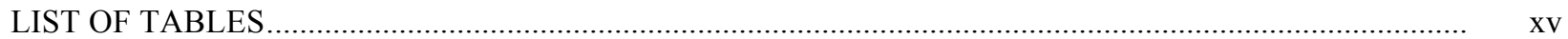

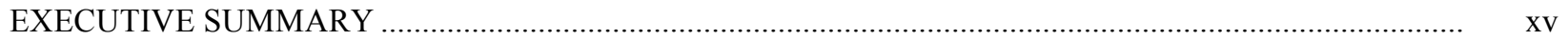

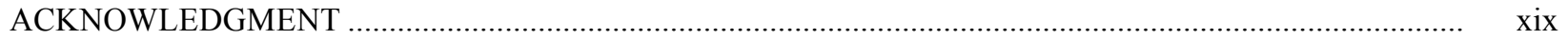

1. INTRODUCTION.......

1.1 BACKGROUND

1.2 OBJECTIVE AND POTENTIAL APPLICATION OF RESULTS

1.3 SCOPE

1.4 REFERENCES.

2. NUCLEAR POWER PLANT SAFETY-RELATED STRUCTURES

2.1 GENERAL DESCRIPTION

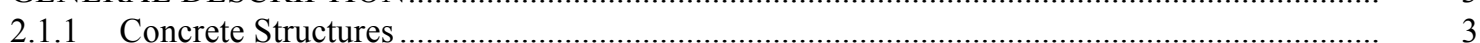

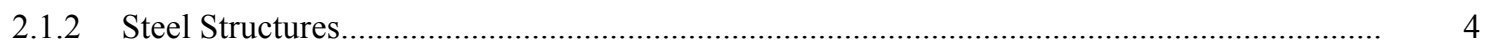

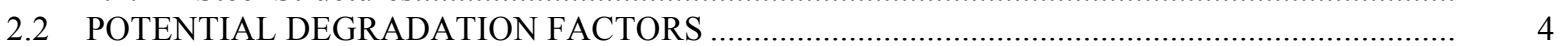

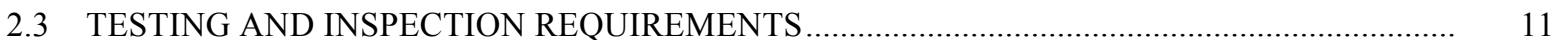

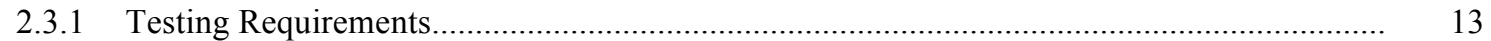

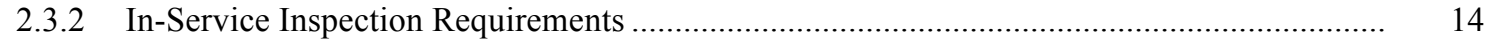

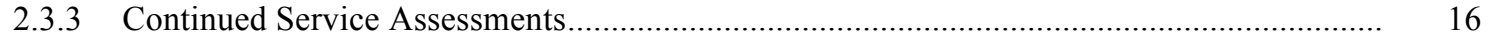

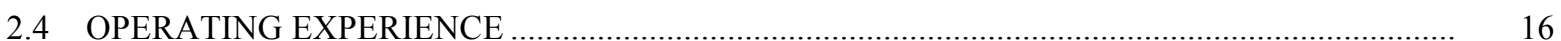

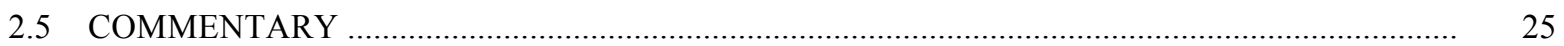

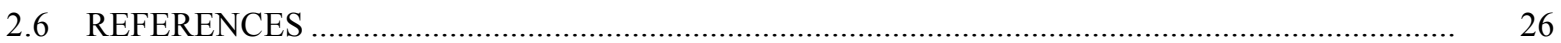

3. REVIEW OF METHODS FOR DETECTION OF DEGRADATION

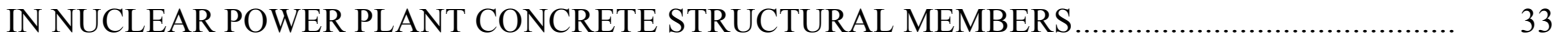

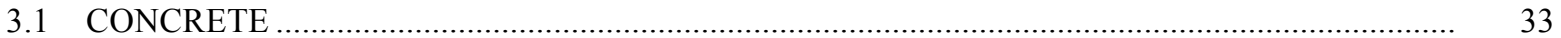

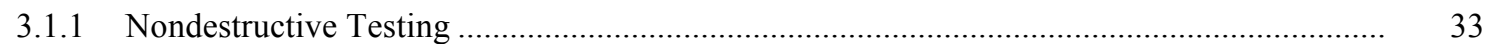

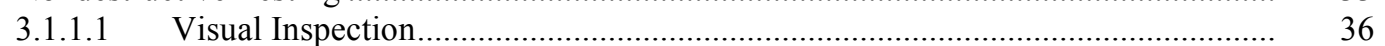

3.1.1.2 Acoustic/Stress Waves ................................................................................. 37

3.1.1.3 Nuclear/Radiographic Techniques ............................................................... 45

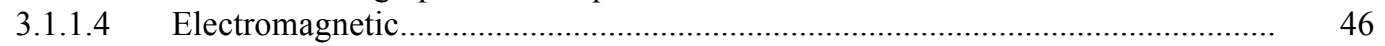

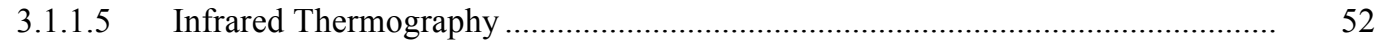

3.1.1.6 Audio ............................................................................................. 53

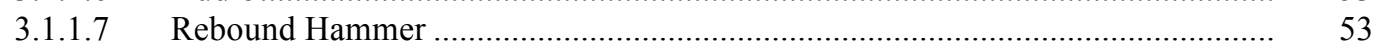

3.1.1.8 Fluid Penetrability .................................................................................. 54

3.1.1.9 Concrete Moisture Content .............................................................................. 55

3.1.1.10 Laser-Induced Breakdown Spectroscopy .................................................. 57

3.1.2 Destructive or Partially Destructive Testing ............................................................ 59

3.1.2.1 Break-Off ........................................................................................... 59

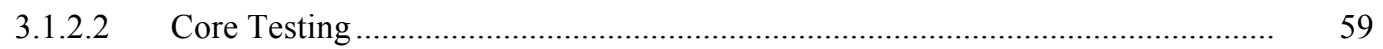

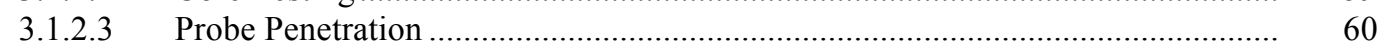

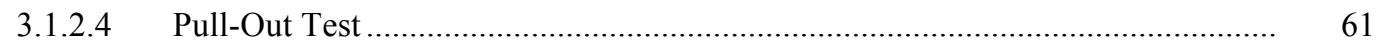

3.1.2.5 Pull-Off Test......................................................................................... 62

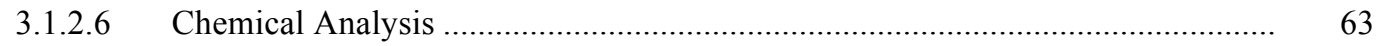

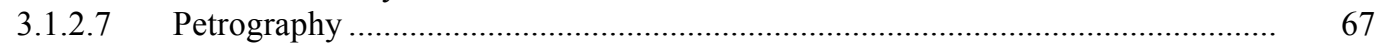

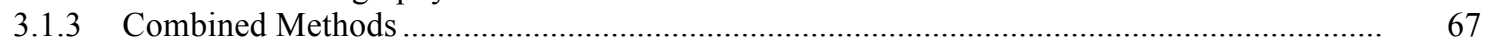

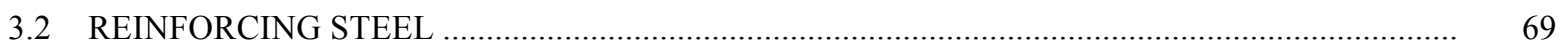

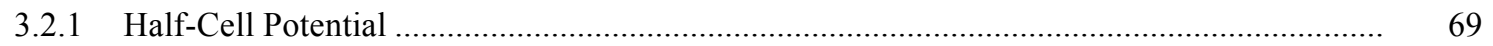

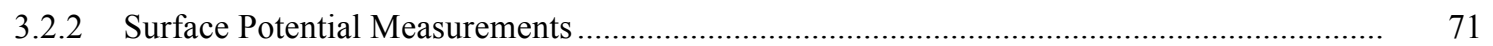

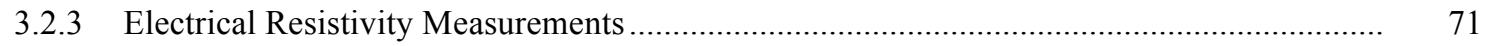

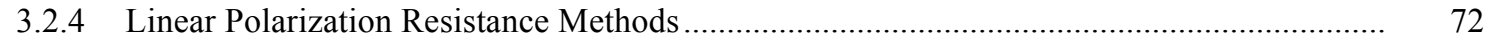

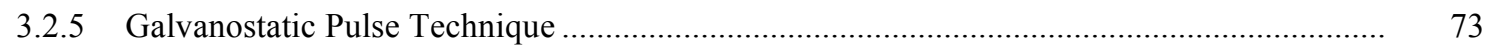

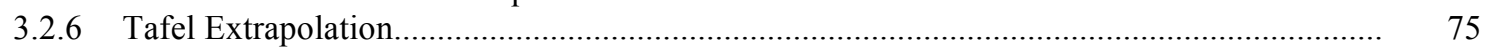




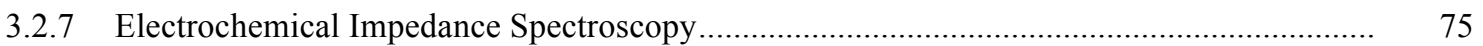

3.2.8 Embeddable Corrosion Monitoring Sensors ……….............................................................. 76

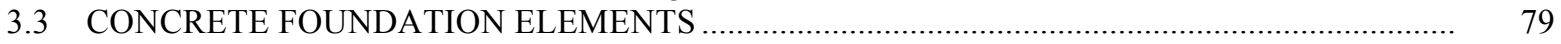

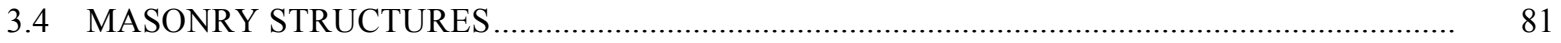

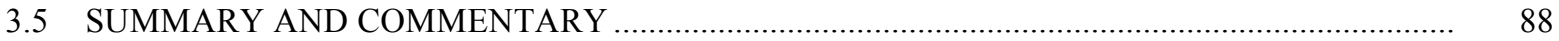

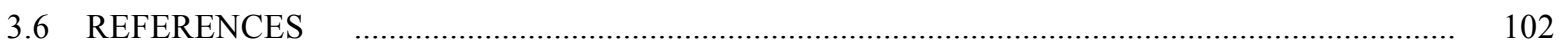

4. REVIEW OF METHODS FOR DETECTION OF DEGRADATION

IN NUCLEAR POWER PLANT METALLIC PRESSURE BOUNDARIES ........................................... 115

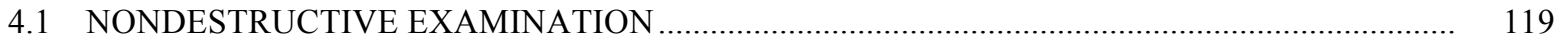

4.1.1 Visual and Optical Testing (VT) ............................................................................. 120

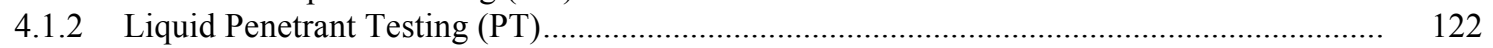

4.1.3 Electromagnetic (ET) or Eddy Current Testing ............................................................... 123

4.1.4 Magnetic Particle Testing (MT) .................................................................................... 126

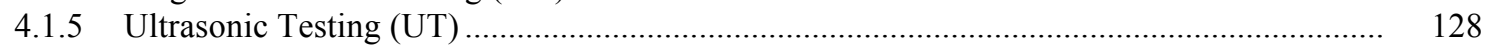

4.1.6 Radiography Testing (RT) ......................................................................... 135

4.1.7 Acoustic Emission Testing (AE) ............................................................................... 137

4.1.8 Infrared and Thermal Testing (IR) ……….................................................................... 139

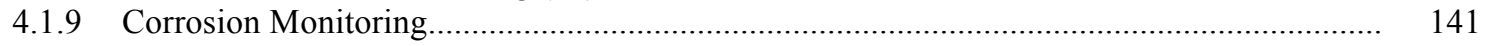

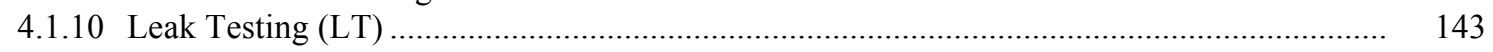

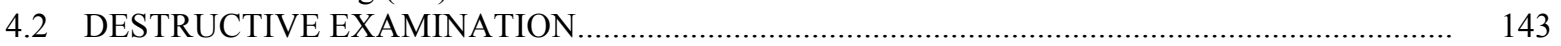

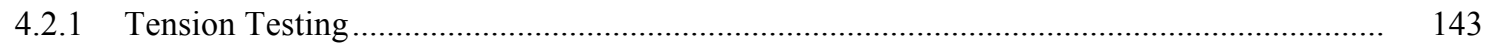

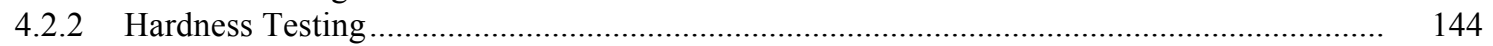

4.2.3 Metallography …………….............................................................................. 145

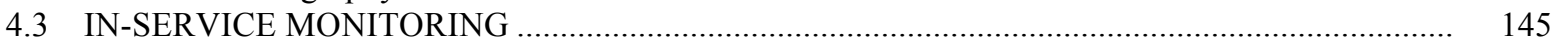

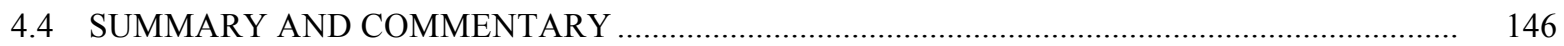

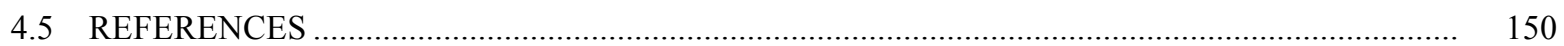

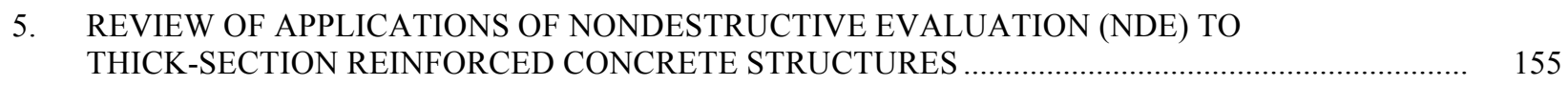

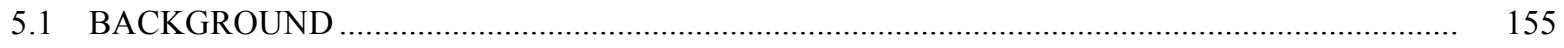

5.2 REVIEW OF RESEARCH INVOLVING THICK-SECTION

5.2.1 CONMOD Project....

5.2.1.1 Introduction............................................................................................. 156

5.2.1.2 Demonstrator 1 - Barsebäck 1 …..................................................................... 157

5.2.1.3 Demonstrator 2 - MAEVA Mock-up ………….................................................... 161

5.2.1.4 CONMOD Conclusions....................................................................................... 162

5.2.2 Nondestructive Testing for Integrity Determinations of Concrete Structures ....................... 164

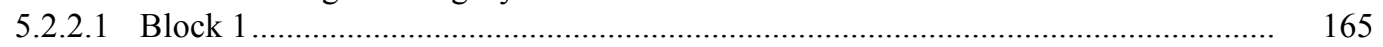

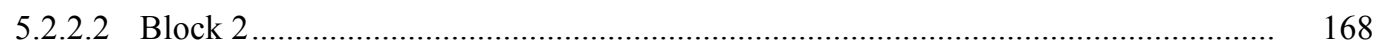

5.2.3 Federal Institute for Materials Research and Testing ….................................................... 171

5.2.3.1 Large Scale Concrete Test Specimen ...................................................................... 171

5.2.3.2 Foundation Slab Test Specimen ....................................................................... 175

5.2.3.3 Simulated Bridge Section with Faults ................................................................... 179

5.2.3.4 Specimen for Imaging Honeycomb and Cracks in Concrete Elements................... 181

5.2.3.5 Slab with Voids of Various Size and Depth ............................................................... 183

5.2.3.6 Slab with Empty Tendon Ducts ............................................................................. 184

5.2.3.7 Test Article with Artificial Grouting Faults ........................................................ 185

5.2.4 Simulated Containment Wall With Artificial Cracks ......................................................... 187

5.2.5 Post-Tensioned Concrete Beam ................................................................................... 189

5.2.6 Mock-up of Containment Ring Beam with Artificial Flaws.................................................. 190

5.2.7 Test Specimen Containing Different Materials.................................................................. 191

5.2.8 Mock-up of Containment Building Structure with Voids................................................. 191

5.2.9 Concrete Slab with Artificial Defects ............................................................................... 193

5.2.10 Test Articles with Voids, Honeycombing, and Tendon Ducts............................................. 195 


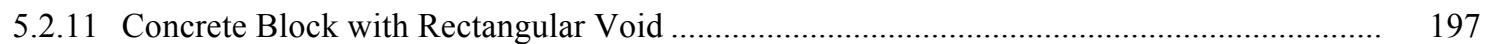

5.2.12 Large Concrete Block with Inclined Crack ......................................................................... 198

5.2.13 Nuclear Power Plant Floor Slab ....................................................................................... 200

5.2.14 Post-Tensioned Reinforced Concrete Bridge Beam …………........................................... 201

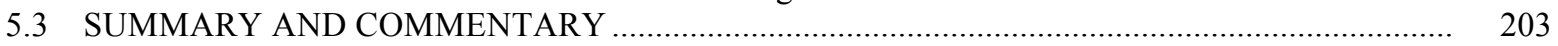

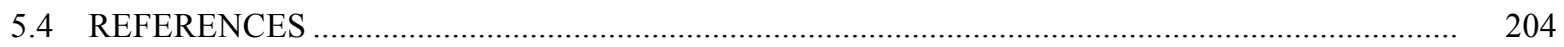

6. REVIEW OF APPLICATIONS OF NONDESTRUCTIVE EVALUATION (NDE)

TO CONTAINMENT METALLIC PRESSURE BOUNDARIES ……............................................. 207

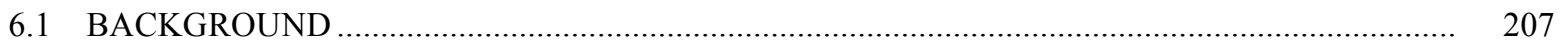

6.2 REVIEW OF RESEARCH HAVING APPLICATION TO INSPECTION

OF INACCESSIBLE PORTIONS OF METALLIC PRESSURE BOUNDARIES ………................ 207

6.2.2 EMAT Detection of Flaws in Plate Structure ……........................................................ 209

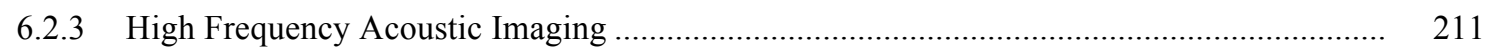

6.2.3.1 Numerical Simulations ……………………........................................................ 211

6.2.3.2 Experimental Simulations................................................................................. 212

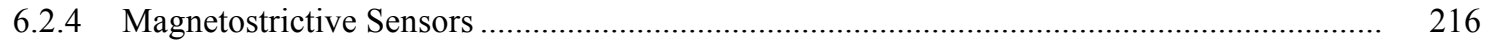

6.2.4.1 Feasibility Investigation....................................................................................... 217

6.2.4.2 Evaluation of Concrete Effects Investigation ....................................................... 225

6.2.5 Multimode Guided Waves ............................................................................................ 231

6.2.5.1 Theoretical and Experimental Investigations ....................................................... 231

6.2.5.2 Elements of Defect Sizing in a Wave Guide Using SH Guided Waves ................... 236

6.2.6 Ultrasonic Testing of Containment Liners Embedded in Concrete ........................................ 242

6.2.7 Electrochemical Technique Detection of Liner Corrosion ................................................. 243

6.2.8 Concrete-Filled Pipe with Internal Voids and Inclusions .................................................... 245

6.2.9 Hole in Steel Plate Embedded in Concrete ....................................................................... 246

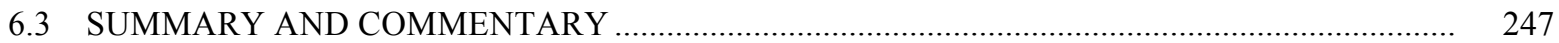

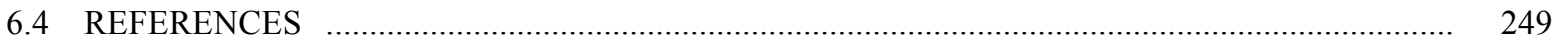

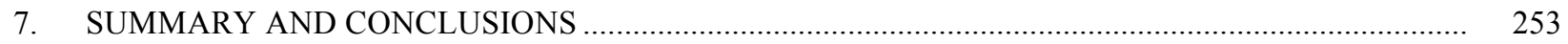

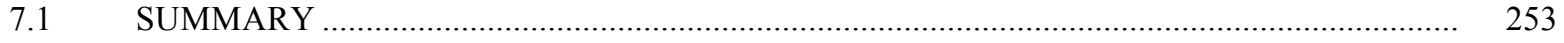

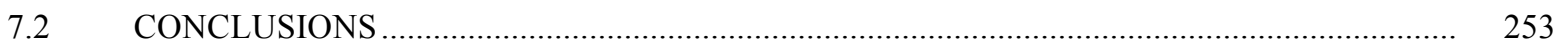




\section{LIST OF FIGURES}

Figure $\quad$ Page

3.1 Building survey system. ……................................................................................................

3.2 Video microscope crack monitoring system ..................................................................................... 37

3.3 Ultrasonic pulse velocity (UPV) system and example of calibration curve........................................... 38

3.4 Ultrasonic pulse echo unit with spring-loaded dry-contact transducers and its application ..................... 39

3.5 Pulse-echo results showing concrete honeycomb below steel reinforcement..........................................

3.6 Impact-echo equipment and operation principle ............................................................................

3.7 Schematic of non-contact method for defect detection in concrete ....................................................

3.8 Illustration of acoustic travel time tomography ............................................................................

3.9 Impulse-response test setup and example results ......................................................................... 43

3.10 SASW test setup and example application......................................................................................

3.11 Acoustic emission principle and schematic of data acquisition .......................................................

3.12 Acoustic monitoring of tendons in post-tensioned structures .........................................................

3.13 Signals recorded by 16 sensors resulting from a prestressing tendon wire break .................................... 46

3.14 Application of Megascan ${ }^{\mathrm{TM}}$ imaging capture system.................................................................... 47

3.15 GPR bowtie dipole and horn antennas ........................................................................................ 48

3.16 Field application and principle of GPR ……............................................................................... 49

3.17 Application of GPR to detect steel reinforcement embedded in concrete ................................................ 49

3.18 Application of GPR to detect concrete delamination and near-surface voids...................................... 50

3.19 Application of GPR to detect concrete cracking ............................................................................... 50

3.20 Application of electromagnetic method to detect rebar location ....................................................... 51

$3.21 \quad$ Application of impulse-thermography method to detect voids ........................................................... 52

3.22 Use of chain drag to indicate delaminated regions of bridge deck ..................................................... 53

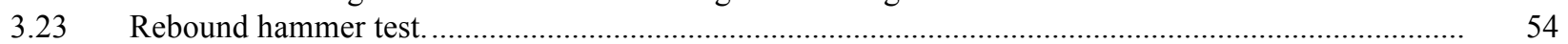

3.24 Measurement of initial surface absorption of concrete .................................................................... 55

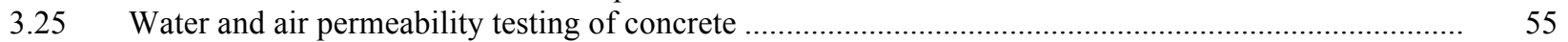

3.26 Concrete moisture content determination using NMR ................................................................ 56

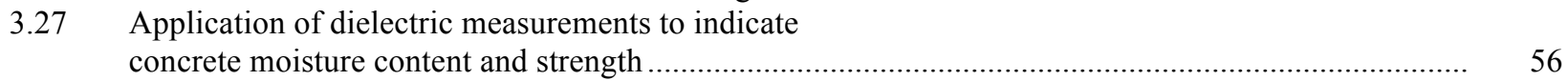

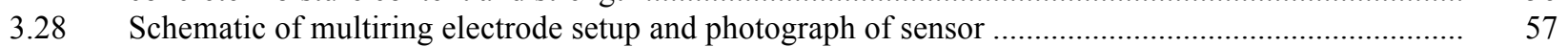

3.29 LIBS physical principle and experimental setup ........................................................................ 58

$3.30 \quad$ Application of LIBS with examples of results obtainable ....................................................................

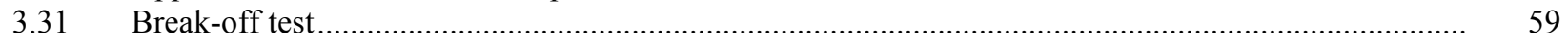

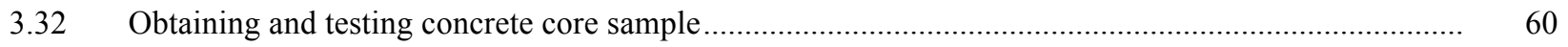

$3.33 \quad$ Windsor probe test ........................................................................................................

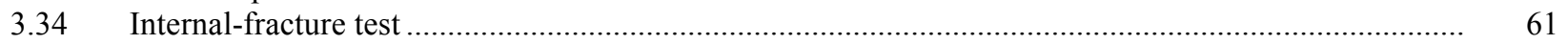

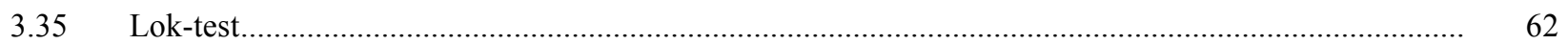

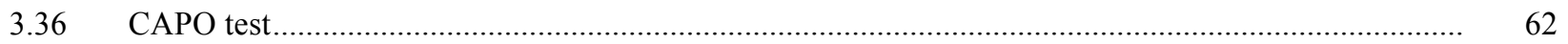

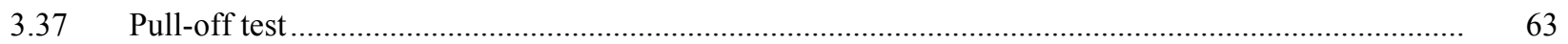

3.38 Comparison of LIBS results with those from standard chemical analysis ............................................. 64

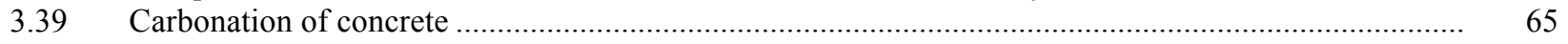

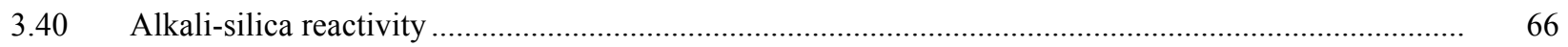

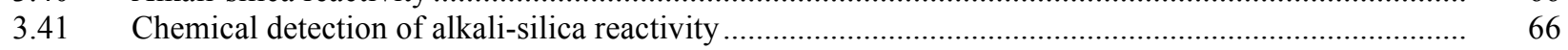

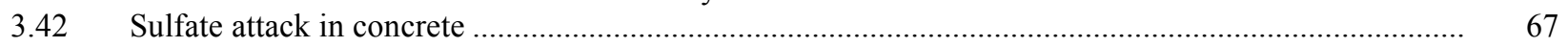

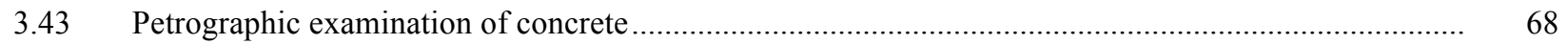

3.44 Example of correlation developed for estimating compressive strength from

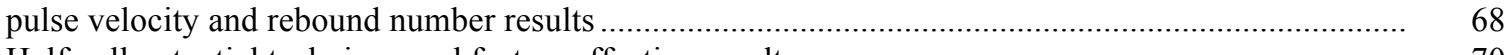

3.45 Half-cell potential technique and factors affecting results ..............................................................

3.46 Half-cell potential instrument and example of results.....................................................................

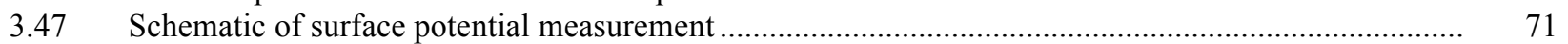

3.48 Electrical resistivity measurements - four point technique........................................................... 
3.49 Wenner four-point probe and example of results.....

3.51 Galvanostatic pulse technique.

3.52 Example of Tafel graph.....

A.C. electrochemical impedance spectroscopy ...........................................................................

Examples of embeddable reference electrodes ...

CorroWatch multisensor and example result

3.56

Anode-ladder system for corrosion monitoring

3.57

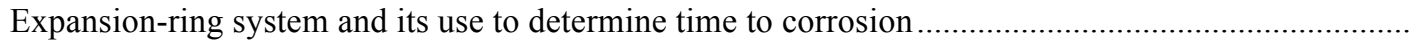

Embedded corrosion instrument.

3.59

Large-scale deep foundation test facilities .....

3.60

In situ deformability test using two flatjacks

3.61 Schematic of "modified" in situ shear test of masonry

3.62 Transducer arrangement for direct and indirect ultrasonic pulse velocity testing of masonry

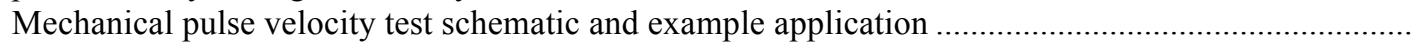

3.64

3.65

3.66

3.67

3.68

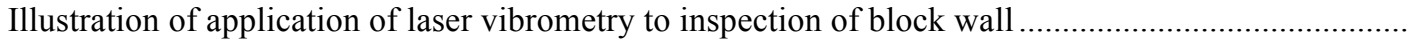

Use of polarized GPR to investigate masonry wall with internal cavity.......

GPR testing of masonry wall with simulated air voids.....

Application of GPR to detect moisture level

Illustration of effect of void in masonry on travel path of ultrasonic wave.....

Acoustic testing of masonry wall with simulated air voids ......

Major topics pertaining to in-service condition assessment.

Damage detection parameters

Damage categories and potential degradation mechanisms

Factors to be considered in determining root cause for component degradation.

Approaches related to the measurement of containment pressure boundary component damage............

Visual inspection examples.

Penetrant testing method

Principle of eddy current testing for crack detection .......

Eddy current testing method 
4.32 Examples of inspection methods for corrosion detection without requirement for insulation removal .

4.33 Pulsed eddy current testing of ferrous objects

Tension testing

Hardness testing

5.2 Methodology for establishing a profile of a structure

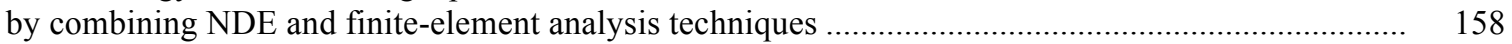

5.5 Graphic profile of Barsebäck wall (outside containment to right) showing tears in concrete due to slipforming, and relative humidity and dynamic modulus profiles ........................ 161

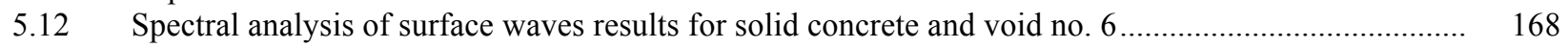

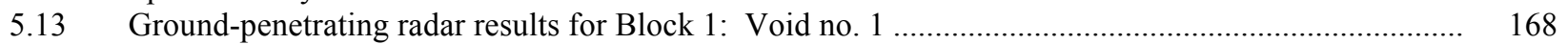

5.14

Details of Block 2 ......

5.15 Ground-penetrating radar profile of Block 2 .......

5.16 Ground-penetrating radar profile of Block 2

indicating maximum depth at which ducts can be identified ....................................................... 170

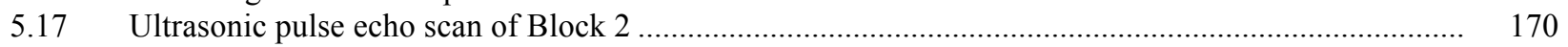

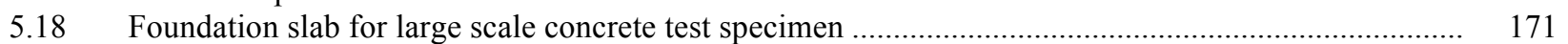

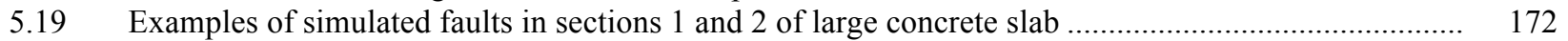

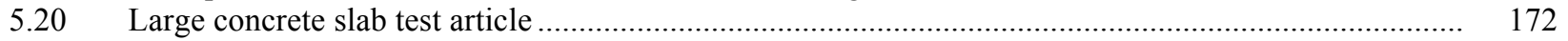

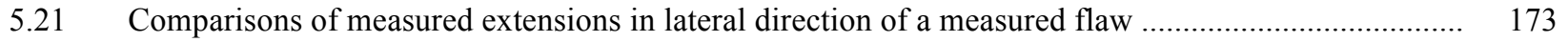

5.22 Detection 0

5.23 Scanner used to investigate tendon duct in large concrete test specimen ....................................... 174

5.24 Two-dimensional/three-dimensional scanner results for tendon duct containing artificial flaw ........... 175

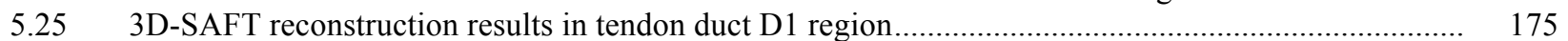

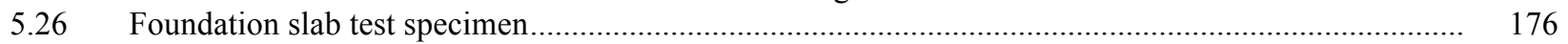

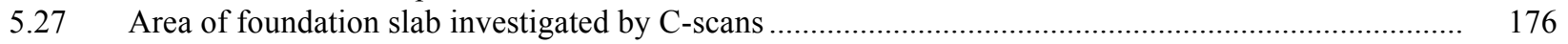

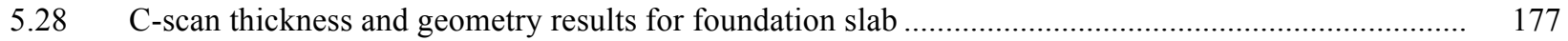

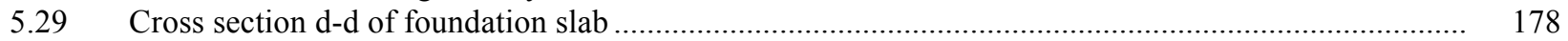

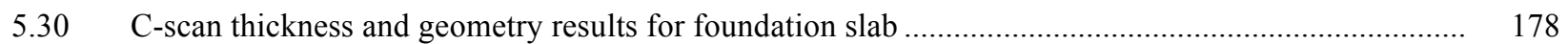

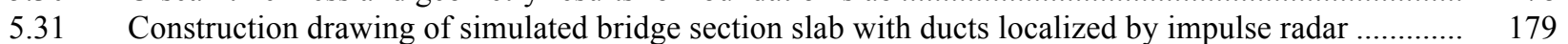

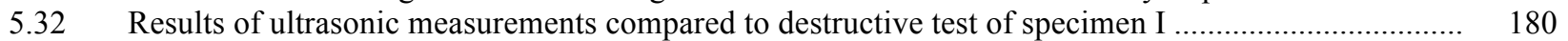

5.33

Slab at Karlsruhe University

Results along scanning line 1 .....

Determination of concrete crack depth by forward scattering of pressure waves...

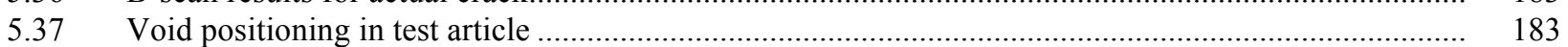

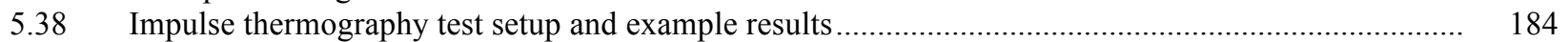

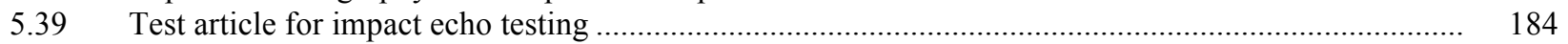

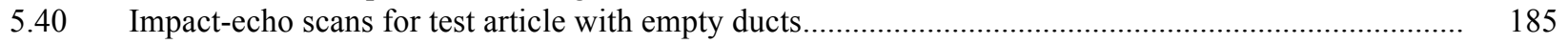

$5.41 \quad$ Construction plan for tendon duct investigation ..................................................................... 186

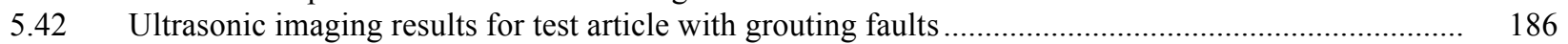

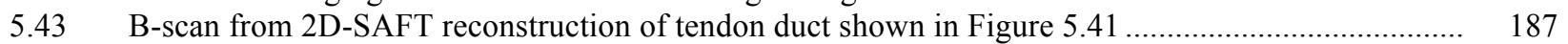

5.44 Concrete block representing containment wall section ............................................................... 187

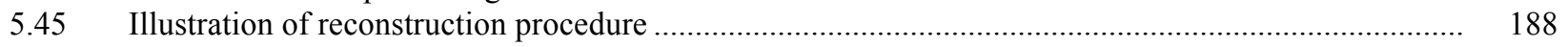


5.46 Comparison between mono element measurement and reconstructed B-scan images resulting from phased array measurements .......

5.47 Test article for post-tensioned beam NDT study

Radiography of tendon ducts.

Details of ring beam mock-up.

190

5.50

Test article containing embedded materials

Amplitude spectra from three areas of test specimen A

Amplitude spectra from three areas of test specimen B

Ground-penetrating radar results test specimens A and B

Arrangement of concrete slab with artificial defects.

194

Comparison of accelerometer waveforms for sections with and without flaws................................. 194

5.56

5.57

Effect of defect diameter and depth on peak frequency

Thermography results for specimen 7 .....

Sonic and impact echo results for specimen 7 .

Ultrasonic results for specimen 7

Test article with rectangular void ....................................................................................... 198

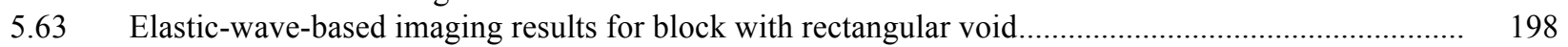

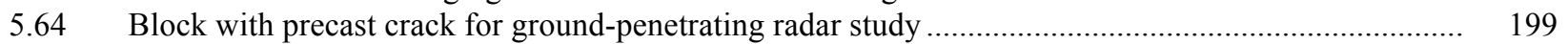

5.65 Ground-penetrating radar results for deep crack in concrete .......................................................... 199

5.66 Ground-penetrating radar results for floor slab ..................................................................... 200

5.67 Comparison of ground-penetrating radar result with typical cage used in floor slab .......................... 200

5.68 More detailed view of radar results in top right grid in Figure 5.67 .......................................... 201

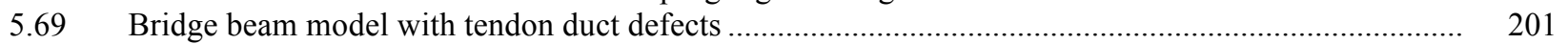

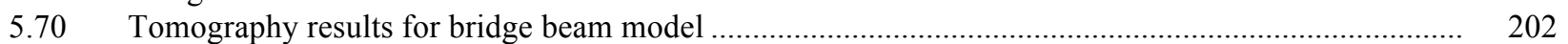

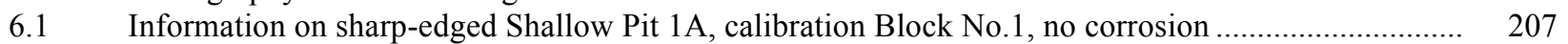

6.2 Information on cambered Shallow Pit 1B, calibration Block No.1, no corrosion ............................. 208

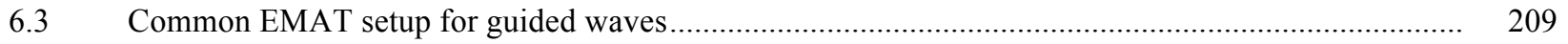

6.4 Plate and setup for EMAT defect experiment ......................................................................... 210

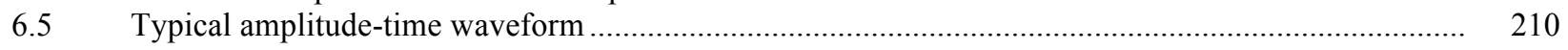

6.6 Range-dependent numerical simulation scenario for steel containment ......................................... 211

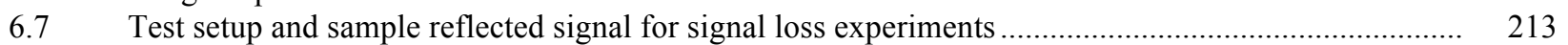

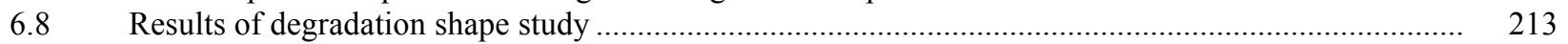

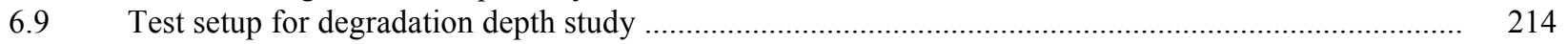

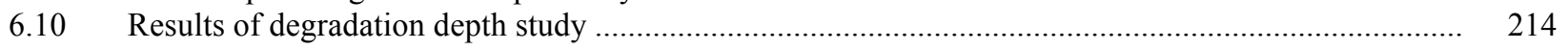

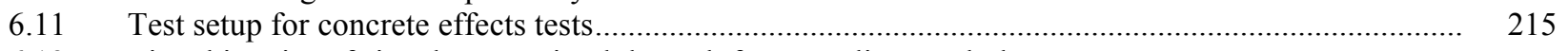

6.12 Time histories of signals transmitted through free-standing steel plate, unbonded steel plate with concrete, and bonded steel plate with concrete ..................................... 215

6.13 Transmitted signal level: (a) free-standing steel plates and

(b) steel plates embedded in concrete over part of their length................................................... 216

6.14 Schematic of magnetostrictive sensor setup for generation and detection of guided waves ................ 217

6.15 Calculated dispersion curves for longitudinal guided waves in a plate for three conditions:(a) plate is free, (b) plate is backed by concrete on one side,

(c) plate is backed by concrete on both sides ....

6.16 Displacements of antisymmetric (A) and symmetric (S) wave modes across plate thickness............... 218

6.17 Calculated wave attenuation for: (a) plate backed by concrete on one side and (b) plate backed by concrete on both sides..................................................... 219

6.18 Schematic of a coil wound around a stack of U-shaped magnets .................................................. 220

6.19 MsS test setup for monitoring plate specimen ...................................................................... 221

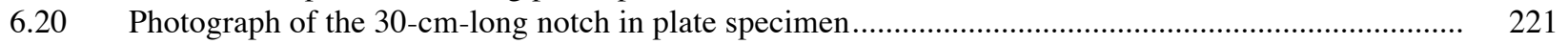

Example of data obtained from plate specimen ....................................................................... 222

6.22 MsS data using pulse-echo mode for steel plate prior to introducing a defect .................................... 223

Examples of data obtained from plate specimen ..................................................................... 


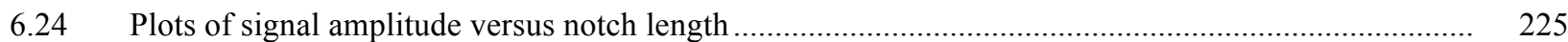

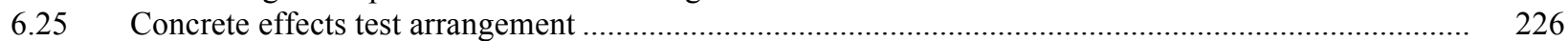

6.26 MsS data for 60-kHz A0 and S0 waves from bare plate: (a) detected signals and (b) spectrogram...... 226

6.27 MsS data for 100-kHz SH0 wave from bare plate: (a) detected signals and (b) spectrogram .............. 227

6.28 Long-range inspection test setup and example of results from bare plate ........................................... 228

6.29 22-kHz A0 wave data with notch present for (a) bare plate,

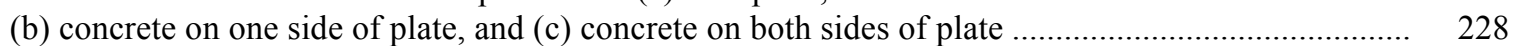

$6.30 \quad$ Construction features test setup and results ......................................................................... 229

6.31 Details of simulated corrosion defects investigation...................................................................... 230

6.32 128-kHz SH wave data for simulated corrosion defects study .................................................. 230

6.33 SH wave propagation where propagation is along $\mathrm{x}_{1}$ and particle displacements are along $\mathrm{x}_{2} \ldots \ldots \ldots \ldots . . . . .231$

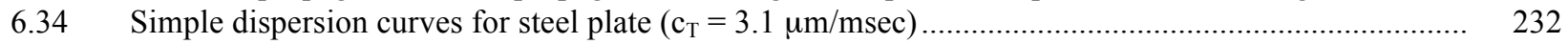

6.35 Wave structure for the pseudo-surface mode and A3 mode at frequency of $565 \mathrm{kHz} \ldots \ldots \ldots \ldots \ldots \ldots \ldots . . . . . . . . . . . . .232$

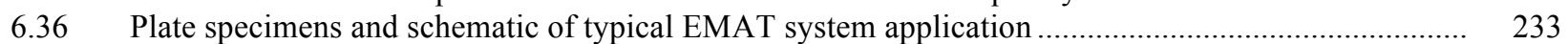

6.37 SH guided wave experimental results with EMAT SH system .................................................... 234

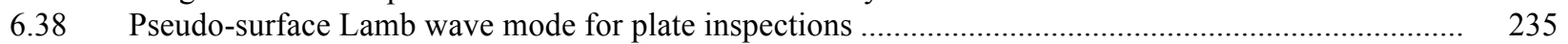

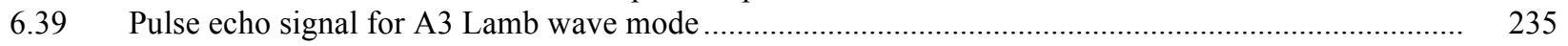

6.40 Boundary element method (BEM) wave scattering model .......................................................... 236

6.41 SH phase and group velocity dispersion curves for 10 -mm-thick steel plate .................................... 238

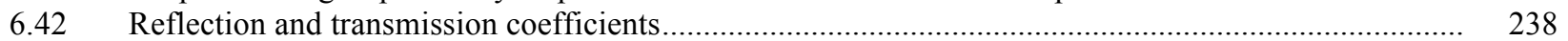

6.43 Reflection and transmission coefficients showing linear increase in amplitude with percent through-wall depth

6.44 Reflection and transmission coefficients for $6.35-\mathrm{mm}$ elliptical defect width and either 10,30, or 50 percent through-plate thickness depth .....

6.45 Reflection and transmission coefficients for 12.7-mm elliptical defect width and

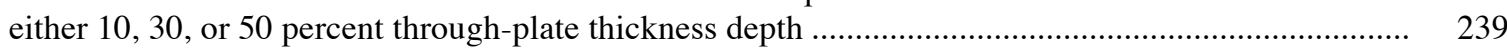

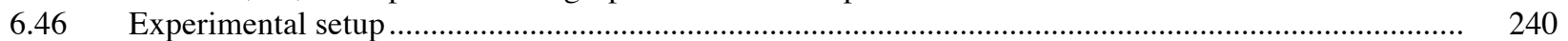

6.47 SH through transmission and pulse echo sample waveforms ................................................... 240

6.48 Theoretical and experimental relative amplitude results for (a) $12.7-\mathrm{mm}$, (b) 6.35 -mm, and (c) 0.305 -mm-wide notches of different depth in a 10 -mm-thick plate .................. 241

6.49 Theoretical and experimental through transmission and pulse echo signal amplitude

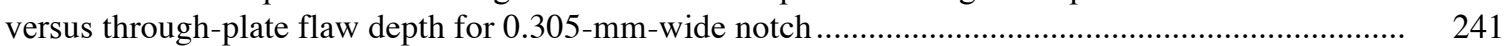

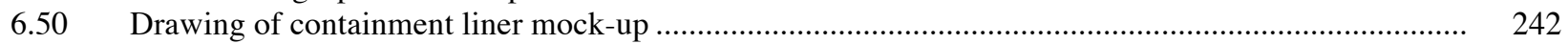

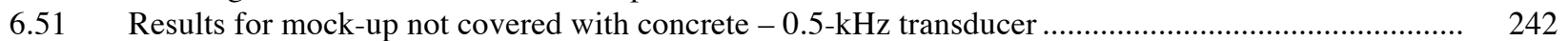

6.52 Results for mock-up covered with concrete - three element, $0.5-\mathrm{kHz}$ transducer.............................. 243

6.53 Drawing of nuclear power plant slab configuration and identification of measurement locations........ 243

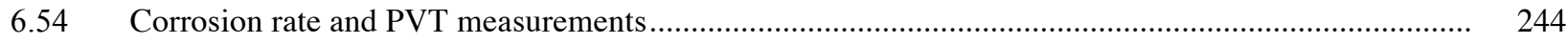

6.55 Corrosion rate versus corrosion potential and concrete resistivity............................................. 244

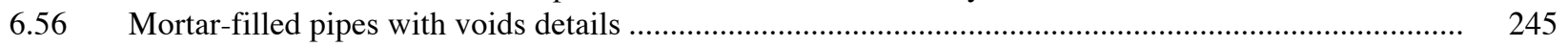

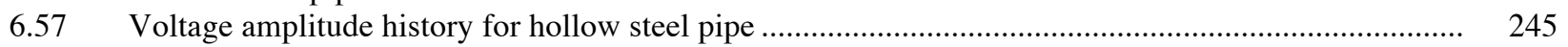

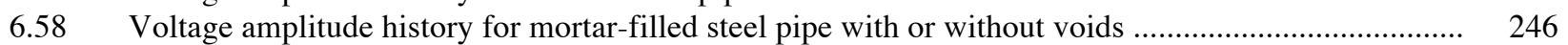

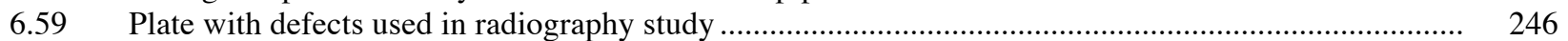

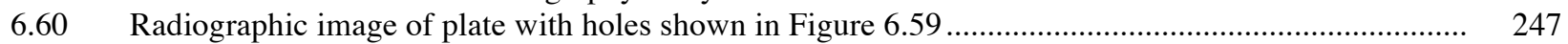




\section{LIST OF TABLES}

Table

Page

2.1 Typical safety-related concrete structures in LWR plants and

their accessibility for visual examination.

2.2 Possible cyclic loads on containment pressure boundary components

2.3a Degradation factors that can impact the performance of reinforced concrete safety-related structures: concrete...

$2.3 \mathrm{~b}$ Degradation factors that can impact the performance of reinforced concrete safety-related structures: reinforcing steel .....

2.3c Degradation factors that can impact the performance of reinforced concrete safety-related structures: prestressing steel ......

2.3d Degradation factors that can impact the performance of reinforced concrete safety-related structures: liner steel

2.4 Steel containment surface areas that could experience accelerated degradation and aging.

2.5 Sampling of documented concrete problem areas in nuclear plants

2.6 Examples of instances of containment pressure boundary degradation at commercial nuclear power plants in the United States .

3.1 Nondestructive test methods to determine structural properties and assess conditions of concrete.

3.2 Nondestructive test methods for determining material properties of hardened concrete in existing structures ....

Nondestructive test methods for evaluating repairs

Causes and symptoms of concrete degradation that can be observed

during a visual inspection....

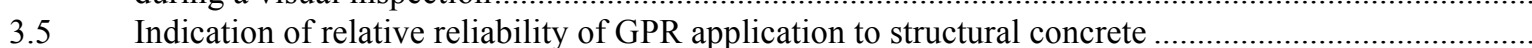
Advantages and disadvantages of GPR

Typical techniques used for corrosion assessment of reinforced concrete

3.8 Ranges of corrosion current values related to its significance in terms of service life of reinforcement

Examples of test methods and references for environmental assessments

3.12 Typical coefficients of variation $(\mathrm{COV})$ of test results and maximum accuracies of in situ strength prediction for principal methods utilized

3.13 Nondestructive testing objectives.

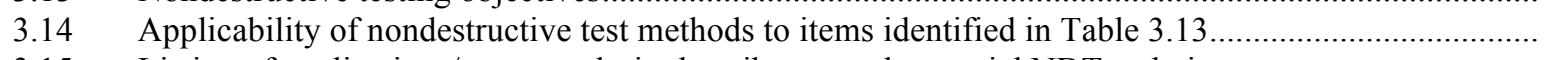
Listing of applications/purpose, desired attributes, and potential NDT techniques.......

Summary of testing methods for deep foundations. 


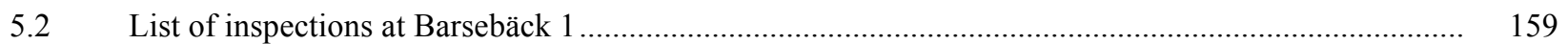

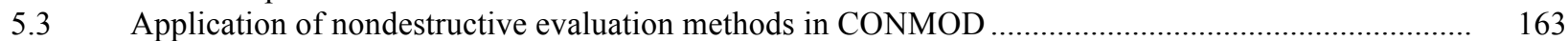

5.4 Application and capability of NDE techniques to reinforcing steel, cable ducts, and steel liner .......... 164

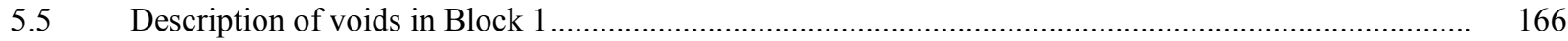

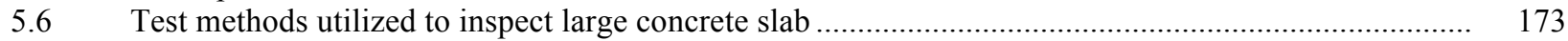

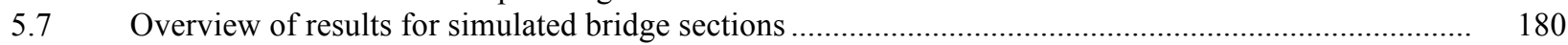

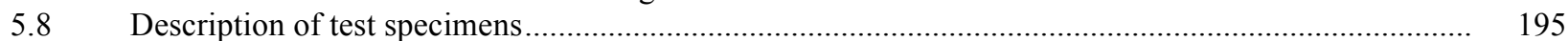

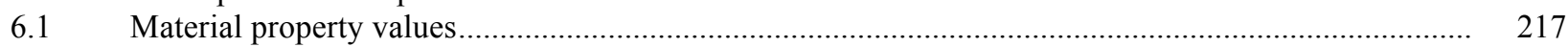




\section{EXECUTIVE SUMMARY}

The objectives of this limited study were to provide an overview of the methods that are available for inspection of nuclear power plant reinforced concrete and metallic structures, and to provide an assessment of the status of methods that address inspection of thick, heavily-reinforced concrete and inaccessible areas of the containment metallic pressure boundary. In meeting these objectives a general description of nuclear power plant safety-related structures was provided as well as identification of potential degradation factors, testing and inspection requirements, and operating experience; methods for inspection of nuclear power plant reinforced concrete structures and containment metallic pressure boundaries were identified and described; and applications of nondestructive evaluation methods specifically related to inspection of thick-section reinforced concrete structures and inaccessible portions of containment metallic pressure boundaries were summarized. Recommendations are provided on utilization of test article(s) to further advance nondestructive evaluation methods related to thicksection, heavily-reinforced concrete and inaccessible portions of the metallic pressure boundary representative of nuclear power plant containments. Conduct of a workshop to provide an update on applications and needed developments for nondestructive evaluation of nuclear power plant structures would also be of benefit. 


\section{ACKNOWLEDGMENT}

The author would like to acknowledge the continuing support and guidance throughout the program provided by the U.S. Nuclear Regulatory Commission Technical Monitor, Mr. Herman L. Graves, III. 


\section{INTRODUCTION}

\subsection{BACKGROUND}

In the year 2003 nuclear power provided in excess of 20 percent of the net electricity generation in the United States. In the year 2004 about $38 \%$ of the 104 nuclear power plants (NPPs) licensed for commercial operation had been inservice for over 30 years, with an additional $33 \%$ of the plants having been in service for over 20 years (1.1). Starting in the year 2009, the first of these plants is scheduled to reach the end of its initial 40 -year operating license period. By the year 2015 more than $40 \%$ of the remaining operating plants will reach the end of their initial operating license period. Faced with the prospect of having to replace the lost generating capacity from other sources and the potential for substantial shutdown and decommissioning costs, most utilities are seeking extensions to their initial plant operating licenses. As of February 2007, 24 facilities (48 units) had completed the application process for a renewal of their initial operating license, 7 additional facilities were under review, and 25 additional facilities had announced that they intend to do so.

One of the primary factors that could affect the continued operation and development of nuclear power relates to aging of the plants and its potential impact on performance. Nuclear power plants are designed, built, and operated to standards that aim to reduce the releases of radioactive materials to levels as low as reasonably achievable. Nuclear power plants, however, involve complex engineering structures and components operating in demanding environments that potentially can challenge the high level of safety (i.e., safety margins) required throughout the operating life of the plant. It is necessary that safety issues related to plant aging and continuing the service of the nuclear plants be resolved through development of sound scientific and engineering understanding. One specific area noted is that the capacity of the safety-related structures to mitigate extreme events must not deteriorate unacceptably due either to aging or environmental stressor effects. Although major mechanical and electrical equipment items in a plant could be replaced, if necessary, replacement of many of the safety-related structural components would be economically unfeasible. Approval for a continuation of service must be supported by evidence that these structures will continue to be capable of withstanding potential future extreme events.

\subsection{OBJECTIVE AND POTENTIAL APPLICATION OF RESULTS}

The "Environmental Effects on Containments and Other NPP Structures Program" has overall primary objectives of (1) understanding the significant factors relating corrosion occurrence, efficacy of inspection, and structural capacity reduction of steel containments and liners of concrete containments, and the long-term behavior of other NPP structures subjected to high temperature; (2) providing recommendations, as appropriate, on information to be requested of licensees for guidance that could be utilized by U.S. Nuclear Regulatory Commission (USNRC) reviewers in assessing the seriousness of reported incidences of containment degradation; and (3) providing recommendations, as appropriate, on the performance of structural materials under various environmental conditions not considered above. The objectives of this limited study were to provide an overview of the methods that are available for inspection of nuclear power plant reinforced concrete and metallic materials, and to provide an assessment of the status of methods that address inspection of thick, heavily-reinforced concrete structures that in some cases may have limited accessibility due to presence of liners or they may be located below ground, and inaccessible areas of the containment metallic pressure boundary.

Results of this study will contribute to providing an improved basis for the USNRC staff to evaluate nuclear power plants for continued service. More specifically, potential regulatory applications of this research include (1) improved predictions of long-term material and structural performance and available safety margins at future times, (2) establishment of limits on exposure to environmental stressors, (3) reduction in total reliance by licensing on inspection and surveillance through development of a methodology that will enable the integrity of structures to be assessed (either pre- or post-accident), and (4) improvements in damage inspection methodology through potential incorporation of program results into national standards that could be referenced by Standard Review Plans.

\subsection{SCOPE}

In meeting the objective of this study, safety-related nuclear power plant structures are briefly described, testing and inspection requirements outlined, potential degradation factors identified, and operating experience reviewed. 
Methods for conduct of condition assessments of reinforced concrete and metallic materials are summarized and input on areas for needed development presented. As two of the primary areas of interest noted in previous studies related to assessments of NPP safety-related structures were inspection methods for thick, heavily-reinforced concrete structures and inaccessible regions of the containment metallic pressure boundary $(1.2,1.3)$, pertinent investigations addressing these areas of interest are addressed in particular. Finally conclusions and recommendations are provided.

\subsection{REFERENCES}

1.1 U.S. Nuclear Regulatory Commission, Information Digest, NUREG-1350, Vol. 17, Division of Planning, Budget and Analysis, Office of the Chief Financial Officer, U.S. Nuclear Regulatory Commission, Washington, D.C., July 2005.

1.2 D. J. Naus, C. B. Oland and B. R. Ellingwood, Report on Aging of Nuclear Power Plant Concrete Structures, NUREG/CR-6424 (ORNL/TM-13148), Lockheed Martin Energy Research Corporation, Oak Ridge National Laboratory, Oak Ridge, Tennessee, 1996.

1.3 D. J. Naus, C. B. Oland, and B. R. Ellingwood, Final Report Inspection of Aged/Degraded Containments Program, ORNL/TM-2005/170, Oak Ridge National Laboratory, Oak Ridge, Tennessee, August 2005. 


\section{NUCLEAR POWER PLANT SAFETY-RELATED STRUCTURES}

All commercial nuclear power plants (NPPs) in the U.S. contain structures whose performance and function are necessary for the protection of the safety of plant operating personnel and the general public, as well as the environment. The basic laws that regulate the design (and construction) of NPPs are contained in Title 10 of the Code of Federal Regulations (CFR) (2.1) that is clarified by Regulatory Guides (e.g., R.G. 1.29) (2.2), NUREG reports, Standard Review Plans (e.g., Concrete and Steel Internal Structures of Steel or Concrete Containments) (2.3), etc. In addition, R.G. 1.29 and Part 100 to Title 10 of the CFR state that NPP structures important to safety must be designed to withstand the effects of earthquakes without the loss of function or threat to public safety. These "safety-related" structures are designed as seismic Category I. Seismic Category I structures typically include those classified by the American Society of Mechanical Engineers (ASME) and the American Nuclear Society (ANS) as Classes 1, 2, and 3 (i.e., safety related).

\subsection{GENERAL DESCRIPTION}

The containment structure is a vital engineered safety feature of a nuclear power plant. From a safety standpoint, the containment is one of the most important components of a nuclear power plant because it serves as the final barrier to the release of fission products to the outside environment under postulated accident conditions. During normal operating conditions the containment is subject to various operational and environmental stressors (e.g., ambient pressure fluctuations, temperature variations, earthquakes, and windstorms). In some containment designs, the principal leak-tight barrier is surrounded by another structure (e.g., reactor or shield building) that protects the containment from external events. Ensuring that the structural capacity and leak-tight integrity of the containment has not deteriorated unacceptably due either to aging or environmental stressor effects is essential to reliable continued service evaluations and informed aging management decisions.

Each boiling-water reactor (BWR) or pressurized-water reactor (PWR) unit in the U.S. is located within a much larger metal or concrete containment that also houses or supports the primary coolant system components. Although the shapes and configurations of the containment can vary significantly from plant-to-plant, leak tightness is assured by a continuous pressure boundary consisting of nonmetallic seals and gaskets, and metallic components that are either welded or bolted together. There are several Code of Federal Regulations (CFR) (2.1) General Design Criteria (GDC) and American Society of Mechanical Engineers (ASME) Code sections that establish minimum requirements for the design, fabrication, construction, testing, and performance of containment structures. The GDC serve as fundamental underpinnings for many of the most important safety commitments in licensee design and licensing bases. General Design Criterion 16, "Containment Design," requires the provision of reactor containment and associated systems to establish an essentially leak-tight barrier against the uncontrolled release of radioactivity into the environment and to ensure that the containment design conditions important to safety are not exceeded for as long as required for postulated accident conditions. Criterion 53, "Provisions for Containment Testing and Inspection," requires that the reactor containment be designed to permit: (1) appropriate periodic inspection of all important areas, such as penetrations; (2) an appropriate surveillance program; and (3) periodic testing at containment design pressure of leak tightness of penetrations that have resilient seals and expansion bellows. Additional information on NPP light-water reactor containments is available $(2.4,2.5)$.

\subsubsection{Concrete Structures}

All commercial nuclear power plants contain concrete structures whose performance and function are necessary for protection of the safety of plant operating personnel, the general public, and the environment. Initially, existing building codes, such as American Concrete Institute (ACI) Standard 318, Building Code Requirements for Reinforced Concrete (2.6), were used in the nuclear industry as the basis for design and construction of concrete structural members. However, because the existing building codes did not cover the entire spectrum of design requirements and because they were not always considered adequate, the U.S. Nuclear Regulatory Commission (USNRC) developed its own criteria for design of seismic Category 1 (i.e., safety related) structures (e.g., definitions of load combinations for both operating and accident conditions). Plants that used early ACI codes for design were reviewed by the USNRC through the Systematic Evaluation Program to determine if there were any unresolved safety concerns (2.7). Current rules for construction of concrete containments are provided in Section III, Division 2 of the ASME Code. The USNRC has developed supplemental load combination criteria and 
provides information related to concrete and steel internal structures of steel and concrete containments $(2.3,2.8)$. Information on an approach considered acceptable by the USNRC staff in satisfying several of the GDC related to containment design is available (2.9). The American Concrete Institute has published requirements for nuclear safety-related concrete structures other than reactor vessels and containments (2.10). Rules for design and construction of the metal liner that forms the pressure boundary for the reinforced concrete containments are found in ASME Section III, Division 1, Subsection NE of the ASME Code. Seventy-two of the NPPs licensed for commercial operation in the U.S. employ either a reinforced concrete (37 plants) or post-tensioned concrete (35 plants) containment.

Typical safety-related concrete structures for light-water reactor plants can be grouped into four general categories: primary containments, containment internal structures, secondary containments/reactor buildings, and other structures. Table 2.1 lists typical safety-related concrete structures in light-water reactor plants and their accessibility for examination. The primary containment is a vital engineered safety feature of a nuclear plant that is subjected to various operating and environmental stressors (e.g., ambient pressure fluctuations, temperature variations, and earthquakes). Concrete containments are metal lined, reinforced concrete pressure-retaining structures that in some cases may be post-tensioned. The concrete containment includes the concrete shell and shell components, shell metallic liners, and penetration liners that extend the containment liner through the surrounding shell concrete. The reinforced concrete shell, which generally consists of a cylindrical wall with a hemispherical or ellipsoidal dome and flat base slab, provides the necessary structural support and resistance to pressure-induced forces. Leak tightness is provided by a steel liner fabricated from relatively thin plate material (e.g., 6-mm thick) that is anchored to the concrete shell by studs, structural steel shapes, or other steel products. In addition to the containment, there are a number of other concrete structures contained as part of a light-water plant to support and protect safety-related systems and components. The other structures are primary, secondary, and biological shield walls, as well as floors and supporting structures in the containments, reactor buildings, auxiliary (or intermediate) buildings, diesel generator buildings, intake structures, and service-water pump houses. The exterior walls and roofs, shield walls and buildings, interior floors that support heavy equipment and piping, and foundation mats are constructed of reinforced concrete. Some of the interior walls of these structures are constructed of (reinforced or unreinforced) masonry blocks. Beams and columns that support the floors are either of structural steel or reinforced concrete. Safety-related tanks are generally fabricated from structural steel. Guidance to licensees and applicants on methods acceptable to USNRC staff for complying with the USNRC's regulations in the design, evaluation, and quality assurance of safety-related nuclear concrete structures, excluding concrete reactor vessels and containments, is available (2.11).

\subsubsection{Steel Structures}

Prior to 1963, metal containments for nuclear power plants were designed according to rules for unfired pressure vessels that were provided in Section VIII of the ASME Code (2.12). Subsequent metal containments were designed either as Class B vessels or as Class MC components according to rules provided in Section III of the ASME Code (2.13). Almost every aspect of metal containment design is addressed by the Code. The Code also recognizes that service-related degradation to pressure-retaining components is possible, but rules for material selection and in-service degradation are outside its scope. It is the Owner's responsibility to select materials suitable for the service conditions and to increase minimum required thickness of the base metal to offset material thinning due to corrosion, erosion, mechanical abrasion, or other environmental effects. Current rules for construction of metal containments are provided in Section III, Division 1, Subsection NE of the ASME Code. Currently operating metal containments are freestanding, welded steel structures that are enclosed in a reinforced concrete reactor or shield building. The reactor or shield buildings are not part of the pressure boundary and their primary function is to provide protection for the containment from external missiles and natural phenomena (e.g., tornadoes or site-specific environmental events). Thirty-two of the NPPs licensed for commercial operation in the US employ a metal containment.

\subsection{POTENTIAL DEGRADATION FACTORS}

Safety-related structures are designed to withstand loadings from a number of low-probability external and internal events, such as earthquake, tornado, and loss-of-coolant accidents. Thus, they are robust and during normal plant operation are not subjected to stresses of sufficient magnitude to result in appreciable degradation. Over its operating lifetime the containment pressure boundary can be subjected to a significant number of cycles of low- 
Table 2.1. Typical safety-related concrete structures in LWR plants and their accessibility for visual examination

Concrete Structure

Primary containment

Containment dome/roof

Containment foundation/basemat

Slabs and walls

Containment internal structures

Slabs and walls

Reactor vessel support structure (or pedestal)

Crane support structures

Reactor shield wall (biological)

Ice condenser dividing wall (ice condenser plants)

NSSS equipment supports/vault structures

Weir and vent walls (Mark III)

Pool structures (Mark III)

Diaphragm floor (Mark II)

Drywell/wetwell slabs and walls

(Mark III)

Secondary Containment/Reactor Buildings

Slabs, columns, and walls

Foundation

Sacrificial shield wall (metallic containments)

Fuel/Equipment Storage Pools

Walls, slabs, and canals

Auxiliary building

Fuel storage building

Control room (or building)

Diesel generator building

Piping or electrical cable ducts or tunnels

Radioactive waste storage building

Stacks

Intake structures (inc. concrete water intake piping and canal embankments)

Pumping stations

Cooling towers

Plant discharge structures

Emergency cooling water structures

Dams

Water wells

Turbine building
Accessibility

Internal liner/complete external

Internal liner (not embedded) or top surface

Internal liner/external above grade

Generally accessible

Typically lined or hard to access

Generally accessible

Typically lined

Lined or hard to access

Generally accessible

Lined with limited access

Lined

Lined with limited access

Internal liner/partial external access

Accessible on multiple surfaces

Top surface

Internal lined/external accessible

Internal lined/partial external

Generally accessible

Generally accessible

Generally accessible

Generally accessible

Limited accessibility

Generally accessible

Partial internal/external above grade

Internal accessible/external above grade and waterline

Partially accessible

Accessible above grade

Internal accessible/external above grade and waterline

Limited accessibility

External surfaces above waterline

Limited accessibility

Generally accessible

Source: C.J. Hookham, In-Service Inspection Guidelines for Concrete Structures in Nuclear Power Plants, ORNL/NRC/LTR-95/14, Lockheed Martin Energy Systems, Inc., Oak Ridge National Laboratory, Oak Ridge, Tennessee, 1995.

stress transients. Design rules for fatigue of steels used to construct containment pressure boundary components are included in the ASME Code, therefore, fatigue resulting from cyclic loads such as the ones listed in Table 2.2 are not expected to be a generic concern for either liners of reinforced concrete containments or the shells of metal containments (2.14). The NPP structures also can be subjected to various types of degradation or distress as a result of design or construction errors, accidental loadings, or environmental effects. As the plants are relatively mature, design or construction errors in all likelihood would have been addressed by now and accidental loadings would be 
Table 2.2 Possible cyclic loads on containment pressure boundary components

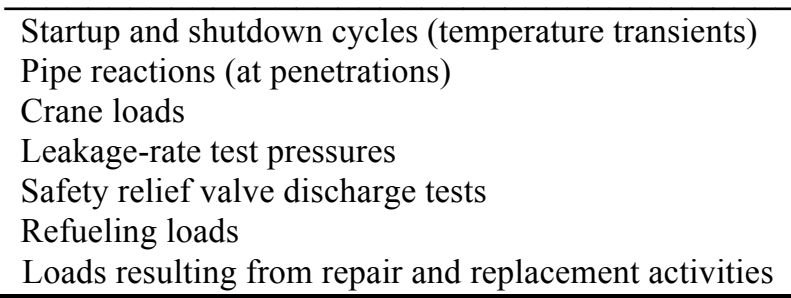

Source: V.N. Shah, S.K. Smith, and U.P. Sinha, Insights for Aging Management of Light Water Reactor Components, NUREG/CR-5314, (EGG-2562), Vol. 5, Idaho National Engineering Laboratory, Idaho Falls, Idaho, March 1994.

addressed after occurrence. Therefore the primary mechanisms of interest to the present study are related to environmental, aging, or a combination of these effects. As the NPPs age, incidences of age-related (e.g., environmental) degradation are likely to increase.

Service-related degradation can affect the ability of a nuclear power plant containment to perform satisfactorily in the unlikely event of a severe accident by reducing its structural capacity or jeopardizing its leak-tight integrity. Degradation is considered to be any phenomenon that decreases the load-carrying capacity of a containment, limits its ability to contain a fluid medium, or reduces its service life. The root cause for containment degradation can generally be linked to a design or construction problem, inappropriate material application, a base-metal or weldmetal flaw, maintenance or inspection activities, or excessively severe service conditions.

Primary mechanisms that can produce premature deterioration of reinforced concrete structures include those that impact either the concrete or steel reinforcing materials (i.e., mild steel reinforcement or post-tensioning system). Degradation of concrete can be caused by adverse performance of either its cement-paste matrix or aggregate materials under chemical or physical attack. Chemical attack may occur in several forms: efflorescence or leaching; attack by sulfate, acids, or bases; salt crystallization; and alkali-aggregate reactions. Physical attack mechanisms for concrete include freeze/thaw cycling, thermal expansion/thermal cycling,

abrasion/erosion/cavitation, irradiation, and fatigue or vibration. Degradation of mild steel reinforcing materials can occur as a result of corrosion, irradiation, elevated temperature, or fatigue effects. Post-tensioning systems are susceptible to the same degradation mechanisms as mild steel reinforcement plus loss of prestressing force, primarily due to tendon relaxation and concrete creep and shrinkage. A summary of degradation factors that can impact the performance of reinforced concrete safety-related structures is provided in Table 2.3 (2.15). Degradation of the concrete materials and structures was addressed under the Structural Aging Program (2.16). Additional information on pertinent factors affecting the durability of NPP reinforced concrete structures is available $(2.15,2.17)$.

Steel containment and other safety-related metallic structure's degradation can be classified as either material or physical damage. Material damage occurs when the microstructure of the metal is modified causing changes in its mechanical properties. Degradation mechanisms that can potentially cause material damage to metallic materials include (1) low-temperature exposure, (2) high-temperature exposure, (3) intergranular corrosion, (4) dealloying corrosion, (5) hydrogen embrittlement, and (6) neutron irradiation. Material damage to the containment metallic pressure boundary from any of these sources is not considered likely, however. Physical damage occurs when the geometry of a component is altered by the formation of cracks, fissures, or voids, or its dimensions change due to overload, buckling, corrosion, erosion, or formation of other types of surface flaws. Changes in component geometry, such as wall thinning or pitting caused by corrosion, can affect structural capacity by reducing the net section available to resist applied loads. In addition, pits that completely penetrate the component can compromise the leak-tight integrity of the component. Primary degradation mechanisms that can potentially cause physical damage to containment pressure boundary components include (1) general corrosion (atmospheric, aqueous, galvanic, stray-electrical current, and general biological); (2) localized corrosion (filiform, crevice, pitting, and localized biological); (3) mechanically-assisted degradation (erosion, fretting, cavitation, corrosion fatigue, surface flaws, arc strikes, and overload conditions); (4) environmentally-induced cracking (stress-corrosion and hydrogen- 
Table 2.3a Degradation factors that can impact the performance of reinforced concrete safety-related structures: concrete

\begin{tabular}{|c|c|c|c|c|}
\hline \multicolumn{5}{|c|}{ Concrete } \\
\hline $\begin{array}{c}\text { Aging } \\
\text { Stressors/Service } \\
\text { Conditions }\end{array}$ & Aging Mechanism & Aging Effect & $\begin{array}{c}\text { Potential } \\
\text { Degradation Sites }\end{array}$ & $\begin{array}{l}\text { Remarks (e.g., } \\
\text { Significance) }\end{array}$ \\
\hline $\begin{array}{l}\text { Percolation of fluid } \\
\text { through concrete due } \\
\text { to moisture gradient }\end{array}$ & $\begin{array}{l}\text { Leaching and } \\
\text { efflorescence }\end{array}$ & $\begin{array}{l}\text { Increased porosity } \\
\text { and permeability; } \\
\text { lowers strength }\end{array}$ & $\begin{array}{l}\text { Near cracks; areas of } \\
\text { high moisture } \\
\text { percolation }\end{array}$ & $\begin{array}{l}\text { Makes concrete } \\
\text { more vulnerable to } \\
\text { hostile } \\
\text { environments; may } \\
\text { indicate other } \\
\text { changes to cement } \\
\text { paste; unlikely to be } \\
\text { an issue for high } \\
\text { quality, low } \\
\text { permeability } \\
\text { concretes }\end{array}$ \\
\hline $\begin{array}{l}\text { Exposure to alkali } \\
\text { and magnesium } \\
\text { sulfates present in } \\
\text { soils, sea water, or } \\
\text { ground water }\end{array}$ & Sulfate attack & $\begin{array}{l}\text { Expansion and } \\
\text { irregular cracking }\end{array}$ & $\begin{array}{l}\text { Subgrade structures } \\
\text { and foundations }\end{array}$ & $\begin{array}{l}\text { Sulfate-resisting } \\
\text { cements or partial } \\
\text { replacement of } \\
\text { cements used to } \\
\text { minimize occurrence }\end{array}$ \\
\hline $\begin{array}{l}\text { Exposure to } \\
\text { aggressive acids and } \\
\text { bases }\end{array}$ & $\begin{array}{l}\text { Conversion of } \\
\text { hardened cement to } \\
\text { soluble material that } \\
\text { can be leached }\end{array}$ & $\begin{array}{l}\text { Increased porosity } \\
\text { and permeability }\end{array}$ & $\begin{array}{l}\text { Local areas subject } \\
\text { to chemical spills; } \\
\text { adjacent to pipework } \\
\text { carrying aggressive } \\
\text { fluids }\end{array}$ & $\begin{array}{l}\text { Acid rain not an } \\
\text { issue }\end{array}$ \\
\hline $\begin{array}{l}\text { Combination of } \\
\text { reactive aggregate, } \\
\text { high moisture levels, } \\
\text { and alkalis }\end{array}$ & $\begin{array}{l}\text { Alkali-aggregate } \\
\text { reactions leading to } \\
\text { swelling }\end{array}$ & $\begin{array}{l}\text { Cracking; gel } \\
\text { exudation; aggregate } \\
\text { pop-out }\end{array}$ & $\begin{array}{l}\text { Areas where } \\
\text { moisture levels are } \\
\text { high and improper } \\
\text { materials utilized }\end{array}$ & $\begin{array}{l}\text { Eliminate potentially } \\
\text { reactive materials; } \\
\text { use low alkali- } \\
\text { content cements or } \\
\text { partial cement } \\
\text { replacement }\end{array}$ \\
\hline $\begin{array}{l}\text { Cyclic } \\
\text { loads/vibration }\end{array}$ & Fatigue & $\begin{array}{l}\text { Cracking; strength } \\
\text { loss }\end{array}$ & $\begin{array}{l}\text { Equipment/piping } \\
\text { supports }\end{array}$ & $\begin{array}{l}\text { Localized damage; } \\
\text { fatigue failure of } \\
\text { concrete structures } \\
\text { unusual }\end{array}$ \\
\hline $\begin{array}{l}\text { Exposure to flowing } \\
\text { gas or liquid } \\
\text { carrying particulates } \\
\text { and abrasive } \\
\text { components }\end{array}$ & $\begin{array}{l}\text { Abrasion; erosion; } \\
\text { cavitation }\end{array}$ & $\begin{array}{l}\text { Section loss; loss of } \\
\text { cover to expose } \\
\text { rebar to corrosion }\end{array}$ & $\begin{array}{l}\text { Cooling water intake } \\
\text { and discharge } \\
\text { structures }\end{array}$ & $\begin{array}{l}\text { Unlikely to be an } \\
\text { issue for } \\
\text { containment } \\
\text { structures; intake } \\
\text { structures at most } \\
\text { risk }\end{array}$ \\
\hline $\begin{array}{l}\text { Exposure to thermal } \\
\text { cycles at relatively } \\
\text { low temperatures }\end{array}$ & $\begin{array}{l}\text { Freezing and } \\
\text { thawing }\end{array}$ & Cracking; spalling & $\begin{array}{l}\text { External surfaces } \\
\text { where geometry } \\
\text { supports moisture } \\
\text { accumulation }\end{array}$ & $\begin{array}{l}\text { Air-entrainment } \\
\text { utilized to minimize } \\
\text { potential occurrence }\end{array}$ \\
\hline
\end{tabular}

Source: Assessment and Management of Major Nuclear Power Plant Components Important to Safety: Concrete Containment Buildings, IAEA- TECDOC-1025, International Atomic Energy Agency, Vienna, Austria, June 1998. 
Table 2.3a (cont.) Degradation factors that can impact the performance of reinforced concrete safety-related structures: concrete (cont.)

\begin{tabular}{|c|c|c|c|c|}
\hline \multicolumn{5}{|c|}{ Concrete (cont.) } \\
\hline $\begin{array}{c}\text { Aging } \\
\text { Stressors/Service } \\
\text { Conditions }\end{array}$ & Aging Mechanism & Aging Effect & $\begin{array}{c}\text { Potential } \\
\text { Degradation sites }\end{array}$ & $\begin{array}{l}\text { Remarks (e.g., } \\
\text { Significance) }\end{array}$ \\
\hline $\begin{array}{l}\text { Thermal } \\
\text { exposure/thermal } \\
\text { cycling }\end{array}$ & $\begin{array}{l}\text { Moisture content } \\
\text { changes and material } \\
\text { incompatibility due } \\
\text { to different thermal } \\
\text { expansion values }\end{array}$ & $\begin{array}{l}\text { Cracking; spalling; } \\
\text { reduced modulus of } \\
\text { elasticity }\end{array}$ & $\begin{array}{l}\text { Near hot process and } \\
\text { steam piping }\end{array}$ & $\begin{array}{l}\text { Generally an issue } \\
\text { for hot spot } \\
\text { locations; can } \\
\text { increase concrete } \\
\text { creep that can } \\
\text { increase prestressing } \\
\text { force loss }\end{array}$ \\
\hline Irradiation & $\begin{array}{l}\text { Aggregate } \\
\text { expansion; } \\
\text { hydrolysis }\end{array}$ & $\begin{array}{l}\text { Cracking; loss of } \\
\text { mechanical } \\
\text { properties }\end{array}$ & $\begin{array}{l}\text { Structures proximate } \\
\text { to reactor vessel }\end{array}$ & $\begin{array}{l}\text { Containment } \\
\text { irradiation levels } \\
\text { likely to be below } \\
\text { threshold levels to } \\
\text { cause degradation } \\
\text { (e.g., }<10^{19} \\
\text { neutrons } / \mathrm{cm}^{2} \text { or } \\
<10^{10} \mathrm{rads} \text { dose) }\end{array}$ \\
\hline $\begin{array}{l}\text { Consolidation or } \\
\text { movement of soil on } \\
\text { which structure } \\
\text { founded }\end{array}$ & $\begin{array}{l}\text { Differential } \\
\text { settlement }\end{array}$ & $\begin{array}{l}\text { Equipment } \\
\text { alignment; cracking }\end{array}$ & $\begin{array}{l}\text { Compacted } \\
\text { structures on } \\
\text { independent } \\
\text { foundations }\end{array}$ & $\begin{array}{l}\text { Allowance made in } \\
\text { design; soil sites } \\
\text { generally include } \\
\text { settlement } \\
\text { monitoring } \\
\text { instrumentation }\end{array}$ \\
\hline $\begin{array}{l}\text { Exposure to water } \\
\text { containing dissolved } \\
\text { salts (e.g. sea water) }\end{array}$ & Salt crystallization & Cracking and scaling & $\begin{array}{l}\text { Surfaces subject to } \\
\text { salt spray; intake } \\
\text { structures; } \\
\text { foundations }\end{array}$ & $\begin{array}{l}\text { Minimized through } \\
\text { use of low } \\
\text { permeability } \\
\text { concretes, sealers, } \\
\text { and barriers }\end{array}$ \\
\hline
\end{tabular}

Source: Assessment and Management of Major Nuclear Power Plant Components Important to Safety: Concrete Containment Buildings, IAEA- TECDOC-1025, International Atomic Energy Agency, Vienna, Austria, June 1998. 
Table 2.3b (cont.) Degradation factors that can impact the performance of reinforced concrete safety-related structures: reinforcing steel

\begin{tabular}{|c|c|c|c|c|}
\hline \multicolumn{5}{|c|}{ Mild Steel Reinforcement } \\
\hline $\begin{array}{c}\text { Aging } \\
\text { Stressors/Service } \\
\text { Conditions }\end{array}$ & Aging Mechanism & Aging Effect & $\begin{array}{c}\text { Potential } \\
\text { Degradation sites }\end{array}$ & $\begin{array}{l}\text { Remarks (e.g., } \\
\text { Significance) }\end{array}$ \\
\hline $\begin{array}{l}\text { Depassivation of } \\
\text { steel due to } \\
\text { carbonation or } \\
\text { presence of } \\
\text { chlorides }\end{array}$ & $\begin{array}{l}\text { Composition or } \\
\text { corrosion cells } \\
\text { leading to corrosion }\end{array}$ & $\begin{array}{l}\text { Concrete cracking } \\
\text { and spalling; loss of } \\
\text { reinforcement cross- } \\
\text { section }\end{array}$ & $\begin{array}{l}\text { Outer layer of steel } \\
\text { reinforcement in all } \\
\text { structures where } \\
\text { cracks or local } \\
\text { defects (e.g., joints) } \\
\text { are present }\end{array}$ & $\begin{array}{l}\text { Prominent potential } \\
\text { form of degradation; } \\
\text { leads to reduction of } \\
\text { load-carrying } \\
\text { capacity }\end{array}$ \\
\hline $\begin{array}{l}\text { Elevated } \\
\text { temperature }\end{array}$ & $\begin{array}{l}\text { Microcrystalline } \\
\text { changes }\end{array}$ & $\begin{array}{l}\text { Reduction of yield } \\
\text { strength and } \\
\text { modulus of elasticity }\end{array}$ & $\begin{array}{l}\text { Near hot process and } \\
\text { steam piping }\end{array}$ & $\begin{array}{l}\text { Of significance only } \\
\text { where temperatures } \\
\text { exceed } \sim 200^{\circ} \mathrm{C}\end{array}$ \\
\hline Irradiation & $\begin{array}{l}\text { Microstructural } \\
\text { transformation }\end{array}$ & $\begin{array}{l}\text { Increased yield } \\
\text { strength; reduced } \\
\text { ductility }\end{array}$ & $\begin{array}{l}\text { Structures proximate } \\
\text { to reactor vessel }\end{array}$ & $\begin{array}{l}\text { Irradiation levels } \\
\text { likely to be below } \\
\text { threshold levels to } \\
\text { cause degradation }\end{array}$ \\
\hline Cyclic loading & Fatigue & $\begin{array}{l}\text { Loss of bond to } \\
\text { concrete; failure of } \\
\text { steel under extreme } \\
\text { conditions }\end{array}$ & $\begin{array}{l}\text { Equipment/piping } \\
\text { supports }\end{array}$ & $\begin{array}{l}\text { Localized damage; } \\
\text { fatigue failure of } \\
\text { concrete structures } \\
\text { unusual }\end{array}$ \\
\hline
\end{tabular}

Source: Assessment and Management of Major Nuclear Power Plant Components Important to Safety: Concrete Containment Buildings, IAEA- TECDOC-1025, International Atomic Energy Agency, Vienna, Austria, June 1998. 
Table 2.3c (cont.) Degradation factors that can impact the performance of reinforced concrete safety-related structures: prestressing steel

\begin{tabular}{|c|c|c|c|c|}
\hline \multicolumn{5}{|c|}{ Prestressing Systems } \\
\hline $\begin{array}{c}\text { Aging } \\
\text { Stressors/Service } \\
\text { Conditions }\end{array}$ & Aging Mechanism & Aging Effect & $\begin{array}{c}\text { Potential } \\
\text { Degradation sites }\end{array}$ & $\begin{array}{l}\text { Remarks (e.g., } \\
\text { Significance) }\end{array}$ \\
\hline $\begin{array}{l}\text { Localized pitting, } \\
\text { general corrosion, } \\
\text { stress corrosion, or } \\
\text { hydrogen } \\
\text { embrittlement }\end{array}$ & $\begin{array}{l}\text { Corrosion due to } \\
\text { specific } \\
\text { environmental } \\
\text { exposure (e.g., } \\
\text { electrochemical, } \\
\text { hydrogen, or } \\
\text { microbiological) }\end{array}$ & $\begin{array}{l}\text { Loss of cross-section } \\
\text { and reduced ductility }\end{array}$ & $\begin{array}{l}\text { Tendon and } \\
\text { anchorage hardware } \\
\text { of prestressed } \\
\text { concrete } \\
\text { containments }\end{array}$ & $\begin{array}{l}\text { Potential } \\
\text { degradation } \\
\text { mechanism due to } \\
\text { lower tolerance for } \\
\text { corrosion than mild } \\
\text { steel reinforcement }\end{array}$ \\
\hline $\begin{array}{l}\text { Elevated } \\
\text { temperature }\end{array}$ & $\begin{array}{l}\text { Microcrystalline } \\
\text { changes }\end{array}$ & $\begin{array}{l}\text { Reduction of } \\
\text { strength; increased } \\
\text { relaxation and creep }\end{array}$ & $\begin{array}{l}\text { Near hot process and } \\
\text { steam piping }\end{array}$ & $\begin{array}{l}\text { Thermal exposure } \\
\text { not likely to reach } \\
\text { levels that can } \\
\text { produce aging } \\
\text { effects in } \\
\text { prestressing }\end{array}$ \\
\hline Irradiation & $\begin{array}{l}\text { Microstructural } \\
\text { transformation }\end{array}$ & $\begin{array}{l}\text { Increased strength; } \\
\text { reduced ductility }\end{array}$ & $\begin{array}{l}\text { Structure proximate } \\
\text { to reactor vessel }\end{array}$ & $\begin{array}{l}\text { Containment } \\
\text { irradiation levels } \\
\text { likely to be below } \\
\text { threshold levels to } \\
\text { cause degradation }\end{array}$ \\
\hline $\begin{array}{l}\text { Cyclic loading due } \\
\text { to diurnal or } \\
\text { operating effects }\end{array}$ & Fatigue & $\begin{array}{l}\text { Failure of } \\
\text { prestressing under } \\
\text { extreme conditions }\end{array}$ & $\begin{array}{l}\text { Tendon and } \\
\text { anchorage hardware } \\
\text { of prestressed } \\
\text { concrete } \\
\text { containments } \\
\end{array}$ & $\begin{array}{l}\text { Not likely as cyclic } \\
\text { loadings are } \\
\text { generally small in } \\
\text { number and } \\
\text { magnitude }\end{array}$ \\
\hline Long-term loading & $\begin{array}{l}\text { Stress relaxation; } \\
\text { creep and shrinkage } \\
\text { of concrete }\end{array}$ & $\begin{array}{l}\text { Loss of prestressing } \\
\text { force }\end{array}$ & $\begin{array}{l}\text { Prestressed concrete } \\
\text { containments }\end{array}$ & $\begin{array}{l}\text { Larger than } \\
\text { anticipated loss of } \\
\text { prestressing forces }\end{array}$ \\
\hline
\end{tabular}

Source: Assessment and Management of Major Nuclear Power Plant Components Important to Safety: Concrete Containment Buildings, IAEA- TECDOC-1025, International Atomic Energy Agency, Vienna, Austria, June 1998. 
Table 2.3d (cont.) Degradation factors that can impact the performance of reinforced concrete safety-related structures: liner steel

\begin{tabular}{|c|c|c|c|c|}
\hline \multicolumn{5}{|c|}{ Containment Liners } \\
\hline $\begin{array}{c}\text { Aging } \\
\text { Stressors/Service } \\
\text { Conditions }\end{array}$ & Aging Mechanism & Aging Effect & $\begin{array}{c}\text { Potential Degradation } \\
\text { sites }\end{array}$ & $\begin{array}{l}\text { Remarks (e.g., } \\
\text { Significance) }\end{array}$ \\
\hline $\begin{array}{l}\text { Electrochemical } \\
\text { reaction with } \\
\text { environment } \\
\text { (metallic liners) }\end{array}$ & $\begin{array}{l}\text { Composition or } \\
\text { concentration cells } \\
\text { leading to general or } \\
\text { pitting corrosion }\end{array}$ & $\begin{array}{l}\text { Loss of cross- } \\
\text { section; reduced } \\
\text { leak tightness }\end{array}$ & $\begin{array}{l}\text { Areas of moisture } \\
\text { storage/accumulation, } \\
\text { exposure to chemical } \\
\text { spills, or borated water }\end{array}$ & $\begin{array}{l}\text { Corrosion has been } \\
\text { noted in several } \\
\text { containments near } \\
\text { where the liner } \\
\text { becomes embedded } \\
\text { in the concrete }\end{array}$ \\
\hline $\begin{array}{l}\text { Elevated } \\
\text { temperature } \\
\text { (metallic liners) }\end{array}$ & $\begin{array}{l}\text { Microcrystalline } \\
\text { changes }\end{array}$ & $\begin{array}{l}\text { Reduction of } \\
\text { strength; } \\
\text { increased ductility }\end{array}$ & $\begin{array}{l}\text { Near hot process and } \\
\text { steam piping }\end{array}$ & $\begin{array}{l}\text { Thermal exposure } \\
\text { not likely to reach } \\
\text { levels that can } \\
\text { produce aging } \\
\text { effects in metal } \\
\text { liners }\end{array}$ \\
\hline $\begin{array}{l}\text { Irradiation (metallic } \\
\text { and nonmetallic } \\
\text { liners) }\end{array}$ & $\begin{array}{l}\text { Microstructural } \\
\text { transformation } \\
\text { (metallic); increased } \\
\text { cross-linking } \\
\text { (nonmetallic) }\end{array}$ & $\begin{array}{l}\text { Increased } \\
\text { strength; reduced } \\
\text { ductility }\end{array}$ & $\begin{array}{l}\text { Structures proximate to } \\
\text { reactor vessel }\end{array}$ & $\begin{array}{l}\text { Containment } \\
\text { irradiation levels } \\
\text { likely to be below } \\
\text { threshold levels to } \\
\text { cause degradation }\end{array}$ \\
\hline $\begin{array}{l}\text { Cyclic loading due } \\
\text { to diurnal or } \\
\text { operating effects } \\
\text { (metallic and } \\
\text { nonmetallic liners) }\end{array}$ & Fatigue & $\begin{array}{l}\text { Cracking; reduced } \\
\text { leak tightness }\end{array}$ & $\begin{array}{l}\text { Inside surfaces of } \\
\text { concrete containment } \\
\text { building }\end{array}$ & $\begin{array}{l}\text { Not likely as cyclic } \\
\text { loadings are } \\
\text { generally small in } \\
\text { number and } \\
\text { magnitude }\end{array}$ \\
\hline $\begin{array}{l}\text { Localized effects } \\
\text { (nonmetallic liners) }\end{array}$ & $\begin{array}{l}\text { Impact loadings; } \\
\text { stress concentrations; } \\
\text { physical and chemical } \\
\text { changes of concrete }\end{array}$ & $\begin{array}{l}\text { Cracking; reduced } \\
\text { leak tightness }\end{array}$ & $\begin{array}{l}\text { Inside surfaces of } \\
\text { concrete containment } \\
\text { building }\end{array}$ & $\begin{array}{l}\text { Potential problem } \\
\text { in high traffic areas }\end{array}$ \\
\hline
\end{tabular}

Source: Assessment and Management of Major Nuclear Power Plant Components Important to Safety: Concrete Containment Buildings, IAEA- TECDOC-1025, International Atomic Energy Agency, Vienna, Austria, June 1998.

induced); and (5) fatigue. Material degradation due to either general or pitting corrosion represents the greatest potential threat to the containment pressure boundary. Steel containment surface areas that could experience accelerated degradation and aging are listed in Table $2.4(2.4,2.5,2.18,2.19)$. Degradation of containment metallic pressure boundary materials was addressed under the Inspection of Aged/Degraded Containments Program (2.20). Additional information on degradation of the containment metallic pressure boundary is available $(2.4,2.5,2.21)$.

\subsection{TESTING AND INSPECTION REQUIREMENTS}

Surveillance and maintenance is essential to the safety of nuclear power plant structures, and a clear link exists between effective surveillance, maintenance, and safety. To reduce the likelihood of failures due to degradation, the "Maintenance Rule" was issued by the USNRC as 10 CFR 50.65 ("Requirements for Monitoring the Effectiveness of Maintenance at Nuclear Power Plants") on July 10, 1991. As discussed in the rule summary, in order to maintain safety, it is necessary to monitor the effectiveness of maintenance, and to take timely and appropriate corrective action, when necessary, to ensure that the maintenance process continues to be effective for the lifetime of nuclear 
Table 2.4 Steel containment surface areas that could experience accelerated degradation and aging

\begin{tabular}{|c|c|c|}
\hline $\begin{array}{c}\text { Environmental or Operating } \\
\text { Conditions }\end{array}$ & Typical Areas & Likely Locations \\
\hline $\begin{array}{l}\text { Areas subject to accelerated } \\
\text { corrosion with no or minimal } \\
\text { corrosion allowance } \\
\text { or } \\
\text { Areas where the absence or } \\
\text { repeated loss of protective } \\
\text { coatings has resulted in } \\
\text { substantial corrosion or pitting }\end{array}$ & $\begin{array}{l}\text { Areas exposed to standing water } \\
\text { Areas exposed to repeated wetting } \\
\text { and drying } \\
\text { Areas where persistent leakage has } \\
\text { occurred } \\
\text { Areas subject to microbiological } \\
\text { attack } \\
\text { Areas with geometries that permit } \\
\text { water accumulation }\end{array}$ & $\begin{array}{l}\text { Penetration sleeves and bellows } \\
\text { Surfaces wetted during refueling } \\
\text { Concrete-to-steel shell or liner } \\
\text { interface } \\
\text { Shell regions embedded in concrete } \\
\text { including areas shielded by } \\
\text { diaphragm floors } \\
\text { Leak-chase channels } \\
\text { Drain areas including sand pocket } \\
\text { regions } \\
\text { Sump liners } \\
\text { Interior surfaces of BWR Mark I } \\
\text { and II suppression pools } \\
\text { Exterior surfaces of BWR Mark I } \\
\text { and II drywells } \\
\text { Emergency core cooling system } \\
\text { suction intake at the bottom of BWR } \\
\text { suppression pool } \\
\text { Dissimilar metal welds }\end{array}$ \\
\hline $\begin{array}{l}\text { Areas subject to excessive wear } \\
\text { from abrasion or erosion }\end{array}$ & $\begin{array}{l}\text { Areas where mechanical wear, } \\
\text { abrasion, or erosion cause a loss of } \\
\text { protective coatings, deformations, or } \\
\text { material loss } \\
\text { Areas that experience frequent } \\
\text { vibration }\end{array}$ & $\begin{array}{l}\text { Surfaces subject to substantial } \\
\text { traffic } \\
\text { Sliding pads or supports (baseplates } \\
\text { of BWR Mark I suppression } \\
\text { chamber support columns) } \\
\text { Pins or clevises } \\
\text { Shear lugs } \\
\text { Seismic restraints } \\
\text { Surfaces exposed to water jets from } \\
\text { testing operations } \\
\text { Safety relief valve discharge areas } \\
\text { BWR drywell head, vent system } \\
\text { supports, and downcomers and } \\
\text { bracing } \\
\text { Personnel airlocks, equipment } \\
\text { hatches, and control rod drive } \\
\text { (CRD) hatches }\end{array}$ \\
\hline
\end{tabular}

Sources: S. Smith and F. Gregor, BWR Containments License Renewal Industry Report; Revision 1, EPRI TR-103840, prepared by MDC-Ogden Environmental and Energy Services Co., Inc., for the Electric Power Research Institute, Palo Alto, California, July 1994.

D. Deng, J. Renfro, and J. Statton, PWR Containments License Renewal Industry Report; Revision 1, EPRI TR-103835, prepared by Bechtel Power Corporation for the Electric Power Research Institute, Palo Alto, California, July 1994.

V.N. Shah and P.E. MacDonald, Eds., Residual Life Assessment of Major Light Water Reactor Components - Overview, NUREG/CR-4731, (EGG-2469) Vol. 1, Idaho National Engineering Laboratory, Idaho Fall, Idaho, June 1987.

V.N. Shah and P.E. MacDonald, Eds., Residual Life Assessment of Major Light Water Reactor Components - Overview, NUREG/CR-4731, (EGG-2469) Vol. 2, Idaho National Engineering Laboratory, Idaho Fall, Idaho, November 1989. 
power plants, particularly as plants age. The rule requires that plant owners monitor the performance or condition of structures, systems, and components (SSCs) against owner-established goals, in a manner sufficient to give reasonable assurance that such SSCs are capable of fulfilling their intended functions. It is further required that the licensee take appropriate corrective action when the performance or condition of a SSC does not conform to established goals. In order to verify the implementation of 10 CFR 50.65, the USNRC issued Inspection Procedure 62002, "Inspection of Structures, Passive Components, and Civil Engineering Features at Nuclear Power Plants." Implementation of structure's monitoring under 10 CFR 50.65 is addressed in USNRC Regulatory Guide 1.160 (Rev. 2) (2.22) and NUMARC 93-01 (Rev. 2) (2.23). These two documents provide guidelines for development of licensee-specific programs to monitor the condition of structural components within the scope of the "Maintenance Rule" such that there is no loss of structure or structural component intended function.

Subsequently, on May 8, 1995, the USNRC published a final rule amending 10 CFR Part 54, "Requirements for Renewal of Operating Licenses for Nuclear Power Plants," that contained the requirements an applicant must meet to renew an operating license. The final rule is intended to ensure that important SSCs will continue to perform their intended function in the period of extended operation. Only passive, long-lived structures and components are subject to an aging management review for license renewal, and the USNRC license renewal review will focus on the adverse effects of aging. The USNRC concluded that passive, long-lived components should be subject to an aging management review because, in general, functional degradation of these components may not be apparent so that the regulatory process and existing licensee programs may not adequately manage detrimental effects of aging in the period of extended operation.

In June 1995, the USNRC published NUREG-1522, “Assessment of Inservice Conditions of Safety-Related Nuclear Plant Structures." The report contains information from various sources on the condition of structures and civil engineering features at operating nuclear plants. The most significant information came from inspections performed by the USNRC Staff of six plants licensed before 1977. Types of containment-related potential problem areas found included coating degradation and base metal pitting, leakage of tendon corrosion inhibitor, lower than anticipated tendon prestressing forces, bulging and spot corrosion of liner plate, concrete surface cracking, deteriorating concrete repair patches, and torus corrosion. The main conclusion of the report was that a properly established and periodically applied inspection and maintenance program would be beneficial to the plant owners in ensuring the integrity of the plant structures. The importance of periodic inspections of structures, as part of the systematic maintenance program, cannot be over emphasized. Substantial safety and economic benefit can be derived if the scope of the investigations is comprehensive and includes degradation sites having difficult access that may not otherwise be inspected. Timely remedial actions to arrest continuing or address benign degradation will ensure continued safety of the structures, particularly in areas of difficult access.

Many of the degradation occurrences (see Section 2.4) were first identified by the USNRC through its inspections or audits of plant structures, or by licensees while performing an unrelated activity or after they were alerted to a degraded condition at another site. At that time, none of the existing requirements for containment inspection provided specific guidance on how to conduct the necessary containment examinations so there was a large variation with regard to the performance and effectiveness of licensee containment examination programs. Furthermore, based on results of the inspections and audits, the USNRC was concerned because many licensee containment examination programs did not appear to be adequate to detect degradation that could potentially compromise the containment leak-tight integrity. The number of occurrences and extent of degradation experienced by a few of the structures at some plants resulted in the USNRC publishing new rules regarding testing and in-service inspection.

\subsubsection{Testing Requirements}

One of the conditions of all operating licenses for water-cooled power reactors is that the primary reactor containments shall meet the containment leakage test requirements set forth in Appendix J, "Primary Reactor Containment Leakage Testing for Water-Cooled Power Reactors," to 10 CFR 50 (2.24). These test requirements provide for preoperational and periodic verification by tests of the leak-tight integrity of the primary reactor containment, and systems and components that penetrate containment of water-cooled power reactors, and establish the acceptance criteria for such tests. The purpose of these tests is to assure that (1) leakage through the primary reactor containment and the systems and components penetrating primary reactor containment shall not exceed allowable leakage-rate values as specified in the technical specifications or associated bases, and (2) periodic surveillance of reactor containment penetrations and isolation valves is performed so that proper maintenance and 
repairs are made during the service life of the containment, and systems and components that penetrate primary containment.

Contained in this regulation are requirements pertaining to Type A, B, and C leakage-rate tests that must be performed by each licensee as a condition of their operating license. Type A tests are intended to measure the primary reactor containment overall integrated leakage rate (1) after the containment has been completed and is ready for operation, and (2) at periodic intervals thereafter. Type B tests are intended to detect local leaks and to measure leakage across each pressure-containing or leakage-limiting boundary for primary reactor containment penetrations (e.g., penetrations that incorporate resilient seals, gaskets, or sealant compounds; and air lock door seals). Type $\mathrm{C}$ tests are intended to measure containment isolation valve leakage rates. Requirements for system pressure testing and criteria for establishing inspection programs and pressure-test schedules are contained in Appendix J to 10 CFR 50.

On September 26, 1995, the USNRC amended Appendix J (60 FR 49495) to provide a performance-based option for leakage-rate testing as an alternative to the existing prescriptive requirements. The amendment is aimed at improving the focus of the body of regulations by eliminating prescriptive requirements that are marginal to safety and by providing licensees greater flexibility for cost-effective implementation methods for regulatory safety objectives. Now that Appendix J has been amended, either Option A-Prescriptive Requirements or Option BPerformance-Based Requirements can be chosen by a licensee to meet the requirements of Appendix J. Option B allows licensees with good integrated leakage-rate test performance histories to reduce the Type A testing frequency from three tests in ten years to one test in 10 years. For Type B and C tests, Option B allows licensees to reduce testing frequency on a plant-specific basis based on the operating experience for each component and establishes controls to ensure continued performance during the extended testing interval. However, a general inspection of accessible interior and exterior surfaces of the containment structure and components must be performed prior to each Type A test and during two other refueling outages before the next Type A test if the interval for the Type A test has been extended to ten years. The USNRC position on performance-based containment leakage-rate testing is discussed in Regulatory Guide 1.163 (2.25). Methods considered acceptable to the USNRC Staff for complying with the provisions of Option B are provided in guidance documentation (2.26).

The Nuclear Energy Institute document (2.26) presents an industry guideline for implementing the performancebased option and contains an approach that includes continued assurance of the leak-tight integrity of the containment without adversely affecting public health and safety, licensee flexibility to implement cost-effective testing methods, a framework to acknowledge good performance, and utilization of risk and performance-based methods. The guideline delineates the basis for a performance-based approach for determining Type A, B, and C containment leakage-rate surveillance testing frequencies using industry performance data, plant-specific performance data, and risk insights. It does not address how to perform the tests because these details can be found in existing documents (2.27). Licensees may elect to use other suitable methods or approaches to comply with Option B, but they must obtain USNRC approval prior to implementation. A revision to the NEI document dated December 8, 2005 proposes that upon successful completion of two successive Type A tests, subsequent Type A tests may be performed at a frequency of at least one test per 15 years. Furthermore it is proposed that intervals for Type B and Type C tests, following successful completion of two successive tests, be increased from 30 months up to a maximum of 120 months for Type $B$ tests and up to a maximum of 60 months for Type $C$ tests.

\subsubsection{In-Service Inspection Requirements}

Appendix J to 10 CFR Part 50, requires a general inspection of the accessible interior and exterior surfaces of the containment structures and components to uncover any evidence of structural deterioration that may affect either the containment structural integrity or leak tightness. The large number of reported occurrences (see Section 2.4) and the extent of the degradation led the USNRC to conclude that this general inspection was not sufficient. Thus, on August 8, 1996, the USNRC published an amendment (61 FR 41303) to 10 CFR 50.55a of its regulations to require that licensees use portions of the American Society of Mechanical Engineers Boiler and Pressure Vessel Code (ASME Code) (2.28) for containment in-service inspection. The regulations were amended to assure that critical areas of the containments are routinely inspected to detect and to take corrective action for defects that could compromise a containment's structural integrity. The amended rule became effective September 9, 1996.

Specifically, the rule required that licensees adopt the 1992 Edition with the 1992 Addenda of Subsection IWE, "Requirements for Class MC and Metallic Liners of Class CC Components of Light-Water Cooled Power Plants," 
and Subsection IWL, "Requirements for Class CC Concrete Components of Light-Water Cooled Power Plants," of Section XI, of the ASME Code. In addition, several supplemental requirements with respect to the concrete and metal containments were included in the rule. A five-year implementation period was permitted for licensees to develop and implement the examinations of Subsections IWE and IWL (i.e., no later than September 9, 2001). Also, any containment repair and replacement activity to be performed after the effective date of the amended rule has to be carried out in accordance with respective requirements of Subsections IWE and IWL of the ASME Code. However, the Director of the Office of Nuclear Reactor Regulation, at his discretion, can grant relief from the requirements of 10 CFR 50.55a relative to repair and replacement activities to licensees who submit a justifiable need to use an alternative that provides an acceptable level of safety or who encounter extreme hardship or unusual difficulty without a compensating increase in the level of quality or safety.

Subsection IWE of ASME Section XI addresses steel containments (Class MC) and steel liners of concrete containments (Class MC). The full scope of Subsection IWE includes steel containment shells and their integral attachments; containment hatches and airlocks; seals, gaskets, and moisture barriers; and pressure-retaining bolting. Examination categories are specified in Subsection IWE with the parameters monitored or inspected dependent on the particular examination category (e.g., Category E-A covers metallic surfaces and Category E-C addresses containment surfaces requiring augmented examinations). The primary in-service inspection method specified in Subsection IWE is visual examination (general visual, VT-3, VT-1). Limited volumetric examination (e.g., ultrasonic thickness measurement) and surface examination (e.g., liquid penetrant) may also be necessary in some cases. In-service examinations and pressure tests are performed in accordance with one of two inspection programs. Program A has four inspection intervals (at 3, 10, 23, and 40 years) for which $100 \%$ of the required examinations must be completed. After 40 years of operation future examinations are performed in accordance with Program B. Under inspection Program B, starting with the time the plant is placed into service, there is an inspection interval of 10 years and successive inspection intervals of 10 years each, during which $100 \%$ of the required examinations are completed. The scope and frequency of examination specified in 10 CFR 50.55a and Subsection IWE ensure that aging effects would be detected before they would compromise the design-basis requirement. Furthermore, $10 \mathrm{CFR}$ $50.55 \mathrm{a}(\mathrm{b})(2)(\mathrm{ix})$ specifies additional requirements for inaccessible areas when conditions exist in accessible areas that could indicate the presence of or result in degradation to such inaccessible areas.

Subsection IWL of ASME Section XI addresses reinforced and post-tensioned concrete containments (Class CC). Two examination categories are provided in Subsection IWL. Examination Category L-A addresses accessible concrete surfaces and examines them for evidence of damage or degradation, such as cracks. The concrete is examined at 1,3 , and 5 years following the containment structural integrity test and every 5 years thereafter. The primary inspection method of Category L-A is visual examination (general or detailed). Examination Category L-B addresses the unbonded post-tensioning system. The unbonded post-tensioning system examination schedule is the same as for the concrete. For post-tensioned concrete containments, tendon wires are tested for yield strength, ultimate tensile strength, and elongation. Tendon corrosion protection medium is analyzed for alkalinity, water content, and soluble ion concentrations. Prestressing forces are measured for selected sample tendons.

Subsection IWL specifies acceptance criteria, corrective actions, and expansion of the inspection scope when degradation exceeding the acceptance criteria is found. Additional requirements for inaccessible areas are specified in 10 CFR $50.55 \mathrm{a}(\mathrm{b})(2)$ (viii). The acceptability of concrete in inaccessible areas is to be evaluated when conditions exist in accessible areas that could indicate the presence or result in degradation to such inaccessible areas.

Information on aging management programs for masonry walls $(2.29,2.30)$ and water-control structures $(2.31)$ is available.

The ASME Code has been revised on a continuing basis over the years to provide updated provisions for the design, construction, in-service inspection of pressure boundary components, and the testing of pumps and valves. New editions of the ASME Code are issued every three years. Addenda to the editions are issued annually except in years when a new edition is issued. It is the policy of the USNRC to periodically update 10 CFR 50.55a to keep current the ASME Code editions and addenda incorporated by reference. An amendment to 10 CFR 50.55a published by USNRC on October 1, 2004 (69 FR 58804) requires licensees to adopt the 2001 Edition up to and including the 2003 Addenda. Licensees are required by 10 CFR 50.55a to revise their in-service inspection (ISI) and in-service testing (IST) programs every 120 months to the latest edition and addenda of Section XI of the ASME Boiler and Pressure Vessel Code and ASME Code for Operation and Maintenance of Nuclear Power Plants incorporated by reference into $10 \mathrm{CFR} 50.55 \mathrm{a}$ that are in effect 12 months prior to the start of a new 120 -month ISI and IST interval. 


\subsubsection{Continued Service Assessments}

Operating experience has demonstrated that periodic inspection, maintenance, and repair are essential elements of an overall program to maintain an acceptable level of reliability over the service life of a nuclear power plant containment, or in fact, of any structural system. Knowledge gained from conduct of an in-service condition assessment can serve as a baseline for evaluating the safety significance of any degradation that may be present, and defining subsequent in-service inspection programs, and maintenance strategies.

Effective in-service condition assessment of a structure such as a containment requires knowledge of the expected type of degradation, where it can be expected to occur, and application of appropriate methods for detecting and characterizing the degradation. Degradation is considered to be any phenomenon that decreases a structure's loadcarrying capacity, limits its ability to contain a fluid medium, or reduces its service life. Degradation detection is the first and most important step in the condition assessment process. Routine observation, general visual inspections, leakage-rate tests, and nondestructive examinations are approaches used to identify areas of a structure that have experienced degradation. Techniques for establishing time-dependent change such as section thinning due to corrosion, or changes in component geometry and material properties, involve monitoring or periodic examination and testing. Knowing where to inspect and what type of degradation to anticipate often requires information about the design features of the NPP structures as well as the materials of construction and environmental factors. A number of documents are available to assist in development and conduct of structural condition assessment programs (2.4,2.5,2.13,2.15-2.17,2.20,2.32-2.41). Furthermore, The Generic Aging Lessons Learned Report (2.42) has been developed by USNRC to provide a technical basis for the Standard Review Plan for License Renewal (2.43). The document can be used to evaluate existing aging management programs and documents the technical basis for determining where existing programs are adequate without modification and where existing programs should be augmented. Sections of the report address containment structures, other Class 1 structures, and component supports. Each structure and/or component is identified as well as its material(s) of construction, environment, aging effects/mechanisms, acceptable programs to manage the effects of aging, and if further evaluation is required.

\subsection{OPERATING EXPERIENCE}

In general, the performance of nuclear power plant safety-related structures has been very good. However, there have been several isolated incidences that if not remedied could challenge the capacity of the containment and other safety-related structures to meet future functional and performance requirements.

Many of the instances related to degradation of nuclear power plant reinforced concrete structures in the U.S. occurred early in their life and have been corrected. Causes were primarily related either to improper material selection or construction/design deficiencies. Examples of some of these problems include low 28-d concrete compressive strengths; voids under the post-tensioning tendon bearing plates resulting from improper concrete placement; cracking of post-tensioning tendon anchor heads due to stress corrosion or embrittlement; and containment dome delaminations due to low quality aggregate materials and absence of radial steel reinforcement or unbalanced prestressing forces. Other construction-related problems have included occurrence of honeycombed and spalled concrete under equipment hatches, fuel-transfer channels, and other penetrations; contaminated concrete; cold joints; cadweld (steel reinforcement connector) deficiencies; materials out of specification; higher than codeallowable concrete temperatures; misplaced steel reinforcement; post-tensioning system button-head deficiencies; and water-contaminated corrosion inhibitors. As the plants age, incidences of degradation are likely to increase, primarily due to environmental effects. Examples of some of environmental-related problems experienced by NPP reinforced concrete structures include corrosion of steel reinforcement in water intake structures, corrosion of posttensioning tendon wires, leaching of tendon gallery concrete, low prestressing forces, and leakage of corrosion inhibitors from tendon sheaths. Other related problems include cracking and spalling of containment dome concrete due to freeze-thaw damage, cement erosion from containment subfoundations, and cracking and deterioration of masonry-wall joints. Table 2.5 provides a sampling of documented concrete problem areas in nuclear power plants in the U.S. Additional information on the durability of U.S. nuclear power plant reinforced concrete structures is available $(2.14,2.44-2.55)$. Documented information on problem areas experienced with nuclear power plant concrete structures in other countries is also available (2.15). 
Table 2.5 Sampling of documented concrete problem areas in nuclear power plants

\begin{tabular}{|c|c|c|c|}
\hline Plant & Problem Area & Remedial Measure Implemented & Ref. \\
\hline Wolf Creek & $\begin{array}{l}\text { Voids up to } 1.8-\mathrm{m} \text { wide and through the } \\
\text { wall thickness occurred under equipment } \\
\text { and personnel hatches in reactor } \\
\text { containment building. }\end{array}$ & $\begin{array}{l}\text { Voids and quality assurance program } \\
\text { updated }\end{array}$ & 2.45 \\
\hline Callaway 1 & $\begin{array}{l}\text { Nineteen randomly located areas of } \\
\text { honeycomb extending to bottom layers of } \\
\text { rebar of reactor building basemat in } \\
\text { annular area of tendon access area, cause } \\
\text { was use of low-slump concrete in } \\
\text { congested area. }\end{array}$ & $\begin{array}{l}\text { Defective material removed from } 33 \text { of } \\
172 \text { tendon trumplates and voids } \\
\text { repaired }\end{array}$ & 2.45 \\
\hline \multirow[t]{3}{*}{ South Texas 1,2} & $\begin{array}{l}\text { Crack in fuel handling wall due to } \\
\text { shrinkage. }\end{array}$ & No structural significance. & 2.45 \\
\hline & $\begin{array}{l}\text { Rebars improperly located in buttress } \\
\text { region of Unit } 1 \text { containment. }\end{array}$ & $\begin{array}{l}\text { Detailed analysis of as-built condition } \\
\text { determined that no safety hazard to } \\
\text { public occurred. }\end{array}$ & 2.45 \\
\hline & $\begin{array}{l}\text { Voids occurred behind liner plate of Unit } 1 \\
\text { reactor containment building exterior wall } \\
\text { because of planning deficiencies, long } \\
\text { pour times, and several pump breakdowns. }\end{array}$ & $\begin{array}{l}\text { Sounding and fiber optic exam through } \\
\text { holes drilled in liner plate were used to } \\
\text { determine extent, areas were repaired } \\
\text { by grout injection. }\end{array}$ & 2.45 \\
\hline Palo Verde $2 / 3$ & $\begin{array}{l}\text { Honeycombing around vertical tendon } \\
\text { sheaths blockouts with most voids at } \\
\text { buttress/shell interface above last dome } \\
\text { hoop tendon. }\end{array}$ & $\begin{array}{l}\text { Condition was localized so area was } \\
\text { repaired with grout. }\end{array}$ & 2.45 \\
\hline Farley 1 & $\begin{array}{l}\text { Cracks detected in six containment tendon } \\
\text { anchors during refueling outage. } \\
\text { Leaching of concrete walls in tendon } \\
\text { gallery. }\end{array}$ & $\begin{array}{l}\text { Anchorheads replaced. } \\
\text { N.A. }\end{array}$ & $\begin{array}{l}2.45 \\
2.50 \\
2.85\end{array}$ \\
\hline Farley 2 & $\begin{array}{l}\text { Three anchorheads on bottom ends of } \\
\text { vertical tendons failed and } 18 \text { cracked with } \\
\text { several tendon wires fractured, occurred } \\
\text { about } 8 \text { years after tensioning, cause was } \\
\text { attributed to hydrogen stress cracking. }\end{array}$ & $\begin{array}{l}\text { All tendons and anchorheads from } \\
\text { same heat were inspected with no } \\
\text { further problems noted, } 20 \text { tendons } \\
\text { replaced. }\end{array}$ & $\begin{array}{l}2.45 \\
2.50\end{array}$ \\
\hline La Salle 1,2 & Low concrete strength at 90 days. & $\begin{array}{l}\text { In-place strength determined acceptable } \\
\text { from cores, cement contents for future } \\
\text { pours increased, strength low in only a } \\
\text { small percent of pours so did not } \\
\text { threaten structural integrity. }\end{array}$ & 2.45 \\
\hline Brunswick 1,2 & $\begin{array}{l}\text { Voids occurred behind liner during } \\
\text { construction of suppression chamber. }\end{array}$ & $\begin{array}{l}\text { Grout injected into voids through holes } \\
\text { drilled in liner, some grout in Unit } 1 \\
\text { did not harden but was left in place to } \\
\text { provide limited resistance. }\end{array}$ & 2.45 \\
\hline Sequoyah 2 & $\begin{array}{l}\text { Concrete in outer } 2.5 \text { to } 5 \mathrm{~cm} \text { of Unit } 2 \\
\text { shield building was under strength because } \\
\text { of exposure to freezing temperatures at } \\
\text { early concrete age }\end{array}$ & $\begin{array}{l}\text { Determined not to affect shield } \\
\text { building capability. }\end{array}$ & 2.45 \\
\hline Diablo Canyon & Rebar corrosion and concrete cracking & Cathodic protection system & 2.44 \\
\hline San Onofre 1 & $\begin{array}{l}\text { Exterior concrete walls of intake structure } \\
\text { and concrete beams supporting service } \\
\text { water pumps were cracked extensively. }\end{array}$ & N.A. & 2.44 \\
\hline
\end{tabular}


Table 2.5 (cont.) Sampling of documented concrete problem areas in nuclear power plants

\begin{tabular}{|c|c|c|c|}
\hline Plant & Problem Area & Remedial Measure Implemented & Ref. \\
\hline "Beaver Valley 1 & $\begin{array}{l}\text { Void } \sim 0.9-\mathrm{m} \text { long and } 0.9-\mathrm{m} \text { deep in outer } \\
\text { containment wall in concrete ring around } \\
\text { equipment hatch. }\end{array}$ & $\begin{array}{l}\text { No threat to structural integrity, void } \\
\text { repaired with dry pack. }\end{array}$ & 2.45 \\
\hline North Anna & $\begin{array}{l}\text { Cracks }>1.6-\mathrm{mm} \text { wide in containment floor } \\
\text { slab occurred around neutron shield tank } \\
\text { anchor bolts following pressure testing of } \\
\text { seal chambers due to inadvertent } \\
\text { pressurization, cores showed cracks } \\
\text { extended into concrete vertically. } \\
\text { Cracked basemat }\end{array}$ & $\begin{array}{l}\text { Cracks no structural threat, routed and } \\
\text { sealed to prevent fluid penetration. }\end{array}$ & 2.44 \\
\hline San Onofre 3 & $\begin{array}{l}\text { Tendon liftoff forces in excess of } \\
\text { maximum value listed in plant technical } \\
\text { specifications, cause was lower relaxation } \\
\text { rate than expected. }\end{array}$ & No threat to structural integrity. & 2.45 \\
\hline Zion 1 & $\begin{array}{l}\text { Excessive pitting in some tendon wires in } \\
\text { Unit } 2 \text { during installation, cause was } \\
\text { outdoor storage in conjunction with high } \\
\text { precipitation and inadequate protection. }\end{array}$ & Defective tendons replaced. & 2.45 \\
\hline \multirow[t]{2}{*}{ Crystal River 3} & $\begin{array}{l}28 \text {-day concrete strength was low due to } \\
\text { failure of cement to meet specifications. }\end{array}$ & $\begin{array}{l}\text { Design review revealed strength } \\
\text { attained to be adequate, cement } \\
\text { inspection increased. }\end{array}$ & 2.45 \\
\hline & $\begin{array}{l}\text { Dome delaminated over } \sim 32-\mathrm{m} \text { diameter } \\
\text { area due to low concrete properties and no } \\
\text { radial reinforcement to accommodate } \\
\text { radial tension due to post-tensioning. }\end{array}$ & $\begin{array}{l}\text { Upper delaminated section removed, } \\
\text { additional rebars provided, concrete } \\
\text { replaced, dome retensioned, and } \\
\text { structural integrity test conducted. }\end{array}$ & 2.45 \\
\hline Three Mile Is. 1 & $\begin{array}{l}\text { Cracking }<0.02-\mathrm{cm} \text {-wide in containment } \\
\text { building ring girder and around tendon } \\
\text { bearing plates. }\end{array}$ & $\begin{array}{l}\text { Cracks repaired and monitored during } \\
\text { subsequent surveillance. }\end{array}$ & 2.45 \\
\hline Salem 2 & $\begin{array}{l}\text { Incomplete concrete pour near equipment } \\
\text { hatch due to wrong concrete mix. }\end{array}$ & $\begin{array}{l}\text { Voids repaired with high-strength } \\
\text { nonshrink grout. }\end{array}$ & 2.45 \\
\hline \multirow[t]{2}{*}{ Calvert Cliffs 1,2} & $\begin{array}{l}11 \text { of top bearing plates at Units } 1 \& 2 \\
\text { depressed into concrete because of voids, } \\
190 \text { plates of each containment exhibited } \\
\text { voids upon further inspection. }\end{array}$ & $\begin{array}{l}\text { Tendons detensioned, plates grouted, } \\
\text { and tendons retensioned. }\end{array}$ & 2.45 \\
\hline & $\begin{array}{l}\text { Broken tendon wires at top of vertical } \\
\text { tendons. }\end{array}$ & $\begin{array}{l}\text { Approximately one-third of vertical } \\
\text { tendons or each unit replaced. }\end{array}$ & 2.50 \\
\hline Ginna & $\begin{array}{l}\text { Excessive loss of prestressing force due to } \\
\text { higher than estimated tendon relaxation as } \\
\text { a result of high temperatures around } \\
\text { tendons. }\end{array}$ & $\begin{array}{l}\text { Tendons retensioned with no } \\
\text { recurrence noted in subsequent } \\
\text { inspections. }\end{array}$ & $\begin{array}{l}2.44 \\
2.50\end{array}$ \\
\hline Indian Point 2 & $\begin{array}{l}\text { Concrete temperature local to hot } \\
\text { penetration }>66^{\circ} \mathrm{C} \text { but }<93^{\circ} \mathrm{C} \text {. }\end{array}$ & $\begin{array}{l}\text { No safety problem due to relatively } \\
\text { short periods of exposure. }\end{array}$ & 2.45 \\
\hline Grand Gulf 1,2 & $\begin{array}{l}7 \text { of } 19 \text { cylinders for control building base } \\
\text { slab concrete did not meet } 28 \text {-day design } \\
\text { strength. }\end{array}$ & 90-day values were acceptable. & 2.45 \\
\hline Waterford & Cracked basemat. & N.A. & 2.44 \\
\hline Millstone 3 & $\begin{array}{l}\text { Cement erosion of porous concrete } \\
\text { subfoundation. }\end{array}$ & $\begin{array}{l}\text { Surveillance of sumps for cement } \\
\text { erosion, settlement monitoring. }\end{array}$ & 2.51 \\
\hline Pilgrim & Rebar corrosion and concrete cracking. & N.A. & 2.44 \\
\hline
\end{tabular}


Table 2.5 (cont.) Sampling of documented concrete problem areas in nuclear power plants

\begin{tabular}{|c|c|c|c|}
\hline Plant & Problem Area & Remedial Measure Implemented & Ref. \\
\hline \multirow[t]{9}{*}{ Turkey Point 3} & $\begin{array}{l}\text { Voids below containment wall and near } \\
\text { reactor pit. }\end{array}$ & Repaired with high-strength grout. & 2.45 \\
\hline & Dome delamination. & $\begin{array}{l}\text { Delaminated concrete removed, } \\
\text { additional rebars provided, concrete } \\
\text { replaced. }\end{array}$ & 2.45 \\
\hline & $\begin{array}{l}\text { Grease leakage from } 110 \text { of } 832 \text { tendons } \\
\text { at casing. }\end{array}$ & Tendon casing repaired. & 2.45 \\
\hline & $\begin{array}{l}\text { Concrete spalling of horizontal joint at } \\
\text { containment ring girder with cavities } 3 \text { to } \\
5 \text {-cm wide by } 7 \text { to } 10-\mathrm{cm} \text { deep. }\end{array}$ & $\begin{array}{l}\text { No threat to structural integrity, } \\
\text { repaired by drypacking. }\end{array}$ & 2.45 \\
\hline & Small void under equipment hatch barrel. & $\begin{array}{l}\text { No threat to structural integrity, } \\
\text { repaired by grouting. }\end{array}$ & 2.45 \\
\hline & $\begin{array}{l}\text { Water accumulation in Unit } 3 \\
\text { containment vertical tendons. }\end{array}$ & N.A. & 2.44 \\
\hline & $\begin{array}{l}\text { Corrosion of tendon bearing plates in } \\
\text { Unit } 3 \text { containment. }\end{array}$ & N.A. & 2.44 \\
\hline & Active corrosion in intake structure walls. & N.A. & 2.44 \\
\hline & $\begin{array}{l}\text { Excessive loss of prestressing force due } \\
\text { to higher than estimated tendon relaxation } \\
\text { as a result of high temperatures around } \\
\text { tendons. }\end{array}$ & Tendons retensioned. & 2.50 \\
\hline \multirow[t]{3}{*}{ Oconee } & $\begin{array}{l}\text { Spalled concrete beneath anchor bearing } \\
\text { plate along outer edge. }\end{array}$ & Repair concrete spall. & 2.50 \\
\hline & $\begin{array}{l}\text { Tendon grease leakage from several hoop } \\
\text { tendons. }\end{array}$ & Monitor grease quantity. & 2.50 \\
\hline & $\begin{array}{l}\text { Water infiltration and standing water at } \\
\text { several locations. }\end{array}$ & $\begin{array}{l}\text { Tendon galleries purged periodically to } \\
\text { remove excess water. }\end{array}$ & 2.50 \\
\hline Brunswick 1,2 & $\begin{array}{l}\text { Corrosion of drywell liner at junction of } \\
\text { base floor and liner. }\end{array}$ & $\begin{array}{l}\text { Cleaned joints, repaired pitted liner } \\
\text { plate, resealed gap. }\end{array}$ & 2.44 \\
\hline \multirow[t]{4}{*}{ Trojan } & $\begin{array}{l}\text { Grease leakage from vertical cracks in } \\
\text { containment wall }\end{array}$ & Monitored and isolated leaking grease & 2.44 \\
\hline & Water infiltration into tendon gallery & N.A. & 2.44 \\
\hline & $\begin{array}{l}\text { Cracks in concrete wall of auxiliary } \\
\text { building }\end{array}$ & N.A. & 2.44 \\
\hline & $\begin{array}{l}\text { Concrete cracking and leaching in } \\
\text { bioshield wall, auxiliary building, control } \\
\text { building, fuel building, and service water } \\
\text { pump room. }\end{array}$ & N.A. & 2.44 \\
\hline
\end{tabular}


Table 2.5 (cont.) Sampling of documented concrete problem areas in nuclear power plants

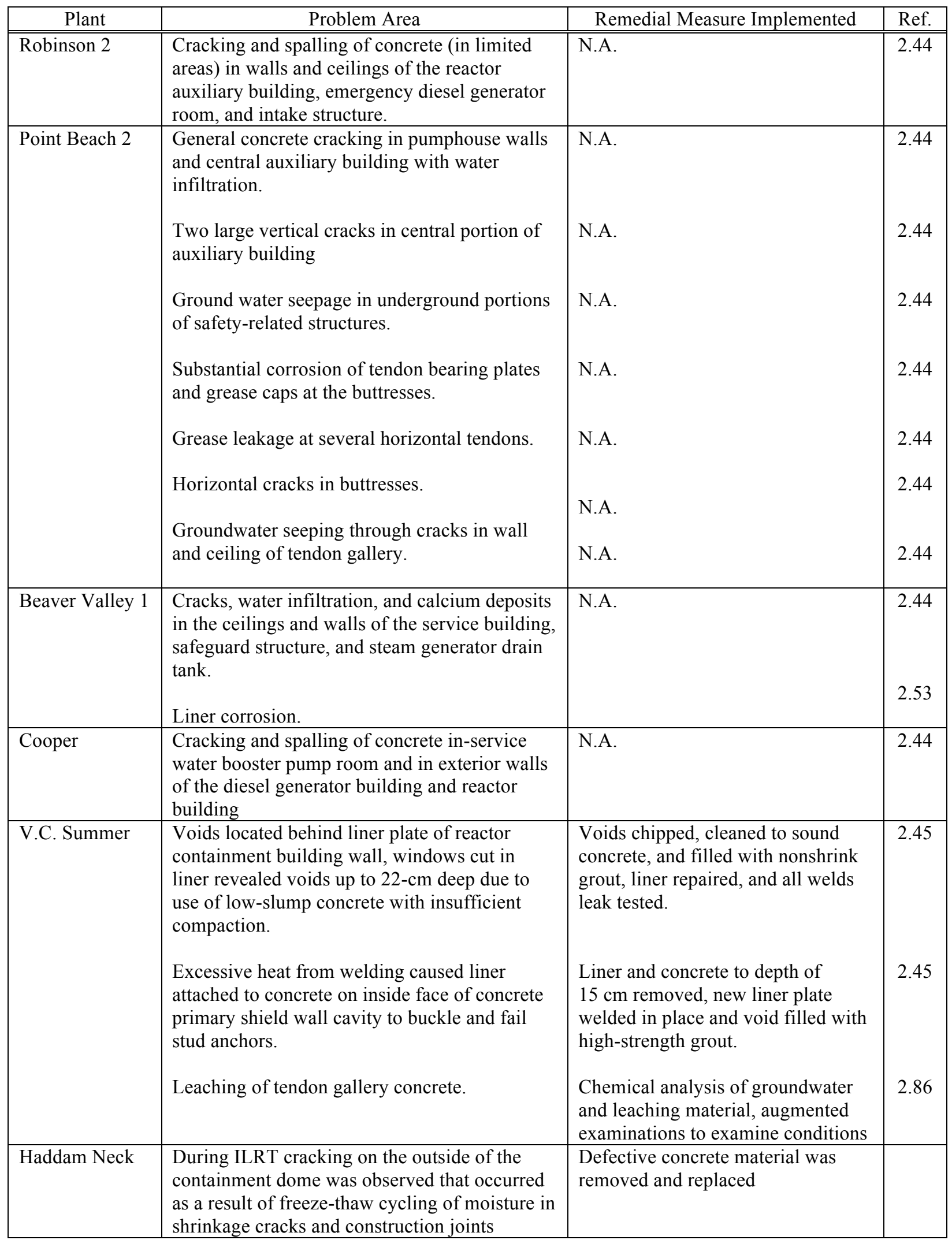


Table 2.5 (cont.) Sampling of documented concrete problem areas in nuclear power plants

\begin{tabular}{|l|l|l|c|}
\hline Fort Saint Vrain & $\begin{array}{l}\text { Tendon wire failures due to corrosion caused } \\
\text { by microbiological attack of corrosion } \\
\text { inhibitor. }\end{array}$ & $\begin{array}{l}\text { Analysis revealed sufficient tendons } \\
\text { intact to provide structural integrity, } \\
\text { surveillance increased and tendons } \\
\text { inerted by nitrogen blanket. }\end{array}$ & 2.45 \\
\hline
\end{tabular}

There also have been a number of occurrences of degradation of steel containments or liners of reinforced concrete containments. In two cases, thickness measurements of the walls of steel containments revealed areas that were below the minimum design thickness. Two instances have been reported where corrosion has completely penetrated the liner of reinforced concrete containments. There have been four additional cases where extensive corrosion of the liner has reduced the thickness locally by nearly one-half. Some specific examples of problems identified include corrosion of the steel containment shell in the drywell sand cushion region, shell corrosion in ice condenser plants, corrosion of the torus of the steel containment shell, coating degradation, and concrete containment liner corrosion. Also there have been incidences of transgranular stress corrosion cracking in bellows. Table 2.6 presents a listing of several reported instances of containment pressure boundary degradation that have been identified at commercial nuclear power plants in the U.S. $(2.44,2.56-2.84)$.

Table 2.6 Examples of instances of containment pressure boundary component degradation at commercial nuclear power plants in the United States

\begin{tabular}{|c|c|c|c|}
\hline $\begin{array}{c}\text { Plant Designation } \\
\text { (Occurrence Date) } \\
\text { Plant Type } \\
\text { (Source)* }\end{array}$ & $\begin{array}{l}\text { Containment } \\
\text { Description }\end{array}$ & $\begin{array}{l}\text { Degradation } \\
\text { Description }\end{array}$ & $\begin{array}{l}\text { Detection } \\
\text { Method }\end{array}$ \\
\hline $\begin{array}{c}\text { Vermont Yankee } \\
(1978) \\
\text { BWR/4 } \\
\text { (Ref. 2.56) }\end{array}$ & $\begin{array}{c}\text { Mark I } \\
\text { Steel drywell } \\
\text { and wetwell }\end{array}$ & $\begin{array}{l}\text { Surface cracks in the overlay } \\
\text { weld-to-torus base metal heat- } \\
\text { affected zone }\end{array}$ & $\begin{array}{l}\text { Visual examination } \\
\text { (As part of modifications to } \\
\text { restore the originally intended } \\
\text { design safety margins) }\end{array}$ \\
\hline $\begin{array}{c}\text { Hatch } 2 \\
(1984) \\
\text { BWR/4 } \\
\text { (Refs. } 2.57-2.59)\end{array}$ & $\begin{array}{c}\text { Mark I } \\
\text { Steel drywell } \\
\text { and wetwell }\end{array}$ & $\begin{array}{l}\text { Through-wall cracks around } \\
\text { containment vent headers within } \\
\text { the containment torus (Brittle } \\
\text { fracture caused by injection of } \\
\text { cold nitrogen into torus during } \\
\text { inerting) }\end{array}$ & $\begin{array}{l}\text { Visual examination of torus } \\
\text { interior }\end{array}$ \\
\hline $\begin{array}{c}\text { Hatch } 1 \\
(1985) \\
\text { BWR/4 } \\
\text { (Ref. 2.59) } \\
\end{array}$ & $\begin{array}{c}\text { Mark I } \\
\text { Steel drywell } \\
\text { and wetwell }\end{array}$ & $\begin{array}{l}\text { Through-wall crack in nitrogen } \\
\text { inerting and purge line (Brittle } \\
\text { fracture caused by injection of } \\
\text { cold nitrogen during inerting) }\end{array}$ & $\begin{array}{l}\text { In-service inspection testing using } \\
\text { magnetic particle method }\end{array}$ \\
\hline $\begin{array}{l}\text { Monticello } \\
\text { (1986) } \\
\text { BWR/3 } \\
\text { (Ref. 2.19) }\end{array}$ & $\begin{array}{c}\text { Mark I } \\
\text { Steel drywell } \\
\text { and wetwell }\end{array}$ & $\begin{array}{l}\text { Polysulfide seal at the concrete- } \\
\text { to-shell interface became brittle } \\
\text { allowing moisture to reach the } \\
\text { steel shell }\end{array}$ & $\begin{array}{l}\text { Visual examination } \\
\text { (A small portion of the drywell } \\
\text { shell was excavated as a part of a } \\
\text { life extension study) }\end{array}$ \\
\hline $\begin{array}{l}\text { Dresden } 3 \\
(1986) \\
\text { BWR/3 } \\
\text { (Ref. 2.60) }\end{array}$ & $\begin{array}{c}\text { Mark I } \\
\text { Steel drywell } \\
\text { and wetwell }\end{array}$ & $\begin{array}{l}\text { Coating degradation due to } \\
\text { exposure to fire with peak metal } \\
\text { temperatures of } 260^{\circ} \mathrm{C}\left(500^{\circ} \mathrm{F}\right) \\
\text { and general corrosion of metal } \\
\text { shell by water used to extinguish } \\
\text { fire }\end{array}$ & $\begin{array}{l}\text { Visual examination } \\
\text { (Polyurethane between the } \\
\text { drywell shell and concrete shield } \\
\text { wall was ignited by arc-air cutting } \\
\text { activities producing smoke and } \\
\text { heat) }\end{array}$ \\
\hline $\begin{array}{c}\text { Oyster Creek } \\
(1986) \\
\text { BWR/2 } \\
\text { (Refs. } 2.61-2.63) \\
\end{array}$ & $\begin{array}{c}\text { Mark I } \\
\text { Steel drywell } \\
\text { and wetwell }\end{array}$ & $\begin{array}{l}\text { Defective gasket at the refueling } \\
\text { pool allowed water to eventually } \\
\text { reach the sand cushion region } \\
\text { causing drywell shell corrosion }\end{array}$ & $\begin{array}{l}\text { Visual examination of uncoated } \\
\text { areas and ultrasonic inspection }\end{array}$ \\
\hline
\end{tabular}


Table 2.6 (cont.) Examples of instances of containment pressure boundary component degradation at commercial nuclear power plants in the United States

\begin{tabular}{|c|c|c|c|}
\hline $\begin{array}{c}\text { Plant Designation } \\
\text { (Occurrence Date) } \\
\text { Plant Type } \\
\text { (Source)* } \\
\end{array}$ & $\begin{array}{l}\text { Containment } \\
\text { Description }\end{array}$ & $\begin{array}{l}\text { Degradation } \\
\text { Description }\end{array}$ & $\begin{array}{l}\text { Detection } \\
\text { Method }\end{array}$ \\
\hline $\begin{array}{c}\text { Fitzpatrick } \\
\text { (1987) } \\
\text { BWR/4 } \\
\text { (Refs. } 2.19 \text { and 2.64) }\end{array}$ & $\begin{array}{c}\text { Mark I } \\
\text { Steel drywell } \\
\text { and wetwell }\end{array}$ & $\begin{array}{l}\text { Degradation of torus coating with } \\
\text { associated pitting }\end{array}$ & $\begin{array}{l}\text { Visual examination of uncoated } \\
\text { areas and ultrasonic inspection } \\
\text { (Technical specification } \\
\text { surveillance performed during } \\
\text { outage) }\end{array}$ \\
\hline $\begin{array}{l}\text { Millstone } 1 \\
\text { (1987) } \\
\text { BWR/3 } \\
\text { (Ref. 2.64) } \\
\end{array}$ & $\begin{array}{c}\text { Mark I } \\
\text { Steel drywell } \\
\text { and wetwell }\end{array}$ & Degradation of torus coating & $\begin{array}{l}\text { Visual examination of uncoated } \\
\text { areas and ultrasonic inspection } \\
\text { (The torus had been drained for } \\
\text { modifications) }\end{array}$ \\
\hline $\begin{array}{c}\text { Oyster Creek } \\
(1987) \\
\text { BWR/2 } \\
\text { (Ref. 2.64) } \\
\end{array}$ & $\begin{array}{c}\text { Mark I } \\
\text { Steel drywell } \\
\text { and wetwell }\end{array}$ & $\begin{array}{l}\text { Degradation of torus coating with } \\
\text { associated pitting }\end{array}$ & $\begin{array}{l}\text { Visual examination of uncoated } \\
\text { areas and ultrasonic inspection }\end{array}$ \\
\hline $\begin{array}{l}\text { D.C. Cook } \\
(2001) \\
\text { PWR } \\
\text { (Ref. 2.84) }\end{array}$ & $\begin{array}{c}\text { Ice Condenser } \\
\text { Reinforced concrete } \\
\text { with liner }\end{array}$ & $\begin{array}{l}\text { Through-wall hole in containment } \\
\text { liner plate with corrosion } \\
\text { initiating on embedded side due to } \\
\text { wire brush handle lodged in } \\
\text { concrete at interface }\end{array}$ & Visual examination \\
\hline $\begin{array}{c}\text { Brunswick } 1 \\
\text { (1987) } \\
\text { BWR/4 } \\
\text { (Ref. 2.65) } \\
\end{array}$ & $\begin{array}{c}\text { Mark I } \\
\text { Reinforced concrete } \\
\text { with steel liner }\end{array}$ & Corrosion of steel liner & $\begin{array}{l}\text { General visual examination of } \\
\text { coated areas }\end{array}$ \\
\hline $\begin{array}{c}\text { Nine Mile Point } 1 \\
\text { (1988) } \\
\text { BWR/5 } \\
\text { (Ref. 2.66) } \\
\end{array}$ & $\begin{array}{c}\text { Mark I } \\
\text { Steel drywell } \\
\text { and wetwell }\end{array}$ & $\begin{array}{l}\text { Corrosion of uncoated torus } \\
\text { surfaces }\end{array}$ & $\begin{array}{l}\text { Visual examination of uncoated } \\
\text { areas and ultrasonic inspection }\end{array}$ \\
\hline $\begin{array}{c}\text { Pilgrim } \\
(1988) \\
\text { BWR/3 } \\
\text { (Ref. } 2.64) \\
\end{array}$ & $\begin{array}{c}\text { Mark I } \\
\text { Steel drywell } \\
\text { and wetwell }\end{array}$ & Degradation of torus coating & $\begin{array}{l}\text { Visual examination of uncoated } \\
\text { areas and ultrasonic inspection } \\
\text { (Licensee inspection as a result of } \\
\text { occurrences at similar plants) }\end{array}$ \\
\hline $\begin{array}{c}\text { Brunswick } 2 \\
\quad(1988) \\
\text { BWR/4 } \\
\text { (Ref. 2.65) } \\
\end{array}$ & $\begin{array}{c}\text { Mark I } \\
\text { Reinforced concrete } \\
\text { with steel liner }\end{array}$ & Corrosion of steel liner & $\begin{array}{l}\text { General visual examination of } \\
\text { coated areas }\end{array}$ \\
\hline $\begin{array}{c}\text { Dresden } 2 \\
(1988) \\
\text { BWR/3 } \\
\text { (Ref. } 2.67)\end{array}$ & $\begin{array}{c}\text { Mark I } \\
\text { Steel drywell } \\
\text { and wetwell }\end{array}$ & $\begin{array}{l}\text { Coating, electrical cable, and } \\
\text { valve operator component } \\
\text { degradation due to excessive } \\
\text { operating temperatures }\end{array}$ & $\begin{array}{l}\text { Visual examination of uncoated } \\
\text { areas and ultrasonic inspection } \\
\text { (Ventilation hatches in the } \\
\text { drywell refueling bulkhead } \\
\text { inadvertently left closed) }\end{array}$ \\
\hline $\begin{array}{l}\text { Hatch } 1 \text { and } 2 \\
\text { (1989) } \\
\text { BWR/4 } \\
\text { (Ref. 2.68) } \\
\end{array}$ & $\begin{array}{c}\text { Mark I } \\
\text { Steel drywell } \\
\text { and wetwell }\end{array}$ & $\begin{array}{l}\text { Bent anchor bolts in torus } \\
\text { supports (due to weld induced } \\
\text { radial shrinkage) }\end{array}$ & Visual examination \\
\hline $\begin{array}{l}\text { McGuire } 2 \\
\text { (1989) } \\
\text { PWR } \\
\text { (Ref. 2.69) } \\
\end{array}$ & $\begin{array}{c}\text { Ice Condenser } \\
\text { Reinforced concrete } \\
\text { with steel liner }\end{array}$ & $\begin{array}{l}\text { Corrosion on outside of steel } \\
\text { cylinder in the annular region at } \\
\text { the intersection with the concrete } \\
\text { floor }\end{array}$ & $\begin{array}{l}\text { General visual examination } \\
\text { prior to Type A leakage-rate test }\end{array}$ \\
\hline
\end{tabular}


Table 2.6 (cont.) Examples of instances of containment pressure boundary component degradation at commercial nuclear power plants in the United States

\begin{tabular}{|c|c|c|c|}
\hline $\begin{array}{l}\text { Plant Designation } \\
\text { (Occurrence Date) } \\
\text { Plant Type } \\
\text { (Source)* }\end{array}$ & $\begin{array}{l}\text { Containment } \\
\text { Description }\end{array}$ & $\begin{array}{l}\text { Degradation } \\
\text { Description }\end{array}$ & $\begin{array}{l}\text { Detection } \\
\text { Method }\end{array}$ \\
\hline $\begin{array}{l}\text { McGuire } 1 \\
\text { (1989) } \\
\text { PWR } \\
\text { (Ref. 2.69) } \\
\end{array}$ & $\begin{array}{c}\text { Ice Condenser } \\
\text { Reinforced concrete } \\
\text { with steel liner }\end{array}$ & $\begin{array}{l}\text { Corrosion on outside of steel } \\
\text { cylinder in the annular region at } \\
\text { the intersection with the concrete } \\
\text { floor }\end{array}$ & $\begin{array}{l}\text { Visual examination (Inspection } \\
\text { initiated as a result of corrosion } \\
\text { detected at McGuire 2) }\end{array}$ \\
\hline $\begin{array}{c}\text { Catawba } 1 \\
(1989) \\
\text { PWR } \\
\text { (Refs. 2.69 and 2.70) } \\
\end{array}$ & $\begin{array}{l}\text { Ice Condenser } \\
\text { Steel cylinder }\end{array}$ & $\begin{array}{l}\text { Corrosion on outside of steel } \\
\text { cylinder in the annular region at } \\
\text { the intersection with the concrete } \\
\text { floor }\end{array}$ & $\begin{array}{l}\text { Visual examination (Inspection } \\
\text { initiated as a result of corrosion } \\
\text { detected at McGuire 2) }\end{array}$ \\
\hline $\begin{array}{l}\text { Catawba } 2 \\
(1989) \\
\text { PWR } \\
\text { (Ref. 2.69) }\end{array}$ & $\begin{array}{l}\text { Ice Condenser } \\
\text { Steel cylinder }\end{array}$ & $\begin{array}{l}\text { Corrosion on outside of steel } \\
\text { cylinder in the annular region at } \\
\text { the intersection with the concrete } \\
\text { floor }\end{array}$ & $\begin{array}{l}\text { Visual examination (Inspection } \\
\text { initiated as a result of corrosion } \\
\text { detected at McGuire 2) }\end{array}$ \\
\hline $\begin{array}{l}\text { D.C. Cook } \\
\text { (1998) } \\
\text { PWR } \\
\text { (Ref. 2.84) } \\
\end{array}$ & $\begin{array}{c}\text { Ice Condenser } \\
\text { Reinforced concrete } \\
\text { with liner }\end{array}$ & $\begin{array}{l}\text { Pitting corrosion of containment } \\
\text { liner at moisture barrier seal }\end{array}$ & Visual examination \\
\hline $\begin{array}{l}\text { Turkey Point } 3 \\
\text { (1992) } \\
\text { PWR } \\
\text { (Ref. 2.44) } \\
\end{array}$ & $\begin{array}{c}\text { Post-tensioned } \\
\text { concrete with liner }\end{array}$ & $\begin{array}{l}\text { Liner coating degraded, corrosion } \\
\text { of some liner seam welds, bulging } \\
\text { of liner at operating deck level } \\
\text { and above polar crane }\end{array}$ & Visual examination \\
\hline $\begin{array}{l}\text { McGuire } 1 \\
\text { (1990) } \\
\text { PWR } \\
\text { (Ref. 2.71) }\end{array}$ & $\begin{array}{c}\text { Ice Condenser } \\
\text { Reinforced concrete } \\
\text { with steel liner }\end{array}$ & $\begin{array}{l}\text { Corrosion on outside of steel } \\
\text { cylinder in the annular region }\end{array}$ & $\begin{array}{l}\text { Visual examination (Follow-up } \\
\text { inspection by licensee) }\end{array}$ \\
\hline $\begin{array}{c}\text { McGuire } 1 \\
\text { (1990) } \\
\text { PWR } \\
\text { (Ref. } 2.71-2.73 \text { ) } \\
\end{array}$ & $\begin{array}{c}\text { Ice Condenser } \\
\text { Reinforced concrete } \\
\text { with steel liner }\end{array}$ & $\begin{array}{l}\text { Corrosion on inside surface of } \\
\text { coated containment shell under } \\
\text { the ice condenser and between the } \\
\text { floors near the cork filler material }\end{array}$ & $\begin{array}{l}\text { Visual examination and ultrasonic } \\
\text { inspection (Degradation possibly } \\
\text { caused by moisture from the ice } \\
\text { condenser or condensation) }\end{array}$ \\
\hline \begin{tabular}{|c|} 
Quad Cities 1 \\
(1991) \\
BWR/3 \\
(Refs. $2.74,2.75$, and \\
2.44 ) \\
\end{tabular} & $\begin{array}{c}\text { Mark I } \\
\text { Steel drywell } \\
\text { and wetwell }\end{array}$ & $\begin{array}{l}\text { Two-ply containment penetration } \\
\text { bellows leaked due to } \\
\text { transgranular stress-corrosion } \\
\text { cracking }\end{array}$ & $\begin{array}{l}\text { Visual examination (Excessive } \\
\text { leakage detected) }\end{array}$ \\
\hline \begin{tabular}{|c|} 
Quad Cities 2 \\
(1991) \\
BWR/3 \\
(Refs. 2.74 and 2.75) \\
\end{tabular} & $\begin{array}{c}\text { Mark I } \\
\text { Steel drywell } \\
\text { and wetwell }\end{array}$ & $\begin{array}{l}\text { Two-ply containment penetration } \\
\text { bellows leaked due to } \\
\text { transgranular stress-corrosion } \\
\text { cracking }\end{array}$ & $\begin{array}{l}\text { Visual examination (Excessive } \\
\text { leakage detected) }\end{array}$ \\
\hline $\begin{array}{l}\text { Dresden } 3 \\
(1991) \\
\text { BWR/3 } \\
\text { (Ref. 2.75) } \\
\end{array}$ & $\begin{array}{c}\text { Mark I } \\
\text { Steel drywell } \\
\text { and wetwell }\end{array}$ & $\begin{array}{l}\text { Two-ply containment penetration } \\
\text { bellows leaked due to } \\
\text { transgranular stress-corrosion } \\
\text { cracking }\end{array}$ & $\begin{array}{l}\text { Visual examination (Excessive } \\
\text { leakage detected) }\end{array}$ \\
\hline $\begin{array}{l}\text { Point Beach } 2 \\
\text { (1992) } \\
\text { PWR } \\
\text { (Ref. 2.44) } \\
\end{array}$ & $\begin{array}{l}\text { Post-tensioned } \\
\text { concrete cylinder } \\
\text { with steel liner }\end{array}$ & $\begin{array}{l}\text { Liner plate separated from } \\
\text { concrete, } 1 / 8 \text { " deep gouge in liner } \\
\text { plate at two locations }\end{array}$ & Visual examination \\
\hline
\end{tabular}


Table 2.6 (cont.) Examples of instances of containment pressure boundary component degradation at commercial nuclear power plants in the United States

\begin{tabular}{|c|c|c|c|}
\hline $\begin{array}{c}\text { Plant Designation } \\
\text { (Occurrence Date) } \\
\text { Plant Type } \\
\text { (Source)* } \\
\end{array}$ & $\begin{array}{l}\text { Containment } \\
\text { Description }\end{array}$ & $\begin{array}{l}\text { Degradation } \\
\text { Description }\end{array}$ & $\begin{array}{l}\text { Detection } \\
\text { Method }\end{array}$ \\
\hline $\begin{array}{c}\text { H. B. Robinson } \\
(1992,1996) \\
\text { PWR } \\
\text { (Ref. 2.44 and 2.84) }\end{array}$ & $\begin{array}{c}\text { Post-tensioned } \\
\text { concrete cylinder } \\
\text { (vertical only) with steel } \\
\text { liner }\end{array}$ & Degradation of liner coating & Visual examination \\
\hline $\begin{array}{c}\text { Cooper } \\
(1992) \\
\text { BWR/4 } \\
\text { (Ref. 2.44) }\end{array}$ & $\begin{array}{c}\text { Mark I } \\
\text { Steel drywell } \\
\text { and wetwell }\end{array}$ & $\begin{array}{l}\text { Corrosion of interior torus } \\
\text { surfaces and corrosion stains on } \\
\text { exterior torus surface in one area }\end{array}$ & Visual examination \\
\hline \begin{tabular}{|c|} 
Beaver Valley 1 \\
(1992) \\
PWR \\
(Refs. 2.44 and 2.76) \\
\end{tabular} & \begin{tabular}{|c|} 
Subatmospheric \\
Reinforced concrete \\
cylinder with steel liner
\end{tabular} & $\begin{array}{l}\text { Corrosion of steel liner, } \\
\text { degradation of liner coating, and } \\
\text { instances of liner bulging }\end{array}$ & $\begin{array}{l}\text { General visual examination prior } \\
\text { to Type A leakage-rate test }\end{array}$ \\
\hline $\begin{array}{c}\text { Salem } 2 \\
(1993) \\
\text { PWR } \\
\text { (Ref. 2.77) } \\
\end{array}$ & $\begin{array}{c}\text { Reinforced concrete } \\
\text { cylinder with steel liner }\end{array}$ & Corrosion of steel liner & $\begin{array}{l}\text { General visual examination prior } \\
\text { to Type A leakage-rate test }\end{array}$ \\
\hline $\begin{array}{c}\text { Dresden } 2 \\
(2001) \\
\text { BWR } 3 \\
\text { (Ref. 2.84) } \\
\end{array}$ & $\begin{array}{c}\text { Mark I } \\
\text { Steel drywell } \\
\text { and wetwell }\end{array}$ & $\begin{array}{l}\text { Missing coating and primer } \\
\text { encircling drywell shell adjacent } \\
\text { to basemat floor }\end{array}$ & Visual examination \\
\hline $\begin{array}{l}\text { Sequoyah } 1 \\
\text { (1993) } \\
\text { PWR } \\
\text { (Ref. 2.78) } \\
\end{array}$ & \begin{tabular}{|c|} 
Ice Condenser \\
Steel cylinder with \\
concrete shield building
\end{tabular} & $\begin{array}{l}\text { Degradation of moisture barriers } \\
\text { resulting in corrosion of the steel } \\
\text { shell }\end{array}$ & $\begin{array}{l}\text { General visual examination and } \\
\text { visual examination of coated } \\
\text { areas }\end{array}$ \\
\hline $\begin{array}{l}\text { Sequoyah } 2 \\
(1993) \\
\text { PWR } \\
\text { (Ref. } 2.78) \\
\end{array}$ & \begin{tabular}{|c|} 
Ice Condenser \\
Steel cylinder with \\
concrete shield building
\end{tabular} & $\begin{array}{l}\text { Degradation of moisture barriers } \\
\text { resulting in corrosion of the steel } \\
\text { shell }\end{array}$ & $\begin{array}{l}\text { General visual examination and } \\
\text { visual examination of coated } \\
\text { areas }\end{array}$ \\
\hline $\begin{array}{c}\text { Brunswick } 2 \\
(1993) \\
\text { BWR } \\
\text { (Refs. 2.65 and 2.79) }\end{array}$ & $\begin{array}{l}\text { Mark I } \\
\text { Reinforced concrete } \\
\text { drywell and wetwell } \\
\text { with steel liner }\end{array}$ & Corrosion of steel liner & $\begin{array}{l}\text { General visual examination and } \\
\text { visual examination of coated } \\
\text { areas (Follow-up inspection } \\
\text { based on conditions noted in } \\
1988 \text { ) }\end{array}$ \\
\hline $\begin{array}{l}\text { Brunswick } 1 \\
\text { (1993) } \\
\text { BWR/4 } \\
\text { (Ref. 2.79) }\end{array}$ & $\begin{array}{c}\text { Mark I } \\
\text { Reinforced concrete } \\
\text { drywell and wetwell } \\
\text { with steel liner }\end{array}$ & Corrosion of steel liner & $\begin{array}{l}\text { General visual examination and } \\
\text { visual examination of coated } \\
\text { areas (Inspection initiated as a } \\
\text { result of corrosion detected } \\
\text { at Brunswick 2) }\end{array}$ \\
\hline $\begin{array}{c}\text { McGuire } 1 \\
\text { (1993) } \\
\text { PWR } \\
\text { (Ref. 2.80) }\end{array}$ & $\begin{array}{l}\text { Ice Condenser } \\
\text { Reinforced concrete } \\
\text { with steel liner }\end{array}$ & $\begin{array}{l}\text { Main steam isolation line } \\
\text { bellows leakage }\end{array}$ & $\begin{array}{l}\text { Leakage testing conducted on } \\
\text { bellows following successful } \\
\text { Type A leakage-rate test }\end{array}$ \\
\hline $\begin{array}{l}\text { Braidwood } 1 \\
\text { (1994) } \\
\text { PWR } \\
\text { (Ref. 2.81) } \\
\end{array}$ & $\begin{array}{c}\text { Post-tensioned } \\
\text { concrete cylinder with } \\
\text { steel liner }\end{array}$ & $\begin{array}{l}\text { Liner leakage detected but not } \\
\text { located }\end{array}$ & Type A leakage-rate test \\
\hline
\end{tabular}


Table 2.6 (cont.) Examples of instances of containment pressure boundary component degradation at commercial nuclear power plants in the United States

\begin{tabular}{|c|c|c|c|}
\hline $\begin{array}{c}\text { Plant Designation } \\
\text { (Occurrence Date) } \\
\text { Plant Type } \\
\text { (Source) }^{*} \\
\end{array}$ & $\begin{array}{l}\text { Containment } \\
\text { Description }\end{array}$ & $\begin{array}{l}\text { Degradation } \\
\text { Description }\end{array}$ & $\begin{array}{l}\text { Detection } \\
\text { Method }\end{array}$ \\
\hline $\begin{array}{l}\text { North Anna } 2 \\
\text { (1999) } \\
\text { PWR } \\
\text { (Ref. 2.82) } \\
\end{array}$ & $\begin{array}{c}\text { Subatmospheric } \\
\text { Reinforced concrete } \\
\text { with steel liner }\end{array}$ & $\begin{array}{l}\text { 6-mm-diameter hole in liner due } \\
\text { to corrosion }\end{array}$ & $\begin{array}{l}\text { General visual examination and } \\
\text { visual examination of coated } \\
\text { areas }\end{array}$ \\
\hline $\begin{array}{l}\text { H.B. Robinson } 2 \\
\text { (1996) } \\
\text { PWR } \\
\text { (Ref. 2.44) }\end{array}$ & $\begin{array}{c}\text { Post-tensioned concrete } \\
\text { with steel liner }\end{array}$ & Liner radial bulging & Visual examination \\
\hline $\begin{array}{c}\text { Brunswick } 2 \\
(1999) \\
\text { BWR/4 } \\
\text { (Ref. } 2.83 \text { and 2.84) }\end{array}$ & $\begin{array}{c}\text { Mark I } \\
\text { Reinforced concrete } \\
\text { drywell and wetwell } \\
\text { with steel liner }\end{array}$ & $\begin{array}{l}\text { Corrosion of liner ranging from } \\
\text { clusters of surface pitting } \\
\text { corrosion to a } 2-\mathrm{mm} \text {-diameter } \\
\text { hole }\end{array}$ & $\begin{array}{l}\text { General visual examination and } \\
\text { visual examination of coated } \\
\text { areas (Inspection initiated as a } \\
\text { result of corrosion detected } \\
\text { at Surry) }\end{array}$ \\
\hline $\begin{array}{c}\text { Surry } 2 \\
(2003) \\
\text { PWR } \\
\text { (Ref. 2.84) }\end{array}$ & \begin{tabular}{|c|} 
Subatmospheric \\
reinforced concrete \\
cylinder with steel liner
\end{tabular} & $\begin{array}{l}\text { Degraded coatings and rust on } \\
\text { containment liner at junction of } \\
\text { metal liner and interior concrete } \\
\text { floor }\end{array}$ & Visual examination \\
\hline $\begin{array}{c}\text { Palisades } \\
\text { (1999) } \\
\text { PWR } \\
\text { (Ref. 2.84) } \\
\end{array}$ & $\begin{array}{c}\text { Post-tensioned concrete } \\
\text { with steel liner }\end{array}$ & $\begin{array}{l}\text { Liner corrosion due to floor-to- } \\
\text { liner moisture barrier not having } \\
\text { been installed }\end{array}$ & Visual examination \\
\hline $\begin{array}{l}\text { Davis Besse } \\
\quad(2002) \\
\text { PWR } \\
\text { (Ref. 2.84) }\end{array}$ & \begin{tabular}{|c|} 
Steel cylinder with \\
concrete shield building
\end{tabular} & $\begin{array}{l}\text { Corrosion where containment } \\
\text { meets floor }\end{array}$ & Visual examination \\
\hline $\begin{array}{l}\text { Sequoyah } 2 \\
(2002) \\
\text { PWR } \\
\text { (Ref. 2.84) } \\
\end{array}$ & \begin{tabular}{|c|} 
Ice condenser steel \\
cylinder with concrete \\
shield building
\end{tabular} & $\begin{array}{l}\text { Deterioration of steel } \\
\text { containment vessel coatings with } \\
\text { rust }\end{array}$ & Visual examination \\
\hline $\begin{array}{c}\text { Trojan } \\
(1991) \\
\text { PWR } \\
\text { (Ref. 2.44) }\end{array}$ & $\begin{array}{c}\text { Post-tensioned concrete } \\
\text { with steel liner }\end{array}$ & $\begin{array}{l}\text { Bulging and ripples in liner plate } \\
\text { at several locations }\end{array}$ & Visual examination \\
\hline
\end{tabular}

\subsection{COMMENTARY}

Safety-related nuclear power plant structures are designed to withstand loadings from a number of low-probability external and internal events. Loads occurring during normal plant operation therefore generally are not significant enough to cause appreciable degradation. Overall the performance of these structures has been very good; however, there have been several isolated incidences that if not remedied could eventually degrade the structural margins. Many of the instances related to degradation occurred early in life and have been corrected. As these structures age, incidences of degradation are likely to increase, primarily due to environmental effects.

Effective in-service condition assessment of the safety-related structures requires knowledge of the expected type of degradation, where it can be expected to occur, and application of appropriate methods for detecting and characterizing the degradation. The ASME Code (2.28) documents the conditions that must be monitored, the inspection techniques adequate to observe those conditions, the frequency of the inspections and the acceptance criteria that the results of the inspections must meet in order to assure the integrity of the safety-related structures. 
The USNRC has incorporated the ASME Code into the regulations in 10 CFR 50.55a. Overall the testing and inspection requirements for these structures have been effective in identifying and addressing potential problem areas in a timely manner. Operating experience, however, indicates that there are two areas with respect to inspection of safety-related structures where additional criteria (or methods) are desirable - inspection of thick, heavily-reinforced concrete structures that in some cases may have limited accessibility due to presence of liners or they may be located below ground, and inaccessible areas of the containment metallic pressure boundary.

Inspection of nuclear power plant concrete structures presents challenges different from conventional civil engineering structures in that wall thicknesses can be in excess of one meter; the structures often have increased steel reinforcement density with more complex detailing; there can be a number of penetrations or cast-in-place items present; and accessibility may be limited due to the presence of liners and other components, harsh environments, or the structures may be located below ground. Noninvasive techniques for characterization, inspection, and monitoring of these structures to provide additional assurances of their continued structural integrity are desirable (e.g., identification of honeycombed areas, voids adjacent to the liner, and embedded items; inspection of thick-section concrete). Current assessments of below-grade concrete structures are based on examinations of representative samples of below-grade concrete when excavated for any reason and monitoring of below-grade water chemistry (including consideration of potential seasonal variations) $(2.28,2.42)$. If the water chemistry indicates that the $\mathrm{pH}>5.5$, chloride ion content is below $500 \mathrm{ppm}$, and sulfates are below 1500 ppm, the environment is considered to be non-aggressive. Methods that can be used to inspect the basemat without the requirement for removal of material and thick-section, heavily-reinforced concrete sections are of particular interest.

Inspection of inaccessible portions of metal pressure boundary components of nuclear power plant containments (e.g., fully embedded or inaccessible containment shell or liner portions, the sand pocket region in Mark I and II drywells, and portions of the shell obscured by obstacles such as platforms or floors) requires special attention. Embedded metal portions of the containment pressure boundary may be subjected to corrosion resulting from groundwater permeation through the concrete; a breakdown of the sealant at the concrete-containment shell interface that permits entry of corrosive fluids from spills, leakage, or condensation; or in areas adjacent to floors where the gap contains a filler material that can retain fluids. Examples of this type of degradation were presented in the previous section. Current assessments of the inaccessible portions of the containment metallic pressure boundary rely on visual inspections (e.g., examination of the moisture barrier at the junction where the containment shell or liner becomes embedded and the concrete to ensure that it is free of penetrating cracks that potentially provide a pathway for water seepage to the surface of the containment metallic pressure boundary $(2.28,2.42)$. Suspect areas that exhibit flaws or evidence of degradation require supplemental evaluation that may involve examination methods or techniques. Often a supplemental evaluation may require excavation of material to provide access for examination and assessment. A method(s) that can be used to inspect the containment metallic pressure boundary at locations such as this to identify corrosion activity or any loss of section that has occurred without the requirement for removal of material is desirable.

\subsection{REFERENCES}

2.1 Code of Federal Regulations, Title 10 - Energy, Office of the Federal Register, National Archives and Records Administration, Washington, D.C., January 1, 2006.

2.2 U.S. Nuclear Regulatory Commission, Seismic Design Classification, Regulatory Guide 1.29 (Rev. 4), Office of Nuclear Regulatory Research, Washington, D.C., March 2007.

2.3 U.S. Nuclear Regulatory Commission, "Concrete and Steel Internal Structures of Steel and Concrete Containments," Sect. 3.8.3 in Regulatory Standard Review Plan, NUREG-0800, Directorate of Licensing, Washington, D.C., 1981.

2.4 S. Smith and F. Gregor, BWR Containments License Renewal Industry Report; Revision 1, EPRI TR-103840, Electric Power Research Institute, Palo Alto, California, July 1994.

2.5 D. Deng, J. Renfro, and J. Statton, PWR Containments License Renewal Industry Report; Revision 1, EPRI TR-103835, Electric Power Research Institute, Palo Alto, California, July 1994. 
2.6 Building Code Requirements for Structural Concrete and Commentary, ACI Standard 318-05/318R-05, ACI Committee 318, American Concrete Institute, Farmington Hills, Michigan, 2005.

2.7 "Containment Integrity of SEP Plants Under Combined Loads," in Proceedings of the ASCE Conference on Structural Engineering in Nuclear Facilities, J. Ucciferro (ed.), American Society of Civil Engineers, New York, New York, 1984.

2.8 U.S. Nuclear Regulatory Commission, "Concrete Containment," Sect. 3.8.1 in Regulatory Standard Review Plan, NUREG-0800, Directorate of Licensing, Washington, D.C., 1981.

2.9 Design Limits, Loading Combinations, Materials, Construction and Testing of Concrete Containments, Regulatory Guide 1.136, Rev. 3, U.S. Nuclear Regulatory Commission, Washington, D.C., March 2007.

2.10 Code Requirements for Nuclear Safety Related Concrete Structures and Commentary, ACI 349-01, American Concrete Institute, Farmington Hills, Michigan, June 2001.

2.11 Safety-Related Concrete Structures for Nuclear Plants (Other than Reactor Vessels and Containments), Regulatory Guide 1.142, Rev. 2, U.S. Nuclear Regulatory Commission, Washington, D.C., November 2002.

2.12 American Society of Mechanical Engineers, "Rules for Construction of Unfired Pressure Vessels," ASME Boiler and Pressure Vessel Code, Sect. VIII, New York, New York, 1965.

2.13 American Society of Mechanical Engineers, "Rules for Construction of Nuclear Power Plant Components," ASME Boiler and Pressure Vessel Code, Sect. III, New York, New York, 2007.

2.14 V.N. Shah, S.K. Smith, and U.P. Sinha, Insights for Aging Management of Light Water Reactor Components, NUREG/CR-5314, (EGG-2562), Vol. 5, Idaho National Engineering Laboratory, Idaho Falls, Idaho, March 1994.

2.15 Assessment and Management of Ageing of Major Nuclear Power Plant Components Important to Safety: Concrete Containment Buildings, IAEA-TECDOC-1025, International Atomic Energy Agency, Vienna, Austria, June 1998.

2.16 D.J. Naus, C.B. Oland and B.R. Ellingwood, Report on Aging of Nuclear Power Plant Concrete Structures, NUREG/CR-6424 (ORNL/TM-13148), Lockheed Martin Energy Research Corporation, Oak Ridge National Laboratory, Oak Ridge, Tennessee, 1996.

2.17 D.J. Naus, Primer on Durability of Nuclear Power Plant Reinforced Concrete Structures -A Review of Pertinent Factors, NUREG/CR-6927 (ORBL/TM-2006/529), Oak Ridge National Laboratory, Oak Ridge, Tennessee, February 2007.

2.18 V.N. Shah and P.E. MacDonald, Eds., Residual Life Assessment of Major Light Water Reactor Components - Overview, NUREG/CR-4731, (EGG-2469) Vol. 1, Idaho National Engineering Laboratory, Idaho Fall, Idaho, June 1987.

2.19 V.N. Shah and P.E. MacDonald, Eds., Residual Life Assessment of Major Light Water Reactor Components - Overview, NUREG/CR-4731, (EGG-2469) Vol. 2, Idaho National Engineering Laboratory, Idaho Fall, Idaho, November 1989.

2.20 D.J. Naus, C.B. Oland, and B.R. Ellingwood, Final Report Inspection of Aged/Degraded Containments Program, ORNL/TM-2005/170, Oak Ridge National Laboratory, Oak Ridge, Tennessee, August 2005.

2.21 Class 1 Structures License Renewal Industry Report, NUMARC 90-06, Nuclear Management and Resources Council, Nuclear Energy Institute, Washington, D.C., June 1990. 
2.22 Monitoring the Effectiveness of Maintenance at Nuclear Power Plants, Regulatory Guide 1.160, Rev. 2, U.S. Nuclear Regulatory Commission, Washington, D.C., March 1997.

2.23 Industry Guideline for Monitoring the Effectiveness of Maintenance at Nuclear Power Plants, NUMARC 93-01, Rev, 2, Nuclear Energy Institute, Washington, D.C., April 1996.

2.24 Primary Reactor Containment Leakage Testing for Water-Cooled Power Reactors, Nuclear Regulatory Commission, Federal Register, Vol. 60, No. 186, pp. 49495-49505, Washington, D.C., September 26, 1995.

2.25 Performance-Based Containment Leak-Test Program, Regulatory Guide 1.163, U.S. Nuclear Regulatory Commission, Washington, D.C., September 1995.

2.26 Industry Guideline for Implementing Performance-Based Option of 10 CFR Part 50, Appendix J, NEI 94-01, Revision 0, Nuclear Energy Institute, Washington, D.C., July 26, 1995.

2.27 Containment System Leakage Testing Requirements, ANSI/ANS-56.8, American Nuclear Society, La Grange Park, Illinois, 2002.

2.28 ASME Boiler and Pressure Vessel Code, American Society of Mechanical Engineers, New York, New York, 2005.

2.29 Masonry Wall Design, Inspection Enforcement Bulletin 80-11, Office of Inspection and Enforcement, U.S. Nuclear Regulatory Commission, Washington, D.C., May 8, 1980.

2.30 Lessons Learned from Regional Inspections of Licensee Actions in Response to IE Bulletin 80-11, Inspection Notification 87-67, Office of Nuclear Reactor Regulation, U.S. Nuclear Regulatory Commission, Washington, D.C., December 31, 1987.

2.31 Inspection of Water-Control Structures Associated With Nuclear Power Plants, Regulatory Guide 1.127, Rev.1, U.S. Nuclear Regulatory Commission, Washington, D.C., March 1978.

2.32 Guide for Making a Condition Survey of Concrete In Service, ACI 201.1R-92, American Concrete Institute, Farmington Hills, Michigan, 1992.

2.33 Evaluation of Existing Nuclear Safety Related Concrete Structures, ACI 349.3R-02, American Concrete Institute, Farmington Hills, Michigan, 2002.

2.34 W.C. Liu, P.T. Kuo, and S.S. Lee, Aging Management of Nuclear Power Plant Containments for License Renewal, NUREG-1611, Division of Reactor Program Management, U.S. Nuclear Regulatory Commission, Washington, D.C., September 1997.

2.35 Maintenance Rule, Inspection Procedure 62706, U.S. Nuclear Regulatory Commission, Washington, D.C., December 13, 2000.

2.36 Inspection of Structures, Passive Components, and Civil Engineering Features at Nuclear Power Plants, Inspection Procedure 62002, U.S. Nuclear Regulatory Commission, Washington, D.C., December 31, 1996.

2.37 Inspection of Steel and Concrete Containment Structures, Inspection Procedure 62003, U.S. Nuclear Regulatory Commission, Washington, D.C., June 11, 1997.

2.38 License Renewal Inspection, Inspection Procedure 71002, U.S. Nuclear Regulatory Commission, Washington, D.C., February 2, 2005. 
2.39 Inservice Inspection, Inspection Procedure 73753, U.S. Nuclear Regulatory Commission, Washington, D.C., June 24, 1998.

2.40 Industry Guidelines for Monitoring the Condition of Structures at Nuclear Power Plants, NEI 96-03, Nuclear Energy Institute, Washington, D.C., July 1996.

2.41 F.E. Gregor and J.J. Carey, COSTAR - Concrete Structures Aging Reference Manual - A Structures Condition Assessment Tool, Paper 1310, Transactions of the 16th International Conference on Structural Mechanics in Reactor Technology, Washington, D.C., August 2001.

2.42 Generic Aging Lessons Learned (GALL) Report, NUREG-1801, Rev. 1, Division of Regulatory Improvement Programs, U.S. Nuclear Regulatory Commission, Washington, D.C., September 2005.

2.43 Standard Review Plan for Review of License Renewal Applications for Nuclear Power Plants, NUREG1800, Rev. 1, Division of Regulatory Improvement Programs, U.S. Nuclear Regulatory Commission, Washington, D.C., September 2005.

2.44 H. Ashar and G. Bagchi, Assessment of Inservice Conditions of Safety-Related Nuclear Plant Structures, NUREG-1522, U.S. Nuclear Regulatory Commission, Washington, D.C., July 1995.

2.45 D.J. Naus, Concrete Component Aging and Its Significance Relative to Life Extension of Nuclear Power Plants, NUREG/CR-4652 (ORNL/TM-10059), Martin Marietta Energy Systems, Inc., Oak Ridge National Laboratory, Oak Ridge, Tennessee, September 1986.

2.46 H. Ashar, D.J. Naus, and C.P. Tan, "Prestressed Concrete in U.S. Nuclear Power Plants (Part 1)," pp. 30-34 in Concrete International 16(5), American Concrete Institute, Farmington Hills, Michigan, May 1994.

2.47 H. Ashar, C.P. Tan, and D.J. Naus, "Prestressed Concrete in U.S. Nuclear Power Plants (Part 2)," pp. 58-61 in Concrete International 16(6), American Concrete Institute, Farmington Hills, Michigan, June 1994.

2.48 H. Ashar and D. Jeng, "Effectiveness of In-Service Inspection Requirements of Prestressed Concrete Containments - U.S. Experience," Proceedings of Second International Conference on Containment Design and Operation, Toronto, Ontario, Canada, October 1990.

2.49 J.I. Braverman, C.A. Miller. B.R. Ellingwood, D.J. Naus, C. H. Hofmayer, S. Shteyngart, and P. Bezler, Probability-Based Evaluation of Degraded Reinforced Concrete Components in Nuclear Power Plants, NUREG/CR-6715, U. S. Nuclear Regulatory Commission, Washington, D.C., March 2001.

2.50 Degradation of Prestressing Tendon Systems in Prestressed Concrete Containments, NRC Information Notice 99-10, Rev. 1, U. S. Nuclear Regulatory Commission, Washington, D.C., October 7, 1999.

2.51 Settlement Monitoring and Inspection of Plant Structures Affected by Degradation of Porous Concrete Subfoundations, NRC Information Notice 98-26, U. S. Nuclear Regulatory Commission, Washington, D.C., July 24, 1998.

2.52 Liner Plate Corrosion in Concrete Containments, NRC Information Notice 97-10, U. S. Nuclear Regulatory Commission, Washington, D.C., March 13, 1997.

2.53 J.I. Braverman, C.H. Hofmayer, R.J. Morante, S. Shteyngart, and P. Bezler, Assessment of Age-Related Degradation of Structures and Passive Components for U.S. Nuclear Power Plants, NUREG/CR-6679, U. S. Nuclear Regulatory Commission, Washington, D.C., August 2000.

2.54 F.E. Gregor and C.J. Hookham, "Remant Life Preservation of LWR Plant Structures," pp. 453-459 in Transactions of the 12th International Conference on Structural Mechanics in Reactor Technology held August 15-20, 1993, in Stuttgart, Germany, Paper DH06/2, Elsevier Science Publishers, Amsterdam, The Netherlands, 1993. 
2.55 P.D. Krauss, Repair Materials and Techniques for Concrete Structures in Nuclear Power Plants, ORNL/NRC/LTR-93/28, Martin Marietta Energy Systems, Inc., Oak Ridge National Laboratory, Oak Ridge, Tennessee, Mary 1994.

2.56 Examination of Mark-1 Containment Torus Welds, U.S. Nuclear Regulatory Commission, Office of Inspection and Enforcement, IE Bulletin 78-11, pp. 1-3, Washington, D.C., July 24, 1978.

2.57 Cracks in Boiling Water Reactor Mark I Containment Vent Headers, U.S. Nuclear Regulatory Commission, Office of Inspection and Enforcement, IE Bulletin No. 84-01, pp. 1-2, Washington, D.C., February 3, 1984.

2.58 Problems with Liquid Nitrogen Cooling Components Below the Nil Ductility Temperature, U.S. Nuclear Regulatory Commission, Office of Inspection and Enforcement, IE Information Notice No. 84-17, pp. 1-2, Washington, D.C., March 5, 1984.

2.59 Cracking in Boiling-Water-Reactor Mark I and Mark II Containments Caused by Failure of the Inerting System, U.S. Nuclear Regulatory Commission, Office of Inspection and Enforcement, IE Information Notice No. 85-99 including Attachment 1, pp. 1-3, Washington, D.C., December 31, 1985.

2.60 Fire in Compressible Material at Dresden Unit 3, U.S. Nuclear Regulatory Commission, Office of Inspection and Enforcement, IE Information Notice No. 86-35, pp. 1-2, Washington, D.C., May 15, 1986,.

2.61 Degradation of Steel Containments, U.S. Nuclear Regulatory Commission, Office of Inspection and Enforcement, IE Information Notice No. 86-99 including Attachment 1, pp. 1-3, Washington, D.C., December 8, 1986.

2.62 Generic Letter 87-05, U.S. Nuclear Regulatory Commission To All Licensees of Operating Reactors, Applicants for Operating Licenses, and Holders of Construction Permits for Boiling Water Reactors (BWRs) with Mark I Containments, Subject: Request for Additional Information-Assessment of Licensee Measures to Mitigate and/or Identify Potential Degradation of Mark I Drywells, pp. 1-8, Washington, D.C., March 12, 1987.

2.63 Docket No. 50-219, Summary of July 24, 1991 Meeting with GPU Nuclear Corporation (GPUN) to Discuss Matters Related to Oyster Creek Drywell Corrosion and Containment Reliability, (Fishe 58722, Frame 320 to Fishe 58723, Frame 039), U.S. Nuclear Regulatory Commission, Washington, D.C., August 2, 1991.

2.64 Survey of Licensees for Torus Coating and Surveillance, letter from J. P. Durr, Chief, Engineering Branch, Region I, U.S. Nuclear Regulatory Commission, to G. Bagchi, Chief, Structural and Geosciences Branch, Office of Nuclear Reactor Regulation, U.S. Nuclear Regulatory Commission, Washington, D.C., May 19, 1988.

2.65 NRC Inspection Report Nos. 50-325/93-02 and 50-324/93-02, Brunswick Units 1 and 2, U.S. Nuclear Regulatory Commission, Region II, Atlanta, Georgia, March 4, 1993.

2.66 Torus Shells with Corrosion and Degraded Coatings in BWR Containments, U.S. Nuclear Regulatory Commission, Office of Inspection and Enforcement, IE Information Notice No. 88-82, pp. 1-2, Washington, D.C., October 14, 1988.

2.67 Heat Damage to Upper Elevation Drywell Components Due to Closed Ventilation Hatches, Dresden Nuclear Station, Unit 2, Licensee Event Report (LER) 88-022-02, Docket No. 50-237, pp. 1-28, Washington, D.C., December 13, 1988.

2.68 Bent Anchor Bolts in Boiling Water Reactor Torus Supports, U.S. Nuclear Regulatory Commission, Office of Inspection and Enforcement, IE Information Notice No. 89-06, pp. 1-2, Washington, D.C., January 24, 1989. 
2.69 Degraded Coatings and Corrosion of Steel Containment Vessels, U.S. Nuclear Regulatory Commission, Office of Nuclear Reactor Regulation, IE Information Notice No. 89-79, pp. 1-3, Washington, D.C., December 1, 1989.

2.70 Abnormal Degradation of Steel Containment Vessels Due to Corrosion Caused by Standing Water in the Annulus Area, Catawba Nuclear Station, Unit 1, Licensee Event Report (LER) 89-020-00, Docket No. 50-413, pp. 1-5, Washington, D.C., January 9, 1990.

2.71 Abnormal Degradation of Steel Containment Vessels Due to Corrosion Caused by Standing Water in the Annulus Area Because of Unknown Causes, McGuire Nuclear Station, Unit 1, Licensee Event Report (LER) 89-020-00, Docket No. 50-369, pp. 1-9, Washington, D.C., September 25, 1989.

2.72 Degraded Coatings and Corrosion of Steel Containment Vessels, U.S. Nuclear Regulatory Commission, Office of Nuclear Reactor Regulation, NRC Information Notice No. 89-79, Supplement 1, pp. 1-2, Washington, D.C., June 29, 1990.

2.73 Corrosion Occurred on the Steel Containment Vessel because of Design Deficiency Caused by Unanticipated Environmental Interactions, McGuire Nuclear Station, Unit 1, Licensee Event Report (LER) 90-006-00, Docket No. 50-369, pp. 1-9, Washington, D.C., May 30, 1990.

2.74 Quad Cities Nuclear Power Station Unit 1 and 2, 10 CFR Part 21 Notification, letter from T. J. Kovach, Nuclear Licensing Manager, Commonwealth Edison, Lisle, Illinois, to A. B. Davis, Regional Administrator, U.S. Nuclear Regulatory Commission, March 27, 1991.

2.75 Quad Cities Nuclear Power Station Unit 1, Primary Containment Penetration Bellows Assembly, letter from R. Stols, Nuclear Licensing Administrator, Commonwealth Edison, Lisle, Illinois, to T. E. Murley, Director, Office of Nuclear Reactor Regulation, U.S. Nuclear Regulatory Commission, Washington, D.C., April 19, 1991.

2.76 Beaver Valley Power Station Trip Report; Assessment of Structures and Civil Engineering Features at Operating Plants; FIN L-1521, Task Assignment No. 6, letter from J. Braverman, Engineering Research and Applications Division, Brookhaven National Laboratory Associated Universities, Inc., Upton, Ney York, to H. Polk, U.S. Nuclear Regulatory Commission, Washington, D.C., July 24, 1992.

2.77 Ninety-Day Containment Integrated Leak Rate Report, Ninth Refueling Outage, Salem Generating Station, Unit No. 1, Docket No. 50-272, letter from S. LaBruna, Vice President Nuclear Operations, Public Service Electric and Gas Company, to Document Control Desk, U.S. Nuclear Regulatory Commission, Washington, D.C., July 3, 1991.

2.78 NRC Inspection Report Nos. 50-327/93-52 and 50-328/93-52, Sequoyah Units 1 and 2, U.S. Nuclear Regulatory Commission, Region II, Atlanta, Georgia, December 23, 1993.

2.79 NRC Inspection Report Nos. 50-325/93-31 and 50-324/93-31, Brunswick Units 1 and 2, U.S. Nuclear Regulatory Commission, Region II, Atlanta, Georgia, September 28, 1993.

2.80 McGuire Nuclear Station, Units 1 and 2, Proposed Technical Specification Change, letter dated, from T. C. McMeekin, Duke Power Company, to Document Control Desk, U.S. Nuclear Regulatory Commission, Washington, D.C., June 23, 1993.

2.81 Integrated Leak Rate Test Report for Braidwood 1, March 4 to April 22, 1994, Commonwealth Edison provided ILRT report to the U.S. Nuclear Regulatory Commission, Washington, D.C.

2.82 Docket No. 50-330, North Anna-2, Virginia Power, Richmond, Virginia, 1999.

2.83 Docket No. 50-324, Brunswick-2, Carolina Power \& Light Co., Raleigh, North Carolina, April, 27, 1999. 
2.84 Corrosion of Steel Containment and Liner, Information Notice 2004-09, U.S. Nuclear Regulatory Commission, Office of Nuclear Reactor Regulation, Washington, D.C., April 27, 2004.

2.85 Inspection Report 50-348/2004-009, 50-364/2004-009, Docket Nos. 50-348 and 50-364, J.M. Farley Nuclear Plant, Birmingham, Alabama, November 15, 2004.

2.86 Inspection Report 50-395/03-08, Docket No. 50-395, V.C. Summer Nuclear Station, Jenkinsville, South Carolina, September 29, 2003. 


\section{REVIEW OF METHODS FOR DETECTION OF DEGRADATION IN NUCLEAR POWER PLANT CONCRETE STRUCTURAL MEMBERS}

Reinforced concrete structures in nuclear power plants are subjected in use to many types of environmental influence that can impact their ability to continue to meet functional and performance requirements. Due to the significant safety as well as economic influences that could result if these structures were to deteriorate to unacceptable performance levels, it is important that they be inspected at regular intervals. As many of the products of concrete degradation manifest themselves as visual indications, the inspections primarily involve a general visual examination of the concrete surfaces. If a suspect area is identified during a visual examination (e.g., cracking or spalling of concrete) or there are indications that the environment adjacent to a concrete structure may be aggressive (e.g., ground water with high chloride ion content adjacent to a basemat) more detailed examinations are required. These examinations in some cases may involve the use of destructive or nondestructive testing, or removal of material adjacent to the structure. As continuing satisfactory performance of a reinforced concrete structure over an extended period of time is dependent in large measure on the durability of its basic components, techniques for detection of degradation should therefore concentrate on these elements (i.e., concrete and reinforcing steel)."

There are a vast variety of test methods available for use in performing inspections of reinforced concrete structures and their materials of construction. Information provided below focuses on methods most commonly used and on those that represent good practice for the detection of degradation of elements used in the construction of reinforced concrete structures. Often the most effective approach to detecting aging effects is to use a combination of testing methods. Additional information to that provided below on concrete, reinforcing steel, foundation elements, and masonry structures is available elsewhere (3.6-3.10).

\subsection{CONCRETE}

Primary manifestations of distress that are present or can occur in concrete used to fabricate NPP reinforced concrete structures include cracking, voids, delaminations, and strength losses.** Methods used to detect discontinuities in concrete structures generally fall into two categories: direct and indirect. Direct methods involve a visual inspection of the structure, removal/testing/analysis of material(s), or a combination of the two. The indirect methods generally measure some parameter from which an estimate of the extent of degradation can be made through existing correlations. Most nondestructive testing methods for concrete are indirect. Quite often, however, evaluation of concrete structures and materials requires use of a combination of test methods since no single testing technique is available that will detect all potential degradation factors. For discussion purposes, testing methods are grouped into categories of nondestructive and destructive or partially destructive testing. Assessments of inaccessible concrete components would be done either through removal of material to expose the component of interest and applying the methods described below, or indirectly through environmental evaluations (i.e., quantification of the aggressiveness of the ambient environment). ${ }^{* *}$

\subsubsection{Nondestructive Testing}

Nondestructive testing (NDT) is a branch of materials science that utilizes noninvasive techniques to determine the integrity of a material, component, or structure, or quantitatively measure some characteristic of an object.

Objectives of NDT are to: (1) determine material properties; (2) detect, characterize, locate, and size

discontinuities/defects; (3) determine the quality of manufacturing or fabrication of a component or structure; and (4) check for deterioration after a period of service for a component or structure (3.11). For purposes of definition, a

\footnotetext{
*Guidelines for development of surveillance programs for post-tensioning system are available (3.1-3.3). As programs developed in compliance with these guidelines are acceptable to the USNRC for providing reasonable assurance (when properly implemented) that the structural integrity of the post-tensioning system is maintained, post-tensioning systems will not be addressed. Information on NDE methods for condition evaluation of postensioning systems is available $(3.4,3.5)$.

** Corrosion of embedded steel reinforcement, which is the primary mode of degradation of concrete structures is addressed in Section 3.2.

*** If the ambient environment is determined to be potentially aggressive, additional testing and evaluation is required that may involve removal of material to expose the component for direct inspection and testing.
} 
flaw is a detectable lack of continuity or a detectable imperfection in a physical or dimensional attribute of the component or structure. A discontinuity can occur as a result of material selection, manufacturing process, handling, geometric configuration, service loads, or environmental conditions.

With respect to application of nondestructive test methods to concrete, they can be used to indicate the strength, density and quality; locate and characterize voids or cracks; locate steel reinforcement and indicate depth of concrete cover; and indicate corrosion of reinforcing materials. Tables $3.1-3.3$ present nondestructive test methods to determine structural properties and assess conditions of concrete, determine material properties of hardened concrete in existing structures, and evaluate concrete repairs.

Table 3.1. Nondestructive test methods to determine structural properties and assess conditions of concrete

\begin{tabular}{|c|c|c|c|}
\hline \multirow[b]{2}{*}{ Property } & \multicolumn{2}{|c|}{ Methods } & \multirow[b]{2}{*}{ Comment } \\
\hline & Primary & Secondary & \\
\hline Reinforcement location & $\begin{array}{l}\text { Covermeter; Ground- } \\
\text { penetrating radar (GPR) } \\
\text { (ASTM D 4748) }\end{array}$ & $\begin{array}{l}\text { X-ray and } \gamma \text {-ray } \\
\text { radiography }\end{array}$ & $\begin{array}{l}\text { Steel location and } \\
\text { distribution; concrete } \\
\text { cover }\end{array}$ \\
\hline $\begin{array}{l}\text { Concrete component } \\
\text { thickness }\end{array}$ & $\begin{array}{l}\text { Impact-echo (I-E); GPR } \\
\text { (ASTM D 4748) }\end{array}$ & Intrusive probing & $\begin{array}{l}\text { Verify thickness of } \\
\text { concrete; provide more } \\
\text { certainty in structural } \\
\text { capacity calculations; I-E } \\
\text { requires knowledge of } \\
\text { wave speed, and GPR of } \\
\text { dielectric constant }\end{array}$ \\
\hline Steel area reduction & $\begin{array}{l}\text { Ultrasonic thickness gage } \\
\text { (requires direct contact } \\
\text { with steel) }\end{array}$ & $\begin{array}{l}\text { Intrusive probing; } \\
\text { radiography }\end{array}$ & $\begin{array}{l}\text { Observe and measure } \\
\text { rust and area reduction in } \\
\text { steel; observe corrosion } \\
\text { of embedded post- } \\
\text { tensioning components; } \\
\text { verify location and extent } \\
\text { of deterioration; provide } \\
\text { more certainty in } \\
\text { structural capacity } \\
\text { calculations }\end{array}$ \\
\hline $\begin{array}{l}\text { Local or global strength } \\
\text { and behavior }\end{array}$ & $\begin{array}{l}\text { Load test, deflection or } \\
\text { strain measurements }\end{array}$ & $\begin{array}{l}\text { Acceleration, strain, and } \\
\text { displacement } \\
\text { measurements }\end{array}$ & $\begin{array}{l}\text { Ascertain acceptability } \\
\text { without repair or } \\
\text { strengthening; determine } \\
\text { accurate load rating }\end{array}$ \\
\hline Corrosion potentials & $\begin{array}{l}\text { Half-cell potential (ASTM } \\
\text { C 876) }\end{array}$ & & $\begin{array}{l}\text { Identification of location } \\
\text { of active reinforcement } \\
\text { corrosion }\end{array}$ \\
\hline Corrosion rate & $\begin{array}{l}\text { Linear polarization } \\
\text { (SHRP-S-324 and S-330) }\end{array}$ & & $\begin{array}{l}\text { Corrosion rate of } \\
\text { embedded steel; rate } \\
\text { influenced by } \\
\text { environmental conditions }\end{array}$ \\
\hline $\begin{array}{l}\text { Location of delaminations, } \\
\text { voids, and other hidden } \\
\text { defects }\end{array}$ & $\begin{array}{l}\text { Impact-echo; Infrared } \\
\text { thermography (ASTM } \\
\text { D 4788); Impulse- } \\
\text { response; Radiography; } \\
\text { GPR }\end{array}$ & $\begin{array}{l}\text { Sounding (ASTM } \\
\text { D 4580); pulse-echo; } \\
\text { SASW; intrusive drilling } \\
\text { and borescope }\end{array}$ & $\begin{array}{l}\text { Assessment of reduced } \\
\text { structural properties; } \\
\text { extent and location of } \\
\text { internal damage and } \\
\text { defects; sounding limited } \\
\text { to shallow delaminations }\end{array}$ \\
\hline
\end{tabular}

Source: ACI Committee 228, Nondestructive Test Methods for Evaluation of Concrete in Structures, ACI 228.2R98, American Concrete Institute, Farmington Hills, Michigan, 1998. 
Table 3.2. Nondestructive test methods for determining material properties of hardened concrete in existing structures

\begin{tabular}{|c|c|c|c|}
\hline \multirow[b]{2}{*}{ Property } & \multicolumn{2}{|c|}{ Possible Methods } & \multirow[b]{2}{*}{ Comment } \\
\hline & Primary & Secondary & \\
\hline Compressive strength & $\begin{array}{l}\text { Cores for compression testing } \\
\text { (ASTM C } 42 \text { and C 39) }\end{array}$ & $\begin{array}{l}\text { Penetration resistance } \\
\text { [ASTM C 803; pullout } \\
\text { testing (drilled-in)] }\end{array}$ & $\begin{array}{l}\text { Strength of in-place concrete; } \\
\text { comparison of strength in different } \\
\text { locations. Drilled-in pullout test not } \\
\text { standardized. }\end{array}$ \\
\hline $\begin{array}{l}\text { Relative compressive } \\
\text { strength }\end{array}$ & $\begin{array}{l}\text { Rebound number (ASTM } \\
\text { C 805); Ultrasonic pulse velocity } \\
\text { (ASTM C 597) }\end{array}$ & & $\begin{array}{l}\text { Rebound number influenced by near } \\
\text { surface properties; Ultrasonic pulse } \\
\text { velocity gives average result } \\
\text { through thickness }\end{array}$ \\
\hline Tensile strength & $\begin{array}{l}\text { Splitting-tensile strength of core } \\
\text { (ASTM C 496) }\end{array}$ & $\begin{array}{l}\text { In-place pulloff test (ACI } \\
\text { 503R; BS 1881, Part 207) }\end{array}$ & Assess tensile strength of concrete \\
\hline Density & $\begin{array}{l}\text { Specific gravity of samples } \\
\text { (ASTM C 642) }\end{array}$ & Nuclear gage & \\
\hline Moisture content & Moisture meters & Nuclear gage & \\
\hline $\begin{array}{l}\text { Static modulus of } \\
\text { elasticity }\end{array}$ & $\begin{array}{l}\text { Compression test of cores } \\
\text { (ASTM C 469) }\end{array}$ & & \\
\hline $\begin{array}{l}\text { Dynamic modulus of } \\
\text { elasticity }\end{array}$ & $\begin{array}{l}\text { Resonant frequency testing of } \\
\text { sawed specimens (ASTM C 215) }\end{array}$ & $\begin{array}{l}\text { Ultrasonic pulse velocity } \\
\text { (ASTM C 597); impact- } \\
\text { echo; spectral analysis of } \\
\text { surface waves (SASW) }\end{array}$ & $\begin{array}{l}\text { Requires knowledge of density and } \\
\text { Poisson's ratio (except ASTM } \\
\text { C 215); dynamic elastic modulus is } \\
\text { typically greater than static elastic } \\
\text { modulus }\end{array}$ \\
\hline Shrinkage/expansion & $\begin{array}{l}\text { Length change of drilled or } \\
\text { sawed specimens (ASTM C 341) }\end{array}$ & & $\begin{array}{l}\text { Measure of incremental potential } \\
\text { length change }\end{array}$ \\
\hline $\begin{array}{l}\text { Resistance to chloride } \\
\text { penetration }\end{array}$ & $\begin{array}{l}\text { 90-day ponding test (AASHTO- } \\
\text { T-259) }\end{array}$ & $\begin{array}{l}\text { Electrical indication of } \\
\text { concrete's ability to resist } \\
\text { chloride ion penetration } \\
\text { (ASTM C 1202) }\end{array}$ & $\begin{array}{l}\text { Establishes relative susceptibility of } \\
\text { concrete to chloride ion intrusion; } \\
\text { assess effectiveness of chemical } \\
\text { sealers, membranes, and overlays }\end{array}$ \\
\hline $\begin{array}{l}\text { Air content; cement } \\
\text { content; and aggregate } \\
\text { properties (scaling, alkali- } \\
\text { aggregate reactivity, } \\
\text { freeze/thaw susceptibility) }\end{array}$ & $\begin{array}{l}\text { Petrographic examination of } \\
\text { concrete samples removed from } \\
\text { structure (ASTM C 856, ASTM } \\
\text { C 457); Cement content (ASTM } \\
\text { C 1084) }\end{array}$ & $\begin{array}{l}\text { Petrographic examination } \\
\text { of aggregates (ASTM C } \\
\text { 294, ASTM C 295) }\end{array}$ & $\begin{array}{l}\text { Assist in determination of cause(s) } \\
\text { of distress; degree of damage; } \\
\text { quality of concrete when originally } \\
\text { cast and current }\end{array}$ \\
\hline Alkali-silica reactivity & $\begin{array}{l}\text { Cornell/SHRP rapid test (SHRP- } \\
\text { C-315) }\end{array}$ & & $\begin{array}{l}\text { Establish in field if observed } \\
\text { deterioration is due to alkali-silica } \\
\text { reactivity }\end{array}$ \\
\hline Carbonation, $\mathrm{pH}$ & $\begin{array}{l}\text { Phenolphthalein (qualitative } \\
\text { indication); } \mathrm{pH} \text { meter }\end{array}$ & $\begin{array}{l}\text { Other } \mathrm{pH} \text { indicators (e.g., } \\
\text { litmus paper) }\end{array}$ & $\begin{array}{l}\text { Assess corrosion potential value of } \\
\text { concrete with depth and } \\
\text { susceptibility of steel reinforcement } \\
\text { to corrosion; depth of carbonation }\end{array}$ \\
\hline Fire damage & $\begin{array}{l}\text { Petrography; rebound number } \\
\text { (ASTM C 805) }\end{array}$ & $\begin{array}{l}\text { SASW; ultrasonic pulse } \\
\text { velocity; impact-echo; } \\
\text { impulse-response }\end{array}$ & $\begin{array}{l}\text { Rebound number permits } \\
\text { demarcation of damaged concrete }\end{array}$ \\
\hline $\begin{array}{l}\text { Freezing and thawing } \\
\text { damage }\end{array}$ & Petrography & SASW; Impulse-response & \\
\hline Chloride ion content & $\begin{array}{l}\text { Acid-soluble (ASTM C 1152) } \\
\text { and water soluble (ASTM } \\
\text { C 1218) }\end{array}$ & $\begin{array}{l}\text { Specific ion probe } \\
\text { (SHRP-S-328) }\end{array}$ & $\begin{array}{l}\text { Chloride ingress increases } \\
\text { susceptibility of steel reinforcement } \\
\text { to corrosion }\end{array}$ \\
\hline Air permeability & $\begin{array}{l}\text { SHRP surface airflow method } \\
\text { (SHRP-S-329) }\end{array}$ & & $\begin{array}{l}\text { Measure in-place permeability } \\
\text { index of the near-surface concrete } \\
(15 \mathrm{~mm})\end{array}$ \\
\hline $\begin{array}{l}\text { Electrical resistance of } \\
\text { concrete }\end{array}$ & $\begin{array}{l}\text { AC resistance using four-probe } \\
\text { resistance meter }\end{array}$ & $\begin{array}{l}\text { SHRP surface resistance } \\
\text { test (SHRP-S-327) }\end{array}$ & $\begin{array}{l}\text { AC resistance useful for evaluating } \\
\text { the effectiveness of admixtures and } \\
\text { cementitious additions; SHRP } \\
\text { method useful for evaluating } \\
\text { effectiveness of sealers }\end{array}$ \\
\hline
\end{tabular}

Source: ACI Committee 228, Nondestructive Test Methods for Evaluation of Concrete in Structures, ACI 228.2R98, American Concrete Institute, Farmington Hills, Michigan, 1998. 
Table 3.3 Nondestructive test methods for evaluating repairs

\begin{tabular}{|l|l|l|l|}
\hline \multirow{2}{*}{ Property/Condition } & \multicolumn{1}{|c|}{ Method } & \multirow{2}{*}{ Comment } \\
\cline { 2 - 3 } & \multicolumn{1}{|c|}{ Primary } & \\
\hline Bond strength & $\begin{array}{l}\text { Pulloff test (ACI 503R); } \\
\text { CAN/CSA A23.2-6B; } \\
\text { BS 1881: Part 207 }\end{array}$ & & \\
\hline $\begin{array}{l}\text { Bond quality (absence of } \\
\text { voids at interface) }\end{array}$ & Pulloff test (as above) & $\begin{array}{l}\text { Impact-echo; SASW; } \\
\text { Impulse-response }\end{array}$ & $\begin{array}{l}\text { SASW good for layered } \\
\text { systems }\end{array}$ \\
\hline $\begin{array}{l}\text { Injection of cracks or } \\
\text { voids }\end{array}$ & $\begin{array}{l}\text { Ultrasonic pulse velocity; } \\
\text { Impact-echo }\end{array}$ & SASW & $\begin{array}{l}\text { Proper geometry required } \\
\text { for reliability of UPV }\end{array}$ \\
\hline
\end{tabular}

Source: ACI Committee 228, Nondestructive Test Methods for Evaluation of Concrete in Structures, ACI 228.2R98, American Concrete Institute, Farmington Hills, Michigan, 1998.

Nondestructive testing techniques are continually evolving and research continues to enhance existing methods as well as develop new methods. Information that follows is intended to provide an overview of techniques commonly used as well as several that are under development.

\subsubsection{Visual Inspection}

Visual inspection generally is the basic method used as a first step in a typical inspection program. Visual testing is performed in accordance with applicable codes, standards, specifications, and procedures (e.g., ASME Section XI Subsection IWL). A high quality visual inspection of exposed concrete surfaces is able to detect and define areas of age-related distress that result in visible effects on the surface of the structure (e.g., cracking, moisture movement, mechanical degradation, spalling, volume change, or cement-aggregate interactions). Five basic elements of a visual test are the test object, the inspector, the optical instrument, illumination, and recording (3.12). Table 3.4 identifies several causes and symptoms that might be observed during a visual inspection of concrete structures (3.13). Visual inspections also include periodic mapping and measurements to provide a history of crack appearance and

Table 3.4 Causes and symptoms of concrete degradation that can be observed during a visual inspection

\begin{tabular}{|l|l|}
\hline \multicolumn{1}{|c|}{ Cause } & \multicolumn{1}{c|}{ Symptoms } \\
\hline \hline Construction faults & Bug holes; cold joints; exposed reinforcing; honeycombing; irregular surface \\
\hline Cracking & $\begin{array}{l}\text { Checkering; crazing; D-cracking; diagonal; hairline; longitudinal; map pattern; } \\
\text { random; vertical; horizontal }\end{array}$ \\
\hline Erosion & Abrasion; cavitation; joint-sealant failure \\
\hline Spalling & Popouts; spall \\
\hline Distortion or movement & Buckling; curling; warping; faulting; settling; tilting \\
\hline Disintegration & Blistering; chalking; delamination; dusting; peeling; scaling; weathering \\
\hline Seepage & Corrosion; discoloration; staining; exudation; efflorescence; incrustation \\
\hline
\end{tabular}

Source: U.S. Army Corps of Engineers, Evaluation and Repair of Concrete Structures - Engineering Manual, EM1110-2-2-2002, Waterways Experiment Station, Vicksburg, Mississippi, 1995.

development that can assist in identifying the cause, and establish whether the crack is active or dormant. Tools that can aid in performing a visual inspection include items such as a field book, clipboards, markers, flashlight, camera, measuring tapes, calipers, optical magnification device, mirror, feeler gages, crack comparator, straight edge, level, pocket knife, wire and paint brushes, screwdriver, pliers, chipping hammer, binoculars, and sounding line. Optical aids such as fiberscopes and borescopes allow inspection of regions that might otherwise be inaccessible to the naked eye. Selection of an optical aid mainly depends on factors such as object geometry and access, expected defect size, and resolution requirements. Also, video cameras provide a means of recording current conditions for future reference. Such a system has been developed for monitoring cooling towers in Belgium (3.14). The monitoring principle is based on results obtained from topographic surveys, inventory of deterioration types, and analysis of the structure's materials. Markers are used as reference points on the outer surface of the cooling tower shell and a long-focal length telescope coupled to a video recording system consisting of a camera and image storage system is used to obtain and record the results. Information (e.g., type and number of defects, classification 
of defects by elevation and orientation, and defect density) is fed into a database that is used to trace defect evolution and generate inspection reports. A video microscope with image acquisition, image display, and image analysis capabilities has been developed for monitoring of cracks in structures (3.15). Figures 3.1 presents an example of a building survey system and Figure 3.2 a video microscope crack monitoring system.

The primary limitation of the visual method is that it cannot reveal internal degradation of the concrete structure when there are no visible symptoms on the surface (e.g., subsurface cracking, voids, and delaminations; and extent of cracking). Broad knowledge in structural engineering, concrete materials, and construction methods is needed in order to extract the most information from the visual inspection. Useful guides are available to help recognize and classify different types of damage as well as the probable cause (3.16-3.20).

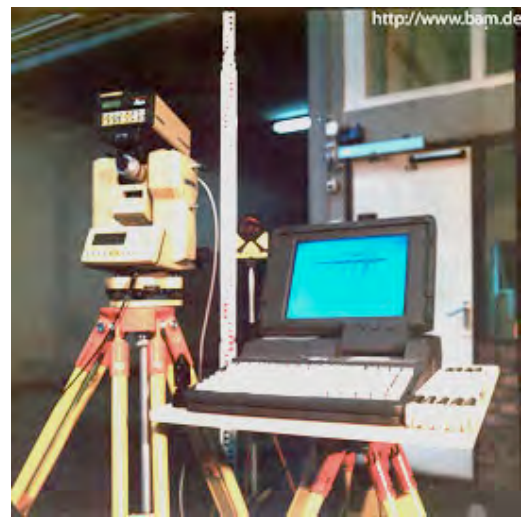

Figure 3.1 Building survey system.

Source: Federal Institute for Materials Research and Testing, Berlin, Germany (http://www.bam.de/en/kompetenzen/fachabteilungen/abteilung 8/).

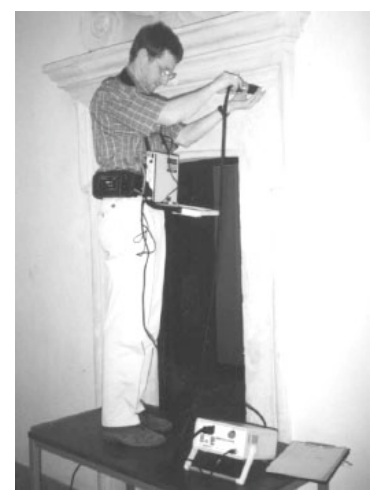

(a) Test setup.

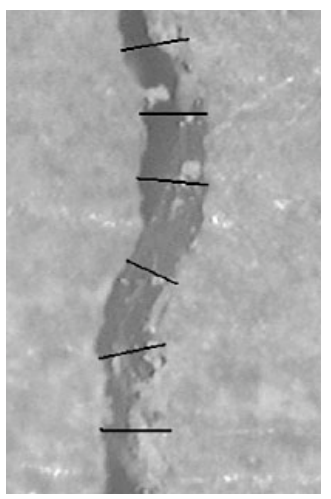

(b) Use of lines of defined length to determine crack width.

Fig. 3.2 Video microscope crack monitoring system.

Source: G. De Schutter, "Advanced Monitoring of Cracked Structures Using Video Microscope and Automated Image Analysis," NDT\&E International 35(4), pp. 209-212, Elsevier Ltd., June 2002.

\subsubsection{Acoustic/Stress Waves}

Acoustic methods are based on elastic wave propagation in solids. Propagation of sound takes place in the form of compression (P) waves, shear (S) waves in the solid, and surface waves or Rayleigh (R) waves along the surface. Stress waves occur when pressure or deformation is suddenly applied to the surface of a material and they are 
propagated in a manner analogous to how sound travels through air. Inhomogeneities in the concrete cause scattering of the sound waves that can be recorded and analyzed. The speed of stress-wave propagation in an elastic solid is a function of the modulus of elasticity, Poisson's ratio, density, and geometry. This dependence is used to infer characteristics about the solid by monitoring wave propagation. Several test methods based on stress-wave propagation can be used for nondestructive testing of concrete structures. Ultrasonic methods can be used for locating discontinuities or abnormalities in concrete structures. The stress-pulse echo methods are useful for flaw detection and thickness determinations, and spectral analysis of surface waves is useful for thickness determinations of layered media.

Ultrasonic pulse velocity methods utilizing ultrasound at a pitch too high to be detected by the human ear are commonly used to examine homogeneous materials such as metals. Ultrasonic pulse velocity equipment for examination of concrete materials is essentially the same as that used for metallic materials except a 30 to $200 \mathrm{kHz}$ transducer is used instead of a 0.1 to $25 \mathrm{MHz}$ transducer because of the greater attenuation characteristics of concrete materials. Basic components of the equipment include a means for producing and introducing repetitive pulses into the material examined, and a means of accurately measuring the time required for the pulse to travel through the material to a receiver. Figure 3.3 presents an example of a portable ultrasonic test system and the application of results to estimate compressive strength. The condition of the material is assessed through

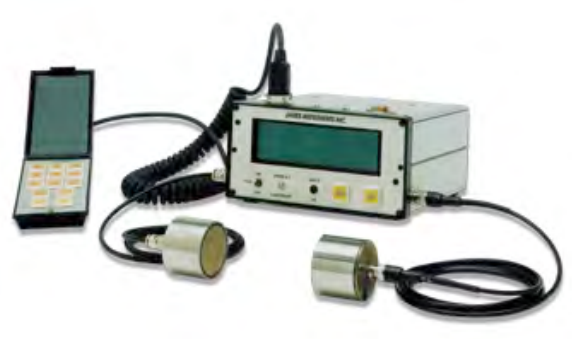

(a) Example of portable UPV test equipment.

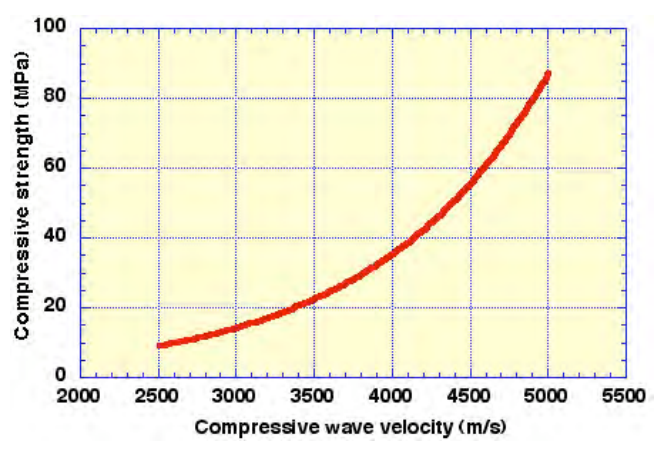

(b) Example of calibration curve relating P-wave velocity to concrete compressive strength.

Fig. 3.3 Ultrasonic pulse velocity (UPV) system and example of calibration curve.

Source: (a) James Instruments, Inc., Skokie, Illinois (http://www.ndtjames.com/catalog/ultrasonicTesting/vMeter.html).

determination of the pulse velocity and the amplitude of the stress wave at the receiver (3.21). When displaying the travel time of the stress waves between the generator and receiver versus the location, there will be a deviation in the curve at the position of the subsurface defect. For detecting internal structural changes, the method is limited by segregation/inhomogeneity of the concrete and quality of the acoustical contact. Transmission of ultrasonic waves into the concrete directly influences the image quality in many respects such as signal-to-noise ratio and resolution. Coupling to fill the space between the transducer and concrete is typically provided by viscous agents or water. Recently, broadband ultrasonic electrostatic transducers that can accurately emit chirps defined by signal generators rather than being confined to resonant narrowband signals (e.g., piezoelectric transducers) have been designed to operate in air (3.22). Aggregate, pores, defects, and steel reinforcement have acoustical properties much different from those of the cement matrix that gives rise to scattering and mode conversion of propagating ultrasonic waves. By using ultrasonic pulse velocity it is possible to determine the concrete dynamic modulus of elasticity, Poisson's ratio, thickness, and estimate in situ compressive strength. The method also can be used to detect concrete internal structure changes, cracking or voids, and changes due to freezing and thawing or other aggressive environments. For strength and related properties, the test must be calibrated to the specific concrete as the results are influenced by aggregate size, type, and gradation; cement type; water-cementitious materials ratio; admixtures; degree of compaction; curing conditions and age of the concrete; acoustical contact; concrete temperature; moisture content; size and shape of specimen; and presence of reinforcement. Despite the dependence on so many variables, the ultrasonic pulse velocity method can be used effectively. It is most useful when carrying out comparative surveys of 
concrete quality in or between similar concrete structures. Changes in signal amplitude or attenuation characteristics can be used to indicate changes in material properties that occur with time (e.g., detection of the action of frost or alkali-silica reactions through measurement of frequency-dependent attenuation of direct transmission ultrasonic pulses). Accuracy of concrete compressive strength estimates at the $95 \%$ confidence limits using ultrasonic pulse velocity is on the order of $\pm 20 \%$ with a coefficient of variation of $2.5 \%$ (3.10)

The pulse-echo method is the acoustic method most similar to conventional ultrasonic testing such as used for examining metallic materials. Ultrasonic pulse echo is based on the propagation and reflection of mechanical waves that are generated at the concrete surface by an array of transducers that resonate horizontally. It involves the use of transmitting and receiving transducers that are normally placed close to each other on the testing surface or the transmitter also may be designed as a receiver. This method thus overcomes the drawback of the ultrasonic pulse velocity methods that require access to both surfaces. The pulsed signal input may be produced by a piezoelectric transducer or surface impacts may be utilized. The pulse propagates into the test object and is reflected by flaws or interfaces. The echo signals are analyzed and their transmission times may be converted to velocities if the wave speed is known. In this way it is possible to measure the depth to reflectors (e.g., cracks or large voids). Because of the heterogeneity of concrete, it may be difficult to distinguish actual defects. Large aggregates have a significant scattering affect on the signals thus restricting the method to relatively low frequency inputs. Modern pulse-echo equipment has achieved some success in this respect by using "arrays" of transducers. Ultrasonic arrays offer two key advantages over standard monolithic transducers: (1) a particular array is able to undertake a range of different inspections from a single location and (2) most types of array can be used to produce images at each test location permitting rapid visualization of the internal structure of a component (3.23). Phased arrays consist of collections of similar transducers that are fed by a set of pulsars that can fire an impulse or a predefined signal with an appropriate delay and amplitude to reach a desired beam direction (3.24). Electronic scans are performed by multiplexing along an array. Signals transmitted and received between combinations of transducers and with the response averaged makes it possible to more clearly define relevant reflectors. The pulse-echo method has the potential to locate and identify discrete defects or objects if sufficient focusing is achieved by the transducers. The synthetic aperture focusing technique utilizes information content from many single measurements to suppress noise and improve image location capability and measurement accuracy (3.25,3.26). Also, dry point contact transducers can input longitudinal and shear waves into the concrete while enabling some of the problems associated with coupling to be overcome (i.e., the size of the acoustical contact zone of the oscillating probe surface with the surface of the test object is many times smaller than the wavelength of the ultrasound wave) $(3.25,3.27)$. Figure 3.4 shows an ultrasonic pulse echo unit with spring-loaded dry-contact transducers and results of concrete thickness

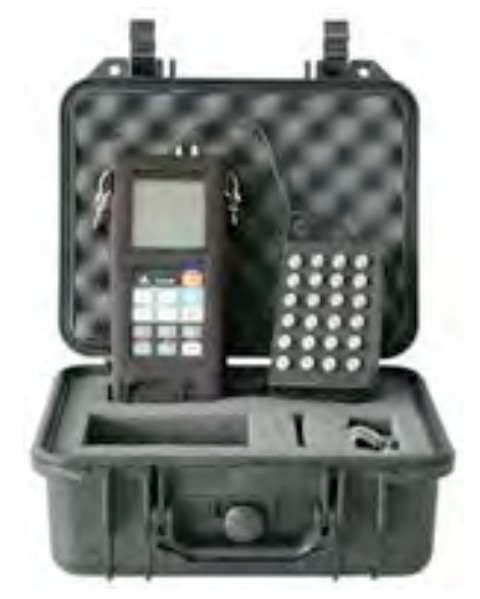

(a) Ultrasonic pulse echo unit employing an array of dry-contact transducers.

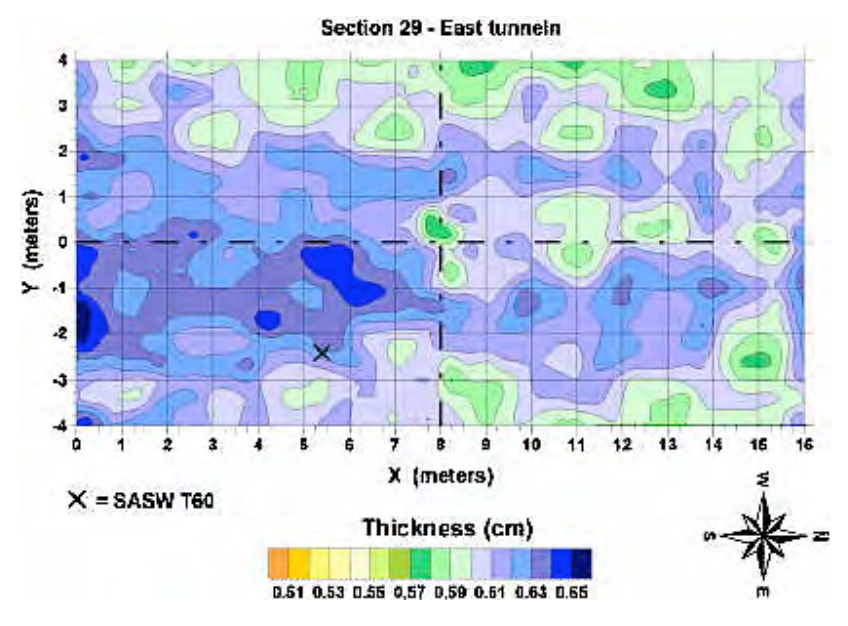

(b) C-scan showing thickness of concrete tunnel wall.

Fig. 3.4 Ultrasonic pulse echo unit with spring-loaded dry-contact transducers and its application.

Source: A. Kovalev, "Ultrasonic Testing of Concrete Structures," Proceedings of $8^{\text {th }}$ European Conference on Non-Destructive Testing, Barcelona, Spain, June 2002. 
measurements of a tunnel wall (3.28). Figure 3.5 illustrates identification of honeycombed concrete located below steel reinforcement after synthetic aperture focusing technique (SAFT) reconstruction of data obtained from an ultrasonic array (3.29). The ultrasonic pulse-echo method can be used for thicknesses up to 1000 to $1200 \mathrm{~mm}$ if the maximum size aggregate is $16 \mathrm{~mm}$ or less (3.30).

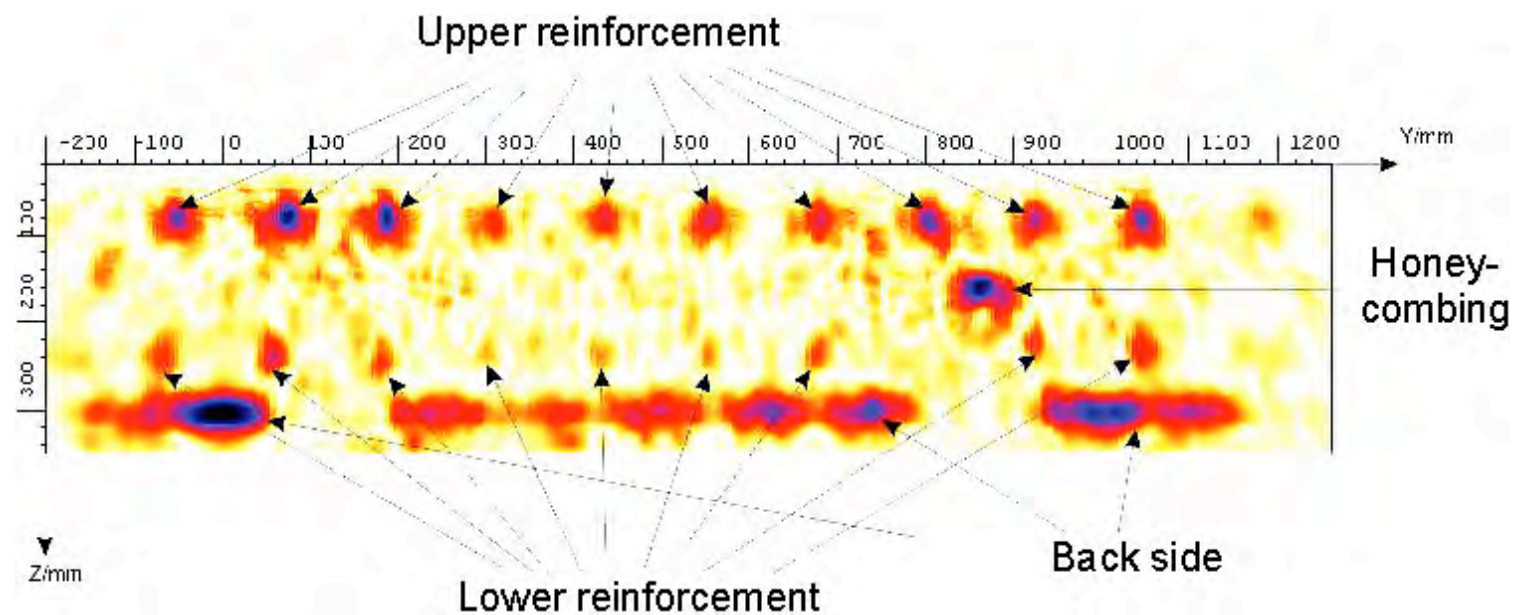

Figure 3.5 Pulse-echo results showing concrete honeycomb below steel reinforcement.

Source: C. Maierhofer, M. Krause, E. Niederleithinger, and H. Wiggenhauser, "Non-Destructive Testing Methods at BAM for Damage Assessment and Quality Assurance in Civil Engineering," International Symposium on Non-Destructive Testing in Civil Engineering 2003, (NDT-CE-2003), Bundesanstalt für Materialforschung und -prüfung, Berlin, Germany, 2003.

The impact-echo method is a send-receive nondestructive test method based on the use of short-duration mechanical impact. An impact-echo test system is composed of three components: an impact source; a receiving transducer; and a digital processing oscilloscope or waveform analyzer that is used to capture the transient output of the transducer, store the digitized waveforms, and perform signal analysis (3.31). A transient stress pulse is introduced into the concrete by mechanical impact of the surface and propagates into the concrete along spherical wave fronts as $\mathrm{P}$ - and $\mathrm{S}$-waves. In a true pulse-echo mode the transmitter and receiver are one transducer, however, there are technical problems associated with this setup relative to development of a suitable transducer for concrete. Current applications primarily place the impact source and receiving transducer adjacent to each other on the concrete surface (pitch-catch method). Some control of the input can be achieved by varying the size of the impactor thus determining the frequency of the input signals (i.e., smaller diameter impactors create higher frequency waves that are more sensitive to small reflectors at shallower depths, and vice versa). The sound pulse or compression wave is reflected from the backside of the concrete element, internal reflectors (e.g., cracks), or from other objects that may cause changes in the acoustic impedance and material density along the path of pulse propagation. Figure 3.6 presents the impact-echo principle. Information is obtained related to the complete, or a significant volume of the concrete (i.e., the signal can not be focused as with the ultrasonic pulse-echo method). In this respect it can be seen as a global measuring technique that may be an advantage, but it also might complicate the process of interpretation. Testing normally involves a study of the compression wave only and frequencies usually are below the ultrasonic level. Both time-domain and frequency-domain analyses are used to identify the transient resonance conditions resulting from multiple reflections of waves between impact surfaces, defects, and/or other external surfaces that can be used to determine the locations of defects or member thickness (3.32). The response signal is analyzed in the frequency domain using a Fast Fourier Transform technique. Reflections or echoes are indicated by frequency peaks in the resultant spectral plots that are used to locate discontinuities. Although in principle the impact-echo technique may be used for thicknesses up to several meters, it normally is used in concrete structures up to about one meter in section. Applications of the method include determining the thickness and detecting flaws in plate-like structural members; detecting flaws in beams, columns, and hollow cylindrical structural members; assessing the quality of bond in overlays; crack-depth measurements; and detecting the degree of grouting in post-tensioning ducts. Impact echo is most effectively used for testing large concrete areas and if the geometry of the structure is 
quite simple, the analysis procedure is also relatively simple. Since the signal input is by mechanical impact, the testing can be carried out quickly without the need for a coupling medium. A non-contact form of the impact-echo method for defect detection in concrete has been developed that utilizes a compressed air shock tube to produce the

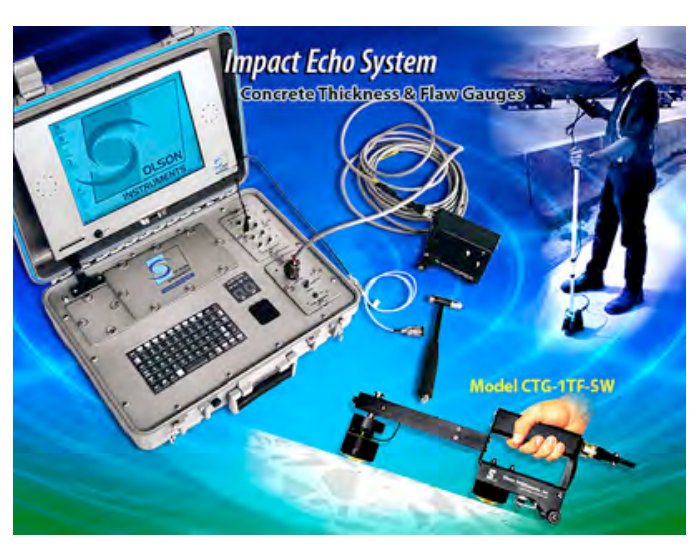

(a) Impact echo equipment.
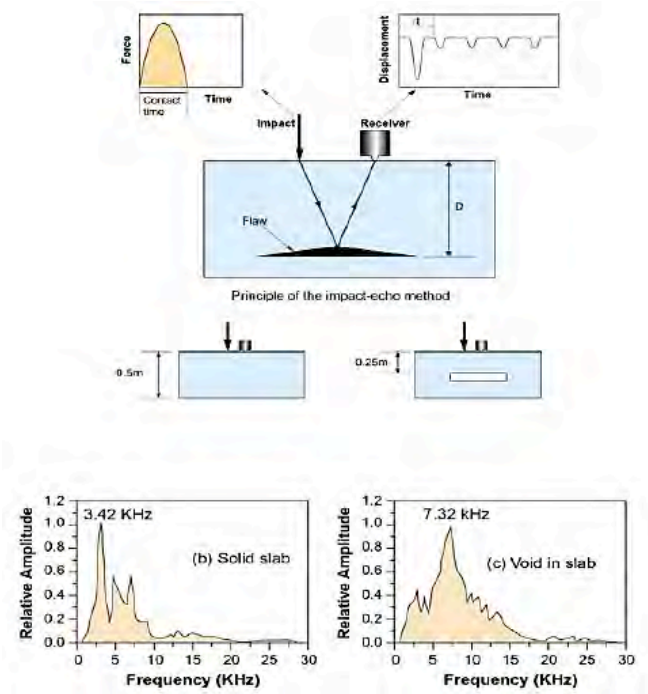

(b) Principle of operation

Figure 3.6 Impact-echo equipment and operation principle.

Source: (a) Olson Instruments, Wheat Ridge, Colorado (http://www.olsoninstruments.com).

(b) P.K. Mehta and P. Monteiro, Concrete - Microstructure, Properties, and Materials, $3^{\text {rd }}$ Edition, McGraw Hill Companies, Inc., New York, New York, 2006.

transient stress pulses and a laser vibrometer to measure concrete surface velocity (3.33). Figure 3.7 presents a schematic of the method. Lasers can also be utilized to introduce sound waves into concrete (3.34). The procedure for measuring the thickness of concrete plates using the impact-echo method has been standardized (3.35).

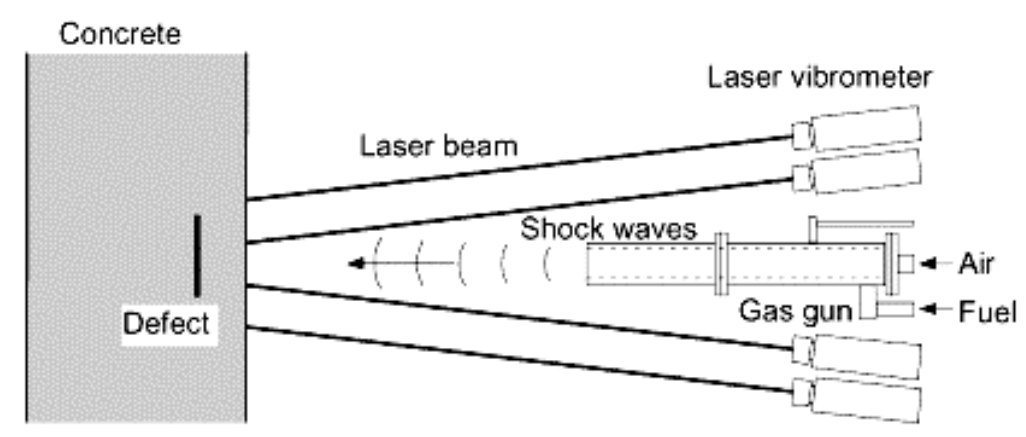

Figure 3.7 Schematic of non-contact method for defect detection in concrete.

Source: K. Mori, A. Spagnoli, Y. Murakami, G. Kondo, and I. Torigoe, "A New Non-Contacting Non-Destructive Testing Method for Defect Detection in Concrete," NDT\&E 35(6), pp. 399-406, Elsevier Ltd., September 2002.

Tomographic imaging algorithms can be used in conjunction with ultrasonic pulse velocity testing to reconstruct an image of the inclusions or inhomogeneities in the concrete. Acoustic tomography is an advanced nondestructive examination method, based on the same approach as used for X-ray computerized tomography, that is used to examine concrete structures for cracks, voids, and other internal defects (3.36-3.38). The collection of data consists 
of propagating mechanical waves through the surveyed plane section from different source locations to different receiver positions. During the propagation between sources and receivers, mechanical waves interact with the material. Local variations in the elastic properties of the material result in corresponding variations in the characteristics of received signals. Information from stress wave transmissions is used to reconstruct a map of velocities on a slice through the interior of a body. Results are analyzed with sophisticated computer software that has been developed especially for this application. Defects usually observed in concrete (e.g., microcracks, honeycomb, and voids) generally have a greater effect on the concrete modulus than on the density and the Poisson's ratio (3.39). Thus the variations of velocity give a useful and indirect measurement of the variations of the dynamic modulus over the concrete mass. The advantage of this method over radiography is that it provides the possibility of internal inspections through development of three-dimensional displays from a series of reconstructed digitized detector measurements obtained from planes or slices through the thickness of the object inspected. The primary limitations of this method are that if a complete examination is not possible because of geometrical boundary conditions, additional calculations must be made for those areas, and the method is presently costly to perform. Figure 3.8 illustrates the application of acoustic travel time tomography to detect cracks in a dam structure.

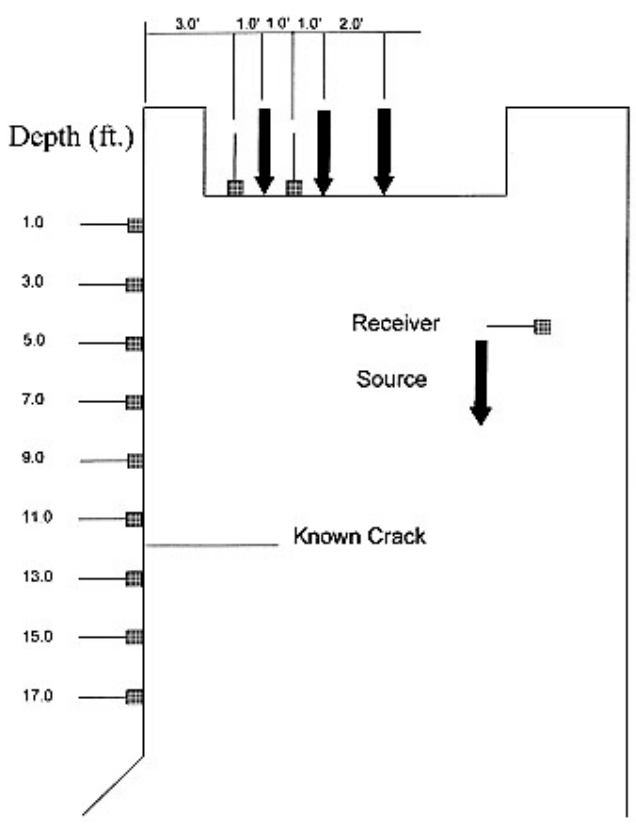

(a) Dam cross-section.

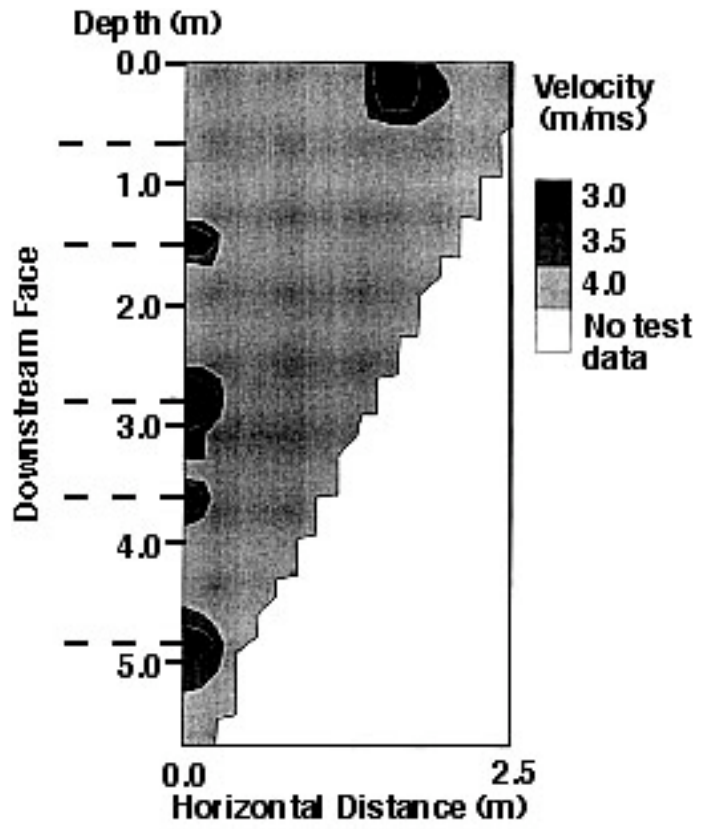

(b) Tomograph of dam (five dashed lines indicate known crack locations).

Fig. 3.8 Illustration of acoustic travel time tomography.

Source: F. Kepler, L.J. Bond, and D.M. Frangopol, "Improved Assessment of Mass Concrete Dams Using Acoustic Travel Time Tomography. Part I I- Application,” Construction and Building Materials 14, pp. 147-156, Elsevier Publishers, New York, 2000.

The impulse-response method is a descendent of the forced vibration method for evaluating the integrity of concrete cast-in-place bored piles (3.40). Global structural health monitoring techniques such as this are based on either finding shifts in resonant frequency or changes in structural mode shapes. Impulse-response uses low-strain impact to send a stress wave through the tested element. The impactor is usually a sledgehammer (approximately $1 \mathrm{~kg}$ ) with a load cell built into the hammerhead and linked to a computer. The compressive stress at the point of concrete impact is related to the elastic properties of the hammer tip. Typical peak stress levels range from $5 \mathrm{MPa}$ (hardrubber tip) to more than $50 \mathrm{MPa}$ (aluminum tip). The impulse-response test generates a compressive wave that is approximately 100 times that of the impact-echo test resulting in a plate responding in a bending mode over a much lower frequency range. Response to the input stress is measured by a velocity transducer (geophone) that is connected to the computer. A Fast-Fourier Transform algorithm is used to process the signal in which the resulting 
velocity spectrum is divided by the force spectrum to obtain a transfer function (i.e., mobility). A graph of mobility plotted against frequency contains information on the condition and integrity of the structure under test based on measured parameters - dynamic stiffness, mobility and damping, and peak/mean mobility. The dynamic stiffness is used to determine the concrete quality, element thickness, and element support conditions. Mobility and damping can indicate surface unbonding and presence of any honeycomb or cracking. The peak/mean mobility ratio is an indicator of the presence and degree of either unbonding within the element or voiding/loss of support beneath a slab on grade. The detection of voids or poorly compacted areas behind or below plate-like structures is one application of this method (3.41). Figure 3.9 presents the impulse-response test setup and a comparison of results between sound and delaminated slabs. Applications of impulse-response to evaluate concrete tunnel-liner thickness is also presented in the figure. More detailed information on the general topic of global structural health monitoring techniques is available (3.42). It is noted in this reference that these methods tend to be effective as the damage level increases and developments are needed in several areas: (1) advanced sensing systems with improved and optimized placement of networkable sensors, (2) tetherless sensors and data transmission systems, (3) advanced signal processing techniques to increase signal-to-noise ratio, (4) damage model development, and (5) software and hardware integration.

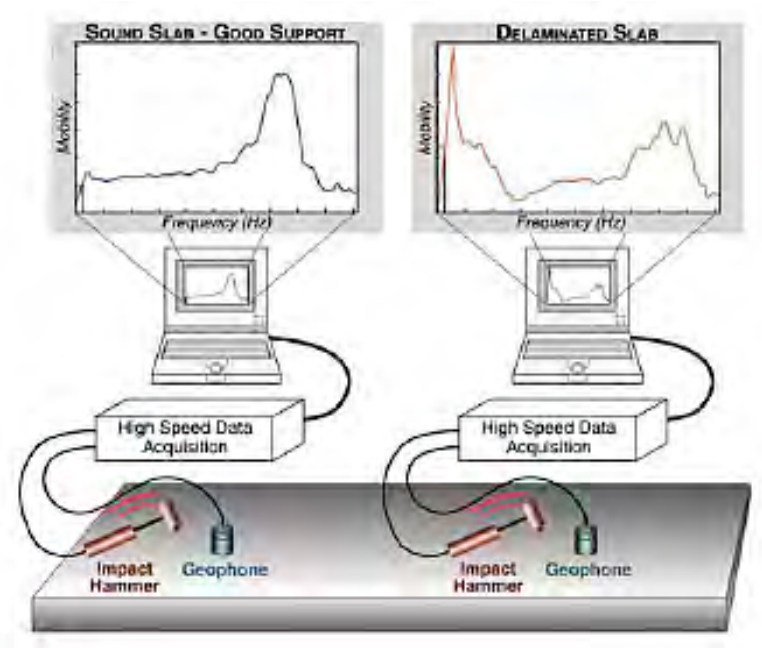

(a) Test setup

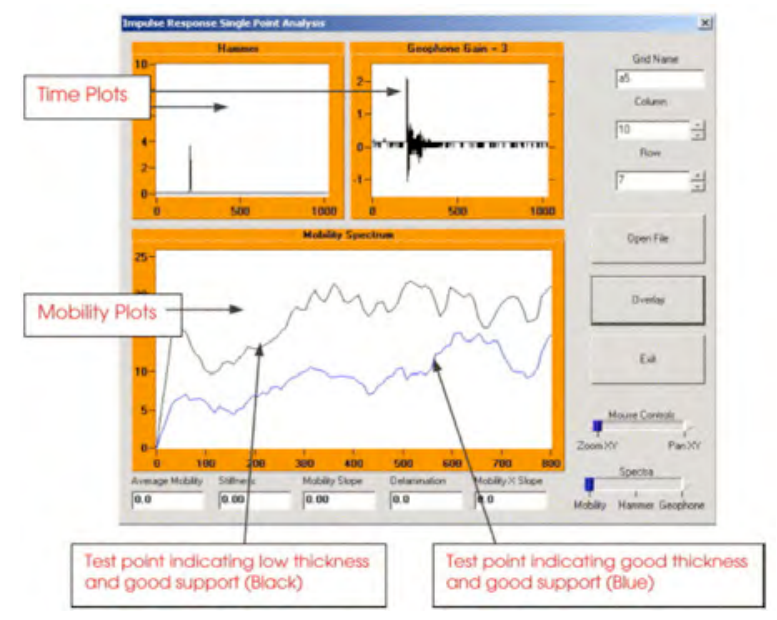

(b) Application to tunnel liner.

Figure 3.9 Impulse-response test setup and example results.

Source: (a) "Impulse-Response Testing," CTL Group, Construction Technology Laboratory, Skokie, Illinois, 2007.

(b) A. G. Davis, M.K. Lim, and C.G. Petersen, "Rapid and Economical Evaluation of Concrete Tunnel Linings with Impulse Response and Impulse Radar Non-Destructive Methods," NDT\&E International 38(3), pp. 181-186, Elsevier Ltd., April 2005.

Spectral analysis of surface waves (SASW) has found use in testing concrete and in geophysical surveys. It requires accessibility to one surface. A mechanical impact on the surface of the concrete structure is used to generate surface waves of different wavelengths that are picked up by transducers placed at fixed distances from the impact source and the velocity of each wavelength component evaluated. The transducers are placed in line with the impact source and their spacing is determined by the depth to be measured. In the case of a massive concrete element this may require access to a large surface area. The technique uses dispersion of surface waves to produce a surface wave velocity cross-section of the subsurface. The velocity of the Rayleigh wave is related to the shear modulus (stiffness) and density of the material. The velocities of different wavelengths can be determined by calculating the phase difference between two receivers for each wavelength generated (3.43). The shear wave velocity profiles are determined from the experimental dispersion curves (surface wave velocity versus wavelength) obtained from the SASW measurements. Once the shear wave velocity profiles are determined, shear and Young's moduli of the materials can be calculated. The depth to which the surface waves are affected by the material is dependent on the wave frequency, with lower frequency waves affected by material stiffness at greater depths. The method is particularly well suited for testing large surfaces, layered systems, condition assessments of liners of concrete tunnels, mapping of subsurface cavities, and for determining the depths of foundations or the condition of underlying material. SASW measurements are accurate to within 5\% for determination of the thickness and 
stiffness of the top layer of a pavement system, or liner thickness (3.44). Figure 3.10 provides a schematic of the basic test setup and the use of wavelength to investigate different depths of a layered system.

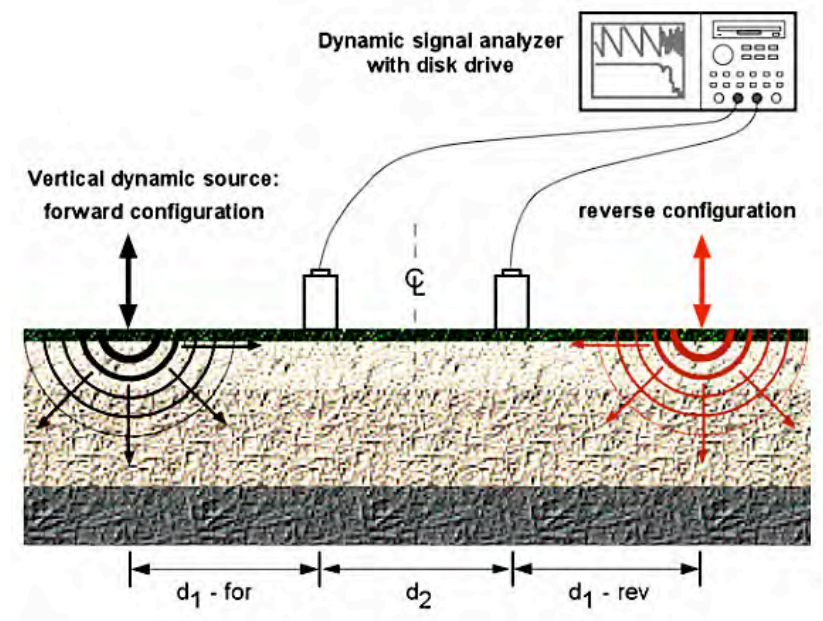

(a) Test setup.

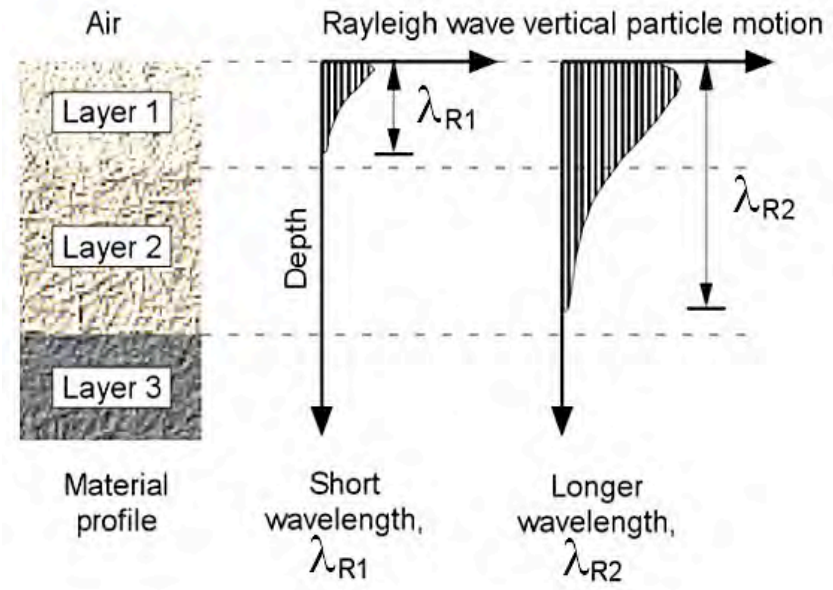

(b) Use of different wavelengths to examine different depths of layered system.

Fig. 3.10 SASW test setup and example application.

Source: http://www.geovision.com/SASW\%20method.htm.

Acoustic emission monitoring is passive in that it listens for sound waves generated by stresses within a material. Acoustic emission is the class of phenomena whereby an elastic wave, in the range of ultrasound usually between $20 \mathrm{KHz}$ and $1 \mathrm{MHz}$, is generated by the rapid release of energy from a source within a material (3.45). Acoustic emissions in concrete are due primarily to cracking processes, slip between concrete and steel reinforcement, and fracture or debonding of fibers in fiber reinforced concrete. The elastic wave propagates through the solid to the surface where it can be recorded by one or more piezoelectric sensors and analyzed (Figure 3.11). The sensor is a

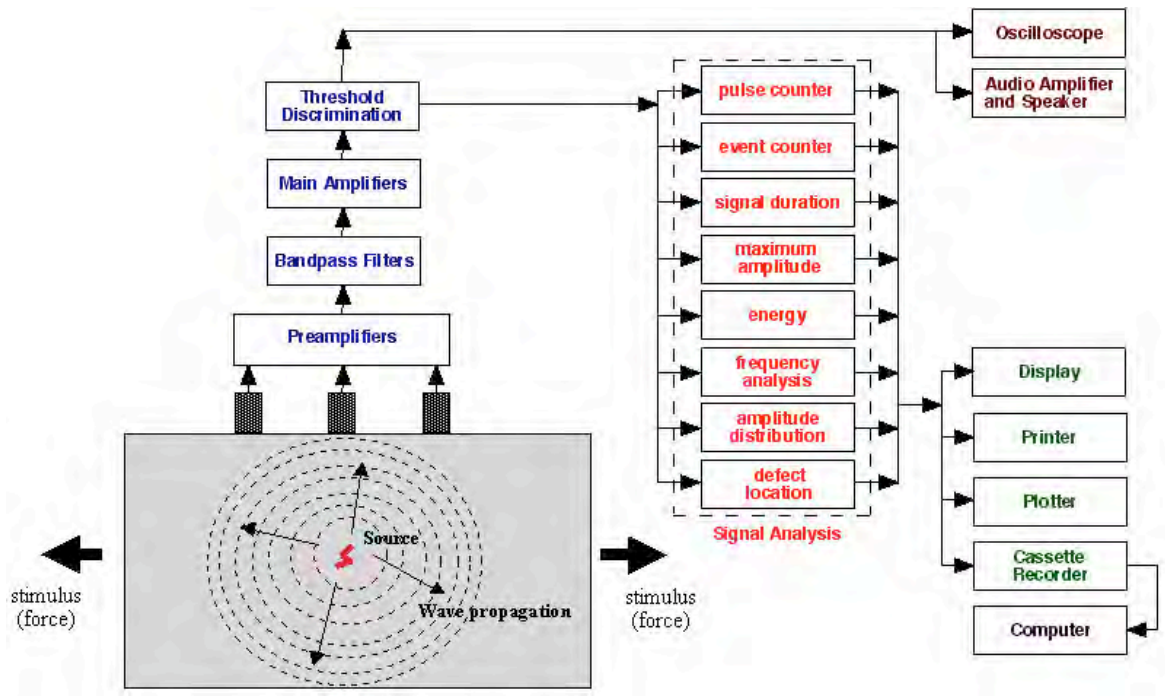

Figure 3.11 Acoustic emission principle and schematic of data acquisition.

Source: Adaptation of figure in "What is Acoustic Emission?" Nondestructive Testing Encyclopedia, Kirchwald, Germany (http://www.ndt.net) and Figure 5 in Sidney Mindess, “Acoustic Emission Methods," Chapter 14 in Handbook of Nondestructive Testing of Concrete, V.M. Malhotra and N. J. Carino Editors, CRC Press, Boca Raton, Florida, 1991. 
transducer that converts the mechanical wave into an electrical signal enabling information about the existence of a source and its location to be obtained. Acoustic emission analysis is a useful method for investigation of local damage in materials and enables damage processes to be observed during the entire load history. Typical applications of acoustic emission include: detect and examine material and structural flaws, monitor flaw growth or micro-damage progression, detect leaks, assess differences caused by manufacturing variations, study fundamental deformation behavior and failure of materials, proof or requalification testing of structural components, and monitor in real time certain manufacturing processes (3.46). Acoustic emission has been successfully applied to concrete members to investigate: hardening of concrete, deformation and fracture, the condition of reinforced concrete beams, the deformation and destruction mechanisms of concrete pipe elements, condition of foundation structures, and corrosion of steel reinforcement (3.47). A wireless acoustic emission sensor network based on micro-electromechanical systems (MEMS) has been developed for structural health monitoring of civil engineering structures (3.48). Acoustic emission, unless a baseline exists from a series of prior tests, generally only estimates how much damage has occurred to a material and how long a component will last. Also, service environments can be noisy making signal discrimination and noise reduction difficult. Acoustic emission methods have found widespread use for the detection and location of wire failures in prestressed concrete structures $(3.49,3.50)$. Continuous acoustic monitoring has been used since 1994 to monitor failures in bonded and unbonded tendon systems. For the system to be successful it must be demonstrated that the signals generated by a wire break can be detected above general noise levels and distinguished from events that are not of interest. A typical system includes an array of broadband piezoelectric accelerometers fixed directly to the concrete member and connected to an acquisition system with a coaxial communication cable. Figure 3.12 presents a standard sensor used for monitoring buildings, bridges, and parking structures and time domain and frequency spectrum plots of wire break detected by a sensor $10 \mathrm{~m}$ from the event. Figure 3.13 presents wire break results obtained from monitoring the superstructure of a prestressed concrete bridge consisting of a continuous beam with two spans of $30 \mathrm{~m}$ each (3.51). By analyzing the time taken by the energy wave caused by the break as it travels throughout the concrete to arrive at different sensors, the software can calculate the location of the wire break, usually within 300-600 mm of the actual break. Characteristics of the acoustic events including frequency spectrum are used to classify breaks and reject environmental noise. In most applications the data is transmitted over the internet for processing and analysis.

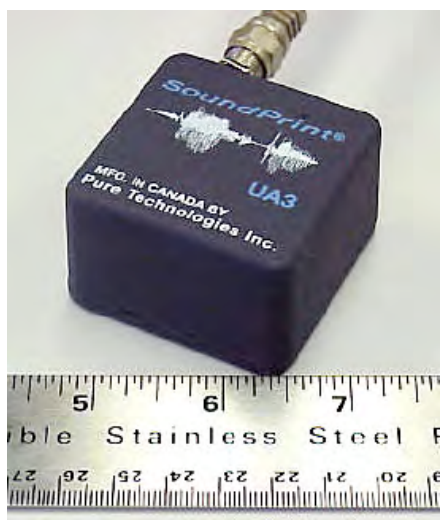

(a) Building sensor.

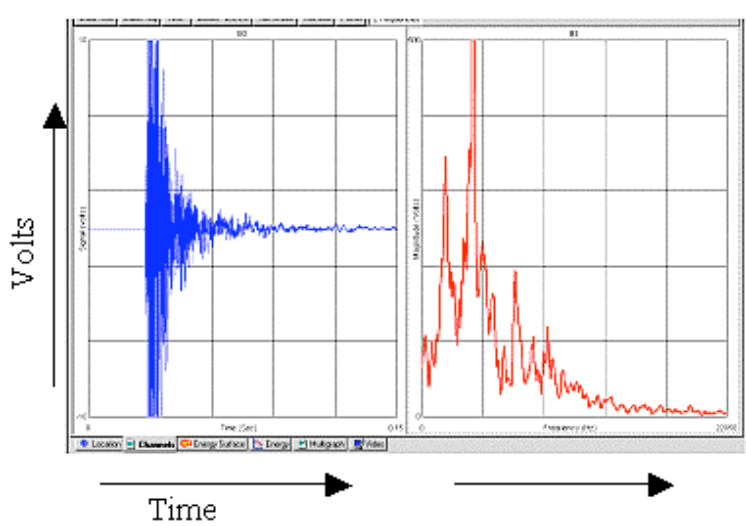

(b) Time domain and frequency spectrum plots of wire break detected by sensor $10 \mathrm{~m}$ from event.

Fig. 3.12 Acoustic monitoring of tendons in post-tensioned structures.

Source: P.O. Paulson, “The Use of Acoustic Monitoring to Manage Concrete Structures, “ International Symposium on Non-Destructive Testing in Civil Engineering (NDT-CE-2003), Bundesanstalt für Materialforschung und -prüfung, Berlin, Germany, 2003.

\subsubsection{Nuclear/Radiographic Techniques}

Nuclear methods for nondestructive examination of concrete can be subdivided into three groups: radiographic, radiometric, and neutron source. All are based on the interaction between high-energy electromagnetic radiation and the material inspected. Radiography is the method most often used to examine the quality of construction or materials in concrete (e.g., location of reinforcement and voids). The basic system consists of a radiation source (Xray or gamma ray) emitting a beam through the test article and a photographic film placed on the opposite side of the test article from the source. Since a high-density medium absorbs a greater amount of emitted energy, the density 
of the material determines the energy being absorbed by the film. A two-dimensional projection of the area being inspected is displayed on the film. Commonly used sources of radiation for industrial radiography are isotopes such as Iridium (concrete thickness $\leq 300 \mathrm{~mm}$ ) and Cobalt (concrete thickness $\leq 600 \mathrm{~mm}$ ). Linac systems are used to

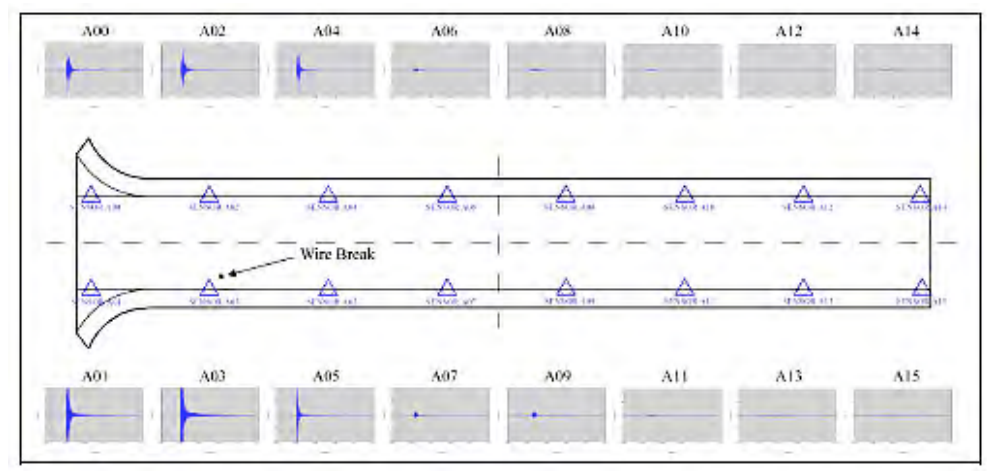

Figure 3.13 Signals recorded by 16 sensors resulting from a prestressing tendon wire break.

Source: T. Vogel, B. Schechinger, and S. Fricker, "Acoustic Emission Analysis as a Monitoring Method for Prestressed Concrete Structures,” European Conference on NDT, Paper We.4.4.3, 13 pp., Berlin, Germany, 25-29 September 2006.

produce directed high-energy X-ray beams of far greater energy and radiation intensity than from isotopes of Iridium or Cobalt (3.52). These devices have been used to penetrate steel members up to 406-mm thick and concrete members up to $1.57-\mathrm{m}$. thick. Although $\gamma$-scintillation can be used in members greater than $1-\mathrm{m}$ thick, most systems are capable of detecting small voids in members up to about 700-mm thick. Radiography is one of the most-capable nondestructive examination techniques when considering the amount of detail produced and the relative ease in understanding the data produced, but the entire volume of the concrete and reinforcing is projected onto a flat surface image, and the geometry of rebars and internal voids displayed is somewhat distorted (3.30). Techniques are available to calculate the depth of the steel reinforcement and its diameter (3.53). Radiometry is used to address the density of fresh or hardened concrete by measuring the intensity of electromagnetic radiation (gamma rays) that passes through the concrete. Gamma radiometry systems consist of a source that emits gamma rays through the specimen and a radiation detector and counter. Direct transmission or backscattering modes can be used to make measurements. The count or count rate is used to measure the specimen dimensions or physical characteristics (e.g., density and composition). Neutron methods consist of an emission source and a gamma ray collection and counting system. The method can be used to measure the moisture content in a structure. In this method neutrons emitted by the decay of an X-ray source provide the ability to detect hydrogen present in water in the concrete. The concrete moisture content can be determined to a depth of approximately $90-\mathrm{mm}$, and the accuracy of the measurement improves with increasing moisture content. X-ray and gamma-ray computerized tomography involving the reconstruction of a cross-sectional image of an object from its measured intensities has also been investigated (3.54). The computed tomography image is derived from a large number of systematic observations at different viewing angles and an image is reconstructed with the aid of a computer (3.55). Primary limitations of the most commonly used of the above methods, radiography, are that radiation protection has to be observed while applying this method, personnel must be licensed or certified, the concrete structure must be accessible from both sides, general necessity for long exposure times, and concrete sections are generally limited to $1 \mathrm{~m}$ or less in thickness. Figure 3.14 presents a Megascan ${ }^{\mathrm{TM}}$ imaging capture system for inspection of posttensioned bridges and other structures and examples of results obtained for voided and fully grouted tendon ducts (3.56).

\subsubsection{Electromagnetic}

Ground-penetrating radar (GPR) is a high-resolution near-surface surveying tool. It involves propagation and scattering of electromagnetic energy through materials, is the electromagnetic analogue of sonic and ultrasonic pulse-echo techniques, and is well developed in the geophysical field. It has been adapted and can be used in its various forms to obtain information from concrete structures and their foundations and substrate. Target objects include construction features, buried pipes, cables, steel reinforcement location and estimation of bar size, caverns, cracks and flaws, pavement thickness determination, as well as ground water and moisture. Table 3.5 provides 
information on reliability of GPR for several applications to structural concrete (3.57). One of the advantages of radar is that the antenna used for scanning does not require contact with the test surface and large areas can be

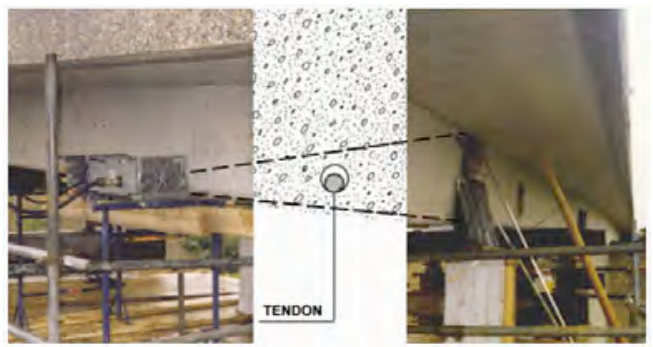

(a) Positioning of Megascan ${ }^{\mathrm{TM}}$ system.

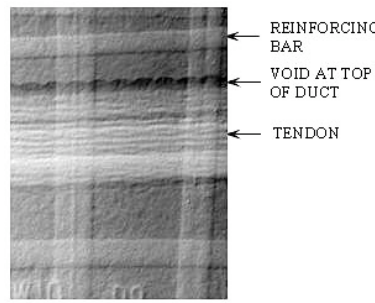

Voided duct

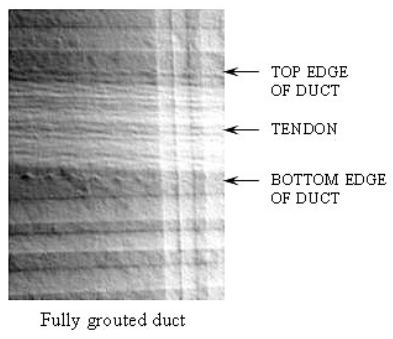

(b) Images showing voided and fully-grouted tendon ducts.

Fig. 3.14 Application of Megascan ${ }^{\mathrm{TM}}$ imaging capture system.

Source: K. Brown and J. St Leger, "Use of the Megascan ${ }^{\mathrm{TM}}$ Imaging Process in Inspection Systems for PostTensioning Bridges and Other Major Structures," International Symposium on Non-Destructive Testing in Civil Engineering (NDT-CE-2003), Bundesanstalt für Materialforschung und -prüfung, Berlin, Germany, 2003.

Table 3.5 Indication of relative reliability of GPR application to structural concrete

\begin{tabular}{|ll|}
\hline Greatest reliability <-------- & $------->$ Least reliability \\
\hline Estimation of element thickness from one surface & \\
$\begin{array}{l}\text { Location of reinforcing bars and metallic ducts, } \\
\text { and estimation of depth }\end{array}$ & $\begin{array}{l}\text { Increasingly } \\
\text { experimental } \\
\text { in nature and concept }\end{array}$ \\
$\begin{array}{l}\text { Determination of major construction features } \\
\text { Location of moisture variations }\end{array}$ & \\
Location of voids & \\
Dimensions of major voids & \\
Location of honeycombing or cracking & \\
Estimation of bar size & \\
\hline
\end{tabular}

Source: J.H. Bungey, "Sub-Surface Radar Testing of Concrete: A Review," Construction and Building Materials 18(1) pp. 1-8, February 2004.

scanned rapidly. Short pulses of electromagnetic energy (microwaves) are transmitted through the structure and the energy is reflected by boundaries between layers of different dielectric properties, with some of the energy passing across an interface by refraction that may in turn be reflected from deeper interfaces. Strength and polarity of the reflection will be determined by the contrast in material properties at the interface with buried metals providing strong reflections. The time delay before the reflected signal is received back at the surface is governed by the depth of the interface and the velocity of the signal in the material. Resolution of GPR is primarily a function of the antenna frequency and the dielectric constant of the medium. Table 3.6 provides a listing of other advantages as well as disadvantages of GPR (3.57). Signal frequencies are typically between $500 \mathrm{MHz}$ and $2.5 \mathrm{GHz}$ for practical applications. Hand-held $900 \mathrm{MHz}$ and $1 \mathrm{GHz}$ dipole antennas are illustrated in Figure 3.15a and achieve effective penetration depths up to 400 to $500 \mathrm{~mm}$ depending on moisture conditions (3.57). Dipole antennas operate most effectively when ground coupled, but they can be air coupled if the gap between the antenna and surface monitored is small. Horn antennas (Figure 3.15b) involving either single or separate transmit/receive systems may be used in some applications. Horn antennas are air coupled and operate with a large air gap and so are more 
Table 3.6 Advantages and disadvantages of GPR

\begin{tabular}{|l|l|}
\hline \multicolumn{1}{|c|}{ Advantages } & \multicolumn{1}{c|}{ Disadvantages } \\
\hline \hline $\begin{array}{l}\text { Can rapidly and effectively investigate large areas from } \\
\text { one surface }\end{array}$ & Equipment specialized and licensing may be required \\
\hline No coupling medium required & $\begin{array}{l}\text { Interpretation of results complex and requires highly } \\
\text { skilled operators, with need for "ground truth" } \\
\text { corroboration }\end{array}$ \\
\hline Totally nondestructive and non-invasive & Extensive signal processing may be expensive \\
\hline $\begin{array}{l}\text { Immediate continuous graphic display of results } \\
\text { possible as radargram }\end{array}$ & $\begin{array}{l}\text { Compromise necessary between } \\
\text { penetration and resolution (antenna selection) }\end{array}$ \\
\hline Digital records and signal processing available & $\begin{array}{l}\text { Cannot penetrate metal, closely-spaced reinforcement } \\
\text { or highly conductive materials (including steel fibers } \\
\text { or metallic "dry-shake") }\end{array}$ \\
\hline $\begin{array}{l}\text { Sensitive to material changes and features of structural } \\
\text { interest including moisture content }\end{array}$ & $\begin{array}{l}\text { Performance affected by many variable features of } \\
\text { materials, configuration, and environment }\end{array}$ \\
\hline $\begin{array}{l}\text { No special safety precautions required relating to } \\
\text { microwave emissions }\end{array}$ & $\begin{array}{l}\text { Technique not well understood by many clients or } \\
\text { their professional advisors }\end{array}$ \\
\hline \begin{tabular}{l} 
Equipment portable \\
\hline
\end{tabular}
\end{tabular}

Source: : J.H. Bungey, “Sub-Surface Radar Testing of Concrete: A Review," Construction and Building Materials 18(1) pp. 1-8, February 2004.

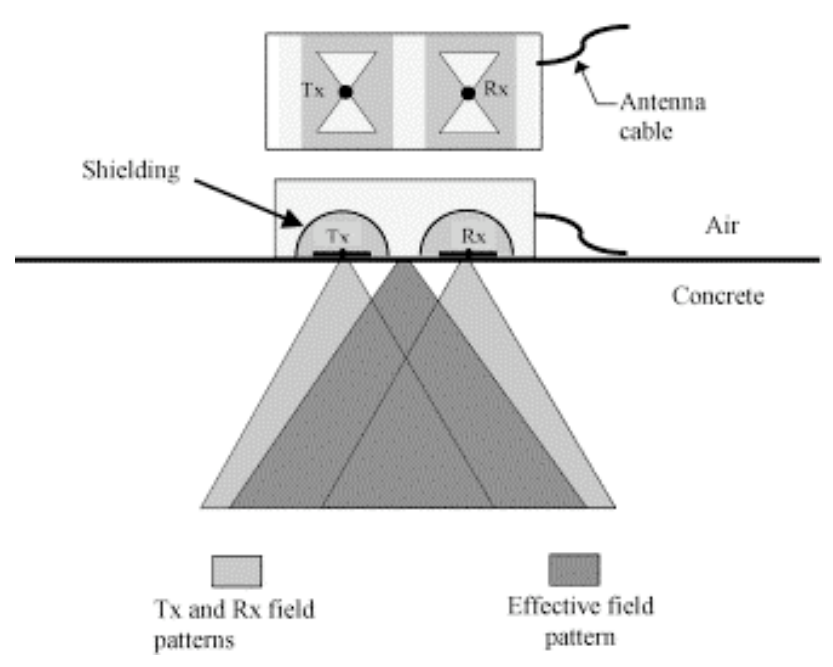

(a) Typical bowtie dipole antenna.

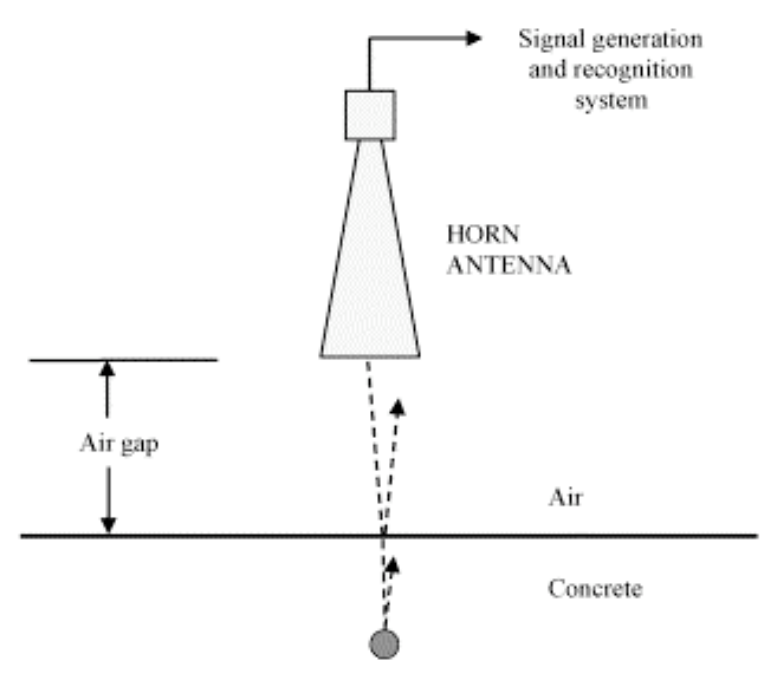

(b) Schematic of horn antenna.

Fig. 3.15 GPR bowtie dipole and horn antennas.

Source: J.H. Bungey, "Sub-Surface Radar Testing of Concrete: A Review," Construction and Building Materials 18(1) pp. 1-8, February 2004. 


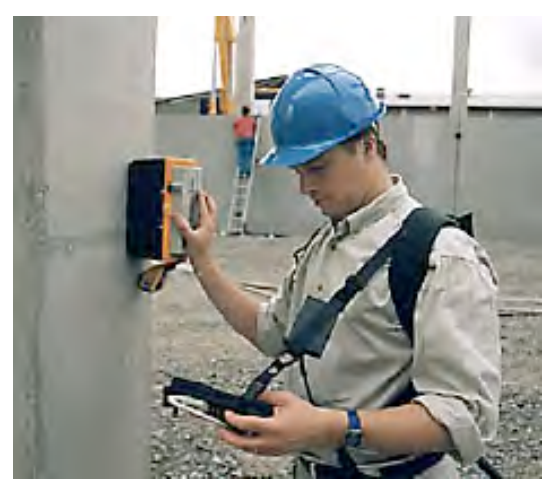

(a) Field application of GPR.

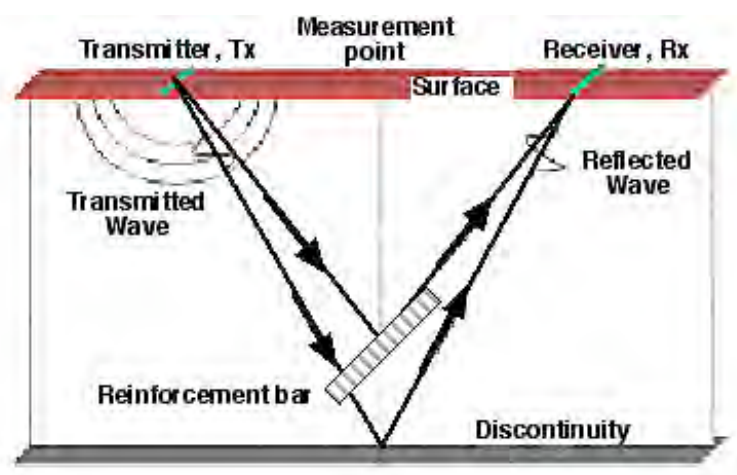

(b) Principle of GPR.

Fig. 3.16 Field application and principle of GPR.

Source: Non-Destructive Testing (NDT) and Examination (NDE), Concrete Inspection and Analysis, Force Technology, Brøndby, Sweden, 2007 (http://www.force.dk).

easily adapted to high-speed surveys. Figure 3.16 presents a GPR system such as used in the field and the principle of testing with a GPR system (3.58). The receiving antenna and readout circuitry indicate the depth to layers having different dielectric properties. The ability to detect the depth of reflectors such as reinforcing bars or tendon ducts is dependent on knowledge of the dielectric properties of the concrete. Greatest penetration is possible when the concrete is dry and frequency low. Study of the waveforms and patterns generated during a scan forms the basis for interpretation with each signal pulse typically having two or three lobes so an interface will appear as a series of bands at a particular reflection time. Reflected wave features of interest in nondestructive testing of concrete include: rebar - waveform is a hyperbola with the top of the hyperbola indicating the rebar position, steel plate - inphase axes of waveform are horizontal with no reflected wave information from below plate, and crack - in-phase axes of waveform are unbalanced with the extent of unbalance increasing with crack depth (3.59). Figure 3.17 shows a schematic of the hyperbolic reflection image from a steel bar in concrete and results obtained from tests
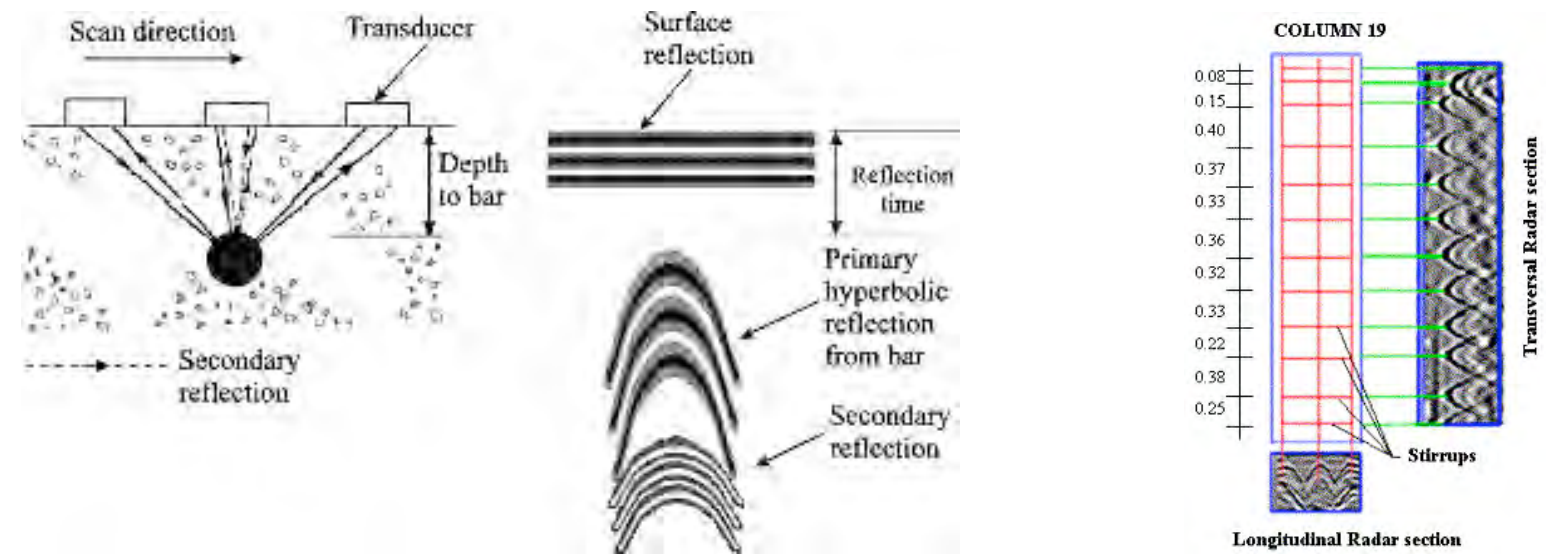

(a) Schematic of hyperbolic reflection from steel bar.

(b) Application of GPR to reinforced concrete column.

Fig. 3.17 Application of GPR to detect steel reinforcement embedded in concrete.

Source: (a) M.R. Shaw, S.G. Millard, T.C.K. Molyneaux, M.J. Taylor, and J.H. Bungey, "Location of Steel Reinforcement in Concrete Using Ground Penetrating Radar and Neural Networks," $N D T \& E$ 38(3), pp. 203-212, April 2005.

(b) V. Barrile and R. Pucinotti, "Application of Radar Technology to Reinforced Concrete Structures: A Case Study,” NDT\&E 38(7), pp. 596-604, October 2005. 
conducted on a reinforced concrete column $(3.60,3.61)$. Studies to indicate the capability of a GPR system to evaluate the effect of concrete cover involving rebar diameters of 13,25 , and $38 \mathrm{~mm}$ and concrete cover depths of 30,60 , and $100 \mathrm{~mm}$ indicate that GPR can determine the in-place location of rebars within $\pm 10 \mathrm{~mm}$, diameter of rebars within approximately $\pm 5 \mathrm{~mm}$, and cover depth within approximately $\pm 10 \mathrm{~mm}$ (3.62). Figure 3.18 illustrates application of GPR to detect a delamination (3.63) and pipe voids below the concrete apron of a weir (3.64). Figure 3.19 presents use of GPR to detect cracking in concrete (3.59). A range of signal processing operations is available to assist in evaluating the data (e.g., filtering, depth scaling, SAFT, and automatic recognition of image features) (3.57). Closely spaced reinforcement near the concrete surface tends to disrupt radar signals and
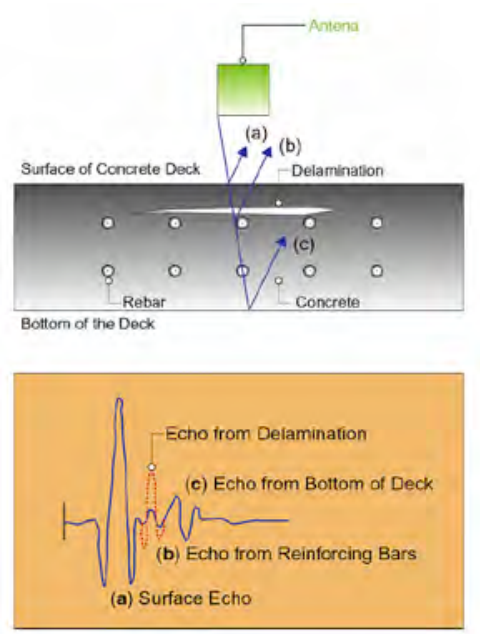

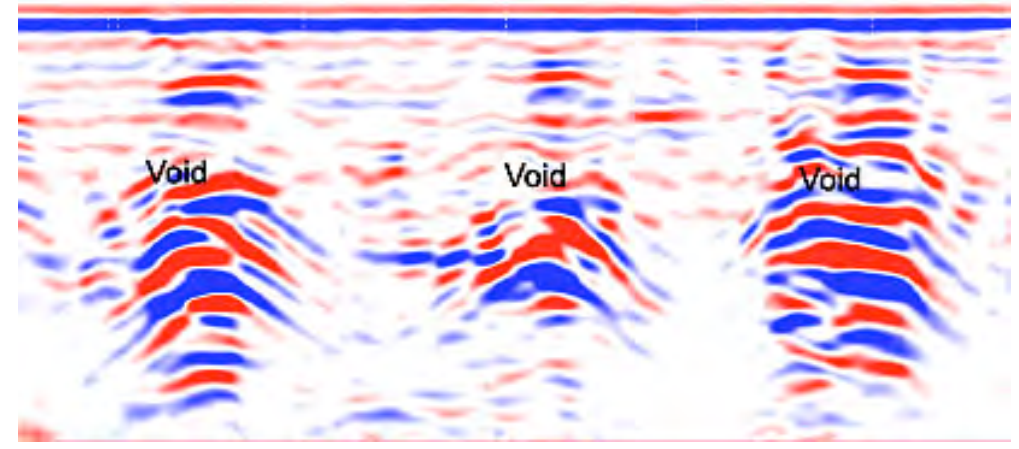

(b) Pipe voids beneath concrete apron of weir detected by GPR.

(a) Delamination detection by GPR.

Fig. 3.18 Application of GPR to detect concrete delamination and near-surface voids.

Source: (a) P.K. Mehta and P. Monteiro, Concrete - Microstructure, Properties, and Materials, $3^{\text {rd }}$ Edition, McGraw Hill Companies, Inc., New York, New York, 2006.

(b) http://www.geophysical.biz/void1.htm

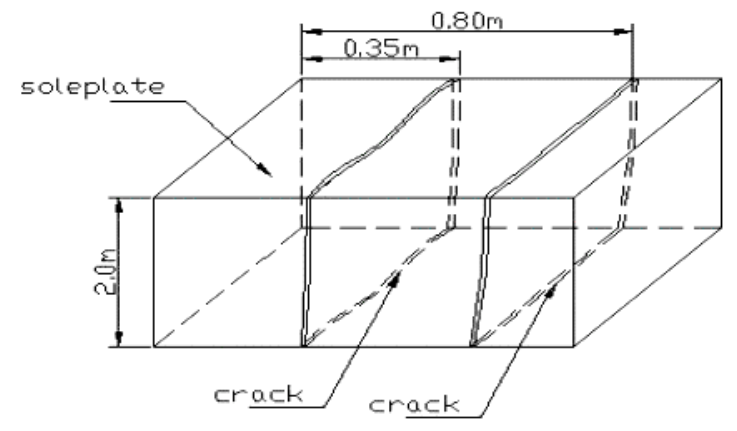

(a) Schematic of cracked section monitored by GPR.

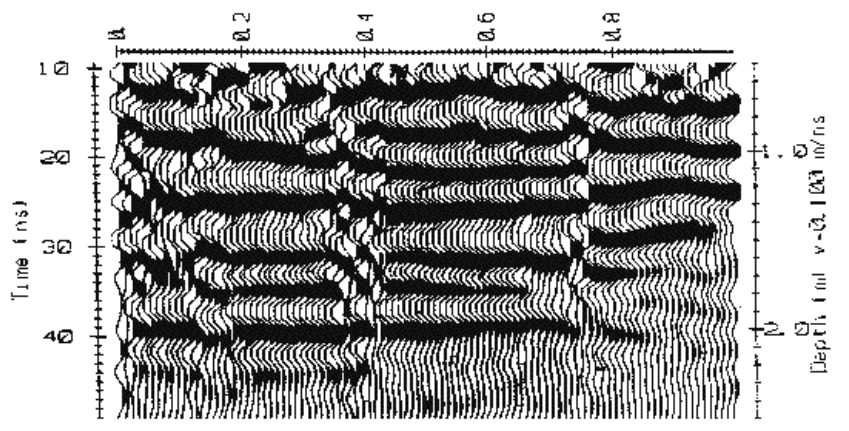

(b) Application of GPR to cracked concrete section.

Fig. 3.19 Application of GPR to detect concrete cracking.

Source: Y. Zhao, J. Wu, J. Wang, and M. Wan, "Ground Penetrating Radar Technique and It's Application in Non-Destructive Testing of Reinforced Concrete," The 10th Asian Pacific NDT Conference, Brisbane, Australia, 17-21 September 2001. 
mask deeper lying objects of interest (e.g., voids). At present, objects such as tendon ducts can be detected in concrete to a depth of at least $300 \mathrm{~mm}$, provided the concrete is not too moist (i.e., high moisture levels hinder radar signals from penetrating concrete, particularly if the water contains salts that increase conductivity). The effects of moisture presence may be an advantage, however, in trying to detect leaks in water-retaining structures such as dam walls or waterproof membranes. The position of reinforcement can be resolved at depths to $500 \mathrm{~mm}$ (3.65), and in some cases two or even three layers of reinforcing can be detected to depths of $300 \mathrm{~mm}$ (3.52). Cracks and delaminations are not easy to detect unless moisture is also present in the cracks or regions of the delamination. Currently the primary limitation of the method is the resolution capability, but there are on-going programs to develop signal processing tools to overcome this limitation. Many significant developments in system hardware, data analysis, and enhancement software are occurring (3.57). The development of antennas with frequencies in the 1-5 GHz range is on-going and will improve resolution and increase the capability of the technique to detect objects that lie behind near-surface reinforcement mats. Other developments include methods of measuring moisture profiles and determining the dielectric constant on site. A system (High-Speed Electromagnetic Roadway Management and Evaluation System) consisting of an array of 64 transmitting and receiving antenna pairs has been developed for bridge inspection (3.66).

Electromagnetic methods are utilized to determine the location and cover to reinforcement embedded in concrete. These methods monitor the interaction of the reinforcing bars with some other process such as a low-frequency, electromagnetic field. Commercial instruments (e.g., covermeters) are of two types: magnetic reluctance and eddy currents. Magnetic reluctance covermeters are based on monitoring changes in the magnetic flux flowing through the magnetic circuit that consists of the path through the yoke, concrete, and reinforcing bar. Eddy-current covermeters depend on the electrical conductivity of the bar, and they will detect magnetic as well as nonmagnetic metallic objects (signal from magnetic materials is stronger). Both methods are useful in locating reinforcing bars, measuring the thickness of the concrete cover, and determining the size of embedded steel reinforcement and its spacing. The accuracy of rebar sizing is better than $90 \%$ when the equipment is properly calibrated. The method has a maximum range of about $300 \mathrm{~mm}$ for a single layer of bars. Accuracy (95\% confidence) should be better than the greater of $\pm 5 \mathrm{~mm}$ or $\pm 15 \%$ for covers of less than $100 \mathrm{~mm}$ if the bar size is known; and bar size estimates can be made within two sizes (3.67). Basic limitations of this method are that accuracy of estimated cover depth is affected by bar size and spacing; cannot identify presence of second layer of reinforcement; ability to discern individual bars is affected by meter design, cover depth, and bar spacing; meters based on magnetic resonance can detect only ferromagnetic objects; and maximum penetration is limited and depends on meter design (3.7). For best results the spacing between two adjacent reinforcement bars must be greater than the concrete cover, and since the method is based on the induction principle, the results are affected by anything that affects the magnetic field within the range of the instrument (e.g., electrical cables, metal tie wires, and iron content of cement). Figure 3.20 illustrates application of the method to detect rebar location.

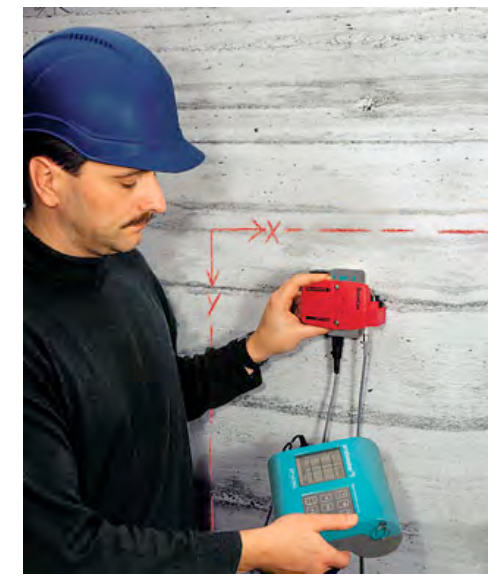

(a) Application of method locate rebar.

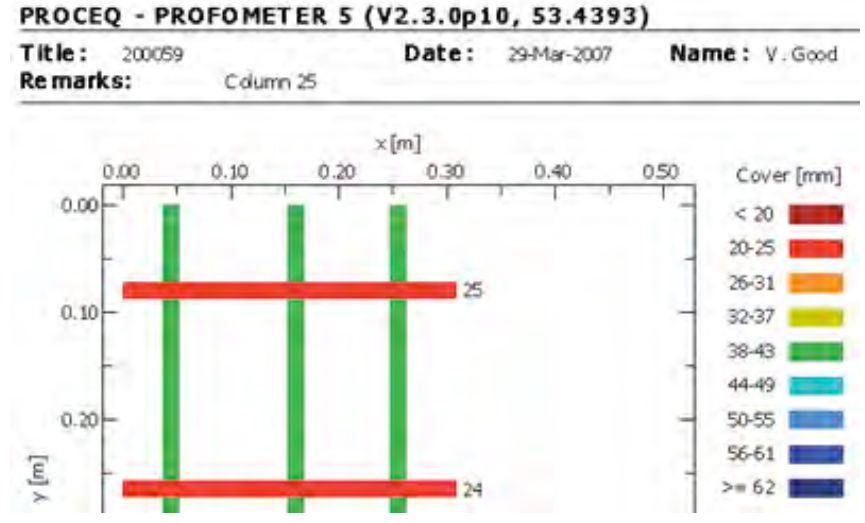

(b) Rebar mapping.

Fig. 3.20 Application of electromagnetic method to detect rebar location.

Source: Proceq USA, Aliquippa, Pennsylvania (http://www.procequsa.com/products/profometer5.php). 


\subsubsection{Infrared Thermography}

Infrared thermography is based on the theory of heat transfer and measures the surface temperature differentials on a concrete member while heating and cooling (3.68). It senses the emission of thermal radiation and produces a visual image from the thermal signal that can be related to the size of an internal defect (e.g., sound concrete is more thermally conductive than low density or cracked concrete) (3.7). Infrared thermography for testing concrete utilizes two heat transfer mechanisms: conduction and radiation. The basic equipment includes an infrared scanner/detector head, a data acquisition/analysis device, and a visual image recorder. The scanner head is an optical camera, with lenses that transmit only infrared radiation in the short- and medium-wavelength ranges. The detector consists of sensors composed of a two-dimensional array of materials sensitive to incident infrared radiation. The data acquisition and analysis system consists of an A/D converter, a computer with high-resolution monitor and data storage device, and data analysis software. Since subsurface anomalies in a material affect heat flow through the material, heat transfer sensed through surface radiance variations can be used to locate subsurface voids, delaminations, or other defects. The magnitude of the temperature difference between deteriorated and sound areas provides an indication of the depth of the defect. Primary advantages of the method are that surface contact is not required, equipment is very sensitive to small temperature changes, results provide an indication of a deteriorated area in a survey region, and its capability to cover a large concrete surface area within a short period of time. Limitations of the method are that application is restricted to comparative situations; complex and expensive equipment may be required; surface textures and finishes will affect the surface radiation properties; depth to a subsurface anomaly cannot be accurately determined; and in order to execute this inspection method, it is necessary to produce a movement of heat in the structure, therefore, some in situ parameters such as surface moisture, ambient temperature, and wind speed could influence the accuracy of the readings. Figure 3.21 illustrates application of impulse thermography to detect voids in a concrete test article (3.69). A dual-band infrared computed tomographic system has been developed for conduct of bridge inspections that locates defects by sensing time-dependent temperature differences (3.70). Pulsed-phase thermography provides a means to image the internal structure of a component. It combines the features of impulse thermography and lock-in thermography and records the coolingdown process with an infrared camera in a way that at each position on the surface a transient curve of the temperature is recorded as a function of time (3.71). It uses Fast Fourier Transformation analysis to separate information obtained according to different frequencies of thermal waves and delivers amplitude and phase images. Analysis of the transient curves permits qualitative location of defects. Advantages of pulse-phase thermography include deeper probing to $10-15 \mathrm{~cm}$, less influence of surface infrared and optical characteristics (i.e., less sensitivity to nonuniform heating), rapid image recording, better defect shape resolution, not necessary to know a priori position of non-defect area, and amplitude images show internal structure of specimen up to a maximum available depth depending on the frequency (band pass filter behavior) (3.71).
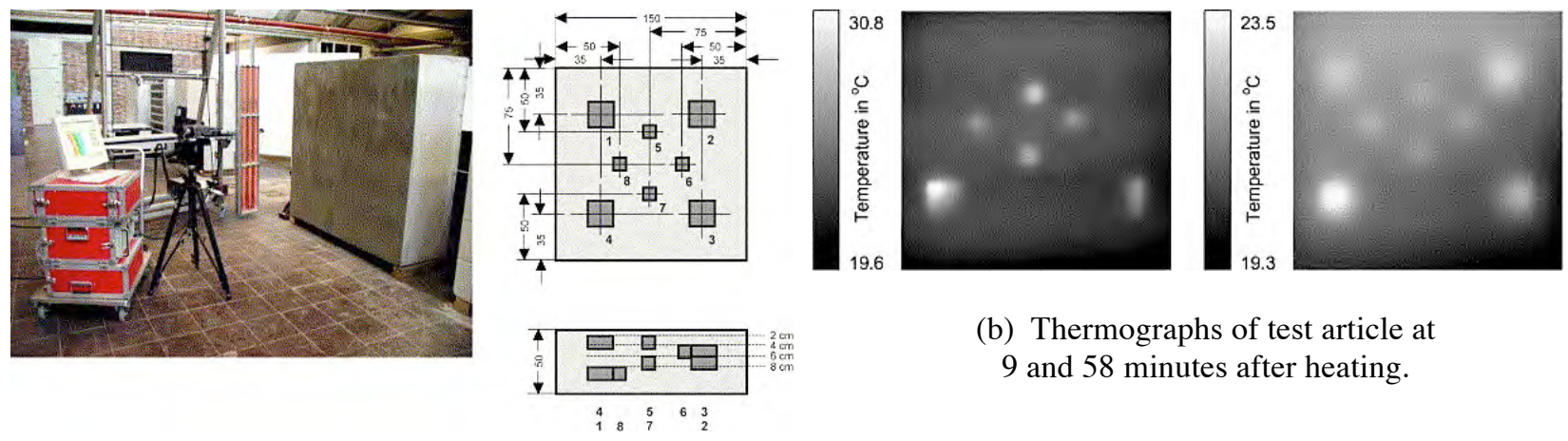

(b) Thermographs of test article at 9 and 58 minutes after heating.

(a) Experimental setup and test article for impulse thermography.

Fig. 3.21 Application of impulse-thermography method to detect voids.

Source: C. Maierhofer, A. Brink, M. Röllig, and H. Wiggenhouser, "Quantitative Impulse-Thermography as NonDestructive Testing Method in Civil Engineering - Experimental Results and Numerical Calculations," Construction and Building Materials 19, pp. 731-737, Elsevier Publishers, August 2005. 


\subsubsection{Audio}

Audio methods are routinely used to detect delaminated areas in structures such as bridge decks. Hammers, steel bars, and chains are often used. By dragging a chain across a concrete surface or using a metallic object to strike the concrete surface, it is possible to locate areas of delamination and voids through sound differentials that occur between good and defective concrete (3.72). Solid areas of concrete will produce a characteristic "metallic ringing" sound when impacted, while defects in the form of debonds, cracks, or other delaminations, will produce a "hollow" sound when struck. The operation is relatively fast and is performed over a grid to map the structure to provide a delamination profile. Basic limitations of this method relative to application to nuclear power plant reinforced concrete structures are that it only can be applied to local and selected test areas because of accessibility constraints and the large size of these structures (i.e., thicknesses up to several meters). Also the technique relies on the subjective judgment of the operator to differentiate between sound and unsound areas, and the results cannot be quantified. The technique is, however, usually effective for defects not exceeding the concrete cover depth, but it may miss small delaminations. Figure 3.22 presents a chain drag system scanning a bridge deck and an example of a defect profile showing areas of delamination.

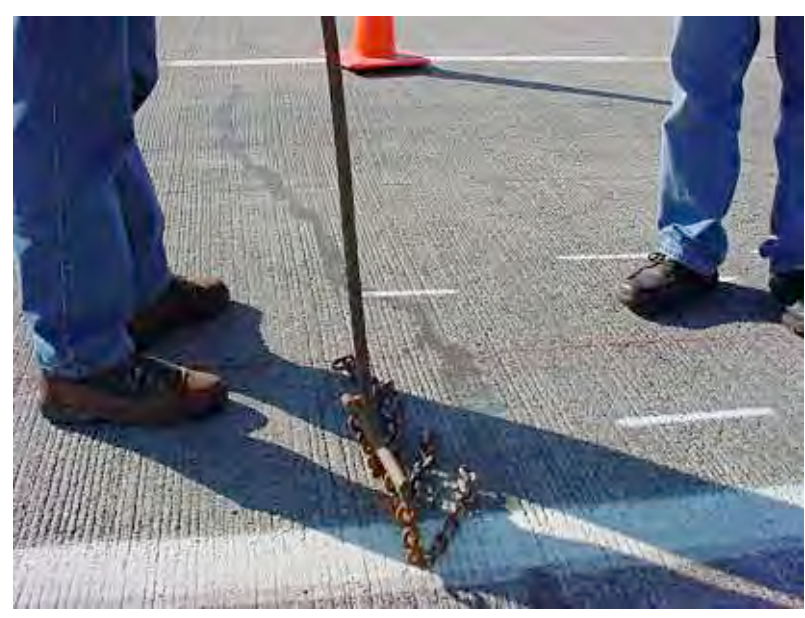

(a) Application of chain drag to bridge deck.

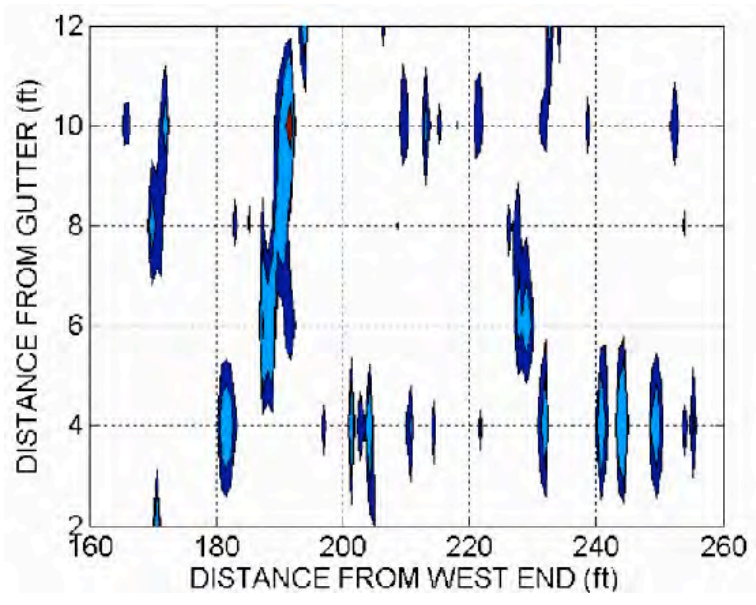

(b) Defect map showing areas of delaminations.

Figure 3.22 Use of chain drag to indicate delaminated regions of bridge deck.

Source: R.D. Costley and G.M. Boudreaux, "Finding Delaminations in Concrete Bridge Decks," $146^{\text {th }}$ Acoustical Society of America Meeting, Austin, Texas, November 2003.

\subsubsection{Rebound Hammer}

The rebound hammer is a well-established, quick, and simple test, as well as one of the most commonly used nondestructive examination methods (3.73). The method uses the rebound distance (measured on an arbitrary scale) of a spring-loaded weight impacted against the concrete to estimate quality or compressive strength of the in situ concrete. The primary usefulness of the rebound hammer is in assessing concrete uniformity in situ, delineating zones (or areas) of poor quality or deteriorated concrete in structures, indicating changes with time of concrete characteristics, and as a means to classify arbrasion resistance. The effectiveness of the rebound hammer method is often enhanced through its combination with other techniques such as ultrasonic pulse velocity measurements. Primary limitations of this method are that the test results only measure surface characteristics and results may be influenced by parameters such as the test surface smoothness and moisture content, orientation of the hammer during impact, type of cement used, type of aggregate, and application-specific calibration curves have to be developed to provide reasonably accurate compressive strength results. Surface treatments also may exclude direct application of the technique. Figure 3.23 provides an illustration of the rebound hammer test method. Strength determinations using this method can be expected to have a coefficient of variation of better than $4 \%$ with an accuracy at $95 \%$ confidence limits of better than $\pm 25 \%$ (3.67). 


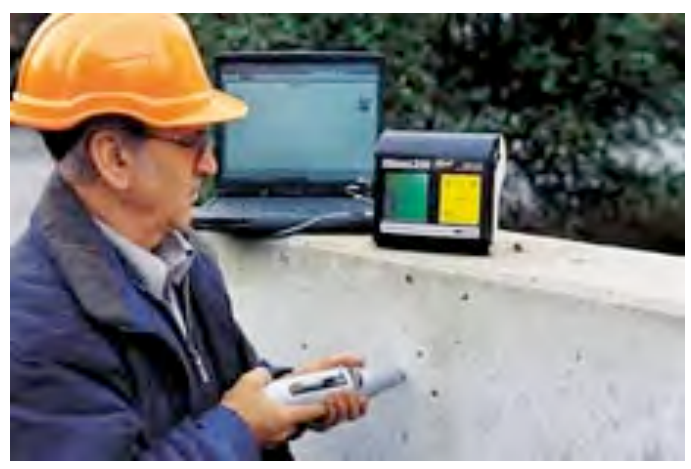

(a) Digi-Schmidt test hammer.

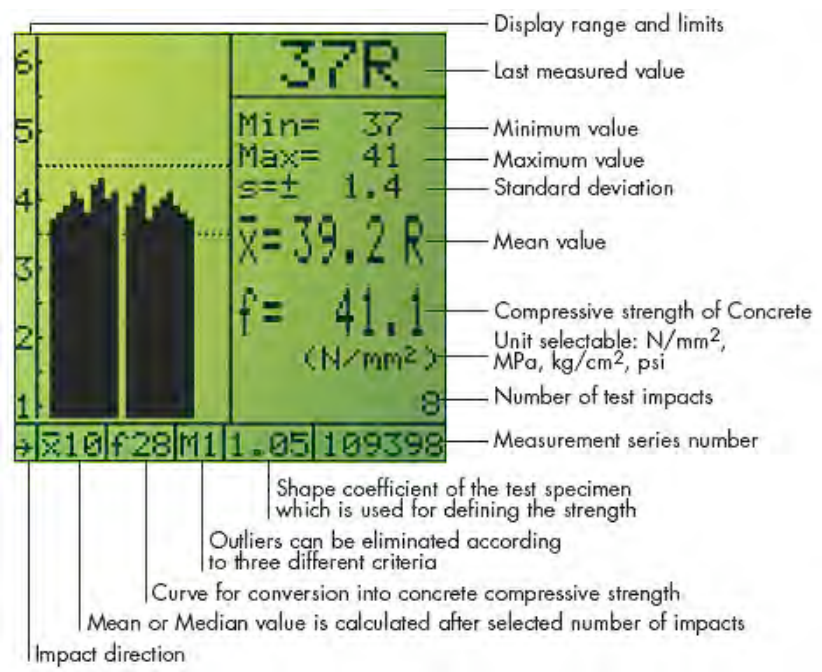

(b) Example of information displayed.

Figure 3.23 Rebound hammer test.

Source: Proceq USA, Aliquippa. Pennsylvania (http://www.proceq-usa.com/products/digischmidt2000.php).

\subsubsection{Fluid Penetrability}

The ability of concrete to withstand environmental deterioration is a function of the materials used to make the concrete, the mixture proportions, the degree of consolidation, and the curing conditions (3.7). Many of the degradation mechanisms in concrete involve the penetration of aggressive materials such as sulfates, carbon dioxide, and chloride ions. In most cases water must also be present to sustain the degradation mechanisms. Low permeability is important to concrete durability. As a result, the condition of the surface zone of concrete is a key factor in concrete durability (3.74).

There are three ingress mechanisms by which external agents can penetrate concrete: absorption (ingress of liquids due to capillary forces), permeation (flow of fluid under action of pressure head), and diffusion (movement of molecular or ionic substances from regions of higher concentrations to regions of lower concentrations). Several methods have been developed to assess the ability of the surface zone of concrete to resist the passage of external agents that may lead either to deterioration of the concrete or depassivation of the steel reinforcement. The methods are based on water absorption, water permeability, or air permeability. Absorption tests measure the rate at which water is absorbed into the concrete under a relatively low-pressure head. Initial surface-absorption, Figg waterabsorption, and Covercrete absorption are examples of water absorption tests. Water permeability tests use higher pressures to obtain indications of the coefficient of permeability. Water permeability tests measure the flow of water into a concrete surface under a fixed pressure and include the CLAM test and the Steinert method. Airpermeability tests are based on the flow of air or other gases through concrete and include Figg air-permeability, Schönlin, and surface-air test. Both the water- and air-based tests involve drilling a hole into the concrete surface or application of a chamber to the surface. Limitations associated with these methods include sensitivity to moisture and temperature changes, changes in transport mechanism during the test, variance of air permeability with applied pressure, and influence of drilling on test values. Additional information on each of these tests is available (3.7, 3.67). Figure 3.24 presents the Initial Surface Absorption Test (ISAT) apparatus for measurement of water flow into a concrete test specimen through a known surface area and an example of results obtained. Figure 3.25 presents examples of methods for determination of concrete water and air permeability. 


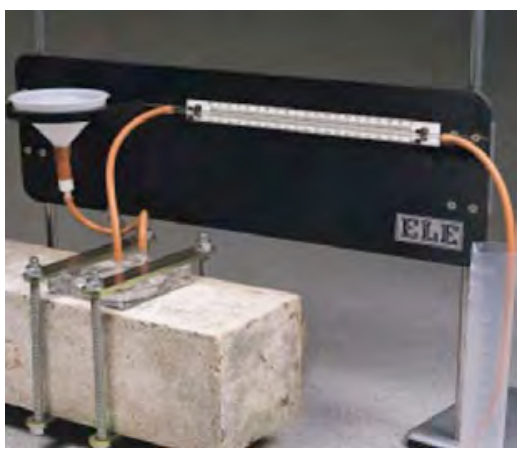

(a) Initial Surface Absorption Test.

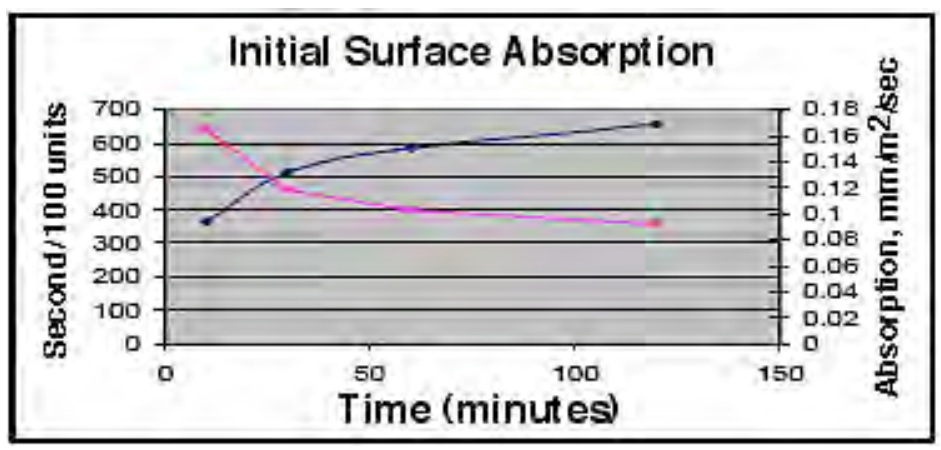

(b) Example of results from Initial Surface Absorption Test.

Figure 3.24 Measurement of initial surface absorption of concrete.

Source: TESTCONSULT, “Structures Data Sheet 7 - Initial Surface Absorption Test," Warrington, United Kingdom, 2007 (www.testconsult.co.uk/library.htm).

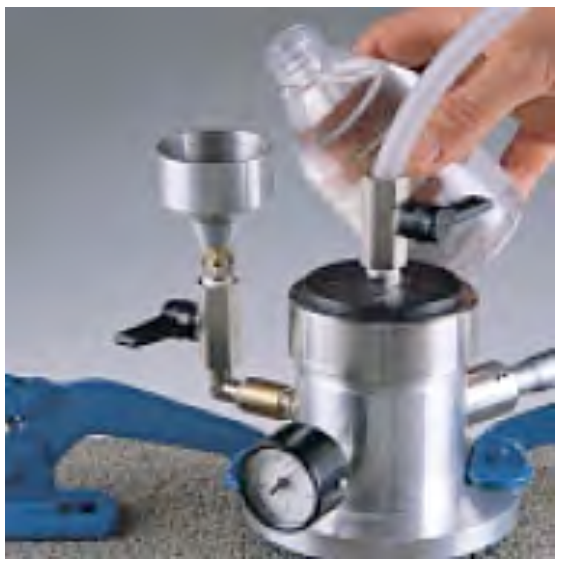

(a) In situ water permeability apparatus.

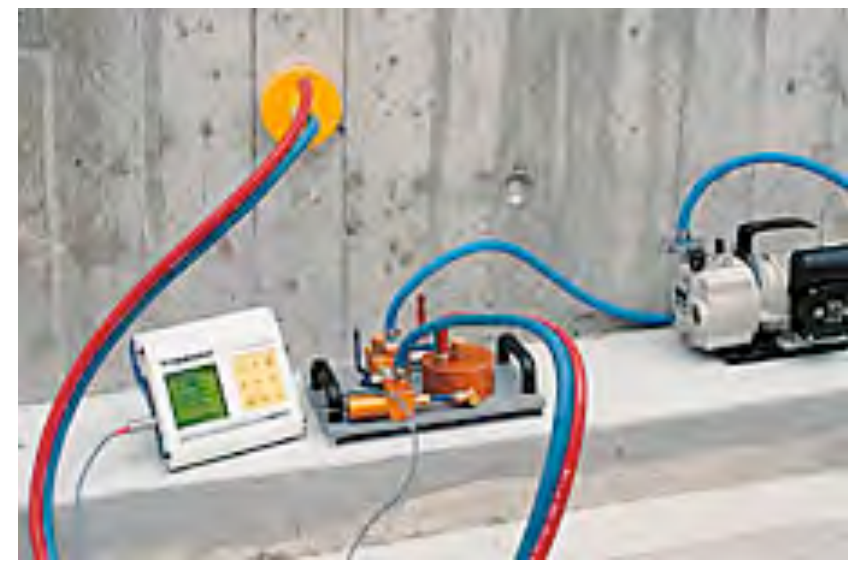

(b) Torrent air permeability test apparatus.

Figure 3.25 Water and air permeability testing of concrete.

Source: (a) ELE International, Bedfordshire, United Kingdom (http://www.ele.int.co.uk).

(b) Proceq USA, Aliquippa, Pennsylvania (http://www.procequsa.com/products/torrent.php).

\subsubsection{Concrete Moisture Content}

Moisture content of concrete is important because in nearly all physical and chemical processes influencing the durability of concrete structures the presence of water is involved. However, measurement of the internal moisture in concrete is not a trivial task. Neutron moisture gages, chemically-based humidity indicators, dew-point sensors, or electronic meter capacitance probes are available providing varying degrees of accuracy for quantitative assessments of moisture content. With the exception of the neutron moisture gages, these techniques require insertion into surface-drilled holes.

Neutron magnetic resonance (NMR) is based on counting the low energy neutrons resulting from the influence of hydrogen present in water upon a beam of high-energy neutrons directed at the concrete (3.67). The amplitude of the signal is a measure of the hydrogen density and thus the moisture content. It can be applied to one side of a structure and provides depth-resolved information about the structure's internal makeup such as moisture depth profile (3.75). Figure 3.26 presents a NMR measuring system for one-sided access application and an example of results obtained. 


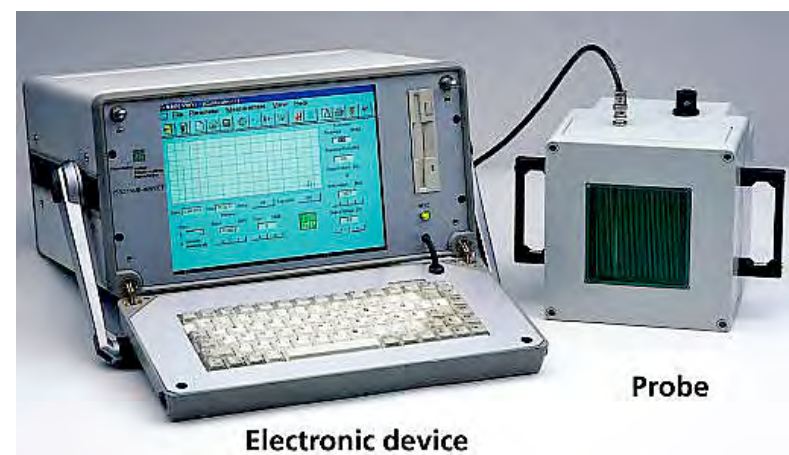

(a) Portable NMR measuring system for one-sided access application.

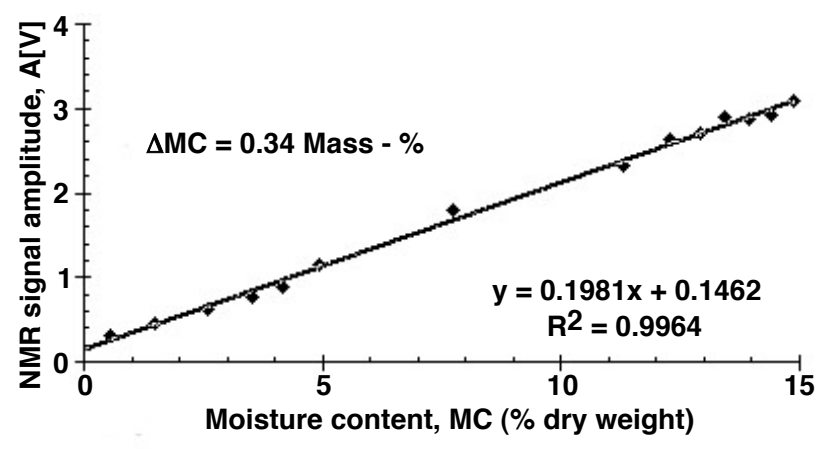

(b) Example of water content measurement in lightweight concrete with NMR (calibration curve).

Figure 3.26 Concrete moisture content determination using NMR.

Source: B. Wolter, F. Kohl, N. Surkowa, and G. Dobmann, "Practical Applications of NMR in Civil Engineering," International Symposium on Non-Destructive Testing in Civil Engineering (NDT-CE-2003), Bundesanstalt für Materialforschung und -prüfung, Berlin, Germany, 2003.

A chemically-based disposable humidity meter is available that is inserted into a pre-drilled surface and moisture content indicated through a color-change scale (3.76). Dew-point sensors are electronically controlled and operate on a cyclic chilled mirror principle and have a claimed accuracy of $\pm 1 \%$ (3.67). Capacitance probes monitor changes in dielectric constant and dissipation factor caused by moisture in the air to provide a relative humidity value. Time-domain reflectometry is based on electromagnetic wave reflections by discontinuities in the electrical impedance of the material (i.e., the dielectric constant is related to the concrete moisture content). By measuring the speed of propagation of an electromagnetic wave in concrete the dielectric constant can be determined (3.77). Figure 3.27 presents an example of a meter based on time-domain reflectometry that can be embedded in a concrete structure for determination of moisture changes. Measurements of dielectric properties in concrete also have been used to indicate the development of concrete strength (i.e., high conductivity = low strength and low conductivity $=$ high strength) (3.77). Application of this is also illustrated in Figure 3.27.

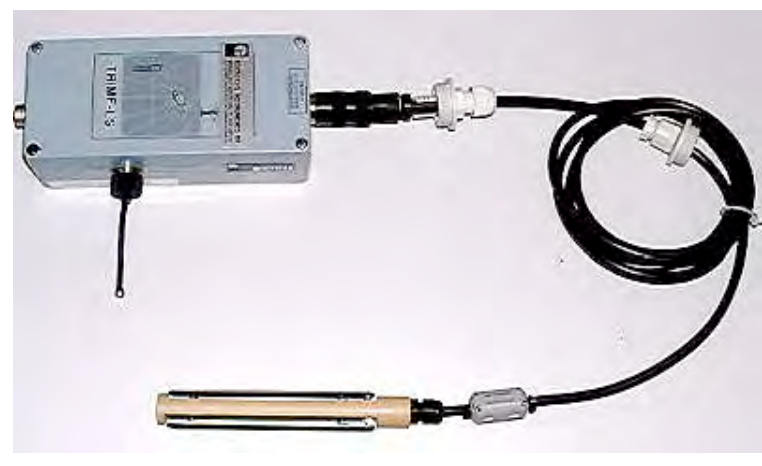

(a) TRIME sensor for moisture determinations.

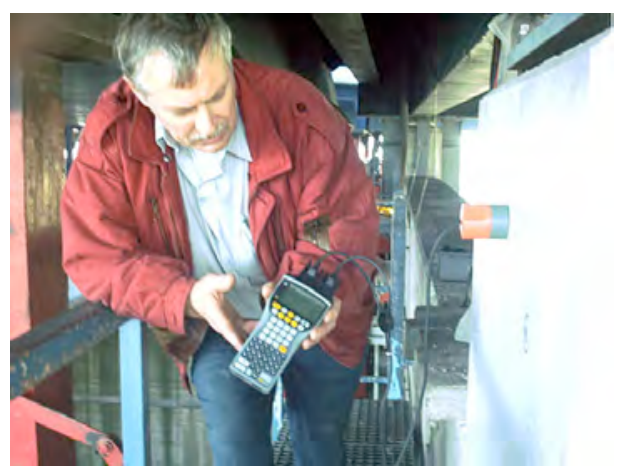

(b) Dielectric measurements for indication of concrete strength

Figure 3.27 Application of dielectric measurements to indicate concrete moisture content and strength.

Source: F. J. Postema and A. van Beek, "NDT Used in the Netherlands from a Principal Point of View," International Symposium on Non-Destructive Testing in Civil Engineering (NDT-CE-2003), Bundesanstalt für Materialforschung und -prüfung, Berlin, Germany, 2003. 
A multiring-electrode method has been developed that can be embedded in new construction or placed into existing structures and uses measurements based on resistivity in conjunction with temperature measurements to determine moisture distribution in the concrete cover zone (3.78). Figure 3.28 presents the multiring electrode and sensor. Moisture and salinity of concrete can also be evaluated based on determination of dielectric permittivity in the microwave frequency range of 1 to $10 \mathrm{GHz}$ using a microwave resonator, but this requires positioning of the antennas on opposite sides of the concrete or into two parallel boreholes (3.79).

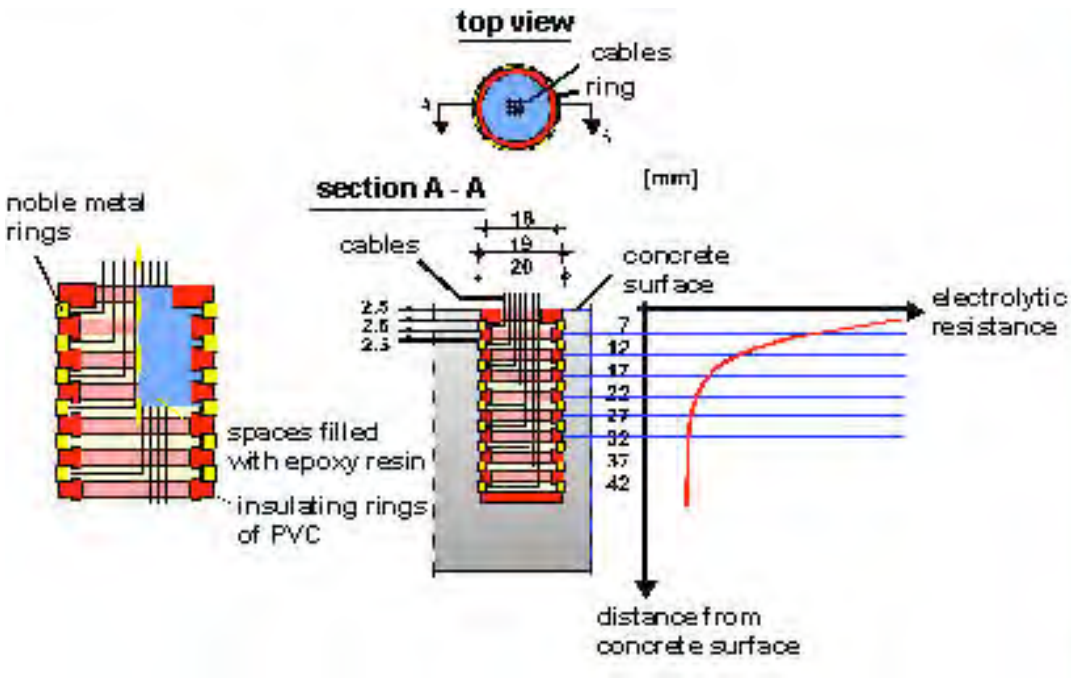

(a) Schematic of multiring electrode setup.

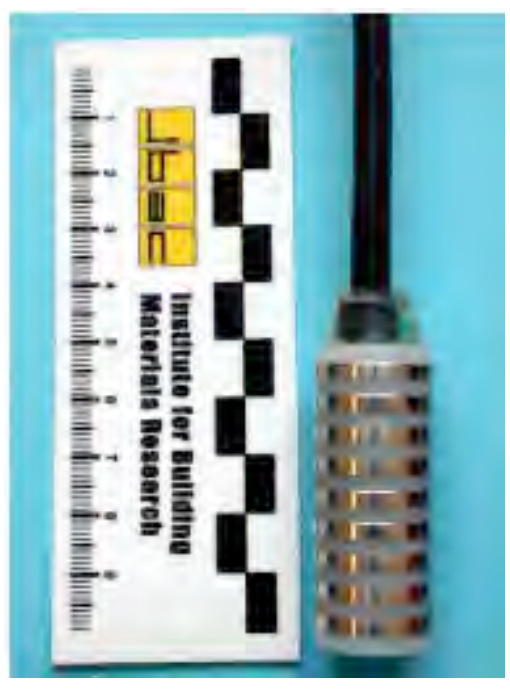

(b) Sensor

Fig. 3.28 Schematic of multiring electrode setup and photograph of sensor.

Source: W. Brameshuber, M. Raupach, S Schröder, and C. Dauberschmidt, "Non-Destructive Determination of the Water Content in the Concrete Cover Using the Multiring Electrode," International Symposium on NonDestructive Testing in Civil Engineering (NDT-CE-2003), Bundesanstalt für Materialforschung und prüfung, Berlin, Germany, 2003.

\subsubsection{Laser-Induced Breakdown Spectroscopy}

Laser-induced breakdown spectroscopy (LIBS) is a real-time method that can be used to identify the elemental composition on the surface of building materials (i.e., characterize concrete) (3.80). A short intense infrared laser pulse is used to ablate and vaporize a small amount of the material investigated. A plasma plume is formed and during the relaxation process atomic emission occurs and the element specific spectra features can be observed. The emitted fluorescence light is directed to a detection unit by an optical fiber where the light intensity is measured as a function of the wavelength (i.e., spectrum) (3.81). The results from measurements on concrete specimens can be represented on a Rankin diagram where the points are plotted according to the determined contents for $\mathrm{Si}, \mathrm{Ca}, \mathrm{Mg}$, $\mathrm{Al}$, and $\mathrm{Fe}$ for each spectrum. The cement type used can be identified by the position of the results in the Rankin diagram. In order for quantitative determinations to be made of element contents a database containing calibration measurements on reference materials with well-defined composition is required. In addition to identification and characterization of concrete and cements, applications of LIBS include measurement of chloride contents at different depths for durability assessments, measurement of sulfur content at different depths, determination of heavy metal contents, and identification of surface layers (3.81). Figure 3.29 presents the physical principle of LIBS and the experimental setup. Figure 3.30 presents application of the laser pulse to a concrete specimen. Also shown in the figure are an area scan of a broken concrete surface showing carbon distribution, and a comparison of chloride profiles obtained by standard chemical analyses and LIBS. 

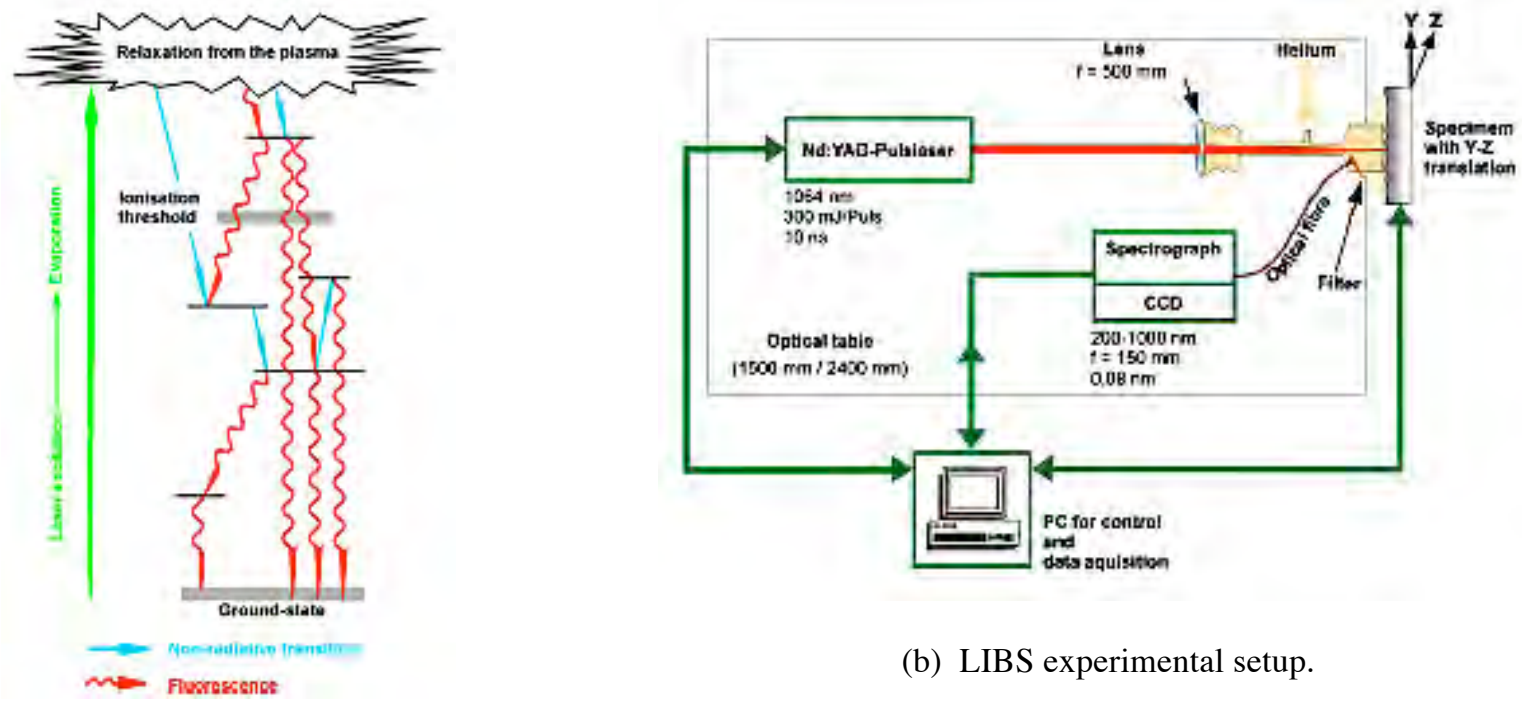

(b) LIBS experimental setup.

(a) Physical principle of LIBS.

Figure 3.29 LIBS physical principle and experimental setup.

Source: A. Taffe, D. Schaurich, F. Weritz, and G. Wilsch, "Laser-Induced Breakdown Spectroscopy (Libs) in Civil Engineering," European Conference on NDT, Poster 15, 6 pp., Berlin, Germany, 25-29 September 2006.

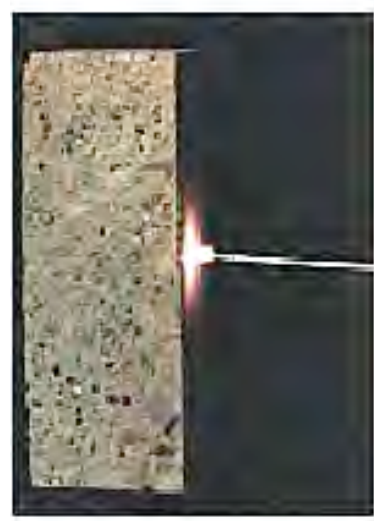

(a) Application of laser pulse to concrete.

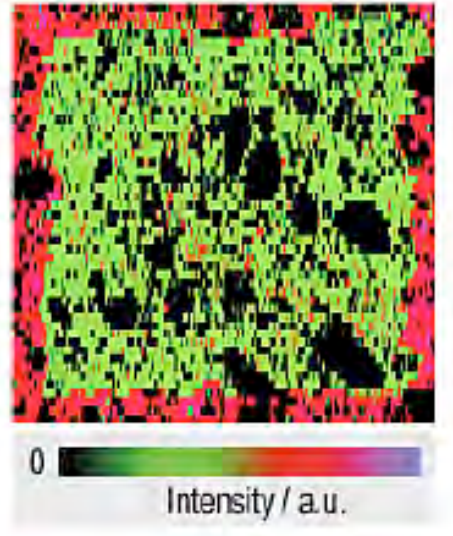

Carbon $=193.1 \mathrm{~nm}$

(b) Carbon distribution in carbonated concrete.

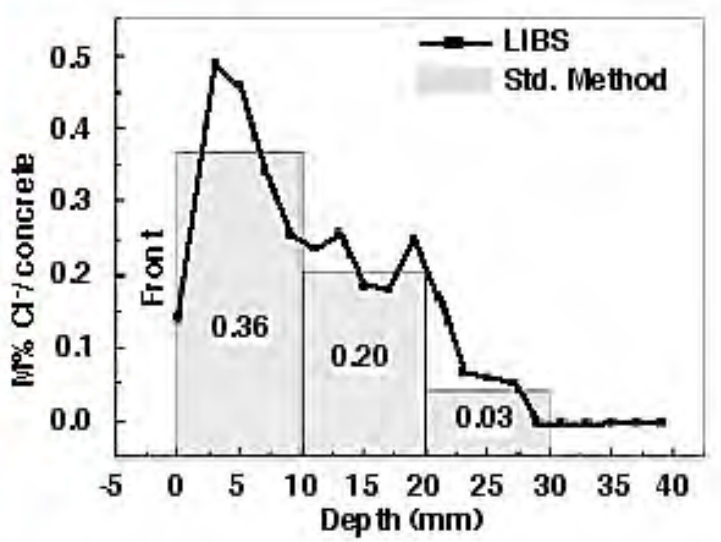

(c) Comparison of chloride profiles obtained by chemical analysis and LIBS.

Figure 3.30 Application of LIBS with examples of results obtainable.

Source: (a) F. Weritz, D. Schaurich, G, Wilsch, J. Wöstmann, and H. Wiggenhauser, "Laser Induced Breakdown Spectroscopy as a Tool for the Characterization and Sorting of Concrete Waste Material in View of High-Order Re-Use," International Symposium on Non-Destructive Testing in Civil Engineering (NDT$C E$-2003), Bundesanstalt für Materialforschung und -prüfung, Berlin, Germany, 2003.

(b) H. Wiggenhauser, G. Wilsch, D. Schaurich, and J. Wöstmann, VII.3 - Division of Building Diagnostic; Non-Destructive Testing in Civil Engineering, Federal Institute for Materials Research and Testing, Berlin, Germany (http://www.bam.de).

(c) A. Taffe, D. Schaurich, F. Weritz, and G. Wilsch, "Laser-Induced Breakdown Spectroscopy (Libs) in Civil Engineering," European Conference on NDT, Poster 15, 6 pp., Berlin, Germany, 25-29 September 2006. 


\subsubsection{Destructive or Partially Destructive Testing}

Destructive or partially destructive testing testing can be utilized to determine concrete strength, density, and quality; locate voids or cracks in concrete; locate steel reinforcement and determine depth of concrete cover; and detect corrosion of steel reinforcing materials. Testing techniques include (1) break-off, (2) core testing, (3) probe penetration, (4) pull-out, (5) pull-off, (6) chemical analysis (e.g., chloride-ion content, carbonation depth, alkaliaggregate reactions, and sulfate attack), and (7) petrography.

\subsubsection{Break-Off}

The break-off method is used in situ primarily as a quality control test for concrete, and makes a direct determination of the flexural strength in a plane parallel and at a certain distance from the concrete surface. The break-off stress at failure can be related to the compressive strength of the concrete using a predetermined relationship for a particular source of concrete. To perform this test, a specimen of 55-mm diameter and 70-mm deep is formed either by using a plastic cylinder placed into the fresh concrete, or drilling a core with the same outer dimensions in existing concrete. A load cell is placed into a circular groove at the top of the concrete surface and load is applied using a hydraulic pump until failure of the specimen occurs in flexure. The pressure reading of the load cell is correlated to the concrete strength by using calibration curves. Limitations of this method are that it cannot be used with concrete mixes having maximum aggregate sizes exceeding $19 \mathrm{~mm}$ or concrete structures having sections less than $100 \mathrm{~mm}$ thick. The coefficient of variation for this test is about $10 \%$ with an accuracy of strength prediction on the order of $\pm 20 \%$ (3.67). Figure 3.31 provides an illustration of the break-off test.

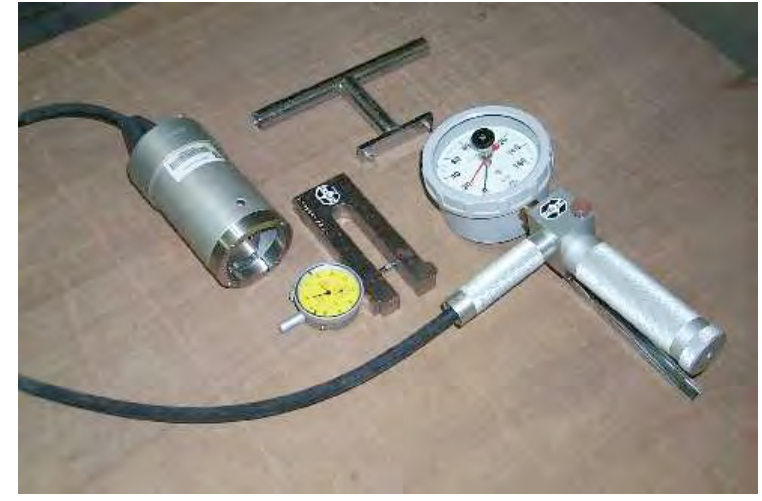

(a) Break-off test fixture.

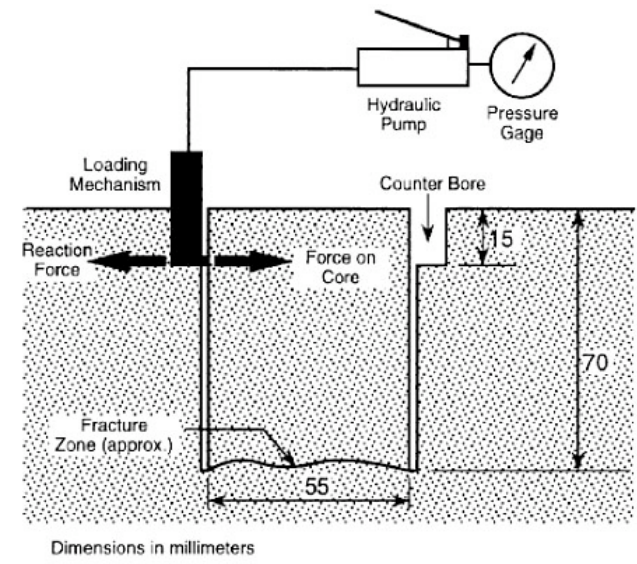

(b) Schematic of test method.

Figure 3.31 Break-off test.

Source: (a) School of Civil \& Environmental Engineering, Nanyang Technological University, Republic of Singapore (http://www.ntu.edu.sg/home/cchtui/index.htm).

(b) J.H. Bungey, Testing of Concrete in Structures, Third Edition, Surrey University Press, London, United Kingdom, 1996.

\subsubsection{Core Testing}

Removal and evaluation of concrete core samples from structures provides a direct method for examination of the concrete. Requirements for obtaining concrete samples to provide a sufficient number of specimens for statistical evaluations are generally described in national codes and standards for building and construction (3.82). When cores are removed from areas exhibiting distress, strength tests and petrographic studies (discussed later in this section) can be used to investigate the cause and extent of deterioration. Other applications of concrete cores include calibrations of nondestructive testing devices, and down-hole cameras can be used to examine the interior of the structure in locations where concrete cores were removed. Primary limitations of the method are with respect to the number of samples that must be removed to meet requirements related to ensuring that the probability of 
obtaining a strength less than desired is below a certain level, the results can be influenced by several factors (e.g., aggregate size, core diameter and slenderness ratio), and areas where cores are removed may require repair. Figure 3.32 illustrates obtaining and testing of a core sample. . The coefficient of variation for this test using standard size cores is about $10 \%$ with an accuracy of strength prediction on the order of $\pm 10 \%$ (3.67).

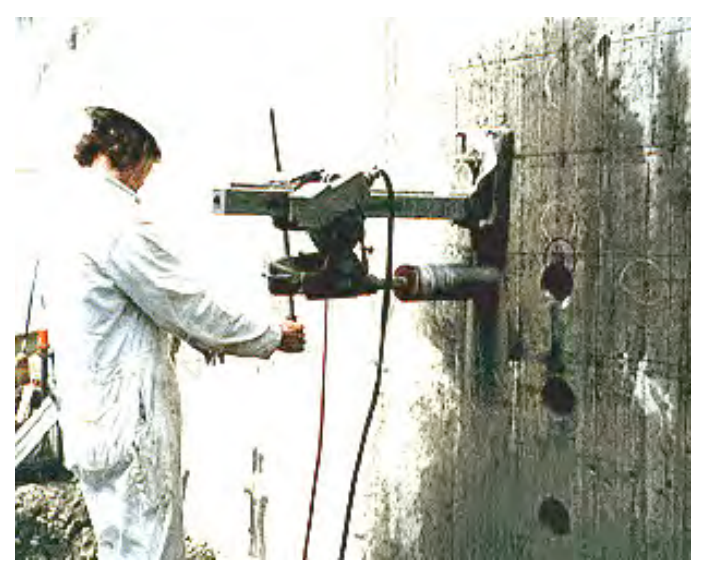

(a) Obtaining concrete core.

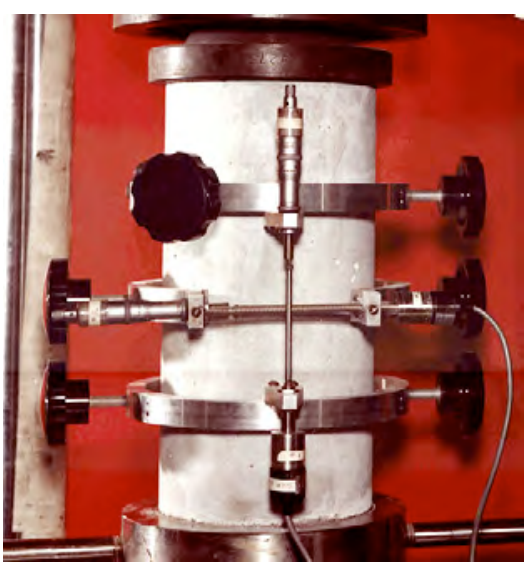

(b) Concrete cylinder test.

Figure 3.32 Obtaining and testing concrete core sample.

\subsubsection{Probe Penetration}

Probe penetration tests estimate concrete compressive strength, uniformity, or general quality through measurements of the resistance of concrete to penetration of a steel probe that is driven by a given amount of energy (3.83). Compressive strength is determined by using calibration curves. The shallower the depth of penetration, the stronger the concrete. Advantages of the method are that it is relatively simple to operate and the results correlate fairly well to concrete compressive strength. Primary limitations of this method are that the thickness of the specimen to be tested has to be at least three times the depth of the penetration, the method should not be applied within about $200 \mathrm{~mm}$ of specimen edges or other tests, and aggregate size and hardness influence results. Steel reinforcement must be avoided. Accuracy of test method is on order of $\pm 20 \%$ with a coefficient of variation of about 5\% (3.84). Figure 3.33 illustrates application of the Windsor probe.

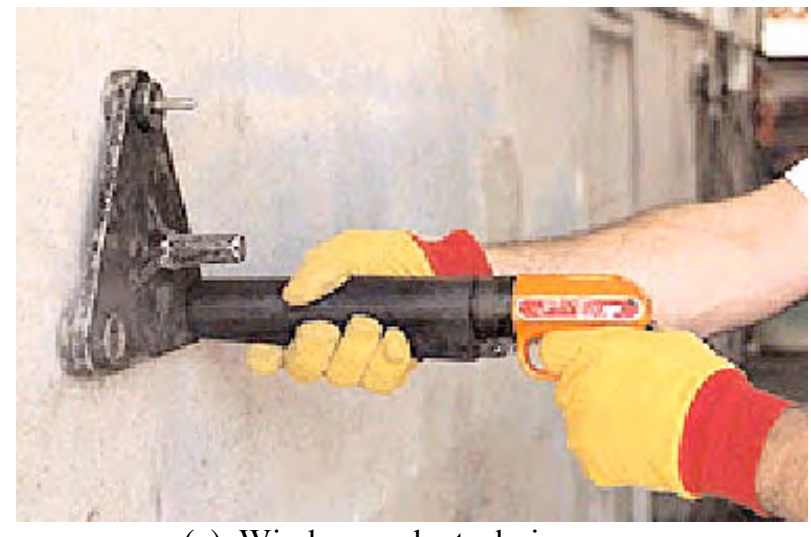

(a) Windsor probe technique.

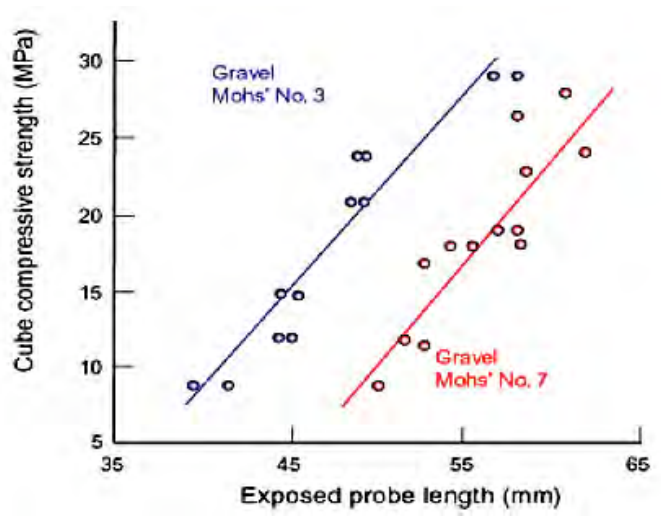

(b) Example of compressive strength as a function of exposed probe.

Figure 3.33 Windsor probe test.

Source: (a) Cement Association of Canada, Ottawa, Ontario, Canada (www.cement.ca/cement.nsf).

(b) P.K. Mehta and P. Monteiro, Concrete - Microstructure, Properties, and Materials, $3^{\text {rd }}$ Edition, McGraw Hill Companies, Inc., New York, New York, 2006. 


\subsubsection{Pull-Out Test}

Originally known as cast-in-place pull-out, this test is performed by using a hydraulic device to pull an embedded metallic insert with an enlarged head from concrete. The concrete compressive strength is related to the pull-out force through calibration curves. Failure involves the fracture, and often removal, of an approximately cone-shaped portion of the concrete. Recent developments have eliminated the requirement that the pullout inserts be cast into the specimen. Several forms of the test exist: internal fracture test, LOK-test, and CAPO test. The internal fracture test involves drilling a hole about 30-35- $\mathrm{mm}$ deep into the concrete, tapping a 6-mm wedge anchor bolt with expanding sleeve into the hole until the sleeve is $20 \mathrm{~mm}$ below the concrete surface, and loading the bolt at a standard rate against a reaction ring until the load required to fracture the concrete is achieved (3.10). Calibration charts are used to relate force to compressive strength. The LOK-test was developed in Denmark to estimate the effects of workmanship in addition to the potential strength as measured by cylinders or cubes (3.85). An insert consisting of a steel sleeve that is attached to a $25-\mathrm{mm}$ diameter, $8-\mathrm{mm}$ thick anchor plate located at a depth of $25 \mathrm{~mm}$ below the concrete surface is cast into the concrete. The estimated concrete cube or cylinder compressive strength is obtained through calibration charts that utilize the force required to cause failure by pulling the disk out of the concrete. The CAPO-test was developed as a version of the Lok-test that can be applied to existing concrete (3.10,3.85). The procedure consists of drilling a $45-\mathrm{mm}$ deep, $18-\mathrm{mm}$ diameter hole, after which a $25-\mathrm{mm}$ groove is cut at a depth of $25 \mathrm{~mm}$ using a portable milling machine. An expanding ring insert is placed into the groove and expanded using a jack until pullout of the concrete occurs. Compressive strength is estimated from correlation curves. Primary limitations of the test are that the results are affected by the size of coarse aggregate, and a correlation relationship between pull-out strength and compressive strength is generally required for each application. Also some repair may be required. An ASTM standard has been developed for pull-out strength of concrete (3.86). Figures 3.34-3.36 provide illustrations of the internal fracture test, Lok-test, and CAPO test, respectively. Accuracy of the internal fracture test method is on order of $\pm 30 \%$ with a coefficient of variation of about $15 \%$; accuracy of the Lok-test is on the order of $\pm 20 \%$ with a coefficient of variation of about $8 \%$; and accuracy of CAPO test method is on order of $\pm 20 \%$ with a coefficient of variation of about $7 \%$ (3.67).

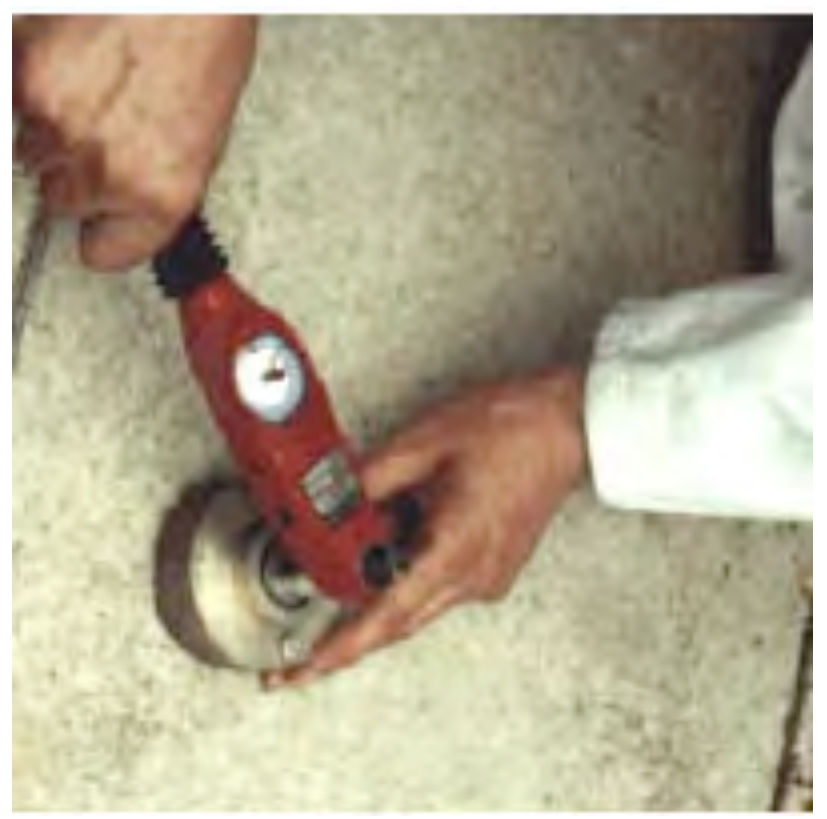

(a) Internal fracture test fixture.

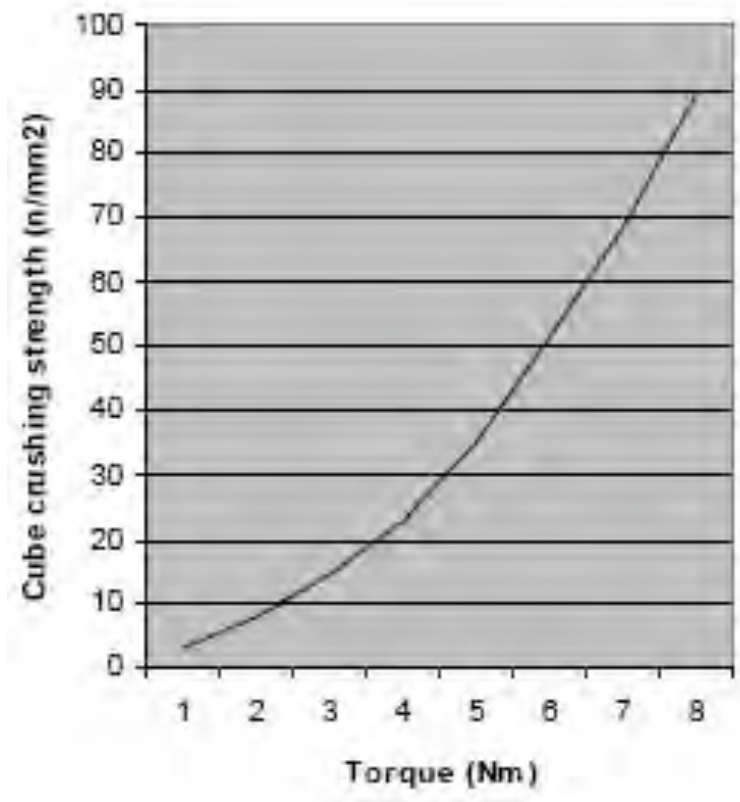

(b) Example of strength - torque relationship.

Figure 3.34 Internal-fracture test.

Source: (a) Hammond Concrete Testing \& Services, Ford, United Kingdom (http://www.hammond-concrete.co.uk/compressivestrength.php).

(b) Testconsult Ltd., Warringron, United Kingdom (http://www.testconsult.co.uk). 


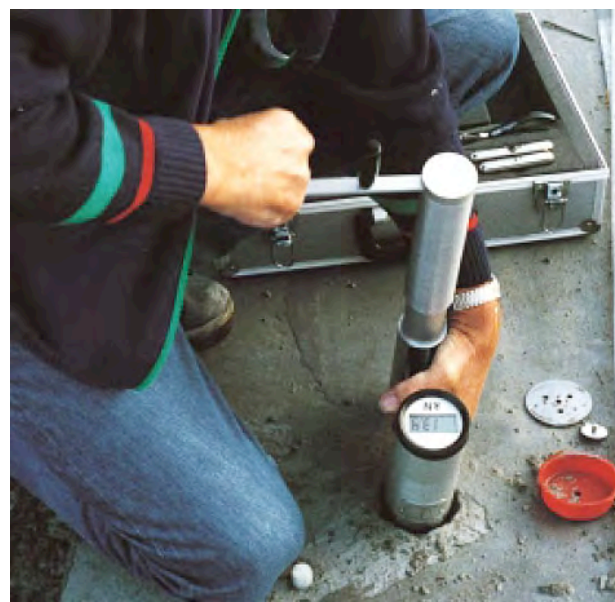

(a) LOK-test fixture.

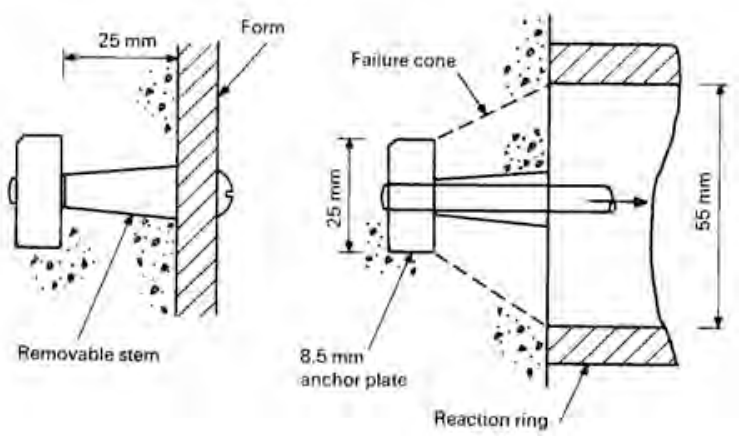

(b) Schematic of test.

Figure 3.35 LOK-test.

Source: (a) Germann Instruments, In-Situ Systems for Concrete and Reinforced Concrete Structures, Copenhagen, Denmark, 2007 (http://www.germann.org).

(b) J.H. Bungey, Testing of Concrete in Structures, Third Edition, Surrey University Press, London, United Kingdom, 1996.

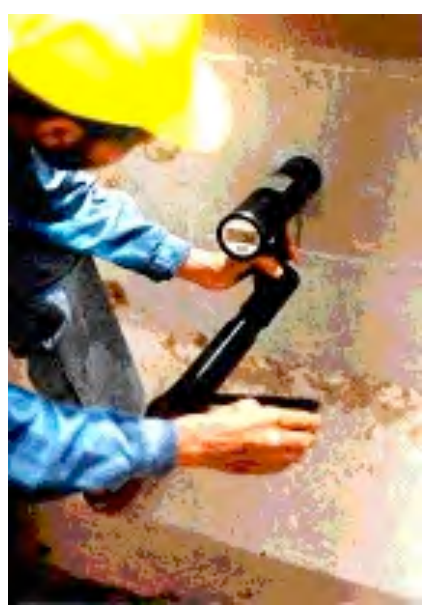

(a) CAPO test fixture.

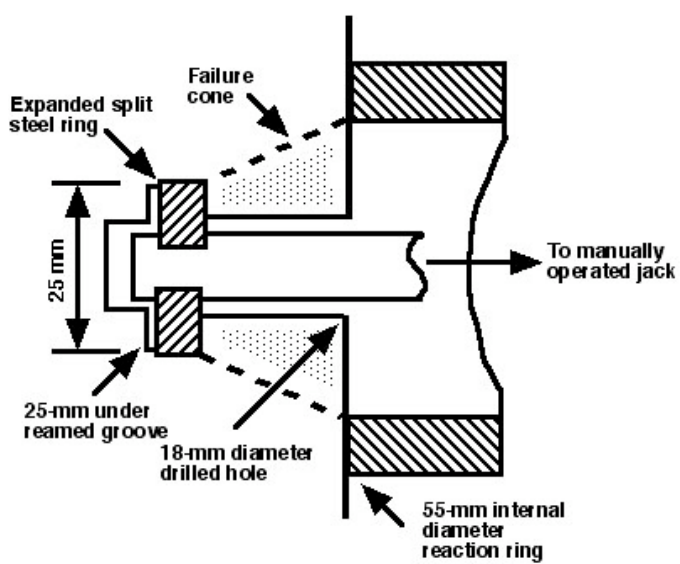

(b) Schematic of test.

Figure 3.36 CAPO test.

Source: (a) Germann Instruments, In-Situ Systems for Concrete and Reinforced Concret Structures, Copenhagen, Denmark, 2007 (http://www.germann.org).

(b) J.H. Bungey, Testing of Concrete in Structures, Third Edition, Surrey University Press, London, United Kingdom, 1996.

\subsubsection{Pull-Off Test}

The pull-off method has been developed to measure the in situ tensile strength of concrete through application of direct force. A disk is glued to the concrete surface with an epoxy resin and jacked off to measure the force necessary to pull a piece of concrete away from the surface (3.10). Partial coring to an approximate depth can be used if surface carbonation or skin effects are present. A nominal strength of the concrete is calculated on the basis of the probe diameter, and this may be converted to compressive strength using a calibration chart appropriate to the 
particular concrete and whether coring was used. In conjunction with partial coring, it is particularly suited to assess bond strength of repair overlays. Figure 3.37 provides illustrations of the pull-off test. Accuracy of the pull-off test method is on order of $\pm 15 \%$ with a coefficient of variation of about $10 \%$ (3.67).

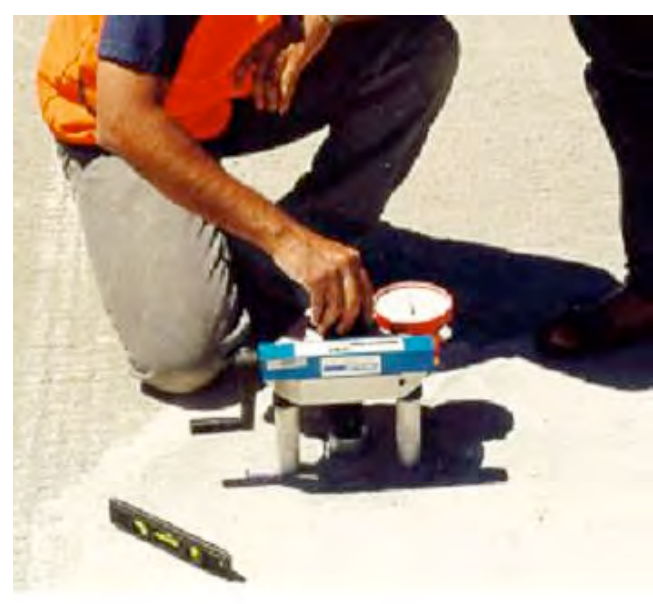

(a) Pull-off test.

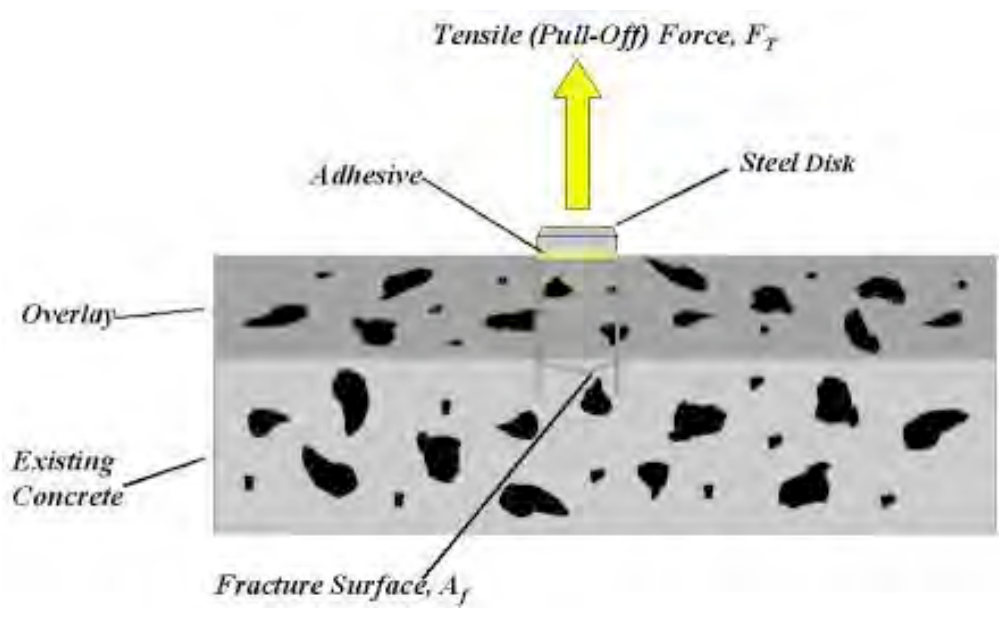

(b) Schematic of test to determine bond strength of overlay.

Figure 3.37 Pull-off test.

Source: Mobile Concrete Laboratory Projects 9904 SD Tensile Bond Strength of a High Performance Concrete Bridge Deck Overlay, U.S. Department of Transportation, Federal Highway Administration, McLean, Virginia, 1999. (http://www.fhwa.dot.gov/pavement/concrete/mcI9904.cfm).

\subsubsection{Chemical Analysis}

Chemical analysis can be utilized to identify the causes of deterioration such as due to chlorides, carbonation, alkaliaggregate reactions, or sulfate attack. Basic procedures for chemical analysis are covered by standards such as those provided by the American Society for Testing and Materials. Chemical analysis of concrete will generally require use of specialized laboratory facilities and an experienced concrete analyst. The most likely sources of lack of precision of results are: aggregate contributions, unusual and unknown cement composition, chemical attack, extraneous materials, and inadequate sampling procedures (3.67). In addition to the items discussed below, chemical analysis is useful for identifying cement type and content, aggregate type and gradation, and original water content.

\section{Chloride-Ion Content}

In good-quality, well-compacted concrete, reinforcing steel with adequate cover should not be susceptible to corrosion because the highly alkaline conditions present within the concrete $(\mathrm{pH}>12)$ causes a passive iron oxide film (gamma $\mathrm{Fe}_{2} \mathrm{O}_{3}$ ) to form on the surface (i.e., metallic iron will not be available for anodic activity). Chloride ions, however, that may be present in the concrete mix as an admixture, absorbed from the surface, or that enter through cracks, can induce local disruption of the passive steel layer leading to pits or localized attack. The chloride ions exist in two forms - chemically bound and soluble in concrete pore water. Determination of the concrete chloride-ion content therefore is an important aspect of the analysis of concrete structures relative to the potential for corrosion of embedded steel reinforcement. Two of the most commonly used methods for determination of chloride contents in concrete are the water-soluble and total-chloride tests $(3.87,3.88)$. The water-soluble test involves obtaining concrete samples by coring or drilling, and grinding the sample to produce a powder. The powder is boiled in water for five minutes and soaked for twenty-four hours. The water is then tested for dissolved chlorides and is presented as a percentage of the cement or concrete. The water-soluble chloride test measures only free ions soluble in the pore water. These ions are linked to initiation of corrosion. However, the water-soluble chloride test is not very accurate or repeatable, so the total-chloride test is normally used (3.89). The total-chloride test is an acid-soluble test and involves digesting a ground sample of hardened concrete in nitric acid. The solution is then tested for chloride content and is presented as a percentage by weight of the material being analyzed. The acid- 
soluble test measures the sum total of all chemically bound and free chloride ions in concrete. Results of chloride content analysis are reported as either percentage chloride by weight of concrete, parts per million of chloride ions, percentage chloride per weight of cement, or weight of chloride per volume of concrete. Other methods used to determine the concentration of chloride ion in concrete include x-ray fluorescence, visible spectrophotometry, atomic absorption spectrophotometry, neutron activation analysis, potentiometric titration, potentiometry by standard additions, ion chromatography, Quantab chloride titrator strips, laser-induced breakdown spectroscopy (LIBS), and measurements of the speed of propagation and damping characteristics of electromagnetic waves in concrete $(3.10,3.90$ - 3.93). Primary limitations of these methods are that they may require coring or drilling to obtain samples at locations in a structure where chloride ion contents are desired, and the chloride content reported includes chlorides that were present in the concrete mix constituents. One technique to determine the original amount of chlorides that were present in the mix is to obtain (if possible) a baseline for the chloride ion content in an area of the structure where chlorides from external sources are known not to be present. Figure 3.38 presents use of LIBS to determine chloride content in a structure. Additional results presenting LIBS determination of chloride profiles and the LIBS experimental setup were provided previously in Figures 3.30c and 3.29b, respectively.

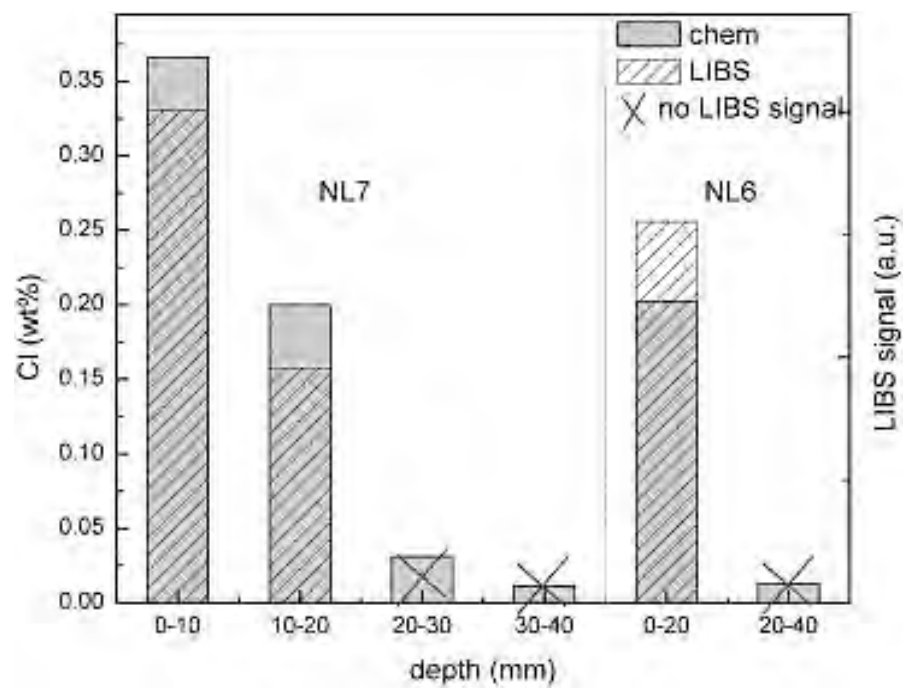

Figure 3.38 Comparison of LIBS results with those from standard chemical analysis.

Source: G. Wilsch, F. Weritz, D. Schaurich, and H. Wiggenhauser, "Determination of Chloride Content in Concrete Structures Using Laser-Induced Breakdown Spectroscopy," Construction and Building Materials 19(10), pp. 724-730, December 2005.

\section{Carbonation Depth}

Although carbonation has an initial effect of increased compressive strength, modulus of elasticity, surface hardness, and resistance to frost and sulfate attack, it reduces the concrete alkalinity which leads to steel reinforcement corrosion. Depth of carbonation can be easily determined either in situ or in a laboratory by treating a freshly broken concrete surface with phenolphthalein. The carbonated portion will be uncolored. Periodic determinations can be used to establish the rate of penetration. Incrementally drilled powder samples also can be extracted and sprayed with phenolphthalein. Presence of carbonation can also be assessed by acid etching (3.94) or microscopic analysis of thin sections cut from the concrete (3.76,3.95). Carbonation testing often is performed in conjunction with chloride-ion content determinations. The primary limitation of this method is that it requires exposure of a fresh concrete surface for each test. Figure 3.39 shows the phenolphthalein reaction with carbonated concrete and results of a depth of carbonation survey versus age for a building (results indicate carbonation depth cannot always be predicted based on concrete age). Assessment of the carbonation front can be determined within $\pm 5 \mathrm{~mm}$ on a single reading or to $95 \%$ confidence limits of $\pm 2 \mathrm{~mm}$ based on five readings (3.67). 


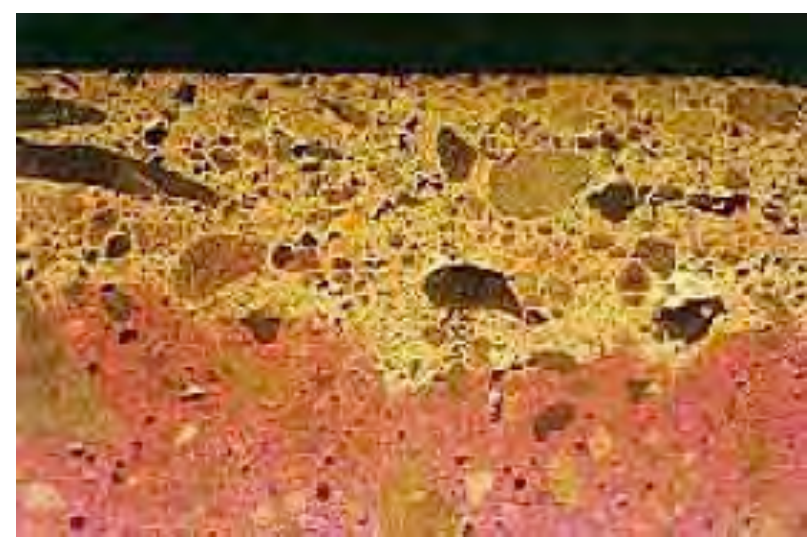

(a) Phenolphtalein reaction with carbonated concrete (pink = uncarbonated, carbonated does not stain).

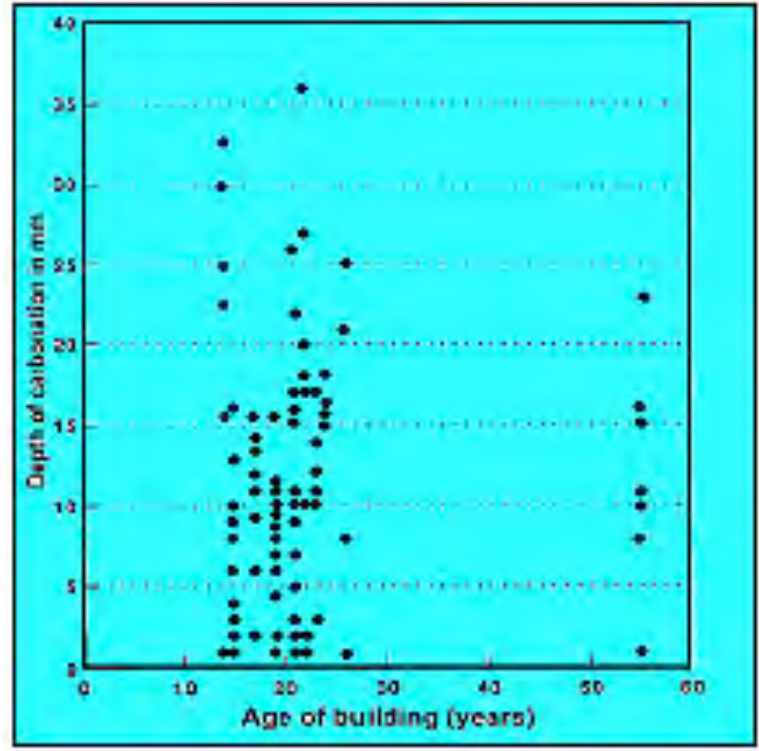

(b) Depth of carbonation versus age of concrete.

Figure 3.39 Carbonation of concrete.

Source: (a) H.N. Walker, D.S. Lane, and P.E. Stutzman, Petrographic Methods of Examining Hardened Concrete: A Petrographic Manual. FHWA-HRT-04-150, U.S. Department of Transportation, Federal Highway Administration, McLean, Virginia, July 2006.

(b) TESTCONSULT, "Structures Data Sheet 5 - Carbonation of Concrete," Warrington, United Kingdom, 2007 (www.testconsult.co.uk/library.htm).

\section{$\underline{\text { Alkali-Aggregate Reactions }}$}

Expansion and cracking, leading to loss of strength, stiffness, and durability of concrete can result from chemical reactions involving alkali ions from the Portland cement, calcium and hydroxyl ions, and certain siliceous constituents in aggregates to form a calcium alkali-silicate gel. ${ }^{+}$This gel takes up pore solution water due to forces of attraction between the polar water molecules and the alkali-silicate ions and expands, which can disrupt the concrete. Figure 3.40 presents the gel resulting from alkali-aggregate reaction (AAR) that causes expansion and cracking, and a representation of cracking patterns that can develop in concrete due to AAR. Visual examination is a critical part in the field diagnosis of alkali-silica reactions in concrete structures. Key features to address include: environmental conditions, nature and extent of cracking, popouts, movements, displacements and deformations, surface discoloration, and surface deposits (3.97). Cores can be obtained in suspect areas for petrographic studies and mechanical testing. A standard exists for rapid identification of alkali-silica reactions (3.98) and two tests are available for assessing the potential presence of alkali-silica reactivity: one for sodium using uranyl acetate solution (3.99) and the other for potassium using a sodium cobaltinitrite solution (3.100). The uranyl acetate test uses the principal of ultraviolet fluorescence of uranyl ion. The sodium cobaltinitrite solution has a strong yellow color in normal light. Figure 3.41 presents examples of application of these solutions to freshly broken concrete surfaces. These tests serve as ancillary to petrographic examinations as positive indications in these tests merely signify the presence of the particular ion in an exchangeable form in the substance being tested (3.101). Alkali-silicate gel morphology can be determined through scanning electron microscope and energy dispersive x-ray analysis (3.102). As moisture is required for alkali-aggregate reactions, determination of moisture content can be an important

\footnotetext{
${ }^{+}$Expansion reactions also can occur as a result of alkali-carbonate reactions (i.e., dedolomitization). A distinguishing feature that differentiates alkali-carbonate reaction from alkali-silica reaction is the lack of a silica gel exudation at cracks (3.96).
} 
method for determination of occurrence (or potential occurrence) of alkali-aggregate reactions, however, measurement of internal moisture in concrete is difficult. Techniques for moisture measurement in concrete were discussed in Section 3.1.1.9.

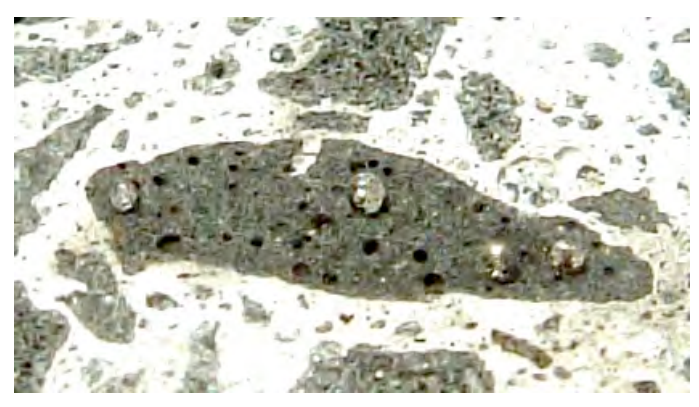

(a) Droplets of alkali gel emerging from porous basaltic aggregate.

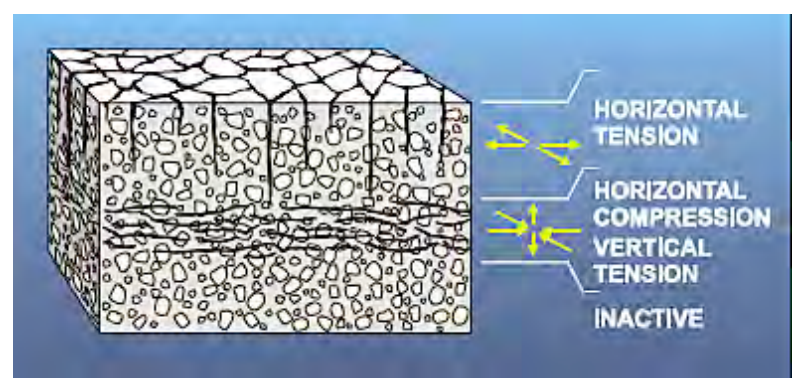

(b) Idealized sketch of cracking pattern in concrete mass caused by internal expansion resulting from AAR.

Figure 3.40 Alkali-silica reactivity.

Source: (a) B.J. Wigum, V.D. Björnsdóttir, H. Ólafsson, and K. Iversen, “Alkali Aggregate Reaction in Iceland New Test Methods,” Report VH 2007-036, VGK HÖNNUM Consulting Engineers, Reykjavik, Iceland, March 2007.

(b) H.N. Walker, D.S. Lane, and P.E. Stutzman, Petrographic Methods of Examining Hardened Concrete: A Petrographic Manual. FHWA-HRT-04-150, U.S. Department of Transportation, Federal Highway Administration, McLean, Virginia, July 2006.

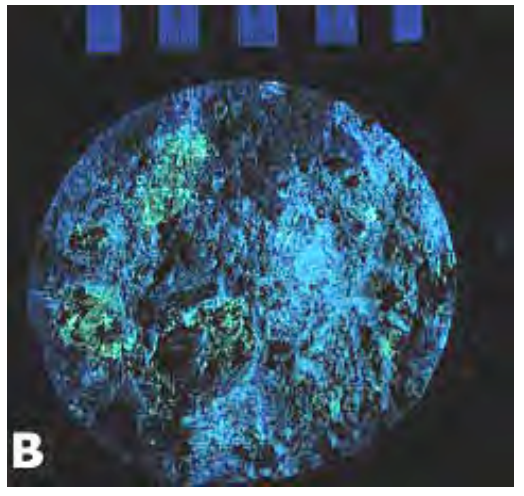

(a) Specimen treated with uranyl acetate: ultraviolet illumination in darkroom causes silica gel to fluoresce.

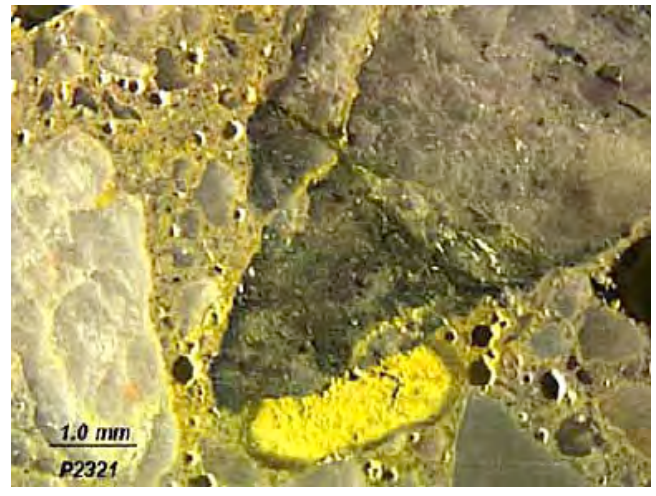

(b) Specimen treated with sodium cobaltinitrite: potassium-bearing compounds are yellow.

Figure 3.41 Chemical detection of alkali-silica reactivity.

Source: H.N. Walker, D.S. Lane, and P.E. Stutzman, Petrographic Methods of Examining Hardened Concrete: A Petrographic Manual. FHWA-HRT-04-150, U.S. Department of Transportation, Federal Highway Administration, McLean, Virginia, July 2006.

\section{Sulfate Attack}

All sulfates are potentially harmful to concrete. Sulfate attack is caused by exposure of concrete products or structures to an excessive amount of sulfate from internal or external sources. The degree of sulfate attack depends on water penetration, the sulfate salt and its concentration and type, the means by which the salt develops in the concrete (e.g., is it rising and drying causing crystallization), and the chemistry of the binder present in the concrete. Examples of laboratory techniques for identification of the presence of sulfates include chemical analysis, optical 
microscopy, scanning electron microscopy, electron probe microanalysis, differential thermal analysis, and x-ray powder diffraction. Sulfate compounds often exist as cryptocrystalline clear to white secondary deposits in voids or cracks and can be distinguished using a barium chloride-potassium permanganate solution (3.103). If sulfate ions are present, $\mathrm{BaSO}_{4}$ will precipitate trapping permanganate in the crystal structure, thus staining purple as shown in Figure 3.42 .

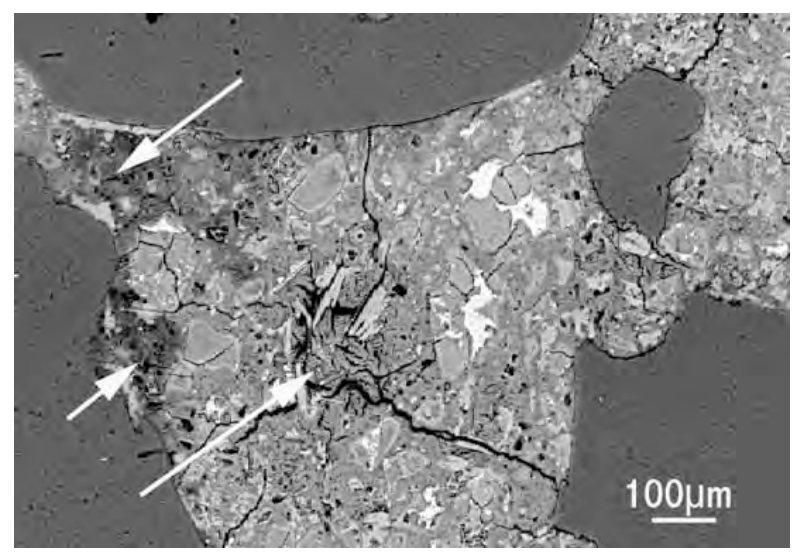

(a) Scanning electron microscope image of sulfate attack in concrete where ettringite (arrows) has replaced some of the calcium silicate hydrate in the cement paste.

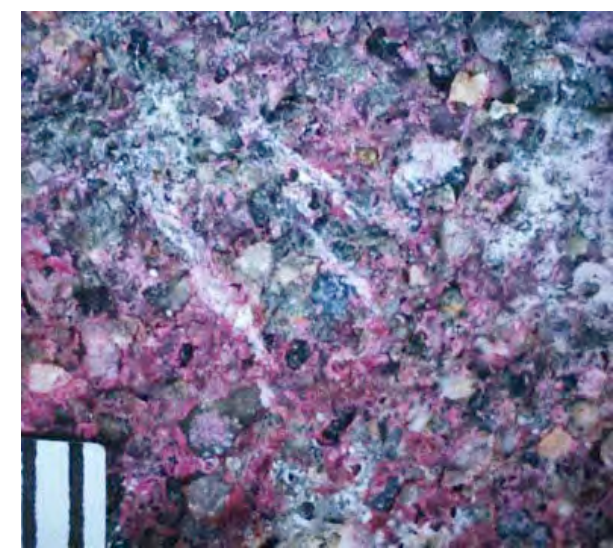

(b) Fractured surface of concrete treated with $\mathrm{BaCl}$ $\mathrm{KMnO}_{4}$ (secondary deposits containing sulfate are stained pink).

Figure 3.42 Sulfate attack in concrete.

Source: (a) Sandberg Laboratories LLP, London, United Kingdom (http://www.sandberg.co.uk/labs/cm_sulphate.php)

(b) H.N. Walker, D.S. Lane, and P.E. Stutzman, Petrographic Methods of Examining Hardened Concrete: A Petrographic Manual. FHWA-HRT-04-150, U.S. Department of Transportation, Federal Highway Administration, McLean, Virginia, July 2006.

\subsubsection{Petrography}

Petrographic examinations of samples of hardened concrete removed from existing concrete structures can provide valuable information for use in an aging management program. Petrographic methods combine inspection with the unaided eye and microscopic examinations using stero and metallographic microscopes. Several purposes for which petrographic examinations of these structures may be conducted include: detailed determination of the condition of the concrete in the structure; determination of causes of inferior quality, distress, or deterioration; determination of whether the concrete in the structure was or was not as specified; description of the cementitious materials matrix (e.g., kind of binder, degree of hydration, nature of hydration products, and presence of mineral admixtures); determination of the presence of alkali-aggregate reactions; determination if the concrete has been subjected to chemical attack or early freezing; determination of the nature of the air void system; and survey of the structure relative to its safety (3.94). Although approximate water-to-cementitious materials ratios and cement contents can be estimated, more accurate values require applications such as chemical, x-ray diffraction analysis, or scanning electron microscopy techniques. The primary disadvantage of petrographic examinations is that they require removal of samples from the structure for test and evaluation. Figure 3.43 presents a flow chart of the petrographic examination process and its application to determination of air void content in hardened concrete. More detailed information on petrographic methods for examining hardened concrete is available (3.101).

\subsubsection{Combined Methods}

While no single nondestructive examination method may be entirely satisfactory for predicting the strength or quality of a composite material such as concrete, combinations of methods may provide more definitive information. Investigators since the 1950's and 1960's have evaluated use of a combination of nondestructive examination methods to improve the reliability and precision of evaluation of a property of concrete (e.g., strength or elastic 


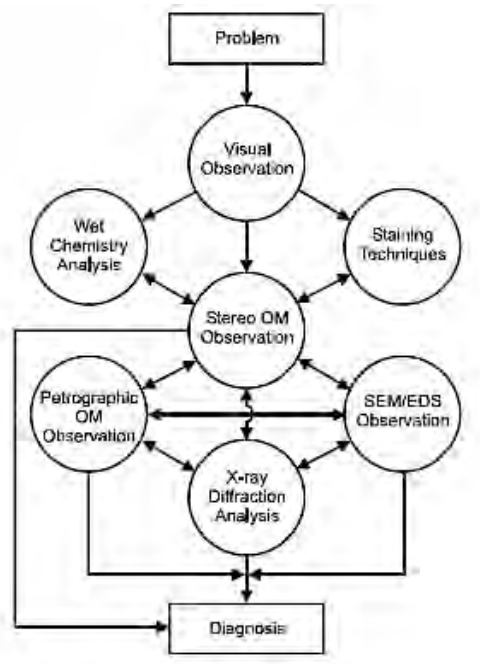

(a) Flow chart of petrographic examination process.

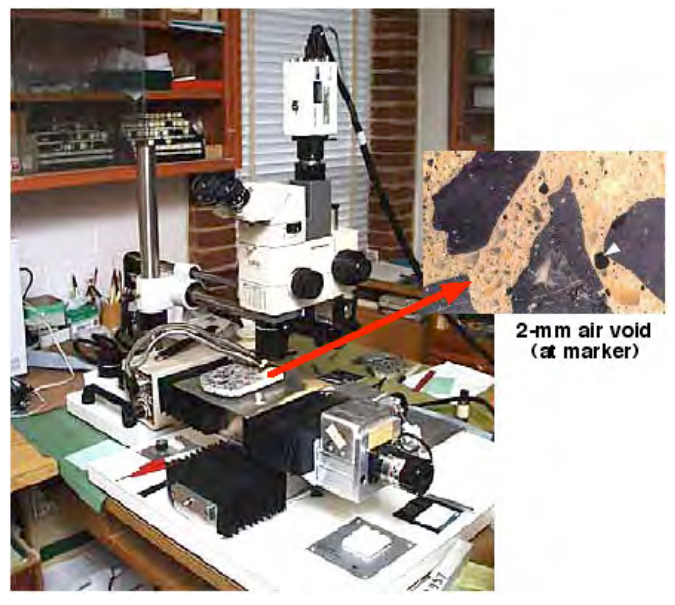

(b) Linear traverse equipment for determining air-void parameters.

Figure 3.43 Petrographic examination of concrete.

Source: H.N. Walker, D.S. Lane, and P.E. Stutzman, Petrographic Methods of Examining Hardened Concrete: A Petrographic Manual. FHWA-HRT-04-150, U.S. Department of Transportation, Federal Highway Administration, McLean, Virginia, July 2006.

modulus) (3.104). Use of combined ultrasonic and rebound hammer methods for determining concrete strength has been a frequent application of combined methods (3.105). In this approach measurements of ultrasonic pulse velocity and rebound hammer are input into a previously derived regression equation to predict compressive strength (3.106). Figure 3.44 presents an example of a correlation curve derived from pulse velocity and rebound hammer results to indicate concrete compressive strength (3.107). When concrete composition is known and test specimen cores are available for calibration purposes an accuracy within 10 to $15 \%$ is achievable. Other combinations include ultrasonic pulse velocity and measurement of damping constant of concrete (3.108), ultrasonic pulse velocity and pulse attenuation methods (3.109), and radar and ultrasonic echo (3.110). With relatively recent advancements in nondestructive examination methods such as automated measurements and application of new software for data processing and visualization, the fusion, or combination, of nondestructive examination methods is receiving increased interest (3.111). Multi-laboratory projects investigating this approach have been undertaken in both Germany (3.111) and France (3.112).

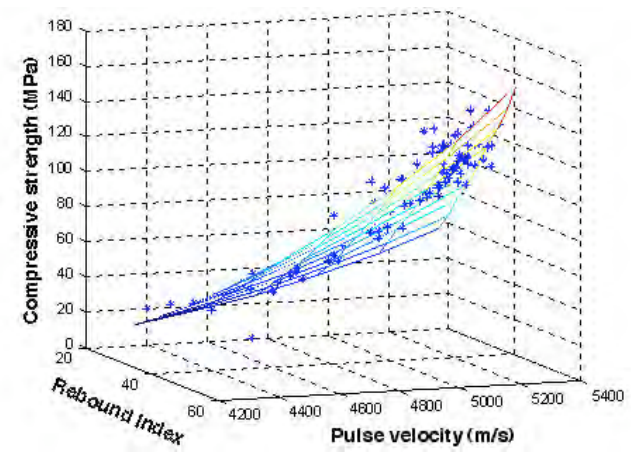

Figure 3.44 Example of correlation developed for estimating compressive strength from pulse velocity and rebound number results.

Source: G. Pascale, A. Di Leo, and V. Bonora, "Evaluation of Actual Compressive Strength of High Strength Concrete by NDT," $15^{\text {th }}$ World Conference on NDT 2000, Rome, Italy, October 16-21, 2000. 


\subsection{REINFORCING STEEL}

Corrosion of the reinforcing steel is probably the main threat to the durability of nuclear power plant reinforced concrete structures. The mechanism of corrosion in aqueous media is of electrochemical nature with the two main causes being carbonation of concrete and presence of chlorides (3.113). Identification and mitigation of corrosion occurrence are important to structural performance because corrosion can cause a loss of structural capacity due to reduction in steel reinforcement cross section, reduction of bond strength between the steel reinforcement and concrete, and loss of concrete integrity resulting from cracking and/or spalling of cover concrete.

Assessments of mild steel reinforcing are primarily related to determining its characteristics (e.g., location and size) and evaluating corrosion occurrence. There are a number of techniques that can be used to carry out a condition survey of reinforced concrete structures to assess the potential for occurrence of corrosion (3.114). Table 3.7 presents a summary of the more widely used techniques for conduct of a condition survey of reinforced concrete structures suffering from corrosion (3.115). In addition to identification of the technique, information is provided in the table on what the technique detects, user requirements, and its approximate application speed. Each of these techniques, whether used either in isolation or in combination, provide an assessment of the structure at the time of the measurement. Condition assessments conducted over a period of time or corrosion monitoring is required to provide an indication of the changing conditions of the structure.

Table 3.7 Typical techniques used for corrosion assessment of reinforced concrete

\begin{tabular}{|l|l|l|l|}
\hline \multicolumn{1}{|c|}{ Technique } & \multicolumn{1}{c|}{ Item detected } & \multicolumn{1}{c|}{ User requirements } & \multicolumn{1}{c|}{ Application speed } \\
\hline \hline Visual & Surface defects & General & $1 \mathrm{~m}^{2} \mathrm{~s}^{-1}$ \\
\hline Hammer/chain drag & Delaminations & General & $0.1 \mathrm{~m}^{2} \mathrm{~s}^{-1}$ \\
\hline Covermeter & Rebar depth and size & General & 1 reading in 5 min \\
\hline Phenolphthalein & Carbonation depth & General & 1 reading in 5 min \\
\hline Chloride content & Chloride-induced corrosion & General + laboratory & $\begin{array}{l}1 \text { reading in 5 min + } \\
\text { lab/site analysis }\end{array}$ \\
\hline Permeability & Diffusion rate & Corer + specialist & Coring + laboratory \\
\hline Impact/ultrasonics & Defects/concrete quality & Specialist & 1 reading in 2 min \\
\hline Petrography & Concrete properties & Corer + specialist & Coring + laboratory \\
\hline Half cell potential & Corrosion risk & General/specialist & 1 reading in 5 sec \\
\hline Linear polarization & Corrosion rate & Specialist & 1 reading in 5-30 min \\
\hline Resistivity & Concrete resistivity & General/specialist & 1 reading in 20 sec \\
\hline
\end{tabular}

Source: J.P. Broomfield, K. Davies, and K. Hladky, "The Use of Permanent Corrosion Monitoring in New and Existing Reinforced Concrete Structures," Cement and Concrete Composites 24(1), Elsevier Science Ltd., 2002.

Several of the methods identified in Table 3.7 have been addressed previously. Only techniques related to evaluation of the occurrence of corrosion are addressed in this section and include: half-cell potential measurements, surface potential measurements, electrical resistivity measurements, polarization methods, Tafel extrapolation, electrochemical impedance spectroscopy, and embeddable corrosion monitoring sensors (3.116).

\subsubsection{Half-Cell Potential}

Electrical methods are used to evaluate corrosion activity of steel reinforcement $(3.117,3.118)$. When a bar is corroding, electrons flow through the bar and ions flow through the concrete. As a result the corrosion potential of the steel reinforcement will shift in the negative direction if the surface changes from the active to the passive state (3.119). When the bar is not corroding, there is no flow of electrons and ions. The half-cell potential method is used to detect this negative charge and thereby provide an indication of corrosion activity. Figure 3.45a provides a schematic illustrating the basics of the half-cell potential measurement technique. The rate of corrosion depends on the potential difference between the anode and cathode which is affected by a number of factors such as listed in Figure $3.45 \mathrm{~b}$. Potential measurements at a number of locations on the concrete surface using a reference half cell 


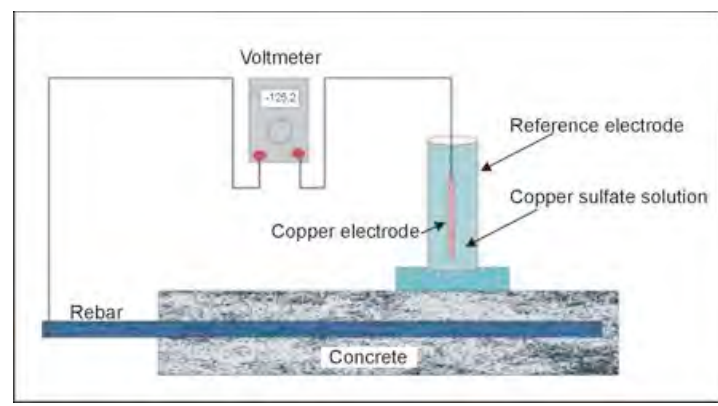

(a) Basics of half-cell potential measurement technique.

\begin{tabular}{|c|c|c|c|}
\hline Situation & $\begin{array}{l}\text { Half-cell } \\
\text { potential shifi }\end{array}$ & $\begin{array}{l}\text { Corrosion of steel } \\
\text { reinforcerment }\end{array}$ & $\begin{array}{l}\text { Applicable } \\
\text { to ASTM CB76 }\end{array}$ \\
\hline $\begin{array}{l}\text { Decrease in oxyger } \\
\text { concentratlon }\end{array}$ & to negative & may not increase & no \\
\hline Carbonatlon/decrease in $\mathrm{pH}$ & to negallive & Increase & yes \\
\hline $\begin{array}{l}\text { Increase in chlorlde } \\
\text { concentration }\end{array}$ & to negartive & tncrease & yes \\
\hline Anodic corrceston inhlbitor & to positive & decrease & yes \\
\hline Cathodlc corroslon Intibitor & to negatlve & decrease & no \\
\hline Milxed corroston Intibitor & to positive or negative & decrease & no \\
\hline Epoxy-coated rebar & to posittive & not related & no \\
\hline Galvanized rebar & to negallve & not related & по \\
\hline Dense concrete cover & to negattve & not related & no \\
\hline Concrete reslstance & to positive & not related & no \\
\hline Dry concrete & to positive & not related & no \\
\hline Reference electrode position & to positive & not related & no: \\
\hline Coatings and sealers & to positive & not related & nо \\
\hline Concrete repair patch & to posittive or negative & not related & no \\
\hline Cathodlc protection & to negarlve & not related & no \\
\hline Stray current & $\begin{array}{l}\text { Fluctuating between } \\
\text { posittye and negative }\end{array}$ & not related & no \\
\hline
\end{tabular}

(b) Effect of various factors on half-cell potential shift and corrosion probability.

Figure 3.45 Half-cell potential technique and factors affecting results.

Source: P. Gu and J.J. Beaudoin, "Obtaining Effective Half-Cell Potential Measurements in Reinforced Concrete Structures," Construction Technology Update No. 18, Institute for Research in Construction, National Research Council of Canada, Ottawa, July 1998.

(e.g., copper-copper sulfate) connected to the steel reinforcement are used to indicate the likelihood of corrosion occurrence (i.e., $>90 \%$ probability of no corrosion, corrosion activity is uncertain, or $>90 \%$ probability that corrosion is occurring). The surface of the concrete being investigated is usually divided into a grid system to define measurement locations. Results generally are plotted in the form of an equipotential diagram so that areas potentially exhibiting corrosion can be readily identified. Examples of a half-cell instrument and half-cell potential results are provided in Figure 3.46. Since potential criteria for corrosion likelihood are not applicable to all structures and in particular environments, potential gradients (contour map) are commonly used to indicate areas of

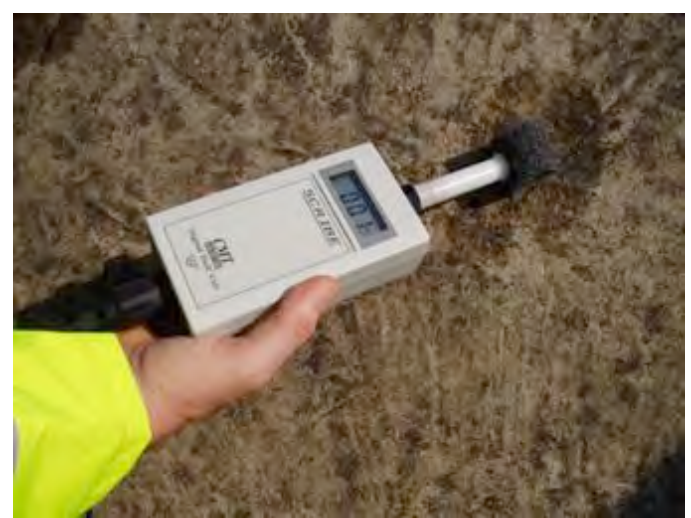

(a) Half-cell potential instrument.

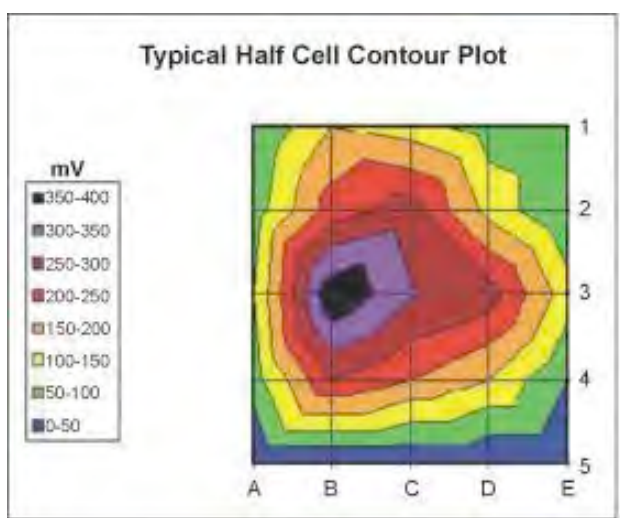

(b) Example of half-cell potential survey (corrosion is suggested at high negative voltage locations).

Figure 3.46 Half-cell potential instrument and example of results.

Source: http://www.cflhd.gov/agm/engapplications/BridgeSystemSubstructure/231DirectMeasurementMethods.htm

active corrosion (e.g., > $100 \mathrm{mV}$ warrants further investigation and > $200 \mathrm{mV}$ indicates corrosion activity) (3.118). Modified types of instrumentation, consisting of a number of half-cells mounted in parallel or on a roller bar, have been developed to accelerate the examination process. Primary limitations of this method are that neither the magnitude nor rate of corrosion are provided, surface coatings or coated steel reinforcement present problems, 
measurements are affected by temperature and moisture, electrical continuity is required, and concrete constituents can affect results (e.g., type of cement and chloride ingress). The half-cell potential method, despite its sensitivity to moisture level, is a useful indicator for locating areas on concrete surfaces where risk of reinforcement corrosion is high. It is a useful complement to other techniques in selecting test points for further analysis, such as chloride measurements. It may be used to detect adverse external effects such as leakage currents that may be detrimental to the reinforcement, or to monitor the effect of cathodic protection systems. Also, results in Sweden from potential mapping of bridge piers in a marine environment indicate that there may be a linear relationship between measured chloride content and the half-cell potential observed (3.120).

\subsubsection{Surface Potential Measurements}

While corrosion is occurring, an electric current flows between the cathode and anode through the concrete that can be detected through measurement of potential drop in the concrete (Figure 3.47). Two reference electrodes are used for surface potential measurements with one electrode remaining fixed while the other electrode is moved over the

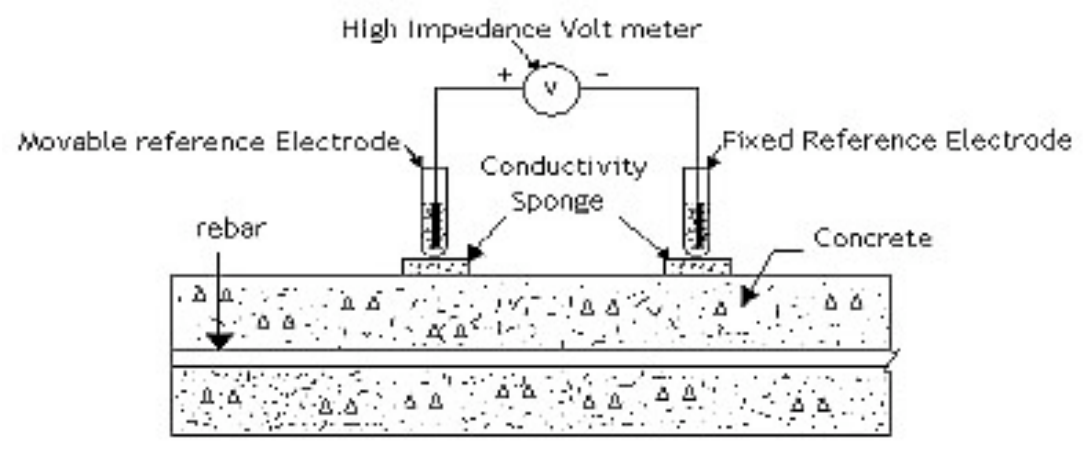

Figure 3.47 Schematic of surface potential measurement.

Source: H-W Song and V. Saraswathy, Corrosion Monitoring of Reinforced Concrete Structures - A Review," International Journal of Electrochemical Science 2, pp. 1-28, 2007.

structure according to a grid. A more positive potential reading represents an anodic area where corrosion is possible. The greater the potential difference between anodic and cathodic areas the greater the probability of corrosion (3.116). This technique differs from the half-cell technique in that an electrical connection is not required to the steel reinforcing.

\subsubsection{Electrical Resistivity Measurements}

Electrical resistivity is defined as the ratio between the applied potential and the current circulating between two electrodes providing the arrangement enables the calculation of the geometrical characteristics (3.113). The electrical resistivity provides an indirect measurement of the porosity and connectivity of the pores (e.g., measures ease with which ions migrate through concrete) (3.121). The measurement of electrical resistivity is used to identify wet areas of the concrete and thus the risk of corrosion. A highly permeable concrete will have high conductivity and low electrical resistance. Under field conditions there is a direct correlation between concrete resistivity and the rate of corrosion of steel (3.122). Conditions such as high pore water content and the presence of electrolyte salts that lead to low resistivity usually favor corrosion. Concrete resistivity can be measured using a four-point technique such as illustrated in Figure 3.48. Four equally spaced probes are installed in a straight line on the concrete to be tested with the electrode spacing equal to the depth to which measurement of the average resistivity is desired. The average resistivity is a function of the voltage drop between the center pair of probes with current flowing between the outside probes. The resistivity is then determined (e.g., in ohm-m or ohm-cm). The likelihood of corrosion is related to the value of resistivity measured (Figure 3.48b). Results may also provide an indication of concrete quality as sensed by the amount of moisture present and to evaluate other concrete characteristics such as chloride ion diffusivity $(3.123,3.124)$. Limitations of the method are that the resistivity measurements are obtained relatively close to the concrete surface, and when the electrode spacings are increased to allow evaluations at deeper concrete depths the steel reinforcement may interfere with results obtained. Figure 3.49 presents the Wenner fourpoint probe and an example of results provided. 


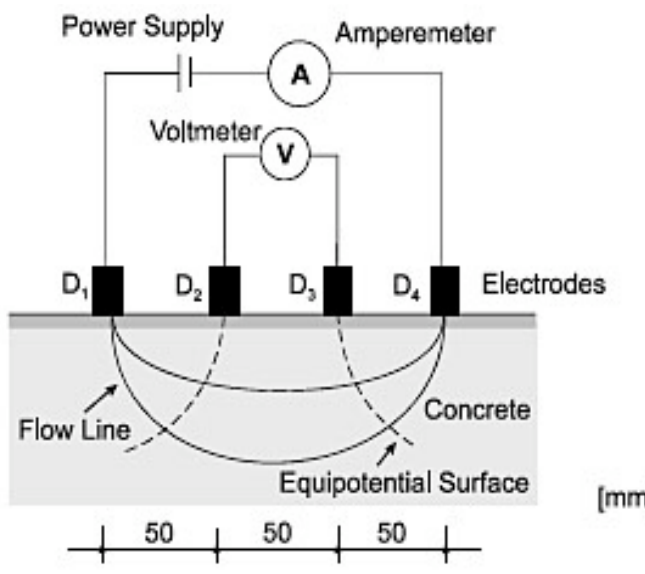

\begin{tabular}{|c|c|}
\hline Resistivity (ohm-m) & Corrosion risk \\
\hline \hline$>200$ & Negligible \\
\hline 100 to 200 & Low \\
\hline 50 to 100 & High \\
\hline$<50$ & Very high \\
\hline
\end{tabular}

(b) Example of results relating corrosion and resistivity.

(a) Four-point technique.

Figure 3.48 Electrical resistivity measurements - four point technique.

Source: (a) "Electrochemical Techniques to Detect Corrosion in Concrete Structures in Nuclear Installations," NEA/CSNI/R(2002)21, Nuclear Energy Agency, Committee on Safety of Nuclear Installations, Paris, France, July 19, 2002.

(b) CEB-192, "Diagnosis and Assessment of Concrete Structures - State-of-the-Art Report," Bulletin D’Information, Case Postale 88, CH-1015 Lausanne, Switzerland, 1989.

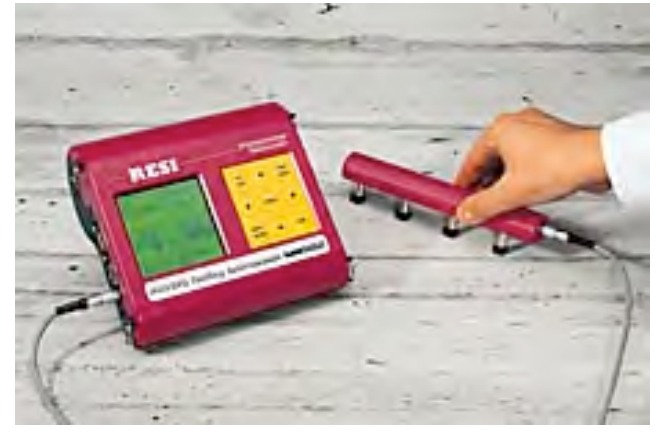

(a) Wenner four-point probe.

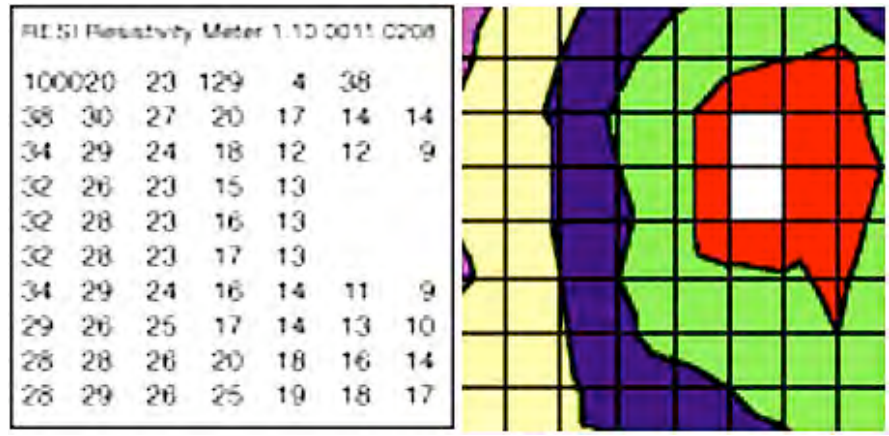

(b) Example of results obtained with Wenner four-point method

Figure 3.49 Wenner four-point probe and example of results.

Source: Proceq USA, Aliquippa, Pennsylvania (http://www.procequsa.com/products/resi/php).

\subsubsection{Linear Polarization Resistance Methods}

The polarization resistance of a steel reinforcement embedded in concrete is defined as the ratio between applied voltage $\Delta \mathrm{E}$ (shift in potential from $\mathrm{E}_{\text {corr }}$ ) and the step in current $\Delta \mathrm{I}$, when the metal is slightly polarized (about 20$50 \mathrm{mV}$ ) from its free corrosion potential, $\mathrm{E}_{\text {corr }}(3.125)$. Polarization resistance can be measured by means of alternating or direct current techniques. In the polarization resistance test the current to cause a small change in the value of the half-cell potential of the corroding bar is measured. For small perturbations about the open circuit potential, a linear relationship exists between the change in voltage and the change in current per unit area of bar surface. A relationship exists between the corrosion rate of the steel reinforcement in concrete and the polarization resistance. The corrosion rate is usually expressed as the corrosion current per unit area of bar. The instantaneous corrosion current density, $\mathrm{I}_{\text {corr }}\left(\mu \mathrm{A} / \mathrm{cm}^{2}\right)$, is obtained by dividing a constant $\mathrm{B}$ (results from a combination of anodic 
and cathodic Tafel slopes (Sec. 3.2.6)) by the polarization resistance value. Values of $\mathrm{I}_{\text {corr }}$ can be used to assess the rate of degradation of concrete structures affected by reinforcement corrosion. Guidance related to the service life of reinforcement has been developed relative to the value of $\mathrm{I}_{\text {corr }}$ and is provided in Table 3.8. It is possible to

Table 3.8 Ranges of corrosion current values related to its significance in terms of service life of reinforcement

\begin{tabular}{|c|c|c|}
\hline $\mathrm{I}_{\text {corr }}\left(\mu \mathrm{A} / \mathrm{cm}^{2}\right)$ & $\mathrm{V}_{\text {corr }}(\mathrm{mm} / \mathrm{yr})$ & Corrosion Level \\
\hline \hline$\leq 0.1$ & $\leq 0.001$ & Negligible \\
$0.1-0.5$ & $0.001-0.005$ & Low \\
$.05-1$ & $0.005-0.010$ & Moderate \\
$>1$ & $>0.010$ & High \\
\hline
\end{tabular}

Source: RILEM TC 154-EMC, "Electrochemical Techniques for Measuring Metallic Corrosion," Materials and Structures 37, pp. 623-643, November 2004.

convert the corrosion rate into the mass of steel that corrodes per unit of time (3.113). If the bar size is known, the corrosion rate can be converted to loss in diameter of the bar. However, the method cannot be simply applied to real size structures because the area polarized is unknown. This is because the applied electrical signal tends to vanish with the distance from the counter electrode rather than spread uniformly across the working electrode. If the metal is actively corroding and the polarization resistance is low, the current applied from a small counter electrode located on the concrete surface is drained very efficiently by the rebars and it tends to confine itself to a small surface area. However, if the metal is passive and polarization resistance is high the current applied tends to spread far away (e.g., $\sim 50 \mathrm{~cm}$ ) from the application point (3.113). Therefore an electrochemical method may provide reliable corrosion rates for actively corroding steel reinforcement, but difficulties are imposed in estimating the typically very low corrosion rates of passive steel reinforcement. Methods to determine the polarization resistance in large reinforced concrete structures can be classified into three groups: confinement of applied electrical signal, measurement or estimation of the lateral spreading of the electrical signal, and minimization of the effect of the lateral spreading of the electrical signal (3.113).

One of the most widely adopted solutions to limit the electrical current lines from the counter electrode to the working electrode is the modulated guard ring whereby the applied signal is confined by using a ring-shaped counter electrode surrounding the main electrode (3.126). A measurement is made using the central counter to apply a galvanostatic step, lasting 30 to 100 seconds. Then another counter current is applied from the external ring and the external current is modulated by means of two reference electrodes in order to equilibrate internal and external currents enabling a correct calculation of the polarization resistance. The electrical current field lines that originate from the central counter electrode are confined within a known area of the steel reinforcement by means of two reference electrodes placed between the central and guard electrodes in order to control the confinement by modulating the electrical current applied from the external ring. The efficiency of the confinement is continuously monitored by means of two extra reference electrodes placed between the central and external counter electrodes. Figure 3.50 presents the principle of the modulated confinement of electrical current. (3.126). The performance of the guard ring has been shown to be an improvement upon that of a single unconfined auxiliary probe. The influence of various parameters such as cover thickness on the current distribution in reinforced concrete has been investigated using a numerical technique (3.127). For example, in some cases where the concrete cover is relatively thick, confinement of the polarization area may not be achievable.

\subsubsection{Galvanostatic Pulse Technique}

The galvanostatic pulse technique is a transient polarization method working in the time domain that has been developed for in situ application and can be used for detecting corrosion in wet and anaerobic environments (3.1283.130). The method set up is similar to the half-cell potential method and involves use of a counter electrode and reference electrode that are placed on the concrete surface above the reinforcement (Figure 3.51). A short-duration anodic current pulse (typically $\sim 3 \mathrm{sec}$. duration) having an amplitude of about $0.1 \mathrm{~mA}$ is impressed galvanostatically from the counter electrode that in turn shifts the reinforcement potential with the shift recorded by a data logger (3.131). The reinforcement is polarized in the anodic direction relative to its free corrosion potential. The extent of polarization depends on the corrosion state. The reinforcement is easy to polarize in the passive state, as noted by the large difference between free corrosion and polarized potential. The difference is much smaller when corrosion 


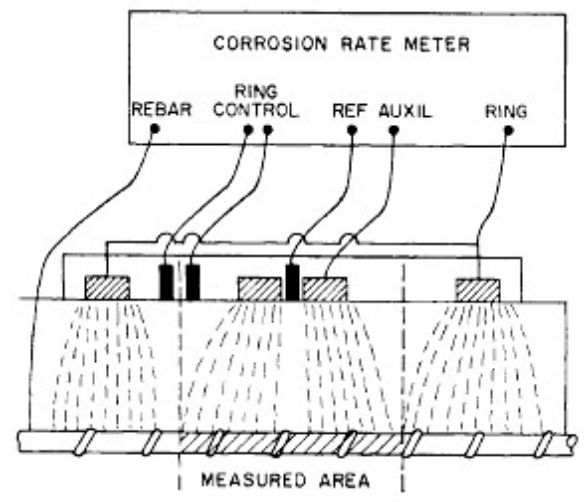

(a) Principle of modulated confinement of electrical current.

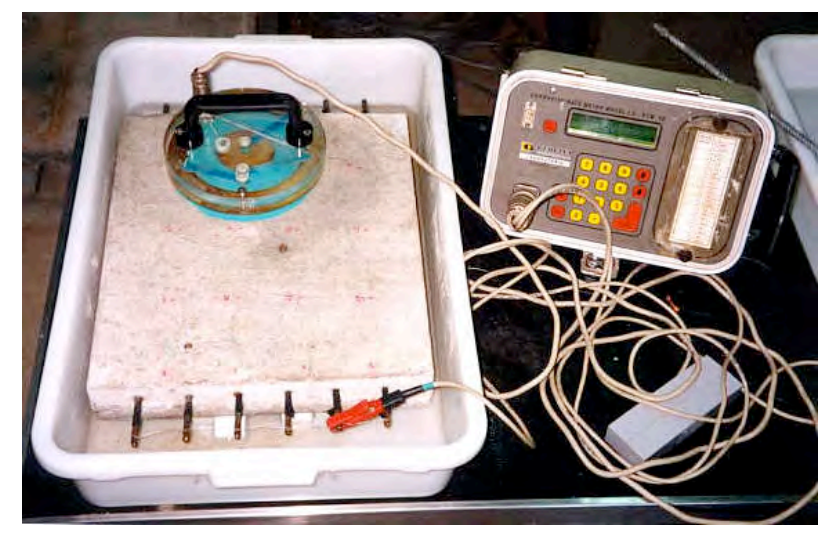

(b) Application to corrosion rate measurements.

Figure 3.50 Modulated confinement of electrical current using a guard ring approach.

Source: C. Andrade and I. Martinez, "Electrochemical Corrosion Rate Measurement Using Modulated Confinement of the Current - Calibration of this Method by Gravimetrics Losses," International Symposium on NonDestructive Testing in Civil Engineering 2003, (NDT-CE-2003), Bundesanstalt für Materialforschung und prüfung, Berlin, Germany, 2003.

is occurring. The method is superior to the half-cell potential method, in particular when testing wet concrete where there is a risk of misinterpretation of results. Together with more reliable qualitative information concerning classification of passive and corroding areas, the galvanostatic pulse technique allows quantitative information to be obtained through calculation of the corrosion current. If the area of the polarized reinforcement is known, then the corrosion current can be converted to a corrosion rate. It is possible in this way to estimate corrosion rate at the time of the measurement in the case of general corrosion, but not in the case of local pitting corrosion. The galvanostatic pulse technique measurements take considerably longer to execute than the half-cell potential measurements and require an experienced person to perform the technique.

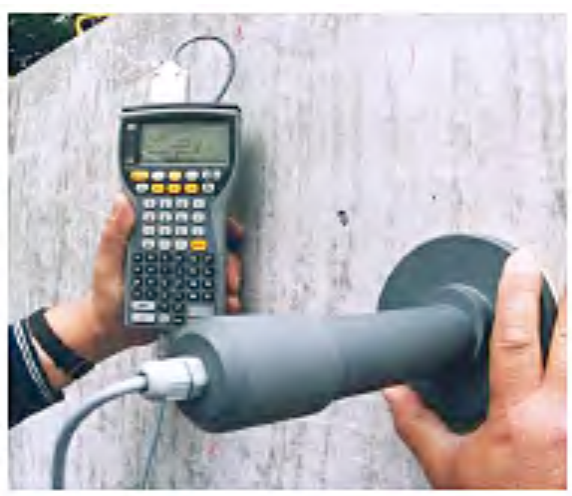

(a) GalvaPulse computer and electrodes.

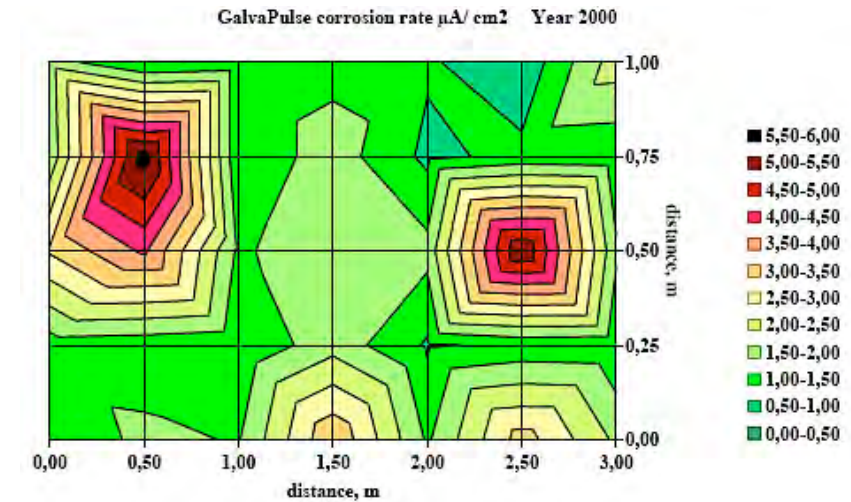

(b) Data plot showing areas (dark color) of high corrosion rate.

Figure 3.51 Galvanostatic pulse technique.

Source: (a) Non-Destructive Testing (NDT) and Examination (NDE), Brochure 2048-2-en (http://www.Force.dk), Force Technology, Brøndby, Sweden, February 16, 2007.

(b) O. Klinghoffer, T. Frølund, and E. Poulsen, "Rebar Corrosion Rate Measurements for Service Life Estimation," ACI 365, "Service Life," American Concrete Institute Fall Convention, Toronto, Canada, 2000. 


\subsubsection{Tafel Extrapolation}

The Tafel extrapolation technique is an electrochemical method for calculating corrosion rate through use of the intensity of current $\left(\mathrm{I}_{\text {corr }}\right)$ and the Tafel slopes. The Tafel extrapolation technique is based on application of either steady fixed levels of current, followed by monitoring of the potential (galvanostatic), or application of specific potential followed by monitoring of the current (potentiostatic) (3.116). This method differs from the linear polarization technique in that the change in potential is kept to less than $\pm 25 \mathrm{mV}$ for the linear polarization technique while the change in potential can go up to $\pm 250 \mathrm{mV}$ for the Tafel extrapolation technique. The Tafel slope values for the anodic and cathodic curves in the Tafel graph (Figure 3.52) are used to obtain the corrosion current which is then used to calculate the corrosion rate. The accuracy of the Tafel extrapolation technique is equal to or greater than the conventional weight loss methods, very low corrosion rates can be measured, monitoring can be continuous, and corrosion rate can be measured directly (3.116).

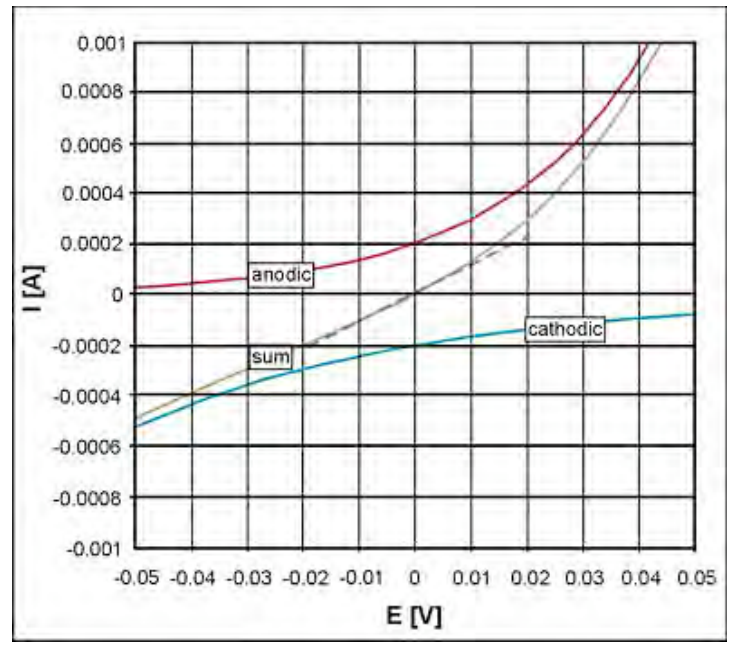

Figure 3.52 Example of Tafel graph.

Source: "Direct Measurement Methods," Federal Highway Administration, Washington, D.C. (http://www.cflhd.gov/agm/engApplications/BridgeSystemSubstructure/231DirectMeasurementMethods.htm).

\subsubsection{Electrochemical Impedance Spectroscopy}

A.C. electrochemical impedance spectroscopy is a technique for characterizing the frequency-dependent electrical behavior of cement-based materials and interfaces. It has been investigated as a tool for quantifying corrosion of steel rebars embedded in concrete $(3.132,3.133)$ and chloride diffusivity in concrete (3.134). The A.C. impedance technique enables information to be obtained about the mechanisms occurring within the system by applying a perturbation to the reinforcing steel and measuring the current flow and the shift in phase of the resulting current (3.135). Typically an alternating current of about 10 to $20 \mathrm{mV}$ is applied to the steel reinforcement and the resultant current and phase angle measured for various frequencies. The response to an A.C. input is a complex impedance that has both real (resistive) and imaginary (capacitive or inductive) components (3.116). By studying the variation of the impedance with frequency an equivalent electrical circuit can be determined that would provide the same response as the corrosion system studied (3.119). The A.C. electrochemical impedance spectroscopy method can provide more information than the linear polarization resistance methods, can estimate a steady-state corrosion rate from the impedance spectrum, and the method can be used to study the effects of corrosion inhibitors, coatings, and pitting corrosion (3.63). A.C. Impedance spectroscopy, however, can be very labor intensive and time consuming requiring lengthy data acquisition times, a physical connection to the steel embedded in concrete, and is presently more suitable for laboratory studies. In the calculation of penetration rates an assumption that uniform corrosion is taking place has to be made (3.119). Figure 3.53 presents an experimental setup for A.C. impedance spectroscopy measurements of corrosion resistance of coated steel dowels in concrete and results from application of A.C. impedance spectroscopy to determine chloride diffusivity in concrete. 


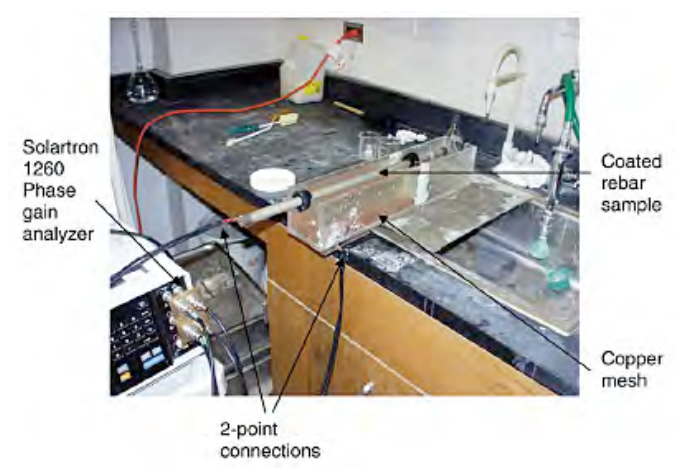

(a) Experimental setup for

A.C. impedance measurements.

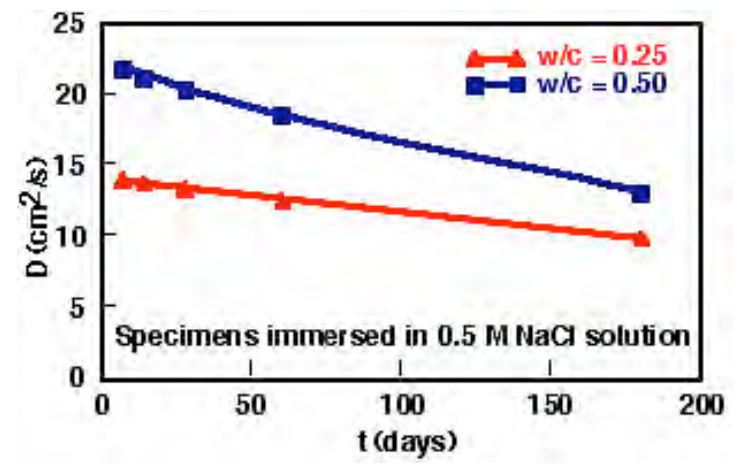

(b) Change of chloride diffusion coefficients with time for mortars with two different water/cement ratios.

Figure 3.53 A.C. electrochemical impedance spectroscopy.

Source: (a) D. Jolivet, D.M. Bonen, and S.P. Shah, "The Corrosion Resistance of Coated Steel Dowels Determined by Impedance Spectroscopy," Cement and Concrete Research 37, Elsevier Ltd., pp. 1134-1143, 2007.

(b) M. Shi, Z. Chen, and J. Sun, "Determination of Chloride Diffusivity in Concrete by AC Impedance Spectroscopy," Cement and Concrete Research 29, Elsevier Ltd., pp. 1111-1115, 1999.

\subsubsection{Embeddable Corrosion Monitoring Sensors}

Results obtained by methods described previously may not be accurate because they operate on the concrete surface and thus there is a concrete layer between the half cell and steel resulting in variations in thickness and resistance (3.136). To help mitigate the negative effects of the concrete layer, reference electrodes have been developed that can be embedded directly in the concrete close to the steel reinforcement.

Permanently embedded corrosion monitoring devices are electronic sensors that provide real-time early warning of conditions that can lead to corrosion damage of steel reinforcement. In addition to providing information relative to planned maintenance and life prediction of reinforced concrete structures, embeddable sensors are also useful for assessing the effectiveness of repairs and to determine future repair cycles (3.115). Figure 3.54 presents examples of embeddable reference electrodes. The MMO Ti probe consists of a titanium probe activated with an iridium enriched metal oxide cast into a specially developed cementitious filler that maintains constant $\mathrm{pH}$ around the probe and guarantees long-term stability of the electrochemical potential (3.137). The probe and filler are housed in a plastic protective cover. Electrical contact with the surrounding concrete is through the exposed bottom part of the

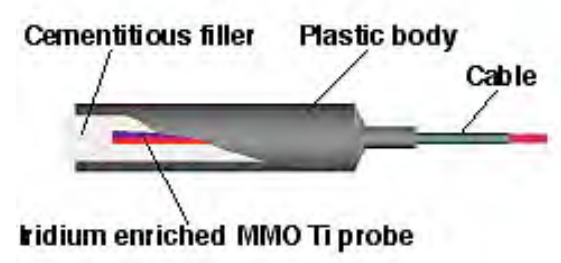

(a) MMO Ti Probe

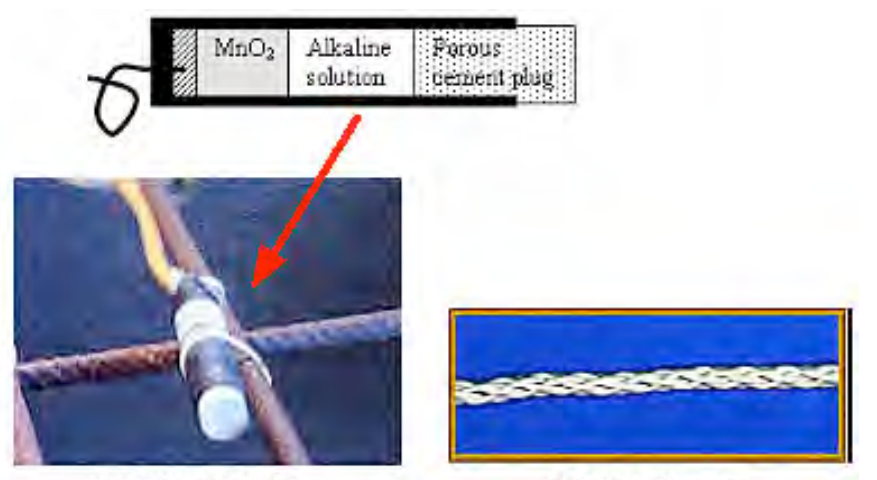

(b) ERE 20 Probe

(c) Wire Sensor

Figure 3.54 Examples of embeddable reference electrodes.

Source: (a) Cescor srl, Milan, Italy (www.cescor.it/eng/pdf/Ti MNO Electrode 2004E.pdf).

(b) Germann Instruments, Copenhagen, Denmark (www.germann.org).

(c) Ingenieurbüro Wietek, Innsbruch, Austria (www.a-bau.co.at/cms/elektrode.htm). 
cementitious filler. The ERE 20 probe uses a magnesium dioxide electrode in a corrosion-resistant steel housing with an alkaline, chloride-free gel and a porous cement plug in front (3.138). The $\mathrm{pH}$ of the gel corresponds to that of pore water in normal concrete. The ERE 20 can be installed in new construction by attaching it to the reinforcement or in existing structures by drilling a hole to the required depth and using mortar to cast it in place. The wire sensor (silver-silver chloride wire) is wrapped around the steel to be monitored (3.139). This method has increased sensitivity making it suitable for measurements of pitting corrosion in large concrete structures.

Embeddable probes have also been developed for corrosion macrocell current measurements to provide direct indication of electrochemical activity (3.136). Figures 3.55-3.58 presents examples of embeddable probes for corrosion macrocell current determination. The CorroWatch multisensor consists of four black electrodes and one noble metal cathode (3.140). The anodes are placed in varying, but defined, distances from the concrete surface. The heights of the anodes can be adjusted according to the concrete cover. In order to predict when the steel reinforcement will start corroding, the current between the single anodes and the cathode is measured, either with an ampere meter or a specially designed data logger. When corrosion starts the current will increase significantly as illustrated in Figure 3.55b. In the anode-ladder system the electrodes are made of steel having a similar composition

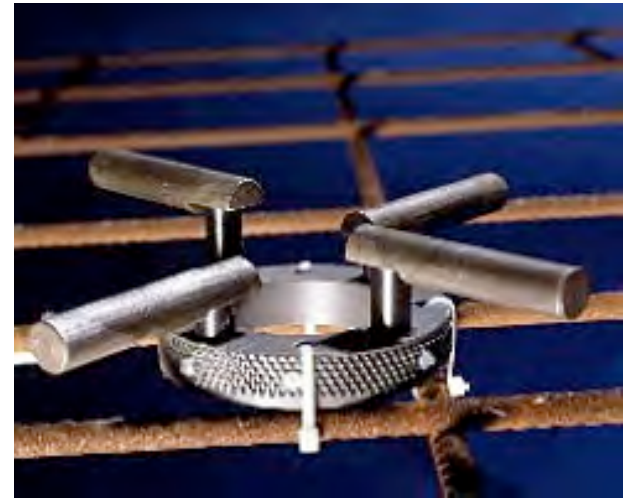

(a) CorroWatch Multisensor.

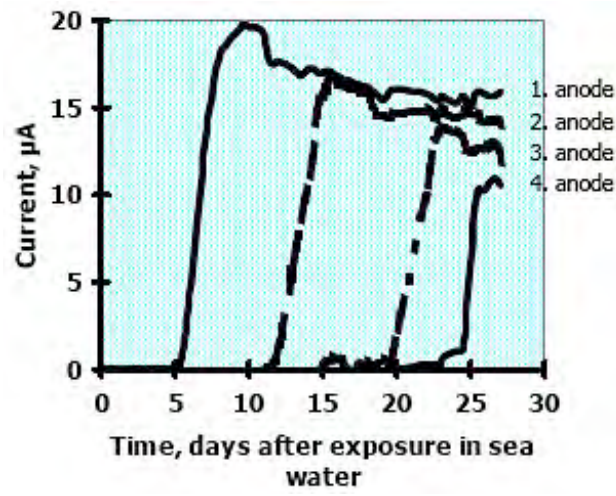

(b) Laboratory result showing corrosion initiation at each anode.

Figure 3.55 CorroWatch multisensor and example result.

Source: Force Technology, Helsingborg, Sweden, 2004

(www.force.dk/en/Menu/Products+and+Concepts/Products/051219_concretemonitoringandequipment.htm).

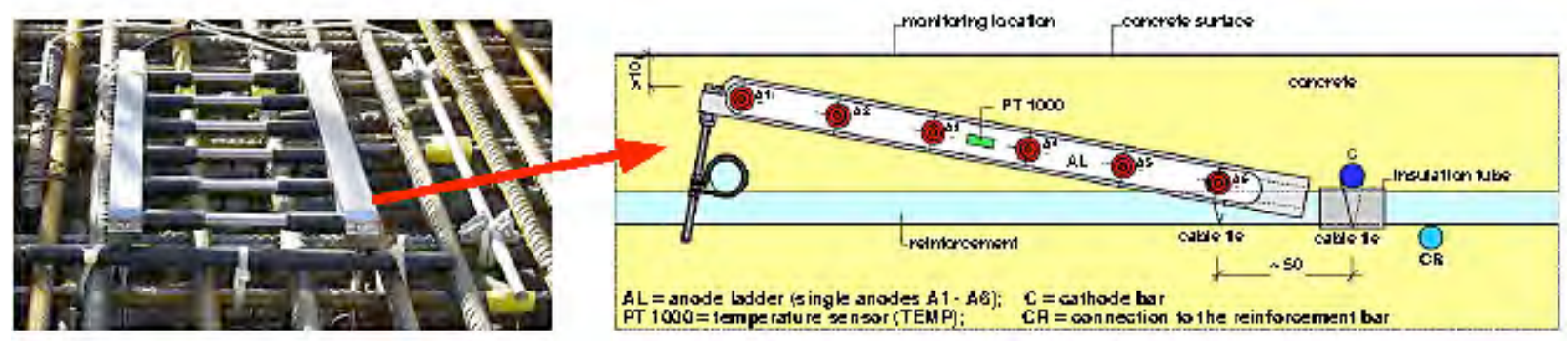

Figure 3.56 Anode-ladder system for corrosion monitoring.

Source: “Anode-Ladder-System for Corrosion Monitoring - Specifications," S + R SENSORTEC GMBH, Munich, Germany, May 2006 (www.sensortec.de/index.htm).

to that of steel reinforcement to ensure that they will start to corrode at the same time that a rebar at the same depth would corrode (3.141). Typically six anodes are utilized and positioned at $50 \mathrm{~mm}$ (Figure 3.56) from one another to prevent interactions between anodes. Using adequate calibration models the time-to-corrosion can be determined at any time related to the cover depth of the reinforcement. Figure 3.57 presents an expansion-ring system version consisting of the expansion-ring anode and a cathode bar (3.142). Similar to the six bars of tha anode-ladder system, the expansion-ring anode system consists of six measuring rings at different distances from the concrete surface in 
1-cm steps from 1 to $6 \mathrm{~cm}$. The expansion-ring anodes and cathode bar are inserted into holes that have been drilled into the concrete and a turning nut used to expand the expansion rings in a way that the sensors make good contact with the concrete. All inner open spaces are then filled with a resin-sealing material to ensure that water or chlorides do not penetrate the inner part of the sensor. The expansion-ring system is recommended for non-submerged conditions only. The basic principle to determine the time to corrosion for the multianode systems is also illustrated in Figure 3.57. The Embedded Corrosion Instrument (ECI), Figure 3.58, is comprised of sensor electrodes and processing electronics integrated within a molded plastic enclosure (3.143). It is installed during construction at the top level of the steel reinforcing with its electrodes facing up and monitors five key factors related to the corrosion of steel embedded in concrete: linear polarization resistance, open circuit potential, resistivity, chloride ion concentration, and temperature. Linear polarization resistance is measured by using a steel working electrode, stainless steel counter electrode, and manganese dioxide reference electrode. The unit initiates measurement of open circuit potential between the working and reference electrodes in the potentiostat circuit, and applies an appropriate

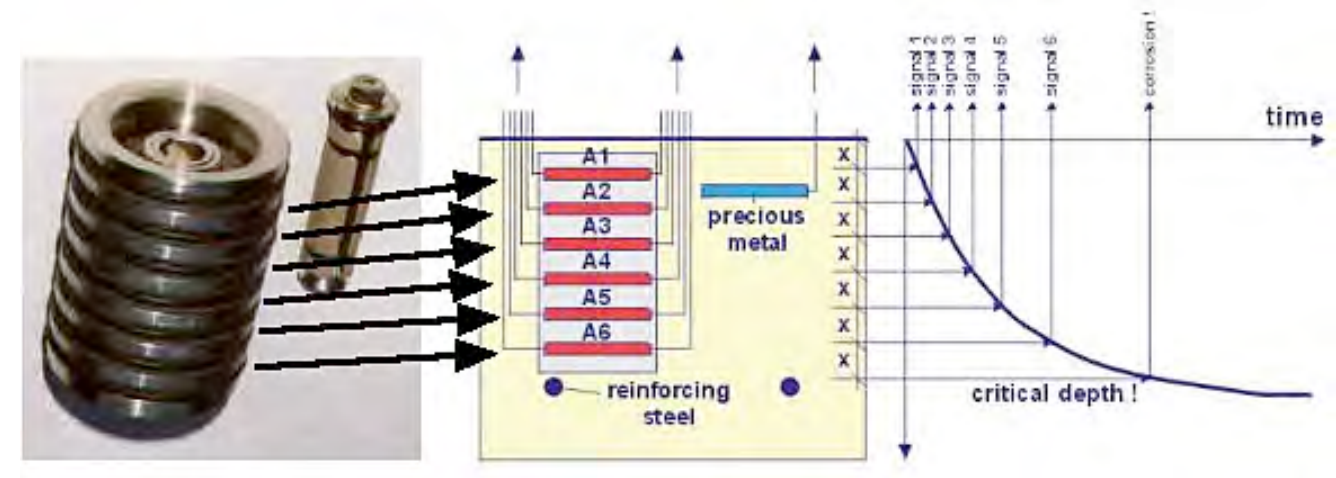

Figure 3.57 Expansion-ring system and its use to determine time to corrosion.

Source: Material abstracted from - M. Raupach and P. Schiessl, "Macrocell Sensor for Monitoring of the Corrosion Risk of the Reinforcement in Concrete Structures," NDT\&E 34(6), pp. 435-442, Elsevier Ltd., September 2001.

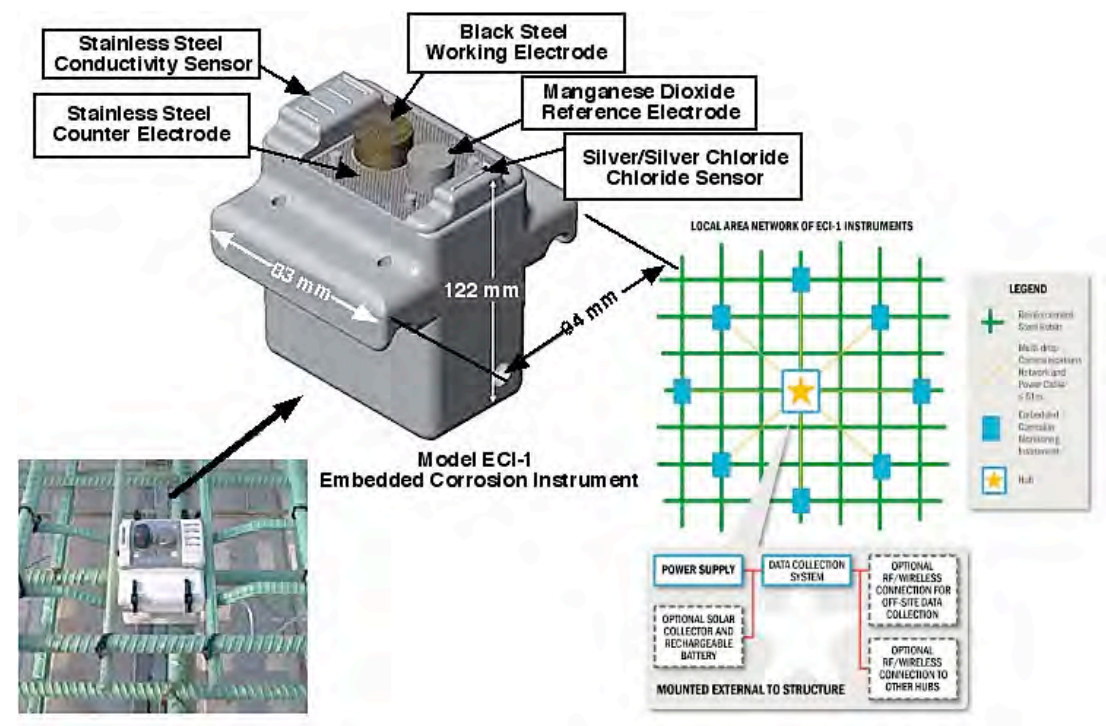

Figure 3.58 Embedded corrosion instrument.

Source: Material abstracted from - "Embedded Corrosion Instrument - For Non-Destructive Evaluation of SteelReinforced Concrete," Virginia Technologies, Inc., Charlottesville, Virginia, 2005 (www.vatechnologies.com/eciIndex.htm). 
potentiostat drive potential between the counter and working electrodes. A zero-resistance ammeter in the potentiostat circuit measures the cell current. Four stainless steel electrodes are used to measure concrete resistivity. A silver/silver chloride ion specific electrode in combination with its reference electrode is used to measure chloride ion concentration. Temperature of the concrete is determined using a solid-state sensor. After conversion of signals from analog to digital, the measurements are automatically transmitted to a datalogger.

\subsection{CONCRETE FOUNDATION ELEMENTS}

If upper surfaces of a concrete foundation (or pile) are available for inspection, a number of nondestructive testing techniques are available for use in assessment of their condition (e.g., impulse echo, sonic mobility, cross-hole seismic logging or tomography, parallel seismic testing, single-hole sonic logging, and ground-penetrating radar) (3.144). (A discussion of the impulse-response method was previously provided in Section 3.1.1.2.) A description and discussion of advantages and disadvantages of these methods for evaluating the structural integrity of deep foundations (i.e., driven piles, cast-in-place piles, and drilled shafts) is available (3.145). The applicability of nondestructive testing methods to evaluate deep foundations under inaccessible-head conditions in a controlled environment has been investigated at the National Geotechnical Experimental Station (NGES) at Northwestern University (3.146). In this study five drilled shafts with lengths between 12.2 and $27.4 \mathrm{~m}$ and diameters between 0.61 and $0.914 \mathrm{~m}$ were constructed, some purposely with defects (a reduced cross-section in one shaft to represent a typical construction deficiency and a thin, soil-filled joint in another to represent a performance-related defect induced by excessive lateral loads). Reinforced concrete caps were cast on the piles. The piles were evaluated using sonic echo and impulse-response testing under both accessible- and inaccessible-head conditions. Additional tests were performed using the parallel seismic method for inaccessible-head conditions. Figure 3.59a presents a schematic of the NGES site. A second large-scale deep foundation site for optimization and validation of

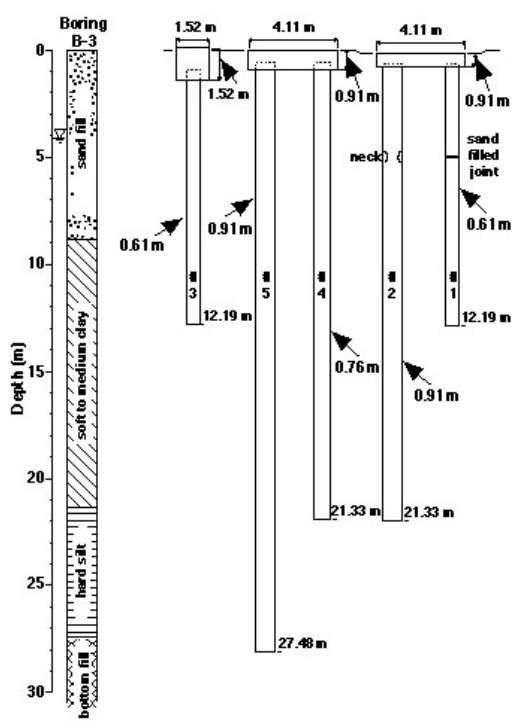

(a) Schematic of NGES site.

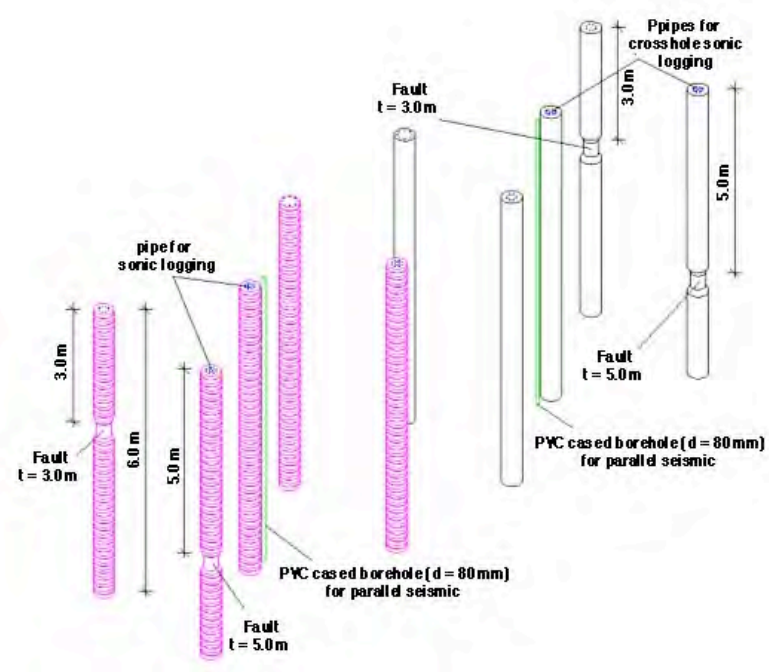

(b) Schematic of Horstwalde, Germany site.

Figure 3.59 Large-scale deep foundation test facilities.

Sources: (a) R.J. Finno and S.L. Gassman, and P.W. Osborn, "Non-Destructive Evaluation of a Deep Foundation Test Section at the Northwestern University National Geotechnical Experimentation Site," Federal Highway Administration, McLean, Virginia, June 1997 (http://www.iti.northwestern.edu/projects/found/dft.html).

(b) E. Niederleithinger and A. Tafe, "Concept for Reference Pile Testing Sites for the Development and Improvement of NDT-CE," International Symposium on Non-Destructive Testing in Civil Engineering 2003, (NDT-CE-2003), Bundesanstalt für Materialforschung und -prüfung, Berlin, Germany, 2003.

nondestructive test methods (e.g., ultrasonic echo, radar, low strain pile integrity testing, and parallel seismic testing) has been built at Horstwalde, Germany (3.147). The site consists of a foundation connected to bored piles, including 
both sound piles as well as piles with flaws and/or geometrical anomalies (3.148). This site has been utilized in the European Community Fifth Framework project, "Re-Use of Old Foundations on Urban Sites (RUFUS)," for training of personnel (3.149). Accurate knowledge of the exact geometry and structure of the piles as well as the presence of embedded instrumentation (i.e., temperature, strain, and vibration) allows evaluation and calibration of measurement devices. Figure $3.59 \mathrm{~b}$ presents a schematic of the site at Horstwalde, Germany. Relative performance of the nondestructive test methods for deep foundations can be obtained from results being developed under the RUFUS Project and the two large-scale test facilities.

The most commonly used type of foundation for both concrete and steel nuclear power plant containments is a mat foundation, which is a flat thick slab supporting the containment, its interior structures, and any shield building surrounding the containment (3.150). As such, the concrete foundation elements of nuclear power plants are typically either partially or totally inaccessible for inspection. Under conditions such as this the foundation structures are only accessible for inspection after removal of adjacent soil, coatings, waterproof materials, or portions of neighboring components or structures. As a result, indirect methods related to environmental qualification are often utilized to indicate the potential for degradation of the nuclear power plant concrete foundations (3.151). This is generally done through an evaluation of the surrounding medium (e.g., air, soil, humidity, groundwater, or cooling water). Methods employed are based primarily on chemical evaluations to assess the presence and concentration of potentially aggressive ions (e.g., sulfates or chlorides). In addition to an assessment of the aggressiveness of the surrounding environment, the Code of Federal Regulations requires a complete description of the effects of groundwater levels and other hydrodynamic effects on the design bases of the plant foundations and other structures, systems, and components important to safety (3.152). Table 3.9 provides a listing of several test methods and references related to evaluation of the air, soil, or groundwater conditions

Table 3.9 Examples of test methods and references for environmental assessments

\begin{tabular}{|c|c|}
\hline Item Measured & Candidate Method(s) or Reference(s)* \\
\hline \multicolumn{2}{|c|}{ Air } \\
\hline Acidity & ASTM D 1654, G 50, and G 92 \\
\hline Carbon dioxide content & $\mathrm{CO}_{2}$ sensors \\
\hline Humidity & ASTM D 4230 and E 337 \\
\hline Temperature & Temperature sensors \\
\hline \multicolumn{2}{|c|}{ Soil } \\
\hline Corrosivity/pH & ASTM G 51; BS 1377-3, Section 9; BR 279 \\
\hline Sulfate ion content & ASTM D 4542; BS 1377-3, Section 5; BR 279 \\
\hline Chloride ion content & ASTM D 4542; BR 279; BS 1377-3, Section 7 \\
\hline Resistivity & ASTM G 57 \\
\hline Moisture content & ASTM D 2216 and D 3017; DIN 18121-1, -2; \\
\hline Nitrate & BR 279 \\
\hline Permeability & $\begin{array}{l}\text { ASTM D 2434; DIN 18130-1; prEN 1997-2, Eurocode 7; } \\
\text { BS 8004; BS 5930 }\end{array}$ \\
\hline \multicolumn{2}{|c|}{ Groundwater } \\
\hline Water table elevation and sampling & $\begin{array}{l}\text { ASTM D 512, D 1293, and D 4448; observation wells; } \\
\text { piezometers }\end{array}$ \\
\hline Corrosivity/pH & $\begin{array}{l}\text { ASTM D 1067, D 1293, and E 70; BR 279; } \\
\text { BS 1377-3, Section } 9\end{array}$ \\
\hline Hydrostatic pressure & Standard sensors \\
\hline Dissolved oxygen content & ASTM D 888 \\
\hline Soluble sulfate & $\begin{array}{l}\text { ASTM D 516, D 4327, D 4130, and D 4327; BR 279, } \\
\text { BS 1377-3, Section 5; DIN 38405-5 }\end{array}$ \\
\hline Nitrate ion & ASTM 4327, BR 279 \\
\hline Chloride ion & $\begin{array}{l}\text { ASTM D 4458, D } 4327 \text { and D 512; BR 279; BS 1377-3, } \\
\text { Section } 7\end{array}$ \\
\hline Carbon dioxide content & EN 13577 \\
\hline Microorganisms and bacteria & ASTM D 4412 \\
\hline \multicolumn{2}{|c|}{$\begin{array}{l}\text { Standard Test Methods or Practices (ASTM), American Society for Testing and Materials, West Conshohocken, Pa.; British } \\
\text { Standards (BS), British Standards Institute, London, United Kingdom; European Standards (prEN), European Committee } \\
\text { for Standardization, Brussels, Belgium; Building Research Report (BR), M.J. Bowley, "Sulfate and Acid Attack on } \\
\text { Concrete in Ground: Recommended Procedures for Soil Analysis," BRE Report 279, Building Research Establishment, } \\
\text { Garston, Watford, United Kingdom, 1995; German Standards (DIN), Deutsches Institut für Normung e.V., Berlin, Germany }\end{array}$} \\
\hline
\end{tabular}


adjacent to a concrete foundation element. Information is available on chemicals in the ground or groundwater that are potentially harmful to concrete (3.153,3.154). Detailed guidelines on assessing and classifying the aggressiveness of chemicals in the ground to concrete have been developed (3.155).

\subsection{MASONRY STRUCTURES}

Masonry block wall structures have been used as structural walls, to hold pipe supports and equipment, and as partitions and shield walls (3.156). When masonry walls are used to support safety-related piping, raceways, and equipment, they are considered Seismic Category I "safety-related" structures (3.157). Masonry structures may be in single or multiple widths and can be designed as bearing walls, shear walls, and piping or equipment support walls. They are generally constructed from concrete and grout, and the cells may or may not contain horizontal or vertical reinforcing steel to provide additional structural strength. For structural block walls, the extent of grouted cells varies with the specific design requirement for the wall (e.g., for shield walls all cells are grouted to provide the desired shielding effect). Although masonry block walls are subject to the same degradation mechanisms as reinforced concrete walls, the primary degradation mechanisms of interest are related to cracking (e.g., joint and through wall), durability of the masonry mortar, and corrosion of metal components. Detailed information on evaluation of the physical conditions of masonry units and masonry assemblages relative to environmental conditions is available (3.158). Information provided below addresses evaluation of the condition and properties of masonry features.

Traditional evaluation methods for the condition and properties of masonry features of structures have been, in addition to visual inspection, largely destructive in nature involving testing of specimens removed from the structure (3.159). Application of destructive methods to nuclear power plant masonry structures, however, is limited because specimen removal may be structurally damaging. Evaluation of masonry structures therefore uses nondestructive examination methods to complement the visual inspections for determining the location of flaws and for assessing material properties. The most commonly used nondestructive examination techniques for masonry structures are listed in Table 3.10 including their advantages and disadvantages. In addition to the techniques provided in the table, relatively recent developments include use of Scanning Laser Doppler Vibrometry, ground-penetrating radar, and acoustic tomography.

The Schmidt (or rebound) Hammer (discussed in Section 3.1.1.7) provides a measure of relative material surface hardness and its primary application is in assessment of material uniformity over large areas of a structure. It is generally not recommended that the Schmidt Hammer be used as a direct indicator of compressive strength, but more for indicating the relative change in compressive strength between locations.

Flatjack methods provide information on the state of stress in a masonry structure and provides a direct physical measurement of material and structural properties (i.e., deformation, shear strength, and compressive stress) (3.1603.162). A flatjack is a flexible steel envelope, thin enough to fit within a masonry mortar unit, that is hydraulically pressurized to apply stress to the surrounding masonry. Two main types of flatjack tests are the single flatjack test and the two flatjack test. Evaluation of the in situ compressive stress is accomplished by removal of a portion of the mortar bed joint, measuring the magnitude of the resulting deformation, inserting a flatjack into the joint, and restoration of the original state of stress by pressurization of the flatjack until the original position of the measuring points is restored. The in situ deformability test is conducted by inserting two parallel flatjacks separated by several courses of masonry and pressurizing the jacks equally and measuring the deformation of the masonry between the two jacks, Figure 3.60. This provides a measure of masonry compressive modulus. The in-place shear test measures the joint shear resistance between masonry units or masonry joints. A single masonry unit is removed as well as a head joint on opposite sides of the test unit. The test unit is then displaced horizontally relative to the surrounding masonry using a hydraulic jack inserted into the location where the masonry unit was removed. The horizontal force required to cause first movement of the test unit is determined. A modified version of this technique has been developed to provide more reliable results. In this approach the vertical stress on the wall at the test unit is determined using the single flatjack test procedure. The normal stress during the in situ shear test is then controlled using flatjacks above and below the test unit. Figure 3.61 presents a schematic of the setup for the "modified in situ shear test. 
Table 3.10 Masonry structures nondestructive evaluation tests

\begin{tabular}{|c|c|c|}
\hline NDE Technique & Advantages & Disadvantages \\
\hline $\begin{array}{l}\text { Rebound } \\
\text { hammer }\end{array}$ & $\begin{array}{l}\text { Simple to use and inexpensive. } \\
\text { Establishes uniformity of properties. }\end{array}$ & $\begin{array}{l}\text { Point evaluation only. } \\
\text { No direct relation to strength or deformation } \\
\text { properties. } \\
\text { Unreliable for flaw detection or inaccessible areas. }\end{array}$ \\
\hline $\begin{array}{l}\text { Single flatjack in } \\
\text { situ strength }\end{array}$ & $\begin{array}{l}\text { Establishes state of compressive stress } \\
\text { in situ. } \\
\text { Easy to use and inexpensive equipment. } \\
\text { ASTM standards available. }\end{array}$ & $\begin{array}{l}\text { Time consuming to prepare test. } \\
\text { Requires removal of mortar. } \\
\text { Repair required after test. }\end{array}$ \\
\hline $\begin{array}{l}\text { Double flatjack } \\
\text { in situ } \\
\text { deformation }\end{array}$ & $\begin{array}{l}\text { Establishes deformation properties in } \\
\text { situ. } \\
\text { Easy to use and inexpensive equipment. } \\
\text { ASTM standards available. }\end{array}$ & $\begin{array}{l}\text { Time consuming to prepare test. } \\
\text { Requires removal of mortar. } \\
\text { Repair required after test. }\end{array}$ \\
\hline $\begin{array}{l}\text { In-place shear } \\
\text { strength }\end{array}$ & $\begin{array}{l}\text { Establishes joint shear strength in situ. } \\
\text { Easy to use and inexpensive equipment. } \\
\text { ASTM standards available. }\end{array}$ & $\begin{array}{l}\text { Time consuming to prepare test. } \\
\text { Requires removal of masonry unit and head joint. } \\
\text { Restricted to masonry with low cement-content } \\
\text { mortar. } \\
\text { Requires unit and mortar replacement after test. } \\
\text { State of compressive stress on test unit must be } \\
\text { estimated. } \\
\text { Contribution of collar joint unknown. }\end{array}$ \\
\hline $\begin{array}{l}\text { Two flatjack } \\
\text { modified } \\
\text { in-place shear } \\
\text { strength }\end{array}$ & $\begin{array}{l}\text { Can establish joint shear strength in } \\
\text { situ. } \\
\text { Permits control of compressive stress } \\
\text { of test unit. } \\
\text { Determines Coulomb failure surface for } \\
\text { material. }\end{array}$ & $\begin{array}{l}\text { Time consuming to prepare test. } \\
\text { Requires removal and replacement of two masonry } \\
\text { units and two mortar joints. } \\
\text { Restricted to masonry with low cement-content } \\
\text { mortar. } \\
\text { Large amount of equipment is required. } \\
\text { Contribution of collar joint unknown. }\end{array}$ \\
\hline $\begin{array}{l}\text { Ultrasonic pulse } \\
\text { velocity }\end{array}$ & $\begin{array}{l}\text { Simple to use and establishes } \\
\text { uniformity of properties. } \\
\text { Can detect flaws, cracks, and voids. } \\
\text { Equipment readily available and } \\
\text { moderately priced. } \\
\text { Trace of stress wave recordable for } \\
\text { analysis. }\end{array}$ & $\begin{array}{l}\text { Requires access to both sides of wall for direct } \\
\text { measurements. } \\
\text { Signal attenuation in older or soft masonry } \\
\text { restricts distance between transducers for indirect } \\
\text { and direct application. } \\
\text { Grinding of rough surface required. } \\
\text { Coupling material needed between masonry } \\
\text { material and transducers. } \\
\text { No direct correlation with material properties. }\end{array}$ \\
\hline $\begin{array}{l}\text { Mechanical } \\
\text { pulse velocity }\end{array}$ & $\begin{array}{l}\text { Simple to use with no damage and } \\
\text { establishes uniformity of properties. } \\
\text { Can detect flaws, cracks, and voids. } \\
\text { Equipment readily available and } \\
\text { moderately priced. } \\
\text { Trace of stress wave recordable. } \\
\text { Capable of testing over long distances. }\end{array}$ & $\begin{array}{l}\text { Several equipment items are required. } \\
\text { Requires separate instrument to record wave } \\
\text { arrival time with wave analysis complicated. } \\
\text { No direct correlation between results and material } \\
\text { properties. }\end{array}$ \\
\hline $\begin{array}{l}\text { Magnetic } \\
\text { methods }\end{array}$ & $\begin{array}{l}\text { Equipment portable and inexpensive. } \\
\text { Large areas of masonry easily } \\
\text { evaluated. } \\
\text { Locates metal ties and connectors and } \\
\text { accurately maps location and } \\
\text { orientation of reinforcineg steel. }\end{array}$ & $\begin{array}{l}\text { Readings can be ambiguous requiring operator } \\
\text { interpretation or supplemental destructive tests. } \\
\text { Misidentification of metal conduit, reinforcing } \\
\text { steel, etc. possible. } \\
\text { Accuracy in determination of bar size and depth } \\
\text { questionable. }\end{array}$ \\
\hline
\end{tabular}

Source: "Nondestructive Evaluation Methods," Chapter 10 of Masonry Structural Design for Buildings, TM 5-8093/NAVFAC DM-2.9/AFM 88-3, Joint Departments of Army, Navy and Air Force, Washington, D.C., October 30, 1992. 


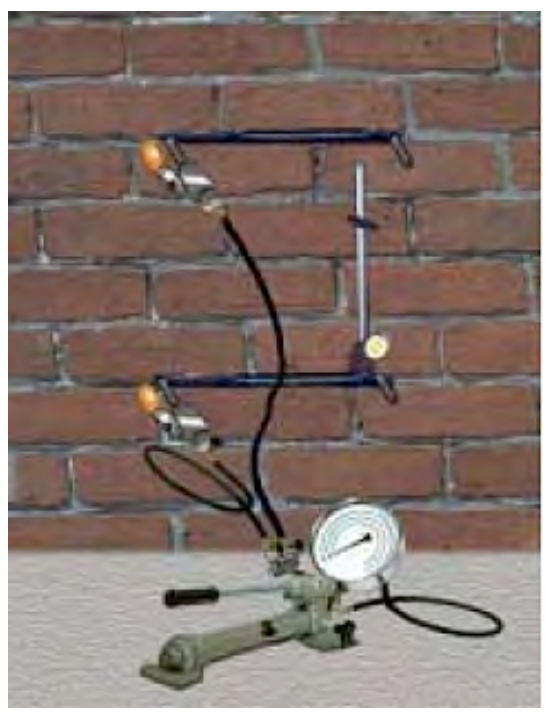

(b) Flatjack testing of masonry.

Figure 3.60 In situ deformability test using two flatjacks.

Source: http://www.quakesafedelhi.net/refresher/YSingh1.pdf.

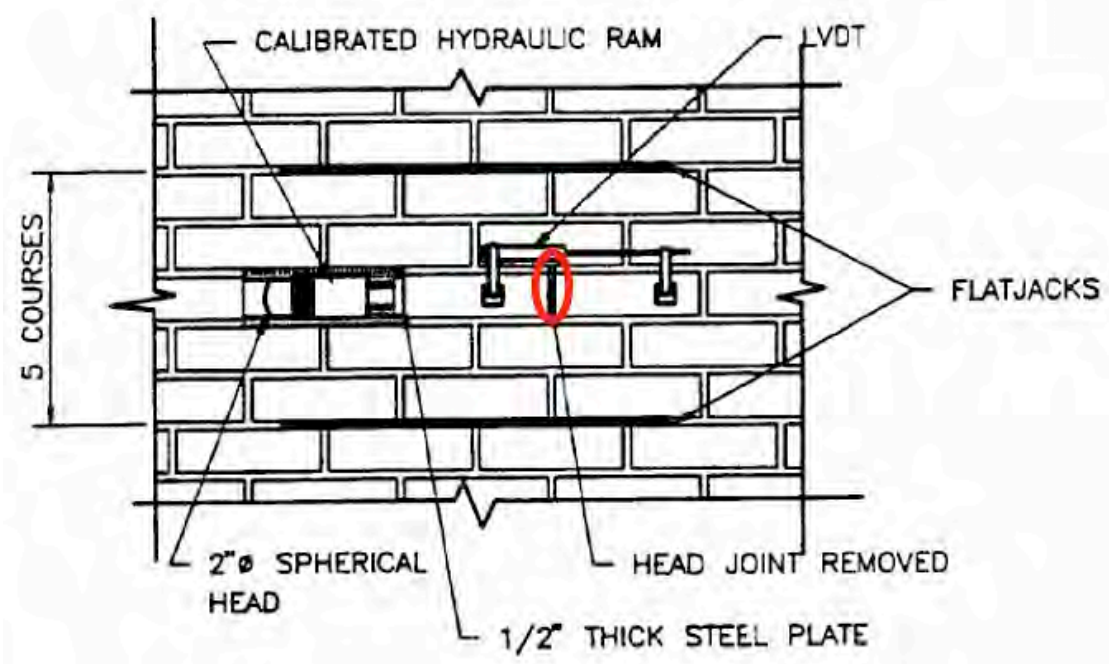

Figure 3.61 Schematic of "modified" in situ shear test of masonry.

Source: "Nondestructive Evaluation Methods," Chapter 10 of Masonry Structural Design for Buildings, TM 5-8093/NAVFAC DM-2.9/AFM 88-3, Joint Departments of Army, Navy and Air Force, Washington, D.C., October 30, 1992.

The ultrasonic pulse velocity method utilizes acoustic transducers $(\sim 50 \mathrm{kHz})$ to pass high frequency stress waves through the masonry. Two types of tests can be conducted: direct and indirect (Figure 3.62). Direct tests, or through-wall tests, are useful in establishing material uniformity and identifying locations where voids are present (e.g., locations exhibiting longer than average arrival times). Indirect tests are used to determine the average velocity through an accessible masonry unit wythe to detect the presence of voids or lower quality material (e.g., reduction in pulse velocity). Heterogeneity of masonry construction limits applicability of ultrasonic pulse velocity methods due to signal attenuation. More details were provided in Section 3.1.1.2. 


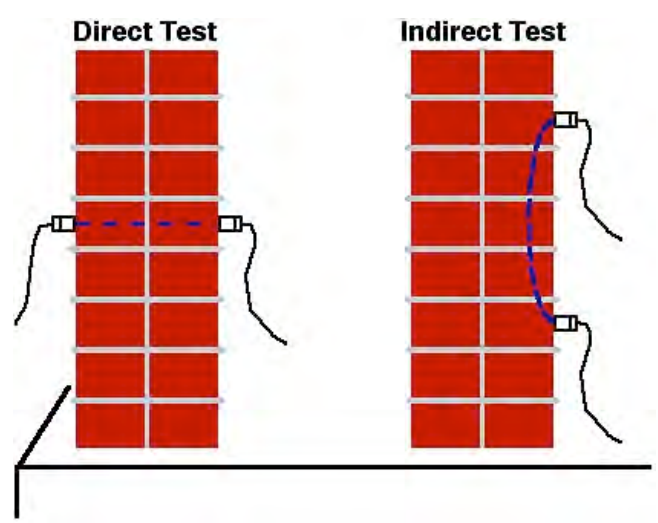

Figure 3.62 Transducer arrangement for direct and indirect ultrasonic pulse velocity testing of masonry.

Source: "Nondestructive Evaluation Methods," Chapter 10 of Masonry Structural Design for Buildings, TM 5-8093/NAVFAC DM-2.9/AFM 88-3, Joint Departments of Army, Navy and Air Force, Washington, D.C., October 30, 1992.

Magnetic (or electromagnetic) methods provide a fairly rapid means to inspect masonry structures to locate vertical, horizontal, and joint steel reinforcement; metal ties; and metal connectors. This technique was discussed in Section 3.1.1.4.

The mechanical pulse velocity test utilizes an object (e.g., hammer) to input a stress wave into the masonry wall and then monitors the subsequent vibrations using an accelerometer. A digital transient recorder is used to record both the hammer input signal and the accelerometer output signals. Stress waves input in this manner are low frequency with high amplitude and of longer wavelength than those input by the ultrasonic pulse velocity method. The quantity of interest is the arrival time of the pulse which when the path length is known provides the pulse velocity. The pulse velocity can be correlated to material properties. The technique can also be used to locate material flaws and discontinuities. Figure 3.63 presents a schematic of the method and an example or its application.

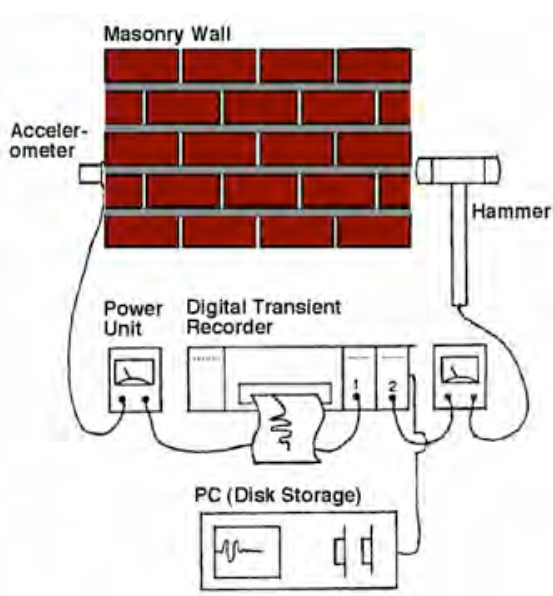

(a) Schematic of mechanical pulse testing apparatus.

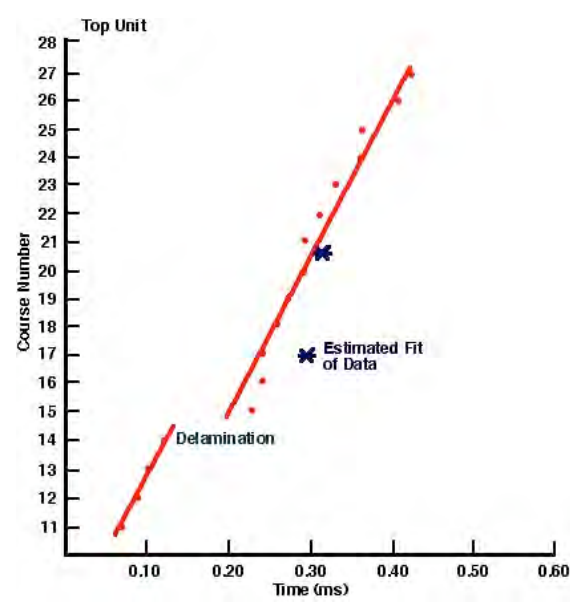

(b) Detection of masonry wall delamination

Figure 3.63 Mechanical pulse velocity test schematic and example application.

Source: "Nondestructive Evaluation Methods," Chapter 10 of Masonry Structural Design for Buildings, TM 5-8093/NAVFAC DM-2.9/AFM 88-3, Joint Departments of Army, Navy and Air Force, Washington, D.C., October 30, 1992. 
Scanning Laser Doppler Vibrometry (SLDV) has been developed for use in diagnosis of civil and historical buildings (3.163). The technique measures point-by-point surface velocities using interferometric techniques with galvanometric driven mirrors steering laser beams. Structural excitation is done by acoustic waves radiated from high power loudspeaker systems. Surface vibrations induce a Doppler frequency shift on the impinging laser beam and this shift is linearly related to the velocity component in the direction of the laser beam. Most diffused SLDVs have a maximum velocity range of $10 \mathrm{~m} / \mathrm{s}$, with a frequency upper limit of $200 \mathrm{KHz}$, a resolution of about $1 \mu \mathrm{m} / \mathrm{s}$, and a base accuracy on the order of 1-3\% of RMS reading. Laser power is less than $1 \mathrm{~mW}$, so no special safety measures are required. Working distances of some 10's of meters are possible with a spatial resolution of $1 \mathrm{~mm}$. Figure 3.64 illustrates application of SLDV to inspection of a block wall $1.8 \times 1.5 \times 0.25 \mathrm{~m}^{3}$. The wall was damaged by hitting it with a hammer to create an irregular groove with a width of some centimeters and a depth of about 2 centimeters. Figure 3.64(c) presents results for the undamaged wall and Figure 3.64(d) the vibration mode shifts as a result of the induced damage.

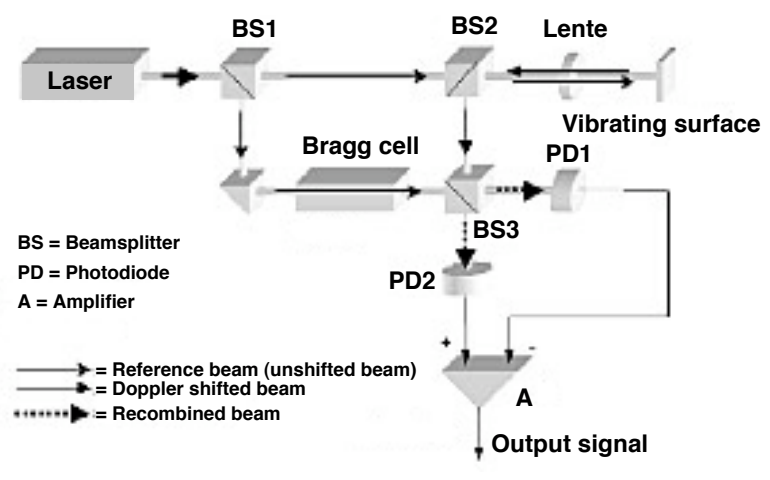

(a) SLDV schematic.

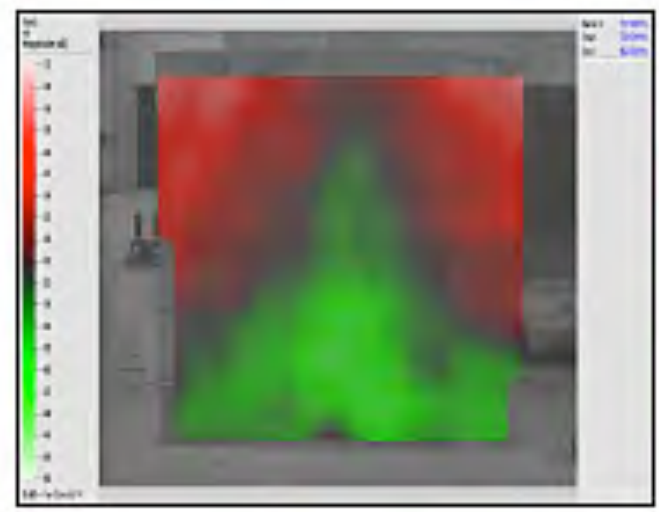

(c) Undamaged wall vibration map.

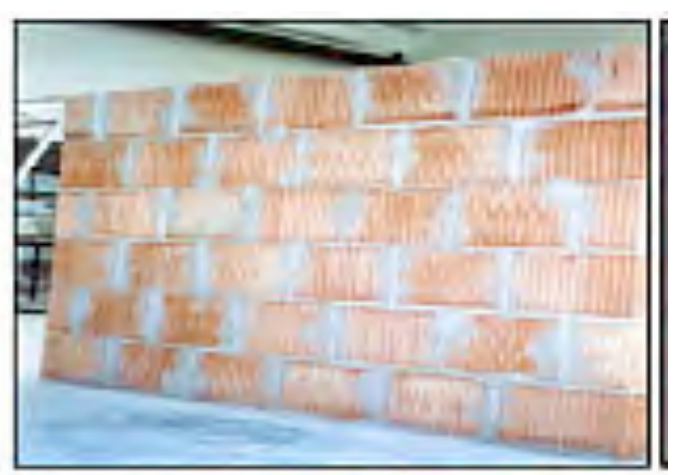

(b) Test article - block wall $1.8 \mathrm{~m}$ long by $1.5 \mathrm{~m}$ high by $0.25 \mathrm{~m}$ wide.

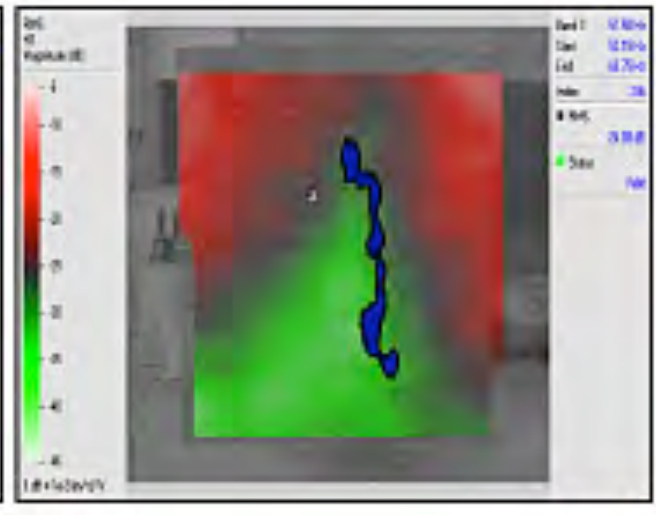

(d) Damaged wall vibration map (dark area indicates area damaged by hammering).

Fig. 3.64 Illustration of application of laser vibrometry to inspection of block wall.

Source: E. Esposito, S. Copparoni, and B. Naticchia, "Recent Progress in Diagnostics of Civil Structures by Laser Vibrometry," $16^{\text {th }}$ World Conference on NDT 2004, Montreal, Canada, August 30 - September 3, 2004.

Ground-penetrating radar (see Section 3.1.1.4) has been applied to nondestructive testing of masonry structures, primarily historical buildings (3.164). The great majority of these applications have been conducted by executing two-dimensional or three-dimensional profiles with the system in the echo configuration (i.e., transmitter and receiver on same side of structure) and using frequencies normally in the $500 \mathrm{MHz}$ to $1 \mathrm{GHz}$ range $(3.165,3.166)$. These investigations demonstrated that pertinent information may be obtained about the physical properties of brick and stone masonry walls (e.g., thickness, number of layers and position of detachments, structural discontinuities or voids, and metal inclusions) (3.167). Ground-penetrating radar $(0.5$ to $1.5 \mathrm{GHz})$ with the capability of transmitting and receiving RF waves linearly polarized along the direction of the dipole (HH or VV directions) has been utilized 
for non-invasive retrieval of information on the internal structure of masonry (3.168). Figure 3.65a presents the test specimen which consisted of three sections in the width direction - a section12-cm thick with complete bricks and lime, a section 12-cm thick with full bricks but without lime that contains a cavity $50 \times 20 \times 12 \mathrm{~cm}^{3}$, and a concrete wall section 50-cm thick. Post-processed images (horizontal-HH, vertical-VV, and combined HH-VV) at a depth of approximately $15 \mathrm{~cm}$ are provided in Figure 3.65b. Both the HH and VV results clearly indicate the cavity. Subtraction of the two focused phase maps (HH-VV) provides a cleaner image of the edges of the cavity.
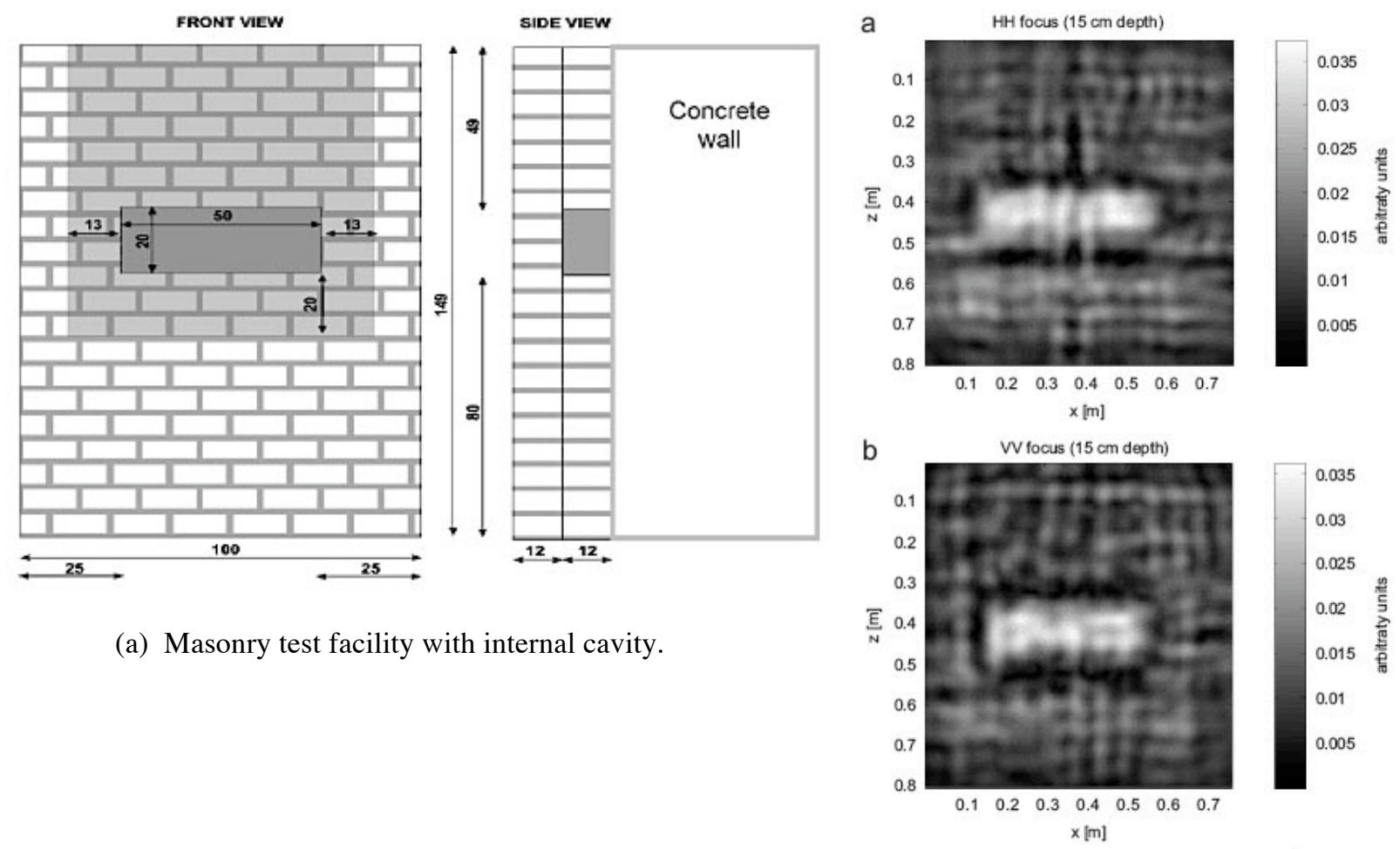

(a) Masonry test facility with internal cavity.

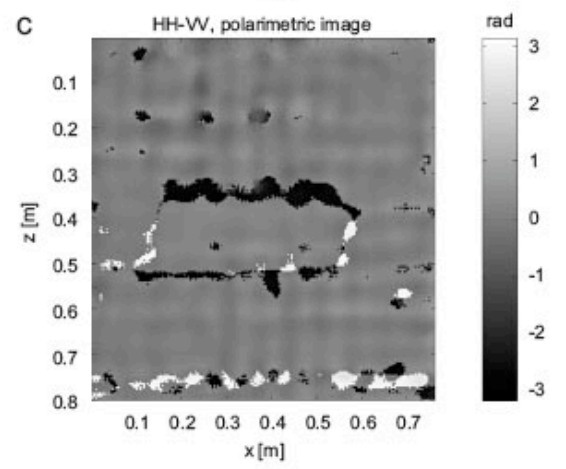

(b) GPR images at $15-\mathrm{cm}$ depth.

Figure 3.65 Use of polarized GPR to investigate masonry wall with internal cavity.

Source: M. Pieraccini, M. Pisaneschi, L. Noferini, and C. Atzeni, "Polarimetric Radar Signature of Masonry Walls," NDT\&E International 40, Elsevier Ltd., pp. 271-271, 2007.

In another application of GPR to masonry structures, a test specimen (Figure 3.66a) was constructed of solid brickwork except for the presence of air voids $\left(6 \times 11 \times 12 \mathrm{~cm}^{3}, 6 \times 11 \times 24 \mathrm{~cm}^{3}\right.$, and $\left.12 \times 11 \times 24 \mathrm{~cm}^{3}\right)$ simulated by skipping bricks, part or all, at three different depths (3.167). The test specimen was investigated using GPR systems having nominal frequencies of either 1.5 or $1.7 \mathrm{GHz}$. Tomograms of results of radar measurements are shown in Figure 3.66b with the void locations marked by dashed lines. Results demonstrate ability of GPR to identify and locate voids $12 \times 11 \times 24 \mathrm{~cm}^{3}$, or larger, in masonry structures. Ground-penetrating radar has also been utilized to 


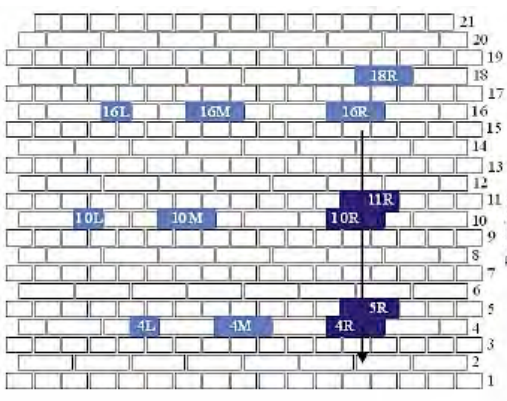

(a) Masonry test specimen containing simulated air voids.
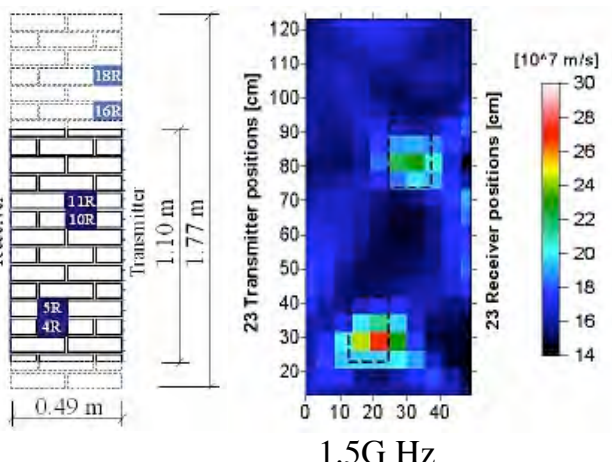

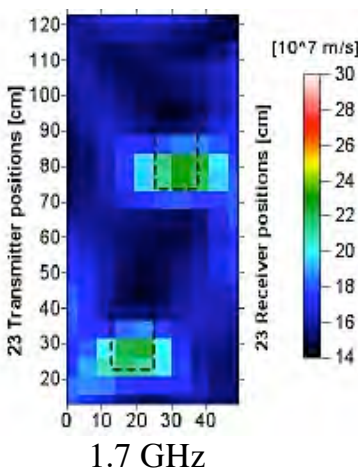

(b) Detection of simulated air voids in masonry wall using ground-penetrating radar.

Figure 3.66 GPR testing of masonry wall with simulated air voids.

Source: A. Wendrich, C. Trela, M. Krause, C. Maierhofer, U. Effner, and J. Wöstmann, "Location of Voids in Masonry Structures by Using Radar and Ultrasonic Traveltime Tomography," $6^{\text {th }}$ European Conference on NDT, Paper Tu.3.2.5, Berlin, Germany, September 25-29, 2006.

detect rising moisture levels in brick work as illustrated in Figure 3.67 (3.169). In this application the delay of the signal due to the higher dielectric constant resulting from the presence of moisture provides a visualization of the qualitative effect of rising moisture and moisture content. In order to determine moisture contents quantitatively calibration of the dielectric constant and moisture content have to be performed (3.170). The influence of dissolved salts also needs to be considered.

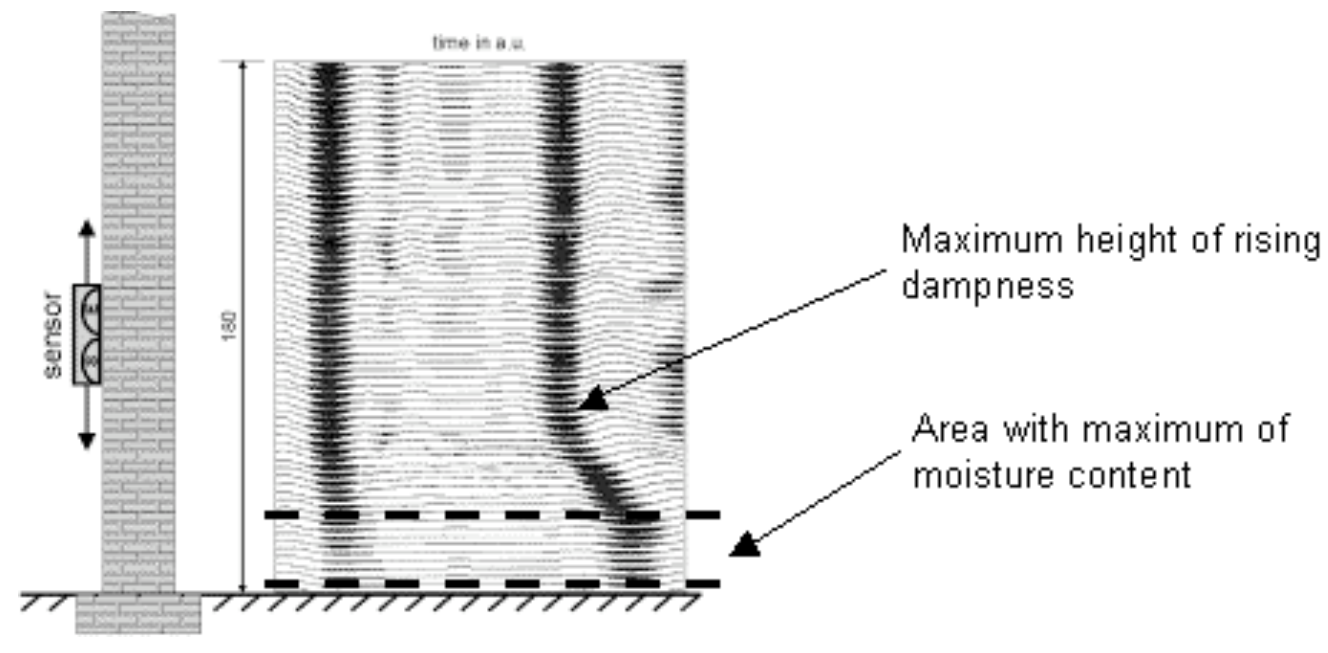

Figure 3.67 Application of GPR to detect moisture level.

Source: A. Taffe and C. Maierhofer, "Guidelines for NDT Methods in Civil Engineering," International Symposium on Non-Destructive Testing in Civil Engineering (NDT-CE-2003), Bundesanstalt für Materialforschung und -prüfung, Berlin, Germany, 2003.

The tomographic imaging method uses sonic or ultrasonic pulse velocity information taken through a section of a structure or component to develop a two- or three-dimensional reconstruction of the velocity distribution in the section. The reconstruction image is used to locate features concealed beneath the material's surface (3.171). Acoustic methods (e.g., acoustic tomography) have been found to be well suited to detection of structural inhomogeneities in brick and stone masonry (3.164). Ultrasonic tomography was also applied to the masonry test specimen shown in Figure 3.66a. The ultrasonic transmission measurements were performed by using two different pairs of transducers emitting longitudinal waves - pairs with a nominal frequencies of 85 and $25 \mathrm{kHz}$. The transmitter was fixed on one side and the position of the receiver was changed covering a distance of $110 \mathrm{~cm}$ in $5 \mathrm{~cm}$ increments ( 23 received positions). The transmitter was moved and the process repeated until the monitored 
section was traversed (23 transmitter locations). Figure 3.68 presents an example of a test setup and the theoretical travel paths for different receiver locations when a void is present, thus indicating an increase in wave travel time due to the existence of the void. Acoustic tomograms shown in Figure 3.69b were obtained from the masonry test specimen containing simulated air voids shown in Figure 3.69a. The tomograms show two significant zones of lower velocity that correspond to the void positions. Results demonstrate ability of acoustic tomography to identify and locate voids $12 \times 11 \times 24 \mathrm{~cm}^{3}$, or larger, in masonry structures.

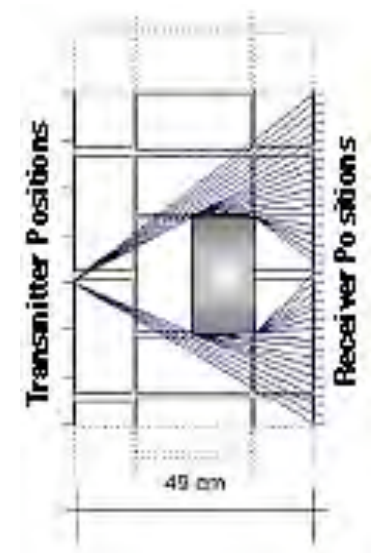

Figure 3.68 Illustration of effect of void in masonry travel path of ultrasonic wave.

Source: Section D7.3 under Deliverables - Summaries at http://www.onsiteformasonry.bam.de/EXT_results.html.

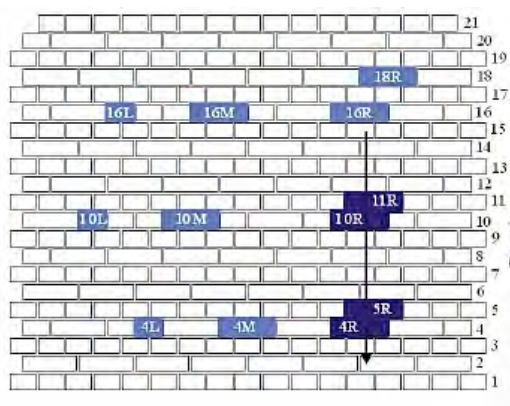

(a) Masonry test specimen containing simulated air voids.
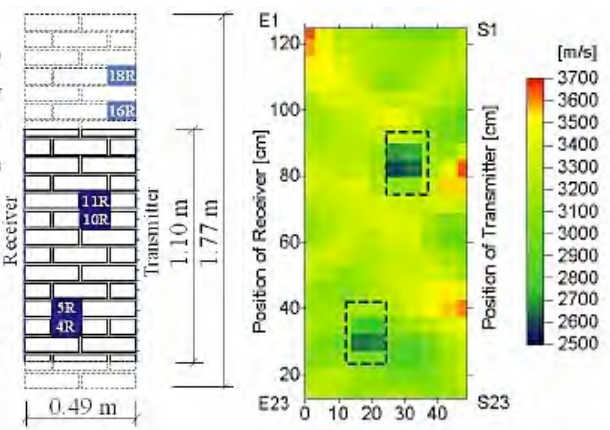

$1.5 \mathrm{G} \mathrm{Hz}$

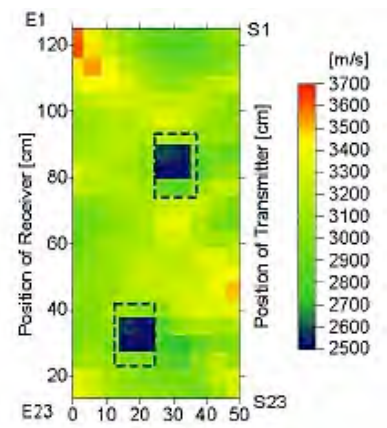

$1.7 \mathrm{GHz}$

(b) Detection of simulated air voids in masonry wall using acoustic tomography,

Figure 3.69 Acoustic testing of masonry wall with simulated air voids.

Source: A. Wendrich, C. Trela, M. Krause, C. Maierhofer, U. Effner, and J. Wöstmann, "Location of Voids in Masonry Structures by Using Radar and Ultrasonic Traveltime Tomography," $6^{\text {th }}$ European Conference on NDT, Paper Tu.3.2.5, Berlin, Germany, September 25-29, 2006.

\subsection{SUMMARY AND COMMENTARY}

Although nondestructive examination techniques find wide application in the medical field and inspection of metallic materials, their development for application to concrete materials and structures has been slow, particularly with respect to nuclear power plant concrete structures. In addition to the challenges that nuclear power plant structures present relative to conventional civil engineering structures (Section 2.5), inspection techniques that image concrete face many challenges due to the composite nature of the concrete materials and the existence of reinforcing or prestressing systems. Grain size distribution of concrete can be highly variable and the properties of the constituent materials vary greatly making it difficult to obtain accurate images (3.172). Concrete in some measures is a living material and in terms of durability and structural aging is governed by moisture content. 
Moisture variations affect testing performance as the speed and penetration of methods such as acoustic and electromagnetic pulses are strongly dependent on this factor. Other sources of difficulty associated with nondestructive examination of concrete include a generally complex geometry, existence of inclusions, restricted accessibility of the object, and problems related to the sensitivity to the inhomogeneities in the concrete of the method used. Despite these difficulties, significant progress has been made recently in imaging concrete in two- and three-dimensions because of advances in computer speed and memory. Table 3.11 provides a summary of the more commonly used nondestructive testing methods for concrete and reinforced concrete structures, including their purpose/application and advantages and limitations.

Table 3.11 Summary of testing methods for concrete structures

\begin{tabular}{|c|c|c|c|}
\hline Method & Purpose/application & Advantages & Limitations \\
\hline Acoustic emission & $\begin{array}{l}\text { Continuous monitoring of } \\
\text { structure during service life to } \\
\text { detect impending failure; } \\
\text { monitoring performance of } \\
\text { structure during proof testing. }\end{array}$ & $\begin{array}{l}\text { Monitors structural } \\
\text { response to applied load; } \\
\text { capable of detecting onset } \\
\text { of failure; capable of } \\
\text { locating source of possible } \\
\text { failure; equipment is } \\
\text { portable and easy to } \\
\text { operate; good for load tests. }\end{array}$ & $\begin{array}{l}\text { Expensive test to run; can be } \\
\text { used only when structure is } \\
\text { loaded and when flaws are } \\
\text { growing; interpretation of } \\
\text { results requires an expert. }\end{array}$ \\
\hline Acoustic impact & $\begin{array}{l}\text { Detect debonds, delaminations, } \\
\text { voids, and hairline cracks. }\end{array}$ & $\begin{array}{l}\text { Portable equipment; easy to } \\
\text { perform with auditory } \\
\text { system; electronic device } \\
\text { requires more equipment. }\end{array}$ & $\begin{array}{l}\text { Geometry and mass of test } \\
\text { object influence results; poor } \\
\text { discrimination for auditory } \\
\text { systems; reference standards } \\
\text { required for electronic } \\
\text { testing. }\end{array}$ \\
\hline Break-off & $\begin{array}{l}\text { Determination of flexural } \\
\text { strength. }\end{array}$ & $\begin{array}{l}\text { Safe, simple, and fast to } \\
\text { perform requiring only } \\
\text { exposed surface. }\end{array}$ & $\begin{array}{l}\text { Limited by maximum } \\
\text { aggregate size and minimum } \\
\text { member thickness. }\end{array}$ \\
\hline Core testing & $\begin{array}{l}\text { Direct determination of concrete } \\
\text { strength; concrete evaluation of } \\
\text { condition of aggregate, cement, } \\
\text { and other components. }\end{array}$ & $\begin{array}{l}\text { Most widely accepted } \\
\text { method to reliably } \\
\text { determine strength and } \\
\text { quality of in place concrete. }\end{array}$ & $\begin{array}{l}\text { Process of drilling and } \\
\text { analyzing cores is expensive; } \\
\text { coring damages structures } \\
\text { and repair may be required; } \\
\text { analysis of cores is time } \\
\text { consuming. }\end{array}$ \\
\hline $\begin{array}{l}\text { Cover meter } \\
\text { (Pachometer) }\end{array}$ & $\begin{array}{l}\text { Locate reinforcement and metal } \\
\text { embedments in concrete and } \\
\text { masonry; measure concrete } \\
\text { cover depth; estimate diameter } \\
\text { of reinforcement. }\end{array}$ & $\begin{array}{l}\text { Portable and lightweight } \\
\text { equipment; good results if } \\
\text { concrete lightly reinforced; } \\
\text { good for locating rebars so } \\
\text { as to avoid damage in } \\
\text { coring. }\end{array}$ & $\begin{array}{l}\text { Difficult to interpret results } \\
\text { if concrete is heavily } \\
\text { reinforced or if wire mesh is } \\
\text { present; not reliable for } \\
\text { cover over } 100 \mathrm{~mm} \text {; form } \\
\text { ties often mistaken for } \\
\text { anchors; cannot identify } \\
\text { presence of second layer of } \\
\text { reinforcement. }\end{array}$ \\
\hline Electrical resistance & $\begin{array}{l}\text { Measure ability of concrete to } \\
\text { conduct corrosion current; } \\
\text { determination of moisture } \\
\text { content in concrete and map } \\
\text { moisture migration patterns. }\end{array}$ & $\begin{array}{l}\text { Inexpensive and easy to } \\
\text { operate equipment; simple } \\
\text { to operate and many } \\
\text { measurements can be } \\
\text { rapidly made; useful when } \\
\text { used in conjunction with } \\
\text { other methods (e.g., half- } \\
\text { cell potential). }\end{array}$ & $\begin{array}{l}\text { Not reliable at high moisture } \\
\text { contents; requires calibration } \\
\text { and precise results not } \\
\text { usually obtained; electrodes } \\
\text { require good contact and } \\
\text { nearby rebars can affect } \\
\text { results; dielectric properties } \\
\text { depend on salt content and } \\
\text { temperature of specimen } \\
\text { which can present problems } \\
\text { in interpretation of results. }\end{array}$ \\
\hline Fiber scope (endoscope) & $\begin{array}{l}\text { Check condition of materials in } \\
\text { cavities, concealed piping, } \\
\text { electrical wiring in cavity walls, } \\
\text { honeycombing in reinforced } \\
\text { masonry construction or detect } \\
\text { voids along grouted stressed } \\
\text { tendons. }\end{array}$ & $\begin{array}{l}\text { Affords direct visual } \\
\text { inspection of otherwise } \\
\text { inaccessible parts of an } \\
\text { element; provides high- } \\
\text { resolution images. }\end{array}$ & $\begin{array}{l}\text { Semi-destructive in that } \\
\text { probe holes usually must be } \\
\text { drilled and must connect to } \\
\text { cavity; equipment expensive. }\end{array}$ \\
\hline
\end{tabular}


Table 3.11 (cont.) Summary of testing methods for concrete structures

\begin{tabular}{|c|c|c|c|}
\hline Method & Purpose/application & Advantages & Limitations \\
\hline Fluid flow - ISAT & $\begin{array}{l}\text { Measure flow of air or water } \\
\text { into concrete under } \\
\text { prescribed test conditions; } \\
\text { flow rate depends on } \\
\text { penetrability characteristics. }\end{array}$ & $\begin{array}{l}\text { Simple and inexpensive to } \\
\text { perform; portable equipment; } \\
\text { sensitive to changes in concrete } \\
\text { quality; totally nondestructive. }\end{array}$ & $\begin{array}{l}\text { Unreliable for concrete with } \\
\text { high sorptivity surface layer; } \\
\text { measures absorption of outer } \\
\text { surface concrete only and is } \\
\text { affected by surface coatings; } \\
\text { difficult to seal to concrete } \\
\text { surface; sensitive to concrete } \\
\text { moisture condition. }\end{array}$ \\
\hline $\begin{array}{l}\text { Fluid flow - Figg } \\
\text { water absorption }\end{array}$ & $\begin{array}{l}\text { Measure flow of water into } \\
\text { concrete under prescribed } \\
\text { test conditions; flow rate } \\
\text { depends on penetrability } \\
\text { characteristics. }\end{array}$ & $\begin{array}{l}\text { Not affected by coatings and } \\
\text { surface concrete layer; inexpensive } \\
\text { and simple to use. }\end{array}$ & $\begin{array}{l}\text { Intrusive because drilling is } \\
\text { necessary which may affect } \\
\text { concrete under test; sensitive } \\
\text { to aggregate characteristics } \\
\text { and concrete moisture } \\
\text { condition. }\end{array}$ \\
\hline $\begin{array}{l}\text { Fluid flow - Figg } \\
\text { air-permeability }\end{array}$ & $\begin{array}{l}\text { Measure flow of air into } \\
\text { concrete under prescribed } \\
\text { test conditions; flow rate } \\
\text { depends on penetrability } \\
\text { characteristics. }\end{array}$ & $\begin{array}{l}\text { Inexpensive and simple to use; not } \\
\text { influenced by surface layer or } \\
\text { coatings; less sensitive to moisture } \\
\text { condition than water test. }\end{array}$ & $\begin{array}{l}\text { Intrusive because drilling is } \\
\text { necessary which may affect } \\
\text { concrete under test; sensitive } \\
\text { to aggregate characteristics; } \\
\text { provides permeability index } \\
\text { and not a coefficient of } \\
\text { permeability. }\end{array}$ \\
\hline $\begin{array}{l}\text { Fluid flow - } \\
\text { CLAM (water } \\
\text { permeability) }\end{array}$ & $\begin{array}{l}\text { Measure flow of water into } \\
\text { concrete under prescribed } \\
\text { test conditions; flow rate } \\
\text { depends on penetrability } \\
\text { characteristics. }\end{array}$ & $\begin{array}{l}\text { Measures flow under constant } \\
\text { pressure conditions. }\end{array}$ & $\begin{array}{l}\text { Provides permeability index } \\
\text { and not a coefficient of } \\
\text { permeability; sensitive to } \\
\text { concrete moisture condition; } \\
\text { concrete surface damaged; } \\
\text { long test time required. }\end{array}$ \\
\hline $\begin{array}{l}\text { Fluid flow - } \\
\text { Surface airflow } \\
\text { test }\end{array}$ & $\begin{array}{l}\text { Measure flow of air into } \\
\text { concrete under prescribed } \\
\text { test conditions; flow rate } \\
\text { depends on penetrability } \\
\text { characteristics. }\end{array}$ & $\begin{array}{l}\text { Nondestructive; less sensitive to } \\
\text { moisture condition than water flow } \\
\text { tests; includes concrete moisture } \\
\text { conditioning procedure. }\end{array}$ & $\begin{array}{l}\text { Provides permeability index } \\
\text { and not a coefficient of } \\
\text { permeability; measures outer } \\
\text { concrete surface and is } \\
\text { affected by surface coatings. }\end{array}$ \\
\hline $\begin{array}{l}\text { Galvanostatic } \\
\text { pulse }\end{array}$ & $\begin{array}{l}\text { Identify corrosion activity of } \\
\text { steel reinforcement. }\end{array}$ & $\begin{array}{l}\text { Applies to general corrosion; can } \\
\text { be applied to water-saturated } \\
\text { concrete; can calculate corrosion } \\
\text { current which can be converted to } \\
\text { corrosion rate if area of polarized } \\
\text { reinforcement is known; results can } \\
\text { be presented as contour maps } \\
\text { showing polarization resistance } \\
\text { gradients. }\end{array}$ & $\begin{array}{l}\text { Not valid for pitting } \\
\text { corrosion; takes considerably } \\
\text { longer than half-cell potential } \\
\text { measurements; requires } \\
\text { experienced person to perform } \\
\text { technique. }\end{array}$ \\
\hline $\begin{array}{l}\text { Ground- } \\
\text { penetrating radar }\end{array}$ & $\begin{array}{l}\text { Locate metal embedments, } \\
\text { voids, depth of cover; } \\
\text { location of cracks, and } \\
\text { regions of high moisture; } \\
\text { determine thickness of } \\
\text { members; locate major } \\
\text { construction features. }\end{array}$ & $\begin{array}{l}\text { Can be used to survey large areas } \\
\text { rapidly; very sensitive to presence } \\
\text { of embedded metal objects; ability } \\
\text { to penetrate across air-concrete } \\
\text { interfaces; sensitive to presence of } \\
\text { moisture; large amounts of data } \\
\text { obtained during scans. }\end{array}$ & $\begin{array}{l}\text { Region interrogated by } \\
\text { antenna limited to cone- } \\
\text { shaped volume directly below } \\
\text { antenna; reinforcement } \\
\text { congestion can limit } \\
\text { penetration depth; cracks and } \\
\text { delaminations not easy to } \\
\text { detect unless moisture is } \\
\text { present in cracks and } \\
\text { delamination; features } \\
\text { screened by steel } \\
\text { reinforcement will not be } \\
\text { recorded; with increasing } \\
\text { depth, low level signals form } \\
\text { small targets that are harder to } \\
\text { detect due to signal } \\
\text { attenuation; expensive to use } \\
\text { and uneconomical for } \\
\text { surveying small areas. }\end{array}$ \\
\hline
\end{tabular}


Table 3.11 (cont.) Summary of testing methods for concrete structures.

\begin{tabular}{|c|c|c|c|}
\hline Method & Purpose/application & Advantages & Limitations \\
\hline Half-cell potential & $\begin{array}{l}\text { Identify region(s) in a } \\
\text { reinforced concrete structure } \\
\text { where there is a high } \\
\text { probability that corrosion is } \\
\text { occurring at time of } \\
\text { measurement. }\end{array}$ & $\begin{array}{l}\text { Lightweight and portable } \\
\text { equipment; provides } \\
\text { indication of likelihood of } \\
\text { corrosion activity at time of } \\
\text { testing; field measurements } \\
\text { can be readily made and } \\
\text { results plotted in form of } \\
\text { equipotential contour } \\
\text { diagram to indicate likely } \\
\text { areas of corrosion activity; } \\
\text { appears to give reliable } \\
\text { results. }\end{array}$ & $\begin{array}{l}\text { Requires a connection to } \\
\text { embedded reinforcement and } \\
\text { reinforcement must be } \\
\text { electrically connected; not } \\
\text { applicable to epoxy-coated } \\
\text { reinforcement; concrete has to } \\
\text { be moist; no indication of } \\
\text { corrosion rate; requires } \\
\text { experienced personnel. }\end{array}$ \\
\hline Infrared thermography & $\begin{array}{l}\text { Detection of internal flaws, } \\
\text { crack growth, internal voids, } \\
\text { and delaminations; detection } \\
\text { of heat loss and moisture } \\
\text { movement through concrete } \\
\text { elements. }\end{array}$ & $\begin{array}{l}\text { Portable and permanent } \\
\text { records can be made; testing } \\
\text { can be done without direct } \\
\text { access to surface; large areas } \\
\text { can be rapidly inspected; } \\
\text { cost effective; results can } \\
\text { provide an indication of } \\
\text { percentage of area in survey } \\
\text { that is deteriorated. }\end{array}$ & $\begin{array}{l}\text { Expensive equipment; heat } \\
\text { source may be required to } \\
\text { produce thermal gradient in test } \\
\text { specimen; depth and thickness of } \\
\text { a subsurface anomaly can not be } \\
\text { measured; variation in test } \\
\text { response occurs with varying } \\
\text { environmental conditions (e.g., } \\
\text { temperature gradient, shaded or } \\
\text { direct sunlight, cloud cover, and } \\
\text { surface water); ability to detect } \\
\text { anomaly decreases as its depth } \\
\text { increases; trained personnel } \\
\text { needed to assure that acquired } \\
\text { data are meaningful and } \\
\text { correctly interpreted. }\end{array}$ \\
\hline Neutron moisture gage & $\begin{array}{l}\text { Measure moisture content of } \\
\text { concrete, soil, and } \\
\text { bituminous materials; map } \\
\text { moisture migration patterns } \\
\text { in masonry walls. }\end{array}$ & $\begin{array}{l}\text { Instrument is portable and } \\
\text { moisture measurements can } \\
\text { be made rapidly of in-place } \\
\text { concrete. }\end{array}$ & $\begin{array}{l}\text { Equipment sophisticated and } \\
\text { expensive; license required to } \\
\text { operate; minimum thickness of } \\
\text { surface layer is required for } \\
\text { backscatter to be measured; } \\
\text { measures only moisture content } \\
\text { of surface layer ( } 50 \mathrm{~mm} \text { ); } \\
\text { moisture gradients in specimen } \\
\text { may make result erroneous; } \\
\text { results inaccurate because } \\
\text { hydrogen atoms of other } \\
\text { building materials are measured } \\
\text { in addition to water; requires } \\
\text { calibration in order to calculate } \\
\text { density or moisture content. }\end{array}$ \\
\hline Neutron probe & $\begin{array}{l}\text { Determine chloride content } \\
\text { in concrete. }\end{array}$ & $\begin{array}{l}\text { Can detect very small } \\
\text { concentration of chloride } \\
\text { content. }\end{array}$ & $\begin{array}{l}\text { An assumption on chloride ion } \\
\text { profile in concrete is required in } \\
\text { order to avoid neutron flux } \\
\text { distribution. }\end{array}$ \\
\hline
\end{tabular}


Table 3.11 (cont.) Summary of testing methods for concrete structures

\begin{tabular}{|c|c|c|c|}
\hline Method & Purpose/application & Advantages & Limitations \\
\hline Petrography & $\begin{array}{l}\text { Determination of the condition of } \\
\text { the concrete in the structure; } \\
\text { determination of causes of } \\
\text { inferior quality, distress, or } \\
\text { deterioration; determination of } \\
\text { whether the concrete in the } \\
\text { structure was or was not as } \\
\text { specified; description of the } \\
\text { cementitious materials matrix } \\
\text { (e.g., kind of binder, degree of } \\
\text { hydration, nature of hydration } \\
\text { products, and presence of mineral } \\
\text { admixtures); determination of the } \\
\text { presence of alkali-aggregate } \\
\text { reactions; determination if the } \\
\text { concrete has been subjected to } \\
\text { chemical attack or early freezing; } \\
\text { determination of the nature of the } \\
\text { air void system; and survey of the } \\
\text { structure relative to its safety. }\end{array}$ & $\begin{array}{l}\text { Common test that provides } \\
\text { very detailed and reliable } \\
\text { information. }\end{array}$ & $\begin{array}{l}\text { Requires removal of sample; } \\
\text { very expensive; needs qualified } \\
\text { petrographer; difficulties may } \\
\text { arise preparing a satisfactory } \\
\text { surface for analysis. }\end{array}$ \\
\hline Polarization & $\begin{array}{l}\text { Determine the instantaneous } \\
\text { corrosion rate of steel } \\
\text { reinforcement below test point. }\end{array}$ & $\begin{array}{l}\text { Lightweight portable } \\
\text { equipment for linear } \\
\text { polarization; provides } \\
\text { indication of corrosion rate } \\
\text { at time of testing. }\end{array}$ & $\begin{array}{l}\text { Requires a connection to } \\
\text { embedded reinforcement and } \\
\text { reinforcement must be } \\
\text { electrically connected; not } \\
\text { applicable to epoxy-coated or } \\
\text { galvanized bars; no standard for } \\
\text { interpreting results; cover depth } \\
\text { generally < } 100 \mathrm{~mm} \text {; concrete } \\
\text { surface should be smooth, } \\
\text { uncracked, free of impermeable } \\
\text { coating, and free of moisture; } \\
\text { testing and interpretation } \\
\text { requires experienced personnel. }\end{array}$ \\
\hline Pull-off & $\begin{array}{l}\text { Estimation of compressive } \\
\text { strength of existing concrete. }\end{array}$ & $\begin{array}{l}\text { Simple and inexpensive; } \\
\text { can be conducted on } \\
\text { horizontal or vertical } \\
\text { surfaces. }\end{array}$ & $\begin{array}{l}\text { Concrete must be repaired at } \\
\text { test location. }\end{array}$ \\
\hline Pull-out & $\begin{array}{l}\text { Estimation of compressive and } \\
\text { tensile strengths of hardened } \\
\text { concrete. }\end{array}$ & $\begin{array}{l}\text { In-place strength of } \\
\text { concrete can be measured } \\
\text { quickly and appears to give } \\
\text { good prediction; only NDE } \\
\text { method that directly } \\
\text { measures concrete strength; } \\
\text { low level of expertise } \\
\text { required. }\end{array}$ & $\begin{array}{l}\text { Pull-out devices must be } \\
\text { preplanned or inserted into hole } \\
\text { drilled into concrete surface; } \\
\text { cone of concrete may be pulled } \\
\text { out requiring repair; can only } \\
\text { test a limited depth of material, } \\
\text { thus assesses cover concrete } \\
\text { quality. }\end{array}$ \\
\hline Radiography - gamma & $\begin{array}{l}\text { Locate internal cracks, voids, and } \\
\text { variations in density of materials; } \\
\text { locating the position and } \\
\text { condition of reinforcing steel; } \\
\text { steel reinforcement diameter can } \\
\text { be determined; determine } \\
\text { concrete density and thickness. }\end{array}$ & $\begin{array}{l}\text { Used for field } \\
\text { measurements; simple to } \\
\text { operate; relatively } \\
\text { inexpensive and portable } \\
\text { compared to X-ray } \\
\text { radiography; permanent } \\
\text { record on film; good detail } \\
\text { with results easy to } \\
\text { interpret. }\end{array}$ & $\begin{array}{l}\text { Skilled personnel required; } \\
\text { method unsuitable for many } \\
\text { applications due to requirement } \\
\text { for suitable positioning of } \\
\text { photographic film; penetration } \\
\text { depth generally limited to about } \\
<700 \mathrm{~mm} \text {; safety precautions } \\
\text { required; equipment expensive. }\end{array}$ \\
\hline
\end{tabular}


Table 3.11 (cont.) Summary of testing methods for concrete structures

\begin{tabular}{|c|c|c|c|}
\hline Method & Purpose/application & Advantages & Limitations \\
\hline Radiography - X-ray & $\begin{array}{l}\text { Density and internal } \\
\text { structure of concrete; } \\
\text { location of steel } \\
\text { reinforcement. }\end{array}$ & $\begin{array}{l}\text { Provides two-dimensional } \\
\text { image of concrete and } \\
\text { variations in density; } \\
\text { internal defects can be } \\
\text { determined; permanent } \\
\text { record on film. }\end{array}$ & $\begin{array}{l}\text { Skilled and licensed personnel } \\
\text { required; field application } \\
\text { limited because equipment is } \\
\text { usually heavy and expensive; } \\
\text { access to both sides of } \\
\text { specimen required; sections up } \\
\text { to about } 1.5 \text {-m thick can be } \\
\text { inspected; high-energy } \\
\text { radiation source (accelerator) } \\
\text { required to penetrate concrete } \\
>600-\mathrm{mm} \text { thick. }\end{array}$ \\
\hline Radiometry - backscatter & $\begin{array}{l}\text { Determine in-place density } \\
\text { of fresh or hardened } \\
\text { concrete. }\end{array}$ & $\begin{array}{l}\text { Requires access only to } \\
\text { surface of test object; } \\
\text { suitable for fresh or } \\
\text { hardened concrete. }\end{array}$ & $\begin{array}{l}\text { Licensed operators required; } \\
\text { precision of density } \\
\text { measurements is lower than for } \\
\text { direct transmission method; } \\
\text { measurement affected by near } \\
\text { surface material; sensitive to } \\
\text { chemical composition. }\end{array}$ \\
\hline Radiometry - direct & $\begin{array}{l}\text { Determine in-place density } \\
\text { of hardened concrete; locate } \\
\text { reinforcing steel or voids. }\end{array}$ & $\begin{array}{l}\text { Portable equipment } \\
\text { available for determination } \\
\text { of in-place density; } \\
\text { minimal operator skill. }\end{array}$ & $\begin{array}{l}\text { Licensed operators required; } \\
\text { available equipment limited to } \\
\text { path lengths of about } 30 \mathrm{~mm} \text {; } \\
\text { requires access to inside of } \\
\text { member or opposite faces. }\end{array}$ \\
\hline Rebound hammer & $\begin{array}{l}\text { Measures surface hardness } \\
\text { of concrete and provides an } \\
\text { estimate of surface } \\
\text { compressive strength, } \\
\text { uniformity, and quality of } \\
\text { concrete. }\end{array}$ & $\begin{array}{l}\text { Simple to operate; } \\
\text { equipment is lightweight } \\
\text { and inexpensive; large } \\
\text { amount of data can be } \\
\text { obtained quickly; good for } \\
\text { determining uniformity of } \\
\text { concrete and areas of } \\
\text { potentially low strength. }\end{array}$ & $\begin{array}{l}\text { Results affected by condition of } \\
\text { concrete surface; does not give } \\
\text { precise prediction of strength; } \\
\text { estimates of strength should be } \\
\text { used with great care; frequent } \\
\text { equipment calibration required. }\end{array}$ \\
\hline $\begin{array}{l}\text { Spectral analysis of surface } \\
\text { waves }\end{array}$ & $\begin{array}{l}\text { Determine the stiffness } \\
\text { profile (elastic properties of } \\
\text { layered systems) and depth } \\
\text { of deteriorated concrete. }\end{array}$ & $\begin{array}{l}\text { Suited for testing large } \\
\text { surface areas, layered } \\
\text { systems, condition } \\
\text { assessments of concrete } \\
\text { tunnel liners, mapping } \\
\text { subsurface cavities, and } \\
\text { determining depth of } \\
\text { foundations. }\end{array}$ & $\begin{array}{l}\text { Experienced operator required; } \\
\text { involves complex signal } \\
\text { processing; requires access to } \\
\text { one surface; ability to detect } \\
\text { and describe relatively small } \\
\text { defects not as good as for } \\
\text { impact echo or ultrasonic pulse } \\
\text { echo. }\end{array}$ \\
\hline Ultrasonic echo & $\begin{array}{l}\text { Locate delaminations and } \\
\text { voids in relatively thin } \\
\text { elements; indicates } \\
\text { uniformity and quality of } \\
\text { concrete; locate rebars; } \\
\text { indicates density and } \\
\text { member thickness. }\end{array}$ & $\begin{array}{l}\text { Access to only one face } \\
\text { required; portable; } \\
\text { photographic records can } \\
\text { be made; provides } \\
\text { information on depth and } \\
\text { size of defects; can operate } \\
\text { in dry or wet conditions. }\end{array}$ & $\begin{array}{l}\text { Applicable to limited member } \\
\text { thickness; experienced operator } \\
\text { required to interpret results; } \\
\text { processing of results generally } \\
\text { best performed back at lab. }\end{array}$ \\
\hline Ultrasonic pulse velocity & $\begin{array}{l}\text { Indication of compressive } \\
\text { strength, uniformity, and } \\
\text { quality of concrete; internal } \\
\text { discontinuities can be } \\
\text { located and their size } \\
\text { estimated. }\end{array}$ & $\begin{array}{l}\text { Equipment relatively } \\
\text { inexpensive and easy to } \\
\text { operate; accurate } \\
\text { assessment of uniformity } \\
\text { and quality; can rapidly } \\
\text { survey large areas and thick } \\
\text { members; compressive } \\
\text { strength can be estimated if } \\
\text { core compressive strength } \\
\text { has been correlated with } \\
\text { wave velocity. }\end{array}$ & $\begin{array}{l}\text { Good coupling between } \\
\text { transducer and substrate } \\
\text { required; interpretation of } \\
\text { results can be difficult; density } \\
\text { and amount of aggregate, } \\
\text { moisture variations, and } \\
\text { presence of metal } \\
\text { reinforcement may affect } \\
\text { results; can be time consuming } \\
\text { since it only takes point } \\
\text { measurements. }\end{array}$ \\
\hline
\end{tabular}


Table 3.11 (concl.) Summary of testing methods for concrete structures

\begin{tabular}{|l|l|l|l|}
\hline \multicolumn{1}{|c|}{ Method } & \multicolumn{1}{|c|}{ Purpose/application } & \multicolumn{1}{c|}{ Advantages } & \multicolumn{1}{c|}{ Limitations } \\
\hline \hline Visual & $\begin{array}{l}\text { Evaluation of concrete } \\
\text { surface condition; determine } \\
\text { joint and water stop } \\
\text { deficiencies; determining } \\
\text { differential movements. }\end{array}$ & $\begin{array}{l}\text { Generally low cost and } \\
\text { rapid method for concrete } \\
\text { evaluation; possible to } \\
\text { provide indication of } \\
\text { interior of member for } \\
\text { degradation conditions that } \\
\text { translate to surface. }\end{array}$ & $\begin{array}{l}\text { Trained personnel required in } \\
\text { order to determine what to look } \\
\text { for, what measurements to take, } \\
\text { and what follow-on testing to } \\
\text { specify; primary evaluation } \\
\text { confined to concrete surface. }\end{array}$ \\
& $\begin{array}{l}\text { Estimates of compressive } \\
\text { strength, quality, and } \\
\text { uniformity of concrete. }\end{array}$ & $\begin{array}{l}\text { Equipment is simple to } \\
\text { operate and durable; does } \\
\text { not require surface } \\
\text { preparation; useful in } \\
\text { assessing the quality and } \\
\text { relative strength of } \\
\text { concrete; damage to } \\
\text { specimen is minor. }\end{array}$ & $\begin{array}{l}\text { Requires minimum edge } \\
\text { distance and member thickness; } \\
\text { probes may be difficult to } \\
\text { remove; may not yield accurate } \\
\text { estimates of concrete } \\
\text { compressive strength; } \\
\text { interpretation of results depends } \\
\text { on correlation curves. }\end{array}$ \\
& \multicolumn{2}{|l}{}
\end{tabular}

Primary sources: Material abstracted from - Tables 3.7.2, 3.7.3, and 3.7.5 of Guidelines for Structural Condition Assessment of Existing Buildings, ASCE Standard SEI/ASCE 11-99, American Society of Civil Engineers, Reston, Virginia, 2000; and "Summary of NDT Methods for Concrete Structures," Inspection \& Testing Services, Inc., Linden, New Jersey, 2006 (http://www.inspecttest.com/technical-info.html).

Testing of concrete is conducted to determine in situ strength, provide information on the relative quality and local integrity, evaluate durability, and identify causes of deterioration. Nondestructive examination methods are capable of performing measurements both on laboratory specimens as well as on objects in situ. The ability to make in situ measurements of concrete materials is important because characteristics of the hardened concrete impacted by factors such as thermal history, presence of moisture, and consolidation in place can be included. Inspection of concrete structures is becoming increasingly important as the structures age and incidences of degradation are likely to increase. NDE methods thus are valuable tools to evaluate the condition of a structure and for conduct of periodic inspections to monitor the extent of deterioration that has resulted from service conditions. Methods related to an assessment of many of the in situ properties of concrete, however, typically provide an indication of the concrete property through an indirect manner in that they measure a characteristic that is then related to the property in question. Therefore the accuracy of property measurements based on NDE methods will depend on: the relationship between the desired property and the quantity actually measured by the NDE method, how insensitive the indirect measurement is to factors that do not affect the property in question, and the precision of the NDE measurement (3.173). Table 3.12 provides a summary of typical coefficients of variation and maximum accuracies

Table 3.12 Typical coefficients of variation (COV) of test results and maximum accuracies of in situ strength prediction for principal methods utilized

\begin{tabular}{|l|c|c|}
\hline Test method & $\begin{array}{c}\text { Typical COV for individual member } \\
\text { of good quality construction }\end{array}$ & $\begin{array}{c}\text { Best 95\% confidence limits on } \\
\text { strength estimates }\end{array}$ \\
\hline \hline Cores - "standard" & $10 \%$ & $\pm 10 \%(3$ specimens $)$ \\
\hline- "small" & $15 \%$ & $\pm 15 \%(9$ specimens $)$ \\
\hline Pull-out & $8 \%$ & $\pm 20 \%(6$ tests $)$ \\
\hline CAPO Test & $7 \%$ & $\pm 20 \%$ \\
\hline Pull-off & $10 \%$ & $\pm 15 \%(3$ tests $)$ \\
\hline Break-off & $10 \%$ & $\pm 20 \%(5$ tests $)$ \\
\hline Windsor probe & $5 \%$ & $\pm 20 \%(3$ tests $)$ \\
\hline Ultrasonic pulse velocity & $2.5 \%$ & $\pm 20 \%(1$ test $)$ \\
\hline Rebound hammer & $4 \%$ & $\pm 25 \%(12$ tests) \\
\hline
\end{tabular}

Sources: J.H. Bungey, Testing of Concrete in Structures, Third Edition, Surrey University Press, London, United Kingdom, 1996.

J. H. Bungey, Testing of Concrete in Structures, Technical Note 143, Construction Industry Research and Information Association, London, United Kingdom, 1992. 
for several of these methods commonly used to indicate in situ concrete compressive strength. Values are for a single site-made unit constructed from a number of batches of concrete. These values should be considered only as an approximate guide for results to be expected from each of the methods. The typical coefficient of variation and accuracy of results for direct determination of concrete compressive strength (i.e., cores) is also provided in the table for comparison. Successful application of NDE methods requires an understanding of their operating principles as well as their inherent limitations.

Table 3.13 identifies a number of items of interest for application of nondestructive testing to concrete (3.174). Table 3.14 presents information based on several years experience by one organization (Force Technology; Helsingborg, Sweden) on potential testing methods, capabilities/limitations, and an indication of a method's reliability/usefulness in assessing the items of interest in Table 3.13 (3.174). Table 3.15 presents a list of end-user desired attributes of techniques for several applications with specific reference to nuclear power plant concrete structures evaluations that has been developed under a project sponsored by the Nordic Innovation Center (Oslo, Norway) (3.30).

Table 3.13 Nondestructive testing objectives

\begin{tabular}{|c|l|}
\hline \multicolumn{1}{|c|}{ Item Number/Objective of Test } & \multicolumn{1}{|c|}{$\begin{array}{c}\text { Description of Item to be Determined - points of } \\
\text { interest/damage type }\end{array}$} \\
\hline \hline 1 & Cracking in surface concrete \\
\hline 2 & Cracking internally (concrete) \\
\hline $2(\mathrm{a})$ & $\begin{array}{l}\text { Deterioration of concrete with time (except crack } \\
\text { development) }\end{array}$ \\
\hline 3 & $\begin{array}{l}\text { Damaged concrete layers (reduced strength and elastic } \\
\text { properties) }\end{array}$ \\
\hline 4 & Voids in concrete and inhomogeneity \\
\hline 5 & Elastic properties of concrete (E, G - moduli) \\
\hline 6 & Thickness of concrete member or layer \\
\hline 7 & Location of reinforcement \\
\hline 8 & Size of reinforcement \\
\hline 9 & Location of prestressing cable ducts \\
\hline 10 & Detection of voids in prestressing cable ducts \\
\hline 11 & $\begin{array}{l}\text { Condition of prestressing cables (corrosion damage or } \\
\text { fracture) }\end{array}$ \\
\hline 12 & $\begin{array}{l}\text { Detectability of actively corroding reinforcement } \\
\text { (electrochemical) }\end{array}$ \\
\hline 13 & $\begin{array}{l}\text { Estimation of reinforcement corrosion rate } \\
\text { (electrochemical) }\end{array}$ \\
\hline 14 & $\begin{array}{l}\text { Concrete resistivity (related to corrosion rate) } \\
\text { Dielectric and conductive properties of concrete }\end{array}$ \\
\hline 15 & \\
\hline & \\
\hline
\end{tabular}

Source: P. Shaw, and A. Xu, "Assessment of the Deterioration of Concrete in NPP - Causes, Effects and Investigative Methods," Proceedings of the Joint EC OECD IAEA Specialists Meeting, Petten, The Netherlands, March 11-13, 1997. 
Table 3.14 Applicability of nondestructive test methods to items identified in Table 3.13

\begin{tabular}{|c|c|c|c|c|}
\hline Test Method & Description & $\begin{array}{l}\text { Application } \\
\text { to Items in } \\
\text { Table } 3.13\end{array}$ & Capability/limitation & Reliability/usefulness* \\
\hline Ultrasonic pulse velocity & $\begin{array}{l}\text { Ultrasonic wave } \\
\text { transmission, measurement } \\
\text { of wave speed and } \\
\text { frequency-dependent } \\
\text { attenuation }\end{array}$ & $\begin{array}{l}1,2,3,4,5 \\
2(a)\end{array}$ & $\begin{array}{l}\text { Unknown factors may affect wave } \\
\text { speed. Interpretation demanding. } \\
\text { Quantification of information requires } \\
\text { complementary technique. }\end{array}$ & $\begin{array}{l}2 / 2 \\
\text { Unknown }\end{array}$ \\
\hline Ultrasonic pulse echo & Transmission and reflection & $\begin{array}{l}1 \\
2 \\
4 \\
6 \\
9 \\
10\end{array}$ & $\begin{array}{l}\text { Crack surfaces open. } \\
\text { Cracks parallel to surface/crack size. } \\
\text { 16-mm aggregate; depth } \sim 700 \mathrm{~mm} . \\
\text { 16-mm aggregate; depth } \sim 1300 \mathrm{~mm} \text {. } \\
\text { 16-mm aggregate. } \\
\text { 16-mm aggregate. Void or lack of } \\
\text { bond? }\end{array}$ & $\begin{array}{l}2 / 2 \\
1 \text { or } 2 / 2 \\
1 / 1 \\
1 / 2 \\
2 / 2 \\
2 / 2 \text { or } 3\end{array}$ \\
\hline SASW & $\begin{array}{l}\text { Spectral analysis of surface } \\
\text { waves }\end{array}$ & $\begin{array}{l}1 \\
2 \\
3 \\
4 \\
5 \\
6\end{array}$ & $\begin{array}{l}\text { Minimum } 50 \mathrm{~mm} \text { depth. } \\
\text { Large voids. } \\
\text { Access to surface dimension. }\end{array}$ & $\begin{array}{l}\text { Unknown } \\
\text { Unknown } \\
1 / 1 \\
\text { Unknown } \\
\text { Unknown } \\
1 / 1 \\
\end{array}$ \\
\hline Impact echo & $\begin{array}{l}\text { Transmission and reflection } \\
\text { of transient stress waves }\end{array}$ & $\begin{array}{l}2 \\
4 \\
6 \\
10\end{array}$ & $\begin{array}{l}\text { Cracks parallel or near // to surface. } \\
\text { Void size = measuring depth. } \\
\text { Resolution \& wave speed determine } \\
\text { acceleration. } \\
\text { Cannot distinguish lack of bond from } \\
\text { void. }\end{array}$ & $\begin{array}{l}1 / 1 \\
1 / 2 \\
1 / 1 \\
2 / 3\end{array}$ \\
\hline $\begin{array}{l}\text { Ground-penetrating } \\
\text { radar }\end{array}$ & $\begin{array}{l}\text { Transmission and reflection } \\
\text { of electromagnetic waves }\end{array}$ & $\begin{array}{l}3 \\
4 \\
6 \\
7 \\
8 \\
9 \\
15\end{array}$ & $\begin{array}{l}\text { Larger stratification. } \\
\text { Large voids. } \\
\text { Moisture restrictive. } \\
\text { Approx. 700-mm depth. } \\
\text { Special processing. } \\
\text { Approx. } 700-\text { mm depth } \\
\text { (1 GHz). } \\
\text { Large amounts of steel have screening } \\
\text { effect. }\end{array}$ & $\begin{array}{l}2 / 2 \\
2 / 2 \\
2 / 2 \\
1 / 1 \\
\text { Unknown } \\
1 / 1 \\
1 / 2\end{array}$ \\
\hline $\begin{array}{l}\text { High energy } \\
\text { radiography }\end{array}$ & $\begin{array}{l}\text { High energy radiography } \\
\text { (x-rays) }\end{array}$ & $\begin{array}{l}4 \\
6 \\
7 \\
8 \\
9 \\
10 \\
11\end{array}$ & $\begin{array}{l}\text { Thickness of member } 1 \mathrm{~m} . \\
\text { Thickness of member } 1 \mathrm{~m} . \\
\text { Thickness/access. } \\
\text { Thickness/access. } \\
\text { Thickness/access. } \\
\text { Approx. } 800-\mathrm{mm} \text { thickness/access. } \\
800-1000 \mathrm{~mm} \text { thickness/access. }\end{array}$ & $\begin{array}{l}1 / 2 \\
2 / 2 \\
1 / 1 \\
1 / 2 \\
1 / 1 \\
1 / 1 \\
1 / 1\end{array}$ \\
\hline Percometer** & $\begin{array}{l}\text { Measurement of } \\
\text { conductivity and dielectric } \\
\text { constant }\end{array}$ & $\begin{array}{l}14 \\
15\end{array}$ & $\begin{array}{l}\text { Surface measurement. } \\
\text { Surface measurement. }\end{array}$ & $\begin{array}{l}\text { Unknown/1 } \\
\text { Unknown/1 }\end{array}$ \\
\hline Half-cell potential & $\begin{array}{l}\text { Measurement of } \\
\text { electrochemical potential of } \\
\text { steel in concrete }\end{array}$ & 12 & $\begin{array}{l}\text { Reinforcement nearest measuring } \\
\text { surface; not in water-saturated } \\
\text { concrete. }\end{array}$ & 1 or $2 / 1$ \\
\hline $\begin{array}{l}\text { Galvanostatic pulse } \\
\text { measurement }\end{array}$ & $\begin{array}{l}\text { Polarization properties of } \\
\text { reinforcement }\end{array}$ & $\begin{array}{l}12 \\
13 \\
\end{array}$ & $\begin{array}{l}\text { Can be used in water-saturated } \\
\text { concrete (slower). } \\
\text { Applies to general corrosion. }\end{array}$ & $\begin{array}{l}1 / 1 \\
\text { Unknown/2 }\end{array}$ \\
\hline
\end{tabular}

*Rating: 1 = good, 2 = fair, 3 = poor.

**Percometer is an instrument used to measure dielectric constant (permittivity), electrical conductivity, and temperature (http://adek.ee/index.php?page=11).

Source: P. Shaw, and A. Xu, "Assessment of the Deterioration of Concrete in NPP - Causes, Effects and Investigative Methods," Proceedings of the Joint EC OECD IAEA Specialists Meeting, Petten, The Netherlands, March 11-13, 1997. 
Table 3.15 Listing of applications/purpose, desired attributes, and potential NDT techniques

\begin{tabular}{|c|c|c|}
\hline Application/Purpose & Desired Attribute & Potential Technique(s) \\
\hline $\begin{array}{l}\text { Measurement of concrete } \\
\text { thickness to obtain as-built } \\
\text { details }\end{array}$ & $\begin{array}{l}\text { Quantification of capability for measuring concrete } \\
\text { thickness for sections }>1 \mathrm{~m} \text { thick. } \\
\text { Enhanced ease and speed of application for measuring } \\
\text { section thickness in all structures. } \\
\text { Measure section thickness with single-sided access with } \\
\text { sensitivity of } \pm 5 \% \text { section thickness. } \\
\text { Measure section thickness in presence of congested } \\
\text { steelwork with sensitivity of } \pm 5 \% \text { section thickness. }\end{array}$ & $\begin{array}{l}\text { Radar, acoustic, radiography } \\
\text { Radar, radiography, acoustic } \\
\text { Radar, acoustic } \\
\text { Acoustic }\end{array}$ \\
\hline $\begin{array}{l}\text { Mapping/sizing of steel } \\
\text { reinforcement and tendons } \\
\text { to establish as-built details }\end{array}$ & $\begin{array}{l}\text { Enhanced resolution to measure reinforcement diameter } \\
\text { with sensitivity of } \pm 10 \% \text { either in thick sections ( }>1 \mathrm{~m} \text { ) } \\
\text { or in presence of congested reinforcement (individual } \\
\text { reinforcement at spacings of } 150 \mathrm{~mm} \text { ). } \\
\text { Resolve multiple layers of reinforcement identifying } \\
\text { individual reinforcement at spacings }<<150 \mathrm{~mm} \text { and } \\
\text { depths }>30 \mathrm{~mm} \text { and measure reinforcement diameter } \\
\text { with sensitivity of } \pm 10 \% \text {. } \\
\text { Quantify existing performance capability for } \\
\text { mapping/sizing of steel reinforcement and tendons with } \\
\text { section depth. }\end{array}$ & $\begin{array}{l}\text { Radar, radiography, ... } \\
\text { Radar, radiography, ... } \\
\text { Radar, radiography,... }\end{array}$ \\
\hline $\begin{array}{l}\text { Detection of corrosion in } \\
\text { post-tensioning tendons }\end{array}$ & $\begin{array}{l}\text { Quantify performance limits for detection of corrosion by } \\
\text { measuring loss of section/hydrogen embrittlement in } \\
\text { post-tensioning tendons in heavily reinforced structures. } \\
\text { Detect evidence of corrosion in grouted prestressing } \\
\text { tendons by measuring loss of section, pitting or hydrogen } \\
\text { embrittlement }\end{array}$ & $\begin{array}{l}\text { Radiography,... } \\
\text { Radiography }\end{array}$ \\
\hline $\begin{array}{l}\text { Detection of voids and } \\
\text { inhomogeneities, typically } \\
\text { to locate construction flaws }\end{array}$ & $\begin{array}{l}\text { Quantify void detection threshold in thick sections } \\
\text { (variables: size of void, depth). } \\
\text { Detection of voids }>20 \mathrm{~mm} \text { diameter in areas of } \\
\text { congested reinforcement/tendons. }\end{array}$ & $\begin{array}{l}\text { Radar, acoustic, radiography } \\
\text { Radiography, radar }\end{array}$ \\
\hline $\begin{array}{l}\text { Detection and sizing (depth, } \\
\text { width, length) of cracks } \\
\text { normal to surface }\end{array}$ & $\begin{array}{l}\text { Combination of techniques may be appropriate; one to } \\
\text { detect, one to characterize. } \\
\text { Improve variable performance statistics associated with } \\
\text { depth measurement of surface cracks, aiming for } \\
\text { sensitivity of } \pm 10 \% \text { for crack widths }>0.2 \mathrm{~mm}\end{array}$ & Acoustic \\
\hline $\begin{array}{l}\text { Detection of delamination } \\
\text { of cracks parallel to surface }\end{array}$ & $\begin{array}{l}\text { Improve variable performance statistics for detecting } \\
\text { large laminar flaws at }>10 \mathrm{~mm} \text { depth and }>100 \mathrm{~mm} \text { in } \\
\text { any particular direction. } \\
\text { Detection of delamination between post-tensioning } \\
\text { tendons in massive concrete }\end{array}$ & $\begin{array}{l}\text { Acoustic } \\
\text { Acoustic }\end{array}$ \\
\hline Additional goals & $\begin{array}{l}\text { Detection of areal dimension }\left(0.5 \mathrm{~m}^{2}\right) \text { with leaking } \\
\text { waterproofing. } \\
\text { Determination of concrete quality with regard to } \\
\text { compressive strength. }\end{array}$ & \\
\hline
\end{tabular}

Source: A Practical Guide to Non-Destructive Examination of Concrete, Nordic Innovation Center Report, Force Technology, Helsingborg, Sweden, 2004. 
A number of methods exist for application to deep foundations (i.e., piles). Table 3.16 presents a summary of these methods including their principle of operation, application, and advantages and limitations. Application of these methods to nuclear power plant foundations is limited due to accessibility requirements.

Table 3.16 Summary of testing methods for deep foundations

\begin{tabular}{|c|c|c|c|}
\hline Method & Application & Advantages & Limitations \\
\hline "Sonic-echo & $\begin{array}{l}\text { Determine length of deep } \\
\text { foundations (piers or } \\
\text { piles); determine the } \\
\text { location of cracks or } \\
\text { constrictions (neck-in) }\end{array}$ & $\begin{array}{l}\text { No pre-placed tubes. } \\
\text { Portable equipment. } \\
\text { Rapid. }\end{array}$ & $\begin{array}{l}\text { Confuses necking and } \\
\text { bulging. Does not } \\
\text { measure diameter. } \\
\text { Unable to determine } \\
\text { defects in shafts }>30 \mathrm{~m} \\
\text { or with } \mathrm{L} / \mathrm{d}>30 \text {. }\end{array}$ \\
\hline $\begin{array}{l}\text { Impulse-response } \\
\text { (mobility) }\end{array}$ & $\begin{array}{l}\text { Determine length of deep } \\
\text { foundation (piers or piles), } \\
\text { location of cracks and } \\
\text { constrictions (neck-in). } \\
\text { Provides information on } \\
\text { low-strain dynamic } \\
\text { stiffness of the shaft/soil } \\
\text { system. }\end{array}$ & $\begin{array}{l}\text { No pre-placed tubes. } \\
\text { Stiffness measurements. } \\
\text { Portable equipment. } \\
\text { Rapid. }\end{array}$ & $\begin{array}{l}\text { Careful interpretation of } \\
\text { results required. } \\
\text { Limitations on geometry } \\
\text { of pile to be tested } \\
\text { similar to those for sonic- } \\
\text { echo method. }\end{array}$ \\
\hline Impedance logging & $\begin{array}{l}\text { Determine the } \\
\text { approximate two- } \\
\text { dimensional shape of the } \\
\text { deep foundation. }\end{array}$ & $\begin{array}{l}\text { No pre-placed tubes. } \\
\text { Stiffness measurements. } \\
\text { Portable equipment. } \\
\text { Rapid. Effective shape of } \\
\text { shaft derived from } \\
\text { analysis. }\end{array}$ & $\begin{array}{l}\text { Requires very good test } \\
\text { data for accurate } \\
\text { analysis. Full analysis } \\
\text { can not yet be completed } \\
\text { on site at time of test. }\end{array}$ \\
\hline Crosshole sonic logging & $\begin{array}{l}\text { Determine the location of } \\
\text { low quality concrete along } \\
\text { the length of the shaft } \\
\text { between transducers. With } \\
\text { drilled holes permits direct } \\
\text { determination of shaft } \\
\text { length. }\end{array}$ & $\begin{array}{l}\text { Relatively fast. Detection } \\
\text { of defects between tubes is } \\
\text { much more accurate than } \\
\text { in surface reflection tests. } \\
\text { Performance is not limited } \\
\text { by depth. }\end{array}$ & $\begin{array}{l}\text { Pre-placed tubes or } \\
\text { coring required. May not } \\
\text { detect defects at edge of } \\
\text { shaft. }\end{array}$ \\
\hline Parallel seismic & $\begin{array}{l}\text { Determine the foundation } \\
\text { depth and determine } \\
\text { whether it is of uniform } \\
\text { quality. }\end{array}$ & $\begin{array}{l}\text { Relatively fast. } \\
\text { Foundations under existing } \\
\text { structures can be tested. } \\
\text { Not affected by soil } \\
\text { damping as much as } \\
\text { surface reflection methods. }\end{array}$ & $\begin{array}{l}\text { Cost of bore hole } \\
\text { adjacent to each } \\
\text { foundation. Signal stops } \\
\text { at first major anomaly. } \\
\text { Can bypass edge effects. }\end{array}$ \\
\hline Gamma-gamma logging & $\begin{array}{l}\text { Locate regions of low } \\
\text { density along length of } \\
\text { foundation; detect } \\
\text { anomalies in cast-in- } \\
\text { drilled hole piles. }\end{array}$ & $\begin{array}{l}\text { Accurate nondestructive } \\
\text { test method. Can see } \\
\text { around and outside steel } \\
\text { reinforcing cage. Results } \\
\text { are repeatable without } \\
\text { time impacts. Data } \\
\text { processing simple. }\end{array}$ & $\begin{array}{l}\text { Utilizes radioactive } \\
\text { source. Requires that } \\
\text { inspection tubes be cast } \\
\text { accurately into structure. } \\
\text { Only investigates } \\
\text { approximately } 75 \mathrm{~mm} \\
\text { into concrete surrounding } \\
\text { the inspection tube. }\end{array}$ \\
\hline
\end{tabular}

Sources: "Summary of NDT Methods for Concrete Structures," Inspection \& Testing Services, Inc., Linden, New Jersey, 2006 (http://www.inspecttest.com/technical-info.html).

B.A. Liebich, "Acceptance Testing of Drilled Shafts by Gamma-Gamma Logging," California Dept. of Transportation, Sacramento,

(http://www.dot.ca.gov/hq/esc/geotech/gg/geophysics2002/ggl_geophysics.pdf). 
Application of nondestructive testing methods to masonry structures is complicated because the masonry, in addition to being a compound material consisting of masonry units and mortar, can also include steel reinforcing, grout, tie rods, embedded metals, anchors, and joint reinforcement. Traditional evaluation methods for the condition and properties of masonry features of buildings have been, in addition to visual inspection, based on destructive testing of samples removed from the structure. Destructive methods of evaluation for nuclear power plant masonry structures are inherently limited because specimen removal could be structurally damaging. In the event that visual inspections reveal areas of uncertain structural reliability, there are a number of nondestructive examination methods" that can provide more quantitative information on the existing structure. The NDE methods can be used in combination with other NDE methods (e.g., impact and stress wave techniques to evaluate condition and indirectly measure quality) or in conjunction with destructive tests. Table 3.17 lists primary nondestructive testing techniques for masonry structures, desired information in terms of material properties or condition, and usefulness. Recently acoustic imaging and ground-penetrating radar have exhibited promise as nondestructive test methods for application to masonry structures.

Table 3.17 Typical nondestructive examination techniques for masonry structures

\begin{tabular}{|c|c|c|c|c|c|c|c|c|c|c|}
\hline \multicolumn{2}{|c|}{$\begin{array}{l}\text { Desired } \\
\text { Information for } \\
\text { Structural Evaluation }\end{array}$} & 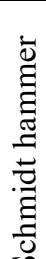 & 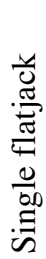 & 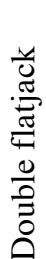 & 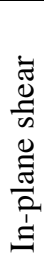 & 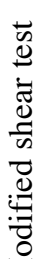 & 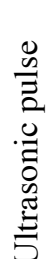 & 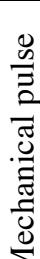 & 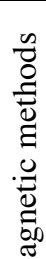 & 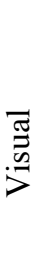 \\
\hline \multirow{5}{*}{ 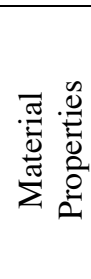 } & Compressive strength (direct) & & & $\bullet$ & & & & & & \\
\hline & Compressive strength (indirect) & $\bullet$ & & & & & $\mathrm{o}$ & $\mathrm{o}$ & & \\
\hline & Deformability & & & • & & & & & & \\
\hline & Joint shear strength & & & & O & • & & & & \\
\hline & Coulomb shear relationship & & & & & $\bullet$ & & & & \\
\hline \multirow{5}{*}{ :0̃ } & Voids between wythes & & & & & & $\bullet$ & $\bullet$ & & \\
\hline & Cracks in outer wythes & & & & & & $\mathrm{O}$ & $\mathrm{O}$ & & $\mathrm{O}$ \\
\hline & In situ stress & & • & & & & & & & \\
\hline & Material uniformity & $\bullet$ & & & & & $\bullet$ & $\bullet$ & & $\mathrm{O}$ \\
\hline & Location of reinforcement & & & & & & & & $\bullet$ & \\
\hline
\end{tabular}

Key: • useful for evaluation,

o useful, but may require additional information regarding loading conditions and crack distributions

Source: "Nondestructive Evaluation Methods," Chapter 10 of Masonry Structural Design for Buildings, TM 5-8093/NAVFAC DM-2.9/AFM 88-3, Joint Departments of Army, Navy and Air Force, Washington, D.C., October 30,1992.

With respect to specific application to nuclear power plant concrete safety-related structures, the status of nondestructive examination methods has been investigated through a workshop and report prepared that identifies NDE development priorities $(3.175,3.176)$. Table 3.18 provides a summary of key applications, current status, and candidate techniques resulting from these activities. With the exception of measurement of concrete cover, detection of changes in physical properties, and measurement of humidity and conductivity profiles, detailed development needs were also established for each of the applications. Specific needs identified that were thought to be of high potential benefit were related to: detection of corrosion in steel liners that are buried (covered by concrete) or inaccessible due to the presence of a moisture barrier, detection of voids $>20$ - $\mathrm{mm}$ diameter in grouted tendon ducts, improved variable performance statistics associated with depth measurements of surface cracks

\footnotetext{
* Several of methods are actually semi-destructive in that they require the removal of a mortar bed joint or a unit for insertion of the test fixture components.
} 
Table 3.18 Summary of key applications and current status of NDE in safety-related structures

\begin{tabular}{|c|c|c|}
\hline Application and purpose & Current status & Existing techniques \\
\hline $\begin{array}{l}\text { Measurement of concrete thickness } \\
\text { Used to obtain as-built details and a } \\
\text { key input for selected NDE } \\
\text { techniques (e.g., impact echo) }\end{array}$ & $\begin{array}{l}\text { Section thickness measurements } \\
\text { limited to thin sections } \\
\text { Limited by constraints such as access } \\
\text { to single sided only, presence of } \\
\text { liners, and congested reinforcement }\end{array}$ & $\begin{array}{l}\text { Acoustic } \\
\text { Radar (limited beyond first rebar; } \\
\text { moisture dependent) } \\
\text { Radiography (dual-sided access) } \\
\text { Gamma densitometers (dual-sided } \\
\quad \text { access) }\end{array}$ \\
\hline $\begin{array}{l}\text { Measurement of concrete cover to } \\
\text { reinforcement } \\
\text { Used to establish as-built details }\end{array}$ & $\begin{array}{l}\text { Existing technique adequate for } \\
\text { measurement of cover up to } 150 \mathrm{~mm} \text {. }\end{array}$ & Covermeter (Pachometer) \\
\hline $\begin{array}{l}\text { Mapping/sizing of steel } \\
\text { reinforcement and tendons } \\
\text { Used to establish as-built details }\end{array}$ & $\begin{array}{l}\text { With double-sided access can } \\
\text { measure reinforcement } \\
\text { diameter/configuration through } \sim 1 \mathrm{~m} \\
\text { section } \\
\text { Radar can be used to detect } \\
\text { reinforcement with } 100 \mathrm{~mm} \\
\text { separation at } 50 \text {-mm depth }\end{array}$ & $\begin{array}{l}\text { Radar (limited beyond first rebar) } \\
\text { Radiography (double-sided access) } \\
\text { Covermeters }\end{array}$ \\
\hline $\begin{array}{l}\text { Detection of corrosion in } \\
\text { embedded steel (both } \\
\text { reinforcement and liners) } \\
\text { Corrosion is considered key issue } \\
\text { for aging of concrete structures - } \\
\text { detect loss of section, pitting, or } \\
\text { hydrogen embrittlement }\end{array}$ & $\begin{array}{l}\text { Radiography provides direct measure } \\
\text { of reinforcement diameter and } \\
\text { indication of corrosion (e.g., through } \\
1 \text { m section) }\end{array}$ & Radiography (dual-sided access) \\
\hline $\begin{array}{l}\text { Detection of corrosion in } \\
\text { prestressing tendons } \\
\text { Corrosion is considered key issue } \\
\text { for aging of concrete structures - } \\
\text { detect loss of section, pitting, or } \\
\text { hydrogen embrittlement }\end{array}$ & $\begin{array}{l}\text { Radiography provides direct measure } \\
\text { of reinforcement diameter and } \\
\text { indication of corrosion (e.g., through } \\
1 \mathrm{~m} \text { section) }\end{array}$ & Radiography (dual-sided access) \\
\hline $\begin{array}{l}\text { Detection of voids and } \\
\text { inhomogeneity } \\
\text { Typically used to detect } \\
\text { construction flaws (e.g., } \\
\text { honeycombing) }\end{array}$ & $\begin{array}{l}\text { Radiography (plus gamma } \\
\text { scintillation) if dual-sided access } \\
\text { permitted, reasonable detectability of } \\
\text { internal damage in sections }<1 \mathrm{~m} \text {. } \\
\text { Acoustic methods have reasonable } \\
\text { detectability of small voids and } \\
\text { discontinuities at depths of } \sim 0.5 \mathrm{~m} \\
\text { in lab trials but cannot distinguish } \\
\text { lack of bond from voids. } \\
\text { Help identify areas at risk }\end{array}$ & $\begin{array}{l}\text { Radiography (dual-sided access); } \\
\text { Backscatter (single-sided access) } \\
\text { Gamma Scintillation (dual-sided } \\
\text { access) } \\
\text { Acoustic (to identify risk) } \\
\text { Radar }\end{array}$ \\
\hline $\begin{array}{l}\text { Detection of surface deposits/visual } \\
\text { symptoms of flaws }\end{array}$ & $\begin{array}{l}\text { Visual inspections of accessible } \\
\text { structures; supported by tools such as } \\
\text { video, fiberscope for reaching } \\
\text { inaccessible areas }\end{array}$ & Visual (accessible surfaces) \\
\hline $\begin{array}{l}\text { Detection and sizing (depth, width, } \\
\text { length) of cracks normal to surface } \\
\text { Combinations of techniques with } \\
\text { one to detect and one to size }\end{array}$ & $\begin{array}{l}\text { Cracks reaching surface detected } \\
\text { through visual examination } \\
\text { (accessible surfaces) } \\
\text { Acoustic techniques may be used to } \\
\text { size open cracks but has exhibited } \\
\text { variable performance }\end{array}$ & $\begin{array}{l}\text { Visual to detect (accessible } \\
\text { surfaces) } \\
\text { Thermography } \\
\text { Acoustic (to size open surface } \\
\text { cracks) } \\
\text { Leak tests (gas flow) through } \\
\text { cracks }\end{array}$ \\
\hline
\end{tabular}


Table 3.18 (cont.) Summary of key applications and current status of NDE in safety-related structures

\begin{tabular}{|l|l|l|}
\hline \multicolumn{1}{|c|}{ Application and purpose } & \multicolumn{1}{|c|}{ Current status } & \multicolumn{1}{|c|}{ Existing techniques } \\
\hline \hline $\begin{array}{l}\text { Detection of delamination/cracks } \\
\text { parallel to surface }\end{array}$ & $\begin{array}{l}\text { Acoustic techniques are effective in } \\
\text { detecting near surface delamination } \\
\text { (to first rebar layer) }\end{array}$ & Acoustic \\
\hline $\begin{array}{l}\text { Measurement of concrete } \\
\text { mechanical properties (e.g., } \\
\text { strength and stiffness) }\end{array}$ & $\begin{array}{l}\text { Map changes in properties over a } \\
\text { section with data typically calibrated } \\
\text { against limited destructive testing } \\
\text { (e.g., cores) } \\
\text { Unlikely that NDE may be } \\
\text { practically employed to determine in } \\
\text { situ properties of concrete }\end{array}$ & $\begin{array}{l}\text { Rebound hammer (surface } \\
\text { properties) }\end{array}$ \\
\hline $\begin{array}{l}\text { Detection of changes in physical } \\
\text { properties (e.g., porosity/ } \\
\text { permeability) }\end{array}$ & $\begin{array}{l}\text { Variety of permeability tests } \\
\text { available, but no standards exist. }\end{array}$ & $\begin{array}{l}\text { Permeability tests (semi- } \\
\text { destructive) }\end{array}$ \\
\hline \hline $\begin{array}{l}\text { Measurement of } \\
\text { humidity/conductivity profiles }\end{array}$ & $\begin{array}{l}\text { Physical probing generally needed } \\
\text { (semi-destructive) }\end{array}$ & Semi-destructive \\
$\begin{array}{l}\text { Assess risk of corrosion and also as } \\
\text { input to selected NDE techniques } \\
\text { (e.g., radar) }\end{array}$ & & \\
\hline
\end{tabular}

Source: Development Priorities for Non-Destructive Examination of Concrete Structures in Nuclear Plant, NEA/CSNI/R(86)6, Nuclear Energy Agency, Committee on Safety of Nuclear Installations, Isy-lesMoulineaux, France, November 2, 1998.

normal to the concrete surface aiming for a sensitivity of $\pm 10 \%$ for crack widths $>0.2 \mathrm{~mm}$, and improved visual/optical scanning techniques with sensitivity equivalent to visual inspection for mapping cracks over large surface areas and for detecting surface deposits/visual symptoms of flaws. Primary conclusions from the workshop and report were that: although NDE techniques have been successfully used on a variety of reinforced and posttensioned concrete structures, there is limited experience in their use to evaluate typical nuclear power plant safetyrelated structures having thick sections, steel liners, and access to only one side; there is general lack of confidence in the techniques because there is very little independent advice on their applicability, capability, accuracy, and reliability; no authoritative international guidance or standard for NDE of concrete structures was identified; NDE of concrete structures is often based on equipment developed for other materials and technologies such as applications to metallic materials or foundations; quantification of the capabilities of NDE techniques is seen as a priority area for development, however, the industry lacks a standard for quantifying the NDE of nuclear safetyrelated concrete structures; and the high cost of developing software and equipment, with no guarantee of success, means that the nuclear industry is unlikely to consider this to be a priority area for future funding. Despite the somewhat negative connotation of several of the these conclusions, NDE is expected to gain an increasingly important role in aging management of nuclear power plant safety-related concrete structures for determination of as-built (or current) structural features, detection of flaws, and characterization and quantification of flaws. Three techniques were identified from the NDE priorities activities as having the greatest potential to meet the challenges provided by the characteristics of nuclear power plant safety-related concrete structures: radar, acoustic (ultrasonic pulse velocity, ultrasonic pulse echo, spectral analysis of surface waves, impact echo, and acoustic tomography), and radiography. As a result of software development for signal and image processing to improve resolution around and immediately beyond the first level of reinforcement, radar was considered to offer considerable possibility for dealing with thick sections, if steel reinforcement is not too concentrated. Acoustic methods based on transmission and reflection of stress waves have capability for indicating the relative quality of concrete in a structure, detection of voids and flaws, testing layered systems, and determining depth of foundations. Radiography, although currently limited to sections $\leq 1.2-\mathrm{m}$ thick and requirement for two-sided access, was judged to be potentially useful in locating internal damage, detection and measurement of reinforcement/prestressing tendons, and voids. The NDE prioritization results also noted the importance of use of techniques in combination to validate results or exploit synergies between techniques where the techniques provide similar coverage, are not sensitive to same parameters 
or features, or where information from one technique can be used as input for interpreting/calibrating the results of another technique.

There are a large number of studies, reports, and publications devoted to development of nondestructive evaluation methods for concrete and concrete structures, but a limited number of methods have been standardized which has had a negative impact on usage of nondestructive testing for concrete (3.177). Existing standards that address testing of concrete are available through organizations such as: American Society for Testing and Materials, British Standards Institute, German Standards Institute (Deutsches Institut für Normung), International Organization for Standardization, American Concrete Institute, DGZfP Recommendations (German Society for NDT), Japanese Society for Nondestructive Inspection, and Japan Concrete Institute. However, standards that specifically address nuclear power plant safety-related concrete structures require development.

Finally, defect detectability functions that provide data on the probability of commonly used nondestructive test methods to detect a flaw in concrete (e.g., void or crack) having a specific size and orientation are not available (3.178). Information such as this is required in order to improve the effectiveness of reliability-based condition assessments of reinforced concrete structures.

\subsection{REFERENCES}

3.1 "Inservice Inspections of Ungrouted Tendons in Prestressed Concrete Containment Structures," Regulatory Guide 1.35, Rev. 3, Office of Standards Development, U.S. Nuclear Regulatory Commission, Washington, D.C., July 1990.

3.2 "Determining Prestressing Forces for Inspection of Prestressed Concrete Containments," Regulatory Guide 1.35.1, Office of Standards Development, U.S. Nuclear Regulatory Commission, Washington, D.C., July 1990.

3.3 "Rules for Inservice Inspection of Nuclear Power Plant Components," ASME Boiler and Pressure Vessel Code, Section XI, Division 1, Subsection IWL, Requirements for Class CC Components of Light-Water Cooled Plants, American Society of Mechanical Engineers, New York, New York, July 1, 2005.

3.4 A.T. Ciolko and H. Tabatabai, "Nondestructive Methods for Condition Evaluation of Prestressing Steel Strands in Concrete Bridges," Final Report Phase I: Technology Review, NCHRP Project 10-53, National Cooperative Highway Research Program, Transportation Research Board, National Research Council, Washington, D.C., March 1999.

3.5 "NDT Assessment and New Systems in Prestressed Concrete," First Workshop of COST 534, European

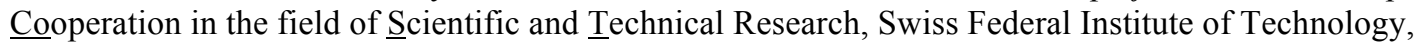
Eidgennössiche Technische Hochschule, Zurich, Switzerland, October 13, 2004.

3.6 ACI Committee 228, In-Place Methods for Determination of Strength of Concrete, ACI 228.1R-03, American Concrete Institute, Farmington Hills, Michigan, 2003.

3.7 ACI Committee 228, Nondestructive Test Methods for Evaluation of Concrete in Structures, ACI 228.2R98, American Concrete Institute, Farmington Hills, Michigan, 1998.

3.8 V.M. Malhotra and N.J. Carino, Handbook of Nondestructive Testing of Concrete, CRC Press, Boca Raton, Florida, 1991.

3.9 H.S. Lew Nondestructive Testing, SP-112, American Concrete Institute, Farmington Hills, Michigan, 1988.

3.10 J.H. Bungey, The Testing of Concrete in Structures, Third Edition, Surrey University Press, London, United Kingdom, 1996.

3.11 B.P.C. Rao, Introduction to Non-Destructive Testing (NDT), http://www.geocities.com/raobpc/NDT.html.

3.12 B.P.C. Rao, Visual Techniques in NDT, (http://geocities.com/raobpc/Visual.html). 
3.13 U.S. Army Corps of Engineers, Evaluation and Repair of Concrete Structures - Engineering Manual, EM1110-2-2-2002, Waterways Experiment Station, Vicksburg, Mississippi, 1995.

3.14 R. Lasudry, "Instrumentation and Monitoring of Belgian Cooling Towers, Workshop on Instrumentation and Monitoring of Concrete Structures, NEA/CSNI/R(2000)15, Nuclear Energy Agency, Committee on the Safety of Nuclear Installations, Issy-les-Molineaux, France, 2001.

3.15 G. De Schutter, "Advanced Monitoring of Cracked Structures Using Video Microscope and Automated Image Analysis," NDT\&E International 35(4), pp. 209-212, Elsevier Ltd., June 2002.

3.16 ACI Committee 201, Guide for Making a Condition Survey of Concrete in Service, ACI 201.1R-92, American Concrete Institute, Farmington Hills, Michigan, 1997.

3.17 ACI Committee 207, Practices for Evaluation of Concrete in Existing Massive Structures for Service Conditions, ACI 207.3R-94, American Concrete Institute, Farmington Hills, Michigan, 1994.

3.18 ACI Committee 224, Causes, Evaluation, and Repair of Cracks in Concrete Structures, ACI 224.1R-07, American Concrete Institute, Farmington Hills, Michigan, 2007.

3.19 ACI Committee 311, Guide for Concrete Inspection, ACI 311.4R-00, American Concrete Institute, Farmington Hills, Michigan, 2000.

3.20 ACI Committee 349, Evaluation of Existing Nuclear Safety Related Concrete Structures, ACI 349.3R-02, American Concrete Institute, Farmington Hills, Michigan, 2002.

3.21 "Standard Test Method for Pulse Velocity Through Concrete," ASTM C 857-04, Annual Book of ASTM Standards, American Society for Testing and Materials, West Conshohocken, Pennsylvania, 2004.

3.22 J. Berriman, T.H. Gan, D.A. Hutchins, and P. Purnell, "Non-Contact Ultrasonic Interrogation of COfig3NCRETE," International Symposium on Non-Destructive Testing in Civil Engineering 2003, (NDT$C E$-2003), Bundesanstalt für Materialforschung und -prüfung, Berlin, Germany, 2003.

3.23 B.W. Drinkwater and P.D. Wilcox, "Ultrasonic Arrays for Non-Destructive Evaluation: A Review," NDT\&E 39(7), pp. 525-541, Elsevier Ltd., October 2006.

3.24 K.J. Langenberg, K. Mayer, R. Marklein, P. Ampha, M. Krause, and F. Mielentz, "Ultrasonic Phased Array and Synthetic Aperture Imaging in Concrete," $16^{\text {th }}$ World Conference on NDT, Paper Code 261, Montreal, Canada, August 30 - September 3, 2004.

3.25 M. Schickert, "Progress in Ultrasonic SAFT-Imaging of Concrete," International Symposium on NonDestructive Testing in Civil Engineering 2003, (NDT-CE-2003), Bundesanstalt für Materialforschung und prüfung, Berlin, Germany, 2003.

3.26 M. Krause, F, Mielentz, B. Milmann, D. Streicher, and W. Müller, "Ultrasonic Imaging of Concrete Elements: State-of-the-Art Using 2D Synthetic Aperture," International Symposium on Non-Destructive Testing in Civil Engineering 2003, (NDT-CE-2003), Bundesanstalt für Materialforschung und -prüfung, Berlin, Germany, 2003.

3.27 V.G. Shevaldykin, A.A. Samokrutov, and V.N. Kozlov, "Ultrasonic Low-Frequency Short-Pulse Transducers with Dry Point Contact - Development and Application," International Symposium on NonDestructive Testing in Civil Engineering 2003, (NDT-CE-2003), Bundesanstalt für Materialforschung und prüfung, Berlin, Germany, 2003.

3.28 A. Kovalev, "Ultrasonic Testing of Concrete Structures," Proceedings of $8^{\text {th }}$ European Conference on NonDestructive Testing, Barcelona, Spain, June 2002. 
3.29 C. Maierhofer, M. Krause, E. Niederleithinger, and H. Wiggenhauser, "Non-Destructive Testing Methods at BAM for Damage Assessment and Quality Assurance in Civil Engineering," International Symposium on Non-Destructive Testing in Civil Engineering 2003, (NDT-CE-2003), Bundesanstalt für Materialforschung und -prüfung, Berlin, Germany, 2003.

3.30 A Practical Guide to Non-Destructive Examination of Concrete, Nordic Innovation Center Report, Force Technology, Helsingborg, Sweden, 2004.

3.31 M. Sansalone and N.J. Carino, "Stress Wave Propagation Methods, Chapter 12 in CRC Handbook on Nondestructive Testing of Concrete, V.M. Malhotra and N.J. Carino Editors, pp. 275-304, CRC Press, Boca Raton, Florida, 1991.

3.32 D.S. Kim, W.S. Seo, and K.M. Lee, "IE-SASW Method for Nondestructive Evaluation of Concrete Structure," NDT\&E 39(2), pp. 143-154, Elsevier Ltd., March 2006.

3.33 K. Mori, A. Spagnoli, Y. Murakami, G. Kondo, and I. Torigoe, "A New Non-Contacting Non-Destructive Testing Method for Defect Detection in Concrete," NDT\&E 35(6), pp. 399-406, Elsevier Ltd., September 2002.

3.34 W. Erfurt, J. Stark, F.A. Finger, and W. Köhler, "The Application of Laser Techniques in the NonContacting Excitation and Recording of Sound Waves," International Symposium on Non-Destructive Testing in Civil Engineering 2003, (NDT-CE-2003), Bundesanstalt für Materialforschung und -prüfung, Berlin, Germany, 2003.

3.35 "Standard Test Method for Measuring the P-Wave Speed and the Thickness of Concrete Plates Using the Impact-Echo Method," ASTM C 1383-04, Annual Book of ASTM Standards, American Society for Testing and Materials, West Conshohocken, Pennsylvania, 2004.

3.36 D.B. Woodham and M.P. Schuller, "Tomographic Imaging for Investigation of Concrete Structures," International Conference on Life Prediction and Aging Management of Concrete Structures, EXPERTCENTRUM, pp. 88-93, Bratislava, Slovakia, 1999.

3.37 L.J. Bond, W.F. Kepler, and D.M. Frangopol, "Improved Assessment of Mass Concrete Dams Using Acoustic Travel Time Tomography. Part I - Theory," Construction and Building Materials 14, pp. 133146, Elsevier Publishers, New York, 2000.

3.38 W.F. Kepler, L.J. Bond, and D.M. Frangopol, "Improved Assessment of Mass Concrete Dams Using Acoustic Travel Time Tomography. Part II- Application," Construction and Building Materials 14, pp. 147-156, Elsevier Publishers, New York, 2000.

3.39 J. Rhazi, "Evaluation of Concrete Structures by the Acoustic Tomography Technique," Structural Health Monitoring 5(4), pp. 333-342, Sage Publications, 2006.

3.40 A.G. Davis and C.G. Petersen, "Nondestructive Evaluation of Prestressed Concrete Bridges Using Impulse Response," International Symposium on Non-Destructive Testing in Civil Engineering (NDT-CE-2003), Bundesanstalt für Materialforschung und -prüfung, Berlin, Germany, 2003.

3.41 A.G. Davis, M.K. Lim, and C.G. Petersen, "Rapid and Economical Evaluation of Concrete Tunnel Linings with Impulse Response and Impulse Radar Non-Destructive Methods," NDT\&E International 38(3), pp. 181-186, Elsevier Ltd., April 2005.

3.42 P.C. Chang, A. Flatau, and S.C. Liu, "Review Paper: Health Monitoring of Civil Infrastructure," Structural Health Monitoring, Sage Publications, Thousand Oaks, California, 2003.

3.43 N. Bandara and R.C. Briggs, Nondestructive Testing of Pavement Structures, Back to Basics, The American Society for Nondestructive Testing, Columbus, Ohio, July 2004. 
3.44 Non-Destructive Testing (NDT) and Examination (NDE), Brochure 2048-2-en (http://www.Force.dk), Force Technology, Brøndby, Sweden, February 16, 2007.

3.45 "What is Acoustic Emission?" Nondestructive Testing Encyclopedia, Kirchwald, Germany (http://www.ndt.net).

3.46 M.A. Hamstad, "What is Acoustic Emission Technology?" (http://www.engr.du.edu/profile/Marvin.htm).

3.47 G. Muravin, Inspection, Diagnostics and Monitoring of Construction Materials and Structures by Acoustic Emission Method, Minerva Press, London, United Kingdom, 2000.

3.48 C.U. Grosse, M. Krüger, and S.D. Glaser, "Wireless Acoustic Emission Sensor Networks for Structural Health Monitoring in Civil Engineering, European Conference on NDT, Paper Tu.1.7.3, 8 pp., Berlin, Germany, 25-29 September 2006.

3.49 P.O. Paulson, "The Use of Acoustic Monitoring to Manage Concrete Structures, "International Symposium on Non-Destructive Testing in Civil Engineering (NDT-CE-2003), Bundesanstalt für Materialforschung und -prüfung, Berlin, Germany, 2003.

3.50 O. Youdan, "The Use of Acoustic Monitoring to Manage Concrete Structures in the Nuclear Industry," Proceedings of the Workshop on the Instrumentation and Monitoring of Concrete Structures,

NEA/CSNI/R(2000)15, Nuclear Energy Agency, Committee on Safety of Nuclear Installations, Isy-lesMoulineaux, France, January 10, 2001.

3.51 T. Vogel, B. Schechinger, and S. Fricker, "Acoustic Emission Analysis as a Monitoring Method for Prestressed Concrete Structures," European Conference on NDT, Paper We.4.4.3, 13 pp., Berlin, Germany, 25-29 September 2006.

3.52 R.D. Owen, "Portable Linear Accelerators for X-Ray and Electron-Beam Applications in Civil Engineering," NDT\&E International 31(6), pp. 401-409, December 1998.

3.53 B. Redmer, F. Weise, U. Ewert, and A. Likhatchev, "Location of Reinforcement in Structures by Different Methods of Gamma-Radiography," International Symposium on Non-Destructive Testing in Civil Engineering (NDT-CE-2003), Bundesanstalt für Materialforschung und -prüfung, Berlin, Germany, 2003.

3.54 G.F. Pla-Rucki and M.O. Eberhard, "Imaging of Reinforced Concrete: State-Of-The-Art Review," Journal of Infrastructure Systems, American Society of Civil Engineers, New York, New York, June 1995.

3.55 C.V. Kropas-Hughes and S.T. Neel, "Basics of Computed Tomography," The American Society of Nondestructive Testing, Columbus, Ohio May 2000 (http://asnt.org/publications/materialseval/basics/may00basics/may00basics.htm).

3.56 K. Brown and J. St Leger, "Use of the Megascan ${ }^{\mathrm{TM}}$ Imaging Process in Inspection Systems for PostTensioning Bridges and Other Major Structures," International Symposium on Non-Destructive Testing in Civil Engineering (NDT-CE-2003), Bundesanstalt für Materialforschung und -prüfung, Berlin, Germany, 2003.

3.57 J.H. Bungey, "Sub-Surface Radar Testing of Concrete: A Review," Construction and Building Materials 18(1) pp. 1-8, February 2004.

3.58 Non-Destructive Testing (NDT) and Examination (NDE), Concrete Inspection and Analysis, Force Technology, Brøndby, Sweden, 2007 (http://www.force.dk).

3.59 Y. Zhao, J. Wu, J. Wang, and M. Wan, "Ground Penetrating Radar Technique and It's Application in NonDestructive Testing of Reinforced Concrete," The 10th Asian Pacific NDT Conference, Brisbane, Australia, 17-21 September 2001. 
3.60 M.R. Shaw, S.G. Millard, T.C.K. Molyneaux, M.J. Taylor, and J.H. Bungey, "Location of Steel Reinforcement in Concrete Using Ground Penetrating Radar and Neural Networks," NDT\&E 38(3), pp. 203-212, April 2005.

3.61 V. Barrile and R. Pucinotti, "Application of Radar Technology to Reinforced Concrete Structures: A Case Study,” NDT\&E 38(7), pp. 596-604, October 2005.

3.62 T. Hamasaki, T. Uomoto, M. Ohtsu, H. Ikenaga, H. Tanana, A. Kishi, and A. Yoshimura, "Identification of Reinforcement in Concrete by Electro-Magnetic Method," International Symposium on Non-Destructive Testing in Civil Engineering (NDT-CE-2003), Bundesanstalt für Materialforschung und -prüfung, Berlin, Germany, 2003.

3.63 P.K. Mehta and P. Monteiro, Concrete - Microstructure, Properties, and Materials, $3^{\text {rd }}$ Edition, McGraw Hill Companies, Inc., New York, New York, 2006.

$3.64 \mathrm{http}: / /$ www.geophysical.biz/void1.htm.

3.65 P. Robery, "Now You See It - Radar, Vibration, and Thermography As Investigative Tools for Structures," Construction, Maintenance, and Repair, pp. 120-124, May/June 1990.

3.66 M. Scott, A. Rezaizadeh, and M. Moore, Phenomenology Study of HERMES Ground Penetrating Radar Technology for Detection and Identification of Common Bridge Deck Features, Report No. FHWA-RD-01090, Office of Infrastructure Research and Development, Federal Highway Administration, McLean, Virginia, April 2001.

3.67 J.H. Bungey, Testing of Concrete in Structures, Technical Note 143, Construction Industry Research and Information Association, London, United Kingdom, 1992.

3.68 "Standard Test Method for Detecting Delaminations in Bridge Decks Using Infrared Thermography," ASTM D 4788-03, Annual Book of ASTM Standards, American Society for Testing and Materials, West Conshohocken, Pennsylvania, 2003.

3.69 C. Maierhofer, A. Brink, M. Röllig, and H. Wiggenhouser, "Quantitative Impulse-Thermography as NonDestructive Testing Method in Civil Engineering - Experimental Results and Numerical Calculations," Construction and Building Materials 19, pp. 731-737, Elsevier Publishers, August 2005.

3.70 N.K. Del Grande and P.F. Durbin, Delamination Detection in Reinforced Concrete Using Thermal Inertia, UCRL-JC-132497 (Preprint), Lawrence Livermore National Laboratory, Livermore, California, November $30,1998$.

3.71 F. Weritz, G. Wedler, A. Brink, M. Röllig, C. Maierhofer, and H. Wiggenhauser, "Investigation of Concrete Structures with Pulse Phase Thermography," International Symposium on Non-Destructive Testing in Civil Engineering 2003, (NDT-CE-2003), Bundesanstalt für Materialforschung und -prüfung, Berlin, Germany, 2003.

3.72 "Standard Practice for Measuring Delaminations in Concrete Bridge Decks by Sounding," ASTM D 458003, Annual Book of ASTM Standards, American Society for Testing and Materials, West Conshohocken, Pennsylvania, 2003.

3.73 "Standard Test for Rebound Number of Hardened Concrete," ASTM C 805-04, Annual Book of ASTM Standards, American Society for Testing and Materials, West Conshohocken, Pennsylvania, 2004.

3.74 J. Kropp and H. K. Hilsdorf (Editors), Performance Criteria for Concrete Durability, E \& F N Spon, London, United Kingdom, 1995.

3.75 B. Wolter, F. Kohl, N. Surkowa, and G. Dobmann, "Practical Applications of NMR in Civil Engineering," International Symposium on Non-Destructive Testing in Civil Engineering (NDT-CE-2003), Bundesanstalt für Materialforschung und -prüfung, Berlin, Germany, 2003. 
3.76 C.G. Petersen and E. Poulsen, "In-situ NDT Methods for Concrete With Particular Reference to Strength, Permeability, Chloride Content and Disintegration," Proc. of $1^{\text {st }}$ International Conference on Deterioration and Repair of Reinforced Concrete in the Arabian Gulf, 1, Construction Industry Research and Information Association, London, United Kingdom, pp. 495-508, 1985.

3.77 F.J. Postema and A. van Beek, "NDT Used in the Netherlands from a Principal Point of View," International Symposium on Non-Destructive Testing in Civil Engineering (NDT-CE-2003), Bundesanstalt für Materialforschung und -prüfung, Berlin, Germany, 2003.

3.78 W. Brameshuber, M. Raupach, S Schröder, and C. Dauberschmidt, "Non-Destructive Determination of the Water Content in the Concrete Cover Using the Multiring Electrode," International Symposium on NonDestructive Testing in Civil Engineering (NDT-CE-2003), Bundesanstalt für Materialforschung und prüfung, Berlin, Germany, 2003.

3.79 H-J Krause, C, Dang, N. Klein, and F, Dumat, "Dielectric Microwave Resonator for Non-Destructive Evaluation of Moisture and Salinity," European Conference on NDT, Poster 18, 12 pp., Berlin, Germany, 25-29 September 2006.

3.80 F. Weritz, D. Schaurich, G, Wilsch, J. Wöstmann, and H. Wiggenhauser, "Laser Induced Breakdown Spectroscopy as a Tool for the Characterization and Sorting of Concrete Waste Material in View of HighOrder Re-Use," International Symposium on Non-Destructive Testing in Civil Engineering (NDT-CE2003), Bundesanstalt für Materialforschung und -prüfung, Berlin, Germany, 2003.

3.81 A. Taffe, D. Schaurich, F. Weritz, and G. Wilsch, "Laser-Induced Breakdown Spectroscopy (Libs) in Civil Engineering," European Conference on NDT, Poster 15, 6 pp., Berlin, Germany, 25-29 September 2006.

3.82 "Standard Test for Obtaining and Testing Drilled Cores and Sawed Beams of Concrete," ASTM C 42-04, Annual Book of ASTM Standards, American Society for Testing and Materials, West Conshohocken, Pennsylvania, 2004.

3.83 "Standard Test Method for Penetration Resistance of Hardened Concrete," ASTM C 803/803M-03, Annual Book of ASTM Standards, American Society for Testing and Materials, West Conshohocken, Pennsylvania, 2004.

3.84 J.H. Bungey and M.N. Soutos, "Reliability of Partially-Destructive Tests to Assess the Strength of Concrete On Site," Construction and Building Materials 15(2-3), pp. 81-92, Elsevier Science Ltd., MarchApril 2001.

3.85 C.G. Petersen, "LOK-TEST and CAPO-TEST, Twenty Years Experience," Non-Destructive Testing in Civil Engineering Conference, 19 pp., Liverpool, England, April 8-11, 1997.

3.86 "Standard Test Method for Pullout Strength of Hardened Concrete," ASTM C 900-06, Annual Book of ASTM Standards, American Society for Testing and Materials, West Conshohocken, Pennsylvania, 2006.

3.87 "Standard Test Method for Water-Soluble Chloride in Mortar and Concrete," ASTM C 1218/C 1218M-99, Annual Book of ASTM Standards, American Society for Testing and Materials, West Conshohocken, Pennsylvania, 2006.

3.88 "Standard Test Method for Acid-Soluble Chloride in Mortar and Concrete," ASTM C 1152/C 1152M-04, Annual Book of ASTM Standards, American Society for Testing and Materials, West Conshohocken, Pennsylvania, 2006.

3.89 A.A. Sohanghpurwala, Manual on Service Life of Corrosion-Damaged Reinforced Concrete Bridge Superstructure Elements, NCHRP Report 558, National Cooperative Research Program, Transportation Research Board, Washington, D.C., 2006. 
3.90 G.G. Clemeña and C. M. Apusen, Final Report - An Alternative Potentiometric Method for Determining Chloride Ion Content in Concrete Samples from Reinforced-Concrete Bridges, VTRC 02-R18, Virginia Transportation Research Council, Charlottesville, Virginia, June 2002.

3.91 N.V. Orlova and J.C. Westall, The Study of Chloride Ion Migration in Reinforced Concrete Under Cathodic Protection, SPR 357, Oregon Department of Transportation, Salem, Oregon, September 1999.

3.92 J. Arai, T. Mizobuchi, and K. Suda, "Study on Measurement of Chloride Content using Electromagnetic Wave in Reinforced Concrete Structures," International Symposium on Non-Destructive Testing in Civil Engineering (NDT-CE-2003), Bundesanstalt für Materialforschung und -prüfung, Berlin, Germany, 2003.

3.93 G. Wilsch, F. Weritz, D. Schaurich, and H. Wiggenhauser, "Determination of Chloride Content in Concrete Structures Using Laser-Induced Breakdown Spectroscopy," Construction and Building Materials 19(10), pp. 724-730, December 2005.

3.94 Standard Practice for Petrographic Examination of Hardened Concrete, ASTM C 856-04, Annual Book of ASTM Standards, American Society for Testing and Materials, West Conshohocken, Pennsylvania, 2006.

3.95 Analysis of Hardened Concrete - A Guide to Tests, Performance and Interpretation of Results, Technical Report 32, Concrete Society, Surrey, United Kingdom, 1989.

3.96 ACI Committee 201, Guide to Durable Concrete, ACI 201.2R-01, American Concrete Institute, Farmington Hills, Michigan, 2001.

3.97 Protocol for Selecting ASR-Affected Structures for Lithium Treatment, Publication No. FHWA-HRT-06071, Federal Highway Administration, U.S. Department of Transportation, McLean, Virginia, February 2006.

3.98 Standard Method of Test For Rapid Identification of Alkali-Silica Reaction Products in Concrete," AASHTO Test Procedure T 299, American Association of State Highway and Transportation Officials, Washington, D.C., 2001.

3.99 D. Stark, "Handbook for the Identification of Alkali-Silica Reactivity in Highway Structures," Report No. SHRP-C-/FR-91-101, Strategic Highway Research Program, National Research Council, Washington, D.C., 1990.

3.100 G.D. Guthrie and J.W. Carey, "A Simple, Environmentally Friendly, and Chemically Specific Method for the Identification and Evaluation of the Alkali-Silica Reaction," Cement and Concrete Research 27(9), pp. 1407-1417, 1997.

3.101 H.N. Walker, D.S. Lane, and P.E. Stutzman, Petrographic Methods of Examining Hardened Concrete: A Petrographic Manual. FHWA-HRT-04-150, U.S. Department of Transportation, Federal Highway Administration, McLean, Virginia, July 2006.

3.102 S. Lim, D.G. Zollinger, and S.L. Sarkar, "Evaluation of ASR Distress in Airfield Concrete Pavements," 2002 Federal Aviation Administration Airport Technology Transfer Conference, Federal Aviation Administration, Atlantic City, New Jersey, May 2002.

3.103 A.B. Poole and A. Thomas, "A Staining Technique the Identification of Sulfates in Aggregates and Concrete, Mineralogical Magazine 40, pp. 315-316, 1975.

3.104 A. Samarin, "Chapter 8, Combined Methods," in Handbook of Nondestructive Testing of Concrete, V.M. Malhotra and N.J. Carino Editors, CRC Press, Boca Raton, Florida, 1991.

3.105 A. Semarin and P. Meynink, "Use of Combined Ultrasonic and Rebound Hammer Method for Determining Strength of Concrete Structural Members, Concrete International Design and Construction 3(3), p. 25, American Concrete Institute, Farmington Hills, Michigan, 1981. 
3.106 I. Facaoaru, "Nondestructive Testing of Concrete in Romania," Symposium on Nondestructive Testing of Concrete and Timber, Paper 4C, Institution of Civil Engineers, London, United Kingdom, 1969.

3.107 G. Pascale, A. Di Leo, and V. Bonora, "Evaluation of Actual Compressive Strength of High Strength Concrete by NDT," $15^{\text {th }}$ World Conference on NDT 2000, Rome, Italy, October 16-21, 2000.

3.108 J.G. Wiebenga, "A Comparison Between Various Combined Nondestructive Testing Methods to Derive the Compressive Strength of Concrete," Report No. B-168-61/IHI.8, Institut TNO Voor Bouwmaterialen en Bouwconstructies, Delft, The Netherlands, 1968.

3.109 A. Galan, "Estimate of Concrete Strength by Ultrasonic Pulse Velocity and Damping Constant," Journal of American Concrete Institute 64(10), p. 678, Farmington Hills, Michigan, 1967.

3.110 C. Kohl and D. Streicher, "Results of Reconstructed and Fused NDT-Data Measured in the Laboratory and On-Site at Bridges," Cement and Concrete Composites 28(4), pp. 402-413, April 2006.

3.111 C. Kohl, M. Krause, C. Maierhofer, J. Wöstmann, H. Wiggenhauser, and K. Mayer. "3-D Visualization of NDT-Data Using Data Fusion Technique," International Symposium on Non-Destructive Testing in Civil Engineering (NDT-CE-2003), Bundesanstalt für Materialforschung und -prüfung, Berlin, Germany, 2003.

3.112 F. Buyle-Bodin, "Contribution of Coupling Non-Destructive Methods for the Diagnosis of Concrete Structures," International Symposium on Non-Destructive Testing in Civil Engineering (NDT-CE-2003), Bundesanstalt für Materialforschung und -prüfung, Berlin, Germany, 2003.

3.113 Electrochemical Techniques to Detect Corrosion in Concrete Structures in Nuclear Installations, NEA/CSNI/R(2002)21, Nuclear Energy Agency, Committee on Safety of Nuclear Installations, Paris, France, July 19, 2002.

3.114 J.P. Broomfield, Corrosion of Steel in Concrete: Understanding, Investigation and Repair, E \& F N Spon, London, United Kingdom, 1997.

3.115 J.P. Broomfield, K. Davies, and K. Hladky, "The Use of Permanent Corrosion Monitoring in New and Existing Reinforced Concrete Structures,” Cement and Concrete Composites 24(1), Elsevier Science Ltd., 2002.

3.116 H-W Song and V. Saraswathy, Corrosion Monitoring of Reinforced Concrete Structures - A Review," International Journal of Electrochemical Science 2, pp. 1-28, 2007.

3.117 "Standard Test Method for Half-Cell Potentials of Uncoated Reinforcing Steel in Concrete," ASTM C 87691, Annual Book of ASTM Standards, American Society for Testing and Materials, West Conshohocken, Pennsylvania, 2004.

3.118 K.R. Gowers and S.G. Millard, "Measurement of Concrete Resistivity for Assessment of Corrosion Severity of Steel Using Wenner Technique," Title No. 96-M66, ACI Materials Journal, American Concrete Institute, Farmington Hills, Michigan, September-October 1999.

3.119 M.A.A. Tullmin, C.M. Hansson, and P.R. Roberge, "Electrochemical Techniques for Measuring Reinforcing Steel Corrosion, $I^{\text {st }}$ Global Internet Corrosion Conference, Session 1, Paper 4, InterCorr/96, 1996 (http://www.corrosionsource.com).

3.120 H. Ingvarsson, "Non-Destructive Condition Assessment of Concrete," Monitoring of Large Structures and Assessment of Their Safety, pp. 65-81, International Association for Bridge and Structural Engineering, Zurich, Switzerland, 1987.

3.121 P.B. Polder, P.B. Bamforth, P.B. Basheer, J. Chapmas-Andrews, R. Cigna, M. Jafar, A. Mazzani, E. Nolan, and H. Wojtas, "Reinforcement Corrosion and Concrete Resistivity - State of the Art Laboratory and Field Results," International Conference on Corrosion and Corrosion Protection of Steel in Concrete held at the University of Sheffield, United Kingdom, R.N. Swamy Editor, pp. 571-580, July 24-28, 1994. 
3.122 J. Flis, S. Sabol. H.W. Pickering, A. Sehgal, K. Osseo-Asare, and P.D. Cady, "Electrochemical Measurements of Bridges for Evaluation of Reinforcement Corrosion Rates," Corrosion 49(7), pp. 601$613,1993$.

3.123 N.S. Berke and M. Hicks, "Estimating the Life Cycle of Reinforced Concrete Decks and Marine Piles Using Laboratory Diffusion and Corrosion Data," in Corrosion Forms and Control for Infrastructure, V. Chaker (Editor), ASTM STP 1137, pp. 207-231, American Society for Testing and Materials, West Conshohocken, Pennsylvania, 1992.

3.124 S. Feliu, C. Andrade, J.A. Gonzalez, and A. Alonso, "A New Method for In-Situ Measurement of Electrical Resistivity of Reinforced Concrete," Materials and Structures 29(6), pp. 362-365, July 1996.

3.125 RILEM TC 154-EMC, "Electrochemical Techniques for Measuring Metallic Corrosion," Materials and Structures 37, pp. 623-643, November 2004.

3.126 C. Andrade and I. Martinez, "Electrochemical Corrosion Rate Measurement Using Modulated Confinement of the Current - Calibration of this Method by Gravimetrics Losses," International Symposium on NonDestructive Testing in Civil Engineering 2003, (NDT-CE-2003), Bundesanstalt für Materialforschung und prüfung, Berlin, Germany, 2003.

3.127 J. Flis, H.W. Pickering, and K. Osseo-Asare, "Interpretation of Impedance Data for Reinforcing Steel in Alkaline Solution Containing Chloride Ions and Acetates," Electrochimica Acta 43, pp. 1921-1929, 1998.

3.128 B. Elsener, H. Wojtas, and H. Bohni, "Galvanostatic Pulse Measurements - Rapid On Site Corrosion Monitoring," International Conference on Corrosion and Corrosion Protection of Steel in Concrete held at University of Sheffield, United Kingdom, R.N. Swamy Editor, Vol. 1, pp. 236-246, July 24-28, 1994.

3.129 C.J. Newton and J.M. Sykes, "A Galvanic Pulse Technique for Investigation of Steel Corrosion in Concrete," Corrosion Science 28, pp. 1051-1073, 1988.

3.130 O. Klinghoffer, "In-Situ Monitoring of Reinforcement Corrosion by Means of Electro-Chemical Methods," Nordic Concrete Research 95, 1995.

3.131 B. Elsener and H. Bohni, "Potential Mapping and Corrosion of Steel in Concrete," ASTM STP 1056, Corrosion Rates of Steel in Concrete, N.S. Berke, V. Chaker, and D. Whiting (Editors), pp. 143-156, 1990.

3.132 D. Jolivet, D.M. Bonen, and S.P. Shah, "The Corrosion Resistance of Coated Steel Dowels Determined by Impedance Spectroscopy," Cement and Concrete Research 37, Elsevier Ltd., pp. 1134-1143, 2007.

3.133 M.F. Montemore, A.M.P. Simoes, M.M. Salta, and M.G.S. Ferreira, "The Assessment of the Electrochemical Behaviour of Flyash-Containing Concrete by Impedance Spectroscopy," Corrosion Science 35(5-8), Pergamon Press, pp. 1571-1578, 1993.

3.134 M. Shi, Z. Chen, and J. Sun, "Determination of Chloride Diffusivity in Concrete by AC Impedance Spectroscopy," Cement and Concrete Research 29, Elsevier Ltd., pp. 1111-1115, 1999.

3.135 D.D. MacDonald, Y.A. El-Tantawy, R.C. Rocha-Filho, and M. Urquide-Macdonald, Evaluation of Electrochemical Impedance Technology for Detecting Corrosion of Rebar in Reinforced Concrete, SHRPID/UFR-91-524, Vol. 1, Strategic Highway research Program, National Research Council, Washington, D.C., September 1991.

3.136 D. Bjegovic, D. Mikulic, and D. Sekulic, "Non-Destructive Corrosion Rate Monitoring for Reinforced Concrete Structures," $15^{\text {th }}$ World Conference on NDT 2000, Rome, Italy, October 16-21, 2000.

3.137 Cescor srl, Milan, Italy (www.cescor.it/eng/pdf/Ti_MNO_Electrode 2004E.pdf).

3.138 Germann Instruments, Copenhagen, Denmark (www.germann.org). 
3.139 Ingenieurbüro Wietek, Innsbruch, Austria (www.a-bau.co.at/cms/elektrode.htm).

3.140 Force Technology, Helsingborg, Sweden, 2004, (www.force.dk/en/Menu/Products+and+Concepts/Products/051219 concretemonitoringandequipment.htm).

3.141 "Anode-Ladder-System for Corrosion Monitoring - Specifications," S + R SENSORTEC GMBH, Munich, Germany, May 2006 (www.sensortec.de/index.htm).

3.142 M. Raupach and P. Schiessl, "Macrocell Sensor for Monitoring of the Corrosion Risk of the Reinforcement in Concrete Structures," NDT\&E 34(6), pp. 435-442, Elsevier Ltd., September 2001.

3.143 "Embedded Corrosion Instrument - For Non-Destructive Evaluation of Steel-Reinforced Concrete," Virginia Technologies, Inc., Charlottesville, Virginia, 2005 (www.vatechnologies.com/eciIndex.htm).

3.144 B. Hertlein and A. Davis, Nondestructive Testing of Deep Foundations, John Wiley \& Sons Ltd., Chichester, West Suffex, United Kingdom, 2006.

3.145 F. Rausche, "Non-Destructive Evaluation of Deep Foundations, Proceedings of Fifth International Conference on Case Histories in Geotechnical Engineering, New York, New York, April 13-17, 2004.

3.146 R.J. Finno and S.L. Gassman, and P.W. Osborn, "Non-Destructive Evaluation of a Deep Foundation Test Section at the Northwestern University National Geotechnical Experimentation Site," Federal Highway Administration, McLean, Virginia, June 1997 (http://www.iti.northwestern.edu/projects/found/dft.html).

3.147 E. Niederleithinger and A. Taffe, "Concept for Reference Pile Testing Sites for the Development and Improvement of NDT-CE," International Symposium on Non-Destructive Testing in Civil Engineering 2003, (NDT-CE-2003), Bundesanstalt für Materialforschung und -prüfung, Berlin, Germany, 2003.

3.148 E. Niederleithinger and A. Taffe, "Early Stage Elastic Wave Velocity of Concrete Piles," Cement and Concrete Composites 28(4), pp. 317-320, April 2006.

3.149 Proceedings of the International Conference: Reuse of Foundations for Urban Sites, A.P. Butcher, J.J.M. Powell, and H.D. Skinner (Editors), BRE Press, British Research Establishment, Bracknell, Berkshire, United Kingdom, 2006.

3.150 "Foundations," Standard Review Plan, NUREG-0800, Revision 2, Section 3.8.5, U.S. Nuclear Regulatory Commission, Washington, D.C., March 2007.

3.151 C.J. Hookham, In-Service Inspection Guidelines for Concrete Structures in Nuclear Power Plants, ORNL/NRC/LTR-95/14, Lockheed Martin Energy Systems, Inc., Oak Ridge National Laboratory, Oak Ridge, Tennessee, 1995.

3.152 “Groundwater," Standard Review Plan, NUREG-0800, Revision 2, Section 2.4.12, U.S. Nuclear Regulatory Commission, Washington, D.C., March 2007.

3.153 Building Code Requirements for Structural Concrete and Commentary, ACI Standard 318-05/318R-05, ACI Committee 318, American Concrete Institute, Farmington Hills, Michigan, 2005.

3.154 Generic Aging Lessons Learned (GALL) Report, NUREG-1801, Rev. 1, Division of Regulatory Improvement Programs, U.S. Nuclear Regulatory Commission, Washington, D.C., September 2005.

3.155 Concrete in Aggressive Ground, BRE Special Digest 1, Building Research Establishment, Garston, Watford, United Kingdom, 2005.

3.156 Class I Structures License Renewal Industry Report: Revision 1, EPRI TR-103842, Electric Power Research Institute, Palo Alto, California, July 1994. 
3.157 "Inspection of Structures, Passive Components, and Civil Engineering Features at Nuclear Power Plants," Inspection Procedure 62002, NRC Inspection Manual, U.S. Nuclear Regulatory Commission, Washington, D.C., December 31, 1996.

3.158 Guidelines for Structural Condition Assessment of Existing Buildings, ASCE Standard SEI/ASCE 11-99, American Society of Civil Engineers, Reston, Virginia, 2000.

3.159 "Nondestructive Evaluation Methods," Chapter 10 of Masonry Structural Design for Buildings, TM 5-8093/NAVFAC DM-2.9/AFM 88-3, Joint Departments of Army, Navy and Air Force, Washington, D.C., October 30, 1992.

3.160 "Standard Test Method for In Situ Measurement of Masonry Mortar Joint Shear Strength Index," ASTM C 1197-04, Annual Book of ASTM Standards, American Society for Testing and Materials, West Conshohocken, Pennsylvania, 2004.

3.161 "Standard Test Methods for In Situ Measurement of Masonry Deformability Properties Using Flatjack Method," ASTM C 1531-03, Annual Book of ASTM Standards, American Society for Testing and Materials, West Conshohocken, Pennsylvania, 2004.

3.162 "Standard Test Method for In Situ Compressive Stress Within Solid Unit Masonry Using Flatjack Method," ASTM C 1196-04, Annual Book of ASTM Standards, American Society for Testing and Materials, West Conshohocken, Pennsylvania, 2004.

3.163 E. Esposito, S. Copparoni, and B. Naticchia, "Recent Progress in Diagnostics of Civil Structures by Laser Vibrometry," $16^{\text {th }}$ World Conference on NDT 2004, Montreal, Canada, August 30 - September 3, 2004.

3.164 "Description of Work, Annex 1," On-Site Investigation Techniques for the Structural Evaluation of Historic Masonry Buildings (ONSITEFORMASONRY), Contract No. EVK4-CT-2002-00060, Fifth Framework Programme, European Union, Brussels, Belgium, March 2, 2004 (www.onsiteformasonry.bam.de).

3.165 C. Maierhofer, M. Krause, and H. Wiggenhauser, "Non-Destructive Investigation of Sluices Using Radar and Ultrasonic Impulse Echo," Proceedings of $7^{\text {th }}$ International Conference on Structural Faults and Repair, Vol. 3, pp. 67-474, Edinburgh, Scotland, July 9, 1997.

3.166 C. Colla, M.C. Forde and P.C. Das, "Radar Imaging in Composite Masonry Structures," Proceedings of $7^{\text {th }}$ International Conference on Structural Faults and Repair, Vol. 3, pp. 493-504, Edinburgh, Scotland, July 9, 1997.

3.167 A. Wendrich, C. Trela, M. Krause, C. Maierhofer, U. Effner, and J. Wöstmann, "Location of Voids in Masonry Structures by Using Radar and Ultrasonic Traveltime Tomography," $\sigma^{\text {th }}$ European Conference on NDT, Paper Tu.3.2.5, Berlin, Germany, September 25-29, 2006.

3.168 M. Pieraccini, M. Pisaneschi, L. Noferini, and C. Atzeni, "Polarimetric Radar Signature of Masonry Walls," NDT\&E International 40, Elsevier Ltd., pp. 271-274, 2007.

3.169 A. Taffe and C. Maierhofer, "Guidelines for NDT Methods in Civil Engineering," International Symposium on Non-Destructive Testing in Civil Engineering (NDT-CE-2003), Bundesanstalt für Materialforschung und -prüfung, Berlin, Germany, 2003.

3.170 C. Maierhofer, S. Leipold, and H. Wiggenhauser, "Investigation of the Influence of Moisture and Salt Content on the Dielectric Properties of Brick Materials Using Radar," Proceedings of the 7th International Conference on Ground Penetrating Radar (GPR), Vol. 2, pp. 477-484, Lawrence, Kansas, May 27-30, 1998.

3.171 M. Schuller, M. Berra, R. Atkinson, and L. Binda, "Acoustic Tomography for Evaluation of Unreinforced Masonry," Construction and Building Materials 11(3), pp. 199-204, Elsevier Sciences Ltd., 1997. 
3.172 O. Büyüköztürk, "Imaging of Concrete Structures," NDT\&E International 31(4), pp. 233-243, Elsevier Science Ltd., 1998.

3.173 J.R. Clifton and N.J. Carino, "Nondestructive Evaluation Methods for Quality Acceptance of Installed Building Materials," Journal of Research of National Bureau of Standards 87(5), pp. 407-438, October 1982.

3.174 P. Shaw, and A. Xu, "Assessment of the Deterioration of Concrete in NPP - Causes, Effects and Investigative Methods," Proceedings of the Joint EC OECD IAEA Specialists Meeting, Petten, The Netherlands, March 11-13, 1997.

3.175 NEA Workshop on Development Priorities for NDE of Concrete Structures in Nuclear Plants (Risely, United Kingdom), NEA/CSNI/R(97)28, Nuclear Energy Agency, Committee on Safety of Nuclear Installations, Isy-les-Moulineaux, France, November 12, 1997.

3.176 Development Priorities for Non-Destructive Examination of Concrete Structures in Nuclear Plant, NEA/CSNI/R(98)6, Nuclear Energy Agency, Committee on Safety of Nuclear Installations, Isy-lesMoulineaux, France, November 2, 1998.

3.177 E.J. Nesvijski, "Perspective Investigation of Ultrasonic Pulse Method for Testing of Concrete in Frame of GOST, ASTM, and ISSO Standards," Proceedings of The American Society for Nondestructive Testing Spring Conference and Fourth Annual Research Symposium, Las Vegas, Nevada, March 20-24, 1995.

3.178 B.R. Ellingwood and Y. Mori, "Condition Assessment and Reliability-Based Life Prediction of Concrete Structures in Nuclear Plants," ORNL/NRC/LTR-92/4, Martin Marietta Energy Systems, Inc., Oak Ridge National Laboratory, Oak Ridge, Tennessee, January 1992. 


\section{REVIEW OF METHODS FOR DETECTION OF DEGRADATION IN NUCLEAR POWER PLANT METALLIC PRESSURE BOUNDARIES}

Nuclear power plant containment metallic pressure boundaries (i.e., metal containments and liners of reinforced concrete containments) under normal operating conditions are subject to various operating and environmental stressors, such as ambient pressure fluctuations and temperature variations. The mechanical stresses and strains generated by transients under normal operating conditions and the effects of high-probability external influences are a small fraction of the limiting conditions for which the containment is designed. Loads incurred during normal plant operation therefore generally are not significant enough to cause appreciable degradation. However, these structures are susceptible to aging by various processes depending on the operating environment and service conditions.

The containment is subjected to various types of internal degradation (i.e., aging-related) caused by its inherent material characteristics, fabrication processes, and construction methods. The rate and extent of such degradation* are influenced by the sustained environmental conditions (e.g., temperature, humidity, water leakage, and acid spills). Thus, the ability of the containment pressure boundary to perform satisfactorily under the design basis as well as under higher loading conditions, such as resulting from a severe accident or seismic margin earthquake, is influenced by the complex interaction between its inherent ability and the various stressors and degradation mechanisms that are present. Analysis of the potential impact of age-related effects must be done in conjunction with all the appropriate system parameters, including the types of material, history of the materials, mechanical and thermal stresses, stress cycles, environment (e.g., chemistry, radiation, humidity, and flow rate), and the local geometry. The effects of these processes may accumulate within these structures over time to cause failure under design conditions, or lead to costly repair. Table 4.1 lists several containment surface areas that could experience accelerated degradation and aging.

Reliable continued service assessments and informed aging-management decisions related to the containment metallic pressure boundary are based in large measure on results developed from conduct of condition assessments. From an aging management viewpoint, metal and concrete containment pressure boundary components that exhibit satisfactory long-term performance and do not experience in-service degradation can be considered acceptable for continued service. However, components found by routine examination or in-service inspection to be deteriorated or damaged must be evaluated to determine whether continued service is appropriate, or whether repairs, replacements, or retrofits are needed. Requirements for corrective actions that are to be taken when evidence of structural deterioration is discovered are provided in 10 CFR 50, Appendix J (4.1). More detailed acceptance standards and evaluation criteria for use in determining the acceptability of degraded components for continued service are provided in Section XI, Division 1, Subsection IWE of the Code (4.2,4.3).

Condition assessments are performed by qualified engineers and authorized personnel who determine the adequacy of degraded components for their intended use (4.4). The decision-making process begins with an understanding of the in-service condition of each containment component. Condition assessments that provide essential information for continued service evaluations involve detecting damage, classifying the types of damage that may be present, determining the root cause of the problem, and quantifying the extent of degradation that may have occurred.

Knowledge gained from condition assessments can serve as a baseline for evaluating the safety significance of any damage that may be present and defining in-service inspection programs and maintenance strategies. Condition assessment results can also be used to estimate future performance and remaining service life. Figure 4.1 lists major topics pertaining to in-service condition assessments of metallic pressure boundry components (i.e., damage detection, damage classification, root-cause determination, and damage measurement) (4.5). A breakdown of each of these topics is presented in Figures 4.2 to 4.5 with more detailed discussion provided elsewhere (4.5).

One way to evaluate the significance of containment pressure boundary component degradation is by comparing its preservice condition to its condition after degradation has occurred. Condition assessment accuracy depends on the availability of quantifiable evidence such as dimensions of corroded surface areas, depths of corrosion penetration, or changes in material properties that indicate the extent and magnitude of the degradation. Methods for quantifying

\footnotetext{
* Degradation is considered to be any phenomenon that decreases the load-carrying capacity of a pressure-retaining component, limits its ability to contain a fluid medium, or reduces its service life. The root cause for component degradation can generally be linked to a design or construction problem, inappropriate material application, a basemetal flaw, or an excessively severe service condition.
} 
Table 4.1 Containment surface areas that could experience accelerated degradation and aging

\begin{tabular}{|c|c|c|}
\hline $\begin{array}{c}\text { Environmental or } \\
\text { operating condition }\end{array}$ & Typical areas & Likely locations \\
\hline $\begin{array}{l}\text { Areas subjected to accelerated } \\
\text { corrosion with no or minimal } \\
\text { corrosion allowance } \\
\text { or } \\
\text { Areas where the absence or } \\
\text { repeated loss of protective } \\
\text { coatings has resulted in } \\
\text { substantial corrosion or pitting }\end{array}$ & $\begin{array}{l}\text { Areas exposed to standing water } \\
\text { Areas exposed to repeated wetting } \\
\text { and drying } \\
\text { Areas where persistent leakage has } \\
\quad \text { occurred } \\
\text { Areas subjected to microbiological } \\
\text { attack } \\
\text { Areas with geometries that permit } \\
\text { water accumulation }\end{array}$ & $\begin{array}{l}\text { Penetration sleeves and bellows } \\
\text { Surfaces wetted during refueling } \\
\text { Concrete-to-steel shell or liner } \\
\text { interface } \\
\text { Shell regions embedded in } \\
\text { concrete including areas } \\
\text { shielded by diaphragm floors } \\
\text { Leak-chase channels } \\
\text { Drain areas including sand } \\
\text { pocket regions } \\
\text { Sump liners } \\
\text { Interior surfaces of BWR MK I } \\
\text { and II suppression pools } \\
\text { Exterior surfaces of BWR MK I } \\
\text { and II drywells } \\
\text { Emergency core cooling system } \\
\text { suction intake at the bottom } \\
\text { of BWR suppression pool } \\
\text { Dissimilar metal welds }\end{array}$ \\
\hline $\begin{array}{l}\text { Areas subjected to excessive wear } \\
\text { from abrasion or erosion }\end{array}$ & $\begin{array}{l}\text { Areas where mechanical wear, } \\
\text { abrasion, or erosion cause loss of } \\
\text { protective coatings, deformations, } \\
\text { or material loss } \\
\text { Areas that experience frequent } \\
\quad \text { vibration }\end{array}$ & $\begin{array}{l}\text { Surfaces subject to substantial } \\
\text { traffic } \\
\text { Sliding pads or supports } \\
\text { (baseplates of BWR MK I } \\
\text { suppression chamber support } \\
\text { columns) } \\
\text { Pins or clevises } \\
\text { Shear lugs } \\
\text { Seismic restraints } \\
\text { Surfaces exposed to water jets } \\
\text { from testing operations } \\
\text { Safety relief valve discharge } \\
\text { areas } \\
\text { BWR drywell head, vent system } \\
\text { supports, and downcomers } \\
\text { and bracing } \\
\text { Personnel airlocks, equipment } \\
\text { hatches, and control rod drive } \\
\text { (CRD) hatches }\end{array}$ \\
\hline
\end{tabular}

Sources: "Rules for Inservice Inspection of Nuclear Power Plant Components," ASME Boiler and Pressure Vessel Code, Section XI, Division 1, Subsection IWE, Requirements for Class MC and Metallic Liners of Class CC Components of Light-Water Cooled Plants, American Society of Mechanical Engineers, New York, New York, 2007.

Residual Life Assessment of Major Light Water Reactor Components - Overview, V.N. Shah and P.E. MacDonald (Eds), NUREG/CR-4731, Vol. 1, Idaho National Engineering Laboratory, Idaho Falls, Idaho, June 1987.

Residual Life Assessment of Major Light Water Reactor Components - Overview, V.N. Shah and P.E. MacDonald (Eds), NUREG/CR-4731, Vol. 2, Idaho National Engineering Laboratory, Idaho Falls, Idaho, November 1989.

S. Smith and F. Gregor, BWR Containments License Renewal Industry Report; Revision 1, EPRI TR103840, Electric Power Research Institute, Palo Alto, California, July 1994.

D. Deng, J. Renfro, and J. Staton, PWR Containments License Renewal Industry Report; Revision 1, EPRI TR-103835, Electric Power Research Institute, Palo Alto, California, July 1994. 


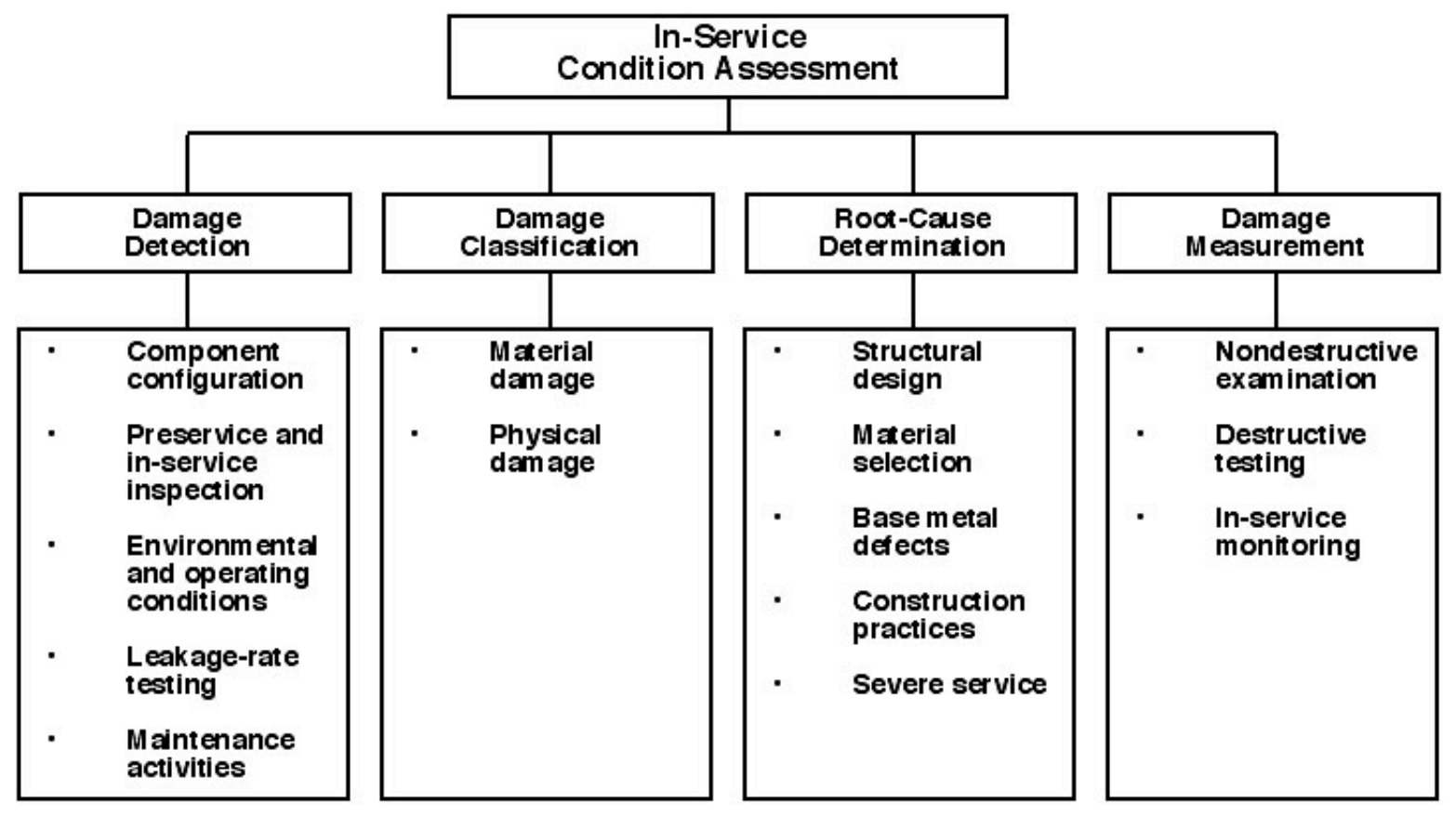

Figure 4.1 Major topics pertaining to in-service condition assessment.

Source: C.B. Oland and D.J. Naus, "Degradation Assessment Methodology for Application to Steel Containments and Liners of Reinforced Concrete Structures in Nuclear Power Plants," ORNLNRC/LTR-95/29, Oak Ridge National Laboratory, Oak Ridge, Tennessee, February 1996.

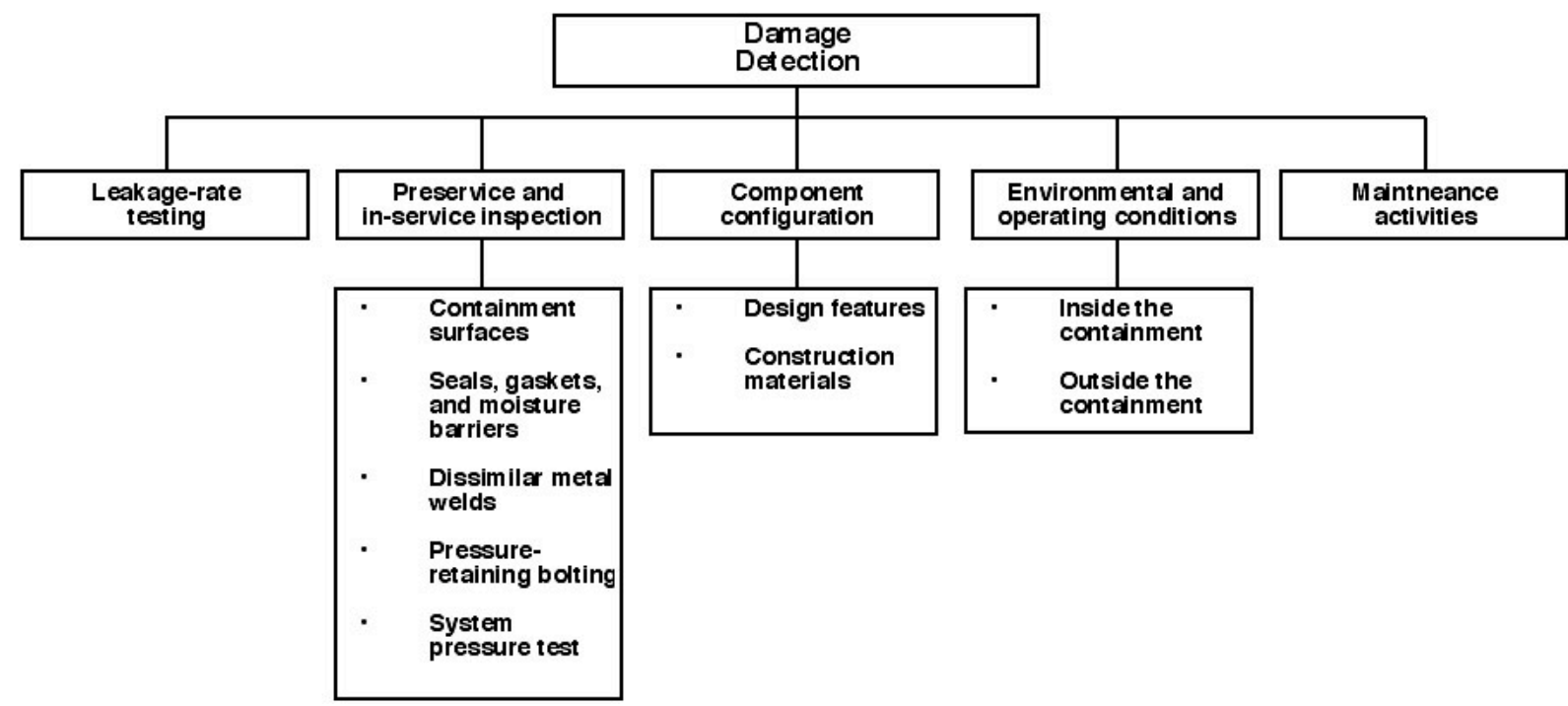

Figure 4.2 Damage detection parameters.

Source: C.B. Oland and D.J. Naus, "Degradation Assessment Methodology for Application to Steel Containments and Liners of Reinforced Concrete Structures in Nuclear Power Plants," ORNLNRC/LTR-95/29, Oak Ridge National Laboratory, Oak Ridge, Tennessee, February 1996. 


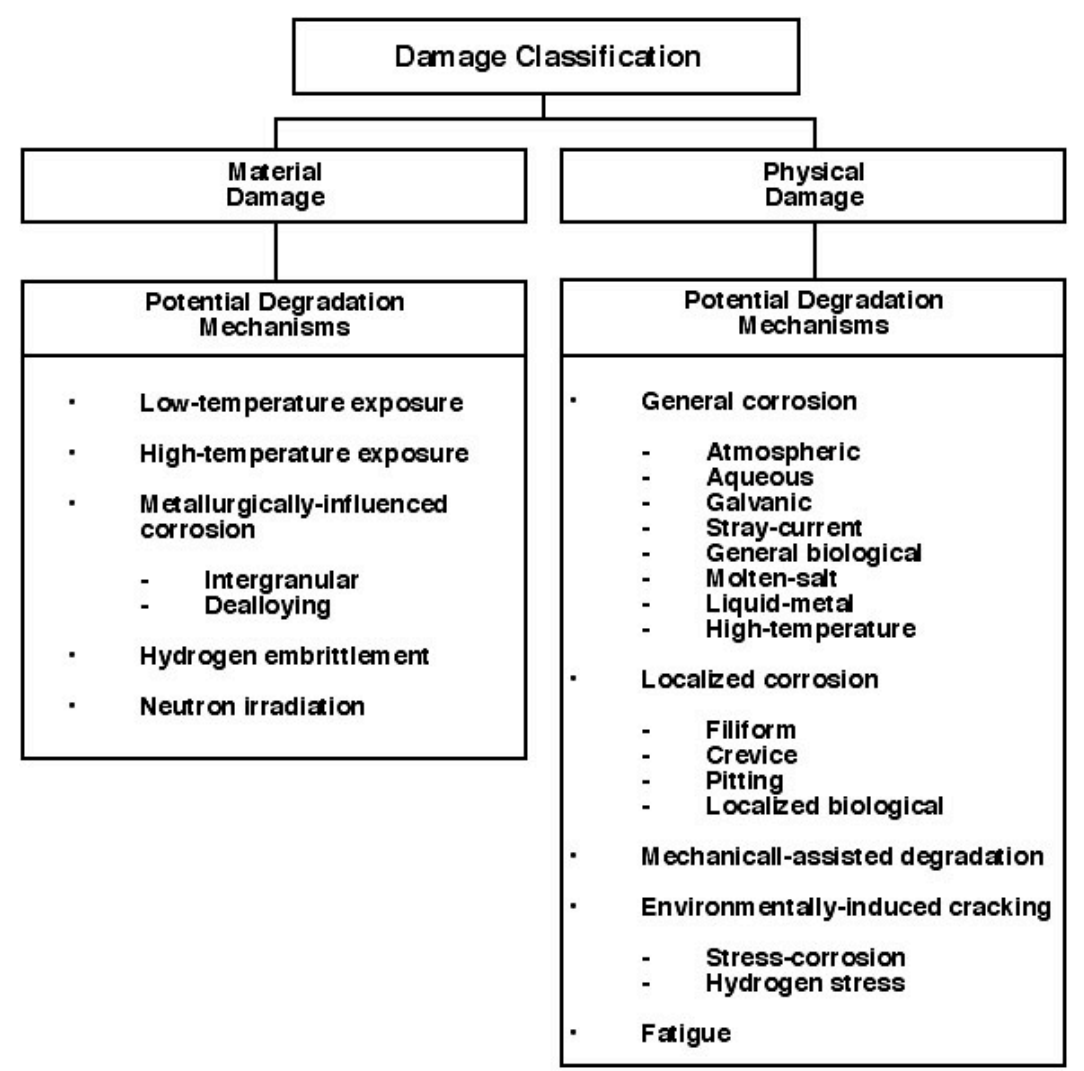

Figure 4.3 Damage categories and potential degradation mechanisms.

Source: C.B. Oland and D.J. Naus, "Degradation Assessment Methodology for Application to Steel Containments and Liners of Reinforced Concrete Structures in Nuclear Power Plants," ORNLNRC/LTR-95/29, Oak Ridge National Laboratory, Oak Ridge, Tennessee, February 1996.

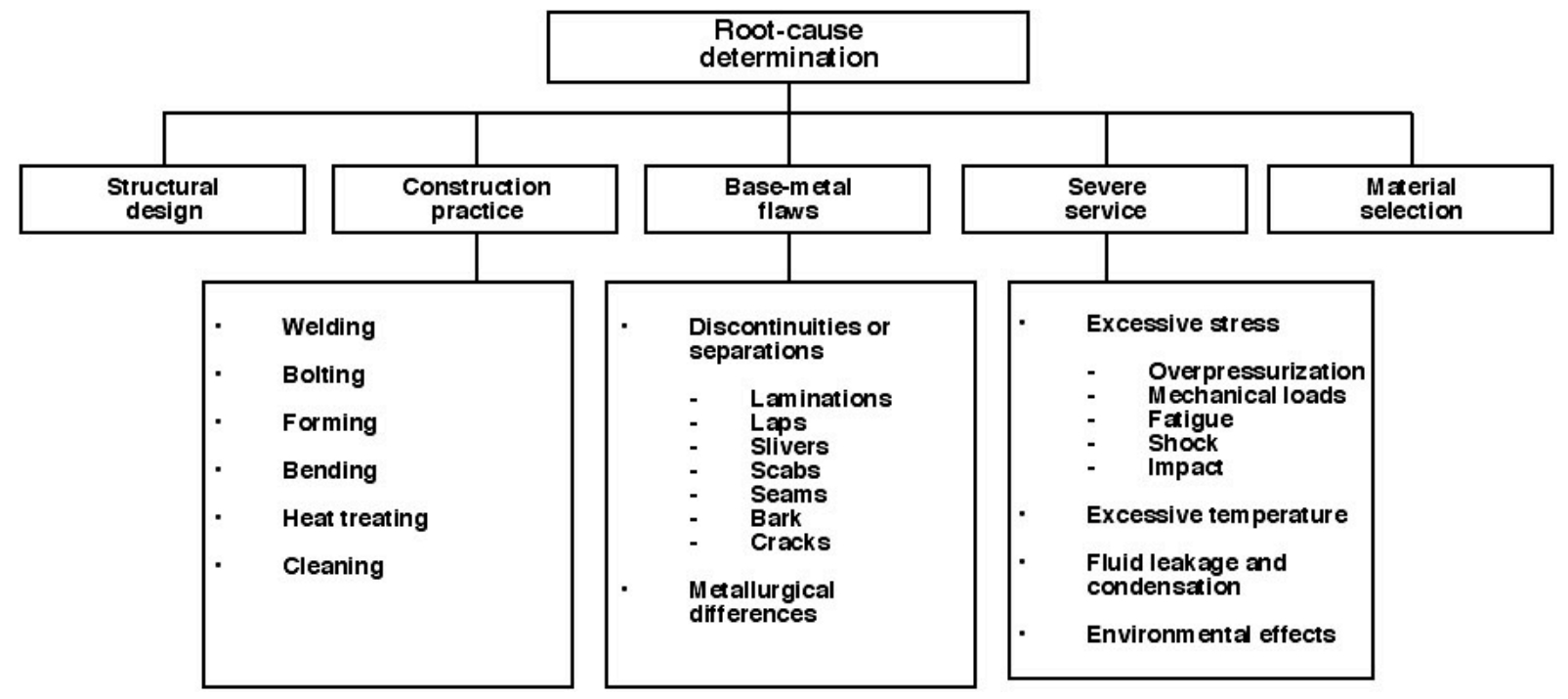

Figure 4.4 Factors to be considered in determining root cause for component degradation.

Source: C.B. Oland and D.J. Naus, "Degradation Assessment Methodology for Application to Steel Containments and Liners of Reinforced Concrete Structures in Nuclear Power Plants," ORNLNRC/LTR-95/29, Oak Ridge National Laboratory, Oak Ridge, Tennessee, February 1996. 


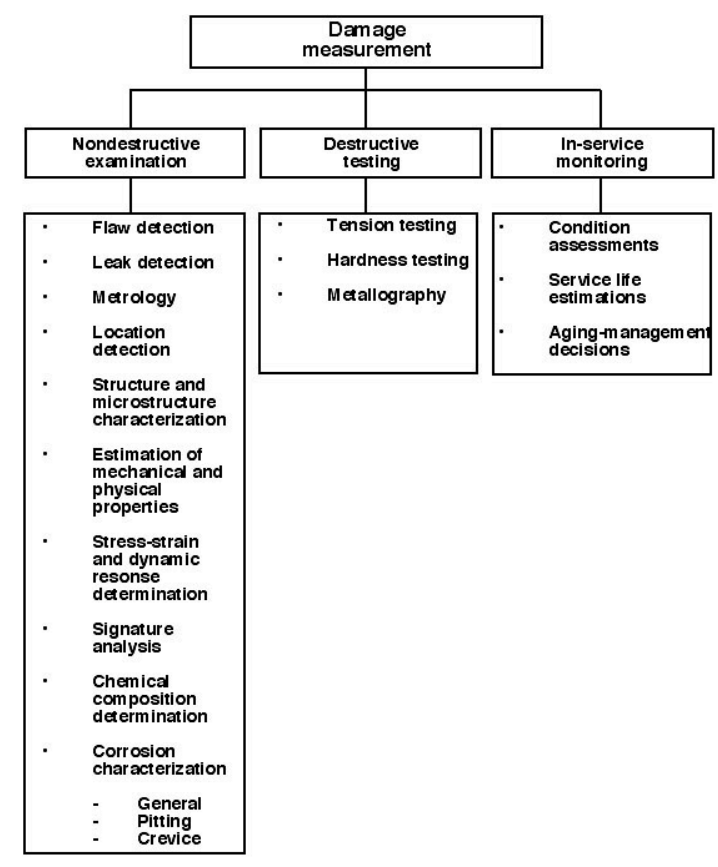

Figure 4.5 Approaches related to the measurement of containment pressure boundary component damage.

Source: C.B. Oland and D.J. Naus, "Degradation Assessment Methodology for Application to Steel Containments and Liners of Reinforced Concrete Structures in Nuclear Power Plants," ORNLNRC/LTR-95/29, Oak Ridge National Laboratory, Oak Ridge, Tennessee, February 1996.

component degradation involve either nondestructive examination or destructive testing. Results from these investigations provide a measure of the extent of degradation at the time the component was examined. Techniques for establishing time-dependent change, such as corrosion and wear rates, involve periodic examination or testing. In-service monitoring provides a way to measure time-dependent changes in component geometry or material properties and to detect undesirable changes in operating conditions that may affect useful service life.

\subsection{NONDESTRUCTIVE EXAMINATION}

The primary goal of an inspection is to identify the location, type, and magnitude of any flaws or structural defects that are present. Relevant indications are caused by a condition or discontinuity that requires evaluation resulting in a decision to either accept or reject the material or component. Flaws are imperfections or unintentional discontinuities that are detectable by a nondestructive examination (4.6). A defect is a flaw, discontinuity, or group of discontinuities whose indications do not meet specified acceptance criteria (4.7). The ASME Code (4.8) requires that when defect flaws or evidence of degradation exist that require evaluation in accordance with ASME Code acceptance criteria, an examination is to be conducted. Nondestructive examination is the primary method used to evaluate the presence and significance of indications of degradation of the containment metallic pressure boundary. Selection of the appropriate method depends on the type and nature of the degradation, the component geometry, type and circumstances of inspection, and cost and availability.

Current in-service testing programs at operating nuclear power plants rely heavily on nondestructive testing to detect the presence of service-induced degradation that may lead to loss of pressure boundary or structural integrity.

Nondestructive examination methods for metallic materials primarily involve surface and volumetric inspections to detect the presence of degradation (i.e., loss of section due to corrosion or presence of cracking). Rules for surface and volumetric examinations of containment pressure boundary components are provided in Subsection IWA of the ASME Code. Examination types identified in the Code for performing in-service inspections include visual, surface (i.e., magnetic particle, liquid penetrant, eddy current, and ultrasonic), and volumetric (i.e., radiographic, ultrasonic, eddy current, and acoustic emission). Alternative techniques, combinations of techniques, and newly developed techniques are permitted provided the results are considered to be equivalent or superior to those of the specified technique. Acceptance standards are defined in Article IWE-3000 of the ASME Code. 
In order to obtain repeatable and reproducible examination results using nondestructive testing methods, several factors must be understood and controlled: material evaluated, evaluation procedure utilized, environment, calibration/baseline reference, acceptance criteria, and human factors. Table 4.2 presents a summary of the applicability by flaw type and important material characteristics for several nondestructive testing methods discussed in more detail below. Table 4.3 presents the dominant sources of variance for these techniques. Quantitative evaluations of nondestructive testing capability is most commonly made through the metric of probability of detection (POD) (4.9). A widely-accepted method of estimating POD for a specific nondestructive testing method as applied to a specific inspection problem is provided in MIL-HDBK-1823 (4.10). Additional information on reliability of NDT is available $(4.11,4.12)$.

Table 4.2 Applicability and important material characteristics of selected metallic materials NDE methods

\begin{tabular}{|c|c|c|c|c|c|}
\hline \multirow{2}{*}{ Technique } & \multicolumn{4}{|c|}{ Applicability by flaw type } & \multirow[b]{2}{*}{$\begin{array}{l}\text { Important material } \\
\text { characteristic }\end{array}$} \\
\hline & Surface & Planar* & Interior & Volumetric & \\
\hline Visual/optical & $\mathrm{X}$ & $\mathrm{X}$ & & $\mathrm{X}^{3}$ & None, independent of size \\
\hline Liquid penetrant & $\mathrm{X}$ & $\mathrm{X}$ & & $\mathrm{X}^{3}$ & Flaw must intercept surface \\
\hline Magnetic particle & $\mathrm{X}$ & $\mathrm{X}$ & $\mathrm{X}^{1}$ & $\mathrm{X}^{3,4}$ & Material must be magnetic \\
\hline Ultrasonic & $\mathrm{X}$ & $\mathrm{X}$ & $\mathrm{X}$ & $\mathrm{X}$ & Acoustic properties \\
\hline Eddy current & $\mathrm{X}$ & $\mathrm{X}$ & $\mathrm{X}$ & $\mathrm{X}$ & Material must be conductive or magnetic \\
\hline Radiography & $\bar{X}$ & $\mathrm{X}$ & $\mathrm{X}$ & $\mathrm{X}$ & $\begin{array}{l}\text { Changes in thickness, density, and/or } \\
\text { elemental composition }\end{array}$ \\
\hline Acoustic emission & $\mathrm{X}$ & $\mathrm{X}$ & $\mathrm{X}$ & $\mathrm{X}$ & Material sensitive since it is AE source \\
\hline Thermography & & & $\mathrm{X}^{2}$ & $\mathrm{X}$ & Material heat transfer characteristics \\
\hline
\end{tabular}

*Thin in one direction. 1 = limited application, $2=$ possible application, $3=$ surface, $4=$ subsurface.

Source: Adaptation of material presented in - J.D. Wood, "Guide to Nondestructive Evaluation Techniques," ASM Handbook, Vol. 17, "Nondestructive Evaluation and Quality Control," ASM International, Materials Park, Ohio, 1992.

Table 4.3 Dominant sources of variance of selected metallic materials NDE methods

\begin{tabular}{|l|c|c|c|c|c|c|}
\hline \multirow{2}{*}{ Technique } & \multicolumn{5}{c|}{ Variance Sources } \\
\cline { 2 - 7 } & Materials & Equipment & Procedure & Calibration & Criteria & Human Factors \\
\hline \hline Visual/optical & & & $\mathrm{X}$ & & $\mathrm{X}$ & $\mathrm{X}$ \\
\hline Liquid penetrant & $\mathrm{X}$ & & $\mathrm{X}$ & & & $\mathrm{X}$ \\
\hline Magnetic particle & $\mathrm{X}$ & $\mathrm{X}$ & $\mathrm{X}$ & & & $\mathrm{X}$ \\
\hline Ultrasonic & & $\mathrm{X}$ & $\mathrm{X}$ & $\mathrm{X}$ & $\mathrm{X}$ & $\mathrm{X}$ \\
\hline Eddy current & & $\mathrm{X}$ & $\mathrm{X}$ & $\mathrm{X}$ & $\mathrm{X}$ & $\mathrm{X}$ \\
\hline Radiography & & $\mathrm{X}$ & $\mathrm{X}$ & & & $\mathrm{X}$ \\
\hline Acoustic emission & $\mathrm{X}$ & $\mathrm{X}$ & $\mathrm{X}$ & $\mathrm{X}$ & $\mathrm{X}$ & $\mathrm{X}$ \\
\hline Thermography & & $\mathrm{X}$ & $\mathrm{X}$ & $\mathrm{X}$ & & $\mathrm{X}$ \\
\hline
\end{tabular}

Source: Adaptation of Table 7-1 in Nondestructive Evaluation (NDE) Capabilities Data Book, prepared by W.D. Rummel and G.A. Matzkanin, Nondestructive Information Analysis Center, Texas Research Institute, Inc., Austin, Texas, May 1996.

\subsubsection{Visual and Optical Testing (VT)}

Visual and optical testing involves using an inspector's eyes to look for defects. Visual inspection is one of the most common and least expensive methods for evaluating the condition of a weld or component (e.g., presence of surface flaws, discontinuities, or corrosion). It is generally the first inspection that is performed as part of an evaluation process and is beneficial for performing gross defect detection and in identifying areas for more detailed examination. Interior and exterior containment surface areas that could experience accelerated degradation and aging were identified in Table 4.1 and several factors associated with pressure-retaining steel component degradation are listed in Table 4.4. Visual inspections can identify where a failure is most likely to occur, and when failure has commenced (e.g., rust staining or coating cracks). Once a suspect area is identified, all surface debris and protective coatings are removed so that the area can be inspected in more detail. 
Table 4.4 Factors associated with pressure-retaining steel component degradation

\begin{tabular}{|l|l|}
\hline \multicolumn{1}{|c|}{ Factor } & \multicolumn{1}{c|}{ Description } \\
\hline \hline $\begin{array}{l}\text { Pressure-retaining } \\
\text { steel component }\end{array}$ & $\begin{array}{l}\text { Degradation can adversely affect the structural capacity or leak-tight integrity of metal } \\
\text { containment shells, concrete containment liners, penetration liners, heads, nozzles, } \\
\text { structural and non-structural attachments, embedment anchors, pipes, tubes, fittings, } \\
\text { fasteners, and bolting items that are used to join other pressure-retaining components. }\end{array}$ \\
\hline $\begin{array}{l}\text { Damage } \\
\text { characteristics }\end{array}$ & $\begin{array}{l}\text { Damage could involve loss of net section or wall thinning, cracks, pits, crevices, } \\
\text { erosion, cavitation, surface flaws, arc strikes, plastic deformation, buckling, fracture, } \\
\text { or bulging. }\end{array}$ \\
\hline Damage indicators & $\begin{array}{l}\text { Rust, discoloration, staining, blistering and peeling of coatings, spalling of concrete, } \\
\text { buckling or separation of liners, leakage from drains, and clogged drains. }\end{array}$ \\
\hline $\begin{array}{l}\text { Potential problem } \\
\text { areas }\end{array}$ & $\begin{array}{l}\text { Locations where degradation could be suspect include areas of water accumulation; } \\
\text { surfaces exposed to chemical or borated water spills; flashed, caulked, or sealed joints; } \\
\text { dissimilar metal connections; penetrations; condensation and leakage paths; sand } \\
\text { pockets or cushions; heat trace areas; and locations with stray electrical currents. }\end{array}$ \\
\hline Damage detection & $\begin{array}{l}\text { Damage detection techniques include leakage-rate testing, visual inspection, } \\
\text { destructive testing, and nondestructive evaluation. }\end{array}$ \\
\hline $\begin{array}{l}\text { Mitigation } \\
\text { procedures }\end{array}$ & $\begin{array}{l}\text { Effects of degradation can potentially be mitigated by eliminating leaks; repairing or } \\
\text { replacing defective components; removing and replacing cracked or torn seals, gaskets, } \\
\text { and caulked joints; opening clogged drains; providing additional drains; repairing or } \\
\text { replacing damaged coatings; providing improved spill response; and installing cathodic } \\
\text { protection systems }\end{array}$ \\
\hline $\begin{array}{l}\text { Petential failure } \\
\text { modes }\end{array}$ & $\begin{array}{l}\text { displacement that could result in loss of leak-tight integrity, decreased load-carrying } \\
\text { capacity, or reduced service life. }\end{array}$ \\
\hline
\end{tabular}

Source: R.F. Sammataro, "Updated ASME Code Rules for Inservice Inspection of Steel and Concrete Containments," Proceedings of the Fifth Workshop on Containment Integrity, NUREG/CP-0120, (SAND92-0173) U.S. Nuclear Regulatory Commission, Washington, D.C., July 1992.

Basic elements of visual inspection include the test object, the inspector, the optical instrument, illumination, and recording. Visual examinations can be performed either with the unaided eye or optical magnifiers. Without material or component removal, visual inspections are limited to accessible areas. In situations where access is limited or normal visual acuity is not sufficient, examination may require the use of visual aids such as the equipment listed in Table 4.5. With the availability of flexible fiber-optic borescopes, charge-coupled device cameras, and computer-based image processing software, it is possible to examine corners, bent surfaces, and inaccessible surfaces (4.13). Mechanical aids may also be required as part of the visual inspection. Mechanical aides may include: measuring rules and tapes; calipers and micrometers; squares and angle measuring devices; thread, pitch, and thickness gages; and plumb lines. Welding fabrication product quality may involve fillet gages to determine width of weld fillet, undercut gages, angle gages, skew fillet weld gages, pit gages, and contour gages (4.14). Since no correlation has been identified between crack-opening dimension and through-wall dimension, volumetric nondestructive methods (e.g., ultrasonic or radiographic testing) may be needed to fully characterize the extent of cracks detected by visual testing methods in order to determine a component's structural integrity (4.15).

Table 4.5 Equipment used to aid visual examinations

\begin{tabular}{|l|l|}
\hline \multicolumn{1}{|c|}{ Equipment } & \multicolumn{1}{c|}{ Purpose } \\
\hline \hline Flexible or rigid borescopes & Illuminating and observing internal closed or inaccessible areas \\
\hline Image sensors & $\begin{array}{l}\text { Remote sensing or for the development of permanent visual records in the } \\
\text { form of photographs, video tapes, or computer-enhanced images }\end{array}$ \\
\hline Magnifying systems & Evaluating surface finish, surface shape, and surface microstructure \\
\hline $\begin{array}{l}\text { Dye and fluorescent penetrants and } \\
\text { magnetic particles }\end{array}$ & Enhancing the observation of cracks \\
\hline
\end{tabular}

Source: "Volume 17 - Nondestructive Evaluation and Quality Control," ASM Handbook, ASM International, 
Materials Park, Ohio, 1989.

Three classifications of visual examinations are specified in the ASME Code: (1) VT-1 (detect discontinuities and imperfections on the surfaces of components such as cracks and corrosion), (2) VT-2 (detect evidence of leakage from pressure-retaining components), and (3) VT-3 (determine general mechanical and structural condition of components and their supports). Subsection IWA of the ASME Code provides rules for remote visual examination and examinations using surface replication methods (4.6). To examine underwater portions of the BWR containment suppression chamber, either the chamber must be drained or underwater examination techniques must be used. Drainage of the chamber relieves the hydrostatic pressure on the coating surfaces and may cause additional blistering or bursting of existing coating blisters. Underwater techniques have been developed that include desludging, ultrasonic mapping of critical areas, coating adhesion tests, dry-film thickness determinations, and repair of localized areas (4.16). Since crevice corrosion is possible at hatch locations, and under bolts, nuts, and gaskets, proper maintenance, use of grease and lubricants, and routine visual inspections are used to address and inspect for corrosion. The effectiveness of a visual inspection is dependent on the experience and competence of the person performing the inspections.

Figure 4.6 provides examples of visual inspection of components. Additional information on remote visual testing system parameters and guidelines for detection of service-induced cracking is available (4.15).

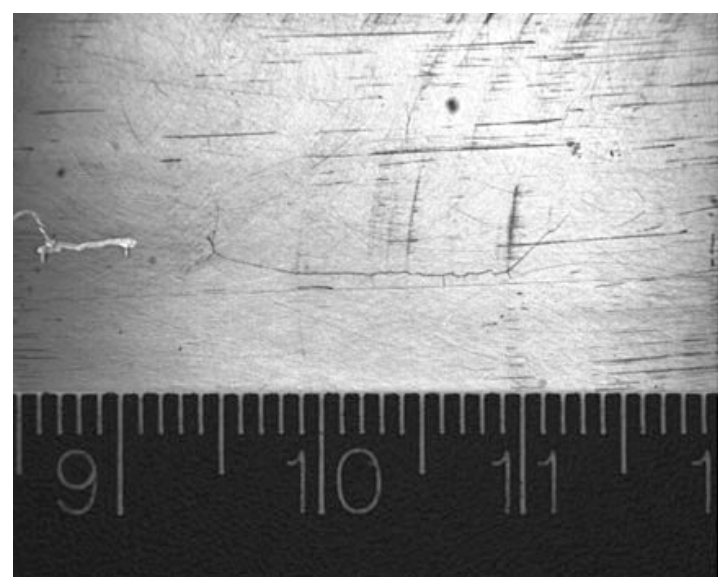

(a) Branched thermal fatigue crack viewed using diffuse lighting.

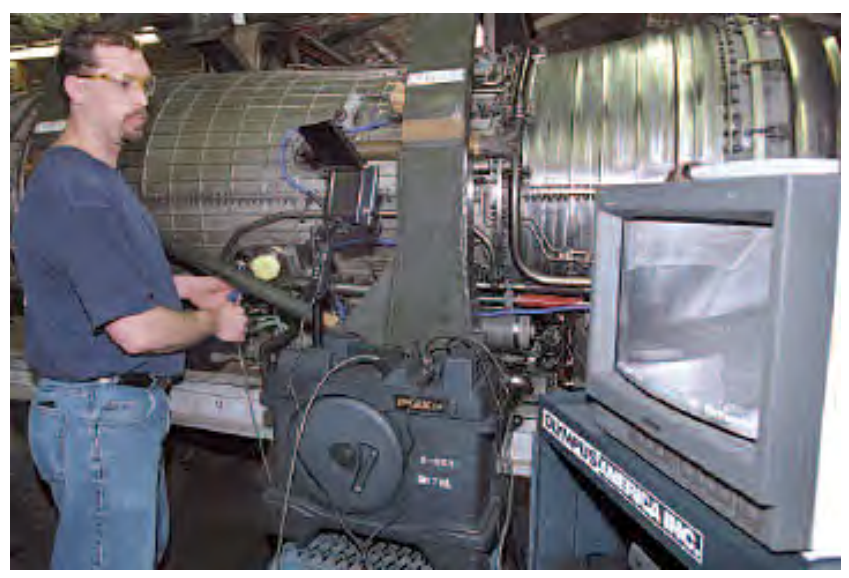

(b) Visual inspection using of fiber-optic borescope to obtain magnified view of an engine's high-pressure turbine area.

Figure 4.6 Visual inspection examples.

Source: (a) M.T. Anderson, S.E. Cumblidge, and S.R. Doctor, "An Assessment of Remote Visual Testing System Capability for the Detection of Service Induced Cracking," Back to Basics, The American Society for Nondestructive Testing, Columbus, Ohio, September 2005.

(b) G.A. Matzkanin, "Techsolutions 2 - Selecting a Nondestructive Testing Method, Part II: Visual Inspection," AMMTIAC Quarterly 1(3), Advanced Materials, Manufacturing and Testing Information Analysis Center, Rome, New York (http://ammtiac.alionscience.com/quarterly).

\subsubsection{Liquid Penetrant Testing (PT)}

Liquid penetrant testing can be used to detect, define and verify flaws that break the surface in solid or essentially nonporus components (e.g., cracks, porosity, laps, seams, laminations, pin holes in welds, or other types of discontinuities that have a capillary opening to the surface) of virtually any size and shape. Indications of a wide spectrum of flaw sizes can be found with little capital expenditure regardless of the configuration of the test article or the flaw orientation. The procedure consists of thoroughly cleaning and drying the surface to be examined followed by application of a liquid penetrant. Surface defects or cracks absorb the penetrant through capillary action. After a dwell period, excess penetrant is removed from the surface and a developer is applied that acts as a blotter to draw penetrant from the defects to reveal their presence. Colored or fluorescent penetrants may be utilized, with white light or black light, respectively, used for viewing. Table 4.6 lists primary advantages and limitations of liquid penetrant testing when compared to other nondestructive evaluation methods. Figure 4.7 presents the basic steps in liquid penetrant testing and an example result. 
Table 4.6 Advantages and limitations of liquid penetrant testing

\begin{tabular}{|c|c|}
\hline Primary advantages & Primary limitations \\
\hline \multirow{2}{*}{$\begin{array}{l}\text { Method has high sensitivity to small surface } \\
\text { discontinuities }\end{array}$} & Only surface breaking defects can be detected \\
\hline & \multirow{2}{*}{$\begin{array}{l}\text { Only materials with a relatively nonporous surface can } \\
\text { be inspected }\end{array}$} \\
\hline \multirow{2}{*}{$\begin{array}{l}\text { Method has few material limitations (i.e., metallic and } \\
\text { nonmetallic, magnetic and nonmagnetic, and } \\
\text { conductive and nonconductive materials can be } \\
\text { inspected) }\end{array}$} & \\
\hline & Chem \\
\hline $\begin{array}{l}\text { Large areas and large volumes of parts/materials can be } \\
\text { inspected rapidly and at low cost }\end{array}$ & $\begin{array}{l}\text { Precleaning is critical since contaminants can mask } \\
\text { defects }\end{array}$ \\
\hline $\begin{array}{l}\text { Parts with complex geometric shapes are routinely } \\
\text { inspected }\end{array}$ & $\begin{array}{l}\text { Metal smearing from machining, grinding, and grit or } \\
\text { vapor blasting must be removed prior to inspection }\end{array}$ \\
\hline $\begin{array}{l}\text { Indications are produced directly on the surface of the } \\
\text { part and constitute a visual representation of the flaw }\end{array}$ & $\begin{array}{l}\text { Inspector must have direct access to surface being } \\
\text { inspected }\end{array}$ \\
\hline $\begin{array}{l}\text { Aerosol spray cans can make penetrant materials very } \\
\text { portable }\end{array}$ & $\begin{array}{l}\text { Surface finish and roughness can affect inspection } \\
\text { sensitivity }\end{array}$ \\
\hline $\begin{array}{l}\text { Penetrant materials and associated equipment are } \\
\text { relatively inexpensive }\end{array}$ & $\begin{array}{l}\text { Multiple process operations must be performed and } \\
\text { controlled }\end{array}$ \\
\hline
\end{tabular}

Source: Center for Nondestructive Evaluation, Iowa State University, Ames, Iowa (www.ndt-ed.org/EducationResources/CommunityCollege/PenetrantTest/Principles/prosandcons.htm).

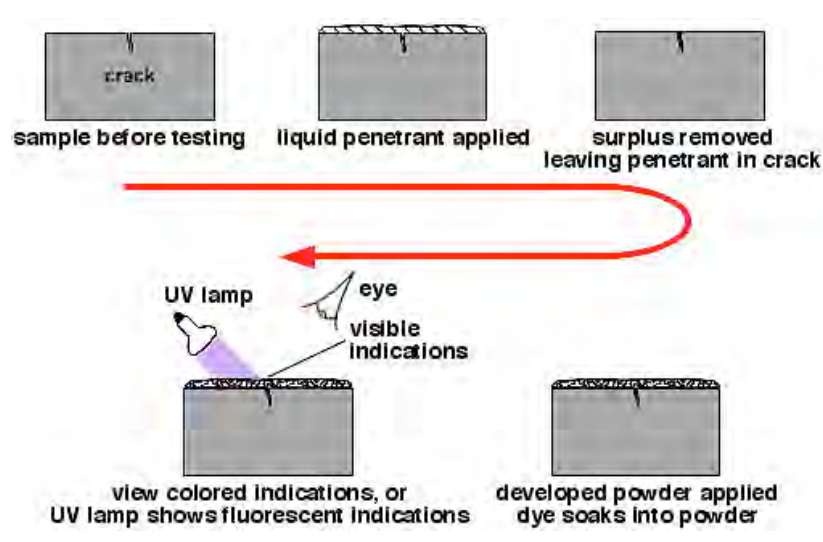

(a) Basic steps in liquid penetrant testing.

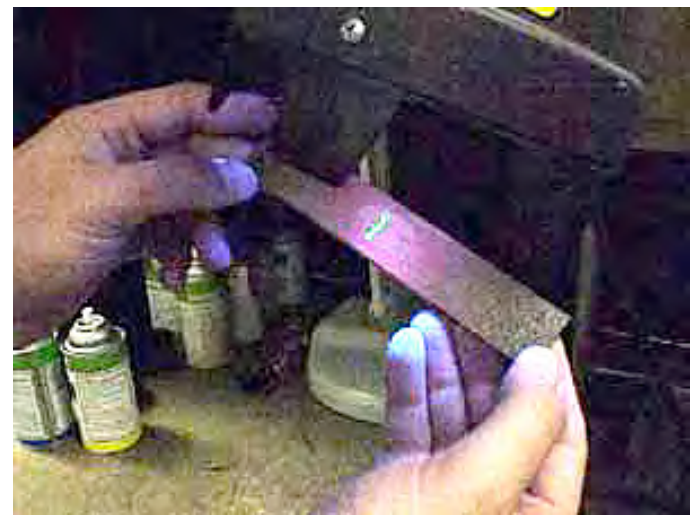

(b) Flaw revealed by fluorescent penetrant testing.

Figure 4.7 Penetrant testing method.

Source:(a) I. Munns, “TWI Knowledge Summary - Liquid Penetrant Inspection,” The Welding Institute Ltd., Great Abington, United Kingdom, 2007 (http://www.twi.co.uk/j32k/protected/band_3/ksijm001.html).

(b) Center for Nondestructive Evaluation, Iowa State University, Ames, Iowa (http://www.ndt.org/ Education/ Resources/CommunityCollege/PenetrantTest/PTMaterials/ptmaterials.htm).

\subsubsection{Electromagnetic (ET) or Eddy Current Testing}

Electromagnetic testing, especially eddy current, is commonly used to inspect objects throughout their life cycle. Eddy current inspection methods are based on electromagnetic induction and can be applied to electricallyconductive materials for detection of cracks, porosity, and inclusions, and to measure the thickness of nonconductive coatings on a conductive metal. Other applications include material thickness measurements, alloy sorting, and monitoring of metallurgical conditions such as hardness and heat treatment. Three types of eddy current sensors are commonly used - probe coil, encircling coil, and bobbin coil (4.17). Probe coils allow for localized testing of 
materials and are generally very sensitive to minor surface imperfections and localized changes in electrical conductivity and magnetic permeability. Outside diameter encircling coils (torroidal) allow for testing of the entire outside diameter (circumference) of the test material. Bobbin coils (inside diameter) allow for testing of the inside diameter of manufactured components and the inside diameters of manufactured and in-service tubes. In the flaw detection mode eddy current can detect surface connected or near surface anomalies. It is based on the principle that alternating current flow in a coil proximate to an electrical conductor will induce current flow in the conductor. The current flow (i.e., eddy current) creates a magnetic field that opposes the primary field created by the alternating current flow in the coil. The presence of a surface or near-surface discontinuity in the conductor will alter the magnetic field (i.e., magnitude and phase) which can be sensed as a change in the flow of current in a secondary coil in the probe or change of inductance of the probe. The output signal from the detection circuit is fed to an output device, typically a meter, oscilloscope, or chart recorder. Flaw size is indicated by extent of response change as the probe is scanned along the test object. Eddy current techniques do not require direct contact with the test piece, and paint or coatings do not have to be removed prior to its application. For discontinuities of a given size, the sensitivity of eddy current decreases with distance below the surface. The depth of penetration of eddy currents is a function of: conductivity of the material tested, magnetic permeability of the material tested, and frequency of the alternating current driving the probe (4.18). Best results are obtained when the magnetic field is in a direction that will intercept the principal plane of the discontinuity. Eddy current testing is significantly more sensitive than liquid penetrant testing in the detection of tight cracks and it can measure crack depths in nonferromagnetic materials. Artificial neural networks have been developed to provide improved detection speeds and more accurate on-line detection of weld defects (4.19). Table 4.7 lists primary advantages and limitations of eddy current testing. Figures 4.8 and 4.9 present the principal of eddy current testing and example results, respectively.

Table 4.7 Advantages and limitations of eddy current testing

\begin{tabular}{|l|l|}
\hline \multicolumn{1}{|c|}{ Advantages } & \multicolumn{1}{c|}{ Limitations } \\
\hline \hline Can test nearly all metallic materials at reasonable cost & $\begin{array}{l}\text { Lack of capability to detect flaws that are deep in } \\
\text { thick-section metallic structures }\end{array}$ \\
\hline High inspection speeds possible $(\sim 5 \mathrm{~m} / \mathrm{s})$ & $\begin{array}{l}\text { Applicable only to conductive materials and results } \\
\text { may be affected by material variations }\end{array}$ \\
\hline $\begin{array}{l}\text { Can readily detect very shallow and tight surface } \\
\text { fatigue cracks and stress-corrosion cracks }(\sim 5 \text { microns } \\
\text { width by } 50 \text { microns depth) }\end{array}$ & Use of calibration standards necessary \\
\cline { 2 - 2 } High temperature and on-line testing possible & $\begin{array}{l}\text { No permanent record provided } \\
\text { Ovaluation skill is necessary for meaningful testing and }\end{array}$ \\
\hline $\begin{array}{l}\text { Non-contact, remote, and inaccessible testing possible } \\
\text { with no couplant required }\end{array}$ & $\begin{array}{l}\text { Adaptability of magnetizing coil and detector limited } \\
\text { for rough or contoured test material surfaces }\end{array}$ \\
\hline Recording and analysis of inspection data possible & Maximum inspectable thickness $\sim 5$ to 10 mm \\
\hline $\begin{array}{l}\text { Capability for quantitative flaw sizing and thickness } \\
\text { measurements (with } \sim 1 \% \text { precision) of specific metals } \\
\text { and alloys }\end{array}$ & $\begin{array}{l}\text { Limited to higher test frequencies and to tests at larger } \\
\text { phase angles on the complex plane otherwise signal } \\
\text { noise can ask results }\end{array}$ \\
\hline Reproducability of measurements & Demagnification may be necessary \\
\hline
\end{tabular}

Sources: R.C. McMaster, "Back to Basics - The Present and Future of Eddy Current Testing" The American Society of Nondestructive Testing, Columbus, Ohio, January 2002 (http://asnt.org/publications/materialseval/basics/jan02basics/jan02basics.htm).

B.P.C Rao, Eddy Current Non Destructive Testing, (http://www.geocities.com/raobpc/EC-Def.html). H.T. Yolken, "Techsolutions 3 - Selecting a Nondestructive Testing Method, Part III: Eddy Current Testing," AMMTIAC Quarterly 1(4), Advanced Materials, Manufacturing and Testing Information Analysis Center, Rome, New York (http://ammtiac.alionscience.com/quarterly). 


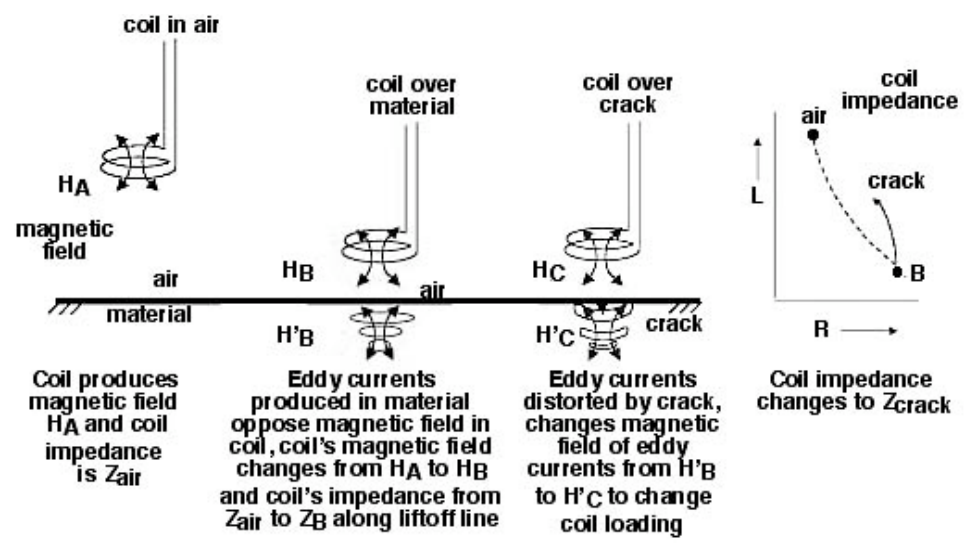

Figure 4.8 Principle of eddy current testing for crack detection.

Source: A.S. Birring and G.A. Marshall, "Back to Basics - Eddy Current Testing in the Petrochemical Industry" The American Society of Nondestructive Testing, Columbus, Ohio, November 2003 (http://asnt.org/publications/materialseval/basics/nov03basics/nov03basics.htm).

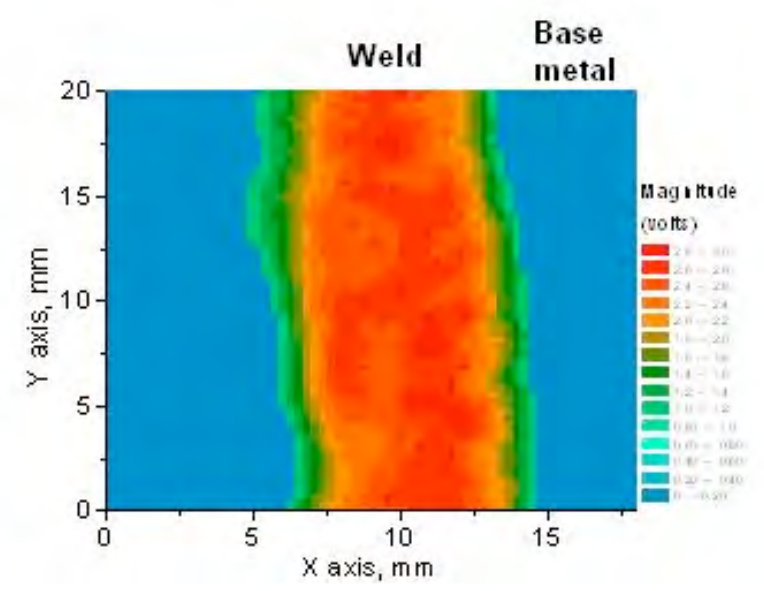

(a) Eddy current image of stainless steel weld.

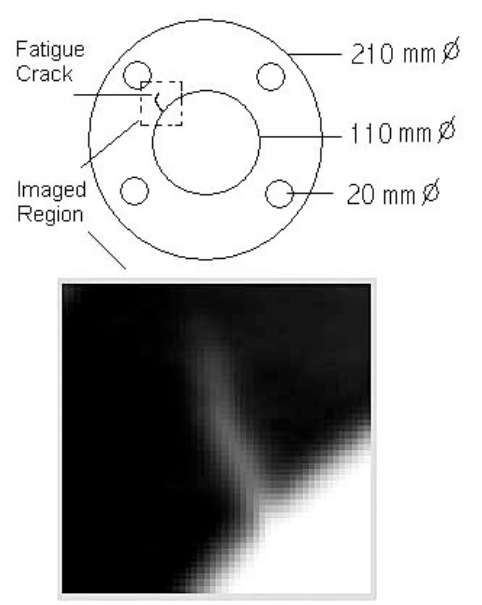

(b) Grey level eddy current image of stainless steel disc with fatigue crack.

Figure 4.9 Eddy current testing method.

Source: B.P.C Rao, Eddy Current Non Destructive Testing, (http://www.geocities.com/raobpc/EC-Def.html).

Pulsed eddy current testing differs from conventional eddy current testing in that the eddy currents are excited by means of a non-sinusoidal coil current (i.e., step function voltage containing a continuum of frequencies excites the probe). Detection is carried out using the excitation coil, a separate pick-up coil, or a magnetic field sensor such as a Hall device. In pulsed eddy current rather than observing phase and amplitude changes, a pulse emf (coil detectors) or field (magnetic field detectors) is observed with shape and amplitude of pulse used to infer material condition. The method has potential advantages of greater penetration (up to ten times the standard penetration depth), the ability to locate discontinuities from time-of-flight determinations, and a ready means of multi-frequency measurement permitting information from a range of depths (4.20). Its main application has been in testing thin metal tubes and sheets, as well as metal cladding for measuring thickness, and for location and sizing of internal defects. A more recent application of pulsed eddy current testing has been to corrosion detection where it has been used to detect wall thinning under insulation without removing the insulation. Figure 4.10 presents the principle of operation for one commercial system that has been used to detect corrosion under insulation, fireproofing materials, coating materials, and corroded surfaces (4.21). 


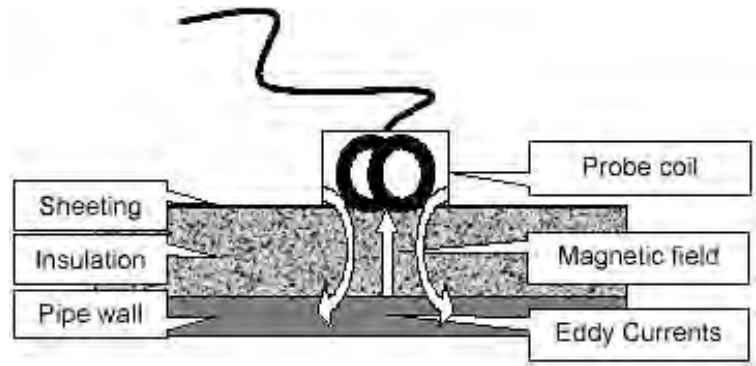

(a) Operating principle of pulsed eddy current inspection.

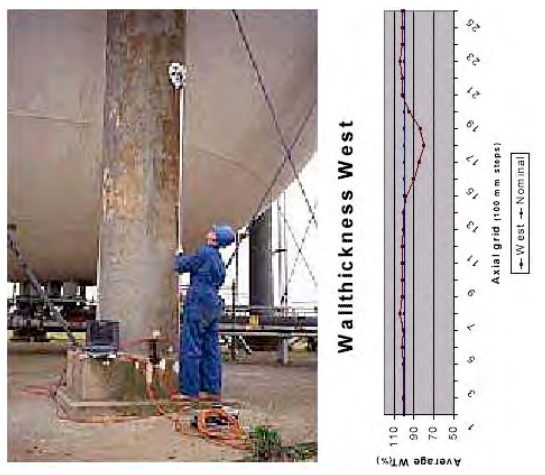

(b) Application of pulsed eddy current testing to concrete covered storage legs of spherical storage tank.

Figure 4.10 Pulsed eddy current testing method.

Source: Material abstracted from - M.A. Roberts and R. Scottini, "Pulsed Eddy Current in Corrosion Detection," Proceedings of $8^{\text {th }}$ European Conference on Nondestructive Testing 7(10), Barcelona, Spain, June 17-21, 2002.

\subsubsection{Magnetic Particle Testing (MT)}

Magnetic particle testing is used to detect surface and shallow subsurface discontinuities in ferromagnetic materials. It operates on the premise that when the material under test is magnetized discontinuities transverse to the direction of the magnetic field will cause a leakage field to be formed at and above the material surface. A magnetic field is induced into the ferromagnetic material by using permanent magnets, electromagnets, or by passing high currents through or around the component (e.g., indirect and direct induction). Figure 4.11 presents examples of magnetization by direct and indirect induction. Special equipment, procedures, and process controls are required to

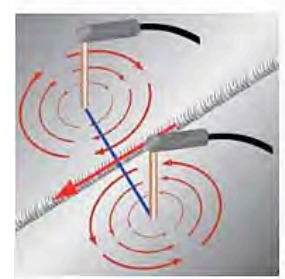

Use of clamps or prods

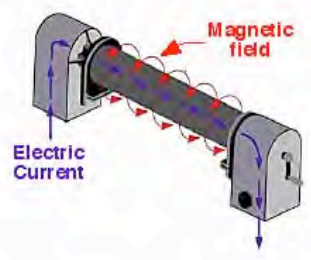

Pass current through component

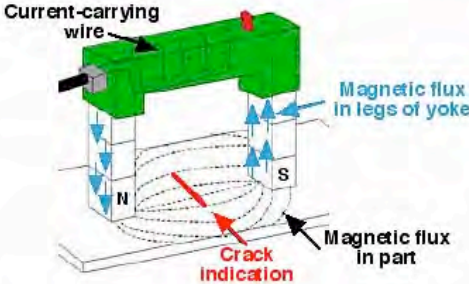

Use of electromagnet

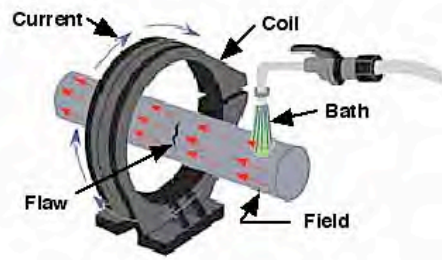

Use of coils or solenoids

Figure 4.11 Direct and indirect magnetization techniques for magnetic particle testing.

Source: Magnetization of Ferromagnetic Materials, Iowa State University, Ames, Iowa (http://www.ndted.org/EducationResources/CommunityCollege/MagParticle/Physics/Magnetization.htm).

induce the required magnetic fields (e.g., use of proper voltage, amperage, and mode of induction). Both direct current and alternating current can magnetize a part for magnetic particle testing. The key difference is that the fields produced by D.C. generally penetrate the cross-section of the part while the fields produced by A.C. are confined to the metal at or near the surface of the part (4.22). The method of magnetization depends on the geometry of the component and whether or not all or only part of the specimen is to be magnetized. Electromagnets are often used (i.e., yokes) because they are easy to remove and the strength of the magnetic field can be varied. In confined spaces hand-held probes can be utilized, however, arc strikes can occur at the prod point of contact to potentially damage the test article. The surface is dusted with iron particles or red or yellow oxides that may be dry, suspended in a liquid, colored, or fluorescent. The magnetic lines of force (flux) are disrupted locally by the presence of the flaw with its presence indicated by the iron particles that are attracted by leakage of the magnetic field at the discontinuity. The resulting magnetically-held collection of particles forms a pattern that indicates the 
size, shape, and location of the flaw. Under ideal conditions it is possible to detect cracks with a width as little as $10^{-3} \mathrm{~mm}$, and when magnetization is by D.C. current subsurface defects may be detected at depths on the order of 3 to $7 \mathrm{~mm}$ (4.23). Figure 4.12 illustrates the principle of magnetic particle testing. Effectiveness of the method quickly diminishes depending on flaw depth and type, and scratches and surface irregularities can give misleading results. Table 4.8 presents several advantages and limitations of magnetic particle testing and Figure 4.13 provides example results.
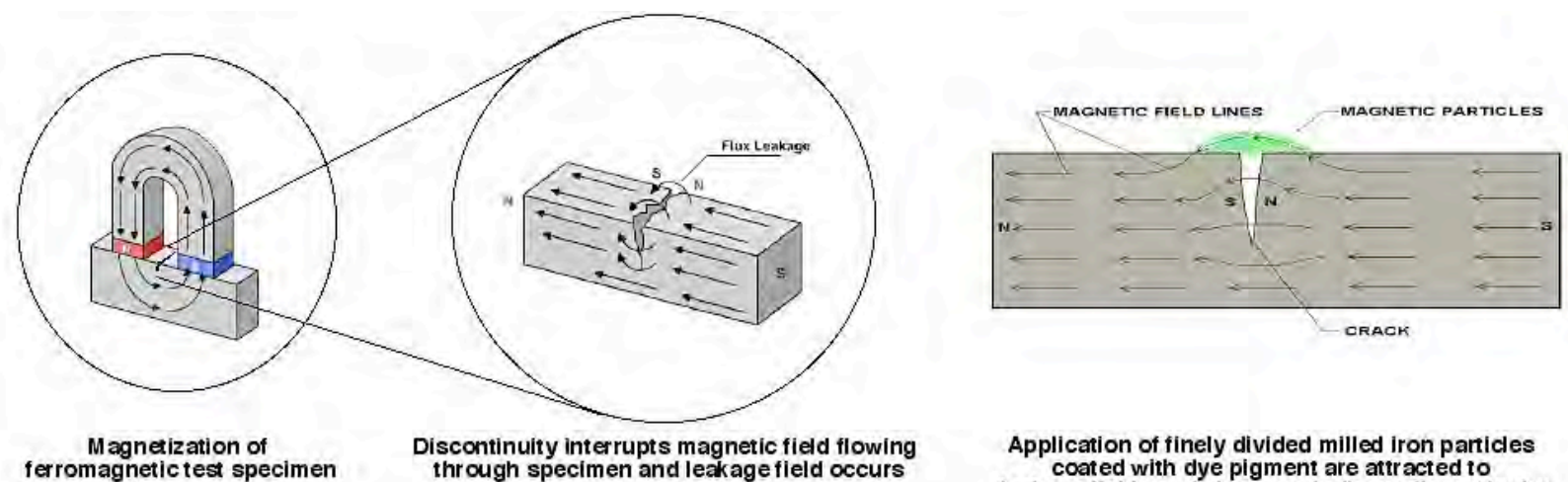

Application of finely divided milled iron particles coated with dye pigment are attracted to leakage fields and cluster to indicate discontinuity

Figure 4.12 Magnetic particle testing.

Sources: Magnetic Particle Testing, Collaboration for NDT Education, Iowa State University, Ames, Iowa (http://www.ndt-ed.org).

Basic Principles, Iowa State University, Ames, Iowa (http://www.ndt-ed.org/EducationResources/ CommunityCollege/MagParticle/Introduction/basicprinciples.htm).

Table 4.8 Advantages and limitations of magnetic particle testing

\begin{tabular}{|l|l|}
\hline \multicolumn{1}{|c|}{ Advantages } & \multicolumn{1}{c|}{ Limitations } \\
\hline $\begin{array}{l}\text { Sensitive means of locating small and shallow surface } \\
\text { cracks in ferromagnetic materials }\end{array}$ & $\begin{array}{l}\text { The deeper the discontinuity lies below the surface } \\
\text { the larger it must be to yield a reliable indication and } \\
\text { the more difficult it is to find (maximum depth of } \\
\text { sensitivity approximately 15 mm) }\end{array}$ \\
\hline $\begin{array}{l}\text { Discontinuities that do not actually break surface can } \\
\text { also be indicated in many cases }\end{array}$ & $\begin{array}{l}\text { Method can not inspect non-ferrous materials (e.g., } \\
\text { aluminum, manganese, and most stainless steels) }\end{array}$ \\
\hline $\begin{array}{l}\text { Indications are produced directly on component surface } \\
\text { and inspection is fairly fast }\end{array}$ & $\begin{array}{l}\text { Magnetic field must be in direction that will intercept } \\
\text { principal plane of discontinuity for best results which } \\
\text { may require two or more sequential inspections with } \\
\text { different magnetization (i.e., discontinuities oriented } \\
\text { parallel to direction of magnetic flux will not be } \\
\text { detected) }\end{array}$ \\
\hline $\begin{array}{l}\text { Little or no limitation on size and shape of part } \\
\text { inspected }\end{array}$ & $\begin{array}{l}\text { Demagnetization often necessary after inspection as } \\
\text { well as post-cleaning to remove remnants of } \\
\text { magnetic particles }\end{array}$ \\
\hline $\begin{array}{l}\text { No elaborate precleaning normally required and cracks } \\
\text { filled with foreign material can be detected }\end{array}$ & $\begin{array}{l}\text { Very large currents sometimes required for large } \\
\text { parts }\end{array}$ \\
\hline $\begin{array}{l}\text { Relatively low cost compared to several other NDT } \\
\text { methods }\end{array}$ & $\begin{array}{l}\text { Some parts may require removal of coating or } \\
\text { plating to achieve desired inspection sensitivity }\end{array}$ \\
\hline $\begin{array}{l}\text { Equipment relatively portable, especially when using } \\
\text { battery-powered equipment }\end{array}$ & \\
\hline
\end{tabular}

Sources: A. Lingren, "Magnetic Particle Inspection," pp. 89-128 in "Volume 17 - Nondestructive Evaluation and Quality Control," ASM Handbook (formerly ninth edition, Metals Handbook), ASM International, Materials Park, Ohio, 1989.

Magnetic Particle Testing, Collaboration for NDT Education, Iowa State University, Ames, Iowa (http://www.ndt-ed.org). 


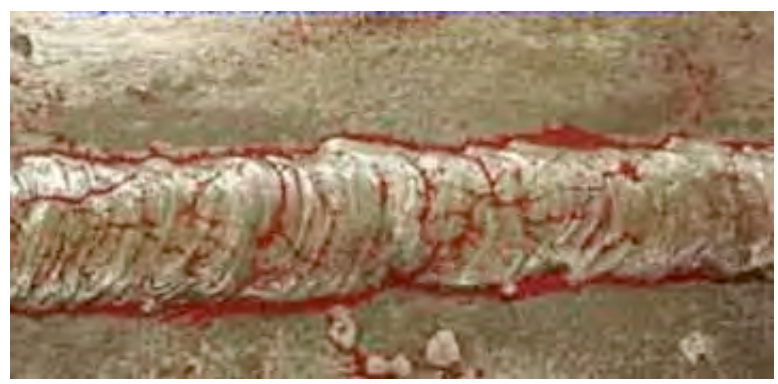

(a) Visible dry magnetic particle indication of cracks in weldment.

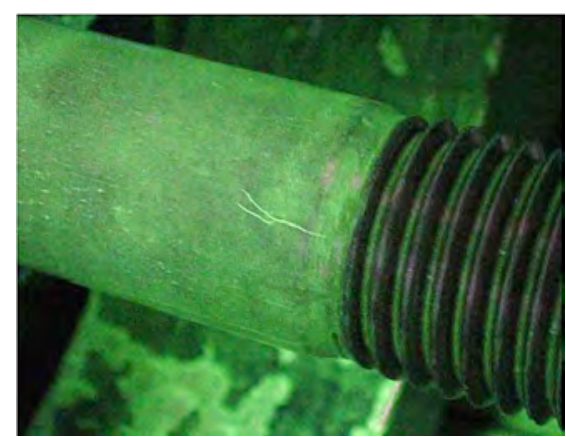

(b) Fluorescent wet particle method indication of service-induced crack in bolt.

Figure 4.13 Examples of magnetic particle indications of cracks.

Sources: (a) Basic Principles, Iowa State University, Ames, Iowa (http://www.ndted.org/EducationResources/CommunityCollege/MagParticle/Indications/DryExamples.htm).

(b) Magnetic Particle Testing, Collaboration for NDT Education, Iowa State University, Ames, Iowa (http://www.ndt-ed.org).

\subsubsection{Ultrasonic Testing (UT)}

Ultrasonic testing uses sound waves of short wavelength and high frequency (e.g., 0.5 to $20 \mathrm{MHz}$ ) to detect and evaluate surface and subsurface flaws, for material characterization, and to measure material thickness. Ultrasonic inspection techniques are commonly divided into three primary classifications: (1) normal beam and angle beam (relates to the angle that the sound energy enters the test article), (2) pulse-echo and through transmission (relates to whether reflected or transmitted energy is used), and (3) contact and immersion (relates to the method of coupling the transducer to the test article) (4.24). Figures 4.14 and 4.15 provide illustrations of direct contact and immersion techniques, respectively.

A transducer, driven by a pulsar that produces a high voltage electrical pulse, generates high frequency ultrasonic energy that is introduced into the material under investigation and propagates in the form of a series of pulses of extremely short duration. During the time interval between transmissions the transducer can detect reflected signals. As the sound wave propagates through a material it continually loses a part of its energy because of scattering and internal friction effects within the material. Attenuation losses, together with beam divergence, account for the major limitation on the depth of penetration that can be achieved for component inspection. The extent of attenuation increases with an increase in frequency. Changing the frequency when the sound velocity is fixed will change the wavelength of the sound that in turn affects the probability of flaw detection (i.e., discontinuity should be
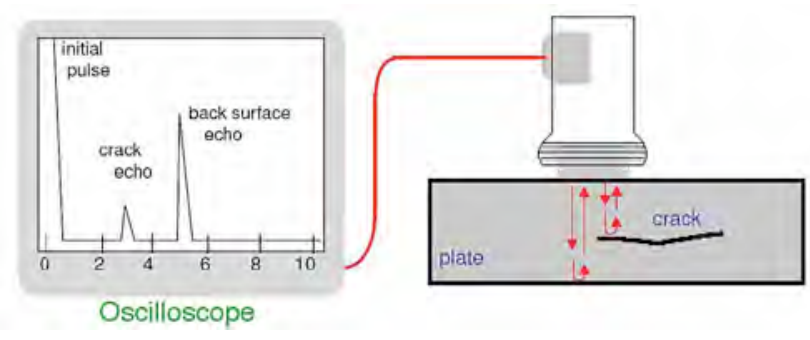

(a) Pulse-echo (normal beam) contact technique.
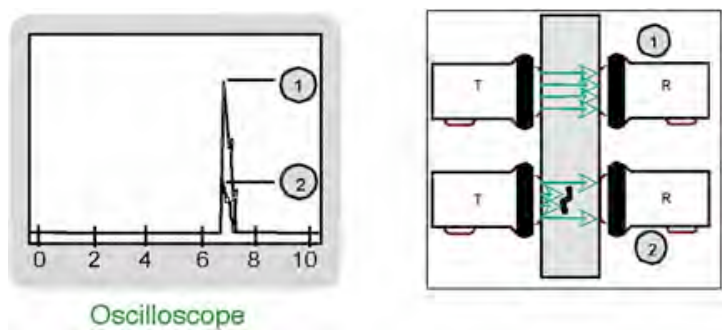

(b) Through-transmission (normal beam) contact technique.

Figure 4.14 Ultrasonic testing examples of direct contact techniques.

Source: Ultrasonic Testing, Collaboration for NDT Education, Iowa State University, Ames, Iowa (http://www.ndt-ed.org). 


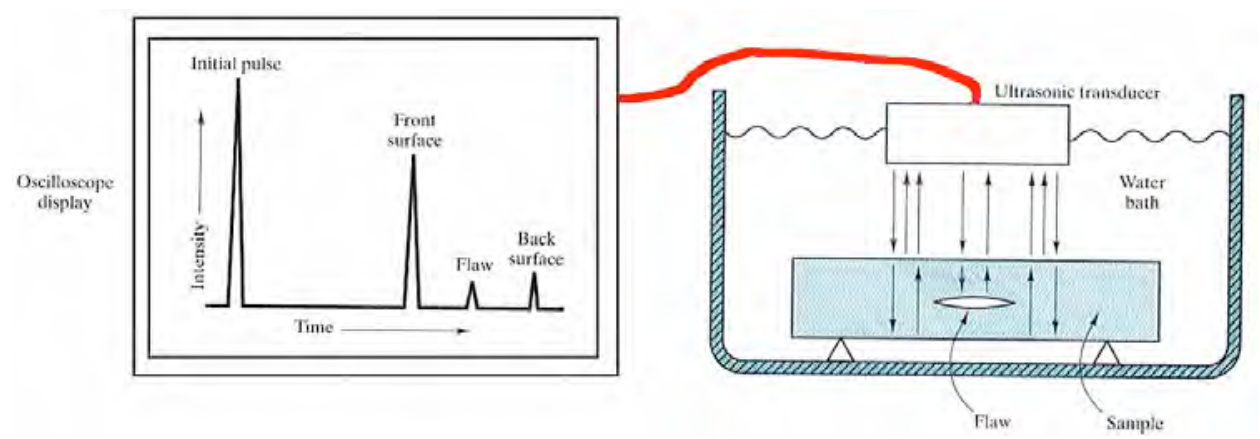

Figure 4.15 Ultrasonic testing immersion technique.

Source: Ultrasonic Testing, Collaboration for NDT Education, Iowa State University, Ames, Iowa (http://www.ndt-ed.org).

larger than one-half the wavelength for detection) (4.25). The ability to locate small discontinuities and resolution generally increase with an increase in frequency. Since conventional piezoelectric transducers typically operate at frequencies higher than $500 \mathrm{kHz}$, the corresponding inspection range is relatively short (a few meters) because of a relatively high wave attenuation in that frequency range. Although piezoelectric transducers are most frequently used to generate the sound waves, the sound waves may also result from other sources such as laser-generated ultrasound and electromagnetic acoustic transducers.

Piezoelectric materials, which dilate or strain when a voltage is applied across the crystal faces, form the basis for electromechanical transducers. ${ }^{*}$ The expansion and contraction produced by alternating voltage generates a compression wave in the surrounding medium. The compression wave can be transmitted at right angles to the component surface, or a coupling wedge can be used to transmit shear or Rayleigh waves into the object. Either one transducer, which acts as both transmitter and receiver, or two transducers, where one transducer transmits the signal and a second receives the signal, have been used. The most commonly used technique is pulse echo in which sound is introduced into the test object and travels through the material examined with some attendant loss of energy (Figure 4.14a). Reflections (echoes) are returned to the receiver from internal imperfections or the component's surfaces. The returning pulse is displayed on a screen that gives the amplitude of the pulse and the time taken to return to the transducer. Inclusions or other imperfections are detected by partial reflection or scattering of the ultrasonic waves, time of transit of the wave through the test object, and features of the spectral response for either a transmitted or reflected signal. Operator interpretation is made by pattern recognition, signal magnitude, timing, and probe positioning. Flaw size, distance, and reflectivity can be interpreted. For thickness measurements digital meters are commonly used. In the pulse-echo mode an ultrasonic transducer transmits waves normal to the component surfaces, signals are reflected from the front and back surfaces, and the difference in arrival times of the two signals is used to indicate the thickness. Cross-section loss is then calculated by taking the difference between the as-built thickness and the thickness measured. Components can also be scanned to detect subsurface abnormalities such as cracks or voids. Information obtained during a test can be displayed as either an " $A$ " scan (displays initial pulse, any defect echoes, and back wall echo), "B" scan (initial signal, defect echoes, and back wall echoes recorded as a function of probe position), or "C" scan (provides plan view of specimen). "A" scans are most commonly used. Ultrasonic testing is commonly used in nuclear plants to monitor wall thinning of the containment vessel caused by corrosion. Rough surface conditions such as could be present on metallic components of containment pressure boundary systems present problems relative to signal scattering. The contact wedge-type transducers are sensitive to the plate surface condition and the coupling state and, therefore, inspection results may not be satisfactory. One major disadvantage of this approach is the requirement of a coupling medium. Focused transducers provide improved results where rough surfaces are present. A coupling medium consisting of a column of water also may provide a suitable approach (4.26,4.27). Table 4.9 presents several advantages and limitations of ultrasonic testing. Example applications of pulse-echo ultrasonic testing are presented in Figure 4.16.

Phased arrays can also be used for volumetric nondestructive testing. Instead of a single transducer and beam, phased arrays use multiple ultrasonic elements and electronic time delays to create beams by constructive and

*Conversely, if the crystal is subjected to a mechanical strain, an electrical field will be created in which the voltage produced is proportional to the amount of strain (4.23). 
Table 4.9 Advantages and limitations of ultrasonic testing

\begin{tabular}{|l|l|}
\hline \multicolumn{1}{|c|}{ Advantages } & \multicolumn{1}{c|}{ Limitations } \\
\hline \hline High sensitivity permitting detection of small flaws & Surface must be accessible to transmit ultrasound \\
\hline $\begin{array}{l}\text { Can provide thickness measurements in addition to } \\
\text { flaw detection }\end{array}$ & $\begin{array}{l}\text { Linear defects oriented parallel to sound beam may go } \\
\text { undetected }\end{array}$ \\
\hline $\begin{array}{l}\text { Increased penetration power permitting detection of } \\
\text { flaws located deeper in a component }\end{array}$ & $\begin{array}{l}\text { Couplant generally required to provide effective } \\
\text { transfer of ultrasound wave energy between transducer } \\
\text { and part inspected }\end{array}$ \\
\hline Volumetric scanning capability & $\begin{array}{l}\text { Discontinuities present in shallow layer immediately } \\
\text { beneath the surface may not be detected }\end{array}$ \\
\hline $\begin{array}{l}\text { Greater accuracy than other nondestructive testing } \\
\text { methods in determining position of internal flaws, } \\
\text { estimating their size, and characterizing their } \\
\text { orientation, shape, and nature }\end{array}$ & $\begin{array}{l}\text { Parts that are rough, irregular in shape, very small or } \\
\text { thin, or not homogeneous are difficult to inspect }\end{array}$ \\
\hline $\begin{array}{l}\text { Only one surface needs to be accessible for pulse echo } \\
\text { and minimum part preparation is required }\end{array}$ & $\begin{array}{l}\text { Manual operation requires careful attention by } \\
\text { technicians with extensive skill and training }\end{array}$ \\
\hline $\begin{array}{l}\text { Detailed images produced with automated equipment } \\
\text { and almost instantaneous indication of flaws }\end{array}$ & $\begin{array}{l}\text { Cast iron and other coarse grained materials are } \\
\text { difficult to inspect due to low sound transmission and } \\
\text { high signal noise }\end{array}$ \\
\hline $\begin{array}{l}\text { Portable and nonhazardous to operators or nearby } \\
\text { personnel with no effect on equipment and materials in } \\
\text { vicinity }\end{array}$ & $\begin{array}{l}\text { Reference standards required for both equipment } \\
\text { calibration and characterization of flaws }\end{array}$ \\
\hline
\end{tabular}

Sources: Y. Bar-Cohen, "Ultrasonic Inspection," in Volume 17 - "Nondestructive Evaluation and Quality Control," ASM Handbook (formerly ninth edition, Metals Handbook), pp. 231-277, ASM International, Materials Park, Ohio, 1989

Basic Principles of Ultrasonic Testing, Collaboration for NDT Education, Iowa State University, Ames, Iowa (http://www.ndt-ed.org/EducationResources/CommunityCollege/Ultrasonics/introduction/ description.htm).

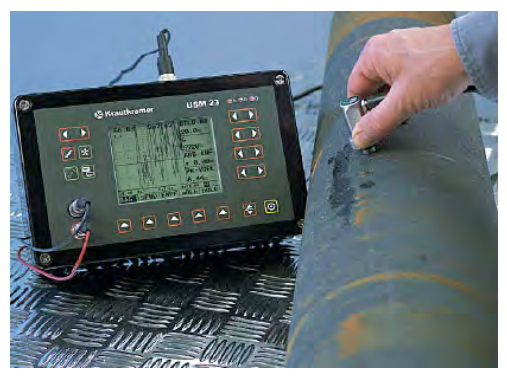

(a) Ultrasonic inspection of pipeline.

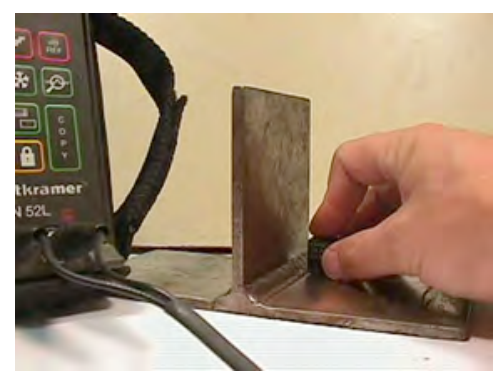

(b) Depth sizing of fillet weld toe crack.

Figure 4.16 Example applications of ultrasonic testing.

Source: (a) "Ultrasonics," GE Inspection Technologies, Lewistown, Pennsylvania, 2007.

(b) Applications, Pfannenstiel Innovative Non Destructive Examinations, Old Saybrook, Connecticut (http://www.pfnde.com/applications.htm).

destructive interference (4.28). Each element is individually wired, pulsed, and time shifted. Phased array probes consist of a transducer assembly with from 16 to 256 small individual elements that may be arranged in a strip (linear array), a ring (annular array), a circular matrix (circular array), or a more complex shape( 4.29). Phased array probes may be designed for direct contact use, as part of an angle beam assembly with a wedge, or for immersion use with water coupling. Transducer frequencies are most commonly in the range of 2 to $10 \mathrm{MHz}$ (4.29). A phased array system also includes a computer-based instrument capable of driving the multi-element probe, receiving and digitizing the return echoes, and plotting the echo information in various formats. The phased array beams can be 
steered, scanned, swept, and focused electronically. Beam steering can be used for mapping components at appropriate angles to optimize the probability of detection of discontinuities. Several potential applications of phased arrays include in-service testing of pipelines for stress corrosion cracking, small diameter austenitic pipe weld testing, hydrogen-induced cracking, flange corrosion under gaskets, and testing of bolts. Advantages of phased arrays relative to conventional ultrasonics for weld inspection include: electronic scanning permits very rapid coverage of the components; tailored angles can be used for mapping components to maximize detection of defects; sectorial scanning is useful for inspections where only a minimal footprint is possible; and electronic focusing permits optimizing the beam shape and size at the expected defect location, consequently to optimize defect detection (4.30). Initial costs for the electronics and software required to operate phased array systems as well as the array probes are higher than for conventional ultrasonic counterparts. Figure 4.17 presents an application of phased array detection to a plate containing small holes.

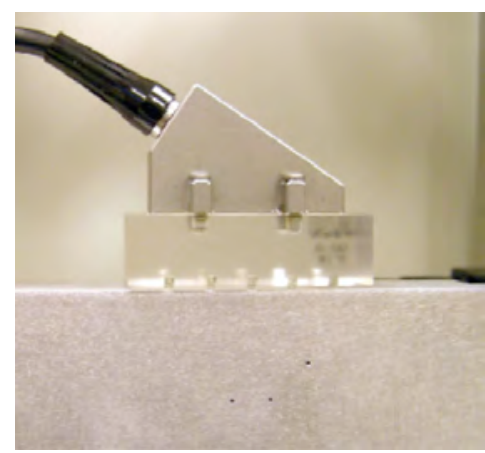

(a) Linear phased array probe.

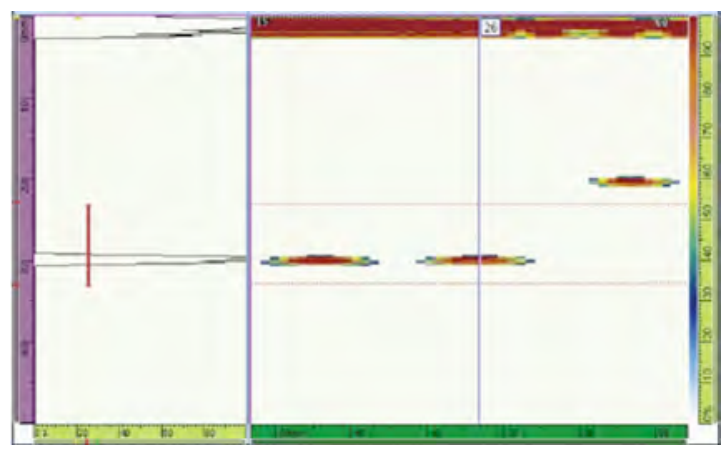

(b) B-scan image showing relative hole position and depth across length of linear array.

Figure 4.17 Use of phased array testing to investigate plate with holes.

Source: T. Nelligan and D. Kass, "An Introduction to Ultrasonic Phased Array Technology," Olympus Corporation, Tokyo, Japan (http://www.olympusndt.com/en/ultrasonics/intro-to-pa/).

Dry-coupled piezoelectric transducers employed for guided-wave inspection of piping (4.31) may also be used for plates. Compared to the thickness vibration of a conventional transducer, the piezoelectric transducer in this case expands or contracts lengthwise. When pressed against the surface of a material under inspection, the lengthwise motion of the transducer imparts the force to the material through friction and generates the guided wave. Detection of the guided wave is achieved by the reverse process. The operating frequency of the dry-coupled transducer is low ( $100 \mathrm{kHz}$ or less) and, therefore, it is well suited for long-range inspection (tens of meters) because of a correspondingly low wave attenuation.

Noncontact ultrasonic pulses can be generated through focusing a series of light impulses from a laser onto the surface of the object inspected (4.23). The remotely positioned laser sends out a series of very short high-energy light impulses that are converted by thermomechanical effects into sound impulses. The laser pulse at the point of incidence on the object surface produces rapid heating (without damage) resulting in a localized temperature rise that generates ultrasonic waves. Lasers can generate compressional, shear, surface, and plate waves. The emission from a second laser illuminates the surface of the test object and ultrasonic echoes returning to the test object surface cause deflections that produce modulation of the reflected light from the illuminating laser. An interferometer analyzes the modulated reflected light signal and converts it into a signal that can be displayed. Laser ultrasonic testing can investigate a number of property related items (e.g., thickness, temperature, hardness, corrosion, grain structure, and porosity; delaminations, cracks, and other defects in solids; properties of welds; and inclusions in molten metal) (4.32). The main advantages of laser-induced ultrasonics are that no mechanical coupling is required, it can make measurements in hostile environments, and the acquisition of results is rapid, however, sensitivity is not as good as more conventional ultrasonic systems.

Electromagnetic acoustic transducers (EMATs) also do not require a couplant. An EMAT consists of a magnet and a coil of wire and relies on electro-magnetic interaction for elastic wave generation. Using Lorentz forces and magnetostriction, the EMAT and the metal test surface interact and generate an acoustic wave within the material. The material being inspected is its own transducer eliminating the need for a couplant. An EMAT can generate 
Rayleigh, creeping, shear vertical, shear horizontal, longitudinal, torsional, and flexural wave modes in frequency ranges from $100 \mathrm{kHz}$ to $12 \mathrm{MHz}$ (4.33). EMATs have primarily been used for flaw detection and material property characterization. EMATs can operate in remote environments at elevated temperatures, are insensitive to surface conditions (e.g., rough, oily, wet, or oxidized), have high inspection speeds ( $>1 \mathrm{~m} / \mathrm{s})$, and are self calibrating, but their designs are relatively narrowband and require strong magnetic fields and large currents to produce ultrasound that is often weaker than that produced by piezoelectric transducers. Figure 4.18 presents a comparison of piezoelectric and EMAT operating principles.

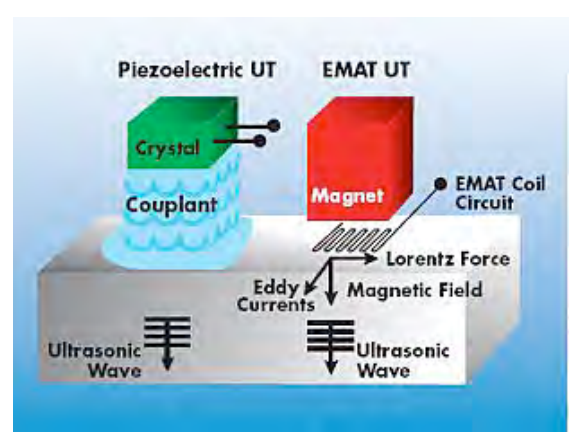

Figure 4.18 Comparison of piezoelectric and EMAT ultrasonic testing.

Source: EMAT Technology, Innerspec Technologies, Lynchberg, Virginia, 2006 (http://www.innerspec.com/site/emat.asp).

Magnetostrictive sensor (MsS) technology uses structure-borne elastic guided waves at relatively low frequencies (e.g., typically $<200 \mathrm{kHz}$ ). The guided waves at these frequencies can propagate long distances in a structure. Magnetostrictive sensors are devices that launch guided waves of a certain wave mode (e.g., longitudinal or torsional for piping inspections) and detect elastic waves in ferromagnetic materials electromagnetically to determine the location and severity of a defect based on timing and signal amplitude. The magnetostrictive force refers to the force that acts in ferromagnetic materials due to strains associated with magnetic domain motion (4.34). Figure 4.19a presents a MsS system setup for launching guided waves in plate or piping structures. With MsS the magnetostrictive force is produced directly in the part under inspection by setting the magnetic domains in the
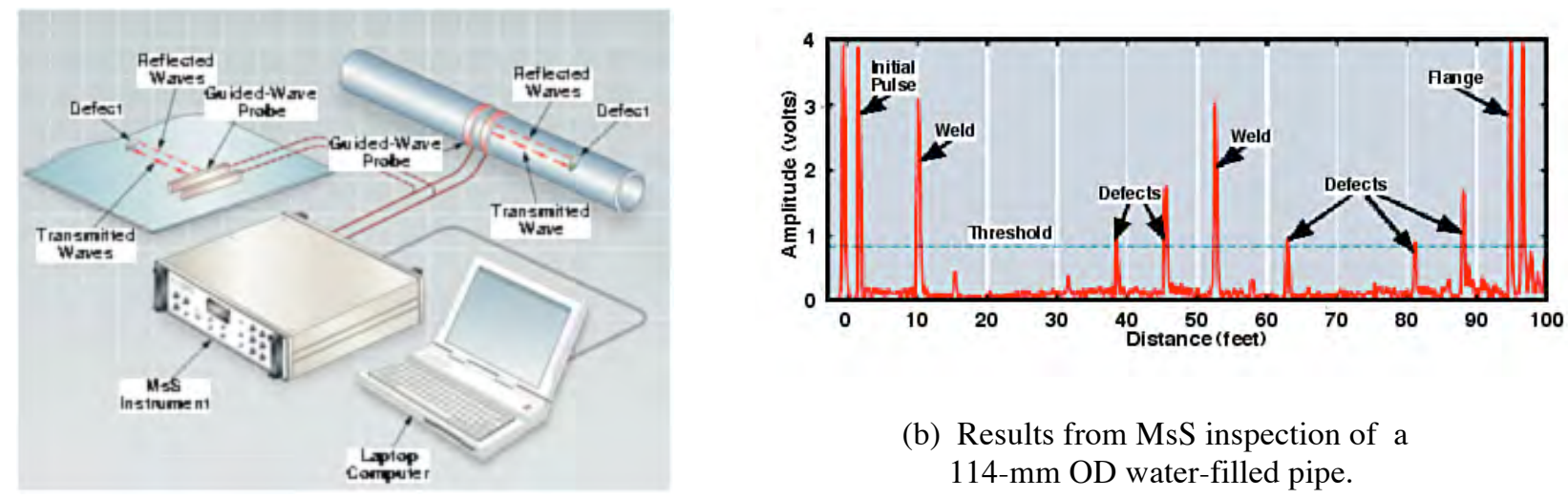

(b) Results from MsS inspection of a 114-mm OD water-filled pipe.

(a) MsS system setup.

Figure 4.19 Magnetostrictive sensor system and results from buried gas transmission line inspection.

Source: H. Kwun, "Waves of the Future," SwRI Technology Today, Southwest Research Institute, San Antonio, Texas, Fall 2003 (http://www.swri.org/3[ubs/ttoday/fall03/Future.htm).

material into a vibrational motion by applying alternating magnetic fields to the material. For piping, the magnetic fields are applied by supplying an alternating electric current to the MsS coil that encircles the pipe. This magnetostrictive force generates the guided waves. When the propagating guided-wave pulse encounters welds or 
defects, such as corrosion wall loss or cracks, some of the waves are reflected back to the original location. Figure 4.19b presents results from MsS inspection of a 114-mm outside diameter water-filled pipeline. Detection of the guided waves can be achieved by the same sensor that launched the wave and involves the reverse process in that the guided waves cause domains to vibrate and, consequently, the magnetic induction of the material to change with time. The changing magnetic induction induces an electric voltage in the MsS coil. The magnetostrictive force is independent of the sign of the applied magnetic field and is in the direction of the applied field. Therefore, in the absence of a static bias magnetic field, the alternating magnetic field results in generation of guided waves of twice the frequency of the applied magnetic field (4.35). To produce the wave of the same frequency and to enhance the efficiency of the sensor (which is proportional to the magnetostriction coefficient), a static magnetic field is also applied to the material $(4.36,4.37)$. The technique is noncontact, couplant free, requires minimum surface preparation, and can operate up to the Curie temperature of the material (i.e., $723.89^{\circ} \mathrm{C}$ for steel). In addition, the technique has a sensing or inspection range from a single sensor location that can exceed several hundred meters on bare metals, the sensor can detect defects on the inside and outside diameters of pipe surfaces, and it can inspect structures whose surfaces are not directly accessible due to the presence of paint or insulation. For noncontact applications, the technique is limited to ferromagnetic materials. Its primary application has been to piping systems, however, magnetostrictive sensors can measure motion, stress or force, torque, magnetic fields, and target characteristics (4.38).

Guided wave propagation differs from bulk wave propagation in that a boundary is required for guided wave propagation (4.39). Two primary techniques for generating guided waves include angle beam and comb transducers (4.40). Figure 4.20 presents examples of angle-beam and comb transducers. In the angle beam approach a

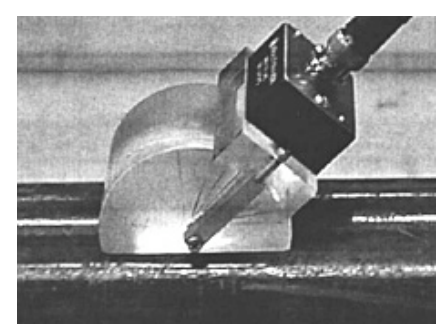

(a) Angle beam probe.

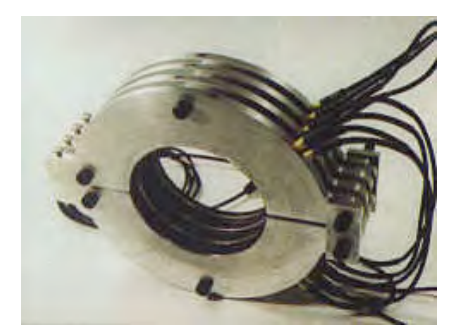

(b) Comb probe for inspection of pipe walls under insulation.

Figure 4.20 Examples of probes used for generating guided waves.

Source: (a) J.L. Rose, “A Baseline and Vision of Ultrasonic Guided Wave Inspection Potential," Journal of Pressure Vessel Technology 124, pp. 273-282, American Society of Mechanical Engineers, New York, New York, August 2002.

(b) “Emerging Technology - Guided Wave Ultrasonics," Krautkramer NDTimes 2(2), Krautkramer Branson, Lewiston, Pennsylvania, Spring and Summer 1998.

piezoelectric element on a wedge is placed on the test object. As a result of refraction at the interface between the wedge and test specimen a variety of waves can propagate in the structure and by way of mode conversion and reflection from the surfaces of the structure can lead to interference patterns as a resulting wave vector propagates along the structure. In the comb transducer technique a number of elements are placed on the structure with some spacing that puts energy into the structure either all in phase or out of phase if using a phased array transducer approach causing ultrasonic guided wave energy to propagate in both directions along the structure. The spacing of elements and frequency selection determines the mode types that propagate in the structure. A countless number of guided wave modes at specific frequencies could be selected for a particular nondestructive evaluation problem, each point producing special sensitivities by way of wave structure across the thickness of the component being studied, and also specific penetration powers as a result of interface and surface displacement values and subsequent energy leakage into neighboring media (4.41). The mode and frequency choice has a strong influence on nondestructive evaluation and flaw detection, classification, and sizing potential as well as the ability to propagate guided waves over long distances, despite the presence of coatings and other surrounding media. Phase velocity dispersion curves serve as the guide to controlling and selecting various guided wave modes (4.42). From a guided wave mode generation point of view the phase velocity curve is necessary to determine an entry angle of the wave excitation since the phase velocity of a mode is related to the entry angle via Snell's law. Dispersion curves for a 
particular structure are generated numerically. Corresponding group velocity curves describe the velocity at which the mode propagates and allows for localization of a defect. With a variable angle shoe, modes can be generated along a horizontal line (i.e., constant velocity which depends on the angle of incidence of the normal beam into the wedge) on the phase velocity dispersion curves. Varying the angle and frequency allows for the possible generation of modes with a phase velocity greater than the phase velocity in the shoe (4.42). Controlling and selecting the guided wave mode/frequency combination is critical in obtaining optimal performance of the guided wave technique. One mode/frequency combination may reflect strongly from a certain type of defect. Hence, the ability to generate guided wave modes at a variety of points on the dispersion curve is key to achieving optimal performance of the guided wave technique. The approach to mode and frequency selection is therefore crucial, which can ultimately be based on theoretical and/or experimental means. One aspect of a theoretical approach beyond dispersion curve analysis includes theory of elasticity computations of displacement distributions across a structure. The focus can be on achieving in-plane or out-of-plane optimal values on a surface or at a specific location inside a structure in an attempt at flaw analysis or improved penetration power. From an experimental point of view, an angle-beam transducer at a specific angle can be used to achieve a particular phase velocity value. Unfortunately, the presence of a phase velocity spectrum due to a transducer source influence, size and velocity pattern, as well as the frequency spectrum itself, often limits the ability to specifically achieve the particular mode and frequency of choice. The multimode guided wave technique is more sensitive than techniques which utilize shear waves (e.g., electromagnetic acoustic transducers); provides a global inspection technique for characterizing corrosion damage; follows the contour of the structure; can travel long distances (e.g., $>100 \mathrm{~m}$ depending on frequency and mode characteristics); has capability to inspect structures under water, coatings, insulation, multilayer structures or concrete with good sensitivity; has the potential with multi-mode and frequency Lamb type, and surface or horizontal shear waves to detect, locate, classify, and size defects; and can interrogate different regions or cross sections (i.e., depths) of the component inspected $(4.39,4.41,4.43-4.48)$. The guided waves can be excited at one point on the structure, propagate over considerable distances, and be received at a remote point on the structure. Multimode guided waves have been used with success to detect defects in piping materials and its applicability to plate-type materials has been demonstrated.

Another ultrasonic testing technique is the time of flight diffraction (TOFD) method that relies on the diffraction of ultrasonic waves from cracks or defect tips, rather than reflection such as in pulse-echo methods. TOFD is based on mapping the positions or edges of anomalies. Figure 4.21 illustrates the principle of TOFD. Usually two probes (transmitter and receiver) are used, with the probes aligned geometrically on either side of the object being inspected (e.g., crack or weld). The transmitter produces both longitudinal and shear waves that spread to give full volumetric coverage of the test article. Two different longitudinal waves are introduced into the test article (4.49). The first L-

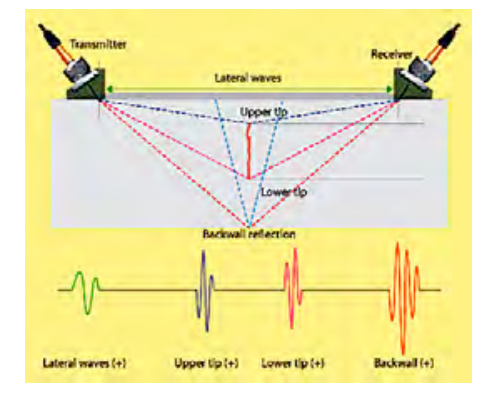

Figure 4.21 Time of flight diffraction method.

Source: TOFD Transducers, Olympus Corporation, Tokyo, Japan (http://www.olympusndt.com/en/panametricsndt-ultrasonic/tofd/).

wave travels between the transmitter and receiver just below the material surface and the second is angled at the back wall and skips to the receiving transducer. From these L-waves shear waves are formed that propagate through the volume of material. When defects are present diffracted energy from the edges or tips is reflected and picked up by the receiving transducer. The wave propagation times are used to indicate and locate the diffraction source. If both tips of a defect can be resolved, then the actual depth and "through-wall" thickness of the flaw can be accurately calculated using the time of flight of the corresponding ultrasonic wave. Anomaly height can be measured by subtracting the depths of lower and higher anomaly edges. A typical figure for accuracy that may be achieved in through-thickness height measurement is $1 \mathrm{~mm}$ (4.50). A complete image over the length of a component such as a weld is achieved by recording the ultrasonic signals at regular intervals. Interpretation of 
results can be difficult, however, because it is hard to achieve clear signals in the "A" scans due to the nature of the weak diffracted signals coupled with noise, and interference derived from very small pores or material nonuniformity (particularly for welds). Data enhancing algorithms such as the synthetic aperture focusing technique can be used to improve defect characterization by eliminating beam-spread effects. One of the best applications of this method has been to on-line weld inspection since it can inspect the full weld with rejection of unwanted signals, and scans are continuous and contain all data from individual "A" scans. One large advantage of TOFD compared to conventional ultrasonics and radiography is that the probability of detection is essentially independent of the anomaly orientation. TOFD, however, is less suitable for coarse-grained materials, and inspection relatively close to the scanning surface may be hampered by the presence of the lateral wave that may obscure anomalies present in this area, although specialized software algorithms may be used to minimize this effect. Also, small anomalies located very close to the root of a weld may sometimes be obscured due to irregularities in the root penetration.

\subsubsection{Radiography Testing (RT)}

Radiographic techniques involve the use of penetrating $\gamma$ - (decay process of radioactive substances) or X-radiation (bombarding a metal target with a beam of high-velocity electrons) and are based on differential absorption of the radiation. Gamma radiation is the product of radioactive atoms while $\mathrm{x}$-rays are produced by an $\mathrm{x}$-ray generator. Xradiographic inspection is applied to the detection of surface connected and internal anomalies as well as the internal configuration of a test object. Iridium 192 and cobalt 60 are typically used as radiation sources. Radiation is capable of detecting any feature in a component or structure provided that there are sufficient differences in thickness or density within the test article. The source is placed close to the material to be inspected and the radiation passes through the material and is captured on film placed on the opposite side of the test article from the source. Sensitized paper (paper radiography), fluorescent screen viewing (fluoroscopy), and detection and monitoring by electronic sensing equipment (xeroradiography) can also be used to monitor the intensity of radiation passing through a material. A two-dimensional projection of the area being inspected is displayed on the film (permanent record). The thickness, density, and absorption characteristics of the material affect the intensity of radiation passing through an object. Possible imperfections are indicated on the film as density changes (i.e., series of gray shades between black and white). The choice of type of source is dependent on the thickness of material to be tested. Gamma rays have the advantage of portability. Gamma radiometry systems consist of a source that emits gamma rays through the specimen and a radiation detector and counter. Direct transmission or backscattering modes can be used to make measurements. The count or count rate is used to measure the specimen dimensions or physical characteristics (e.g., density and composition). Limitations of radiography are that radiation protection has to be observed while applying the method, personnel must be licensed or certified, the structure must be accessible from both sides, detection of crack-like anomalies is highly dependent on the exposure geometry and orientation of the crack with respect to incident irradiation (e.g., cracks are best detected in a radiograph only when they are propagating in a direction that produces a change in thickness that is parallel to the x-ray beam), and it tends to be expensive relative to many other nondestructive evaluation methods. Figure 4.22 illustrates detection of cracks in a weld by radiography.
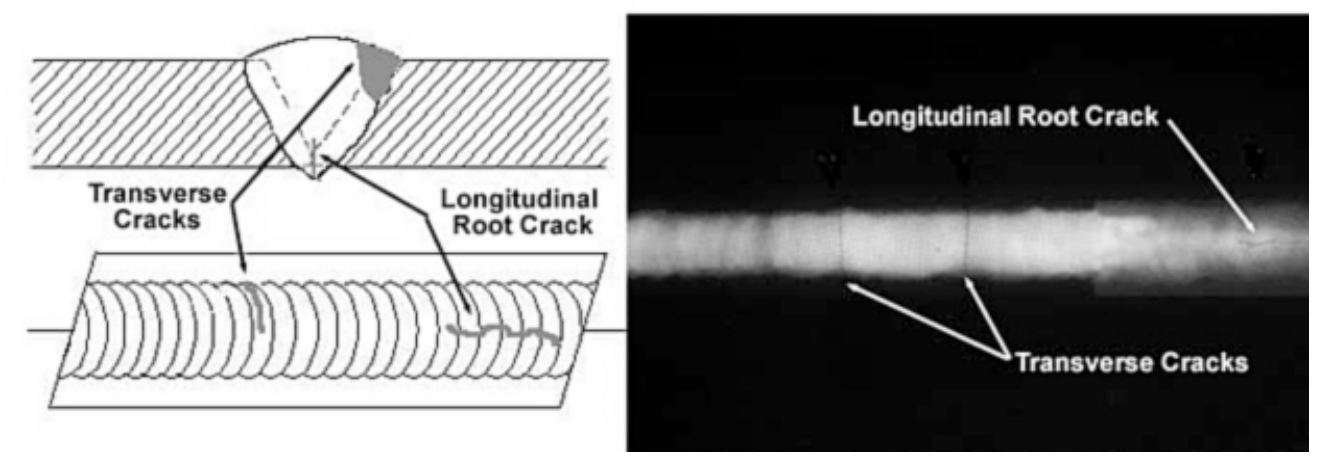

Figure 4.22 Example of crack detection by radiography.

Source: Radiograph Interpretation - Welds, Iowa State University, Ames, Iowa (http://www.ndt.ed.org/ EducationResources/CommunityCollege/Radiography/TechCalibrations/radiographinterp.htm).

Neutron radiography involves the transmission of neutrons through a component with the associated production of a radiograph on film. Sources of neutron beams include a radioactive isotope, a particle accelerator, or a nuclear 
reactor. Neutron emissions are classified according to their kinetic energies as cold (slow neutrons), thermal (medium speed), or fast (4.23). Generally the thermal neutrons are used in neutron radiography. As a neutron beam passes through a medium it will be attenuated due to neutron scatter (collisions with atom nuclei) and capture (absorption of neutron into nucleus creating an isotope of the atom). With neutron beam radiography there is a greater tendency for the thermal neutron beam attenuation to increase as the atomic mass number of the element increases. The general principles of beam attenuation with increasing thickness, shadow formation, and other geometrical effects, are similar to those of $\gamma$ - or X-radiography, however, recording of results differs. Either directexposure or transfer screens are used. In the direct-exposure method the screen is placed in direct contact with the film and neutrons falling on the screen are absorbed and a secondary emission, to which the film emulsion is sensitive, is released. Transfer screens are positioned behind the object to be radiographed, a neutron exposure made, and the transfer screen used to expose the film. Neutron radiation is a highly specialized and costly process, but has been used for a number of applications including inspection of nuclear fuel elements.

A special form of radiograpy, neutron tomography, merges standard neutron radiography with the computed tomography techniques common to most of today's medical scanners to enable two- and three-dimensional external and internal visualizations of objects. The object to be scanned is located in front of the neutron beam port and activation film used to record the results. The activation film is then used to expose photographic film. The object is then rotated a precise amount and the procedure repeated until images have been taken over $180^{\circ}$. After processing the film, the images are digitized on a scanning microdensitometer and stored for computer processing. Data from each of the stored images is aligned and normalized to the same exposure and used to reconstruct images of the scanned object. Computed tomography can produce 2-D or 3-D cross-sectional images of an object such as dimensions, shape, internal defects, and density. Density variations can be indicated using colors. As neutron tomography is particularly effective in detecting hydrogen-based substances, it is useful in identifying corrosion products since they absorb the neutrons, however, since results are averaged, pitting corrosion may not be detectable. Computed tomography also can be used in conjunction with $\gamma$ - and X-radiography beam measurements. Some of the advantages of computed tomography are that it nondestructively provides quantitative densitometric (i.e., density and geometry) images of the cross sections through the body, a lower strength source can be used, the image is stored on computer, the software permits distances to be calculated and areas of special interest to be magnified; however, the object must be small enough to be accommodated by the handling system of the computed tomography equipment and the method is not approved for ASME Code nondestructive testing $(4.23,4.51)$. Another form of volumetric $\mathrm{x}$-ray imaging is the tomosynthesis process that requires a series of projection $\mathrm{x}$-ray images taken from different angles through the test object (4.52). The source is located at an oblique angle with respect to the vertical direction and the object under test is rotated to eight different positions with a two-dimensional x-ray image acquired at each position to show details in the test object from the different imaging perspectives. Any view through the object can then be reconstructed with software using the basic set of oblique incidence images acquired during the test. Figure 4.23 presents schematics of the computed tomography and the tomosynthesis process approaches using an X-ray beam and Figure 4.24 presents an example of a radiographic image.

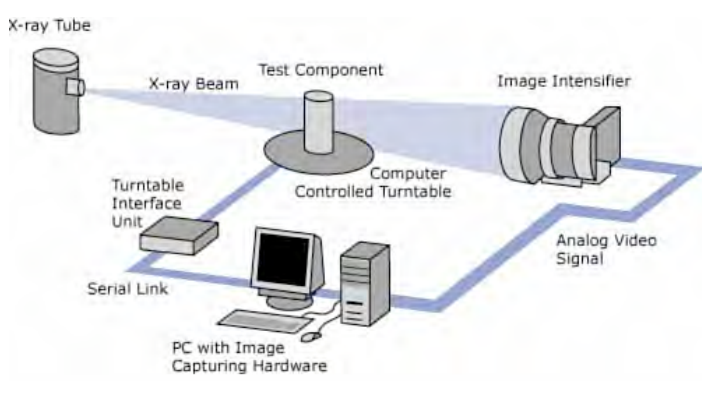

(a) Computed tomography imaging.

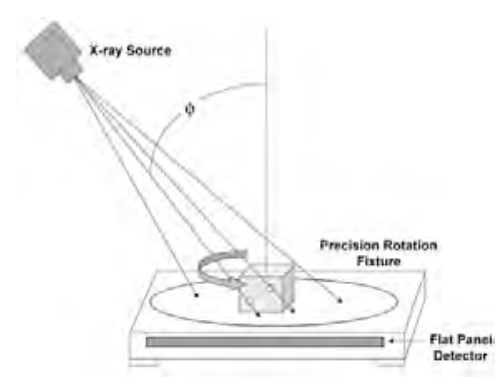

(b) Tomosynthetic imaging.

Figure 4.23 Schematics of volumetric x-ray testing approaches.

Source: (a) Computed Tomography, Iowa State University, Ames, Iowa (http://www.ndt-ed.org/Education EducationResources/CommunityCollege/Radiography/AdvandedTechniques/computed tomography.htm).

(b) H. Berger and R.L. Schulte, "Volumetric X-Ray Testing," Back to Basics, The American Society for Nondestructive Testing, Columbus, Ohio, September 2002 (http://asnt.org/publications/materialseval/basics/sep02basics/sep02basics.htm). 


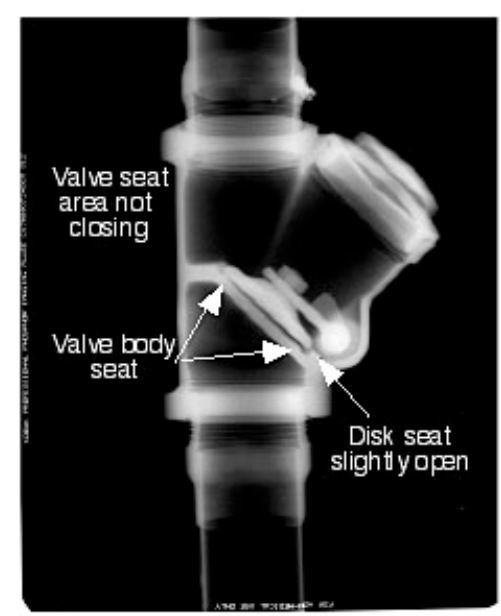

Figure 4.24 Radiographic image of a check valve showing seat area not closing.

Source: G. Pupchek, "Presentation,” Nuclear Industrial Check Valve Group, Summer Meeting, San Diego, California, June 7-9, 2005.

\subsubsection{Acoustic Emission Testing (AE)}

Acoustic emission testing differs from other nondestructive testing methods in that acoustic emission testing detects activities inside materials while other techniques attempt to examine internal structures of materials by sending and receiving some form of energy, and acoustic emission testing deals with dynamic processes in a material. Acoustic emissions are small amplitude stress waves $(50 \mathrm{kHz}$ to $10 \mathrm{MHz}$ frequency) resulting from release of kinetic energy as a material is strained beyond its elastic limit (e.g., crack growth, leakage, and plastic deformation). The stress waves propagate throughout the specimen and may be detected as small displacements by piezoelectric transducers positioned on the surface of the material. Material stress can come from mechanical or thermal loading, as well as from a variety of other means. Figure 4.25 provides a schematic of possible acoustic emission sources during corrosion, stress-corrosion cracking, and corrosion fatigue processes (4.53). There are basically two types of acoustic emissions from materials - a continuous type of low amplitude associated with plastic deformation and movement of dislocations within a material, and a burst type of high amplitude and short duration resulting from

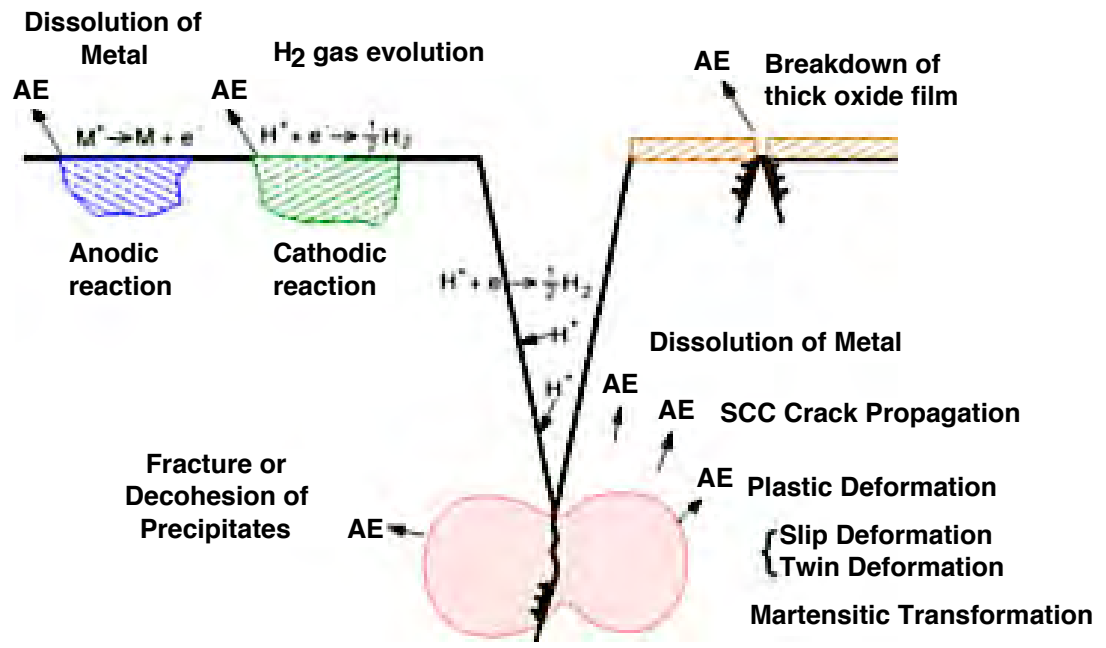

Figure 4.25 Schematic of acoustic emission sources due to corrosion.

Source: S. Yuyama, "Fundamental Aspects of Acoustic Emission Applications to the Problems Caused by Corrosion," Corrosion Monitoring in Industrial Plants Using Nondestructive Testing and Electrochemical Methods, ASTM STP 908 edited by G.C. Moran and P, Labine, pp. 43-74, American Society of Testing and Materials, West Conshohocken, Pennsylvania, 1986. 
development and growth of cracks. Figure 4.26a illustrates a burst acoustic emission signal. Signal measurement parameters most commonly used to interpret results include ring down counts (threshold-crossing pulses), energy counts (area under rectified signal envelope), duration (elapsed time for ring down counts), amplitude (highest peak voltage), and rise time (time from first threshold crossing to signal peak). A typical acoustic emission system consists of a number of sensors, preamplifiers, signal filters, amplifier, and a recording system. A typical acoustic emission setup is illustrated in Figure 4.26b.
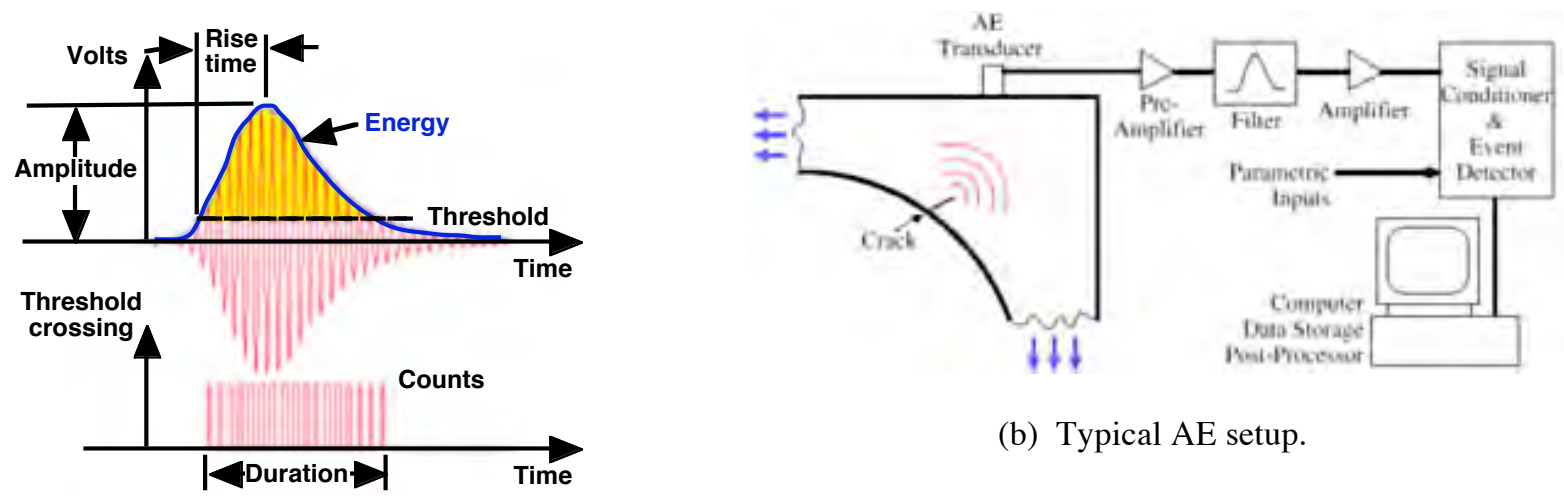

(b) Typical AE setup.

(a) Acoustic emission burst event.

Figure 4.26 Acoustic emission technique.

Source: M. Huang, L. Jiang, P.K. Liaw, C.R. Brooks, R. Seely, and D.L. Klarstrom, "Using Acoustic Emission in Fatigue and Fracture Materials Research,” Journal of Minerals, Metals \& Materials Society 50(11), pp. 13, November 1998.

Primary applications of acoustic emission inspection include continuous monitoring or proof testing of critical structures (e.g., pressure vessels, tanks, piping systems, aerospace structures, and bridges), monitoring of production processes (e.g., inspection and quality assurance), and experimental research related to material behavior (e.g., material properties, failure mechanisms, and damage behavior). Acoustic emission has been used for on-line monitoring of welds with the capability to detect weld cracking associated with phase transformation, nucleation and growth of cracks during welding and subsequent cooling, porosity and slag inclusions, microfissuring, hot and cold cracking, and reheat cracks (4.19). Advantages of acoustic emission are that it is extremely sensitive, the entire structure can be monitored, it is relatively unobtrusive, onset of failure can be identified, and multi-channel systems can be used for linear or zonal source location. Figure 4.27 presents an example of source location by acoustic emission testing. Acoustic emission can detect growing cracks of a much smaller size than are detectable by

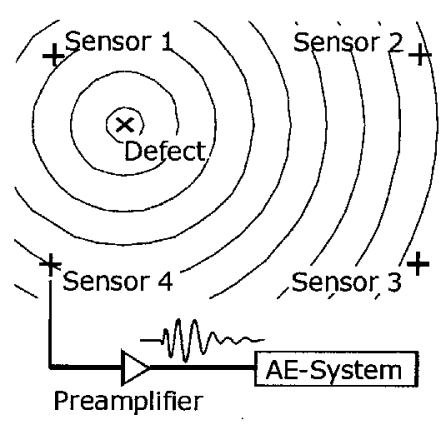

(a) Sound propagation.

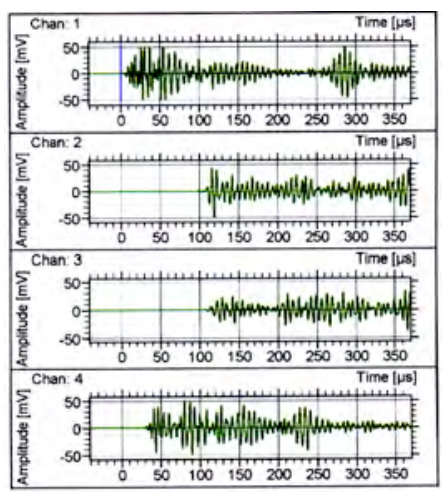

(b) Arrival time differences.

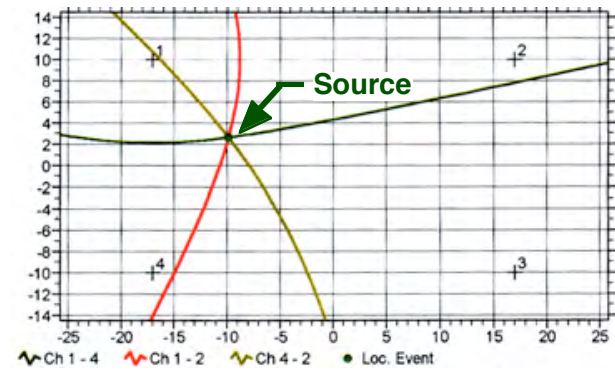

(c) Hyperbolae corresponding to measurements in (b) with intersection indicating source location..

Figure 4.27 Example of use of acoustic emission testing to locate a source.

Source: Acoustic Emission: Fundamentals-Equipment-Data Analysis, Vallen - Systeme GmbH, Munich, Germany, 2007 (http://www.vallen.de/ae/index.htm). 
conventional techniques, and since there is a marked increase in activity when a crack or discontinuity approaches critical size, it can warn of impending instability and catastrophic conditions. Disadvantages of acoustic emission are that it requires considerable technical experience to conduct the test and interpret results, background noise can interfere with signals to affect the sensitivity, commercial acoustic emission systems (without calibration data) only qualitatively estimate how much damage is in the material and how long the component will last, and a material may not emit until the stress level exceeds a prior applied level (i.e., Kaiser effect).

\subsubsection{Infrared and Thermal Testing (IR)}

Themography involves the use of an infrared imaging and measurement camera to visualize and measure thermal energy emitted from an object. All objects emit infrared energy as a function of their temperature due to vibration and rotation of atoms and molecules. Thermal, or infrared energy, is light that is not visible because its wavelength is too long to be detected by the human eye. Figure 4.28 provides an example of an infrared camera and where infrared falls in the electromagnetic spectrum. Thermal imaging systems detect changes in thermal resistance that arise from heat flow through components and are sensitive to surface temperature differences of less than $0.1^{\circ} \mathrm{C}$ $(4.19,4.54)$.

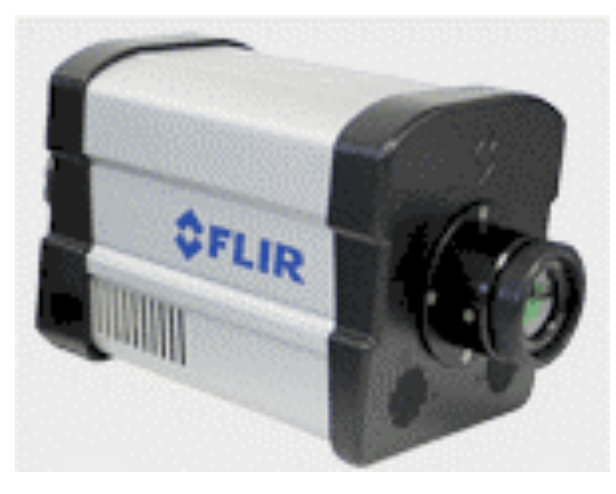

(a) Mega-pixel camera.

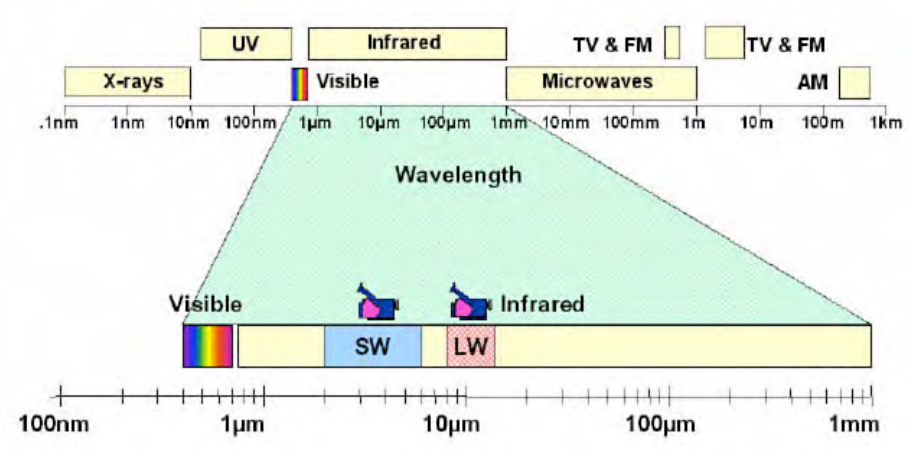

(b) Electromagnetic spectrum.

Figure 4.28 Infrared camera example and electromagnetic spectrum showing infrared wavelength.

Source: (a) ThermoVision SC Researcher, Flir Systems, Boston, Massachusetts, 2007 (http://www.flirthermography.com/cameras/camera/1110).

(b) IR Thermography Primer, Infrared Training Center, Boston, Massachusetts, 2007 (http://www.infraredtraining.com/ir_primer.asp).

Thermography can be applied in any situation where a problem or condition can reveal itself by means of thermal difference. Thermographic inspection methods are applied to measure a variety of material characteristics and conditions. In the flaw detection mode they are used for detection of interfaces and/or variation of properties of interfaces within layered systems. The test object must be thermally conductive and reasonably uniform in color and texture. The procedure involves inputting a pulse of thermal energy that is diffused within the test object according to thermal conductivity, thermal mass, inherent temperature differentials, and time of observation. The thermal state of the test object is monitored by a thermographic scanner camera that has infrared energy spectrum detection capability. Interpretation of results is done through visual monitoring of the relative surface temperature as a function of time and relating the time-dependent temperature differences to the internal condition of the test object. Irregularities in temperature contours can be related to defects as flaws or irregularities that affect the amount of heat conduction in their vicinity. Results are recorded as a function of time and the process is relatively rapid. Specialized equipment is required and since the method is a volume inspection process, resolution is lost near the edges and at locations of nonuniform geometry change. Figure 4.29 presents an application of thermography to monitor the mechanical damage processes during fatigue of a reactor pressure vessel steel. Some other applications of infrared thermography include: electrical systems (e.g., electrical motor inspections and substation inspections of transformers and switchgear), building envelopes and structures (e.g., identify moisture contamination, locate missing or damaged insulation, and assessments of heat loss in plants), roofing systems (e.g., detection of leaks and water damaged areas), mechanical systems (e.g., detect thermal patterns of boiler tubes and mechanical bearing inspections), petrochemical plants (e.g., evaluate process line insulation loss and furnace refractory inspections), and 


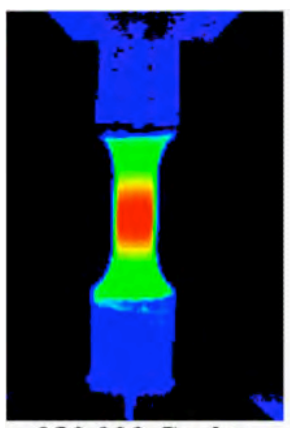

280,000 Cycles

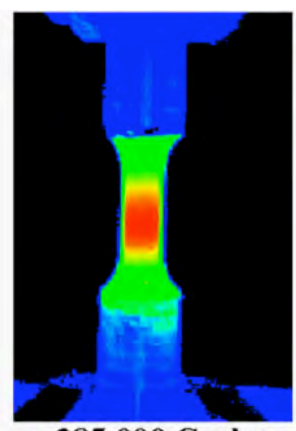

285,000 Cycles

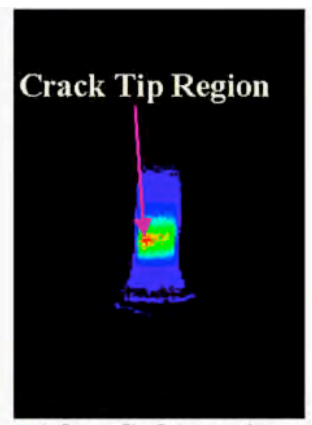

After Subtraction

Figure 4.29 Infrared images of reactor pressure vessel steel specimen subjected to high-cycle fatigue testing at $1,000 \mathrm{~Hz}$ with $\mathrm{S}_{\max }=600 \mathrm{MPa}$ and $\mathrm{R}=0.2$ (subtraction of temperature distribution at 280,000 cycles from that at 285,000 cycles indicates occurrence of cracking).

Source: B. Yang, P.K. Liaw, H. Wang, J.Y. Huang, R.C. Kuo, and J.G. Huang, "Thermography: A New Nondestructive Evaluation Method in Fatigue Damage," Journal of Minerals, Metals \& Materials Society, 8 pp., January 2003 (http:// www.tms.org/pubs/journals/JOM/0301/Yang/Yang-0301.html).

steam turbine and hydroelectric generators (e.g., locate inter-laminar faults in stator cores and effectiveness of stator core repairs) (4.55). Figure 4.30 presents additional examples of application of infrared thermography.

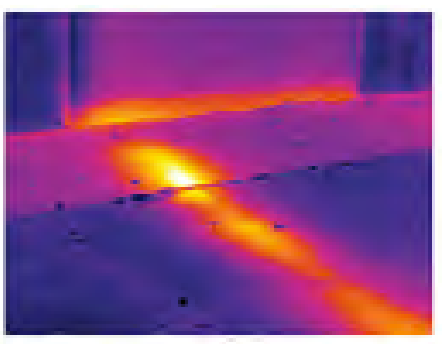

Steam leak 1.2 meters below ground

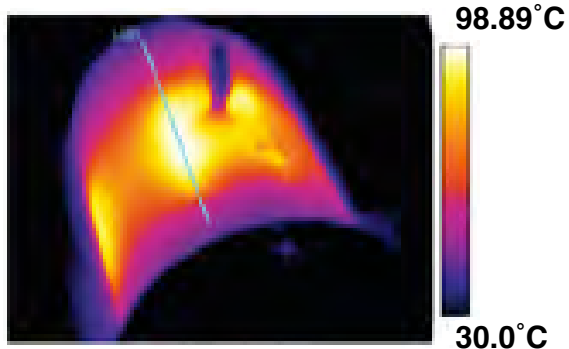

Initiation of motor winding failure

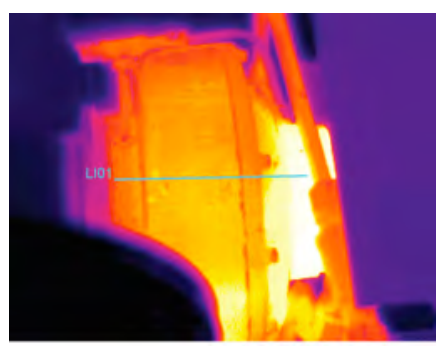

Initiation of bearing failure on a compressor motor

Figure 4.30 Example applications of infrared thermography.

Source: Infrared Thermography Fact Sheet, Energy Services, Western Area Power Administration, U.S. Department of Energy, Lakewood, Colorado, September 2005

(http://www.wapa.gov/es/pubs/fctsheet/default.htm).

Thermal inspection becomes less effective in the detection of subsurface flaws as the thickness of the object increases. Pulse thermography techniques have been developed that can perform inspections through the thickness of test objects. Pulse thermography is based on generation of a defined heat flow in the component to be inspected. The process basically entails providing heat through a high-intensity thermal pulse or step heating with the duration of the pulse varying approximately from a few milliseconds (5 to $15 \mathrm{~ms}$ using flashes) to several seconds (using lamps) depending on the thermophysical properties of both the specimen and the flaw. The specimen is heated from one side while thermal data are collected from the same side (i.e., reflection mode) or from the opposite side (i.e., transmission mode). Reflection is used for inspecting defects closer to the heated surface while transmission is preferred for detecting defects closer to the non-heated surface (4.56). Generally the resolution is higher in the reflection mode and this mode is easier to deploy since both sides of the specimen do not have to be accessible. Although deeper defects are detected in the transmission mode, depth information is lost since thermal waves will travel the same distance whether their strength is reduced by the presence of a defect or not. Defective zones will appear at higher or lower temperature with respect to non-defective zones on the surface depending on the thermal properties of both the defect and the material. Infrared images of the material surface are monitored using an infrared thermal imager and recorded at regular time intervals using a video recording system. Digitized image processing can be used to enhance the images received. Figure 4.31 presents an example of a transient (pulse thermography) system. 


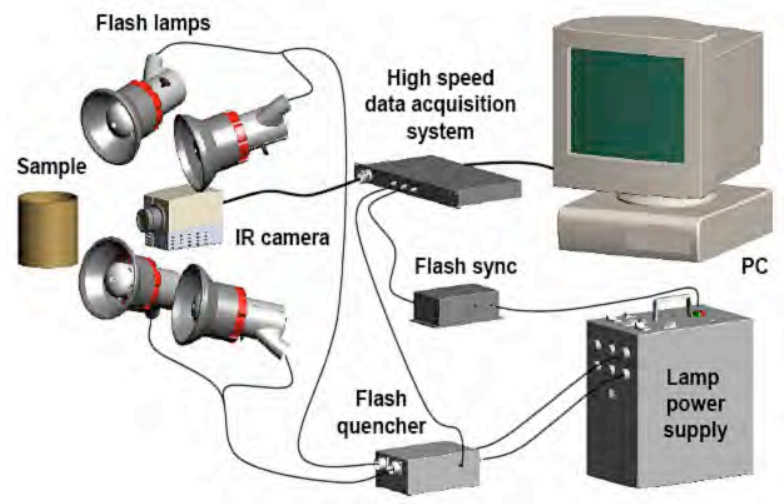

Figure 4.31 Example of infrared thermography transient flash system.

Source: H.I. Ringermacher, D.R. Howard, and B. Knight, "Thermal Imaging at General Electric," Quantitative Nondestructive Evaluation, AIP Conference Proceedings Volume 520, American Institute of Physics, pp. 523-528, Brunswick, Maine, July 31 - August 5, 2005.

In lock-in thermography energy is delivered to the specimen's surface in the form of periodic thermal waves and several applications must be made to cover the entire specimen thickness (4.56). A high frequency is used for the first application to address shallow defects and then the frequency is progressively increased until the entire thickness is covered or the equipment's range of selectable frequencies is utilized. A permanent regime in which no transient effect is present needs to be attained for each measurement. Table 4.10 provides a comparison of pulsed thermography and lock-in thermography.

Table 4.10 Characteristics of pulsed and lock-in thermography.

\begin{tabular}{|l|l|l|}
\hline & \multicolumn{1}{|c|}{ Pulsed thermography } & \multicolumn{1}{c|}{ Lock-in thermography } \\
\hline \hline Heat source & Heat pulse & Periodic thermal waves \\
\hline Regime & Transitory & Permanent \\
\hline Advantages & $\begin{array}{l}\text { - Fast } \\
\text { - A single experience launches a } \\
\text { series of thermal waves at several } \\
\text { frequencies }\end{array}$ & $\begin{array}{l}\text { - Little impact of non-uniform heating, } \\
\text { environmental reflections, emissivity } \\
\text { variations, and non-planar surfaces } \\
\text { - Low power thermal waves } \\
\text { - Depth inversion is straightforward }\end{array}$ \\
\hline Disadvantages & $\begin{array}{l}\text { - Inversion techniques are complex } \\
\text { - Affected by non-uniform heating }\end{array}$ & $\begin{array}{l}\text { - Requires a test for every inspected depth } \\
\text { - Slow: a permanent regime has to be reached }\end{array}$ \\
\hline
\end{tabular}

Source: I.C. Clémente, "Quantitative Subsurface Defect Evaluation by Pulsed Phase Thermography: Depth Retrieval with the Phase," Doctoral Thesis, Université Laval, Québec, Canada, October 2005 (http://theses.ulaval.ca/2005/23016/23016.html).

\subsubsection{Corrosion Monitoring}

Electrochemical corrosion monitoring techniques are available to make measurements directly related to corrosion rate rather than indirectly in terms of the flaws produced by corrosion. Potential surveys, linear polarization, A.C. impedance, zero resistance ammetry, electrochemical noise, and electrochemical impedance spectroscopy are techniques that have been utilized. Electrochemical potential measurements provide a basic indication of the thermodynamic corrosion status by using a standard half-cell (e.g., copper-copper sulfate) to locate anodic portions of a structure (i.e., potential gradients indicate possibility of corrosion). The more negative the value of the standard half-cell potential, the greater the tendency of the metal to lose its electrons (i.e., corrode). Corrosion potential measurements on their own do not provide information on the rate of corrosion. The linear polarization resistance method impresses D.C. current from a counter electrode onto the working electrode (e.g., steel structure) to change the measured potential difference by a known amount with the working electrode being polarized. An electronic meter measures the potential difference between the reference electrode and the working electrode. Measurements 
as a function of D.C. voltage applied across the cell provide an indirect measure of the corrosion current. The polarization resistance is the ratio of applied potential and the resulting current response with the resistance inversely related to the uniform corrosion rate (4.57). The A.C. impedance-polarizing technique utilizes an alternating applied voltage with the data analyzed as a function of frequency. The A.C. technique provides polarization resistance as well as information on polarization mechanisms at the anode and cathode which is important for interpretation of the A.C. impedance data. The technique requires rather sophisticated equipment (e.g., A.C. frequency generator and analyzer system) and the Tafel slopes must be known to convert A.C. impedance data into corrosion rate information (4.58). Each of these methods requires contact with the part of the structure monitored and, where corrosion rates are provided, the rates are only since initiation of monitoring after equipment installation. In the zero resistance ammetry technique a macrocell current is measured between two corrosion sensor elements. This is a useful technique for measuring galvanic current flow between different materials or different microstructures of the same material (4.59). Electrochemical noise refers to the naturally occurring fluctuations in corrosion potential and corrosion current flow (4.60). Electrochemical noise monitoring can be subdivided into electrochemical potential noise and electrochemical current measurements and has been used to distinguish between generalized and localized attack. The combination of potential and current noise measurements has been utilized to estimate corrosion rates. Electrochemical impedance spectroscopy provides a means to measure corrosion rates (4.61). In order to make an electrochemical impedance spectroscopy measurement a small amplitude signal, usually a voltage between 5 and $50 \mathrm{mv}$, is applied to a specimen over a range of frequencies of $0.001 \mathrm{~Hz}$ to $100,000 \mathrm{~Hz}$. In order to access the charge transfer resistance or polarization resistance that is proportional to the corrosion rate at the monitored interface the electrochemical impedance spectroscopy results have to be interpreted with the help of a model of the interface. By fitting the data it is possible to obtain a set of parameters that can be correlated with the condition of a coating and the corrosion of the steel substrate (4.62). Additional information on the method was provided previously in Section 3.2.7.

Corrosion under insulation is a special concern to an inspection program as failures can occur as a result of localized corrosion and not general wasting over a large area. The corrosion generally results from ingress of a corrosive agent such as water into the insulation which acts like a sponge to retain the water in contact with the metal surface. The problem affects carbon steels and 300 series stainless steels (4.63). With carbon steels it manifests as generalized or localized wall loss, while in stainless steel pipes it often occurs as pitting and stress-induced corrosion cracking. A number of methods have been utilized to inspect for corrosion under insulation: profile radiography, ultrasonic thickness measurements, insulation removal, infrared, and neutron backscatter (4.63). Profile radiography is utilized to calculate the remaining wall thickness of piping with each measurement looking at relatively small areas. The method works best for piping less than 254-mm diameter and it will not detect corrosion-induced stress corrosion cracking on stainless steels. X-ray digital fluoroscopy can be used to provide an image of a pipe's outside diameter through insulation. Figure 4.32 provides examples of flash radiography and neutron backscatter equipment for external corrosion identification without the requirement for insulation removal.

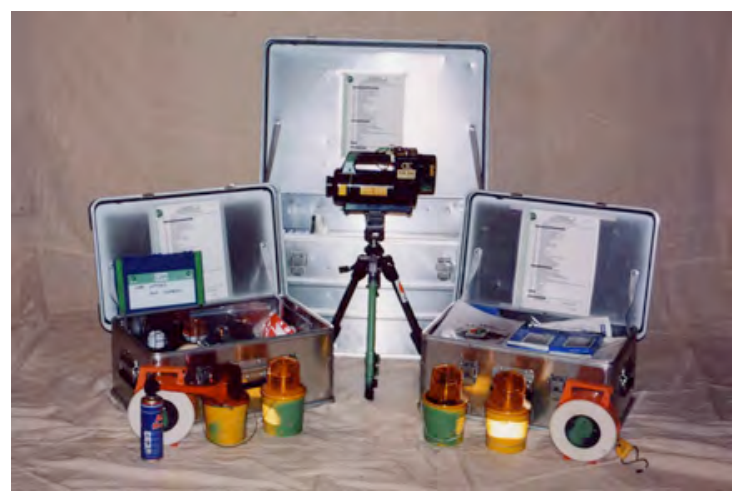

(a) Flash radiography system for pipe profiling to detect wall thinning due to corrosion.

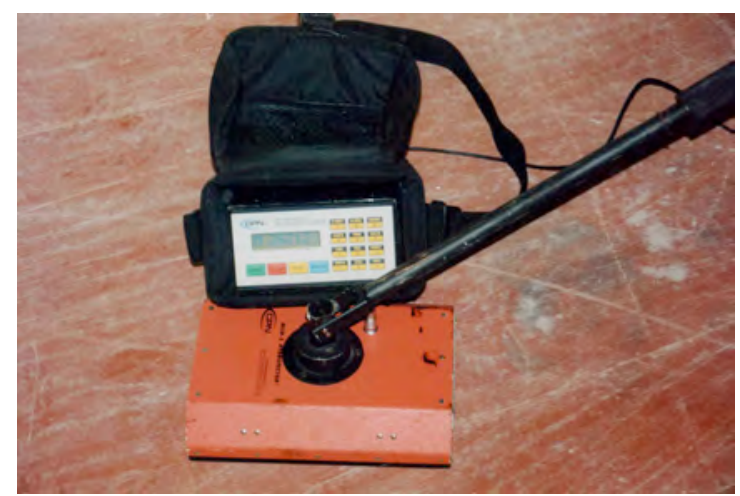

(b) Neutron backscatter system for moisture detection under insulation.

Figure 4.32 Examples of inspection methods for corrosion detection without requirement for insulation removal.

Source: Corrosion Under Insulation, CAN Group Inspection and Nondestructive Testing, London, United Kingdom, 2005 (http://www.cangroup.net/NDT/CUI.htm). 
Ultrasonic thickness measurements are effective but require removal of insulation so they are limited to a relatively small area and also will not detect corrosion-induced stress corrosion cracking on stainless steels. Insulation removal is the most effective approach to check the surface condition of a structure and can detect corrosion-induced stress corrosion cracking on stainless steel, but is the most expensive approach and may require supplemental eddy current or liquid penetrant inspection. Once a small section of insulation has been removed guided wave techniques (e.g., magnetostrictive sensors, electromagnetic acoustic transducers, and multimode guided waves) can be utilized to check for wall thinning (see Section 4.1.5) or acoustic emission transducers can be applied (see Section 4.1.7). Infrared or neutron backscatter can be used to detect damp areas of insulation and thus potential areas for corrosion occurrence. Pulsed eddy current also can be used for corrosion surveys of ferrous objects covered with insulation, asbestos, fireproofing, concrete, or coatings such as insulated vessels and columns, insulated storage tanks/spheres, and insulated pipelines (4.64). Figure 4.33 presents examples of application of pulsed eddy current testing.

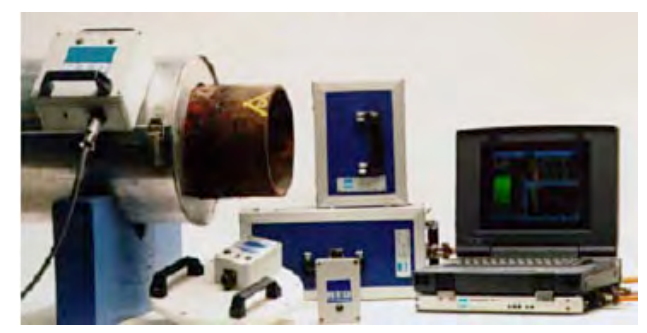

(a) Insulated piping system.

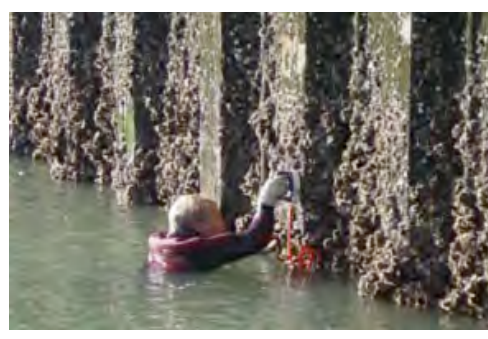

(b) Encrusted marine structure.

Figure 4.33 Pulsed eddy current testing of ferrous objects.

Source: Pulsed Eddy Current (PEC) - Insulated Component Monitoring, Tubi Tak Consulting Engineering \& Inspection Company, Tehran, Iran, 2006 (http://www.tubi-tak.com/pec.htm).

\subsubsection{Leak Testing (LT)}

Several techniques are used to detect leaks in pressure containment parts, pressure vessels, and structures. They include electronic listening devices, pressure gage measurements, liquid and gas penetrant techniques, and/or simple soap-bubble test. Leakage test requirements for containment pressure boundary components were discussed in Section 2.3.1.

\subsection{DESTRUCTIVE EXAMINATION}

Tests that alter the shape, form, size, or structure of the material being tested are considered destructive tests (4.65). These tests may be performed to determine mechanical, physical, chemical, thermal, or other properties of the material, or to examine the material for microstructural imperfections, voids, or inclusions. Destructive tests commonly used to determine mechanical properties of metallic materials involve tension, compression, ductility, shear, torsion, bend, creep, stress-relaxation, hardness, fatigue, or fracture testing. Test methods that require the removal and testing of representative portions of material from a component are also considered destructive tests when the affected component is rendered useless or unfit for future service.

\subsubsection{Tension Testing}

Tension testing involves the gradual application of increasing uniaxial elongation to a test specimen until failure occurs (4.66). Measurements obtained during tension testing can be used to develop stress-strain curves and to establish mechanical property values such as the modulus of elasticity, ultimate tensile elongation, ultimate tensile strength, yield strength, yield point, and reduction of area. Figure 4.34 presents a close up of a tension test and an example result.

Property values obtained from tension testing are generally used to determine conformance or nonconformance with material specifications. However, test results can also be used to compare the performance and properties of replicate specimens tested under a variety of exposure conditions or using different testing methods. Replicate specimen results can provide a basis for establishing limits on environmental exposure, working stresses, or operating temperatures. 


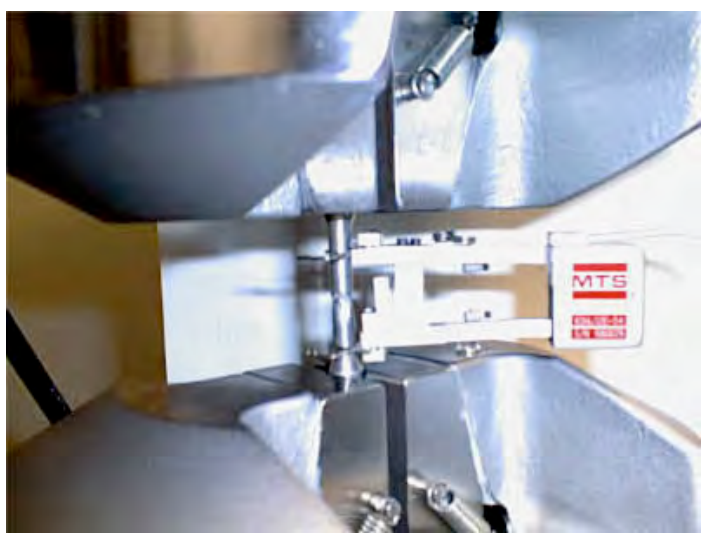

(a) Close up of uniaxial tensile test.

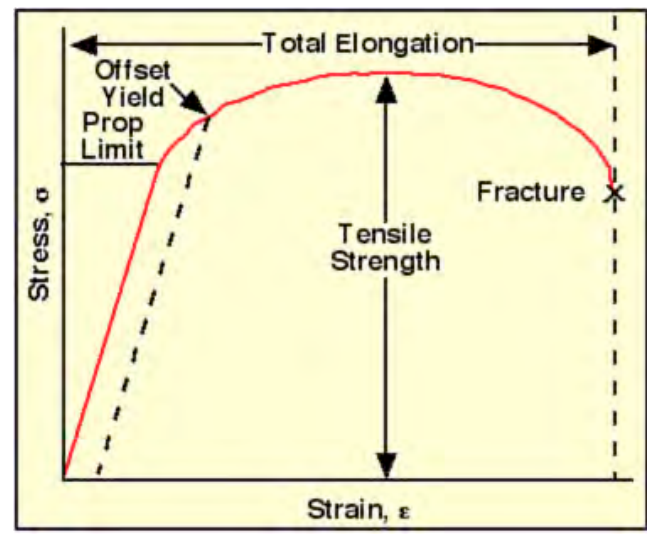

(b) Tensile stress-strain curve.

Figure 4.34 Tension testing.

Source: Mechanical Testing, Tensile Testing of Metals - ASTM E 8, Touchstone Research Laboratory, Triadelphia, West Virginia, 2004 (http://www.Trl.com/services/materialstesting/mechanical tensile 8.html).

\subsubsection{Hardness Testing}

Hardness is the resistance of a metal to plastic deformation, usually by indentation. Hardness testing is widely used for determining the relative quality of a metallic component and to establish the uniformity of its material properties. Common hardness test methods are Brinell, Vickers, Rockwell. Superficial, Knoop, and Scleroscope (4.67). The hardness measurement can be defined as macro-, micro-, or nano-scale according to the forces applied and the displacements obtained. The hardness test is relatively easy to perform, requires very little material or surface preparation, and usually causes minimal surface damage to the material or component. Testing usually involves an indention hardness tester that uses small diamond points or hardened round steel balls to produce permanent indentations or deformations in the surface of the material being tested. Hardness covers several properties: resistance to deformation, resistance to friction, and abrasion. A well-known correlation links hardness with tensile strength while resistance to deformation is dependent on modulus of elasticity (4.68). Figure 4.35 presents the test method principles for the Rockwell hardness test and an example of an automatic microhardness tester.

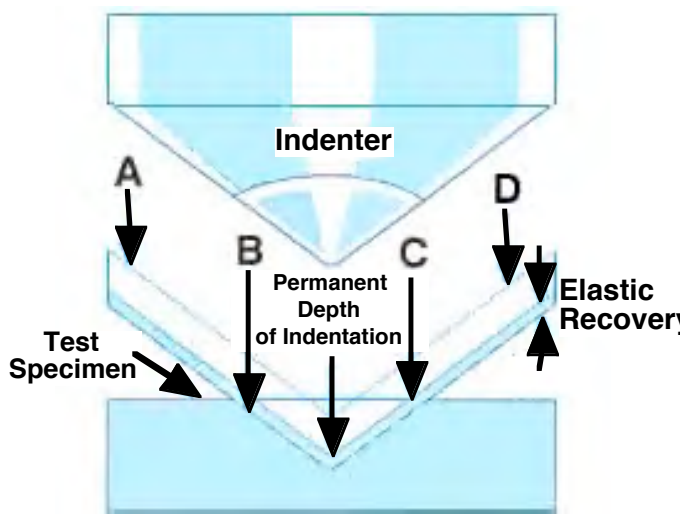

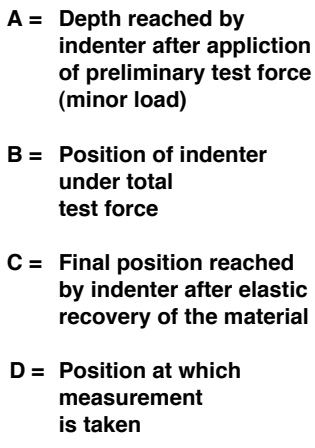
indenter after appliction of preliminary test force (minor load)

B = Position of indenter under total test force

$\mathrm{C}=$ Final position reached by indenter after elastic recovery of the material

$D=$ Position at which measurement is taken

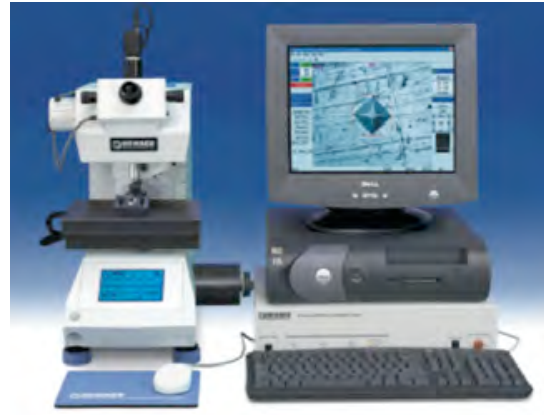

(b) Automatic microhardness tester.

(a) Rockwell test principles.

Figure 4.35 Hardness testing.

Source: (a) Hardness Testing - The Test Methodology Guide, Part 2, Newage Testing Instruments, Southhampton, Pennsylvania (http://www.hardnesstesters.com/hardness-method-3.htm).

(b) Newage Testing Instruments, Southhampton, Pennsylvania (http://www.hardnesstesters.com/microhardness-tester.htm). 


\subsubsection{Metallography}

Metallography is a branch of science that relates to the constitution and structure, and their relation to the properties of metals and alloys (4.69). Metallographic testing begins with the selection of material for examination. After selection and removal, the sample is firmly mounted for grinding and polishing (4.70). The polished surface is then examined visually using a microscope to reveal imperfections such as cracks, voids, or entrapped nonmetallics. Figure 4.36a presents an example of a reflected and transmitted light microscope for metallography. After microscopic examination the sample is treated with an etchant, such as a two-percent solution of nitric acid in alcohol, and reexamined. Etching methods are often used to delineate macrostructure and microstructure features, which provides information on phase distribution, grain size, solidification structure, and thermo-mechanical processing history. A photograph of the polished surface showing the observed microstructure is usually prepared to serve as a record of the examination. Figure $4.36 \mathrm{~b}$ presents an image of pitting and stress-corrosion cracking in a welded stainless steel tube. Metallography is probably the most useful destructive testing method available for identifying differences in material microstructure caused by exposure to high temperatures or severe environments.

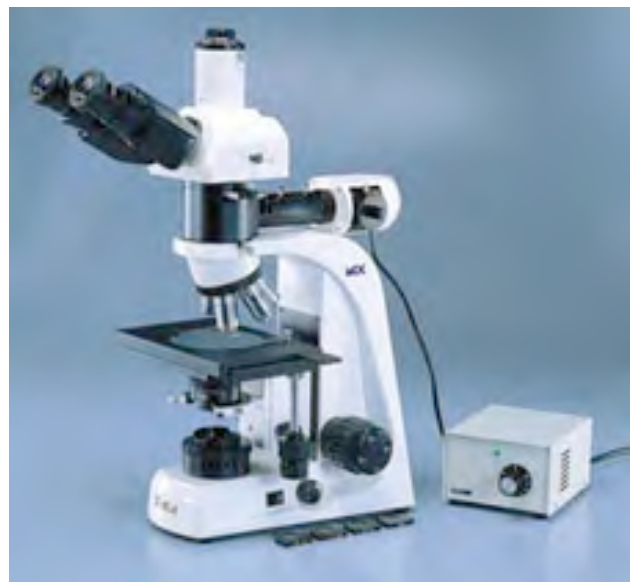

(a) Metallurgical reflected and transmitted light microscope.

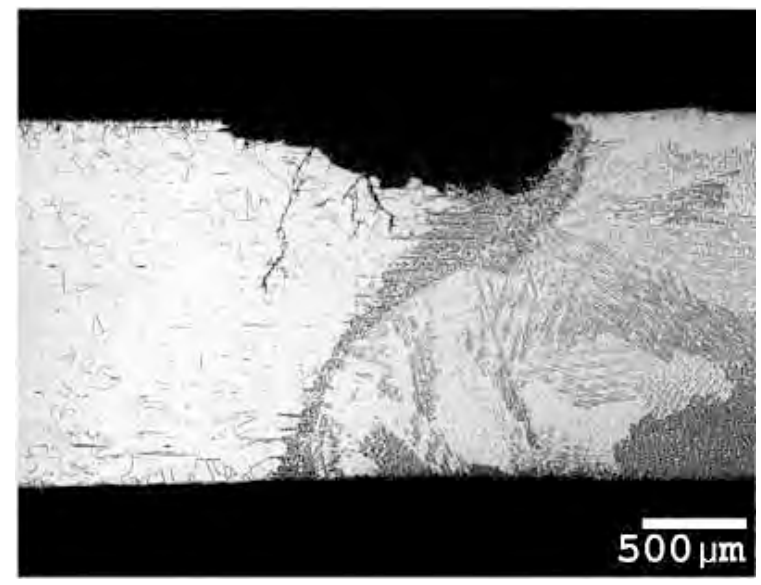

(b) Pitting and stress-corrosion cracking of a welded stainless steel tube.

Figure 4.36 Metallographic examination.

Source: (a) Microscope World, Carlsbad, California (http://microscopeworldprofessional.com/detail.aspx?ID=186).

(b) Handbook of Analytical Methods - Metallography, Materials Evaluation and Engineering, Inc., Plymouth, Minnesota, 2001 (http://www.hardnesstesters.com/microhardness-tester.htm).

\subsection{IN-SERVICE MONITORING}

In-service monitoring involves periodic examination of a containment pressure boundary component while it remains in service. This type of examination is different from the preservice inspection that is conducted before a containment is placed into service and the in-service inspections that are performed on a regular basis over the operating life of the plant. In-service monitoring generally involves repeated examination of a flawed component or suspect area using one or more nondestructive evaluation techniques. Data collection can be performed on a case-by-case basis at irregular intervals, or at prescribed times using a computer-controlled data acquisition system. Results obtained from individual in-service examinations can be used to determine the status of a degraded component and to accurately assess its current condition. Time-dependent results can be used to establish instantaneous or average degradation rates for use in estimating remaining service life. As an aging-management tool, results obtained from in-service monitoring can be used to guide the selection of appropriate examination techniques, specify testing methods, and establish the frequency of subsequent inspections. One of the most important potential benefits from in-service monitoring is the detection of undesirable changes in the operating conditions that can adversely affect the performance and useful life of containment pressure boundary components. Selection of nondestructive evaluation techniques for in-service monitoring requires an understanding of the capabilities and limitations of the various examination options, the types of data that are needed, the frequency and accuracy with which the data are to be collected, and the configuration of the component being monitored. 


\subsection{SUMMARY AND COMMENTARY}

In-service condition assessments play an important part in the aging management of nuclear power plant containment pressure boundary components by providing vital information for continued service evaluations and service life estimations. Knowledge gained can serve as a baseline for evaluating the safety significance of any damage that may be present and defining in-service inspection programs and maintenance strategies. Condition assessment results can also be used in estimating future performance and remaining service life.

Condition assessments involve detecting damage, classifying the types of damage that may be present, determining the root cause of the problem, and quantifying the extent of degradation that may have occurred. Degradation is considered to be any phenomenon that decreases the load-carrying capacity of a pressure-retaining component, limits its ability to contain a fluid medium, or reduces its service life. The four elements of an in-service condition assessment include:

Damage Detection - Damage detection is the first and most important step in the condition assessment process. Routine observation, general visual inspections, leakage-rate testing, and nondestructive evaluations are techniques frequently used to identify areas of the containment that have experienced degradation. However, damage such as wall thinning caused by corrosion can occur in inaccessible locations making detection difficult or impossible. Knowing where to inspect and what type of damage to anticipate often requires information about the design features of the containment and the materials used to construct its pressure-retaining components.

Damage Classification - Damage occurs when the microstructure of a material is modified by exposure to a severe environment or when the geometry of a component is altered. Determining whether material or physical damage has occurred often requires information about the service conditions to which the component was exposed and an understanding of the potential degradation mechanisms.

Root-Cause Determination - The root cause for component degradation can generally be linked to a design or construction problem, inappropriate material application, a base-metal flaw, or an excessively severe service condition. Determining what caused the degradation can help in identifying the type of damage that has occurred and defining appropriate actions to be taken to reduce or eliminate further deterioration.

Damage Measurement - One way to evaluate the significance of containment pressure boundary component degradation on structural capacity and leak-tight integrity is by comparing its preservice condition to its condition after degradation has occurred. Condition assessment accuracy depends on the availability of quantifiable evidence such as dimensions of corroded surface areas, depths of corrosion penetration, or changes in material properties that indicate the extent and magnitude of the degradation. Methods for quantifying component degradation involve either nondestructive evaluation or destructive testing. Results from these investigations provide a measure of the extent of degradation at the time the component was examined. Techniques for establishing time-dependent change such as corrosion and wear rates involve periodic examination or testing. In-service monitoring provides a way to measure time-dependent changes in component geometry or material properties and to detect undesirable changes in operating conditions that could affect useful service life.

Current requirements for in-service condition assessments and continued service evaluations of metal and concrete containment structures and components in nuclear power plants are provided in 10 CFR 50, Appendix J (4.1,4.71). According to these regulations, a general inspection of accessible containment surfaces must be performed prior to each Type A leakage-rate test and at two other refueling outages before the next Type A test, if the interval for the Type A test has been extended to 10 years (4.72), to uncover any evidence of structural deterioration that may affect either the containment structural integrity or leak tightness. When evidence of degradation is detected, corrective actions involving either repair, nondestructive evaluation, or testing must be taken before the containment can be returned to service. Safety-related structures in nuclear power plants present special challenges for development of acceptance criteria because of their massive size, limited accessibility in certain areas, stochastic nature of past and future loads, randomness in strength, uncertainty in material changes due to aging and possibly degradation, and qualitative nature of many nondestructive evaluation techniques.

Inspection requirements, acceptance standards, and evaluation criteria for use in determining the acceptability of degraded pressure boundary components for continued service are provided in Section XI, Division 1, 
Subsection IWE of the ASME Code (4.2,4.3). Components that are not damaged can be considered acceptable for continued service, but damaged components must be evaluated. Evaluations are performed to determine whether the damage is significant enough to adversely affect structural capacity, leak-tight integrity, or remaining service life. Components without significant damage are allowed to remain in service, but components with significant damage must be evaluated further to determine whether repairs, replacements, or retrofits are needed.

Table 4.11 expands on the approaches for nondestructive evaluation of containment pressure boundary damage (see Figure 4.5). Table 4.12 provides a summary and applicability of various techniques for nondestructive testing of welds.

Table 4.11 Approaches related to damage detection using nondestructive evaluation methods

\begin{tabular}{|c|c|}
\hline Issue & Commentary \\
\hline Flaw detection & $\begin{array}{l}\text { Flaw detection is one of the most important objectives of a nondestructive evaluation. Some of the } \\
\text { techniques that have been used to detect flaws include visual inspection, replication microscopy, } \\
\text { liquid penetrant, magnetic particle, magnetic field, eddy current, ultrasonic, radiography, X- } \\
\text { radiography computed tomography, neutron radiography, thermography, optical holography, } \\
\text { speckle metrology, digital image enhancement, electric current perturbation, magabsorption, and } \\
\text { acoustic emission. Selection of a suitable flaw detection technique depends on the flaw's } \\
\text { anticipated size, shape, orientation, and location, and whether it is expected to be a volumetric or } \\
\text { planar flaw. Practical and effective flaw detection often requires use of a variety of techniques that } \\
\text { yield complementary information }\end{array}$ \\
\hline Leak detection & $\begin{array}{l}\text { Leak detection is a nondestructive evaluation technique that can be used to detect special types of } \\
\text { flaws such as through-wall discontinuities or passages through which fluid flows or permeates. } \\
\text { These flaws allow liquids or gases to escape from pressurized (or into evacuated) components or } \\
\text { systems intended to contain these fluids. Leak testing is generally performed to locate a leak, } \\
\text { determine the leakage rate, or monitor for leakage. Leakage rate is the amount of fluid that flows } \\
\text { through a flaw per unit of time under a prescribed set of conditions. Containment-related leakage- } \\
\text { rate testing was discussed earlier. }\end{array}$ \\
\hline Metrology & $\begin{array}{l}\text { Metrology is the measurement of dimensions. It is a widely used nondestructive evaluation } \\
\text { technique for establishing the size and shape of objects including flaws and discontinuities. Tools } \\
\text { for dimensional measurements include conventional hand-held devices such as rulers, gages, and } \\
\text { micrometers as well as coordinate measuring machines and sophisticated systems based on laser } \\
\text { technology. Dimensions are an important part of a condition assessment because they provide an } \\
\text { accurate description of the size of an affected area or the characteristics of a detected flaw. Precise } \\
\text { flaw dimensions are vital to fracture mechanics evaluations. }\end{array}$ \\
\hline Location detection & $\begin{array}{l}\text { Location detection is occasionally used to verify that an assembly actually contains the required parts. } \\
\text { This technique is particularly useful when the parts are not accessible for visual examination. In } \\
\text { nuclear power plants, it could be necessary to use location detection techniques to verify the presence } \\
\text { or determine the location of liner anchors or attachments embedded in a concrete containment. Some } \\
\text { of the techniques that have been used for location detection include X-radiography, X-radiography } \\
\text { computed tomography, and neutron radiography (4.73). }\end{array}$ \\
\hline $\begin{array}{l}\text { Structure or } \\
\text { microstructure } \\
\text { characterization }\end{array}$ & $\begin{array}{l}\text { Field replication microscopy is a nondestructive evaluation technique that was developed for use in } \\
\text { characterizing the structure or microstructure of a material while it remains in service }(4.74) \text {. This } \\
\text { technique does not involve removal of material for laboratory examination but records and preserves } \\
\text { the topography of a metallographic specimen as a negative relief on a plastic film. Results from field } \\
\text { replication microscopy can be used to accurately characterize the microstructure of damaged material } \\
\text { and to help establish the root cause for the degradation. The results also may be used to determine } \\
\text { whether a crack resulted from creep, fatigue, or corrosion. Cracks caused by creep begin as small } \\
\text { holes or cavities at the grain boundaries and eventually link up to cause failure. Fatigue cracks are } \\
\text { generally singular defects that extend across many grain boundaries. Intergranular cracking tends to } \\
\text { follow the grain boundaries. Transgranular cracks such as those caused by stress corrosion extend } \\
\text { across grain boundaries forming an interconnected random pattern. }\end{array}$ \\
\hline $\begin{array}{l}\text { Estimation of } \\
\text { mechanical and } \\
\text { physical properties }\end{array}$ & $\begin{array}{l}\text { Material properties potentially can be estimated using results from nondestructive evaluation } \\
\text { techniques provided the results are influenced by material microstructure (4.73). Eddy current, } \\
\text { ultrasonic, X-radiography and neutron radiography, computed tomography, thermography, and } \\
\text { acoustic microscopy techniques are likely candidates because the results can be related to mechanical } \\
\text { or physical properties. However, these techniques are more suited for locating areas where the } \\
\text { microstructure is different by comparison. }\end{array}$ \\
\hline $\begin{array}{l}\text { Chemical } \\
\text { composition } \\
\text { determination }\end{array}$ & $\begin{array}{l}\text { The chemical composition of a metal can be determined using a sample of the metal obtained during } \\
\text { the pouring of the heat (heat analysis) or a sample of the finished product (product analysis). Chemical } \\
\text { requirements for heat and product analyses are provided in the material specification. }\end{array}$ \\
\hline
\end{tabular}


Table 4.11 (cont.) Approaches related to damage detection using nondestructive evaluation methods

\begin{tabular}{|c|c|}
\hline Issue & Commentary \\
\hline $\begin{array}{l}\text { Corrosion } \\
\text { characterization }\end{array}$ & 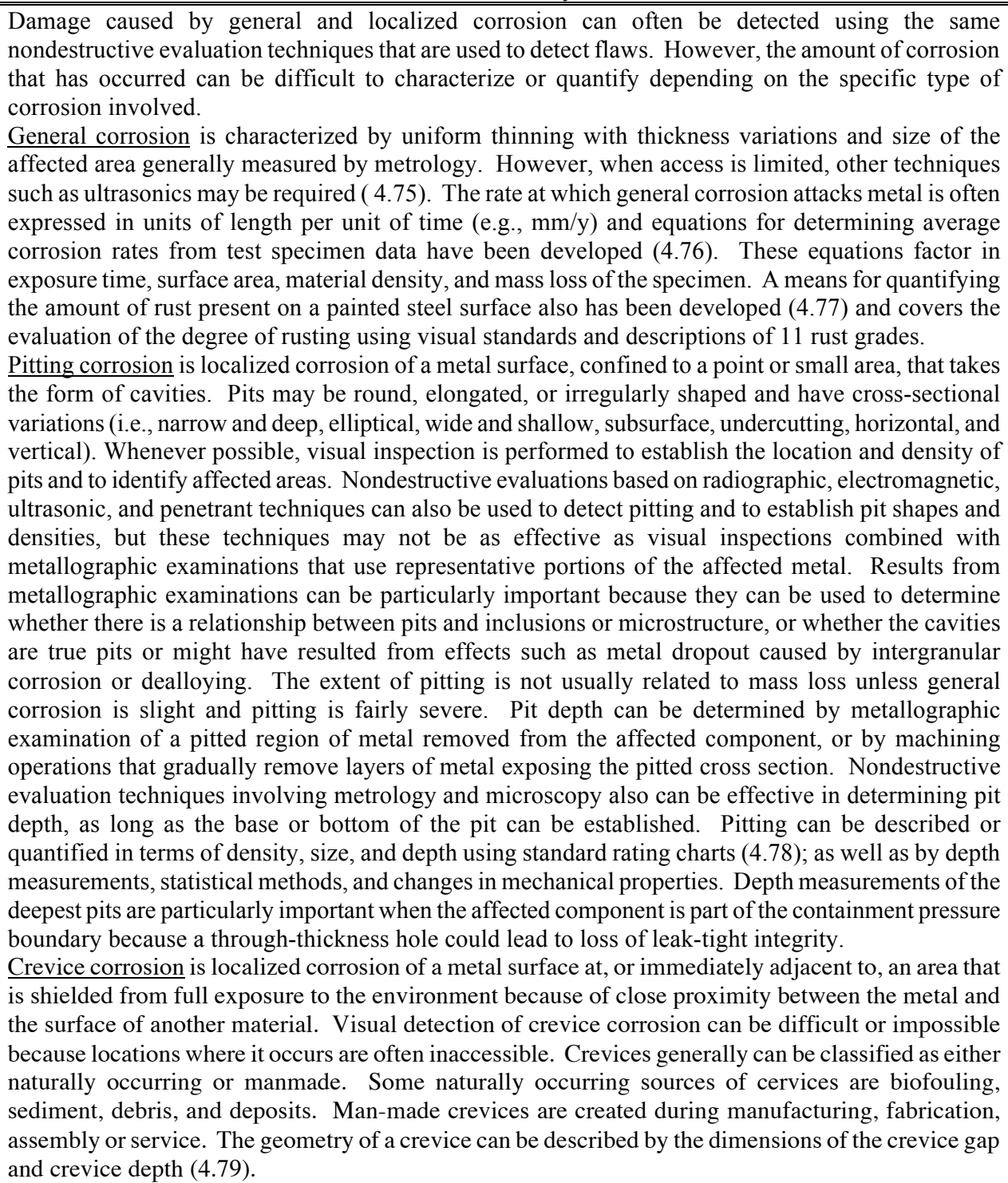 \\
\hline Signature ana & $\begin{array}{l}\text { The dynamic response of a component is called a signature. Accelerometers, acoustic and } \\
\text { displacement transducers, and strain gages can be used to establish the signature of a component } \\
\text { produced by a specified set of loading conditions. Analysis of the signature can be correlated with } \\
\text { machine noise, shock, vibrations, or structural instability such as buckling or cracking. Time- } \\
\text { dependent signature differences may indicate that the component's geometry has changed as a result of } \\
\text { cracking, fracture, or buckling or that its mass has changed due to corrosion or erosion. Changes in } \\
\text { elastic properties can also affect the signature because the structural stiffness of a component is a } \\
\text { function of the modulus of elasticity of the material. }\end{array}$ \\
\hline
\end{tabular}


Table 4.11 (cont.) Approaches related to damage detection using nondestructive evaluation methods

\begin{tabular}{|l|l|}
\hline \multicolumn{1}{|c|}{ Issue } & \multicolumn{1}{c|}{ Commentary } \\
\hline \hline $\begin{array}{l}\text { Stress-strain and } \\
\text { dynamic response } \\
\text { determination }\end{array}$ & $\begin{array}{l}\text { The response of a component to a specific set of loading conditions can be determined using sensing } \\
\text { techniques such as photoelastic coatings, brittle coatings, and strain gages or displacement transducers. } \\
\text { Resulting strain or displacement values combined with known applied stresses can be used to establish } \\
\text { the stress-strain characteristics of the material. Strain sensing and displacement measuring techniques } \\
\text { also can be used to characterize the dynamic response of a component subjected to shock, impact, or } \\
\text { vibration. } \\
\text { Residual stresses in metallic materials can be determined using nondestructive and "semi- } \\
\text { destructive" examination techniques. Near-surface residual stresses can be measured using } \\
\text { nondestructive evaluation techniques that involve either X-radiography diffraction or } \\
\text { electromagnetic methods (4.73). Residual stresses just below the surface can be measured using } \\
\text { the hole-drilling strain gage technique (4.80). This technique is often described as } \\
\text { "semi-destructive" because the damage that it causes is very localized and in many cases does not } \\
\text { significantly affect the usefulness of the component. }\end{array}$ \\
\hline
\end{tabular}

Source: D.J. Naus, C.B. Oland, and B.R. Ellingwood, "Final Report - Inspection of Aged/Degraded Containments Program,” ORNL/TM-2005/520, Oak Ridge National Laboratory, Oak Ridge, Tennessee, September 2005.

Table 4.12 Applicability and capability of various techniques for nondestructive testing of welds

\begin{tabular}{|c|c|c|c|c|c|c|c|}
\hline Technique & $\begin{array}{c}\text { Materials } \\
\text { applicable }\end{array}$ & $\begin{array}{l}\text { Detection } \\
\text { capability }\end{array}$ & $\begin{array}{l}\text { Depth } \\
\text { sizing }\end{array}$ & $\begin{array}{l}\text { Orientation } \\
\text { evaluation }\end{array}$ & $\begin{array}{l}\text { Access } \\
\text { problem }\end{array}$ & $\begin{array}{c}\text { Remote } \\
\text { detection }\end{array}$ & $\begin{array}{c}\text { Automated } \\
\text { detection }\end{array}$ \\
\hline $\begin{array}{c}\text { Liquid } \\
\text { penetrant }\end{array}$ & all & surface & no & no & yes & no & no \\
\hline Ultrasonic & all & volumetric & yes & yes & limited & yes & yes \\
\hline Radiography & all & volumetric & yes & yes & yes & no & yes \\
\hline $\begin{array}{l}\text { Magnetic } \\
\text { particle }\end{array}$ & magnetic & $\begin{array}{c}\text { surface, } \\
\text { near surface }\end{array}$ & no & no & yes & no & no \\
\hline $\begin{array}{c}\text { Magnetic flux } \\
\text { leakage }\end{array}$ & magnetic & $\begin{array}{c}\text { surface, } \\
\text { near surface }\end{array}$ & yes & yes & no & yes & yes \\
\hline Eddy current & conducting & $\begin{array}{c}\text { surface, } \\
\text { near surface }\end{array}$ & yes & yes & yes & yes & yes \\
\hline $\begin{array}{l}\text { Acoustic } \\
\text { emission }\end{array}$ & all & volumetric & yes & no & no & yes & yes \\
\hline Thermography & all & $\begin{array}{c}\text { surface, } \\
\text { near surface }\end{array}$ & no & yes & no & yes & yes \\
\hline Visual & all & surface & no & no & limited & yes & yes \\
\hline $\begin{array}{c}\text { x-ray } \\
\text { diffraction } \\
\end{array}$ & conducting & $\begin{array}{l}\text { surface } \\
\text { stresses }\end{array}$ & yes & no & yes & no & no \\
\hline Potential drop & conducting & surface & yes & no & yes & no & yes \\
\hline
\end{tabular}

Source: B.P.C. Rao, Advances in Non-Destructive Inspection and Evaluation of Welds, (http://www.geocities.com/raobpc/Welding.html).

Inspection of inaccessible portions of metallic pressure boundary components of NPP containments (e.g., fully embedded or inaccessible containment shell or liner portions, the sand pocket region in Mark I and II drywells, and portions of the shell obscured by obstacles such as platforms or floors) requires special attention. Embedded metallic portions of the containment pressure boundary may be subjected to corrosion resulting from ground water permeation through the concrete; a breakdown of the sealant at the concrete-containment shell interface that permits entry of corrosive fluids from spills, leakage, or condensation; or corrosion may occur in areas adjacent to floors where the gap contains a filler material that can retain fluids. Corrosion, should it occur, may challenge the containment structural integrity and, if through-wall, can provide a leak path to the outside environment. At present nondestructive evaluation techniques for use in determining the condition of the containment pressure boundary are time-consuming and costly because they tend to examine only a small area at a time. A nondestructive technique is required that can be used remotely to examine inaccessible regions of the containment metallic pressure boundary. Such a technique ideally should also be capable of performing global inspections so that determination of the overall 
condition of the containment metallic pressure boundary can be achieved in a cost- and performance-effective manner.

Conventional ultrasonic inspection techniques generate ultrasonic beams that tend to spread out as the beam is reflected from the component boundaries to limit the technique's inspection resolution relative to application to inaccessible regions of a containment metallic pressure. Also, mode conversion occurs where both longitudinal and shear waves are present after reflections from component boundaries to potentially influence the signal-to-noise ratio and make the defect echoes difficult to interpret. Furthermore, multiple echoes can be received from the plateconcrete interface and, unless the correct combination of frequency and wedge-input angle is selected, only the first of a series of defects will be detected, or defects may not be detectable at all from the opposite surface of a plate containing a surface defect. Lower frequency methods appear to be best for inspection of plates bounded by concrete because of reduced attenuation, but sensitivity to defects and defect resolution are reduced relative to higher frequency methods. Horizontal shear and Lamb wave modes can be used for inspection of steel containment structures as both are somewhat insensitive to the concrete boundary for specific velocity and frequency values. Therefore, techniques utilizing guided waves that interrogate the specimen cross section (e.g.., provide energy distribution across component cross section) appear to possess the greatest potential for addressing this problem (e.g., electromagnetic acoustic transducers, magnetostrictive sensors, and multimode guided wave methods).

\subsection{REFERENCES}

4.1 "Primary Reactor Containment Leakage Testing for Water-Cooled Power Reactors," Nuclear Regulatory Commission, Federal Register 60(186), pp. 49495-49505, September 26, 1995.

4.2 "Rules for Inservice Inspection of Nuclear Power Plant Components," ASME Boiler and Pressure Vessel Code, Section XI, Division 1, Subsection IWE, Requirements for Class MC and Metallic Liners of Class CC Components of Light-Water Cooled Power Plants, American Society of Mechanical Engineers, New York, New York, July 1, 2004.

4.3 R.F. Sammataro, "Updated ASME Code Rules for Inservice Inspection of Steel and Concrete Containments," Proceeding of the Fifth Workshop on Containment Integrity, NUREG/CP-0120, (SAND92-0173) U.S. Nuclear Regulatory Commission, Washington, D.C., July 1992.

4.4 Guidelines for Structural Condition Assessment of Existing Buildings, ASCE Standard SEI/ASCE 11-99, American Society of Civil Engineers, Reston, Virginia, 2000.

4.5 C.B. Oland and D.J. Naus, "Degradation Assessment Methodology for Application to Steel Containments and Liners of Reinforced Concrete Structures in Nuclear Power Plants," ORNLNRC/LTR-95/29, Oak Ridge National Laboratory, Oak Ridge, Tennessee, February 1996.

4.6 "Rules for Inservice Inspection of Nuclear Power Plant Components," ASME Boiler and Pressure Vessel Code, Section XI, Division 1, Subsection IWA, General Requirements American Society of Mechanical Engineers, New York, New York, July 1, 2004.

4.7 "Standard Terminology for Nondestructive Examinations," ASTM E 1316-07a, Annual Book of ASTM Standards, American Society for Testing and Materials, West Conshohocken, Pennsylvania, 2007.

4.8 ASME Boiler and Pressure Vessel Code, American Society of Mechanical Engineers, New York, New York, 2007.

4.9 D.S. Forsyth, H.T. Yolken, and G.A. Marzkanin, "Techsolutions 1 - A Brief Introduction to Nondestructive Testing," AMMTIAC Quarterly 1(2), Advanced Materials, Manufacturing and Testing Information Analysis Center, Rome, New York (http://ammtiac.alionscience.com/quarterly).

4.10 Nondestructive System Reliability Assessment, MIL-HDBK-1823, Department of Defense, Washington, D.C., February 28, 2007 (Draft).

4.11 W.D. Rummel and G.A. Matzkanin, Nondestructive Evaluation Capabilities Data Book, $3^{\text {rd }}$ Edition, AMMT-019, Nondestructive Testing Information Analysis Center, Austin, Texas, 1997. 
4.12 G.A. Matzkanin and H.T. Yolken, A Technology Assessment of Probability of Detection for Nondestructive Evaluation, ANNT-019, Nondestructive Testing Information Analysis Center, Austin, Texas, 2001.

4.13 B.P.C. Rao, "Visual Techniques in NDT," Encyclopedia of Materials, Science and Technology, pp. 60436046, Elsevier Science, Ltd., September 2001.

4.14 G.A. Metzkanin, "Techsolutions 2 - Selecting a Nondestructive Testing Method, Part II: Visual Inspection," AMMTIAC Quarterly 1(3), Advanced Materials, Manufacturing and Testing Information Analysis Center, Rome, New York (http://ammtiac.alionscience.com/quarterly).

4.15 M.T. Anderson, S.E. Cumblidge, and S.R. Doctor, "An Assessment of Remote Visual Testing System Capability for the Detection of Service Induced Cracking," Back to Basics, The American Society for Nondestructive Testing, Columbus, Ohio, September 2005 (http://asnt.org/publications/materialseval/basics/sep05basics/sep05basics.htm).

4.16 C.O. Stuart, "Underwater Coating Repair Cuts Nuclear Maintenance Costs," Power Engineering 97(7), pp. 31-34, July 1993.

4.17 J. Hansen and R.B. Peoples, "Using Eddy Current Testing to Solve Industrial Problems," Back to Basics, The American Society of Nondestructive Testing, Columbus, Ohio, June 2006 (http://asnt.org/publications/materialseval/basics/jun06basics/jun06basics.htm).

4.18 D. Hagemaier, "Eddy Current Depth of Penetration," Back to Basics, The American Society of Nondestructive Testing, Columbus, Ohio, October 2004 (http://asnt.org/publications/materialseval/basics/oct04basics/oct04basics.htm).

4.19 B.P.C. Rao, Advances in Non-Destructive Inspection and Evaluation of Welds, (http://www.geocities.com/raobpc/Welding.html).

4.20 Background on Pulsed Eddy Current, Center for Nondestructive Evaluation, Iowa State University, Ames, Iowa (http://www.ndt- ed.org/EducationResources/CommunityCollege/EddyCurrents/

AdvancedTechniques/background.htm).

4.21 M.A. Roberts and R. Scottini, "Pulsed Eddy Current in Corrosion Detection," Proceedings of $8^{\text {th }}$ European Conference on Nondestructive Testing 7(10), Barcelona, Spain, June 17-21, 2002.

4.22 M. Twomey, "MT and PT for Maintenance Inspections - A Review of Two Fundamental Nondestructive Testing Methods for Identifying Manufactured Defects and Service Defects in Plant Equipment Components," Maintenance Technology, Barrington, Illinois (http://www.mt-online.com/articles/0398ml.cfm).

4.23 B. Hull and V. John, Non-Destructive Testing, MacMillan Press Ltd., London, England, 1994.

4.24 "Ultrasonic Testing Examination," NRC Inspection Manual, Inspection Procedure 57080, U.S. Nuclear Regulatory Commission, Washington, D.C., March 9, 1999.

4.25 Wavelength and Detection, Iowa State University, Ames, Iowa (http://www.ndted.org/EducationResources/CommunityCollege/Ultrasonics/Physics/defectdetect.htm).

4.26 D.N. Alleyne and P. Cawley, "Optimizations of Lamb Wave Inspection Techniques, NDT\&E International 25, pp. 11-22, 1992.

4.27 T. Ghosh, T. Kundu, and P. Karpur, "Efficient Use of Lamb Modes for Detecting Defects in Large Plates," Ultrasonics 36, pp. 791-801, 1998.

4.28 J. Granillo and M. Moles, "Portable Phased Array Applications," Back to Basics, The American Society for Nondestructive Testing, Columbus, Ohio, April 2005 (www.asnt.org/publications/materialseval/basics/apr05basics/april05basics.htm). 
4.29 T. Nelligan and D. Kass, “An Introduction to Ultrasonic Phased Array Technology," Olympus Corporation, Tokyo, Japan (http://www.olympusndt.com/en/ultrasonics/intro-to-pa/).

4.30 M. Moles, N. Dubé, and S. Labbé, and E. Ginzel, "Review of Ultrasonic Phased Arrays for Pressure Vessel and Pipeline Weld Inspections," Journal of Pressure Vessel Technology 127, pp. 351-356, August 2005.

4.31 D.N. Alleyne and P. Cawley, "The Excitation of Lamb Waves in Pipes Using Dry-Coupled Piezoelectric Transducers," J. NDE 15, pp. 11-20, 1996.

4.32 Laser Ultrasonics, Intelligent Optical Systems, Torrance, California, 2007 (http://www.lasson.com/Lbu.htm).

4.33 EMAT Technology, Innerspec Technologies, Lynchburg, Virginia, 2006 (http://www.innerspec.com/site/emat.asp).

4.34 C. Kittel, "Physical Theory of Ferromagnetic Domains," Rev. Modern Phys 21, pp. 541-583, 1949.

4.35 J. Krautkramer and H. Krautkramer, Ultrasonic Testing of Materials, Chapter 8, $4^{\text {th }}$ Ed., Springer Verlag, New York, New York, 1990.

4.36 H. Kwun and K.A. Bartels, "Magnetostrictive Sensor Technology and Its Applications," Ultrasonics 36, pp. $171-178,1998$.

4.37 R.C. Williams, "Theory of Magnetostrictive Delay Lines for Pulse and Continuous Wave Transmission," IEEE Trans. on Ultrasonics Engineering UE-7, pp. 16-38, New York, New York, 1959.

4.38 F.T. Calkins, A.B. Flatau, and M.J. Dapino, “Overview of Magnetostrictive Sensor Technology," Journal of Intelligent Material Systems and Structures 18(2), February 15, 2007.

4.39 "Emerging Technology - Guided Wave Ultrasonics," Krautkramer NDTimes 2(2), Krautkramer Branson, Lewiston, Pennsylvania, Spring and Summer 1998.

4.40 J.L. Rose, "A Baseline and Vision of Ultrasonic Guided Wave Inspection Potential," Journal of Pressure Vessel Technology 124, pp. 273-282, American Society of Mechanical Engineers, New York, New York, August 2002.

4.41 J.L. Rose, S.P. Pelts, and M.J. Quarry, “A Comb Transducer Model for Guided Wave NDE,” Ultrasonics 36, Elsevier Publishers, New York, NY, pp. 163-169, 1998.

4.42 M.J. Quarry and J.L Rose, "Multimode Guided Wave Inspection of Piping Using Comb Transducers," Materials Evaluation 57(10), pp. 1089-1090, October 1999.

4.43 Y. Cho and J.L. Rose, "Guided Waves in a Water Loaded Hollow Cylinder," Nondestructive Testing \& Evaluation 12, pp. 323-339, 1996.

4.44 J.L. Rose, D. Jiao, and J. Spanner, Jr., "Ultrasonic Guided Wave NDE for Piping," Materials Evaluation 54(11), pp. 1310-1313, November 1996.

4.45 D.N. Alleyne and P. Cawley, "Long Range Propagation of Lamb Wave in Chemical Plant Pipework," Materials Evaluation 45(4), pp. 504-508, April 1997.

4.46 H. Kwun and K.A. Bartels, "Experimental Observation of Elastic-Wave Dispersion in Bounded Solids of Various Configurations," J. Acoustical Society of America 99(2), pp. 962-968, February 1996.

4.47 D.N. Alleyne and P. Cawley, "The Interaction of Lamb Waves With Defects," IEEE Transactions on Ultrasonics, Ferro Electrics, and Frequency Control 39(3), pp. 381-397, 1992. 
4.48 D.N. Alleyne and P. Cawley, “The Long-Range Detection of Corrosion in Pipes Using Lamb Waves," Review of Progress in Quantitative NDE, Plenum Press, New York, NY, pp. 2075-2080, 1995.

4.49 Time of Flight Diffraction, Mechanical Integrity, Inc., Humble, Texas, 2007 (http://www.mechanicalintegrityinc.com/pdf/2007services/TOFD.pdf).

4.50 F.H. Dijkstra, J.A. de Raad, and T. Bouma, "Time of Flight Diffraction and Acceptance Criteria: A Perfect Team," Back to Basics, The American Society for Nondestructive Testing, Columbus, Ohio, March 1998 (www.asnt.org/publications/materialseval/basics/mar98basics/mar98basics.htm).

4.51 Radiography at TVA (info), December 2002 (http://checkvalve.org/Presentations.htm).

4.52 H. Berger and R.L. Schulte, "Volumetric X-Ray Testing," Back to Basics, The American Society for Nondestructive Testing, Columbus, Ohio, September 2002

(http://asnt.org/publications/materialseval/basics/sep02basics/sep02basics.htm).

4.53 S. Yuyama, "Fundamental Aspects of Acoustic Emission Applications to the Problems Caused by Corrosion," Corrosion Monitoring in Industrial Plants Using Nondestructive Testing and Electrochemical Methods," ASTM STP 908 edited by G.C. Moran and P, Labine, pp. 43-74, American Society of Testing and Materials, West Conshohocken, Pennsylvania, 1986.

4.54 B. Yang, P.K. Liaw, H. Wang, J.Y. Huang, R.C. Kuo, and J.G. Huang, "Thermography: A New Nondestructive Evaluation Method in Fatigue Damage," Journal of Minerals, Metals \& Materials Society, pp. 8, January 2003 (http:// www.tms.org/pubs/journals/JOM/0301/Yang/Yang-0301.html).

4.55 IR Thermography Primer, Infrared Training Center, Boston, Massachusetts, 2007 (http://www.infraredtraining.com/ir_primer.asp).

4.56 I.C. Clémente, "Quantitative Subsurface Defect Evaluation by Pulsed Phase Thermography: Depth Retrieval with the Phase," Doctoral Thesis, Université Laval, Québec, Canada, October 2005 (http://theses.ulaval.ca/2005/23016/23016.html).

4.57 M. Stern and A.L. Geary, "Electrochemical Polarization," Journal of the Electrochemical Society 104(1), p. 56, January 1957.

4.58 "Volume 13 - Corrosion," ASM Handbook, ASM International, Materials Park, Ohio, 1992.

4.59 "Standard Practice for Calculation of Corrosion Rates and Related Information from Electrochemical Measurements," ASTM G 102-89, Annual Book of ASTM Standards, American Society for Testing and Materials, West Conshohocken, Pennsylvania, 2007.

4.60 Proceedings of the First International Symposium on Electrochemical Noise Measurements for Corrosion Applications, held May 15-16, 1994 in Montreal, Quebec, Canada, Electrochemical Noise Measurements for Corrosion Applications ASTM STP 1277, American Society for Testing and Materials, West Conshohocken, Pennsylvania, 1996.

4.61 Electrochemical Impedance Spectroscopy Theory: A Primer, Gamry Instruments, Westminster, Pennsylvania, July 26, 2007 (http://www.gamry.com/App_Notes/EIS_Primer.htm\#About_The Primer).

4.62 Electrochemical Impedance Spectroscopy, Corrosion Doctors Website maintained by Dr. P.R. Ruberg, Royal Military College of Canada, Kingston (http://www.corrosion_doctors.org/Electrochem/EIS.htm).

4.63 M. Twomey, "Inspection Techniques for Detecting Corrosion Under Insulation," Back to Basics, The American Society for Nondestructive Testing, Columbus, Ohio, February 1997 (www.asnt.org/publications/materialseval/basics/feb97basics/feb97basics.htm).

4.64 Pulsed Eddy Current (PEC) - Insulated Component Monitoring, Tubi Tak Consulting Engineering \& Inspection Company, Tehran, Iran, 2006 (http://www.tubi-tak.com/pec.htm). 
4.65 R.C. Anderson, Inspection of Metals, Volume II: Destructive Testing, ASM International, Materials Park, Ohio, 1988.

4.66 "Standard Test Methods for Tension Testing of Metallic Materials," ASTM E 8-04, Annual Book of ASTM Standards, American Society for Testing and Materials, West Conshohocken, Pennsylvania, 2007.

4.67 "Standard Hardness Conversion Tables for Metals Relationship Among Brinell Hardness, Vickers Hardness, Rockwell Hardness. Superficial Hardness, Knoop Hardness, and Scleroscope Hardness," ASTM E 140-07, Annual Book of ASTM Standards, American Society for Testing and Materials, West Conshohocken, Pennsylvania, 2007.

4.68 Material Hardness, Center for Advanced Life Cycle Engineering, University of Maryland, College Park, 2001 (http://www.calce.umd.edu/general/Facilities/Hardness_ad_htm).

4.69 "Standard Terminology Related to Metallography," ASTM E 7-03, Annual Book of ASTM Standards, American Society for Testing and Materials, West Conshohocken, Pennsylvania, 2007.

4.70 "Standard Practice for Preparation of Metallographic Specimens," ASTM E 3-01, Annual Book of ASTM Standards, American Society for Testing and Materials, West Conshohocken, Pennsylvania, 2007.

4.71 U.S. Nuclear Regulatory Commission, "Part 50 - Domestic Licensing of Production and Utilization Facilities,” pp. 634 - 784, in Code of Federal Regulations, 10 CFR, January 1, 1995.

4.72 U.S. Nuclear Regulatory Commission, Performance-based Containment Leak-Test Program, Regulatory Guide 1.163, Washington, D.C., September 1995.

4.73 "Volume 17 - Nondestructive Evaluation and Quality Control," ASM Handbook (formerly ninth edition, Metals Handbook), ASM International, Materials Park, Ohio, 1989.

4.74 "Standard Practice for Production and Evaluation of Field Metallographic Replicas," ASTM E 1351-01, Annual Book of ASTM Standards, American Society for Testing and Materials, West Conshohocken, Pennsylvania, 2007.

4.75 B.M. Gordon, "Corrosion Issues in the BWR and Their Mitigation for Plant Life Extension," Proceedings of the Topical Meeting on Nuclear Power Plant Life Extension, held in Snowbird, Utah, July 31-August 3 , 1988, pp. 180-187, American Nuclear Society, LaGrange Park, Illinois.

4.76 "Standard Practice for Preparing, Cleaning, and Evaluating Corrosion Test Specimens," ASTM G 1-03, Annual Book of ASTM Standards, American Society for Testing and Materials, West Conshohocken, Pennsylvania, 2007.

4.77 "Standard Test Method for Evaluating Degree of Rusting on Painted Steel Surfaces,”ASTM D 610-01, Annual Book of ASTM Standards, American Society for Testing and Materials, West Conshohocken, Pennsylvania, 2007.

4.78 "Standard Guide for Examination and Evaluation of Pitting Corrosion," ASTM G 46-94, Annual Book of ASTM Standards, American Society for Testing and Materials, West Conshohocken, Pennsylvania, 2007.

4.79 "Standard Guide for Crevice Corrosion Testing of Iron-Base and Nickel-Base Stainless Alloys in Seawater and Other Chloride-Containing Aqueous Environments," ASTM G 78-01, Annual Book of ASTM Standards, American Society for Testing and Materials, West Conshohocken, Pennsylvania, 2007.

4.80 "Standard Test Method for Determining Residual Stresses by the Hole-Drilling Strain-Gage Method," ASTM E 837-01, Annual Book of ASTM Standards, American Society for Testing and Materials, West Conshohocken, Pennsylvania, 2007. 


\section{REVIEW OF APPLICATIONS OF NONDESTRUCTIVE EVALUATION (NDE) TO THICK-SECTION REINFORCED CONCRETE STRUCTURES}

\subsection{BACKGROUND}

Inspection of nuclear power plant concrete structures presents challenges different from conventional civil engineering structures in that wall thicknesses can be in excess of one meter; the structures often have increased steel reinforcement density with more complex detailing; there can be a number of penetrations or cast-in-place items present; and accessibility may be limited due to the presence of liners and other components, harsh environments, or the structures may be located below ground. Noninvasive techniques for characterization, inspection, and monitoring of these structures to provide additional assurances of their continued structural integrity are desirable (e.g., identification of honeycombed areas, voids adjacent to the liner, and embedded items; inspection of thick-section concrete).

Several years ago the status of nondestructive evaluation methods for application to nuclear power plant concrete structures was assessed through a workshop and report prepared that identified NDE development priorities $(5.1,5.2)$. Table 5.1 provides a summary of needs developed at the workshop for nondestructive evaluation methods development with respect to the reinforced concrete that were classified as being either of high or medium benefit.

Table 5.1 Potential high and medium benefit needs for nondestructive evaluation of NPP concrete structures

\begin{tabular}{|c|c|}
\hline High benefit needs & Medium benefit needs \\
\hline $\begin{array}{l}\text { Quantification of capability for measuring } \\
\text { concrete thickness in sections }>1.0-\mathrm{m} \text { thick }\end{array}$ & $\begin{array}{l}\text { Enhanced ease and speed of application for measuring section thickness in } \\
\text { all structures }\end{array}$ \\
\hline \multirow{2}{*}{$\begin{array}{l}\text { Quantify existing performance capability for } \\
\text { mapping/sizing of steel reinforcement and } \\
\text { tendons (including identification of } \\
\text { reinforcement laps and couplers) with section } \\
\text { depth }\end{array}$} & $\begin{array}{l}\text { Measure section thickness with single-sided access and measure section } \\
\text { thickness in presence of congested steelwork with sensitivity of } \pm 5 \% \\
\text { section thickness }\end{array}$ \\
\hline & $\begin{array}{l}\text { Detect corrosion beyond first layer of rebar where there is only single-sided } \\
\text { access through measurement of loss of section }\end{array}$ \\
\hline $\begin{array}{l}\text { Quantify void detection threshold (and } \\
\text { inhomogeneities, e.g., honeycombing) in thick } \\
\text { sections (variables are size of voids and depth) }\end{array}$ & $\begin{array}{l}\text { Enhanced resolution to measure reinforcement diameter with sensitivity of } \\
\pm 10 \% \text { either in thick sections }(>1 \mathrm{~m} \text { ) or in presence of congested } \\
\text { reinforcement (individual reinforcement at spacings }<<150 \mathrm{~mm} \text { ) }\end{array}$ \\
\hline $\begin{array}{l}\text { Improve visual/optical scanning techniques for } \\
\text { mapping cracks over large surface areas and for } \\
\text { detecting surface deposits/visual symptoms of } \\
\text { flaws with sensitivity equivalent to visual } \\
\text { inspection }\end{array}$ & $\begin{array}{l}\text { Detect voids }>20 \mathrm{~mm} \text { diameter around penetrations and encast items (e.g., } \\
\text { biological shield, prestressed concrete reactor vessels, active process cells), } \\
\text { in areas of congested reinforcement/tendons, and behind liners (e.g., fuel } \\
\text { ponds, prestressed concrete reactor vessels, and containments) }\end{array}$ \\
\hline \multirow[t]{5}{*}{$\begin{array}{l}\text { Detection of voids }>20-\mathrm{mm} \text { diameter in } \\
\text { grouted tendon ducts (e.g., containments and } \\
\text { waste store roofs) }\end{array}$} & $\begin{array}{l}\text { Resolve multiple layers of reinforcement, identifying individual } \\
\text { reinforcement at spacings }<<150 \mathrm{~mm} \text { and depths }>30 \mathrm{~mm} \text { and measure } \\
\text { reinforcement diameter with sensitivity of } \pm 10 \%\end{array}$ \\
\hline & $\begin{array}{l}\text { Improve variable performance statistics for detecting large laminar flaws at } \\
>10-\mathrm{mm} \text { depth and }>100 \mathrm{~mm} \text { in any planar direction }\end{array}$ \\
\hline & $\begin{array}{l}\text { Improve variable performance statistics associated with depth measurement } \\
\text { of surface cracks. For detection and sizing (depth, width, and length) of } \\
\text { cracks normal to surface aiming at sensitivity of } \pm 10 \% \text { for crack widths } \\
>0.2 \mathrm{~mm}\end{array}$ \\
\hline & Detect delamination between prestressing tendons in containments \\
\hline & $\begin{array}{l}\text { Measurement of relative change and spatial variation in concrete } \\
\text { mechanical properties with time (i.e., detecting aging processes) with } \\
\text { sensitivity of } \pm 1 \%\end{array}$ \\
\hline
\end{tabular}

Source: Development Priorities for Non-Destructive Examination of Concrete Structures in Nuclear Plant, NEA/CSNI/R(98)6, Nuclear Energy Agency, Committee on Safety of Nuclear Installations, Issy-lesMoulineaux, France, November 2, 1998.

Workshop conclusions were that: although NDE techniques have been successfully used on a variety of reinforced and post-tensioned concrete structures, there is limited experience in their use to evaluate typical nuclear power plant safety-related structures having thick sections, steel liners, and access to only one side; there is general lack of confidence in the techniques because there is very little independent advice on their applicability, capability, accuracy, and reliability; no authoritative international guidance or standard for NDE of concrete structures was 
identified; NDE of concrete structures is often based on equipment developed for other materials and technologies such as applications to metallic materials or foundations; although quantification of the capabilities of NDE techniques is seen as a priority area for development, the industry lacks a standard for quantifying the NDE of nuclear safety-related concrete structures; and the high cost of developing software and equipment, with no guarantee of success, means that the nuclear industry is unlikely to consider this a priority area for future funding.

Since the time of the workshop (1997), there have been a number of studies conducted related to the development of nondestructive evaluation methods for reinforced concrete structures that will lead to NDE playing an increasingly important role related to managing the aging of nuclear power plant safety-related concrete structures [e.g., determination of as-built (or current) structural features, detection of flaws, and characterization and quantification of flaws]. Several of the needs identified in Table 5.1 have been addressed by these studies. Provided below are summaries of several studies that have either directly addressed nuclear power plant reinforced concrete structures or thick-section reinforced concrete test articles.

\subsection{REVIEW OF RESEARCH INVOLVING THICK-SECTION REINFORCED CONCRETE STRUCTURES}

\subsubsection{CONMOD Project}

The European Commission and a consortium of four parties [Barsebäck Kraft (Sweden), EDF (France), Force Technology (Denmark), and Scanscot Technology (Sweden)] with additional funding provided by the Swedish Nuclear Power Inspectorate (SKI) and Forsmark, OKG, and Ringhals nuclear power plants in Sweden initiated the three-year CONMOD Project in $2002(5.3,5.4)$. The overall objective of the CONMOD project was to find a practical means to determine the condition of a containment structure as well as how this condition can be expected to change with time under the influence of various loading conditions including aging. Figure 5.1 presents the framework for the CONMOD methodology.

\begin{tabular}{|c|c|c|c|}
\hline \multicolumn{2}{|c|}{ Step } & Description & Result \\
\hline 1 & $\begin{array}{l}\text { Inventoring, } \\
\text { survey and } \\
\text { initial analysis }\end{array}$ & $\begin{array}{l}\text { Inventoring and survey of existing documentations, such as, } \\
\text { Regulations and Safety analysis report } \\
\text { Calculations } \\
\text { Visual inspections } \\
\text { Service experience } \\
\text { Leak-tightness tests } \\
\text { Investigations } \\
\text { Construction methods and details } \\
\text { Generic knowledge and data. } \\
\text { Visual inspection. } \\
\text { Initial structural analysis based on nominal data from drawings etc. Sensitivity } \\
\text { studies of vital input parameters. }\end{array}$ & $\begin{array}{l}\text { Relevant events for different limit states (serviceability, ultimate, accidental) and } \\
\text { belonging load conditions and acceptance criterias are identified. } \\
\text { Critical areas and governing parameters with respect to leak-tightness and load } \\
\text { bearing capacity are identified, which in turn forms the basis for planning } \\
\text { inspections on site. }\end{array}$ \\
\hline 2 & $\begin{array}{l}\text { Testing and } \\
\text { examination }\end{array}$ & $\begin{array}{l}\text { Focused examinations based on the results in step } 1 \text { Examples of methods: } \\
\text { Non-destruictive testing } \\
\text { Material testing } \\
\text { Leak-tightness and structural } \\
\text { integration test }\end{array}$ & $\begin{array}{l}\text { The structural condition of the containment is determined. An evaluation is made } \\
\text { of the future condition with regard to any relevant ageing processes and other } \\
\text { factors, e.g. changes from design etc. }\end{array}$ \\
\hline 3 & $\begin{array}{l}\text { Detailed } \\
\text { evaluations } \\
\text { and analysis }\end{array}$ & $\begin{array}{l}\text { Evaluation of test results from step } 2 \text {. Investigations regarding the cause } \\
\text { (phenomena) and extent of identified deviations and their influence (effect) on } \\
\text { structural bebaviour. } \\
\text { If necessary, detailed structural analysis based on present, or estimated future, } \\
\text { strictural condition at chosen times. }\end{array}$ & $\begin{array}{l}\text { Deviations are categorised and limits set regarding tolerable size and position. } \\
\text { Ageing effects from construction to time of inspection are evaluated based on the } \\
\text { data relating to time-dependant factors. } \\
\text { The safery margins w.r.t. leak tightness and load bearing capacity ar given points } \\
\text { in time are determined. The remaining life-time of the containment is estimated. }\end{array}$ \\
\hline 4 & $\begin{array}{l}\text { Maintenance } \\
\text { plan }\end{array}$ & $\begin{array}{l}\text { Time intervals for future periodic inspections and execution of those actions that } \\
\text { might be required to enhance safery, minimise ageing effects or strengthen are } \\
\text { plamned on the basis of the results of the investigations made in step } 3 \text {. } \\
\text { Updated structural models can be used to verify these actions. }\end{array}$ & $\begin{array}{l}\text { On the basis of requirements w. st. safe operation of the plant an economically } \\
\text { optimal maintenance plan is provided. }\end{array}$ \\
\hline 5 & Follow-up & Periodic inspections are made in accordance with the maintenance plan & $\begin{array}{l}\text { Actual behaviour with time is checked against predicted behaviour, e.g. actual } \\
\text { ageing process and status. }\end{array}$ \\
\hline 6 & Actions & $\begin{array}{l}\text { Actions are put into effect at the planned times (where and if required). } \\
\text { The condition, performance and compatibility of maintenance, e.g. protection or } \\
\text { strengthening and possible secondary effects on the old concrete are checked. }\end{array}$ & Sufficient safety margins are achieved for the entire service life of the structure. \\
\hline
\end{tabular}

Figure 5.1 The CONMOD methodology.

Source: O. Jovall, J-A. Larsson, P. Shaw, J-P. Touret, and G. Karlberg, "Concrete Containment Modeling and Management, Conmod," Transactions of the $17^{\text {th }}$ International Conference on Structural Mechanics in Reactor Technology, Paper H04-4, Prague, Czech Republic, 17-22 August 2003.

\subsubsection{Introduction}

The CONMOD Project is a study developed in response to the desire to develop an improved approach to aging management of concrete structures that makes use of new technologies that have been developed (i.e., supplement 
traditional visual inspections and leak-rate tests). The purpose of CONMOD was to create a diagnostic method for evaluation of aging and degradation of concrete containments. This includes obtaining relevant knowledge about the current state and behavior of materials and structures; to locate, diagnose, and manage critical areas or damaged zones; to optimize the maintenance and repair; and to estimate the remaining safe lifetime of the containment.

Relevant aging management issues are considered to fall within three categories: as-built compliance with design, condition and quality of the concrete, and aging processes. In fulfilling the purpose of the project a means by which nondestructive evaluation techniques and finite-element analysis could be combined to provide a diagnostic tool to evaluate the conformity and condition of concrete containments was investigated. Examples of how nondestructive evaluation techniques and finite-element analysis can be combined include (5.3-5.5):

- Identification of critical parts of a structure for nondestructive evaluation including critical parameters,

- Updated structural analyses using input from nondestructive evaluations,

- Prediction of nondestructive responses for a known condition at a given time using finite-element method modeling techniques, and

- Prediction of the nondestructive evaluation responses using finite-element modeling techniques based on a known condition and how this will change due to aging processes.

The initial step is to develop background material including information on design detailing, construction methods, in-service history, and results from leak-rate testing. This information is utilized in conjunction with a structural analysis to find critical sections of a structure as well as identify critical parameters. An initial site investigation is then conducted using nondestructive and traditional (e.g., covermeter) evaluation methods to compare theoretical nondestructive evaluation responses with those measured to establish a general picture of the condition of the structure and its as-built compliance, and to evaluate the nondestructive evaluation methods with respect to capability and accuracy and, if necessary, apply alternative techniques. Site test results were compared with tests on mock-ups and with predicted theoretical responses using finite-element analysis techniques. The main site investigation was then planned with the techniques chosen and decisions made relative to where to test and what to measure. Inspections were carried out at a number of positions in parts of the structure that were representative of the structure as a whole, including parts that were found to have deviated from the normal. The objective of the main site investigation was to subdivide and classify the main parts of the structure in terms of normal and special responses. The normal and special responses may be observed globally and may be due to the effect of different construction techniques, or local environment and/or damage resulting from these factors. The NDE techniques were analyzed with the help of finite-element methods in order to interpret the responses in a way that would describe the geometry and condition of the structure at the time of test. Special investigations were conducted when responses from the structure were found to deviate from the normal established responses. Finite-element analysis was used to predict the changes in NDE responses that may occur with time, including effects of aging. At this time the condition of the structure has been established as well as the as-built conformity and aging processes. Structural analyses were also conducted to verify safety-enhancing actions (e.g., repairs) that have taken place (if any). Figure 5.2 presents the methodology for establishing a profile of a structure by combining NDE and finite-element analysis techniques.

The methodology was evaluated and refined through two demonstrator applications - Barsebäck 1 containment and MAEVA mock-up of a pressurized water reactor containment wall section.

\subsubsection{Demonstrator 1 - Barsebäck 1}

The Barsebäck Nuclear Power Plant has two boiling-water reactor units situated on the Swedish west coast. The containment consists of slip-formed prestressed concrete structures with a steel liner embedded in the concrete approximately $25 \mathrm{~cm}$ from the inner surface to protect it from mechanical damage. Barsebäck 1 construction initiated in 1970 with commercial operation starting in 1975. In 1999 the unit was decommissioned. The investigations at Barsebäck 1 containment took place over a three-year period and involved: (1) NDE site investigations, (2) material sampling, and (3) study of background materials (e.g., reports from prior investigations and data from construction). Information provided below primarily addresses the nondestructive evaluation part of the investigation.

Application of the CONMOD methodology resulted in a number of positions being chosen on the outer presrtressed concrete containment wall for nondestructive evaluation examinations and material sampling. Preliminary finiteelement analysis models of the structural behavior were performed to study the behavior of concrete containments under various loading conditions and thus identify critical sections. This information was then used to plan 


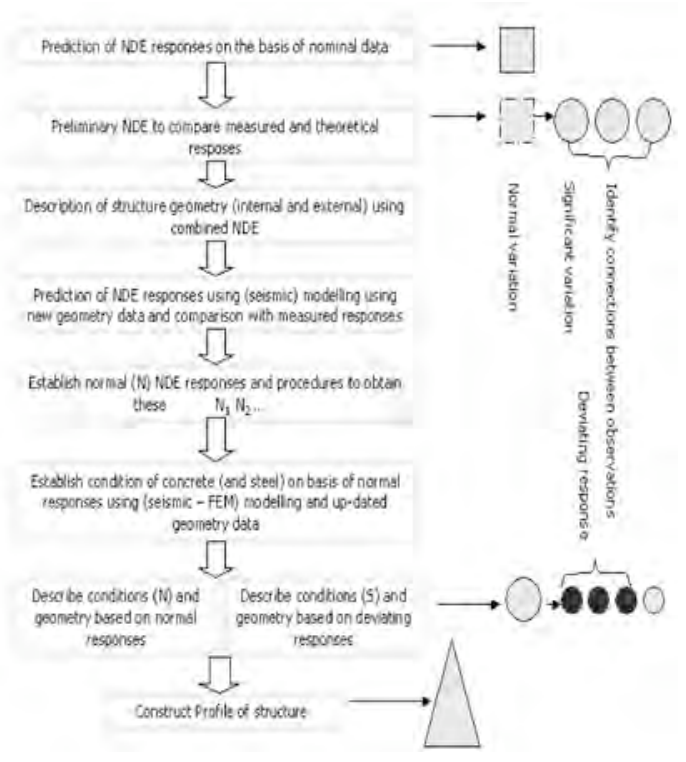

Figure 5.2 Methodology for establishing a profile of a structure by combining NDE and finite-element analysis techniques.

Source: CONMOD - Main Report, Coordinated by Force Technology, Brøndby, Sweden, Contract No: FIKS-CT 2001-00204, European Union Research for Reactor Safety, Fifth Framework Program, (http://cordis.europa.eu/fp5-euratom/src/lib_finalreports.htm).

nondestructive testing in order to obtain a more accurate description of the true nature of the structure at these points. Following this the new information was used as input into finite-element models to permit a more realistic prediction of behavior. Figure 5.3 presents the structural models used during the initial analyses and a section through the containment indicating positions chosen for nondestructive evaluation and material sampling. Inclusion of both slip-formed and fixed-form concrete areas, and consideration of the appearance of the concrete as well as the existence or absence of cracks also entered into the selection process. Initial finite-element analyses showed that the area around a pipe entry was critical with regard to stresses in the steel liner. The location selected for inspection was where the pipe passes through the lower cylindrical wall at the level of the equipment hatch (i.e., just above the

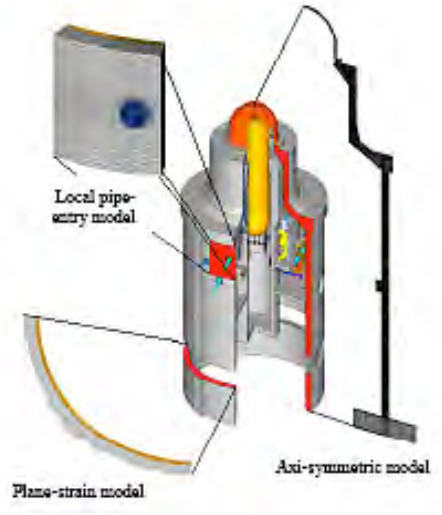

(a) Barsebäck containment structural models.

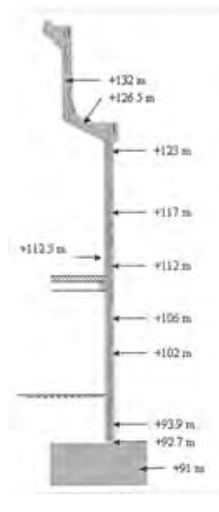

(b) Section through Barsebäck wall showing NDE and material sampling locations.

Figure 5.3 Barsebäck containment.

Source: CONMOD - Main Report, Coordinated by Force Technology, Brøndby, Sweden, Contract No: FIKS-CT 2001-00204, European Union Research for Reactor Safety, Fifth Framework Program, (http://cordis.europa.eu/fp5-euratom/src/lib_finalreports.htm). 
slab separating the condensation pool and compression space from the primary compartment). This pipe entry was chosen because it had easy access from both the outside and inside of the containment. The wall surrounding the pipe entry was also inspected. Table 5.2 provides a listing of inspections performed at the pipe entry and surrounding wall and resulting observations.

Table 5.2 List of inspections at Barsebäck 1

\begin{tabular}{|c|c|c|c|}
\hline Part of structure & $\begin{array}{l}\text { Inspection } \\
\text { type }\end{array}$ & Object of inspection & Inspection result \\
\hline $\begin{array}{l}\text { Pipe entry (concrete } \\
\text { above) }\end{array}$ & X-ray & Voids in concrete & $\begin{array}{l}\text { Positive (void } \sim 350 \times 200 \times 30 \\
\text { mm) }\end{array}$ \\
\hline \multirow[t]{6}{*}{ Surrounding wall } & \multirow[t]{6}{*}{$\mathrm{X}$-ray } & Wall thickness & $\begin{array}{l}\text { Wall thicker than design }(1150 \\
\text { to } 1180 \mathrm{vs} 1000 \mathrm{~mm})\end{array}$ \\
\hline & & Concrete condition (voids) & No voids observed \\
\hline & & Cable duct filler (voids) & No voids observed \\
\hline & & Cables inside ducts & No damage observed \\
\hline & & $\begin{array}{l}\text { Reinforcing details (size, position } \\
\text { (lateral), type) }\end{array}$ & As design \\
\hline & & Reinforcing condition & No damage observed \\
\hline & \multirow[t]{2}{*}{ Radar } & Reinforcing details (depth and position) & $\begin{array}{l}\text { Depth greater than design ( } 170 \\
\text { to } 200 \text { vs } 40 \mathrm{~mm} \text { ). } \\
\text { Positive as design. }\end{array}$ \\
\hline & & Cable duct details (depth and position) & $\begin{array}{l}\text { Depth greater than design }(270 \\
\text { to } 300 \text { vs } 160 \mathrm{~mm}) . \\
\text { Position as design. }\end{array}$ \\
\hline & \multirow[t]{3}{*}{ Impact echo } & Concrete thickness & Suspect $>$ design \\
\hline & & Concrete condition & $\begin{array}{l}\text { OK. Some near-surface } \\
\text { anomalies. }\end{array}$ \\
\hline & & Bond between liner and concrete & Yes \\
\hline & \multirow{4}{*}{$\begin{array}{l}\text { Multichannel } \\
\text { analysis of } \\
\text { surface waves }\end{array}$} & Concrete thickness & Suspect $>$ design \\
\hline & & Concrete condition & $\begin{array}{l}\text { Typical lower containment } \\
\text { wall }\end{array}$ \\
\hline & & Concrete wave velocities & $\begin{array}{l}\text { Typical lower containment } \\
\text { wall }\end{array}$ \\
\hline & & Bond between liner and concrete & Yes \\
\hline & Varisala probe & Concrete relative humidity & $\begin{array}{l}\text { Typical lower containment } \\
\text { wall }\end{array}$ \\
\hline & Cores & Concrete condition & $\begin{array}{l}\text { Typical lower containment } \\
\text { wall. Near-surface } \\
(<250 \mathrm{~mm}) \text { anomalies. }\end{array}$ \\
\hline \multirow[t]{4}{*}{ Pipe entry } & \multirow{3}{*}{$\begin{array}{l}\text { Peep hole and } \\
\text { fiberoptic }\end{array}$} & Suspect void in concrete above & Confirmed void \\
\hline & & Thickness of prestressed wall & $140 \mathrm{~mm}$ greater than design \\
\hline & & Condition of liner plate (visual) & OK \\
\hline & Varisala probe & Relative humidity in air-filled void & $82.1 \%$ \\
\hline
\end{tabular}

Source: CONMOD - Main Report, Coordinated by Force Technology, Brøndby, Sweden, Contract No: FIKS-CT 2001-00204, European Union Research for Reactor Safety, Fifth Framework Program, (http://cordis.europa.eu/fp5-euratom/src/lib_finalreports.htm).

The region above the pipe entry was suspected to contain voids in the injection grout. This was confirmed, however there was no apparent corrosion of the liner plate. Figure 5.4 presents the radiograph setup at the pipe entry, an image of the wall above the pipe entry showing a void, and fiberoptic views of the void. The wall thickness in this 


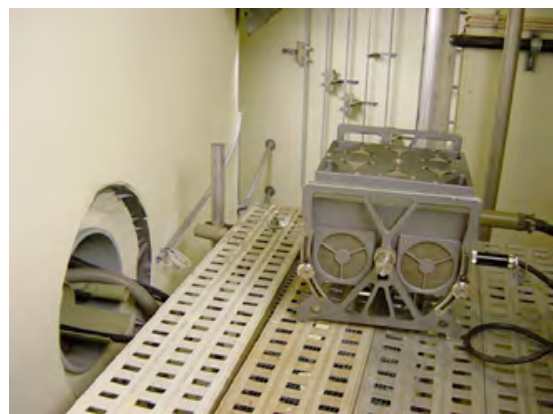

(a) Radiographic setup at pipe entry.

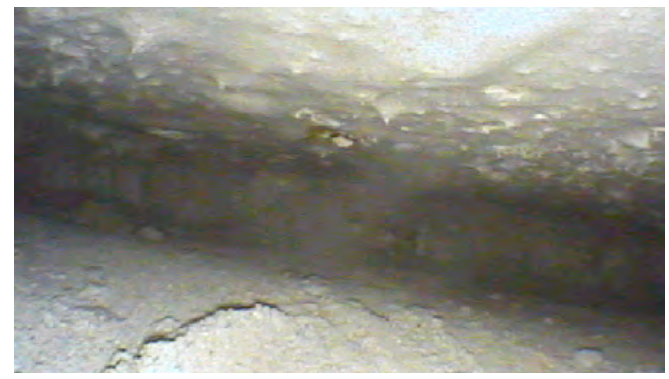

(c) Fiberoptic view of void.

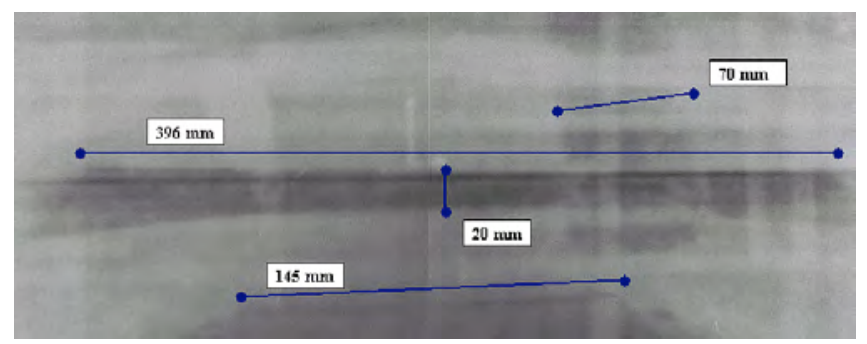

(b) Radiographic image of wall above pipe entry showing void.

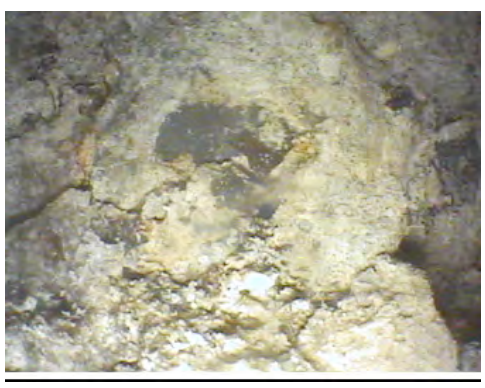

(d) Fiberoptic view of liner plate in void (center) with thin covering of material.

Figure 5.4 NDE and fiberoptic results.

Source: CONMOD - Main Report, Coordinated by Force Technology, Brøndby, Sweden, Contract No: FIKS-CT 2001-00204, European Union Research for Reactor Safety, Fifth Framework Program, (http://cordis.europa.eu/fp5-euratom/src/lib_finalreports.htm).

area was found to be considerably greater than the design value. The wall condition and thickness surrounding the pipe entry were found to be typical of the lower cylinder wall with the outer prestressed wall being $880-\mathrm{mm}$ thick, which is $140 \mathrm{~mm}$ greater than design. Anomalies were found in the outer $250 \mathrm{~mm}$ of the prestressed wall due to the slip-forming process, Figure 5.5, however, the reinforcing and cable ducts were not within this area. Also presented in Figure 5.5 are relative humidity and dynamic elastic modulus profiles. Both the dynamic modulus and relative humidity increase with distance from the containment outer wall. The relative humidity ranges from ambient at the surface to approximately $90 \%$ near the liner. Also the properties of the concrete varied significantly with depth due to the long-term strength gain of the concrete.

The data obtained were used to update the structural analyses (e.g., pipe entry and general wall section). For the pipe entry region several scenarios were considered: void in concrete, friction between steel liner and surrounding concrete, and (fictitious) loss of one prestressing tendon. Finite-element analysis indicated that the void did not reach a critical area identified in a previous analysis so the presence of the void did not produce a reduction in leaktight capacity of the containment. The void was considered mainly as an aging problem with a possible risk of corrosion if the plant was to continue operation. If the coefficient of friction between the concrete and steel liner increased from 0 to 0.6 in the penetration area, a reduction of stresses in the reinforcement, tendons, and steel liner results. Removal of a tendon near the pipe entry results in cracking in the concrete initiating at a lower internal pressure level. For the general wall section, scenarios considered included: increased thickness of containment wall, friction between steel liner and surrounding concrete, $20 \%$ lower than long-time design prestressing force in all tendons (fictitious), loss of one prestressing tendon, loss of prestressing force in one tendon with steel area maintained, and 10\% general reduction in steel rebar area. Wall thickness increase will change radial deformation. A higher friction value will increase ultimate load-bearing capacity somewhat since inner and outer part of wall will 


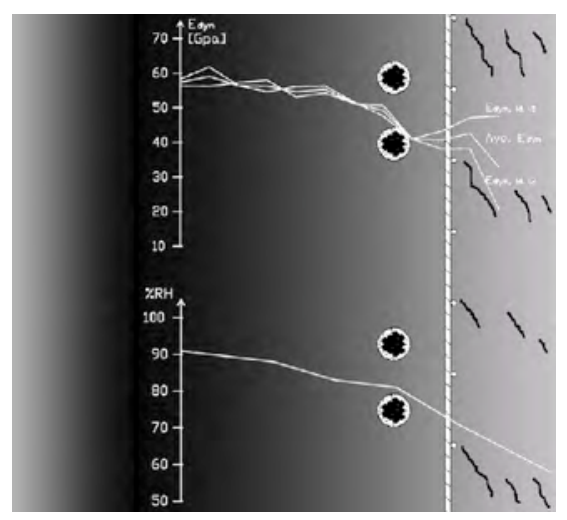

Figure 5.5 Graphic profile of Barsebäck wall (outside containment to right) showing tears in concrete due to slipforming, and relative humidity and dynamic modulus profiles.

Source: CONMOD - Main Report, Coordinated by Force Technology, Brøndby, Sweden, Contract No: FIKS-CT 2001-00204, European Union Research for Reactor Safety, Fifth Framework Program, (http://cordis.europa.eu/fp5-euratom/src/lib_finalreports.htm).

share loading more effectively. Reduction of prestressing force by $20 \%$ had no noticeable affect on ultimate load capacity, but may result in earlier steel yielding. Removal of a horizontal tendon only produced a local effect (i.e., local leak-tight capacity reduced $\sim 5 \%$ in area of tendon removal and ultimate capacity of containment unaffected). Reduction of steel reinforcement area by $10 \%$ affected ultimate capacity only marginally and did not affect leak tightness.

\subsubsection{Demonstrator 2 - MAEVA Mock-up}

Électricité de France (EDF), with contributions from its partners, constructed a concrete test model (mock-up) at CIVAUX in France. The model represents the normal section of a pressurized water reactor (PWR) containment, Figure 5.6. The project is entitled MAEVA (MAquette Enceinte en Vapeur et en Air, Steam and Air Tests) and has

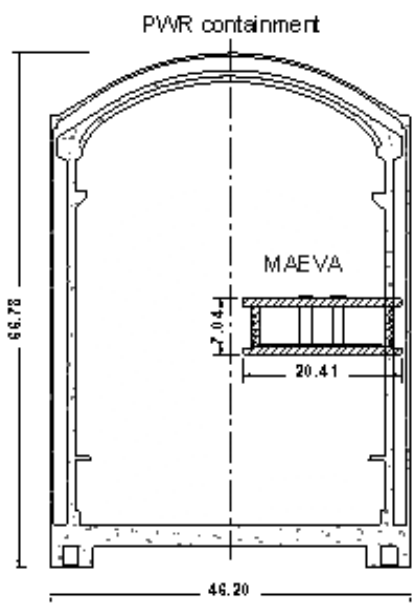

(c) PWR containment.

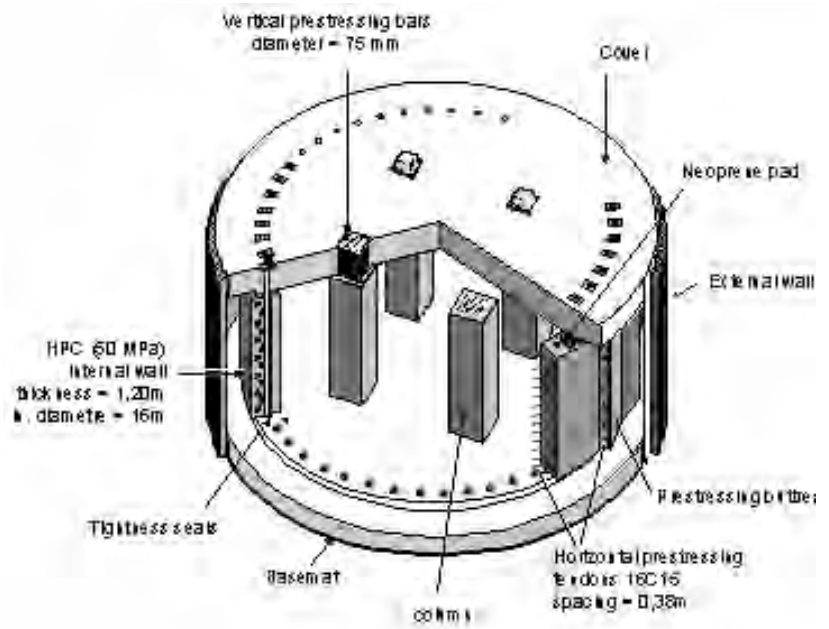

(d) MAEVA model.

Figure 5.6 MAEVA mock-up.

Source: $C O N M O D$ - Main Report, Coordinated by Force Technology, Brøndby, Sweden, Contract No: FIKS-CT 2001-00204, European Union Research for Reactor Safety, Fifth Framework Program,

(http://cordis.europa.eu/fp5-euratom/src/lib finalreports.htm). 
objectives of: obtaining a better understanding of the behavior of a reactor containment subjected to combined loading of pressure and temperature, studying the evolution of the permeability by leak rate measurements and also the state of cracking of the containment wall, and investigating the behavior of a composite liner and its contribution to the leak-tightness of the concrete containment wall. The MAEVA vessel consists of a cylindrical wall with an internal diameter of $16 \mathrm{~m}$ and an external diameter of $18.4 \mathrm{~m}$. The floor and roof of the vessel consist of concrete slabs connected by four concrete columns. The concrete wall is enclosed by a watertight steel bulkhead. For the benefit of CONMOD a continuous concrete crack detection system (i.e., to detect new crack generation and growth of existing cracks) was installed (5.6). Instrumentation consisting of 20 sensors was mounted on the inner wall with an additional 20 sensors mounted on the outer wall of the vessel to confirm the ability of an acoustic monitoring system to detect cracking of the concrete as the pressure changes. Following several previous pressurizations involving either air or steam, two over design pressurization tests to 1.5 times design pressure (up to $0.975 \mathrm{MPa}$ ) were conducted specifically for the CONMOD project as noted in Figure 5.7a. Also shown in the figure is the

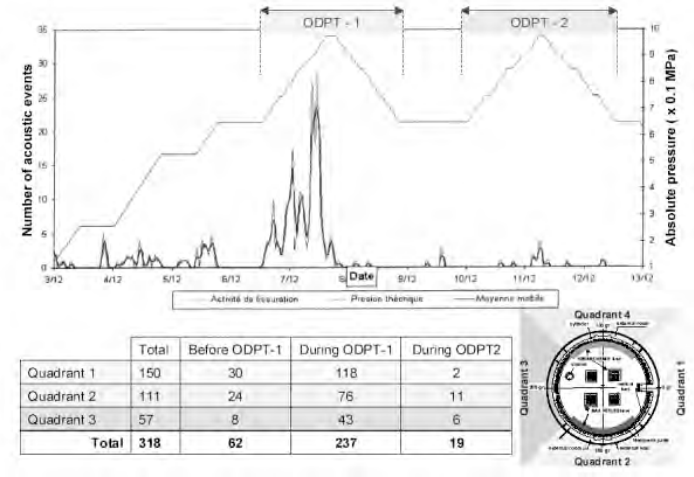

(a) Pressurization and detection of crack events.
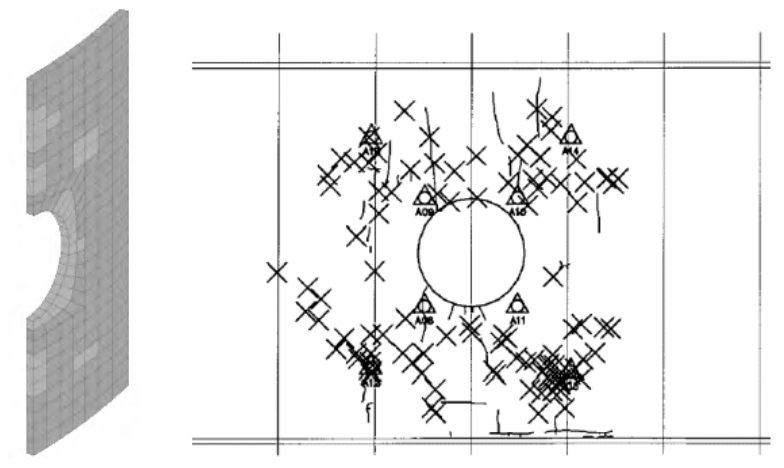

(b) Comparison of cracking in Quadrant 1 deduced by finiteelement analysis and by acoustic events.

Figure 5.7 MAEVA CONMOD pressurization and cracking results for Quadrant 1..

Source: CONMOD - Main Report, Coordinated by Force Technology, Brøndby, Sweden, Contract No: FIKS-CT 2001-00204, European Union Research for Reactor Safety, Fifth Framework Program, (http://cordis.europa.eu/fp5-euratom/src/lib_finalreports.htm).

occurrence of acoustic events which was relatively high during the first pressure rise (ODPT-1) and low during the second (ODPT-2) due to the Kaiser effect. The occurrence of acoustic events was interpreted as the formation and/or growth of cracks in the concrete. Finite-element calculations were conducted based on two models: an axisymmetric model with truss elements representing an area removed from a singularity such as a hatch or buttress; and a 3-D model simulating one-half the structure that takes into account the symmetry of the structure, boundary conditions, and loading. Results of the non-linear calculations for pressurization up to the final test pressure indicate no damage occurrence in the cylinder wall in areas remote from singularities. Non-linear modeling revealed areas where cracks were thought to occur based on computed stress values. These results were found to be consistent with the results of the acoustic emission survey, Figure 5.7b. Displacements predicted by the finite-element analysis were lower than those obtained by monitoring, but this was considered to be due to the presence of cracking resulting from previous loadings that was not included in the analysis. Although time restraints did not permit application of the complete CONMOD methodology, it was generally noted that numerical modeling calculations provided comprehensive predictions of the behavior of the structure, as well as the prediction and localization of new cracks.

\subsubsection{CONMOD Conclusions}

Although the objective of finding a means of predicting the condition and behavior of concrete containments under loading and the effects of aging was not fully achieved and validated, the basic approach combining nondestructive evaluation methods and finite-element analysis into a methodology for condition assessment and aging management of structures was achieved. As-built compliance and quality were determined to be of major importance with respect to evaluation of the condition and characterization and estimation of the time-dependent changes in the condition of a structure. Results from Barsebäck indicate that the concrete structures may not be fabricated as designed and that the condition and changes in the condition of a structure may not be adequately described by what 
can be observed on the surface. Table 5.3 presents information on nondestructive evaluation methods used in CONMOD on the Barsebäck containment or in companion mock-ups. Application and capability of techniques that can provide information on reinforcing steel, cable ducts, and the steel liner based on results from CONMOD and Barsebäck are summarized in Table 5.4. Results from the nondestructive evaluation testing indicate that increased understanding of stress wave motion in structures is required with respect to such things as wave dispersion dependence on the relationship between wavelength and concrete thickness, wave mode dependence on the interaction of concrete and steel, and effects of low-velocity surface waves. The amount and quality of information that can be obtained by nondestructive evaluations is very dependent of the concrete quality (i.e., improved concrete quality results in improved nondestructive evaluation results). Finally, it was noted that development of new containment designs should focus on establishing rules, designs, and novel ideas on how to significantly improve the accessibility of the concrete structures for diagnostic investigations.

Table 5.3 Application of nondestructive evaluation methods in CONMOD*

\begin{tabular}{|c|c|c|}
\hline NDE method & Parameter measured & Information obtained \\
\hline Radar & $\begin{array}{l}\text { Velocity, attenuation, } \\
\text { penetration }\end{array}$ & $\begin{array}{l}\text { Moisture level (relative) } \\
\text { Conductivity (salts) }\end{array}$ \\
\hline Radar & Reflections, damping & $\begin{array}{l}\text { Reinforcing and cable duct position and depth } \\
\text { Cracks (wet or moist) } \\
\text { Voids }\end{array}$ \\
\hline $\begin{array}{l}\text { High energy computed } \\
\text { radiography }\end{array}$ & Density & $\begin{array}{l}\text { Voids } \\
\text { Porosity } \\
\text { Cracks (beam parallel) } \\
\text { Reinforcing and cable duct details } \\
\text { Concrete thickness }\end{array}$ \\
\hline Ultrasonic pulse echo & Shear wave velocity & $\begin{array}{l}\text { Shear modulus } \\
\text { Approximate strength and mechanical properties }\end{array}$ \\
\hline Ultrasonic pulse echo & Reflections & $\begin{array}{l}\text { Cracks } \\
\text { Voids } \\
\text { Honeycombing } \\
\text { Joint and bond strength (relative) } \\
\text { Position and depth of reinforcing and cable ducts }\end{array}$ \\
\hline $\begin{array}{l}\text { Spectral analysis of surface } \\
\text { waves/multichannel analysis } \\
\text { of surface waves }\end{array}$ & $\begin{array}{l}\text { Rayleigh wave velocity } \\
\text { and dispersion }\end{array}$ & $\begin{array}{l}\text { Variations in mechanical properties with } \\
\text { depth } \\
\text { Damaged and deteriorated concrete and } \\
\text { presence of layers with different mechanical } \\
\text { properties } \\
\text { Shear modulus }\end{array}$ \\
\hline Impact echo & P-wave velocity & $\begin{array}{l}\text { Elastic modulus } \\
\text { Approximate strength and mechanical } \\
\text { properties }\end{array}$ \\
\hline Impact echo & Reflections & $\begin{array}{l}\text { Cracks } \\
\text { Voids } \\
\text { Honeycombing } \\
\text { Joint and bond strength (relative) } \\
\text { Thickness }\end{array}$ \\
\hline Impact echo & Flexural response & Delamination \\
\hline $\begin{array}{l}\text { Ultrasonic pulse echo, } \\
\text { spectral analysis of surface } \\
\text { waves, and impact echo }\end{array}$ & $\begin{array}{l}\text { Shear, Rayleigh, And P- } \\
\text { wave velocities }\end{array}$ & $\begin{array}{l}\text { Poisson's ratio (dynamic) } \\
\text { Elastic modulus (dynamic). } \\
\text { Isotropy }\end{array}$ \\
\hline
\end{tabular}

*Techniques and applications having greatest use and benefit to CONMOD are shown in bold text.

Source: CONMOD - Main Report, Coordinated by Force Technology, Brøndby, Sweden, Contract No: FIKS-CT 2001-00204, European Union Research for Reactor Safety, Fifth Framework Program, (http://cordis.europa.eu/fp5-euratom/src/lib finalreports.htm). 
Table 5.4 Application and capability of NDE techniques to reinforcing steel, cable ducts, and steel liner

\begin{tabular}{|c|c|}
\hline NDE method & Application and capability \\
\hline Radar & $\begin{array}{l}\text { Reinforcing steel position and depth } \\
\text { Maximum of } 3 \text { layers and depth of } 250-300 \mathrm{~mm} \\
\text { Will resolve rebars at } 100 \mathrm{~mm} \text { centers }\end{array}$ \\
\hline Radar & $\begin{array}{l}\text { Cable duct position and depth } \\
\text { Maximum of } 1 \text { layer behind surface reinforcing steel and depth } \\
\text { of 300-350 mm depending on moisture content of concrete }\end{array}$ \\
\hline Radar & $\begin{array}{l}\text { Void with } 70-\mathrm{mm} \text { diameter in liner plate at } 260 \mathrm{~mm} \text { depth } \\
\text { Position (dependent on position of reinforcing steel relative to } \\
\text { void) }\end{array}$ \\
\hline Covermeter & $\begin{array}{l}\text { Reinforcing steel position and depth } \\
\text { Maximum of } 2 \text { layers and depth of } 80-100 \mathrm{~mm}\end{array}$ \\
\hline Ultrasonic pulse echo & $\begin{array}{l}\text { Reinforcing steel position and depth } \\
\text { Maximum of } 2 \text { layers and depth of } 100-200 \mathrm{~mm}\end{array}$ \\
\hline Ultrasonic pulse echo & $\begin{array}{l}\text { Cable duct position and depth } \\
\text { Maximum of } 1 \text { layer behind surface reinforcing steel and depth } \\
\text { of } 160-250 \mathrm{~mm} \text { depending on aggregate size and condition of } \\
\text { concrete }\end{array}$ \\
\hline Ultrasonic pulse echo & Void in cable duct \\
\hline Ultrasonic pulse echo & $\begin{array}{l}\text { Void with } 70-\mathrm{mm} \text { diameter in liner plate and depth of } 260 \mathrm{~mm} \\
\text { Position (dependent on position of reinforcing bars relative to } \\
\text { void) }\end{array}$ \\
\hline High energy computed radiography & $\begin{array}{l}\text { Reinforcing steel position, depth, size and condition } \\
\text { Several layers of reinforcing steel and maximum thickness/depth } \\
\text { of } 1400 \mathrm{~mm}\end{array}$ \\
\hline High energy computed radiography & $\begin{array}{l}\text { Cable duct position, depth, size, and condition } \\
\text { Several layers of reinforcing steel and maximum thickness/depth } \\
\text { of } 1400 \mathrm{~mm} \\
\text { Locate voids in grouted cable ducts }\end{array}$ \\
\hline High energy computed radiography & $\begin{array}{l}\text { Void and loss of section in liner } \\
\text { Minimum } 20-\mathrm{mm} \text { diameter void }\end{array}$ \\
\hline $\begin{array}{l}\text { Impact echo/spectral analysis of surface } \\
\text { waves/multichannel analysis of surface } \\
\text { waves }\end{array}$ & Condition of bond between concrete and liner \\
\hline
\end{tabular}

Source: CONMOD - Main Report, Coordinated by Force Technology, Brøndby, Sweden, Contract No: FIKS-CT 2001-00204, European Union Research for Reactor Safety, Fifth Framework Program, (http://cordis.europa.eu/fp5-euratom/src/lib_finalreports.htm).

\subsubsection{Nondestructive Testing for Integrity Determination of Concrete Structures}

Nondestructive evaluations of concrete structures are required for compliance testing, collection of specific data or parameters, condition assessments, and damage assessment. The performance of older structures is often poor due to a number of factors such as variability of concrete quality and other effects of poor workmanship, and inadequate supervision at the construction site. In addition, the condition of the concrete globally or through a thick section may have changed with time, and these conditions cannot always be predicted in an older structure (i.e., less is known about older structures). The quality of results produced by nondestructive evaluation methods is directly related to the quality of the concrete. Modern concretes are usually of higher quality so application of nondestructive testing in all likelihood will produce improved results relative to older concrete structures indicating that nondestructive evaluations will have increased use in the future (5.7).

In 1999 the Nordic Industrial Fund funded an initiative on technology and methodology development on nondestructive testing for integrity determination of concrete structures $(5.8,5.9)$. The project was inspired by the need to know the actual capabilities of nondestructive evaluation methods for use on concrete structures. Two priority problem cases were identified: determination of structural integrity and quality of concrete structures of 
medium thickness $(<2 \mathrm{~m})$ and determination of the condition of pre- and post-tensioned cables in concrete structures. Areas considered to be of prime importance were detection and characterization of voids and cracks in concrete structures. Nondestructive methods evaluated in the study were: high-energy radiography, electromagnetic (e.g., ground-penetrating radar), and acoustic techniques (e.g., impact echo, spectral analysis of surface waves, and ultrasonic pulse echo). Fieldwork included a number of bridges, dams, and a nuclear containment wall. In addition, a number of carefully prepared mock-ups were fabricated for laboratory investigations (radiography primarily) and two large blocks were fabricated with well-defined details and idealized defects. The first block had the purpose of testing the capability of various nondestructive evaluation methods to detect voids of various sizes and depths from the surface. Block 2 was constructed with various reinforcement configurations and ducts (pipes) at different depths. It was designed specifically for radar tests (with some ultrasonic pulse echo testing) to determine which ducts could be detected. A summary of results obtained for Blocks 1 and 2 is provided below.

\subsubsection{Block 1}

The slab of Block 1 had a surface area of $16 \mathrm{~m}^{2}$ and a thickness of $800 \mathrm{~mm}$. Support for the slab was provided by two integral walls having a thickness of $400 \mathrm{~mm}$. Slab reinforcement at top and bottom surfaces was provided by wire mesh consisting of 16-mm-diameter bars at $200 \mathrm{~mm}$ center-to-center spacing. Cover thickness at upper surface was approximately $90 \mathrm{~mm}$. In addition, a mesh of 6-mm-diameter bars at $150 \mathrm{~mm}$ center-to-center spacing was placed above the main reinforcing at the upper surface. The concrete was cast using a crushed granite coarse aggregate having a maximum aggregate size of $25-\mathrm{mm}$, a water-to-cement ratio of 0.37 , and plasticizer additives. The 28-day strength was $53 \mathrm{MPa}$. Cast into the slab were voids of various size formed using polystyrene blocks and hollow plastic spheres. The voids were secured in place using welded bars and stirrups. Plastic sheets were also cast into the slab to simulate cracks. Figure 5.8 presents a drawing of Block 1 and Table 5.5 provides a description of the voids in the block. Not shown in the figure is a steel plate containing semispherical voids attached to its top surface that was cast into the concrete. The plate was located adjacent to the south support wall between void Nos. 11 and 12. Nondestructive evaluation techniques investigated included ultrasonic pulse echo, impact echo, and groundpenetrating radar.
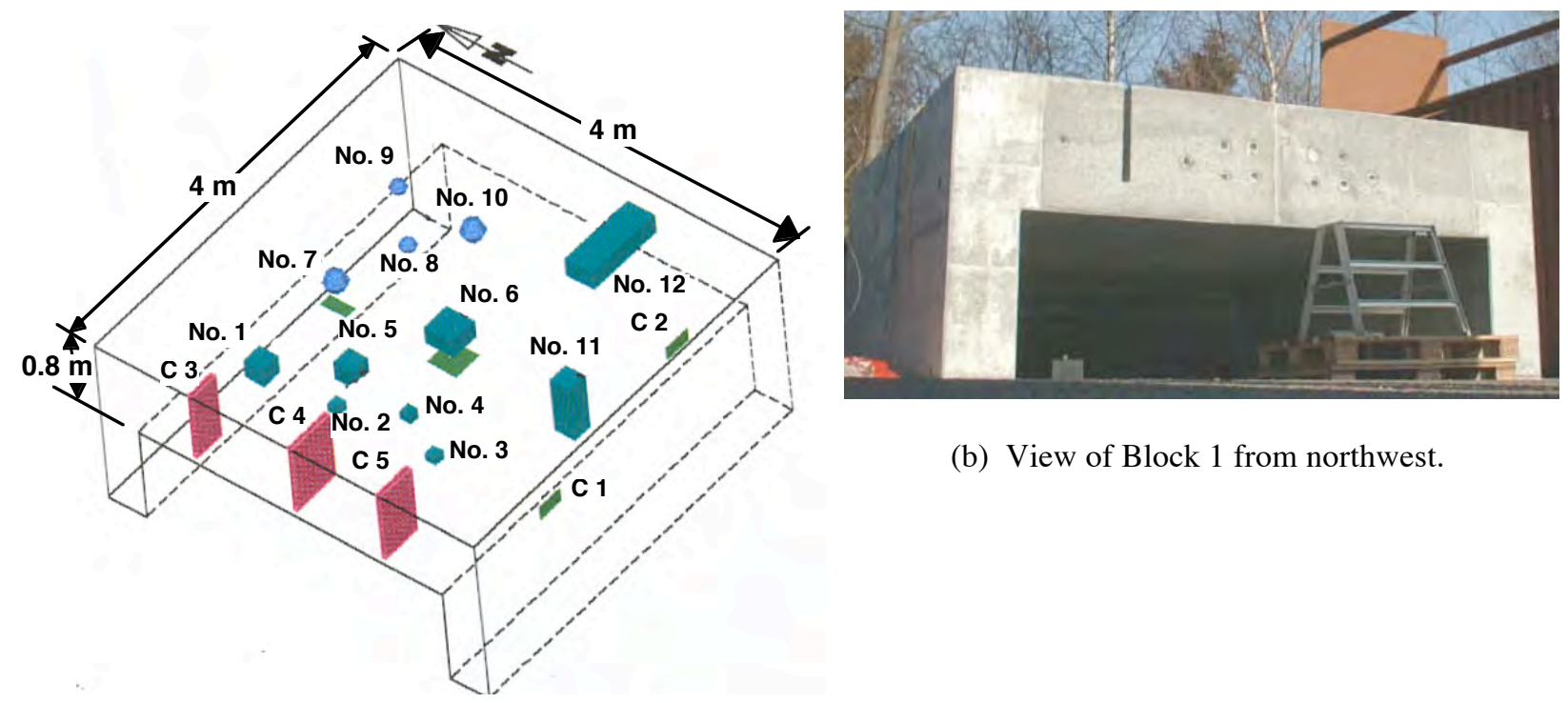

(b) View of Block 1 from northwest.

(a) Block 1 showing defect arrangement.

Figure 5.8 Details of Block 1.

Source: (a) P. Shaw, J. Rasmussen, and T.K. Pedersen, A Practical Guide to Non-Destructive Examination of Concrete, Nordic Innovation Centre, Oslo, Norway, 2004.

(b) Concrete News, No. 2, Force Institute, Brøndby, Sweden, August 2002.

A series of ultrasonic pulse echo B-scans were made at $300 \mathrm{~mm}$ intervals on Block 1. Along each line a separation of $100 \mathrm{~mm}$ was used. Also, each defect was scanned at test intervals of $20 \mathrm{~mm}$ and in some cases $10 \mathrm{~mm}$ and at various frequencies (i.e., 33 to $250 \mathrm{kHz}$ ). The maximum penetration (transmission-reflection) was found to be approximately $1000 \mathrm{~mm}$. Ultrasonic pulse echo testing was able to locate all defects as well as verify solid concrete. 
Table 5.5 Description of voids in Block 1

\begin{tabular}{|l|l|l|l|}
\hline \multicolumn{1}{|c|}{ Void Number } & \multicolumn{1}{c|}{ Size } & \multicolumn{1}{c|}{ Depth from top } & \multicolumn{1}{c|}{ Depth from bottom } \\
\hline \hline No. 1 & $200 \times 200 \times 200 \mathrm{~mm}$ & $220 \mathrm{~mm}$ below & $380 \mathrm{~mm}$ above \\
\hline No. 2 & $100 \times 100 \times 100 \mathrm{~mm}$ & $130 \mathrm{~mm}$ below & $570 \mathrm{~mm}$ above \\
\hline No. 3 & $100 \times 100 \times 100 \mathrm{~mm}$ & $205 \mathrm{~mm}$ below & $495 \mathrm{~mm}$ above \\
\hline No. 4 & $100 \times 100 \times 100 \mathrm{~mm}$ & $305 \mathrm{~mm}$ below & $395 \mathrm{~mm}$ above \\
\hline No. 5 & $200 \times 200 \times 200 \mathrm{~mm}$ & $490 \mathrm{~mm}$ below & $100 \mathrm{~mm}$ above \\
\hline No. 6 & $295 \times 295 \times 200 \mathrm{~mm}$ & $305 \mathrm{~mm}$ below & $295 \mathrm{~mm}$ above \\
\hline No. 7 & $225-\mathrm{mm}$-diameter & $305 \mathrm{~mm}$ below & $270 \mathrm{~mm}$ above \\
\hline No. 8 & $150-\mathrm{mm}$-diameter & $300 \mathrm{~mm}$ below & $350 \mathrm{~mm}$ above \\
\hline No. 9 & $150-\mathrm{mm}$-diameter & $175 \mathrm{~mm}$ below & $475 \mathrm{~mm}$ above \\
\hline No. 10 & $225-\mathrm{mm}$-diameter & $190 \mathrm{~mm}$ below & $385 \mathrm{~mm}$ above \\
\hline No. 11 & $200 \times 200 \times 600 \mathrm{~mm}$ & $100 \mathrm{~mm}$ below & $100 \mathrm{~mm}$ above \\
\hline No. 12 & $810 \times 300 \times 200 \mathrm{~mm}$ & $200 \mathrm{~mm}$ below & $400 \mathrm{~mm}$ above \\
\hline
\end{tabular}

Source: P. Shaw, J. Rasmussen, and T.K. Pedersen, A Practical Guide to Non-Destructive Examination of Concrete, Nordic Innovation Centre, Oslo, Norway, 2004.

Three criteria were utilized to establish whether the concrete was solid or contained voids: (1) the existence or not of a back-wall echo at the test point, (2) the directly reflected signals from defects, or (3) multiple echoes from defects (5.9). A-scans were made at close intervals across each defect and depth measurements were determined within $\pm 20 \mathrm{~mm}$. The width of reflectors could also be determined with good accuracy. Three factors could be used to establish the width of reflectors: (1) width of reflected image, (2) width of back-wall echo window, and (3) width of multiple echoes (where applicable) (5.9). Figure 5.9a presents a view of the top surface of the slab showing the location of voids and Figure 5.9b presents the scan grid for Block 1 using ultrasonic pulse echo. Dark areas in
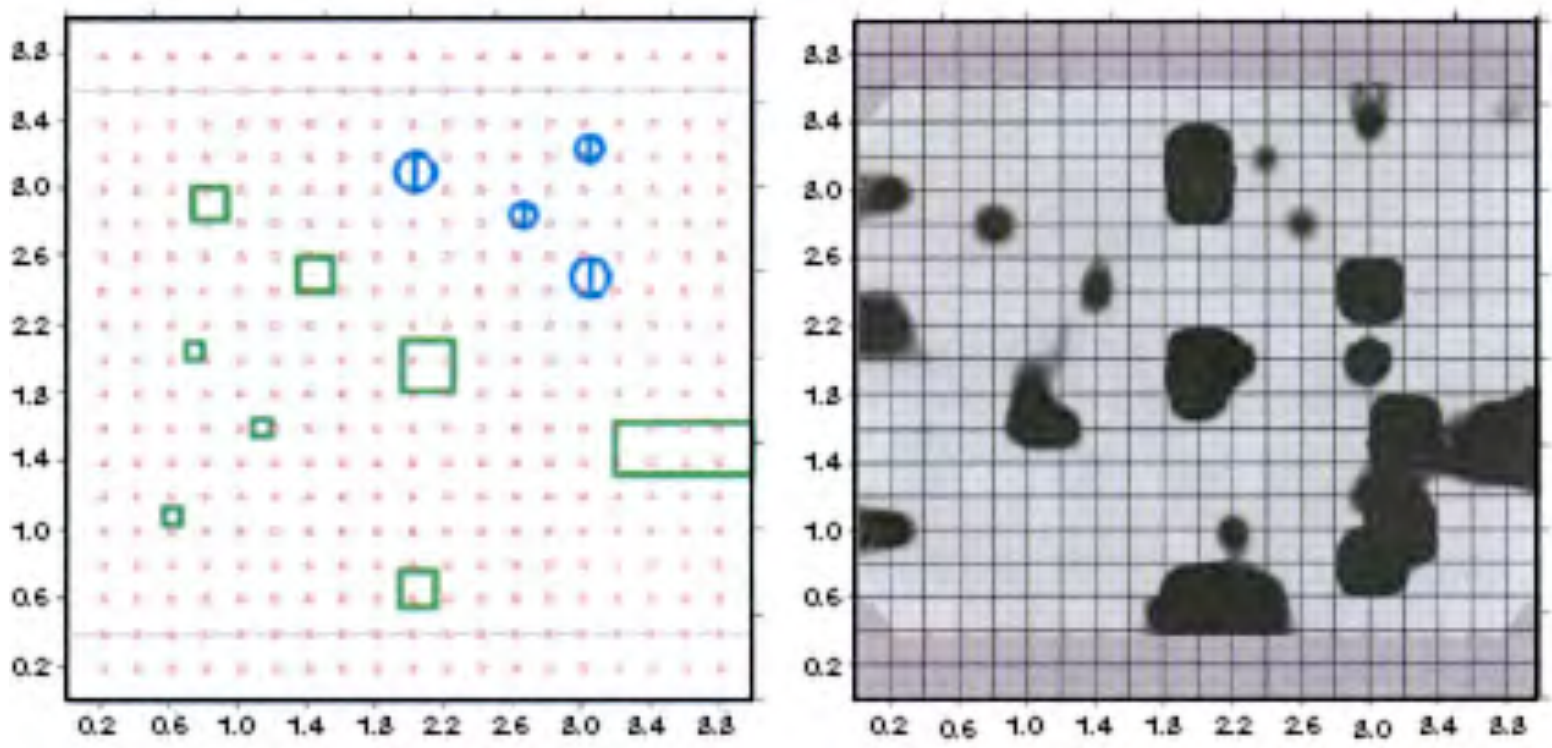

Figure 5.9 Ultrasonic pulse echo results for Block 1.

Source: P. Shaw, J. Rasmussen, and T.K. Pedersen, A Practical Guide to Non-Destructive Examination of Concrete, Nordic Innovation Centre, Oslo, Norway, 2004.

the figure indicates suspect areas. Examples of results from scans over void nos. 1 and 2 are presented in Figure 5.10. These results show a clear indication of void no. 1, however, void no. 2 is not very clear because it is located directly under steel reinforcing. Results showed that echoes could be obtained from eight out of ten of void nos. 1 to 10 with void nos. 1,5 , and 6 having the clearest detectability. The void size could be estimated for void 

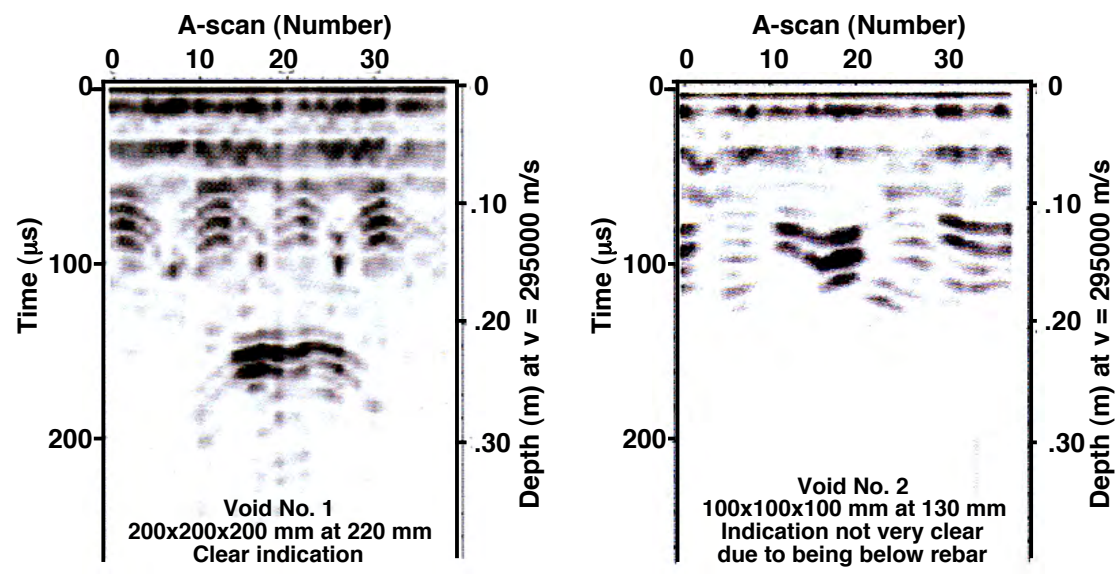

Figure 5.10 Ultrasonic pulse echo B-scan results over void nos. 1 and 2.

Source: P. Shaw, J. Rasmussen, and T.K. Pedersen, A Practical Guide to Non-Destructive Examination of Concrete, Nordic Innovation Centre, Oslo, Norway, 2004.

nos. 1,5 , and 6 , and possibly for void nos. 4,7 , and 10. Two layers of steel reinforcement were located above void no. 2 at $130 \mathrm{~mm}$ depth making its results somewhat unclear.

Impact echo was found to be suitable for locating larger voids in structures with relatively simple geometry, but its capability to detect smaller voids was not as good as ultrasonic pulse velocity. Figure 5.11 presents examples of impact echo results from Block 1. Although void no. 6 was detectable, void no. 5 was not. Results showed that echoes could be obtained from eight out of ten of void nos. 1 to 10 with good echoes received from void nos. 1,2,6,9, and 10. Void nos. 3,7, and 8 provided echoes, but they were weak. No echoes were received from void nos. 4 and 5.
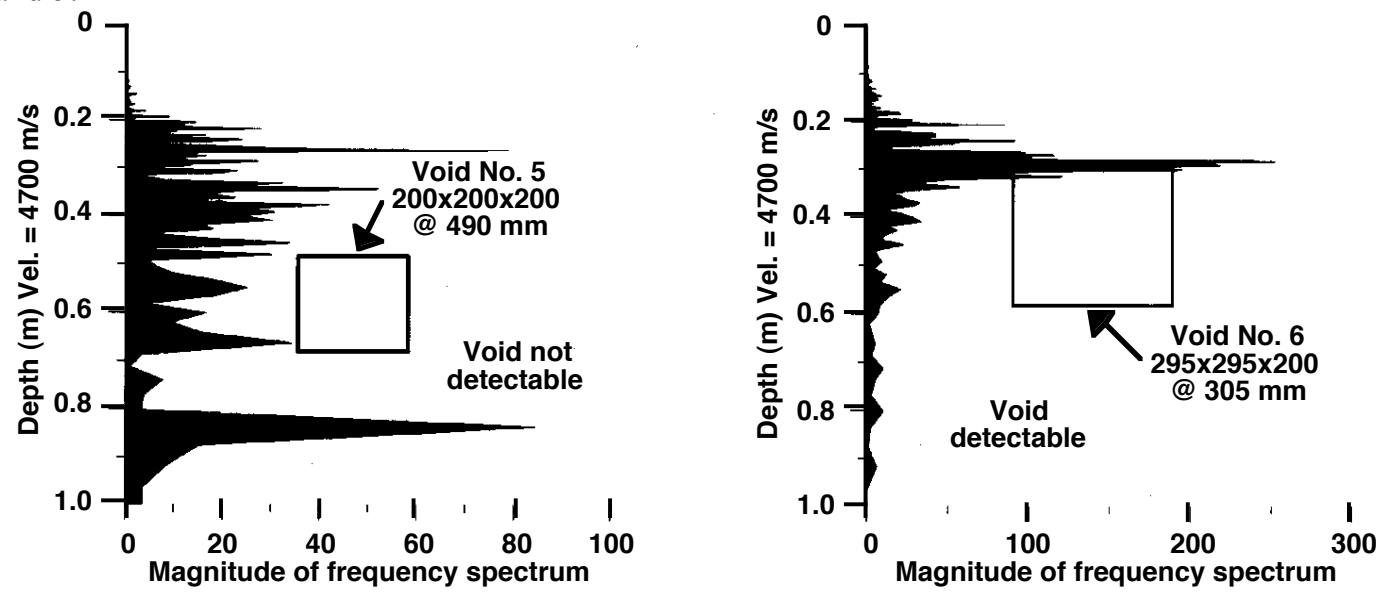

Figure 5.11 Impact echo results for void nos. 5 and 6.

Source: P. Shaw, J. Rasmussen, and T.K. Pedersen, A Practical Guide to Non-Destructive Examination of Concrete, Nordic Innovation Centre, Oslo, Norway, 2004.

Results obtained by the spectral analysis of surface waves technique were not as good as for the other two techniques because of the fairly congested internal geometry of Block 1 (e.g., voids, cracks, and reinforcing). Application of this technique requires considerable experience and production of the dispersion curves is time consuming. Also, depending on the measurement configuration (e.g., accelerometer separation distance) a void can have several signatures making it possible to miss large defects if the wrong configuration is used. However, it was recommended that the technique be tried as it can provide information about the depth of voids and may be useful in distinguishing voids from cracks that are parallel to the surface. Figure 5.12 presents examples of spectral analysis of surface wave dispersion curves for a solid concrete and for void no. 6 . 

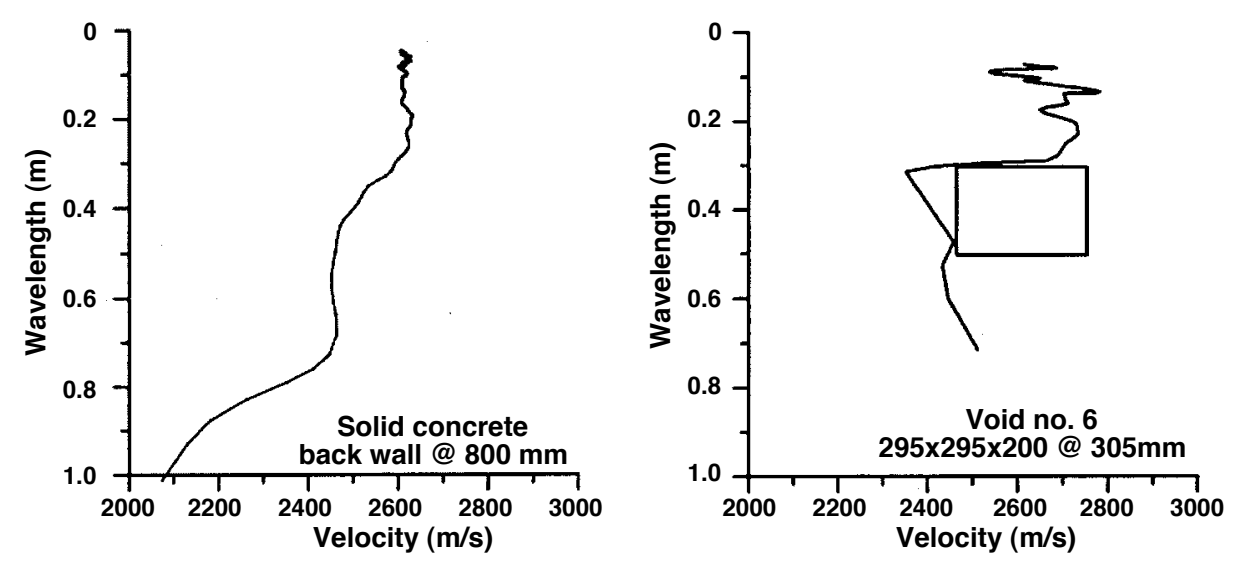

Figure 5.12 Spectral analysis of surface waves results for solid concrete and void no. 6

Source: P. Shaw, J. Rasmussen, and T.K. Pedersen, A Practical Guide to Non-Destructive Examination of Concrete, Nordic Innovation Centre, Oslo, Norway, 2004.

A very limited application of ground-penetrating radar was made to Block 1. Results presented in Figure 5.13 indicate that void no. 1 can be seen. It was noted that the main disadvantage of using radar to locate voids in a concrete structure is that quite often there can be several layers of steel reinforcement that can act as a shield to the radar signal. Also, it was noted that although the size of aggregate particles does not affect radar results, the results are strongly affected by the conductivity of the concrete.

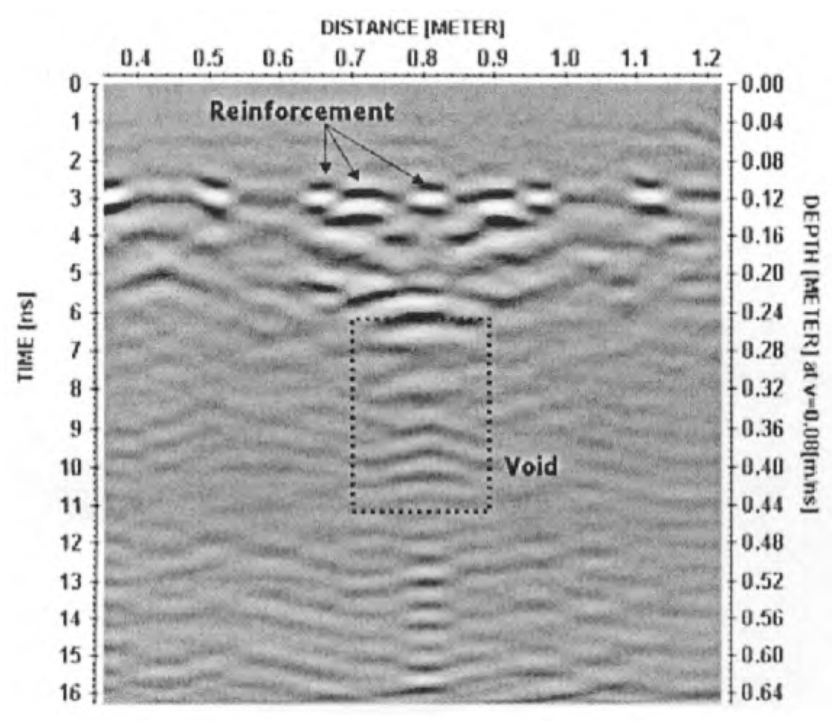

Figure 5.13 Ground-penetrating radar results for Block 1: Void no. 1.

Source: P. Shaw, J. Rasmussen, and T.K. Pedersen, A Practical Guide to Non-Destructive Examination of Concrete, Nordic Innovation Centre, Oslo, Norway, 2004.

\subsubsection{Block 2}

Block 2 was constructed of $40 \mathrm{MPa}$ concrete having a maximum aggregate size of $32 \mathrm{~mm}$ and contained various reinforcement configurations and ducts (pipes) at different depths. The block was designed specifically for radar tests, however, a few ultrasonic pulse echo tests were also conducted. The main objective of Block 2 was to determine which ducts could be detected. Figure 5.14 presents a description of Block 2 . The block was specifically designed with a wedge shape to enable tests to be made at increasing section thicknesses. Also, various rebar spacings were incorporated into the wedge and the block contained a number of $87-\mathrm{mm}$-diameter pipes. 

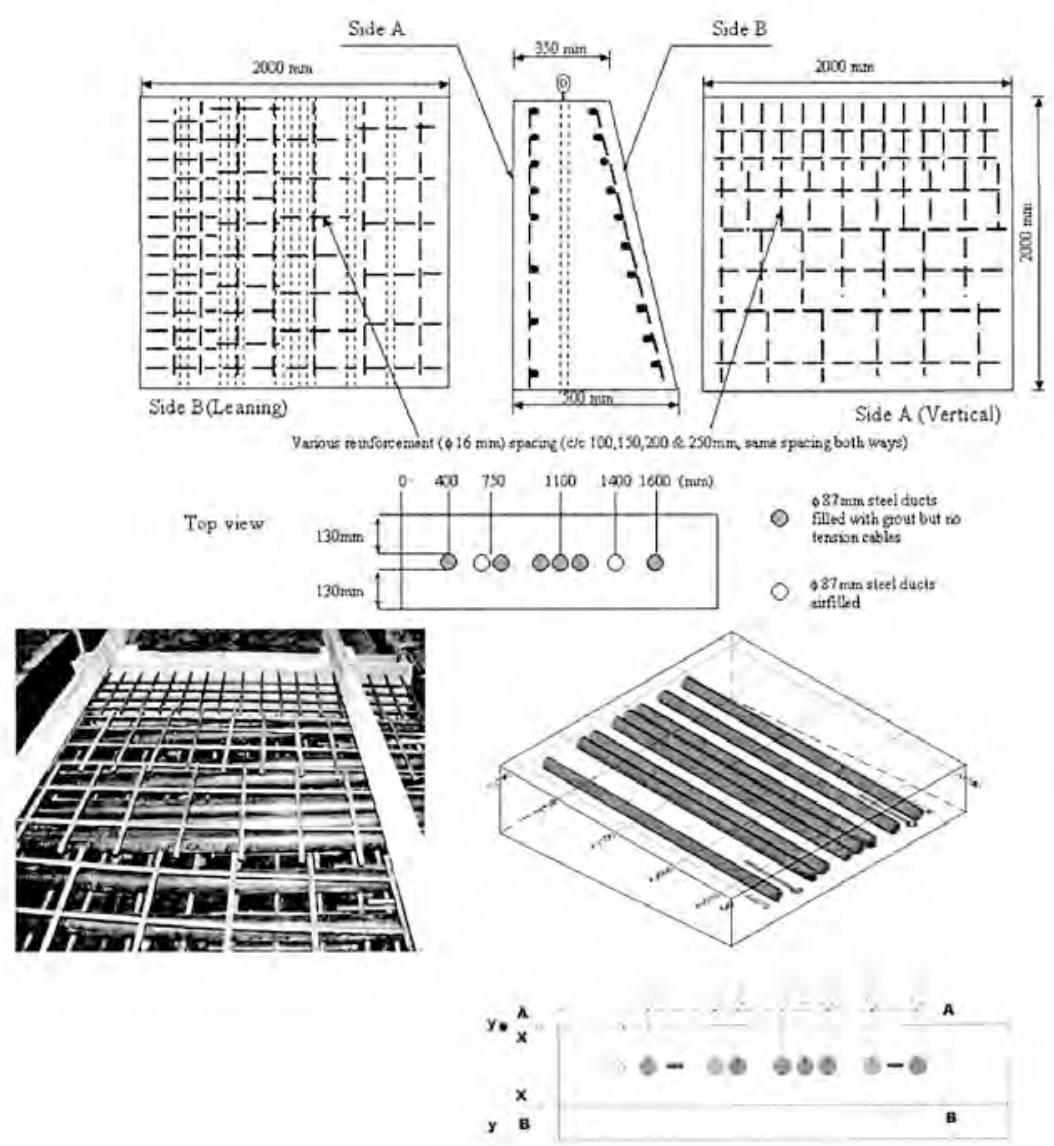

Figure 5.14 Details of Block 2.

Source: P. Shaw, J. Rasmussen, and T.K. Pedersen, A Practical Guide to Non-Destructive Examination of Concrete, Nordic Innovation Centre, Oslo, Norway, 2004.

A ground-penetrating radar profile (after several processing steps to enhance results) presented in Figure 5.15 indicates that positioning of closely spaced steel reinforcement can be difficult. The left part of the profile has a rebar spacing of $100 \mathrm{~mm}$. Small circles in the figure represent actual placement of the reinforcing bars while larger circles [with (x) having grout and ( ) without grout] show cable duct placement. For the equipment used in this project, a rebar spacing of $100 \mathrm{~mm}$ was about the minimum that permitted duct detection. As noted in Figure 5.16, for the conditions of the Block 2 test the maximum depth at which ducts could be located was about $220 \mathrm{~mm}$.

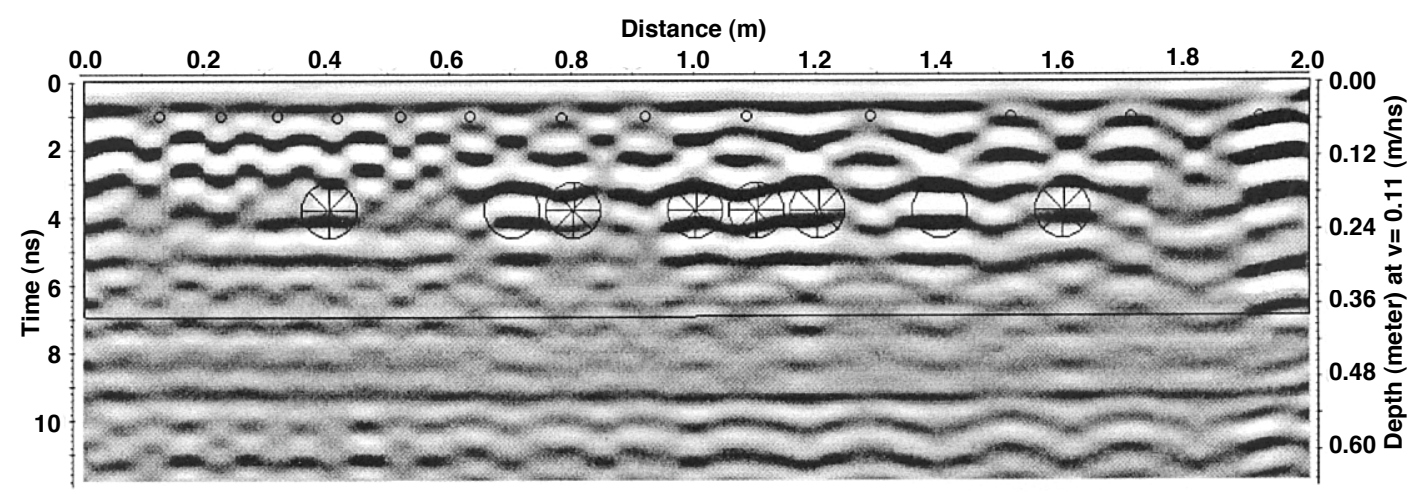

Figure 5.15 Ground-penetrating radar profile of Block 2.

Source: P. Shaw, J. Rasmussen, and T.K. Pedersen, A Practical Guide to Non-Destructive Examination of Concrete, Nordic Innovation Centre, Oslo, Norway, 2004. 
Conclusions from ground-penetrating radar testing of Block 2 were: reinforcement spacing should be $>100 \mathrm{~mm}$ and preferably at least $150 \mathrm{~mm}$ to permit mapping of individual bars and location of deeper-lying bars or ducts; reinforcement mesh size of about $100 \mathrm{~mm}$ can result in bar positioning errors; reinforcement mesh size of $100 \mathrm{~mm}$ will prevent deeper investigations using current equipment setup; it was not possible to reliably detect individual ducts in presence of several adjacent ducts; and ground-penetrating radar performance was dependent on several factors (e.g., reinforcement density-size-depth, concrete type and moisture content, cracking, antenna performance configuration, and processing tools and operational experience) (5.8).

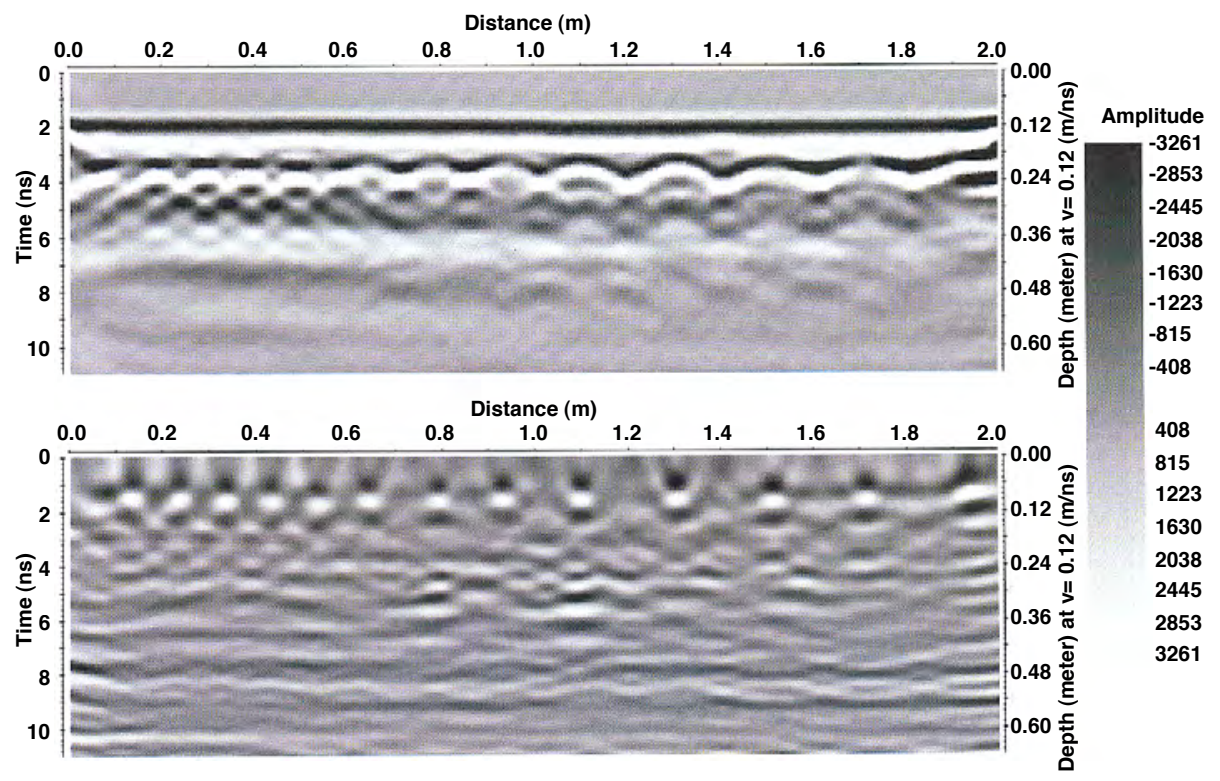

Figure 5.16 Ground-penetrating radar profile of Block 2 indicating maximum depth at which ducts can be identified.

Source: P. Shaw, J. Rasmussen, and T.K. Pedersen, A Practical Guide to Non-Destructive Examination of Concrete, Nordic Innovation Centre, Oslo, Norway, 2004.

Several ultrasonic pulse velocity scans of Block 2 were made. The purpose of the scans was to determine if ducts in concrete could be detected as well as voids in the grout fill of several ducts that had been grouted. Figure 5.17 presents an ultrasonic pulse echo scan of Block 2. Although the reinforcing and some of the air-filled ducts could be seen, the grouted tendon ducts could not be seen because pipes having wall thicknesses much greater than typical tendon ducts had been used as ducts. The air-filled ducts could be detected to a depth of $265 \mathrm{~mm}$.

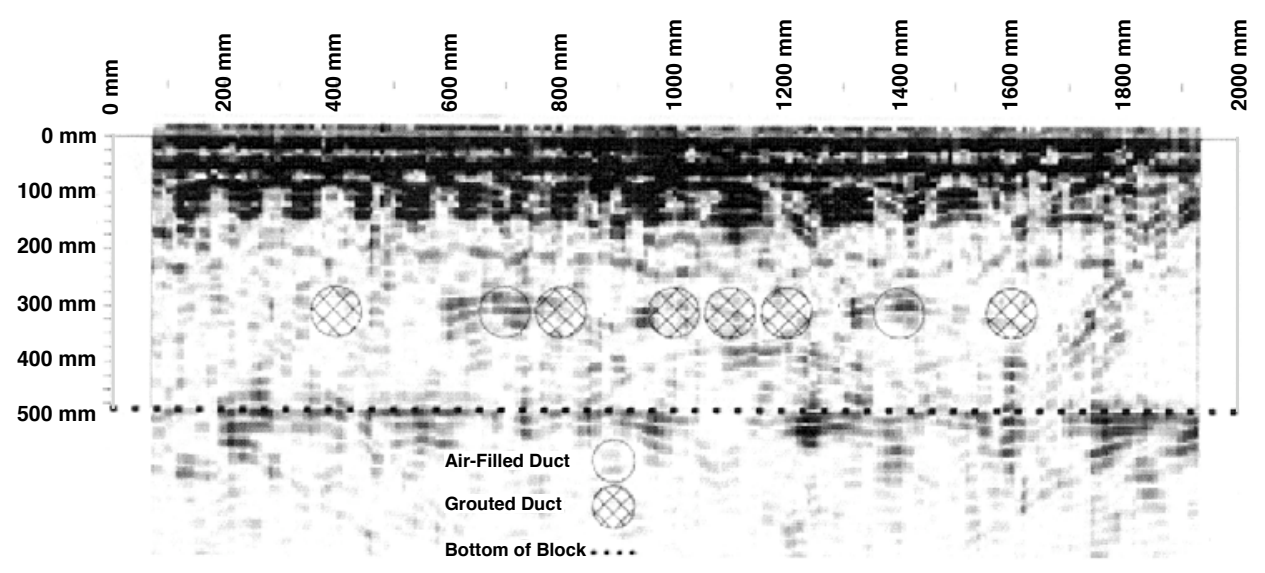

Figure 5.17 Ultrasonic pulse echo scan of Block 2.

Source: P. Shaw, J. Rasmussen, and T.K. Pedersen, A Practical Guide to Non-Destructive Examination of Concrete, Nordic Innovation Centre, Oslo, Norway, 2004. 


\subsubsection{Federal Institute for Materials Research and Testing (Berlin, Germany)}

The Non-Destructive Damage Assessment and Environment Measurement Methods Department at the Federal Institute for Materials Research and Testing (BAM) conducts research related to the promotion, improvement, and enhancement of practical applications of nondestructive testing methods in civil engineering (http://www.bam.de/en/kompetenzen/fachabteilungen/abteilung_8/fg82/index.htm). Several of the programs have addressed applications of nondestructive evaluation methods to large concrete test articles containing known voids or flaws.

\subsubsection{Large Scale Concrete Test Specimen}

A concrete slab $10 \mathrm{~m} \times 4 \mathrm{~m}$ with a regular thickness of $0.3 \mathrm{~m}$ was fabricated to provide a reference specimen with defined flaws to test structures in practice (5.10). The large dimensions of the specimen were necessary to minimize boundary effects on the measured signals and to establish well-defined defects with varying properties. The slab was partitioned into two sections separated by a joint with anchors. One section $\left(4 \times 5 \mathrm{~m}^{2}\right)$ contained tendon ducts with different diameters in varying depths and grouting defects along the prestressing steel. The other section $(4 \mathrm{x}$ $5 \mathrm{~m}^{2}$ ) provided areas with varying thickness and flaws (e.g., voids cast using polystyrene slabs denoted as MD1 to MD4 and precast honeycomb areas denoted as K1 to K3). A steel plate having a high reflection was located at the bottom of the slab to provide a suitable area for calibration of the radar method. The slab was founded on a basemat with $10 \mathrm{~m}$ long polyvinyl chloride ducts located $30 \mathrm{~cm}$ below the slab so that radiography could be applied to every part of the slab. Figure 5.18 presents the foundation of the slab with ducts. Portions of sections 1 and 2 prior to concrete placement are presented in Figure 5.19. A drawing of the large concrete slab showing section 2 in detail and an overall view of the test article are presented in Figure 5.20.
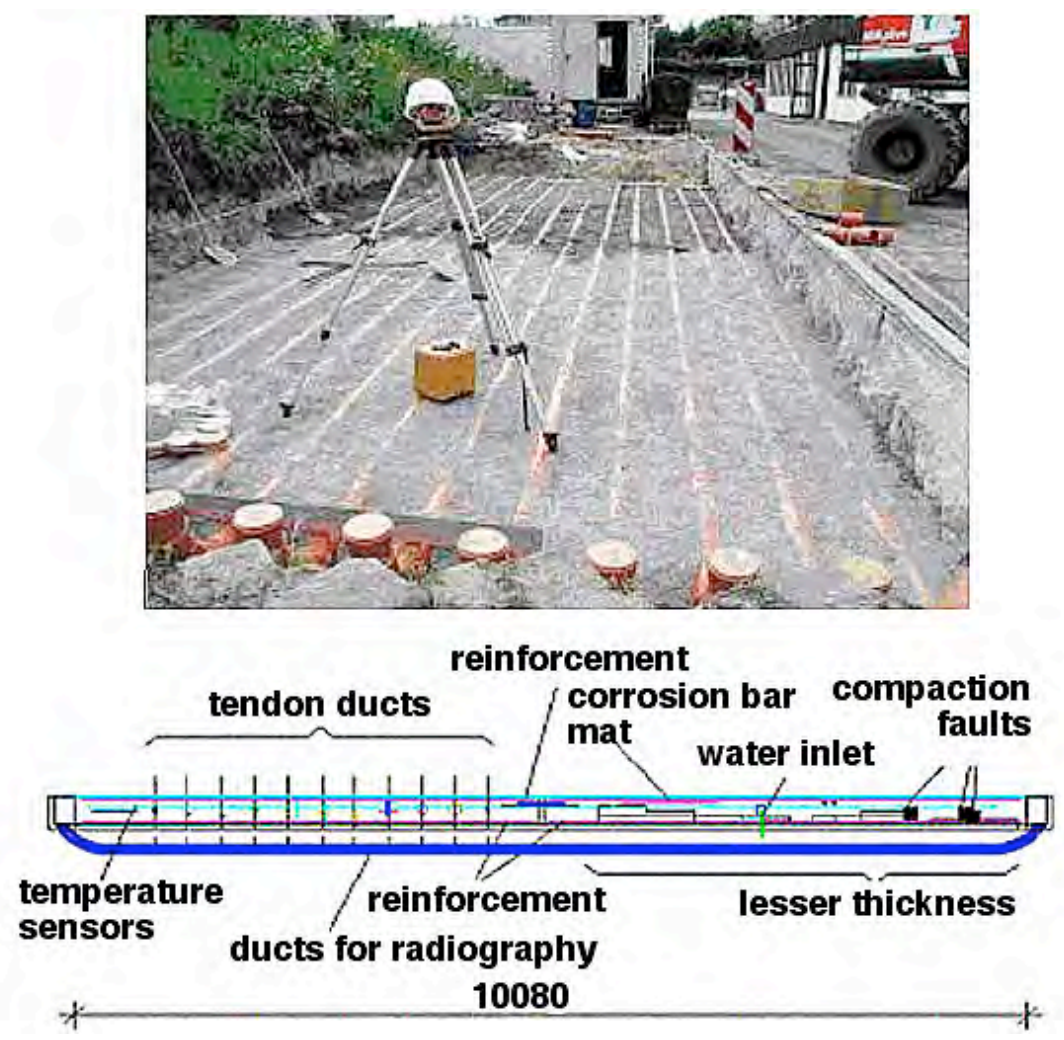

Figure 5.18 Foundation slab for large scale concrete test specimen.

Source: A. Taffe, K. Borchart, and H. Wiggenhauser, "Specimen for the Improvement of NDT Methods - Design and Construction of a Large Concrete Slab for NDT Methods at BAM," International Symposium on NonDestructive Testing in Civil Engineering (NDT-CE-2003), Bundesanstalt für Materialforschung und prüfung, Berlin, Germany, 2003. 

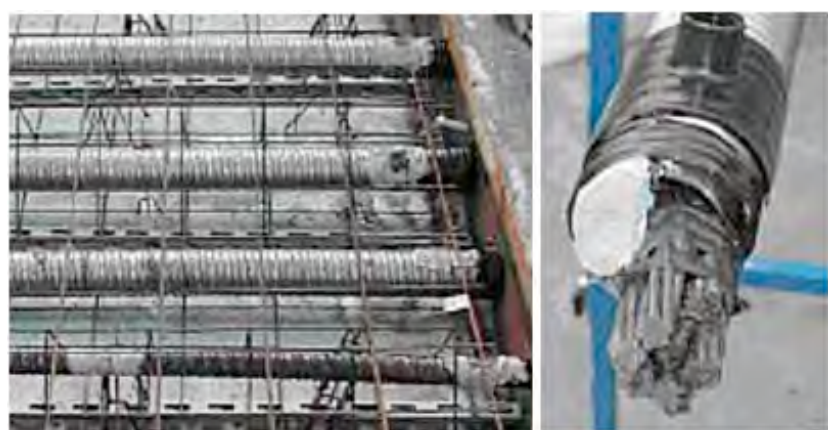

(a) Tendon ducts with different diameters, concrete cover, and simulated grouting faults.

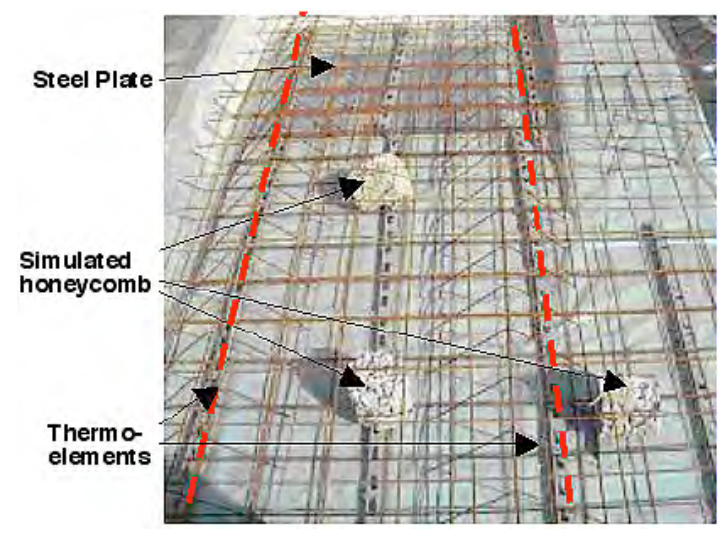

(b) Examples of simulated compaction faults and auxiliary devices.

Figure 5.19 Examples of simulated faults in sections 1 and 2 of large concrete slab.

Source: A. Taffe, K. Borchart, and H. Wiggenhauser, "Specimen for the Improvement of NDT Methods - Design and Construction of a Large Concrete Slab for NDT Methods at BAM," International Symposium on NonDestructive Testing in Civil Engineering (NDT-CE-2003), Bundesanstalt für Materialforschung und prüfung, Berlin, Germany, 2003.

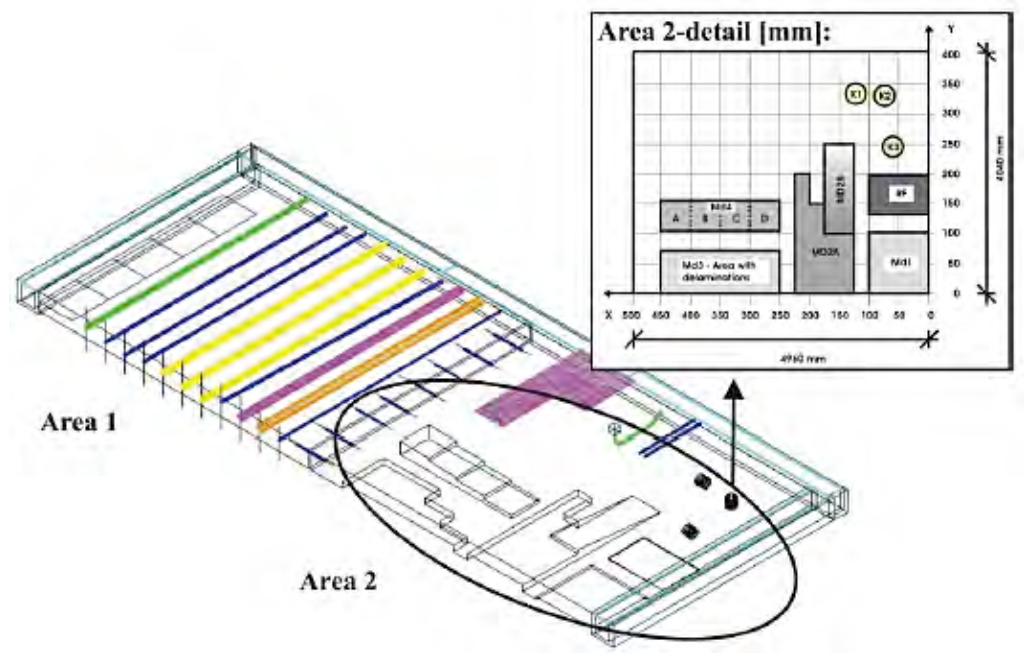

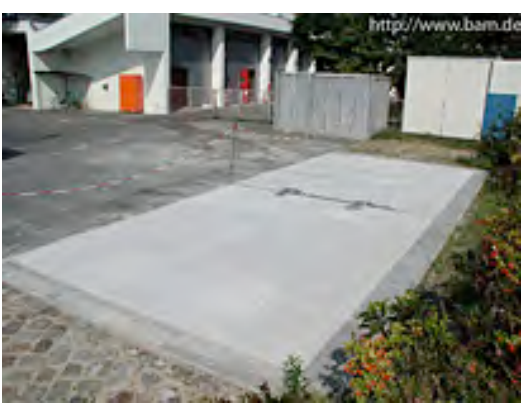

(b) View of large concrete slab.

(a) Drawing of large concrete slab with detail of section 2.

Figure 5.20 Large concrete slab test article.

Source: A. Taffe, K. Borchart, and H. Wiggenhauser, "Specimen for the Improvement of NDT Methods - Design and Construction of a Large Concrete Slab for NDT Methods at BAM," International Symposium on NonDestructive Testing in Civil Engineering (NDT-CE-2003), Bundesanstalt für Materialforschung und prüfung, Berlin, Germany, 2003.

Examinations of the slab were performed with ultrasonic, impact echo, and radar methods to address location of sections having reduced thickness and positioning of tendon ducts (5.11). Institutions participating in the examinations were the Universität Stuttgart (USt), the Universität of Dortmund (UDo), the Institute for Materials Research and Testing at the Bauhaus-Weimar (MFPA), and the Federal Institute for Materials Research (BAM). Table 5.6 provides a summary of the testing methods utilized in the study by each of the institutions. Reference velocities for each of the testing methods were determined at the location where a steel plate was embedded. The 
Table 5.6 Test methods utilized to inspect large concrete slab

\begin{tabular}{|l|l|l|l|}
\hline \multicolumn{1}{|c|}{ Institution } & \multicolumn{1}{c|}{ Testing Method } & \multicolumn{1}{c|}{ Pulse/wave mode } & \multicolumn{1}{c|}{ Velocity of propagation (m/s) } \\
\hline \hline UDo & Ultrasonic echo & Longitudinal waves & $4441^{1}$ \\
\hline MFPA & Ultrasonic echo & Longitudinal waves & - \\
\hline BAM & Ultrasonic echo & Shear waves & $2875^{2}$ \\
\hline USt & Impact echo & Impactor (automatic) & $4282^{1}$ \\
\hline BAM-1 & Impact echo & Impactor (steel balls) & $4281^{1}$ \\
\hline BAM-2 & Impact echo & Impactor (automatic) & $4106^{1}$ \\
\hline BAM & Radar & $1.5 \mathrm{GHz}$ antenna & $1.035^{*} 10^{8}$ \\
\hline
\end{tabular}

Longitudinal wave velocity $c_{p}$ of elastic wave

${ }^{2}$ Shear wave velocity (for $v=0.15$ equal to $c_{p}=4480 \mathrm{~m} / \mathrm{s}$ )

${ }^{3}$ Velocity c of electromagnetic wave, dielectric constant $\varepsilon=8.35[-]$

Source: R. Beutel, H-W. Reinhardt, C.U. Grosse, A. Glaubitt, M. Krause, C. Maierhofer, D. Algernon, H. Wiggenhauser, and M. Schickert, "Performance Demonstration of Non-Destructive Testing Methods," European Conference on NDT, Paper Tu.3.2.2, 9 pp., Berlin, Germany, 25-29 September 2006.

exact depth of the steel plate was determined by endoscopic examination. Calculated velocities are also presented in Table 5.6. Reference velocity for impact echo method was determined by a thickness calculation and reference values for radar and ultrasonic methods by measuring the time of flight. The thickness determinations were performed in Section MD4 shown in Figure 5.20a. Ultrasonic, impact echo, and radar results for thickness determinations were very consistent with small deviations between acquired values of individual methods and the overall average of the values at each of the four areas of reduced thickness. Actual thickness determinations for each of the four areas had not been made when these results were presented because the test article was still in use. Lateral dimensions in the x-direction of a measured flaw at three subareas of Section MD3 of Figure 5.20a were also determined using ultrasonic, impact echo, and radar methods. The results summarized in Figure 5.21 show excellent agreement between reference and measured values.

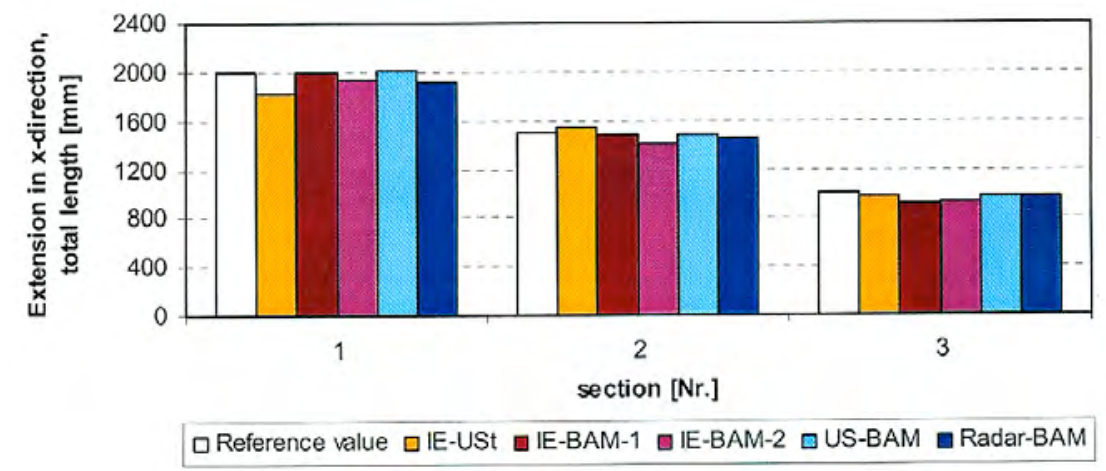

Figure 5.21 Comparisons of measured extensions in lateral direction of a measured flaw.

Source: R. Beutel, H-W. Reinhardt, C.U. Grosse, A. Glaubitt, M. Krause, C. Maierhofer, D. Algernon, H. Wiggenhauser, and M. Schickert, "Performance Demonstration of Non-Destructive Testing Methods," European Conference on NDT, Paper Tu.3.2.2, 9 pp., Berlin, Germany, 25-29 September 2006.

Area 1 of Figure 5.20a was utilized to investigate the accuracy of detecting tendon ducts and to classify ungrouted ducts. Measurements were performed using ultrasonic, impact echo, and radar methods of tendon ducts HR-E1 and HR-E2 located in this section of the slab. Tendon duct HR-E1 had a diameter of $80 \mathrm{~mm}$ and a concrete cover of $170 \mathrm{~mm}$ while tendon duct HR-E2 had a diameter of $40 \mathrm{~mm}$ and a depth of $110 \mathrm{~mm}$. Figure 5.22 presents a comparison of ultrasonic, impact echo, and radar results on localization of the two tendon ducts. Reference values are also presented in the figure. To determine the concrete cover only ultrasonic and radar methods were investigated as impact echo was not able to detect the depth of tendon ducts. Results presented in Figure 5.22b indicate that the accuracy decreases as the tendon depth increases. It was concluded from results of this study that the methods investigated can be applied to localization of sections of smaller thickness and identification of tendon ducts. 

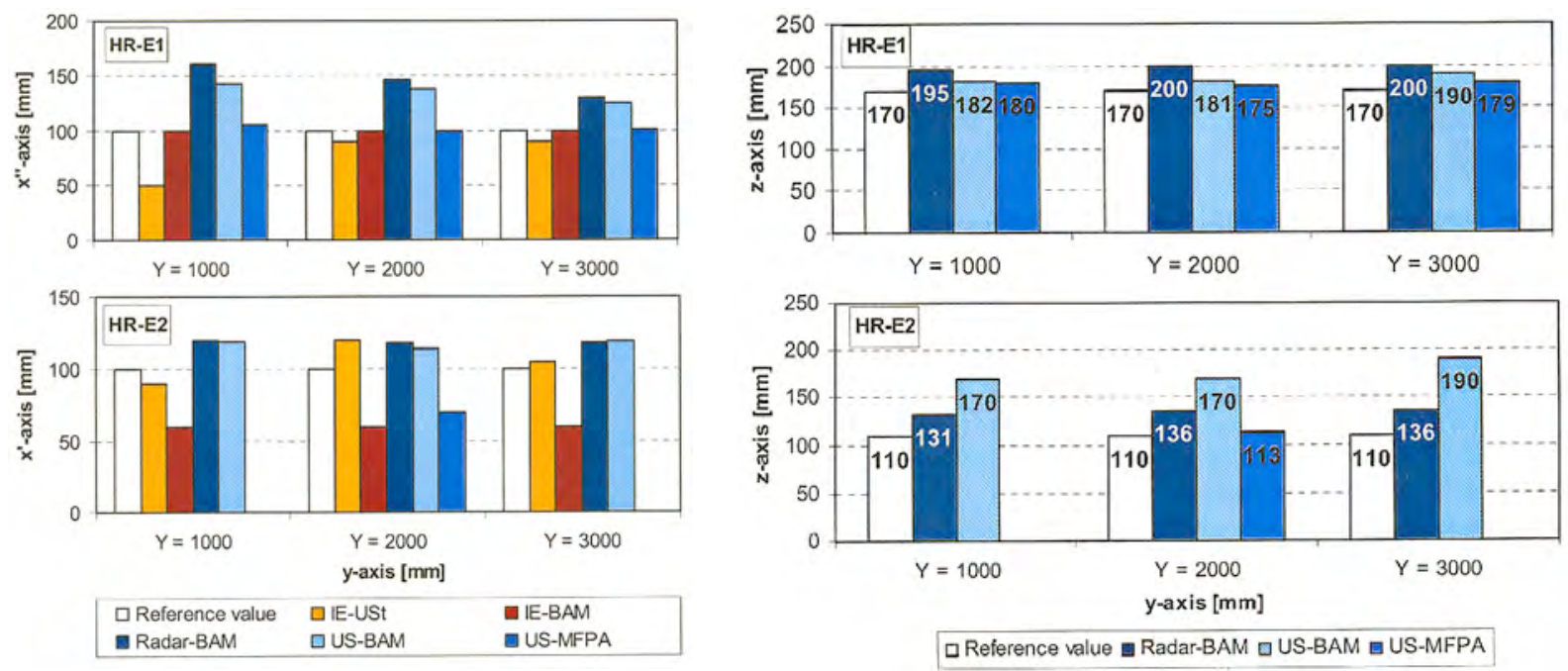

(a) Localization of tendon ducts.

(b) Concrete cover determination.

Figure 5.22 Detection of tendon ducts.

Source: R. Beutel, H-W. Reinhardt, C.U. Grosse, A. Glaubitt, M. Krause, C. Maierhofer, D. Algernon, H. Wiggenhauser, and M. Schickert, "Performance Demonstration of Non-Destructive Testing Methods," European Conference on NDT, Paper Tu.3.2.2, 9 pp., Berlin, Germany, 25-29 September 2006.

A three-dimensional scanner incorporating an ultrasonic transducer and water coupling was applied to the large concrete slab test specimen at BAM to make measurements at a tendon duct (5.12). The tendon duct had a diameter of $80 \mathrm{~mm}$, a concrete cover of $180 \mathrm{~mm}$, and contained an area that was only partly grouted to simulate a defect. The defect area was determined using $\gamma$-radiography. Measurements were carried out on a 2 by $0.4 \mathrm{~m}^{2}$ plane as shown in Figure 5.23. Figure 5.24a presents a two-dimensional cut along the tendon duct. The increased reflectivity in the figure starting at $\mathrm{x}=2035 \mathrm{~mm}$ was due to the presence of the artificial grouting flaw that extended from $\mathrm{x}=1900$ to $\mathrm{x}=2800 \mathrm{~mm}$. Shading at regular intervals of $150 \mathrm{~mm}$ resulted from the presence of lateral reinforcement. A threedimensional image (synthetic aperture focusing technique) of the area shown in Figure 5.24a is provided in Figure $5.24 \mathrm{~b}$. The image of the tendon duct again is more complete where the embedded grouting flaw is present. Part of the steel reinforcement is visible above the tendon duct. While radar or impact echo methods are good for simple thickness or detection measurements, it was concluded that ultrasound seems to have the highest potential for high resolution imaging and difficult measuring tasks. C-scan results from 3D-SAFT reconstruction are presented in

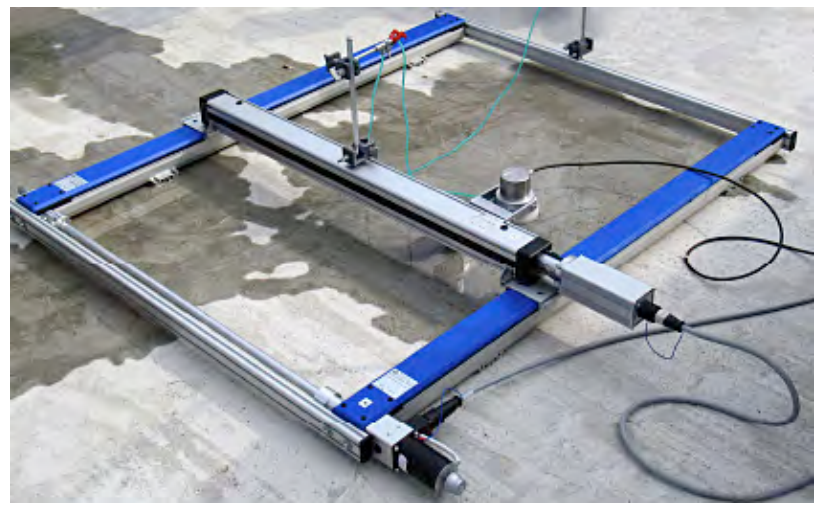

Figure 5.23 Scanner used to investigate tendon duct in large concrete test specimen.

Source: M. Schickert, U. Tümmler, and L. Bühling, "Rapid Scanning Approaches for Ultrasonic imaging of Concrete," European Conference on NDT, Poster 20, 8 pp., Berlin, Germany, 25-29 September 2006. 


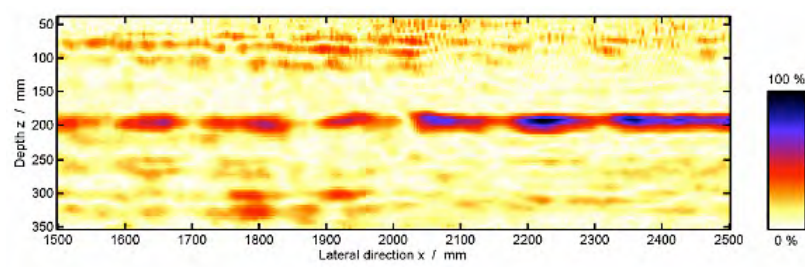

(a) Cross section of tendon duct containing artificial flaw.

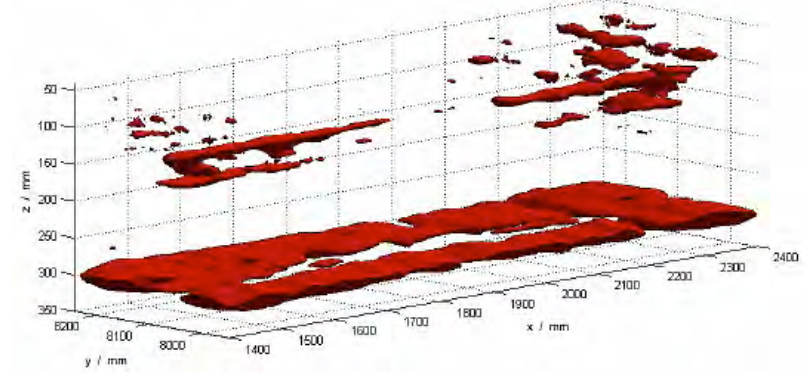

(b) Three-dimensional image of tendon duct containing artificial flaw.

Figure 5.24 Two-dimensional/three-dimensional scanner results for tendon duct containing artificial flaw.

Source: M. Schickert, U. Tümmler, and L. Bühling, "Rapid Scanning Approaches for Ultrasonic imaging of Concrete," European Conference on NDT, Poster 20, 8 pp., Berlin, Germany, 25-29 September 2006.

Figure 5.25a and show the upper side of a tendon duct. B-scan results from 3D-SAFT reconstruction are presented in Figure 5.25b and permit determination of the concrete cover $(\mathrm{z}=110 \mathrm{~mm})$ and indicates the back wall echo $(\mathrm{z}=$ $300 \mathrm{~mm})$.

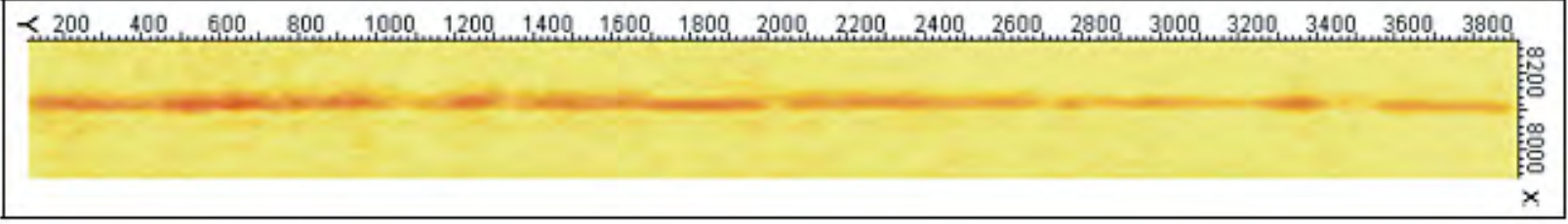

(a) C-scan (shear waves) from 3D-SAFT reconstruction indicating upper side of tendon duct.

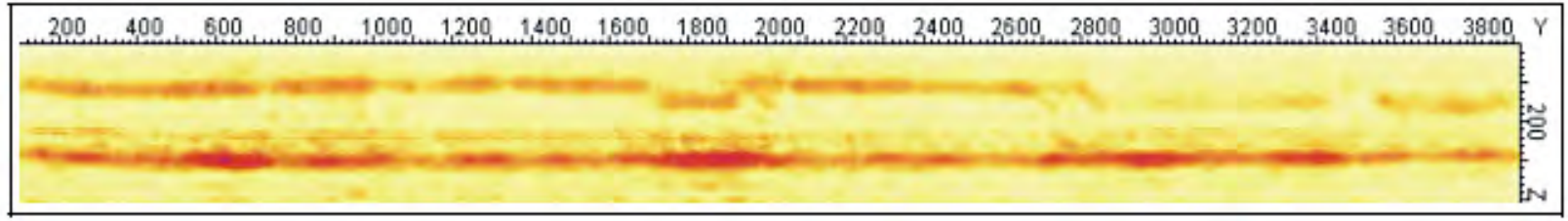

(b) B-scan (transverse waves) from 3D-SAFT reconstruction indicating concrete cover and back wall echo.

Figure 5.25 3D-SAFT reconstruction results in tendon duct D1 region

Source: M. Krause. B. Milmann, M. Schickert, and K. Mayer, "Investigation of Tendon Ducts by Means of Ultrasonic Echo Methods: A Comparative Study," European Conference on NDT, Paper Tu.3.2.1, 12 pp., Berlin, Germany, 25-29 September 2006.

\subsubsection{Foundation Slab Test Specimen}

Under the European Community Fifth Framework project, "Re-Use of Old Foundations on Urban Sites (RUFUS)," a specially designed foundation slab was constructed to investigate measurement of slab thickness and location of construction features such as piles and strip-foundations below a slab $(5.13,5.14)$. The slab had the following features:

- Area of $5 \times 5 \mathrm{~m}^{2}$

- Two sections, one of $70 \mathrm{~cm}$ and other of $120 \mathrm{~cm}$ thickness (including $5 \mathrm{~cm}$ layer of dry concrete;

- Strip foundation (width of $50 \mathrm{~cm}$ and height of $50 \mathrm{~cm}$ ) below $70 \mathrm{~cm} \mathrm{slab}$;

- Low reinforcement ratio (12-mm diameter, spacing of $150 \mathrm{~cm}$ crosswise), one section with only one layer at bottom, one section with one layer at the bottom and top of slab;

- High reinforcement ratio (28-mm diameter, spacing of $100 \mathrm{~mm}$ crosswise), one section with only one layer at bottom, one section with one layer at bottom and top of slab; 
- Pile heads with diameter of $30 \mathrm{~cm}$ below $70 \mathrm{~cm}$ slab; and

- Concrete with compressive strength of $20 \mathrm{~N} / \mathrm{mm}^{2}$ and maximum aggregate size of $32 \mathrm{~mm}$.

Figure 5.26 presents a drawing of the slab and a view inside the slab prior to concrete placement.
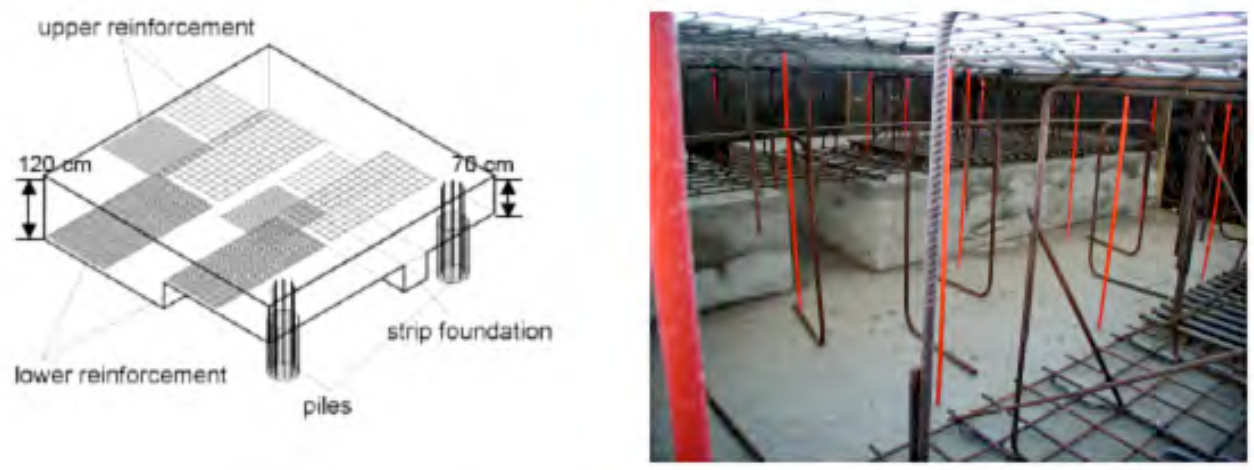

Figure 5.26 Foundation slab test specimen.

Source: A. Taffe and H. Wiggenhauser, "Validation for Thickness Measurement in Civil Engineering with Ultrasonic Echo," European Conference on NDT, Paper Th.2.5.3, 8 pp., Berlin, Germany, 25-29 September 2006.

Investigation of the foundation slab was carried out using an array of 24 dry-point-contact transducers inputting transverse waves with maximum intensity of $25 \mathrm{kHz}$. A measuring grid of $5 \mathrm{~cm}$ was used and the total area investigated was a section 4 by $5 \mathrm{~m}^{2}$ including pile head sections and the strip foundation. Figure 5.27 presents the investigation area of the slab where $\mathrm{C}$-scans were obtained. Figure 5.28a provides scan results at a depth of $125 \mathrm{~cm}$

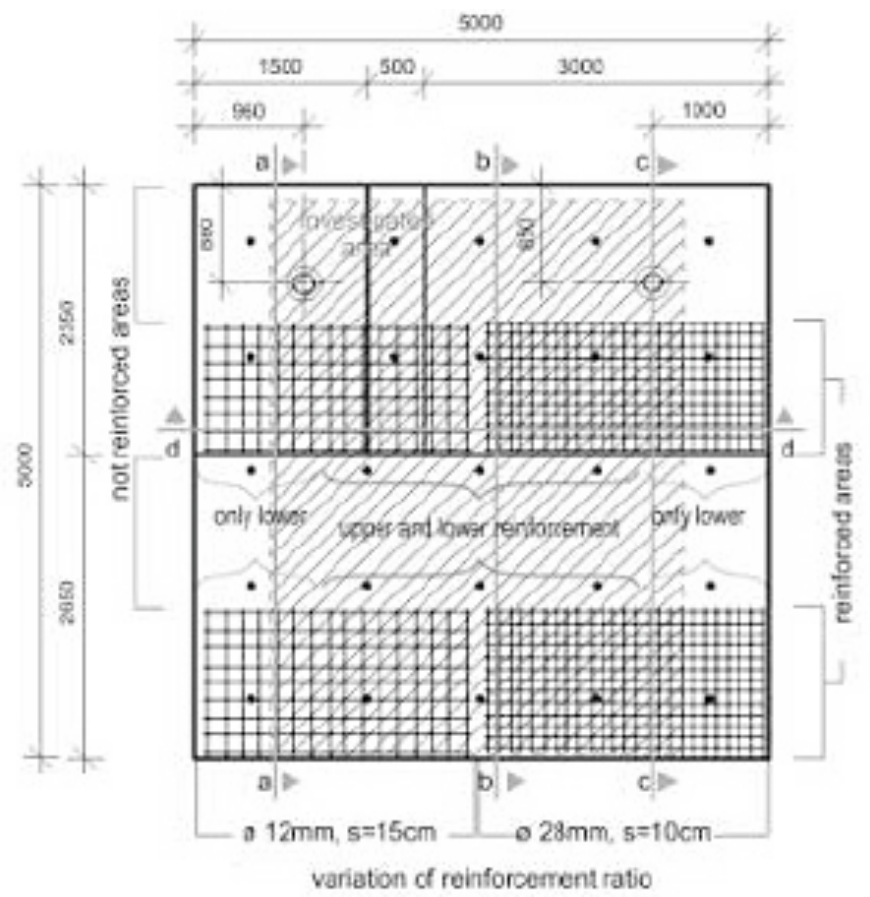

Figure 5.27 Area of foundation slab investigated by C-scans.

Source: A. Taffe, M. Krause, B. Milmann, and E. Niederleithinger, "Assessment of Foundation Slabs with USEcho in the Re-Use Process," Proceedings of International Conference on Concrete Repair, Rehabilitation, and Retrofitting (ICCRRR) held 21-23 November 2005 at University of Cape Town, South Africa, pp. 525$530,2006$. 
(120 cm slab plus $5 \mathrm{~cm}$ of dry concrete) corresponding to the back wall and indicating that the dry concrete and regular concrete layers can not be distinguished. Figure 5.28a exhibits rectangular areas where almost no reflection signals occur because of the presence of both upper and lower reinforcement $(28 \mathrm{~mm} \varnothing$, spacing $=10 \mathrm{~cm}$ crosswise). The strip foundation at $125 \mathrm{~cm}$ depth is also visible. Another scan corresponding to a $75 \mathrm{~cm}$ depth is also presented in Figure 5.28a. The scan shows the back wall reflection as well as two areas in the upper part of the figure where no back wall reflections occur indicating pile locations. Figure 5.28b presents scans at three different sections (a-a, b-b, and c-c) as noted in Figure 5.27. Section a-a results, presented at the top of Figure 5.28b, show that the back wall is clearly visible for both slab depths. The interrupted back wall reflection between $\mathrm{y}=700$ and $\mathrm{y}=1000 \mathrm{~mm}$ is the result of pile heads in this area. Results for section $b-b$ that has the high reinforcement ratio are presented in the middle of Figure 5.28b and indicate a clear back wall signal only where reinforcement is not present. Results for section c-c where reinforcement is only located at bottom of slab are presented in bottom of Figure $5.28 \mathrm{~b}$ and indicate that both the reinforcement and back wall provide reflections, however, reflections from the reinforcement and back wall can only be distinguished in the $75-\mathrm{cm}$ thick section. Section d-d in Figure 5.27 was also scanned.
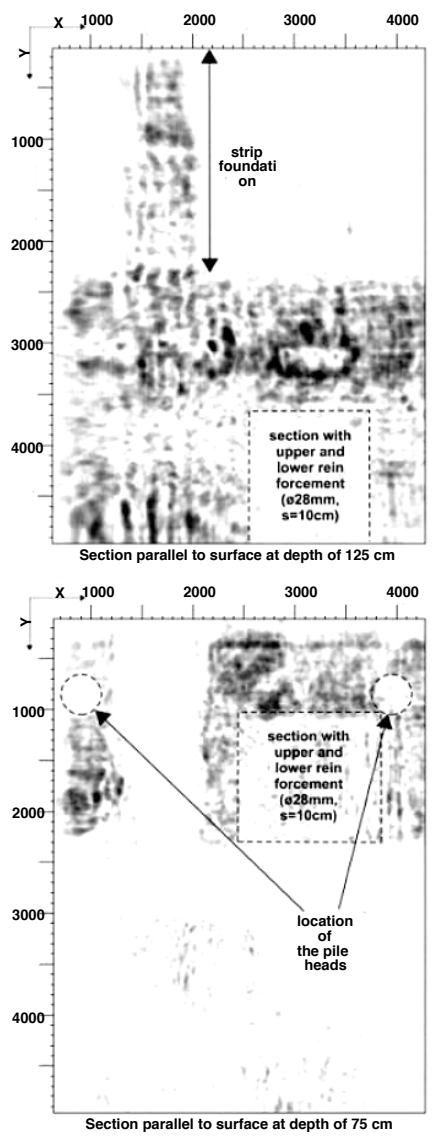

(a) Sections of foundation slab parallel to surface at depths of $125 \mathrm{~cm}$ and $75 \mathrm{~cm}$.

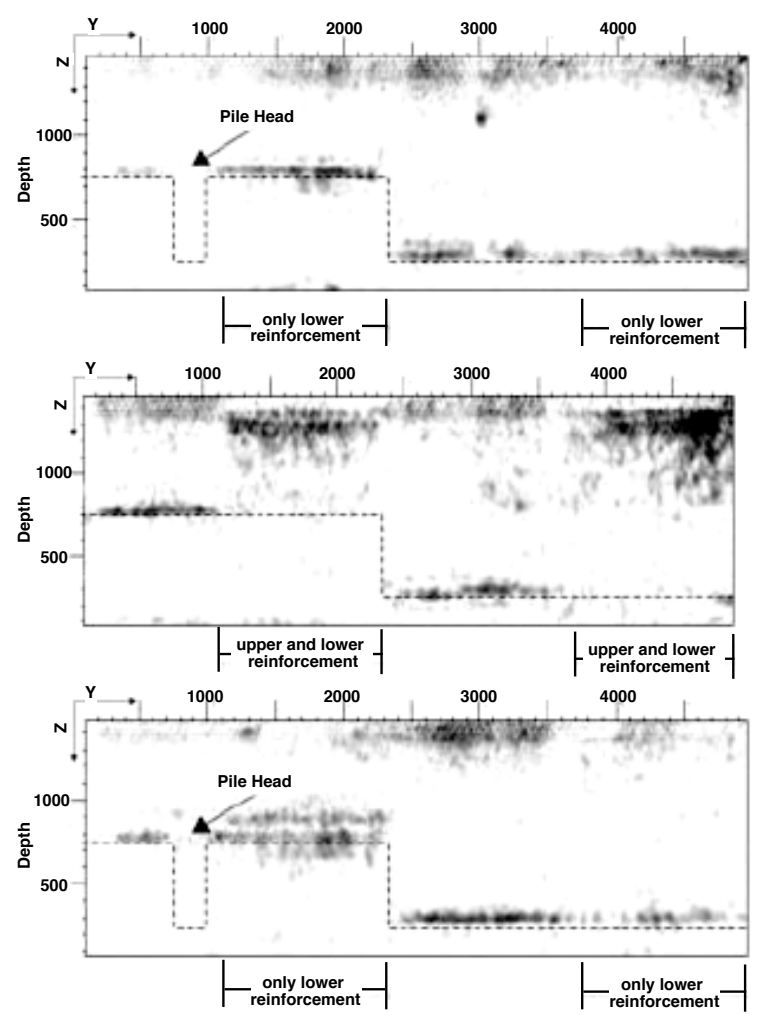

(b) Cross-sections of slab (reference Fig. 5.27): top = section a-a (rebar $\varnothing=12 \mathrm{~mm}$, space $=15 \mathrm{~cm}$, lower reinforcement only); middle $=$ section $\mathrm{b}-\mathrm{b}($ rebar $\varnothing=28 \mathrm{~mm}$, space $=10 \mathrm{~cm}$, upper and lower reinforcement only); bottom $=$ section $\mathrm{c}-\mathrm{c}$ (rebar $\varnothing=28 \mathrm{~mm}$, space $=10 \mathrm{~cm}$, lower reinforcement only).

Figure 5.28 C-scan thickness and geometry results for foundation slab.

Source: A. Taffe, M. Krause, B. Milmann, and E. Niederleithinger, "Assessment of Foundation Slabs with USEcho in the Re-Use Process," Proceedings of International Conference on Concrete Repair, Rehabilitation, and Retrofitting (ICCRRR) held 21-23 November 2005 at University of Cape Town, South Africa, pp. 525530, 2006.

Results of this scan are presented in Figure 5.29 and provide the geometry of the slab and the location of the piles. Back wall reflections at $75 \mathrm{~cm}$ and $125 \mathrm{~cm}$ are clearly visible. The interrupted back wall echoes at $75 \mathrm{~cm}$ between $\mathrm{x}=800$ and $1100 \mathrm{~mm}$ and $\mathrm{x}=3850$ and $4150 \mathrm{~mm}$ indicate the locations of the pile heads. Overall results of this study indicate that reliable thickness measurements can be made for slabs having thicknesses up to $75 \mathrm{~cm}$ and areas with relatively high reinforcement ratios and up to $1.2 \mathrm{~m}$ where reinforcement ratios are low or areas where 
reinforcement is absent. Presence of debonded layers will lead to significant reflections with no possibility of obtaining information at greater depths beyond that point. Back wall and reinforcement reflections can be distinguished only in areas with low reinforcement ratios.

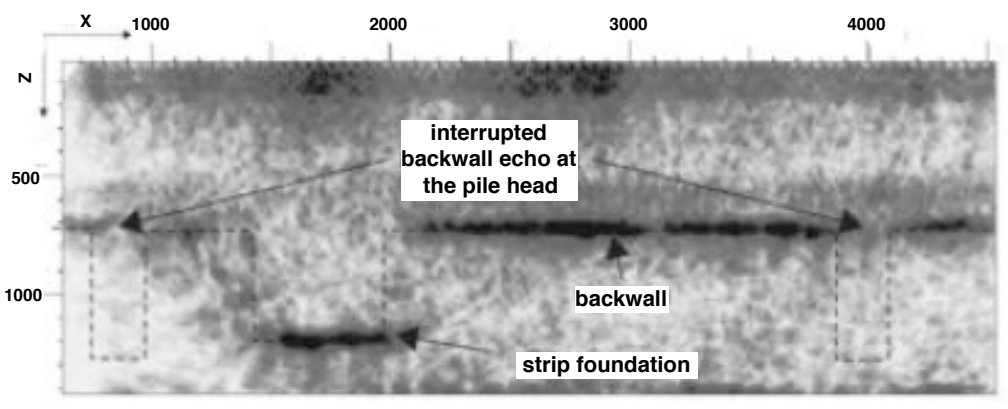

Figure 5.29 Cross section d-d of foundation slab.

Source: A. Taffe, M. Krause, B. Milmann, and E. Niederleithinger, "Assessment of Foundation Slabs with USEcho in the Re-Use Process," Proceedings of International Conference on Concrete Repair, Rehabilitation, and Retrofitting (ICCRRR) held 21-23 November 2005 at University of Cape Town, South Africa, pp. 525$530,2006$.

Additional ultrasonic echo tests were performed on the foundation slab in Figure 5.26 to evaluate the uncertainty in results as influenced by slab thickness and amount of built-in reinforcement (5.14). Thickness of this slab was well defined using reference measuring devices that had been incorporated into the slab that allowed measurement of the as-built thickness in different locations with a total standard deviation of $\pm 10 \mathrm{~mm}$. Figure 5.30a presents an example of an ultrasonic echo scan over the slab depth between the two piles. Figure $5.30 \mathrm{~b}$ presents standard deviation results that were obtained at sections of the slab that were either $70 \mathrm{~cm}$ or $120 \mathrm{~cm}$ thick and contained different reinforcement contents. Data noted as being improved was adjusted through an approach that involved creation of the envelope of the transit time curve, however, how this was done was not discussed in the reference. For the problem addressed it was concluded that ultrasonic echo with transverse waves was valid (standard deviation $\leq 5 \%$ ) for a thickness range between 70 and $120 \mathrm{~cm}$ from areas unreinforced to areas having two layers of reinforcement (28 $\mathrm{mm} \varnothing$ with $10 \mathrm{~cm}$ spacing).

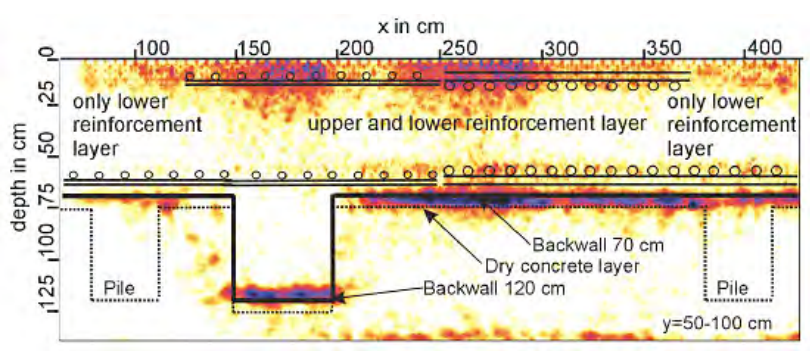

(a) Ultrasonic pulse echo scan between two piles of slab in Figure 5.26.

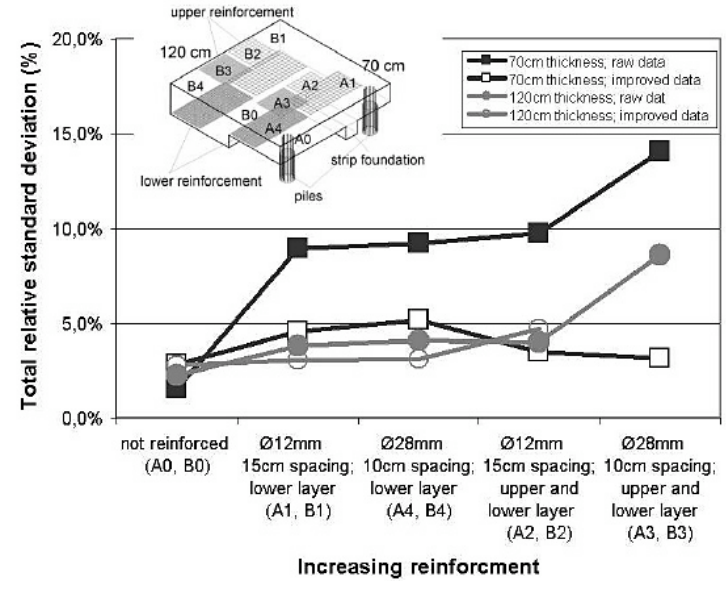

(b) Standard deviation results of thickness measurements in relation to slab thickness, reinforcement content, and data assessment.

Figure 5.30 C-scan thickness and geometry results for foundation slab.

Source: A. Taffe and H. Wiggenhauser, "Validation for Thickness Measurement in Civil Engineering with Ultrasonic Echo," European Conference on NDT, Paper Th.2.5.3, 8 pp., Berlin, Germany, 25-29 September 2006. 


\subsubsection{Simulated Bridge Section with Faults}

A research project was conducted investigating nondestructive test methods that might be applied to examination of bridge structures (5.15). Two test specimens $2 \times 1.5 \times 0.7 \mathrm{~m}^{3}$ were fabricated using a concrete having a nominal compressive strength of $45 \mathrm{MPa}$ and maximum aggregate size of $16 \mathrm{~mm}$. The specimens contained metal ducts with different grouting and compaction faults. Each of the specimens contained two areas with different reinforcing bar arrangements (without rebars; mesh sizes of either 150,75, or $50 \mathrm{~mm}$ ). The rebars had a diameter of $12 \mathrm{~mm}$ and stirrups were included in the test articles. The overall objective was to compare different echo methods employed for nondestructive testing of concrete: impulse-radar, ultrasonic, and impact-echo. The echo methods chosen were methods that only required one-sided access. Figure 5.31 presents the construction plan of test article I (Side B) having an area without reinforcing bars and an area with a mesh size of $150 \mathrm{~mm}$. Elastic and dielectric constants and pore structure of the concrete were determined using core samples removed from the specimen. Specific problems examined included: localization of metal ducts in concrete members with different types of reinforcing rebars, measuring the concrete cover over ducts, localization of compaction faults around ducts and of grouting faults in the ducts, and localization of compaction faults in concrete.

Two groups (BAM, Berlin; HOCHTIEF AG, Frankfurt) utilized impulse-radar to locate the tendon ducts with the results summarized in Figure 5.31. The results shown in red were obtained by HOCHTIEF AG and the ones in blue were obtained by BAM. The measured position of the ducts was confirmed at the end of the testing program by destructive testing. The maximum difference between the radar localization and true position of a duct was $\pm 40 \mathrm{~mm}$. Results thus confirmed that radar could reliably locate tendon ducts even at a depth of $280 \mathrm{~mm}$ in areas

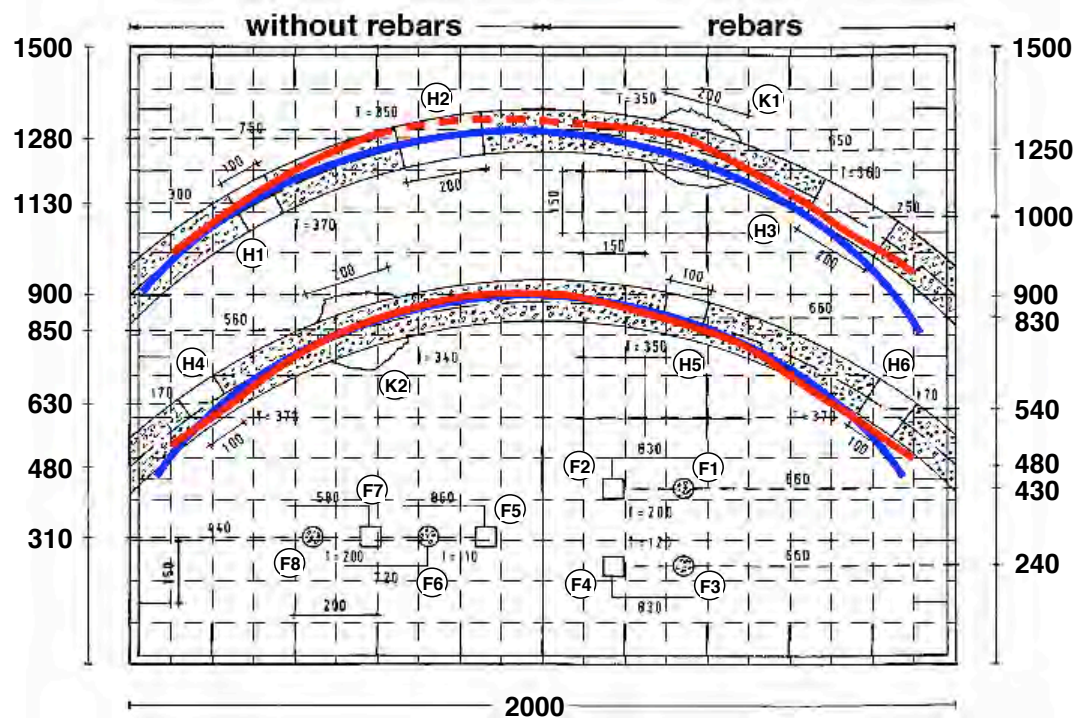

Figure 5.31 Construction drawing of simulated bridge section slab with ducts localized by impulse radar.

Source: H. Wiggenhauser, M. Krause, and J. Krieger, "Tests and Assessments of NDT Methods for Concrete Bridges," Proceedings of $8^{\text {th }}$ International Conference on Structural Faults and Repair 99, Session - NDT of Bridges, London, United Kingdom, July 15-19, 1999.

where the reinforcing congestion is low (e.g., mesh size $150 \mathrm{~mm}$ ). However, for specimen II in which the rebars had a mesh size of either 75 or $50 \mathrm{~mm}$, the reinforcement was too dense for radar to localize the ducts.

The two ducts in specimen I (Figure 5.31) each contained three voids and one compaction defect. Figure 5.32 presents an overview of the results obtained from ultrasonic testing of specimen I. Injection faults $\mathrm{H} 7$ in upper tendon duct and $\mathrm{H} 8$ in lower tendon duct were unintentional. Results obtained by the linear synthetic aperture focusing technique were able to localize several of the defects (e.g., voids $\mathrm{H} 4$ and $\mathrm{H} 5$, and compaction fault K2). Defects near the edges of the specimen could not be localized because they could only be exposed to ultrasonic waves from one direction. Unintentional faults $\mathrm{H} 7$ and $\mathrm{H} 8$ could not be identified. Impact echo was able to correctly determine the specimen thicknesses, but was not able to identify the tendon ducts. Voids F1 to F4 in the area of the specimen without reinforcing bars of specimen I could be localized by impact echo. 


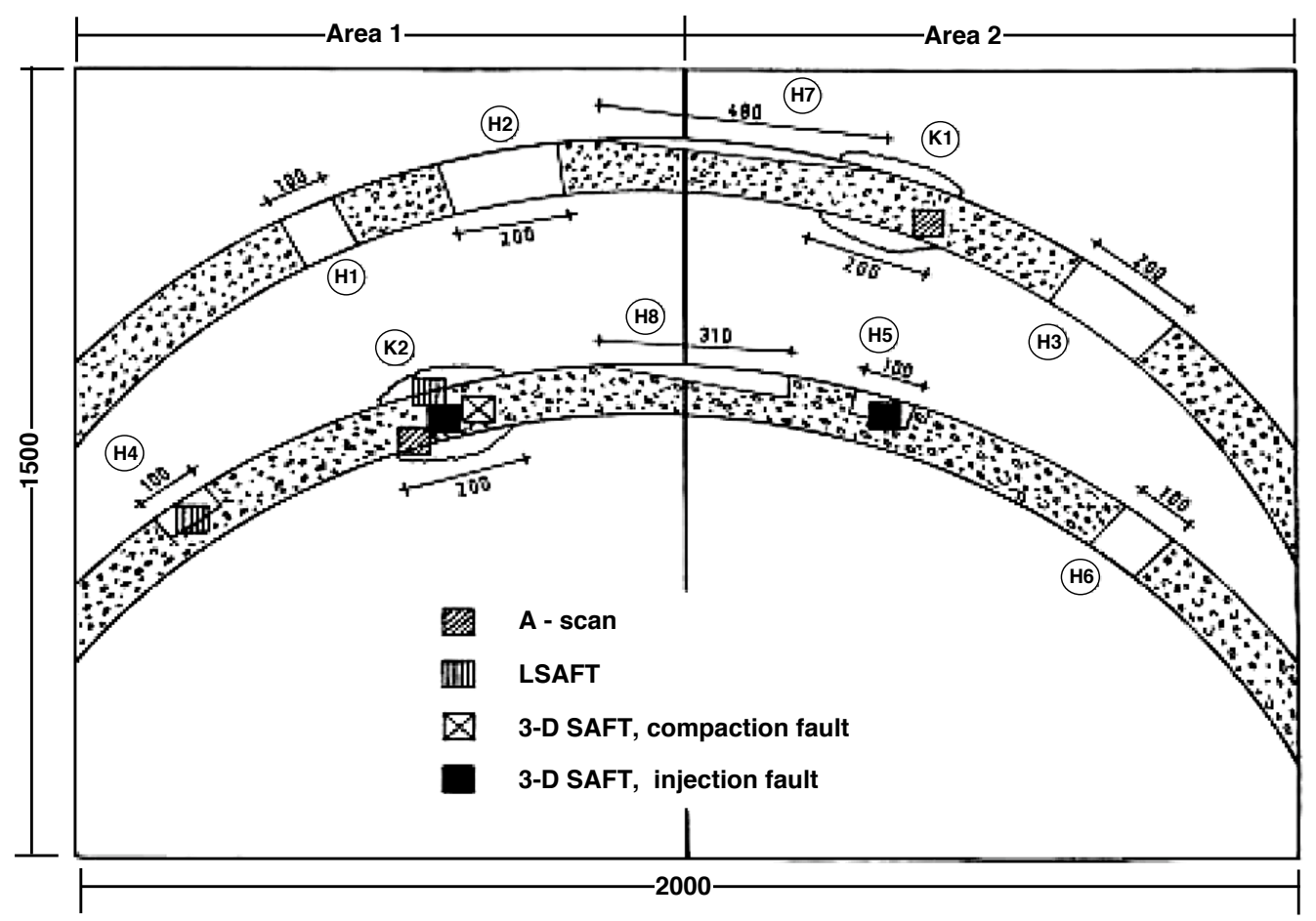

Figure 5.32 Results of ultrasonic measurements compared to destructive test of specimen I.

Source: H. Wiggenhauser, M. Krause, and J. Krieger, "Tests and Assessments of NDT Methods for Concrete Bridges," Proceedings of $8^{\text {th }}$ International Conference on Structural Faults and Repair 99, Session - NDT of Bridges, London, United Kingdom, July 15-19, 1999.

Results obtained from the investigation are summarized in Table 5.7. Radar and ultrasonic methods were found to be efficient means for locating tendon ducts accurately provided the rebars are not too narrowly spaced (e.g., $\geq 150 \mathrm{~mm}$ ). The combination of radar and ultrasonic echo methods was found to be useful. Radar can first be used to locate ducts and large defects followed by more detailed studies utilizing ultrasonics. When rebars have a mesh size of $150 \mathrm{~mm}$, or more, it was demonstrated that injection and compaction faults in and around tendon ducts can be identified.

Table 5.7 Overview of results for simulated bridge sections

\begin{tabular}{|c|c|c|c|c|c|c|c|}
\hline \multirow{3}{*}{ Method } & \multicolumn{4}{|c|}{ Measurement of } & \multicolumn{3}{|c|}{ Localization of } \\
\hline & \multirow[t]{2}{*}{ Thickness } & \multicolumn{3}{|c|}{$\begin{array}{l}\text { Concrete cover of ducts } \\
\text { (Mesh size in mm) }\end{array}$} & Voids in & \multicolumn{2}{|c|}{$\begin{array}{c}\text { Compaction } \\
\text { faults in }\end{array}$} \\
\hline & & (None) & $(150)$ & (75) & \multicolumn{2}{|c|}{ Ducts } & Concrete \\
\hline Radar & Good & Good & Good & No & & & \\
\hline Ultrasonic Echo & & & & & & & \\
\hline A-scan analysis & Good & Good & Good & No & No & Possible & \\
\hline Array & Good & Good & Possible & No & No & No & \\
\hline B-scan analysis & Good & Good & No & No & No & No & \\
\hline B-scan and LSAFT & Good & Good & Good & Possible & Possible & Possible & Possible \\
\hline 2D-Aperture (laser vibrom.) & Good & Good & Good & Good & No & No & \\
\hline 3D-SAFT & Good & Good & Good & Good & Possible & Possible & \\
\hline Impact Echo & Good & No & No & No & No & No & Possible \\
\hline
\end{tabular}

Source: H. Wiggenhauser, M. Krause, and J. Krieger, "Tests and Assessments of NDT Methods for Concrete Bridges," Proceedings of $8^{\text {th }}$ International Conference on Structural Faults and Repair 99, Session - NDT of Bridges, London, United Kingdom, July 15-19, 1999. 


\subsubsection{Specimens for Imaging Honeycomb and Cracks in Concrete Elements}

BAM and the Fraunhofer Institute für Zerstörunfsfreie Prüfverfahren (IZFP - Saarbrücken, Germany) cooperate in the area of ultrasonic imaging with BAM developing the techniques applying monostatic impulse echo measurement, two-dimensional scanning using arrays, and a laser vibrometer as an ultrasonic receiver, and IZFP developing and applying the data evaluation by means of reconstruction calculation (3D-SAFT, synthetic aperture focusing technique). Primary inspection problems addressed include localization and determination of the concrete cover of reinforcement bars and tendons, measuring thickness and geometry of structures, localization of tendon ducts, especially grouting defects and compaction faults around tendon ducts; and localization of delamination in multilayered structures. As a part of the research project FOR 384, "Non-destructive Evaluation of Concrete Structures Using Acoustic and Electro-Magnetic Methods," funded by the Deutsche Forschungsgemeinschaft (DFR) (http://www.for384.uni-stuttgart.de/FOR english/index_FORenglish.htm), a research program was conducted related to localization of grouting defects and honeycombing in concrete foundation slabs and on the characterization of surface cracks (5.16).

The $1.4 \times 1.4 \times 0.34 \mathrm{~m}^{3}$ test slab was prepared at the University of Karlsruhe using concrete having a maximum aggregate size of $32 \mathrm{~mm}$ and contained rebar meshes at the top and bottom of the slab. The diameter of the rebars was $25 \mathrm{~mm}$ and the mesh size was $125 \mathrm{~mm}$. Artificial honeycombing was produced by gravel pockets and styrofoam balls were used to simulate voids in the concrete. Figure 5.33a presents one of the concrete forms prior to concrete placement. An overview of the scanning lines used to investigate the specimen is presented in Figure 5.33b. The results of the 3D-SAFT reconstruction from scanning line 1 are presented in Figure 5.34. The top image is a vertical slice (B-scan parallel to y) showing honeycombing at $\mathrm{y}=900 \mathrm{~mm}$ whereas the honeycombing at $\mathrm{y}=140 \mathrm{~mm}$ can be localized by shading the back wall echo. The upper and lower reinforcement perpendicular to the scan direction can also be seen. The two lower images address the honeycombing and reinforcement, respectively.

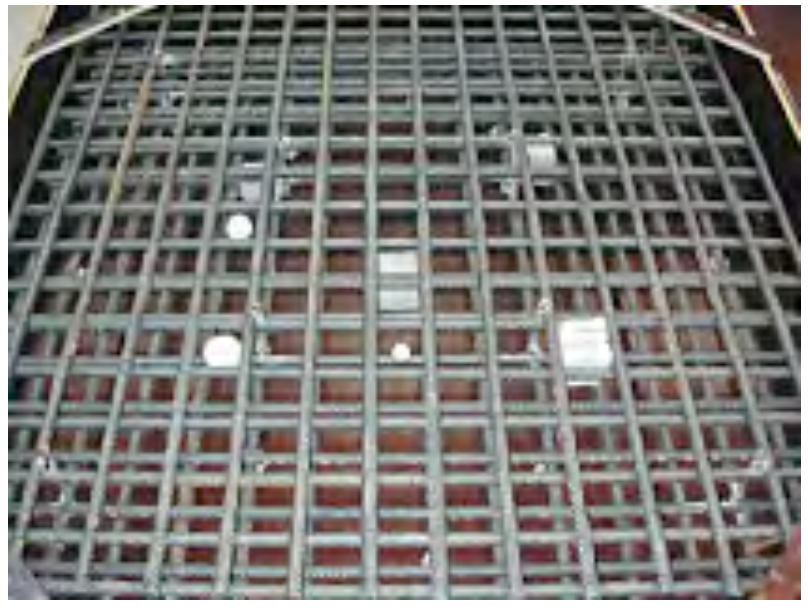

(a) Slab prior to concrete placement showing faults and voids.

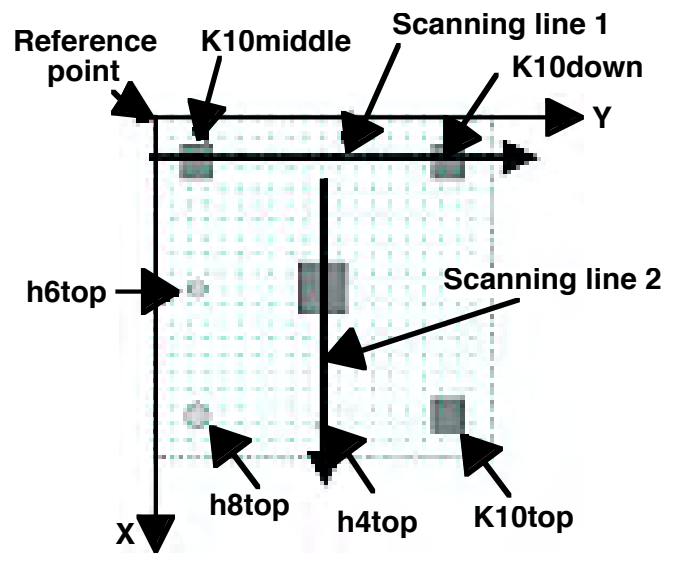

(b) Overview of scanning lines.

Figure 5.33 Slab at Karlsruhe University.

Source: M. Krause, F. Mielentz, B. Milmann, M. Müller, and V. Schmitz, "Imaging of Cracks and Honeycombing in Concrete Elements," Acoustical Imaging 27, pp. 129-137, Kluwe Academic Publishers, London, United Kingdom, 2004.

Crack depth determination is important for concrete structures because the crack depth influences durability and safety considerations. Methods considered were based on time of flight measurement, surface waves, and mechanical pulse excitation (5.16). In this study specimens with notches containing unbroken aggregate and reinforcing bars and specimens with actual cracks were investigated using the principle of forward scattering. Cracks were produced by loading $500 \times 200 \times 300 \mathrm{~mm}^{3}$ specimens in a compression machine. In the forwardscattering approach, an ultrasonic low frequency broadband transducer is placed at one side relatively close to the 


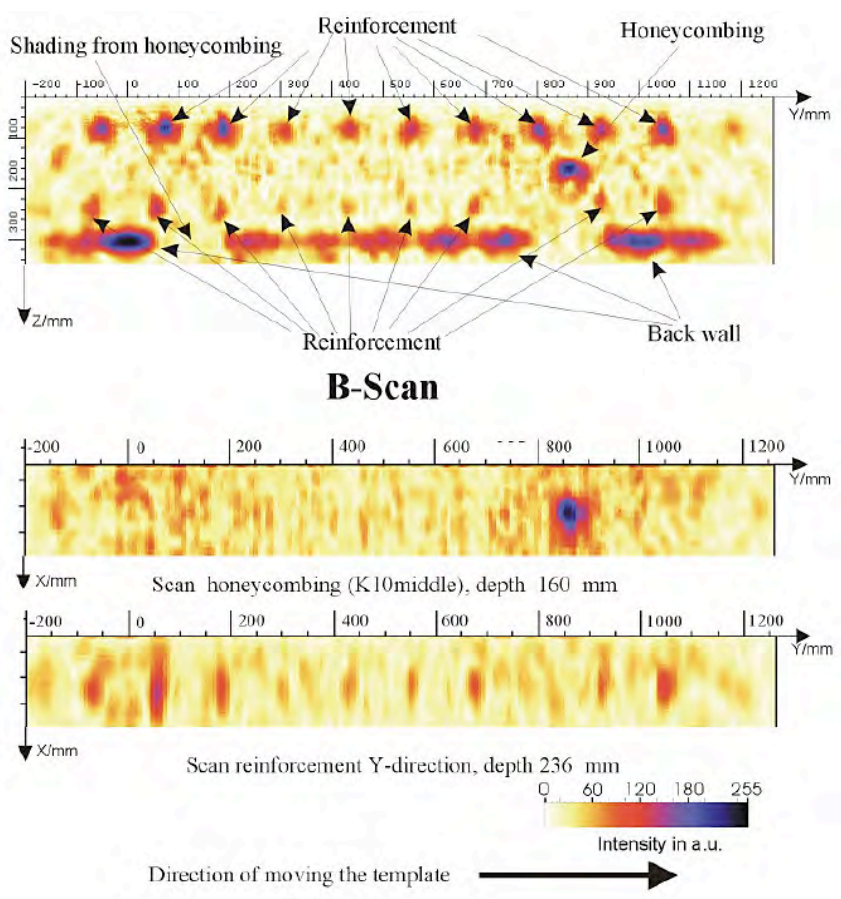

C-Scan

Figure 5.34 Results along scanning line 1.

Source: M. Krause, F. Mielentz, B. Milmann, M. Müller, and V. Schmitz, "Imaging of Cracks and Honeycombing in Concrete Elements," Acoustical Imaging 27, pp. 129-137, Kluwe Academic Publishers, London, United Kingdom, 2004.

crack and a scanning receiver on the other side of the crack to collect the ultrasonic waves. The objective was to image the signals resulting from the scatter at the crack tip as well as where the crack is bridged by rebar or unbroken aggregate. Figure 5.35a presents the principle of imaging of scattered waves and Figure 5.35b presents application of a scanning laser vibrometer as an ultrasonic receiver. A B-scan parallel to the crack axis resulting from 2D-SAFT reconstruction is presented in Figure 5.36. The image of the crack face indicates that there is a broad region of the crack (i.e., depth from 80 to $180 \mathrm{~mm}$ ) from which ultrasonic waves are scattered. The onset at $80 \mathrm{~mm}$ results from the angle distribution of the ultrasonic transducer while the scatter around $180 \mathrm{~mm}$ indicates the changing depth of crack tip. Correct characterization of the crack was verified by destructive testing.

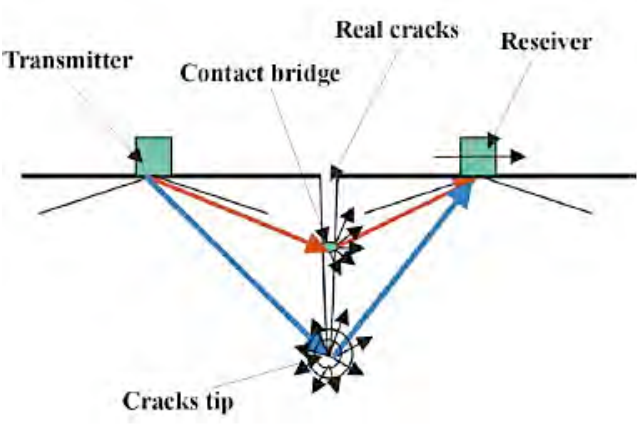

(a) Principle of imaging of scattered waves.

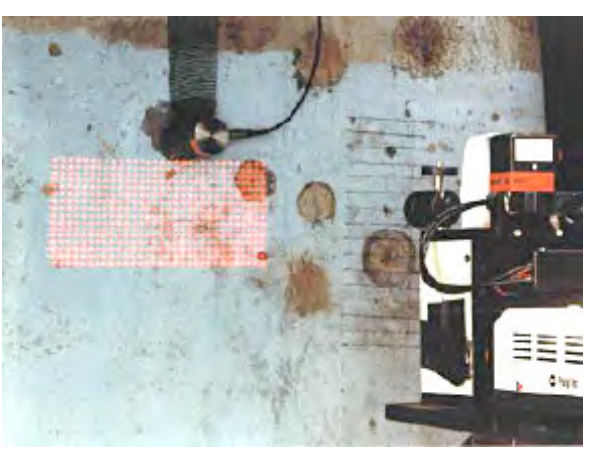

(b) Scanning laser vibrometer.

Figure 5.35 Determination of concrete crack depth by forward scattering of pressure waves.

Source: M. Krause, F. Mielentz, B. Milmann, M. Müller, and V. Schmitz, "Imaging of Cracks and Honeycombing in Concrete Elements," Acoustical Imaging 27, pp. 129-137, Kluwe Academic Publishers, London, United Kingdom, 2004. 


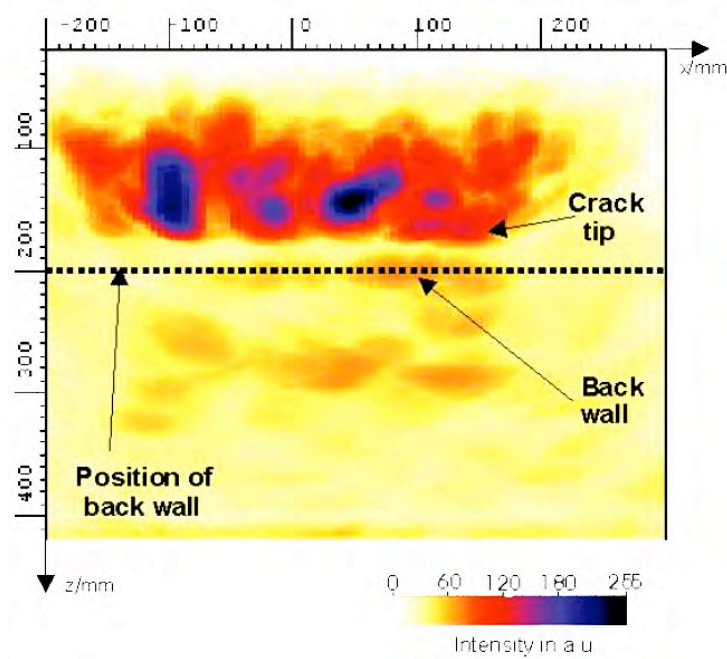

Figure 5.36 B-scan results for actual crack.

Source: M. Krause, F. Mielentz, B. Milmann, M. Müller, and V. Schmitz, "Imaging of Cracks and Honeycombing in Concrete Elements," Acoustical Imaging 27, pp. 129-137, Kluwe Academic Publishers, London, United Kingdom, 2004.

\subsubsection{Slab with Voids of Various Size and Depth}

A concrete test specimen was built for the purpose of investigating the influence of size and depth of voids in concrete on the detectability by active impulse thermography (5.17,5.18). The specimen, presented in Figure 5.37a, had a size of $1.5 \times 1.5 \times 0.5 \mathrm{~m}^{3}$. Prior to concreting eight voids simulated by polystyrene blocks having sizes of $20 \mathrm{x}$ $20 \times 10 \mathrm{~cm}^{3}$ and $10 \times 10 \times 10 \mathrm{~cm}^{3}$ were positioned in the mold. After curing for one year, radar and thermography measurements were initiated. Impulse radar testing was performed to determine the actual depth of the voids. Radargrams obtained using a $1.5 \mathrm{GHz}$ antenna along void nos. 1 and 4 and void nos. 5 and 7 are presented in Figure 5.37b. Results in the figure indicate that void nos. 1 and 4 were tilted slightly during concreting and void no. 7 had less concrete cover than expected.

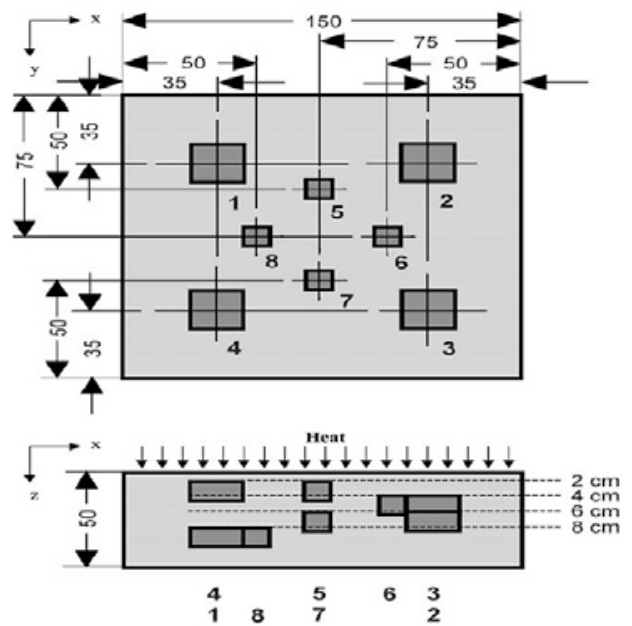

(a) Test article with polystyrene cubes representing voids.
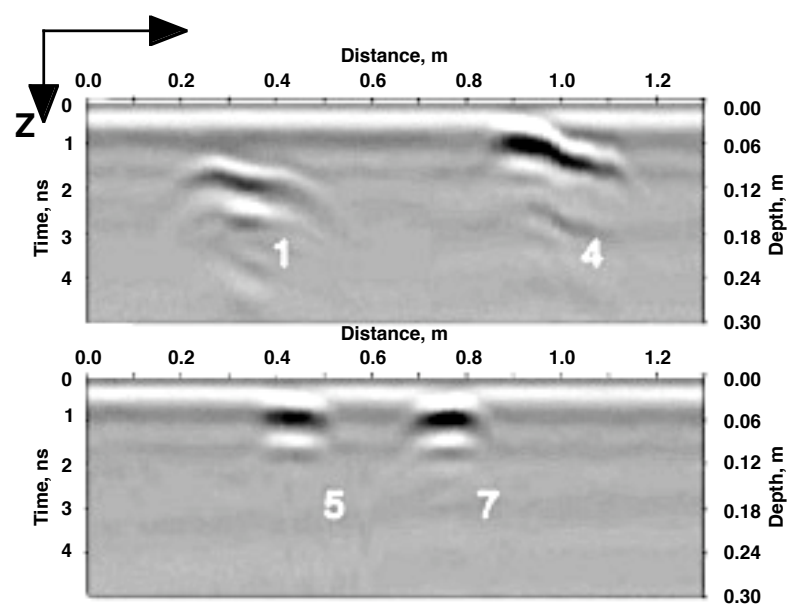

(b) Radargrams.

Figure 5.37 Void positioning in test article.

Source: C. Maierhofer, A. Brink, M. Röllig, and H. Wiggenhauser, "Detection of Shallow Voids in Concrete Structures with Impulse Thermography and Radar," NDT \& E International 36(4), pp. 257-263, June 2003. 
The experimental setup for performing the impulse thermography measurements is presented in Figure 5.38a. The detectability of voids in concrete with active impulse thermography is influenced by the size and depth of voids. Figure $5.38 \mathrm{~b}$ presents thermograms that were recorded at various cooling down periods after an initial heating period of 30 minutes. In the figure the temperature scale ranges from minimum represented by black to maximum

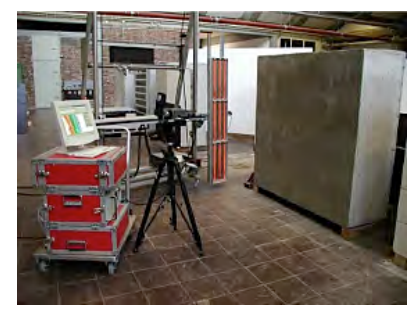

(a) Test article with polystyrene cubes representing voids.

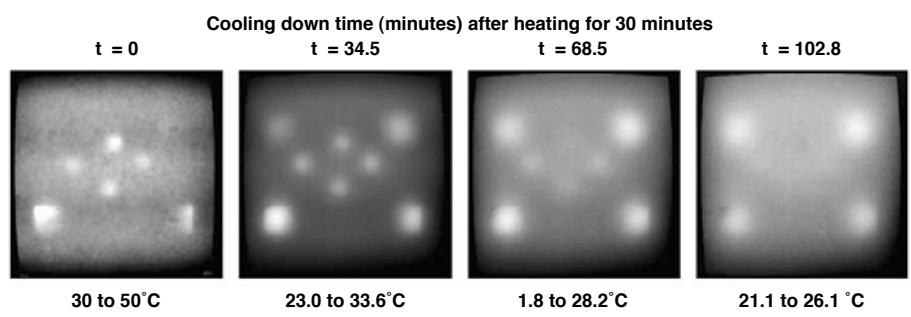

(b) Thermograms recorded at different cooling times after initial 30 minute heating time.

Figure 5.38 Impulse thermography test setup and example results.

Source: C. Maierhofer, H. Wiggenhauser, A. Brink, and M. Röllig, "Quantitative Numerical Analysis of Transient IR-Experiments on Buildings,” Infrared Physics \& Technology 46 (1-2), pp.173-180, December 2004.

represented by white. Immediately after switching off the heating source $(t=0)$ the shallow void nos. 3 and 4 and void nos. 5 to 8 at depths from 1 to $4 \mathrm{~cm}$ can be detected. The deeper voids (e.g., void nos. 1 and 2) appear after a cooling down period of 34.5 minutes.

Results of this study demonstrate that radar and impulse thermography are well suited for detection of voids in concrete structures. With radar the depth and their angular position can be determined taking into account the well known propagation velocity of electromagnetic waves in dry concrete (i.e., $1.22 \times 10^{8} \mathrm{~m} / \mathrm{s} \mathrm{here).} \mathrm{Using} \mathrm{a} 1.5 \mathrm{GHz}$ antenna voids at depths between 1 and $20 \mathrm{~cm}$ can be localized. Impulse thermography is a fast and efficient method that can locate voids in concrete with concrete covers up to $10 \mathrm{~cm}$ after a heating duration of 5 minutes.

\subsubsection{Slab with Empty Tendon Ducts}

In preparation for inspection of a concrete bridge, a test article representing a section of the bridge deck was constructed having the primary purpose of demonstrating that post-tensioning ducts could be located (5.19). The $1.5 \times 2.0 \times 0.25 \mathrm{~m}^{3}$ test article was constructed using concrete having a 32-mm maximum aggregate size. Contained in the test article was a steel reinforcement mat of $12-\mathrm{mm}$ diameter rebars having a $40 \mathrm{~cm}$ mesh with $3 \mathrm{~cm}$ of concrete cover. Three metal ducts having a $4-\mathrm{cm}$ diameter and concrete covers of 6,10 , and $8 \mathrm{~cm}$ were also contained in the test article. Figure 5.39a presents a drawing of the test article and Figure 5.39b presents the test

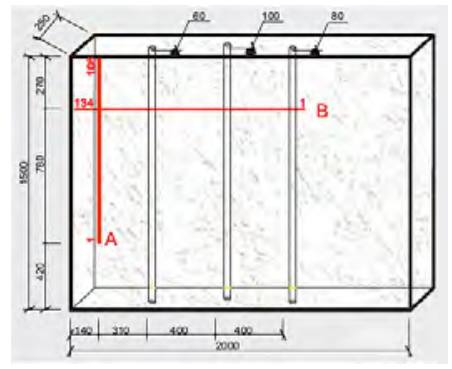

(a) Drawing of test article defining duct location.

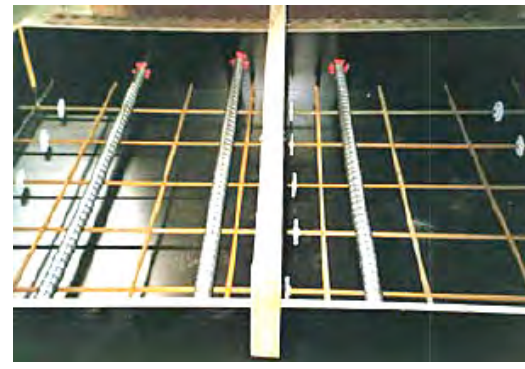

(b) Test article prior to concrete placement.

Figure 5.39 Test article for impact echo testing.

Source: C. Colla, G. Schneider, and H. Wiggenhauser, "Scanning Impact-Echo of Concrete Slab with Empty Ducts," Bundesanstalt für Materialforschung und -prüfung, Berlin, Germany, March 1, 2007 (http://www.bam.de/de/kompetenzen/fachabteilungen/abteilung_8/fg82/fg82_medien/fg82 ie _scannend_m ichelsrombach engl.pdf). 


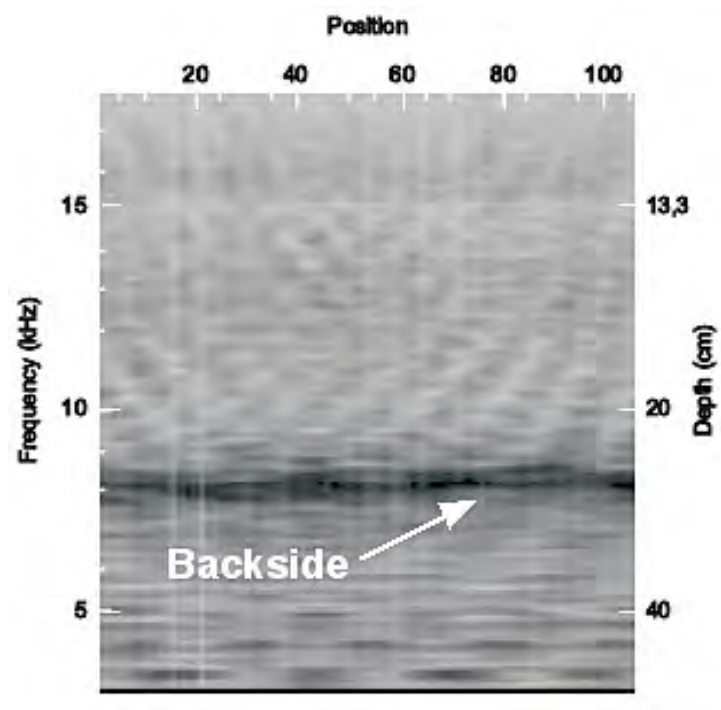

(a) B-scan from measurement line A.

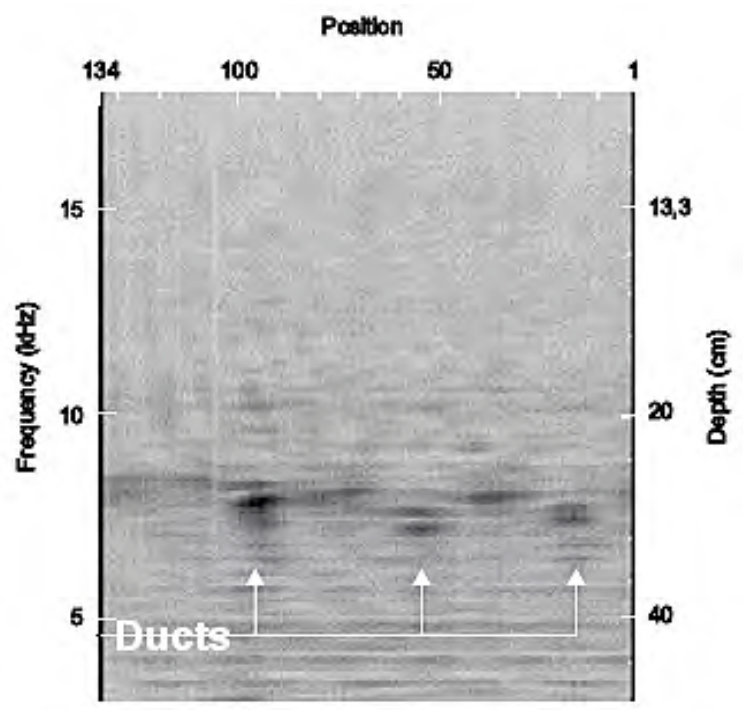

(b) B-scan from measurement line B.

Figure 5.40 Impact-echo scans for test article with empty ducts.

Source: C. Colla, G. Schneider, and H. Wiggenhauser, "Scanning Impact-Echo of Concrete Slab with Empty Ducts," Bundesanstalt für Materialforschung und -prüfung, Berlin, Germany, March 1, 2007 (http://www.bam.de/de/kompetenzen/fachabteilungen/abteilung_8/fg82/fg82_medien/fg82_ie_scannend_m ichelsrombach_engl.pdf).

article prior to concrete placement. Impulse echo measurements were made using an automated scanning system along lines parallel and transverse to the ducts. Test results indicated that impact echo easily identified the slab thickness and located the ducts with good accuracy. Figure 5.40 presents scans from along lines A and B noted in Figure 5.39a. Results demonstrate capability of impact echo to locate back wall and empty tendon ducts.

\subsubsection{Test Article with Artificial Grouting Faults}

As a part of the research project FOR 384, "Non-destructive Evaluation of Concrete Structures Using Acoustic and Electro-Magnetic Methods," funded by the Deutsche Forschungsgemeinschaft (DFR) (http://www.for384.unistuttgart.de/FOR english/index_FORenglish.htm) a research program was conducted that specifically addressed measurement of concrete cover and localization of grouting faults $(5.20,5.21)$. The program utilized relatively recent progress in producing ultrasonic transducers in the low frequency range for pressure waves $(100 \mathrm{ko} 400 \mathrm{kHz})$ and shear waves (30 to $120 \mathrm{~Hz}$ ) to investigate several test arrangements: pressure waves in pulse echo technique (single transducer, impulse-echo mode), shear waves with dry-point-contact transducers (bistatic setup), and shear waves with point-contact transducers (multistatic array).

The construction plan for the test specimen utilized in the study is presented in Figure 5.41. The specimen contained a duct with a slightly abraded surface to provide good bonding between the concrete and duct. The tendon passed through the tube that was sealed at its ends. Only a small opening was present to permit grout to flow from one side to the other. Ungrouted regions in the duct were produced by implementing a plastic tube. Styrofoam balls were also located in the specimen to simulate voids. Locations of the plastic tube inside the duct and the styrofoam balls simulating voids were verified by $\gamma$-radiography.

The specimen was scanned with a shear-wave-point-contact transducer in both orientations of polarization and by pressure waves. Figure 5.42a presents a B-scan image (3D-SAFT) reconstruction for polarization parallel to the $\mathrm{x}$ axis. The figure shows the reflection from the tendon duct with the reflection intensity enhanced from $\mathrm{x}=800 \mathrm{~mm}$ to $\mathrm{x}=1400 \mathrm{~mm}$ corresponding to the location of the void. The reflection from $\mathrm{x}=100 \mathrm{~mm}$ to $\mathrm{x}=200 \mathrm{~mm}$ is probably from an unintentional air void at the upper side of the tendon duct. A C-scan image from upper and lower side of tendon duct in Figure 5.42a is presented in Figure 5.42b and shows the $40-\mathrm{mm}$ wide air void at $\mathrm{x}=300 \mathrm{~mm}$ 


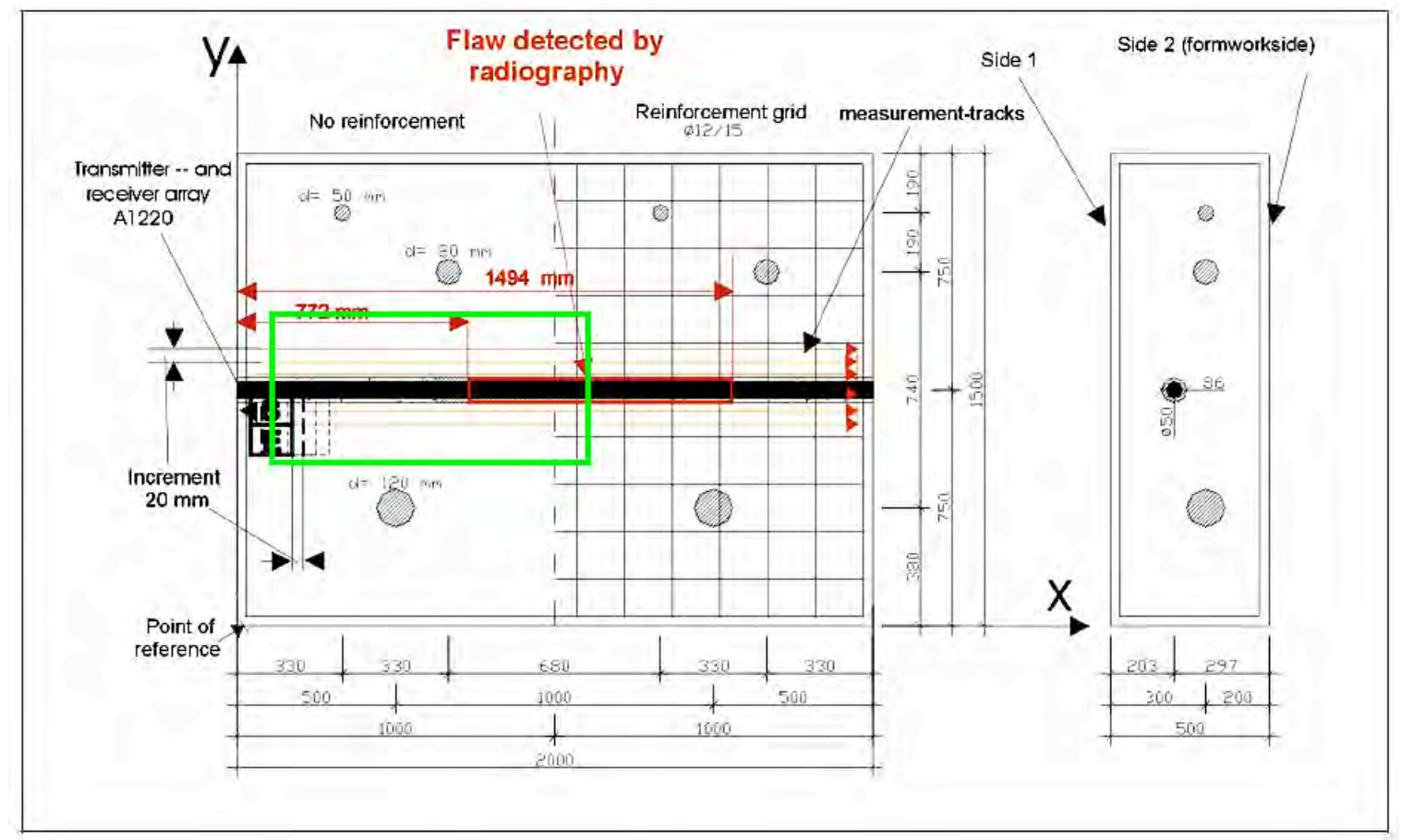

Figure 5.41 Construction plan for tendon duct investigation.

Source: M. Krause. B. Milmann, M. Schickert, and K. Mayer, "Investigation of Tendon Ducts by Means of Ultrasonic Echo Methods: A Comparative Study," European Conference on NDT, Paper Tu.3.2.1, 12 pp., Berlin, Germany, 25-29 September 2006.

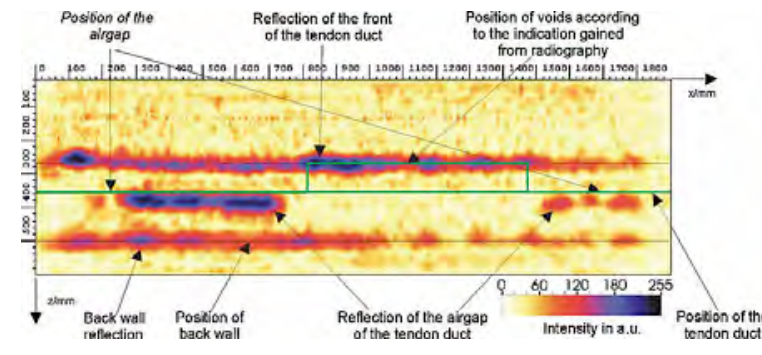

(a) B-scan image from 3D-SAFT reconstruction.

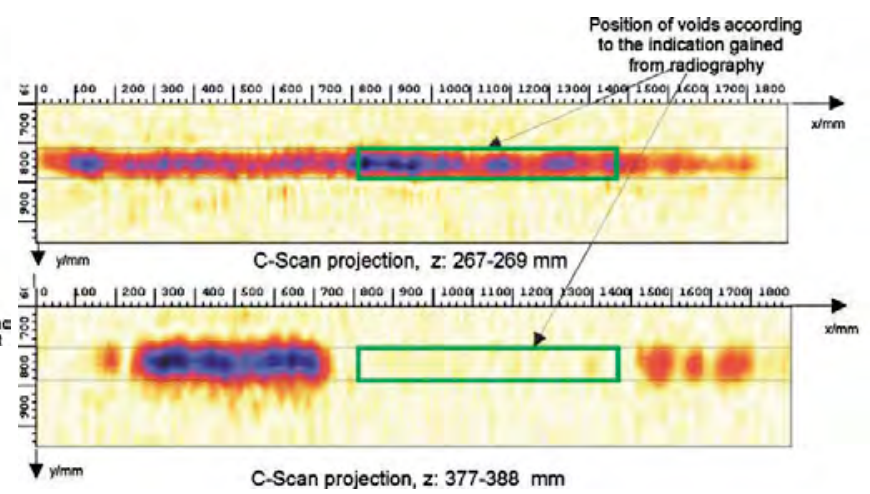

(b) C-scan images from upper and lower side of tendon duct.

Figure 5.42 Ultrasonic imaging results for test article with grouting faults.

Source: M. Krause, F. Mielentz, B. Milmann, D. Streicher, and W. Müller, "Ultrasonic Imaging of Concrete Elements: State of the Art Using 2D Synthetic Aperture," International Symposium on Non-Destructive Testing in Civil Engineering (NDT-CE-2003), Bundesanstalt für Materialforschung und -prüfung, Berlin, Germany, 2003.

to $\mathrm{x}=700 \mathrm{~mm}$. A B-scan image from 2D-SAFT reconstruction of pressure wave measurements is shown in Figure 5.43. The tendon duct imaging indicates a concrete cover of $z=251$ to $263 \mathrm{~mm}$. The variation of reflectivity exhibited in the figure by the tendon duct is the result of different filling conditions. The beginning of the large void area can be located at $x=800 \mathrm{~mm}$. Two additional indications occur in the figure parallel to the tendon duct and at greater depth between $\mathrm{x}=400 \mathrm{~mm}$ and $\mathrm{x}=700 \mathrm{~mm}$. 


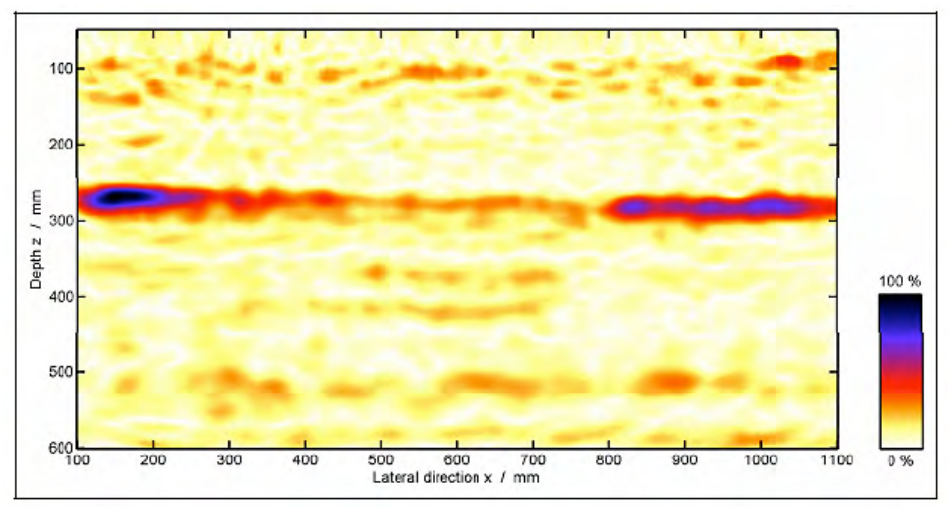

Figure 5.43 B-scan from 2D-SAFT reconstruction of tendon duct shown in Figure 5.41.

Source: M. Krause. B. Milmann, M. Schickert, and K. Mayer, "Investigation of Tendon Ducts by Means of Ultrasonic Echo Methods: A Comparative Study," European Conference on NDT, Paper Tu.3.2.1, 12 pp., Berlin, Germany, 25-29 September 2006.

\subsubsection{Simulated Containment Wall with Artificial Cracks}

A program sponsored by Institut de Radioprotection et de Sureté Nucléaire has the objective of detecting and determining crack size inside the wall of a pressurized water reactor containment and to check the defect growth between inspections (5.22). As concrete is a composite material, propagation of a wave in such a media generates heavy scattering and attenuation of the sound energy providing a poor signal-to-noise ratio of the reflected signal amplitudes. In order to increase the signal-to-noise ratio a phased array approach was selected for investigation.

The concrete test specimen used to represent a section of a containment wall was $800 \times 800 \times 600 \mathrm{~m}^{3}$ and was fabricated of a representative concrete having $25 \mathrm{~mm}$ maximum size aggregate particles. An artificial crack consisting of four facets, each having a $40 \times 70 \mathrm{~mm}^{2}$ surface area, was contained in the concrete block. The facets were located from 200 and $500 \mathrm{~mm}$ below the inspection surface and were inclined between $10^{\circ}$ and $20^{\circ}$. The facets were supposed to represent surface extensions of the crack. The concrete block and details of the simulated cracks are presented in Figure 5.44.

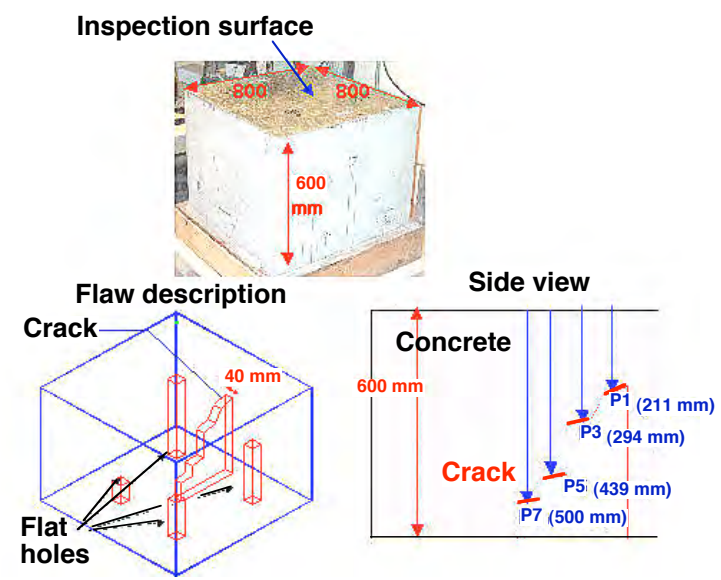

Figure 5.44 Concrete block representing containment wall section.

Source: O. Paris, C. Poidevin, J.M. Rambach, and C. Nahas, "Study of Phased Array Techniques for Concrete Inspection," European Conference on NDT, Paper Tu.3.2.3, 7 pp., Berlin, Germany, 25-29 September 2006.

Broadband transducers $(\varnothing=38 \mathrm{~mm})$ operating at $250 \mathrm{kHz}$ were utilized in the study. Results were obtained both using a single transducer (monoelement) and an array of eight transducers. Where the phased array was utilized, the procedure consisted of mechanically displacing the transducers over the concrete surface. One probe was used as a 
transmitter with the others functioning as receivers. The transmitter was then permutated to increase the data acquisition. After data acquisition, the reconstruction occurs by combining the recorded signals for each channel and position in the scan axis after a fit in time and position. The fit takes into account the delay of the reflected wave introduced by the transmitter-receiver distance. This procedure was utilized to detect the different facets of the artificial crack. Detection of the tilted reflectors was improved by adjusting the orientation of the nominal ultrasonic beam so that it was perpendicular to the flaw surface. The reconstruction procedure of 10 raw B-scans for data obtained from the block during an earlier study (5.23) using a six-transducer array is summarized in Figure 5.45. The variations of color indicate areas of different acoustical response that can correspond to a region of the flaw. A comparison of B-scan results obtained using the eight-transducer phased array with results from the single transducer is presented in Figure 5.46. A profile of the crack is superimposed on the results in order to compare the relative positions of the different facets and the reflected echoes. Comparison of the reconstructed phased array results to the actual flaw facets is shown to be good.

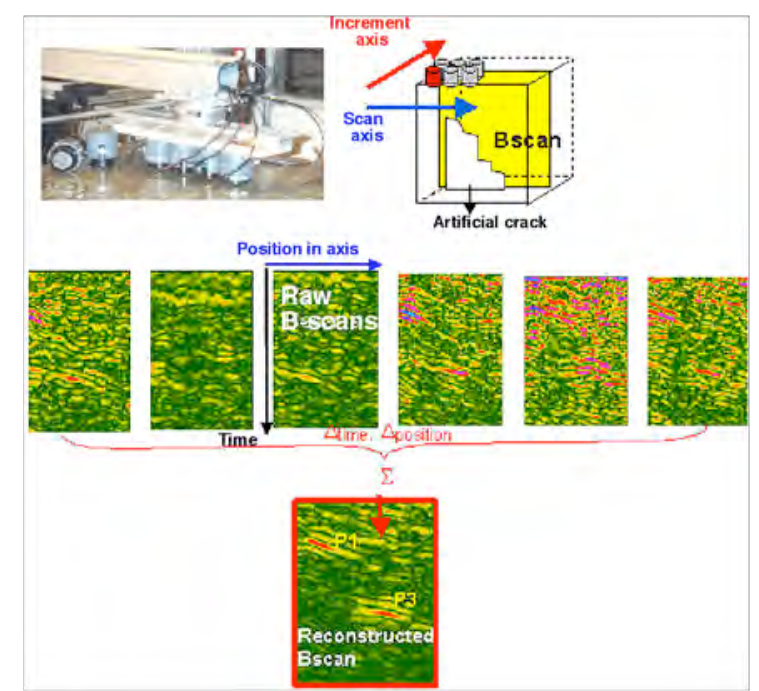

Figure 5.45 Illustration of reconstruction procedure.

Source: O. Paris, Ph. Brédif, O. Roy, J.M. Rambach, and C. Nahas, "Study of Phased Array Techniques for Cracks Characterization in Concrete Structures," International Symposium on Non-Destructive Testing in Civil Engineering (NDT-CE-2003), Bundesanstalt für Materialforschung und -prüfung, Berlin, Germany, 2003.

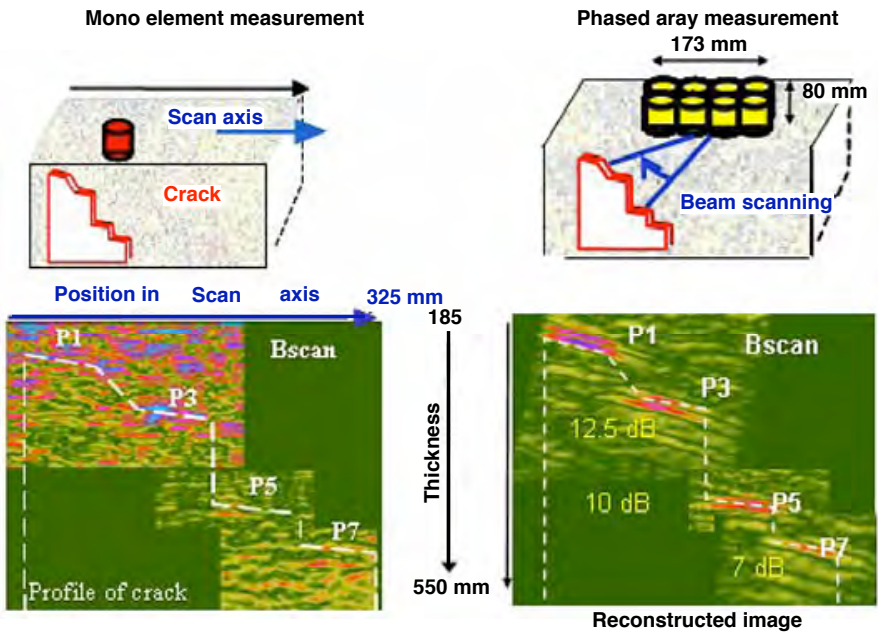

Figure 5.46 Comparison between mono element measurement and reconstructed B-scan images resulting from phased array measurements.

Source: O. Paris, C. Poidevin, J.M. Rambach, and C. Nahas, "Study of Phased Array Techniques for Concrete Inspection," European Conference on NDT, Paper Tu.3.2.3, 7 pp., Berlin, Germany, 25-29 September 2006. 


\subsubsection{Post-Tensioned Concrete Beam}

Following the decision to close and demolish the "Pont Neuf" bridge in southern France, an element of a posttensioned beam was retained for nondestructive evaluation and autopsy by hydrodemolition (5.24). Prior gamma radiography and visual inspections of window and duct openings concluded that the tendon duct grouting had been incomplete leading to water intrusion and potential infiltration of corrosive agents that resulted in tendon corrosion. This conclusion led to monitoring of the bridge by an acoustic device in 1995. An indication of a probable tendon fracture led to closure of the bridge in 1998.

The post-tensioned concrete beam selected for evaluation was $2.1 \mathrm{~m}$ high and approximately $9.1 \mathrm{~m}$ long. The height of the web was $1.10 \mathrm{~m}$ and its thickness was $0.20 \mathrm{~m}$. The beam was reinforced by vertical reinforcement and 11 post-tensioned tendons including five anchorages at the end stringer and six in the top. Figure 5.47a presents the beam and Figure 5.47b provides a ground-penetrating radar profile of the upper beam chamfer showing layout of reinforcement bars and anchorages. The goal of the nondestructive testing was to address specific needs of structural engineers: localization of prestressing tendons (layout, concrete cover thickness) and reinforcement bars (layout, concrete cover thickness, bar diameter); prestressing quality (injection state, severity of rebar corrosion and tendon failures); and concrete quality (physical pathologies, lack of concrete, heterogeneities, cracks) and chemical pathologies (carbonation, presence of chlorides and alkali-aggregate reactivity). Nondestructive testing methods investigated included covermeter, ground-penetrating radar, gamma radiography, and impact echo.
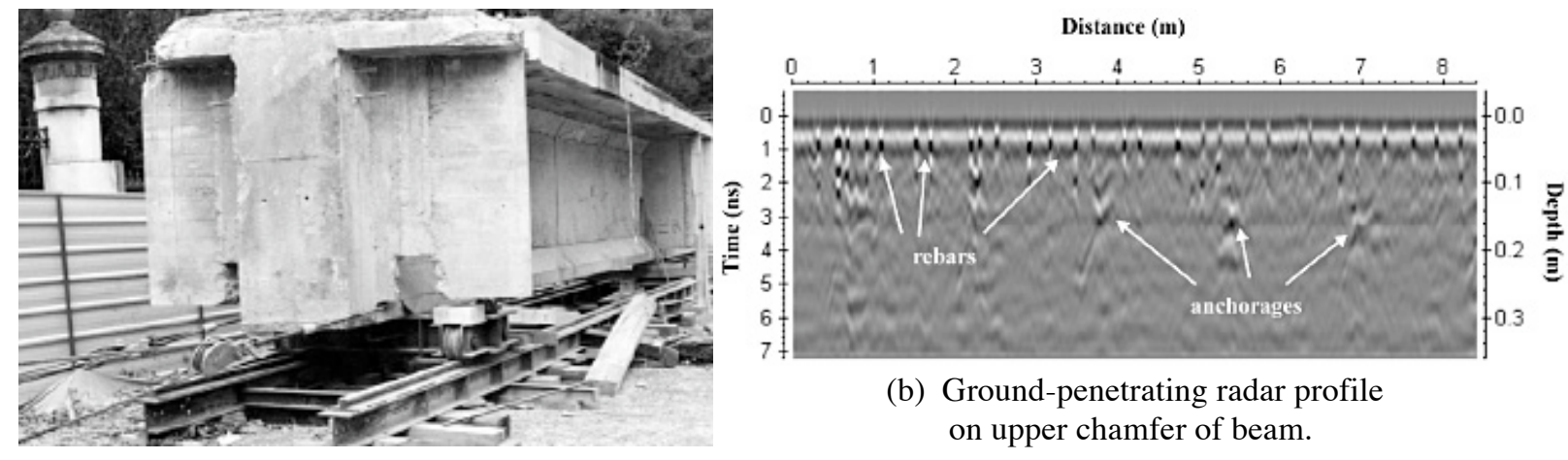

(b) Ground-penetrating radar profile on upper chamfer of beam.

(a) Beam from Pont Neuf bridge.

Figure 5.47 Test article for post-tensioned beam NDT study.

Source: X. Dérobert, C. Aubagnac, and O. Abraham, "Comparison of NDT Techniques on a Post-Tensioned Beam Before Its Autopsy,” NDT \& E International 35(8), pp.541-548, December 2002.

Results provided by the covermeter were somewhat limited in areas of high reinforcement density. The groundpenetrating radar technique was able to perform high-speed inspections and could locate reinforcement bars and tendon ducts at depths of over $30 \mathrm{~cm}$. Ground-penetrating radar $(1.5 \mathrm{GHz})$ was not able to obtain rebar diameters and could not inspect inside the metallic ducts. Gamma radiography could provide a reliable diagnosis of grouting quality and in some cases anomalies such as wire or strand fractures and wire distensions could be detected. The radiographic method used was very point specific $\left(30 \times 40 \mathrm{~cm}^{2}\right)$, had to be operated in the transmission mode with access to two sides of a structure $60 \mathrm{~cm}$ or thinner, and was relatively expensive requiring radiological protection. Figure 5.48 presents radiographs showing examples of incomplete and correct tendon grouting. Impact echo results were not available when this reference was published. Autopsy of the beam revealed a sizeable length of the duct without grout and locations where strand fracture occurred that matched results obtained by the acoustic monitoring system. It was concluded that a combination of ground-penetrating radar followed by gamma radiography provided an effective approach for evaluation of grouting quality. 


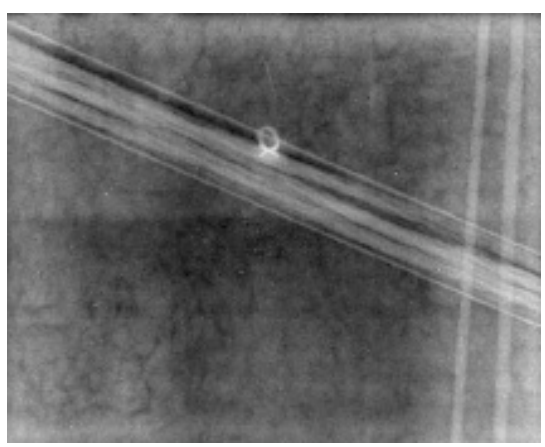

(a) Incomplete grouting (white area around tendon in central area is a void in grout).

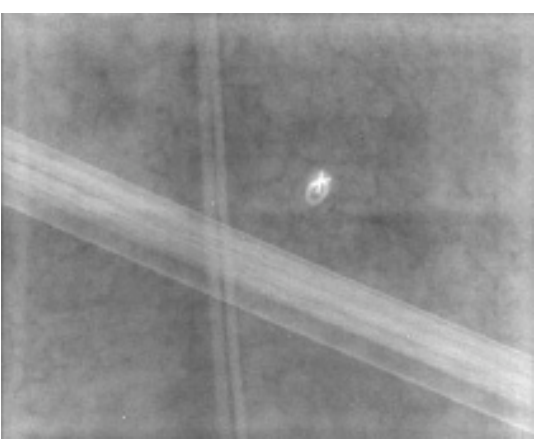

(b) Correct grouting.

Figure 5.48 Radiography of tendon ducts.

Source: X. Dérobert, C. Aubagnac, and O. Abraham, "Comparison of NDT Techniques on a Post-Tensioned Beam Before Its Autopsy," NDT \& E International 35(8), pp.541-548, December 2002.

\subsubsection{Mock-up of Containment Ring Beam with Artificial Flaws}

A large block $\left(4000 \times 4335 \mathrm{~mm}^{2}\right)$ representing a circumferential length equivalent to about $4^{\circ}$ of the ring beam of a pressurized heavy water reactor was fabricated to evaluate the impact echo method (5.25). Contained in the block were simulated voids having cylindrical shape with equal diameter and length and their flat surface facing the block surface $(50,100$, and $200 \mathrm{~mm} \varnothing$ at a depth of $500 \mathrm{~mm}$ ), reinforcing bars (diameters of 20, 32, and $45 \mathrm{~mm}$ at depth of $50 \mathrm{~mm}$, with and without delaminations), and surface opening cracks (25, 50, and $75 \mathrm{~mm}$ depth). Figure 5.49 presents the ring beam mock-up, positioning of voids, and reinforcement. A companion smaller block $(600 \mathrm{x} 600 \mathrm{x}$ $\left.1200 \mathrm{~mm}^{3}\right)$ containing $50 \mathrm{~mm}$ voids at various depths $(100,200$ and $300 \mathrm{~mm})$ and $80-\mathrm{mm}$ diameter sheath at various depths was also fabricated. The blocks were evaluated using the impact echo method.
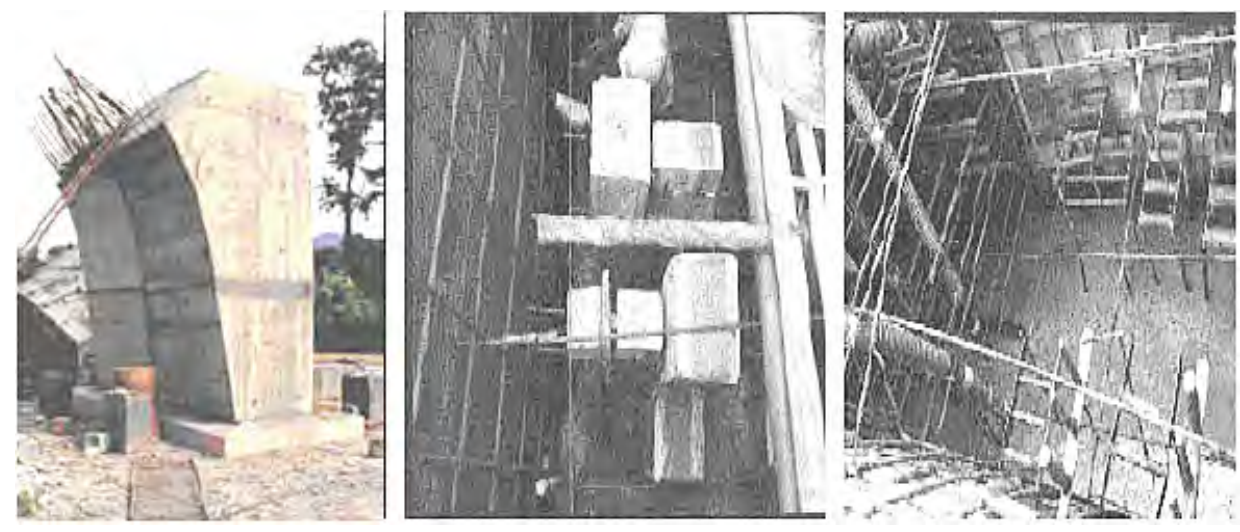

Figure 5.49 Details of ring beam mock-up.

Source: A. Kumar, B. Raj, P. Kalyanasundaram, T, Jayakumar, and M. Thavasimuthu, "Structural Integrity Assessment of a Pressurized Heavy Water Nuclear Reactor Using Impact Echo Technique," NDT \& E International 35(4), pp. 213-220, June 2002.

Impact echo results indicated a block thickness of $1618 \mathrm{~mm}$ at the location where the actual thickness was $1500 \mathrm{~mm}$, which was within the resolution limit of the system $(145 \mathrm{~mm})$. A void could be located if the ratio of its depth to the lateral dimension was less than five and a reinforcement rod could be detected if the ratio of the depth of the location to the diameter of the reinforcement was less than three. The wavelength of the elastic waves generated by the impact echo system should be at least equal to or less than the size of the void or the diameter of the reinforcement rod. Whether or not a reinforcement rod is adequately bonded to the concrete or delaminated could be easily determined with impact echo. The depth of surface opening cracks could be determined with an accuracy of $\pm 10 \%$. 


\subsubsection{Test Specimen Containing Different Materials}

The ability of ground-penetrating radar and impact echo methods to detect internal defects in concrete was evaluated (5.26). A $100 \times 30 \times 18 \mathrm{~cm}^{3}$ test specimen was fabricated in which were embedded a piece of styrofoam, a piece of wood, a section of polyvinylchloride pipe, and two lengths of steel bar. The concrete cover over the embedded objects ranged from 6 to $8 \mathrm{~cm}$. Figure 5.50 presents a plan and side view of the test article.

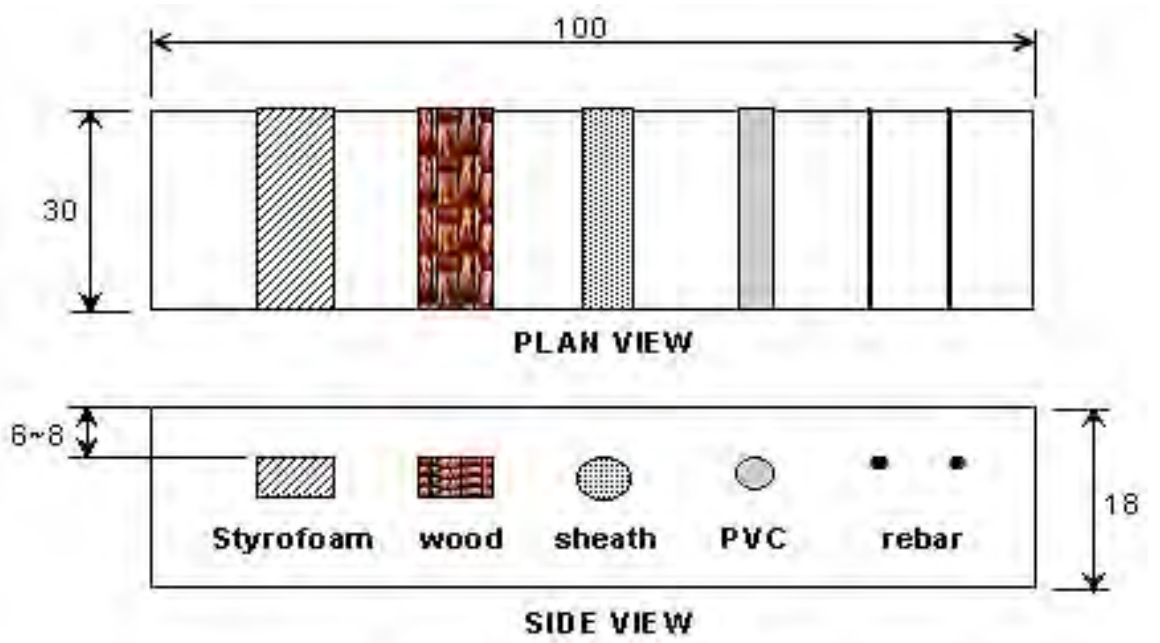

Figure 5.50 Test article containing embedded materials.

Source: S.K. Woo and Y.C. Song, "Non-Destructive Testing Method for the Detection of the Internal Defects Inside Concrete," $10^{\text {th }}$ Asian-Pacific Conference on Non-Destructive Testing, Brisbane, Australia, 17-21 September 2001 (http://www.ndt.net/article/apcndt01/papers/1121/1121.htm).

Results of application of ground-penetrating radar to the test article indicate that the styrofoam, wood, and polyvinylchloride pipe could not be detected, and the sheath tube and steel bar appeared similarly. Groundpenetrating radar was thought to not be able to distinguish type of material embedded in concrete from results that would be obtained from a steel bar. Impact echo was able to determine the embedded depth of the styrofoam and wood within $10 \%$. Depth determination of the polyvinylchloride pipe was determined to be about $15 \%$ greater than actual, which was attributed to the round sectional shape of the pipe. It was concluded from the study that groundpenetrating radar was useful method for detecting the position of embedded rebar, while impact echo is an effective method for detecting a cavity in concrete, a void below a steel bar, and the member thickness.

\subsubsection{Mock-up of Containment Building Structure with Voids}

Impact echo and ground-penetrating radar methods were utilized to investigate specimens fabricated to investigate nondestructive testing of containment building structures in nuclear power plants (5.27). Two test specimens were fabricated. Test specimen A $\left(150 \times 50 \times 30 \mathrm{~cm}^{3}\right)$ included two voids as noted in Figure 5.51a. One void was below the steel reinforcement and the second was located away from the steel reinforcement. The cover depths to the void beneath the steel reinforcement and the remote void were $10 \mathrm{~cm}$ and $15 \mathrm{~cm}$, respectively. The voids were simulated with styrofoam. Test specimen B was 1.2-m thick and simulated a prototype structural member of a containment building in a typical nuclear plant and contained three $150-\mathrm{mm}$ diameter metal sheath pipes that were ungrouted and steel reinforcing bars having a 55-mm diameter. In order to compare the performance of impact echo-spectral analysis of surface waves and ground-penetrating radar methods, a $10 \times 10 \times 10 \mathrm{~cm}^{3}$ styrofoam void, a container filed with water $($ width $=20 \mathrm{~cm}$, height $=40 \mathrm{~cm}$, thickness $=40 \mathrm{~cm}$ ), and a $15-\mathrm{cm}$ diameter polyvinylchloride pipe were intentionally inserted into the specimen during construction at a depth of $30 \mathrm{~cm}$ from the specimen surface. Figure $5.51 \mathrm{~b}$ presents a drawing of test specimen B. 


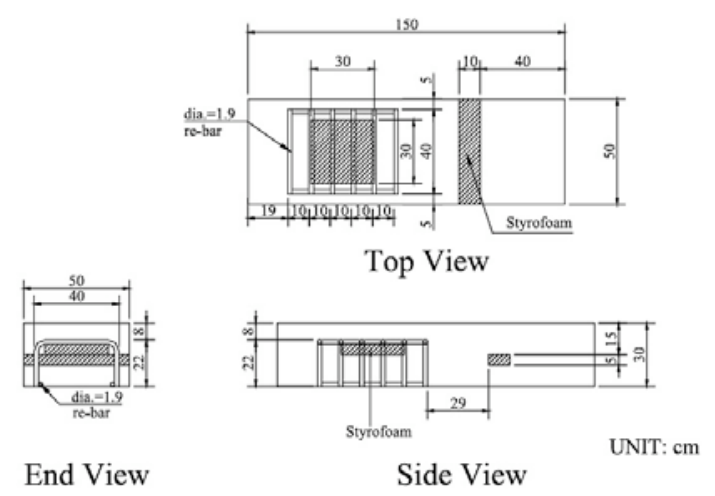

(a) Test specimen A.

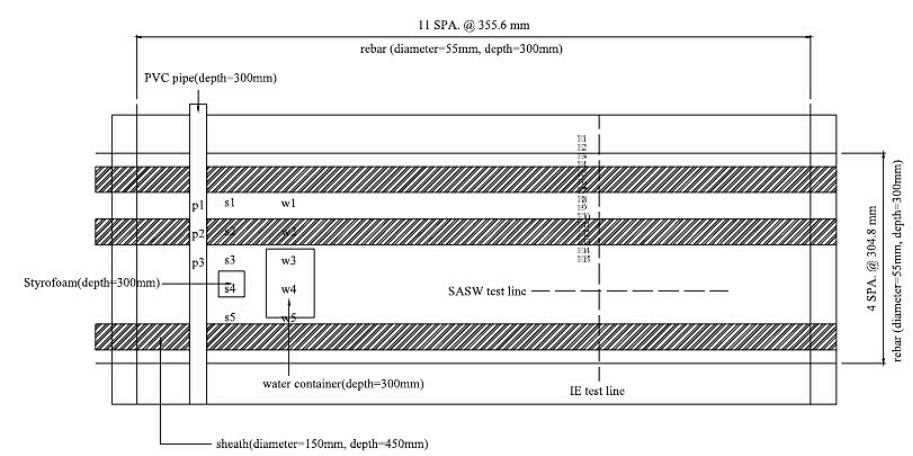

(b) Test specimen B.

Figure 5.51 Schematics of test specimens.

Source: D.S. Kim, H.W. Kim, W.S. Seo, K.C. Choi, and S.K. Woo, "Feasibility Study of the IE-SASW Method for Nondestructive Evaluation of Containment Building Structures in Nuclear Power Plants,' Nuclear Engineering and Design 219(2), pp. 97-110, February 2003.

Impact echo tests were performed at three positions on test specimen A: (1) on the surface above the void behind the steel reinforcing bars, (2) on the surface above the void where there was no steel reinforcement, and (3) on the surface where there was no defect through the specimen thickness. Amplitude spectrums for these three positions are presented in Figure 5.52. Utilizing the resonance peak frequencies from Figure 5.52 for the three positions indicates depths of $10.6,15.1$, and $30.0 \mathrm{~cm}$ that compare well to the true values of $10.0,15.0$, and $30.0 \mathrm{~cm}$, respectively.

Impact echo tests were also performed on test specimen B at 13 locations along IE test line noted in Figure 5.51b. Calculated thickness of the test specimen obtained from the impact echo tests was $1.14 \mathrm{~m}$ that compares well with the actual thickness of $1.2 \mathrm{~m}$. Resonant peak frequency results observed over the metal sheath pipes indicated depths to the metal sheaths of 0.45 to $0.47 \mathrm{~m}$ that compared well to the actual depth of $0.45 \mathrm{~m}$. Difficulties were encountered in determining the depth to the steel reinforcement due to the resulting complex reflected and refracted signal from the concrete/steel interfaces. Amplitude spectra corresponding to the styrofoam, the water container,

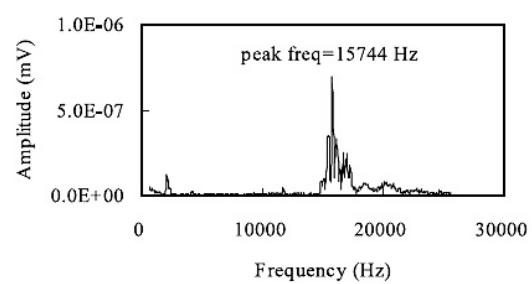

(a) Void behind steel rebars.

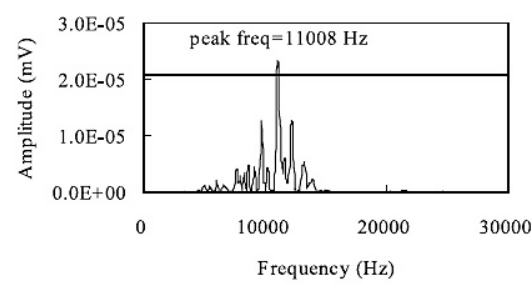

(b) Void with no steel rebars.

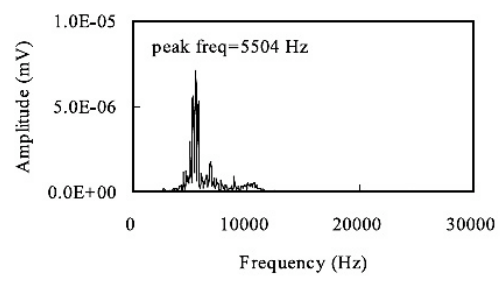

(c) No defects present.

Figure 5.52 Amplitude spectra from three areas of test specimen A.

Source: D.S. Kim, H.W. Kim, W.S. Seo, K.C. Choi, and S.K. Woo, "Feasibility Study of the IE=-SASW Method for Nondestructive Evaluation of Containment Building Structures in Nuclear Power Plants,' Nuclear Engineering and Design 219(2), pp. 97-110, February 2003.

and the polyvinylchloride pipe are presented in Figure 5.53. Calculated depths using the resonant peak frequency results were $0.327 \mathrm{~cm}, 0.345 \mathrm{~cm}$, and $0.297 \mathrm{~cm}$, which agrees fairly well with actual depths of $0.30 \mathrm{~cm}, 0.30 \mathrm{~cm}$, and $0.30 \mathrm{~cm}$. These results indicate that the impulse echo-spectral analysis of surface waves method can be used to detect voids (water filled or not) and an embedded polyvinylchloride pipe. 


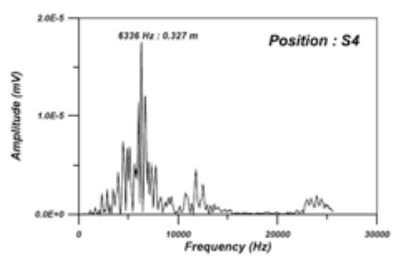

(a) Styrofoam.

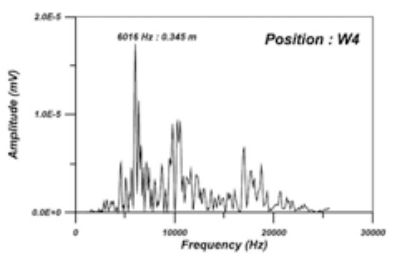

(b) Water container.

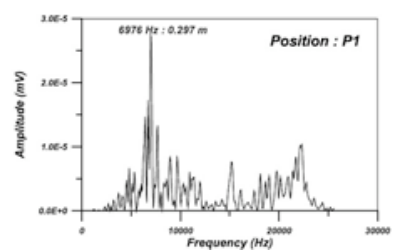

(c) Polyvinylchloride pipe.

Figure 5.53 Amplitude spectra from three areas of test specimen B.

Source: D.S. Kim, H.W. Kim, W.S. Seo, K.C. Choi, and S.K. Woo, "Feasibility Study of the IE=-SASW Method for Nondestructive Evaluation of Containment Building Structures in Nuclear Power Plants,' Nuclear Engineering and Design 219(2), pp. 97-110, February 2003.

Test specimens A and B were also investigated using ground-penetrating radar. Results obtained for test specimen A are presented in Figure 5.54a which shows reflected and diffracted signals in response to the six steel
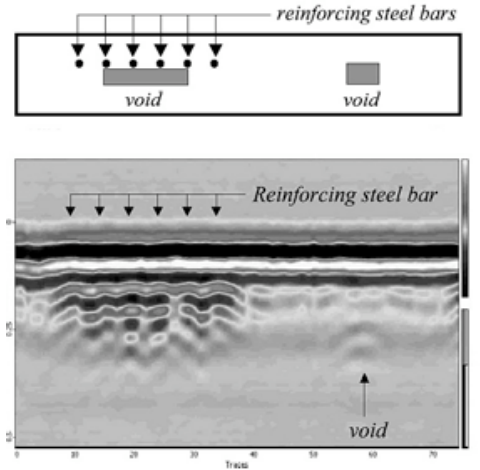

(a) Test specimen A.

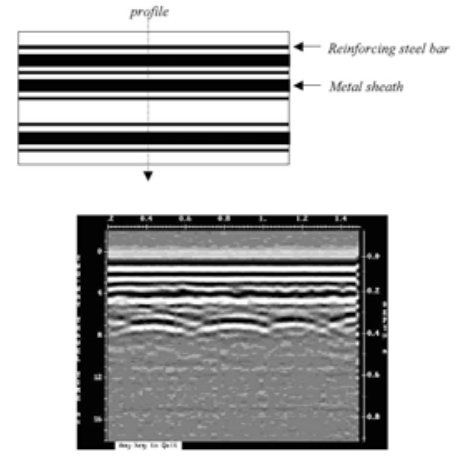

(b) Test specimen B.

Figure 5.54 Ground-penetrating radar results test specimens A and B.

Source: D.S. Kim, H.W. Kim, W.S. Seo, K.C. Choi, and S.K. Woo, "Feasibility Study of the IE-SASW Method for Nondestructive Evaluation of Containment Building Structures in Nuclear Power Plants,' Nuclear Engineering and Design 219(2), pp. 97-110, February 2003.

reinforcing bars and the void where there is no steel reinforcement. The void below the steel reinforcing bars could not be detected by ground-penetrating radar because of electromagnetic shielding. Figure 5.54b provides the profile obtained from test specimen B. A series of equally spaced rebars is designated by hyperbolas. It is difficult to identify the metal sheath pipes located behind the steel reinforcing bars. Also, ground-penetrating radar failed to detect the polyvinyl chloride pipe, the styrofoam, and the water container in test specimen B using a pulse-type dipole antenna $(1.2 \mathrm{GHz})$. It was concluded that ground-penetrating radar can image steel reinforcing bars and defects such as voids, but it was difficult to locate a void that was positioned below steel reinforcing bars.

\subsubsection{Concrete Slab with Artificial Defects}

The capability of the impact echo method to quantitatively identify the size of internal defects and their depths from the surface based on frequency distributions was investigated (5.28). Concrete slab specimens $4 \times 2 \times 0.2 \mathrm{~m}^{3}$ were fabricated that contained disk shaped artificial defects (styrofoam with $0.5 \mathrm{~cm}$ thickness). The diameters of the artificial defects were $5,10,15,20,30$, and $50 \mathrm{~cm}$ and had depths of either $3,5,7$, or $10 \mathrm{~cm}$ from the surface. Figure 5.55 presents details of the slab test specimen. Elastic waves were introduced by impacting the concrete surface using a dropped steel ball. 


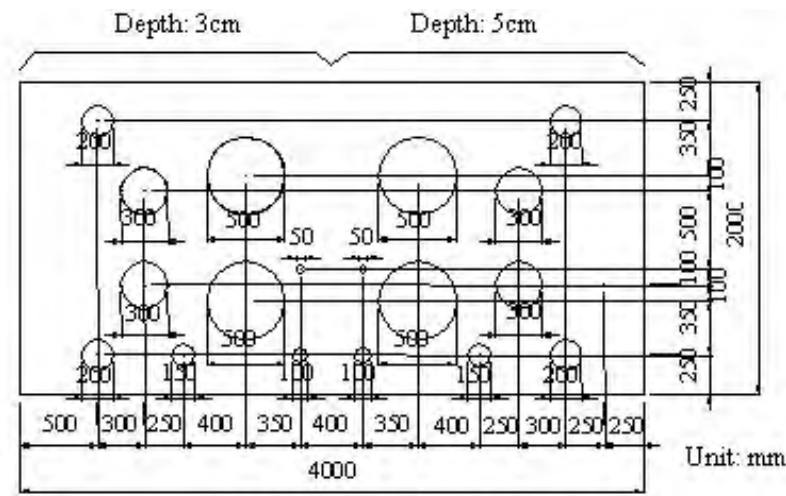

Defect locations
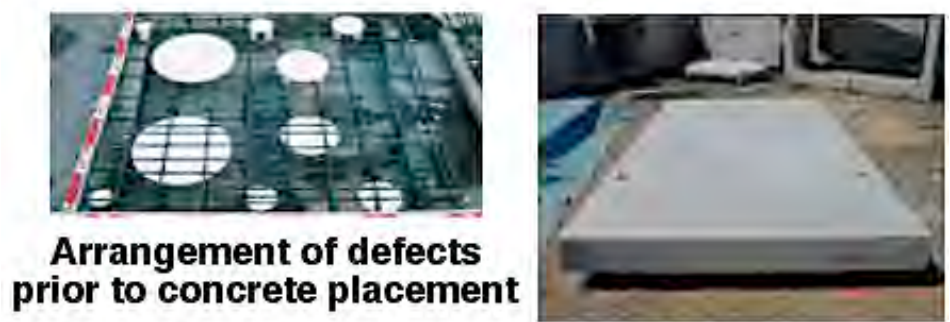

\section{Completed concrete} slab specimen

Figure 5.55 Arrangement of concrete slab with artificial defects.

Source: M. Asano, T. Kamada, M. Kunieda, and K. Rokugo, "Impact Acoustics Methods for Defect Evaluation in Concrete," International Symposium on Non-Destructive Testing in Civil Engineering (NDT-CE-2003), Bundesanstalt für Materialforschung und -prüfung, Berlin, Germany, 2003.

Examples of wave forms recorded by an accelerometer for data corresponding to a $20 \mathrm{~cm}$ defect at a depth of $3 \mathrm{~cm}$, a $20 \mathrm{~cm}$ defect at a depth of $7 \mathrm{~cm}$, and a sound portion of the slab are presented in Figure 5.56. Experimental results

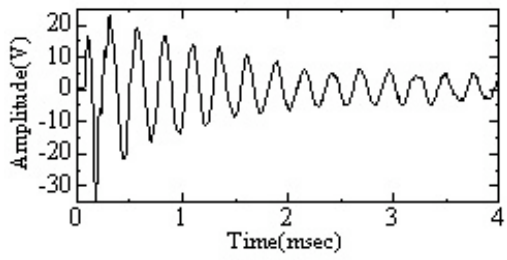

(a) Waveform: $20 \mathrm{~cm}$ flaw at $3 \mathrm{~cm}$ depth.

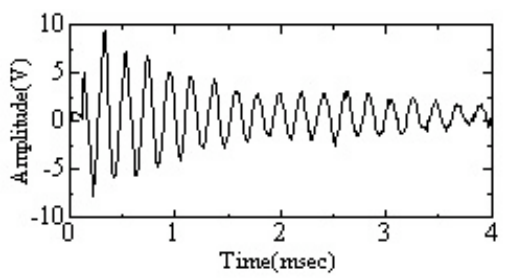

(b) Waveform: $20 \mathrm{~cm}$ flaw at $7 \mathrm{~cm}$ depth.

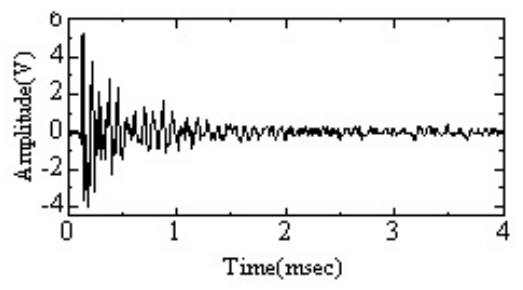

(c) Waveform: sound concrete.

Figure 5.56 Comparison of accelerometer waveforms for sections with and without flaws.

Source: M. Asano, T. Kamada, M. Kunieda, and K. Rokugo, "Impact Acoustics Methods for Defect Evaluation in Concrete," International Symposium on Non-Destructive Testing in Civil Engineering (NDT-CE-2003), Bundesanstalt für Materialforschung und -prüfung, Berlin, Germany, 2003.

relating the peak frequency and defect diameter and depth are presented in Figure 5.57. These results indicate lower peak frequencies for larger defects and higher peak frequencies for deeper defects. Results of numerical analyses using three-dimensional finite-element methods to analyze the relationship between frequency distribution and defect information agreed well with experimental results. 


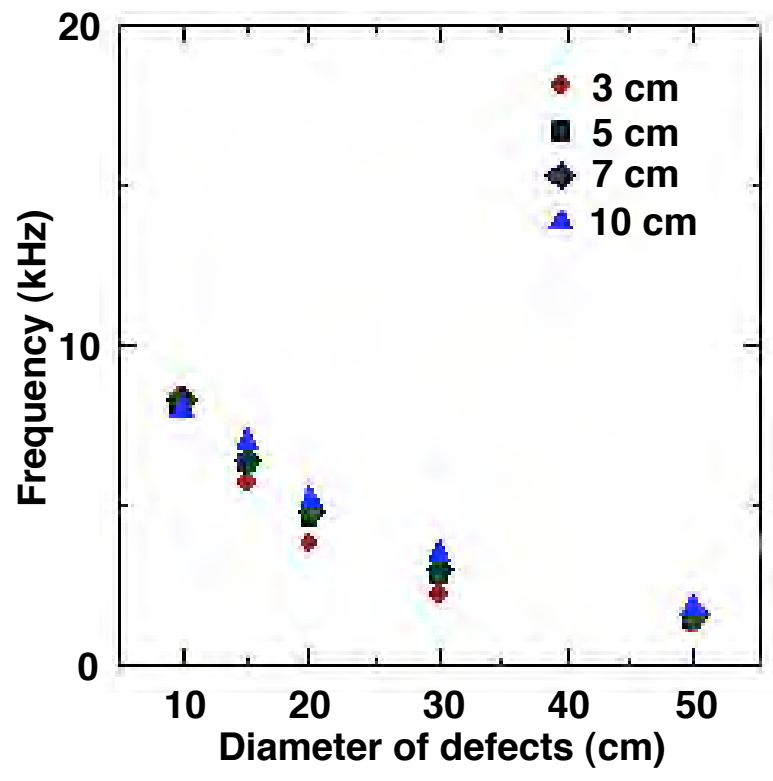

Figure 5.57 Effect of defect diameter and depth on peak frequency.

Source: M. Asano, T. Kamada, M. Kunieda, and K. Rokugo, "Impact Acoustics Methods for Defect Evaluation in Concrete," International Symposium on Non-Destructive Testing in Civil Engineering (NDT-CE-2003), Bundesanstalt für Materialforschung und -prüfung, Berlin, Germany, 2003.

\subsubsection{Test Article with Voids, Honeycombing, and Tendon Ducts}

In order to check the applicability of nondestructive inspection methods for detection of internal voids in reinforced concrete, nine reinforced concrete specimens $1 \times 1 \mathrm{~m}^{2}$ with a thickness of 400 to $500 \mathrm{~mm}$ were fabricated as noted in Table 5.8 (5.29). The nondestructive methods investigated were thermography, sonic, impact echo, and ultrasound.

Specimen 7 having a size of $1 \times 1 \times 0.4 \mathrm{~m}^{3}$ contained a void in the shape of "A" embedded in the concrete. The void was located at a depth of $100 \mathrm{~mm}$ and below a steel reinforcement mesh consisting of 10 steel bars having a diameter of $16 \mathrm{~mm}$. Figure 5.58a presents a schematic of the embedded void and Figure $5.58 \mathrm{~b}$ presents the form with the void prior to casting the concrete.

Table 5.8 Description of test specimens

\begin{tabular}{|c|l|l|}
\hline $\begin{array}{c}\text { Specimen } \\
\text { number }\end{array}$ & \multicolumn{1}{|c|}{ Specimen type } & \multicolumn{1}{c|}{ Description } \\
\hline \hline 1 & Scaling model & $\begin{array}{l}\left.200 \times 500 \times 2 \mathrm{~mm}^{3} \text { (Depth: } 20 \mathrm{~mm}, 40 \mathrm{~mm}\right) \\
\left.200 \times 500 \times 5 \mathrm{~mm}^{3} \text { (Depth: } 20 \mathrm{~mm}, 40 \mathrm{~mm}\right)\end{array}$ \\
\hline 2 & Thickness model & $100 \mathrm{~mm}, 200 \mathrm{~mm}, 300 \mathrm{~mm}, 400 \mathrm{~mm}$ \\
\hline 3 & Honeycomb model & $\begin{array}{l}100 \times 100 \mathrm{~mm}^{2} \\
300 \times 300 \mathrm{~mm}^{2}\end{array}$ \\
\hline 4 & Inclined crack model & $44.4^{\circ}, 58.7^{\circ} ;$ depth $=200 \mathrm{~mm}$ \\
\hline 5 & Grouted PC ducts model & Diameter $50 \mathrm{~mm}$ with prestressed concrete strands \\
\hline 6 & Pressure welded rebar model & 10 to $32 \mathrm{~mm}$ diameter bars with welded portion \\
\hline 7 & Void "A1" & Horizontal; depth $=100 \mathrm{~mm}$ \\
\hline 8 & Void "A2" & Inclined void $15^{\circ}$ \\
\hline 9 & Void "A3" & Inclined void $15^{\circ}$ and tilted $45^{\circ}$ void \\
\hline
\end{tabular}

Source: T. Uomoto, "Utilization of NDI to Inspect Internal Defects in Reinforced Concrete Structures," International Symposium on Non-Destructive Testing in Civil Engineering (NDT-CE-2003), Bundesanstalt für Materialforschung und -prüfung, Berlin, Germany, 2003. 


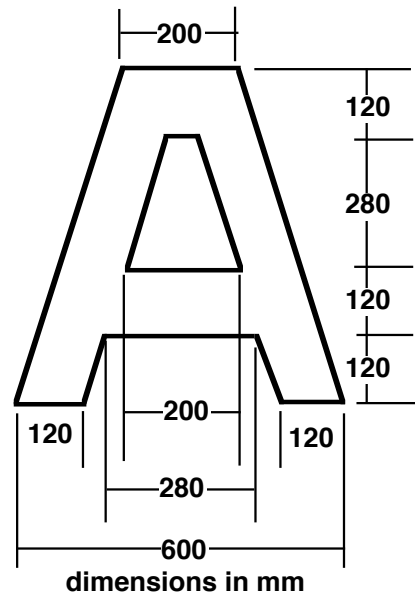

(a) Details of embedded defect.

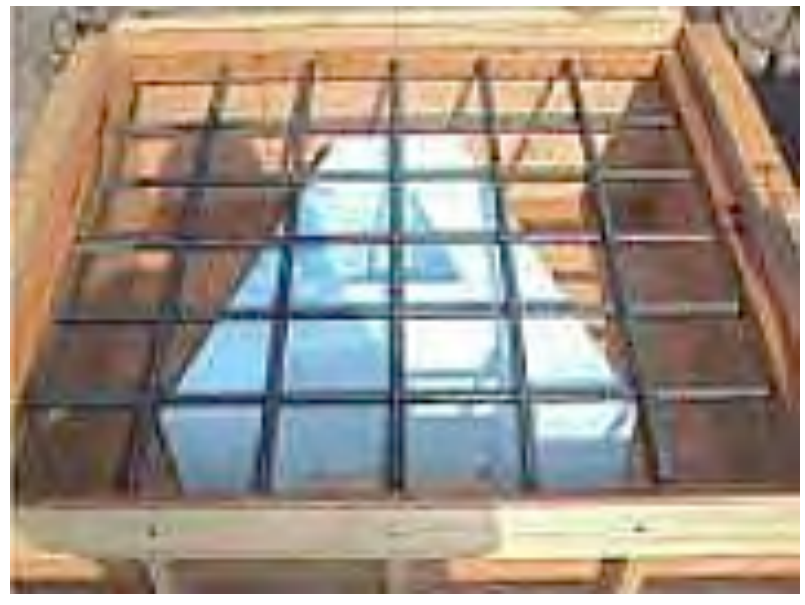

(b) Specimen 7 prior to casting concrete.

Figure 5.58 Details of specimen 7.

Source: T. Uomoto, "Utilization of NDI to Inspect Internal Defects in Reinforced Concrete Structures," International Symposium on Non-Destructive Testing in Civil Engineering (NDT-CE-2003), Bundesanstalt für Materialforschung und -prüfung, Berlin, Germany, 2003.

Figure 5.59 presents thermography results for specimen 7 . The specimen was heated only by sunlight. Figure 5.59a provides the result obtained from passive thermography and Figure $5.59 \mathrm{~b}$ from time subtraction. Time subtraction using scans at two different times provides improved results as it takes into account the effects of uneven heating.

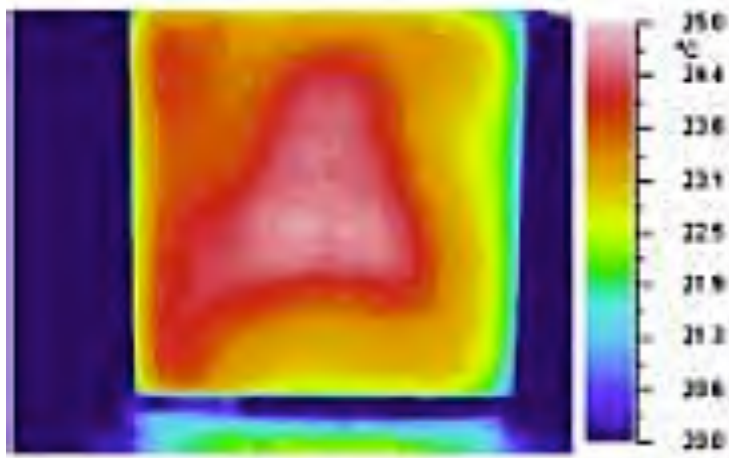

(a) Passive thermography result.

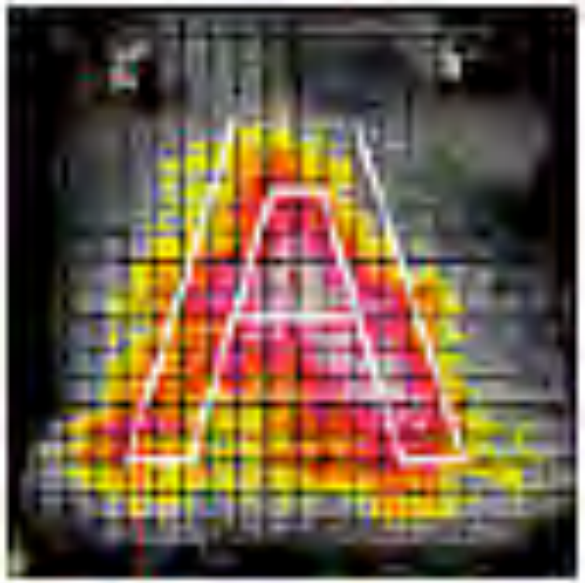

(b) Thermography result using time subtraction.

Figure 5.59 Thermography results for specimen 7.

Source: T. Uomoto, "Utilization of NDI to Inspect Internal Defects in Reinforced Concrete Structures," International Symposium on Non-Destructive Testing in Civil Engineering (NDT-CE-2003), Bundesanstalt für Materialforschung und -prüfung, Berlin, Germany, 2003.

Sonic measurement results are presented in Figure 5.60a. The data show the ratio of responding sonic wave amplitude to the original applied sonic amplitude by the pulse hammer. Good correlation exists between the ratio of the responding amplitude and the thickness of the concrete thus enabling the depth of the void to be determined. Impact echo results are presented in Figure 5.60b. Areas exhibiting darker color are where the depth measured from the surface is shallower and indicates the void location. These results indicate that impact echo can readily detect 
the void even when steel reinforcement is located between the void and the surface. Improved accuracy could be obtained through selection of impactor and filtering to eliminate low frequency waves.

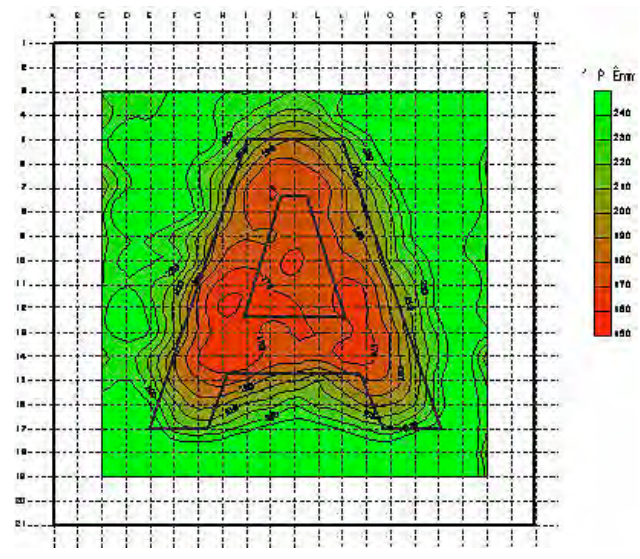

(a) Sonic result.

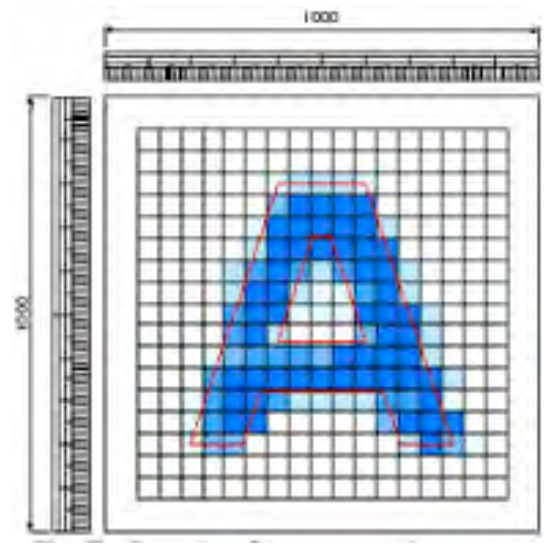

(b) Impact echo result.

Figure 5.60 Sonic and impact echo results for specimen 7.

Source: T. Uomoto, "Utilization of NDI to Inspect Internal Defects in Reinforced Concrete Structures," International Symposium on Non-Destructive Testing in Civil Engineering (NDT-CE-2003), Bundesanstalt für Materialforschung und -prüfung, Berlin, Germany, 2003.

Ultrasonic measurements $(100 \mathrm{kHz})$ were made to determine depths from the surface at points over a 50 -mm grid. The presence of the steel reinforcement mesh affected the results so in areas where this occurred average results were utilized. Figure 5.61a shows that the ultrasonic measurements coincide well with the actual void depth. This is more apparent in Figure 5.61b which presents a two-dimensional presentation of results.

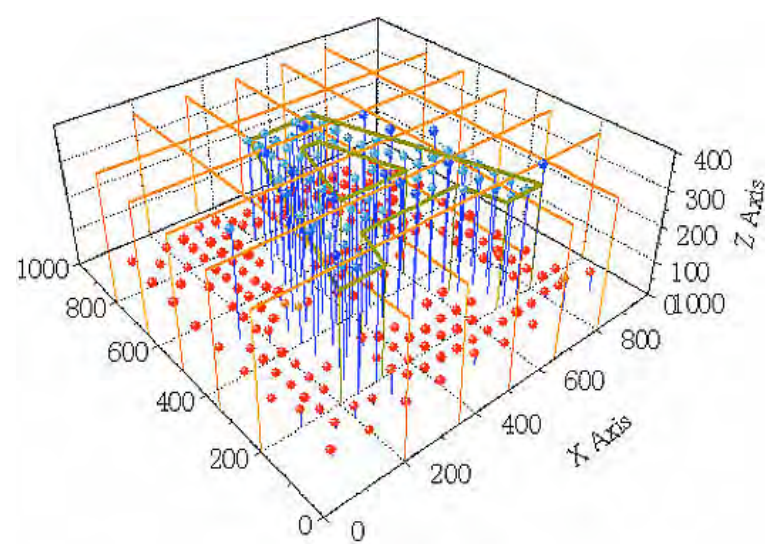

(a) Ultrasonic depth determination.

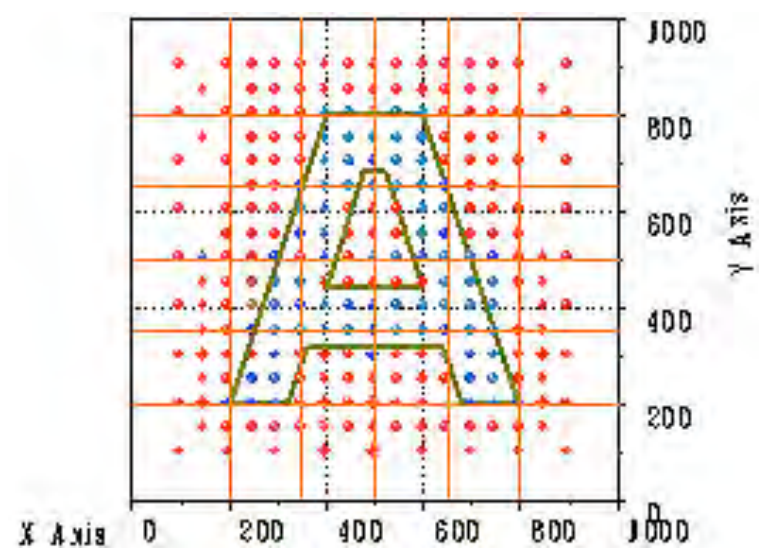

(b) Two-dimension result.

Figure 5.61 Sonic and impact echo results for specimen No. 7.

Source: T. Uomoto, "Utilization of NDI to Inspect Internal Defects in Reinforced Concrete Structures," International Symposium on Non-Destructive Testing in Civil Engineering (NDT-CE-2003), Bundesanstalt für Materialforschung und -prüfung, Berlin, Germany, 2003.

\subsubsection{Concrete Block with Rectangular Void}

An elastic-wave-based imaging method combining the point source/point-receiver scheme was applied to a concrete block (5.30). The test article, $1.5 \times 1.5 \times 1.0 \mathrm{~m}^{3}$, was fabricated from unreinforced concrete and contained a horizontal rectangular void $0.2 \times 0.1 \mathrm{~m}^{2}$ extending through the block at a depth of $0.5 \mathrm{~m}$ as noted in Figure 5.62. 


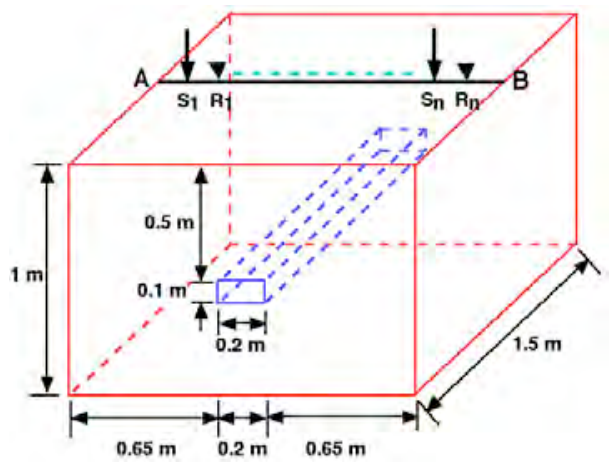

Figure 5.62 Test article with rectangular void.

Source: J-H Tong and S-T Liao, "An Elastic-Wave-Based Imaging Method for Scanning the Defects inside the Structure," $12^{\text {th }}$ Asian-Pacific Conference on Non-Destructive Testing, Auckland, New Zealand, 5-10 November 2006 (http://www.ndt.net/article/apcndt2006/toc.htm).

The experiment was carried out by conducting a series of impact-and-receive operations on the top surface of the block along sampling line $A B$ indicated in Figure 5.62. The elastic wave was generated by impact of a 19-mmdiameter steel ball falling from a height of $15 \mathrm{~cm}$. A B-scan displacement diagram obtained is shown in Figure 5.63a with the dashed vertical line $\mathrm{R}$ indicating the arrival time of the Rayleigh wave and the other two vertical dashed lines marked D and B representing the arrival times of longitudinal waves reflected from the top surface of the void and the bottom surface of the concrete block, respectively. The dashed lines marked RR indicate arrival times of the Rayleigh waves reflected from the side surfaces of the concrete block. Figure 5.63b presents the results after synthetic aperture focusing technique (SAFT) processing of the experimental results and indicates the position of the void and the specimen back wall. It was concluded that SAFT post-processing is able to achieve the same effect as scanning with a phased array system and that in order to have good scanning results the wavelength of the elastic wave used should be much larger than the size of the concrete aggregates. Elastic-wave-based nondestructive testing was felt to exhibit high potential for inspecting for defects in concrete structures.

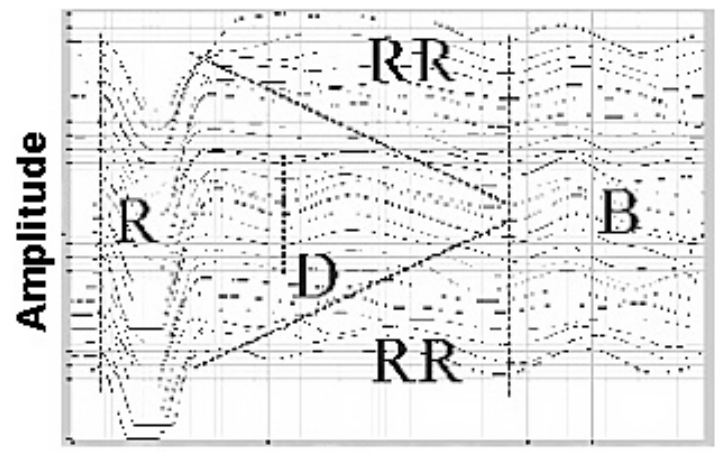

Time

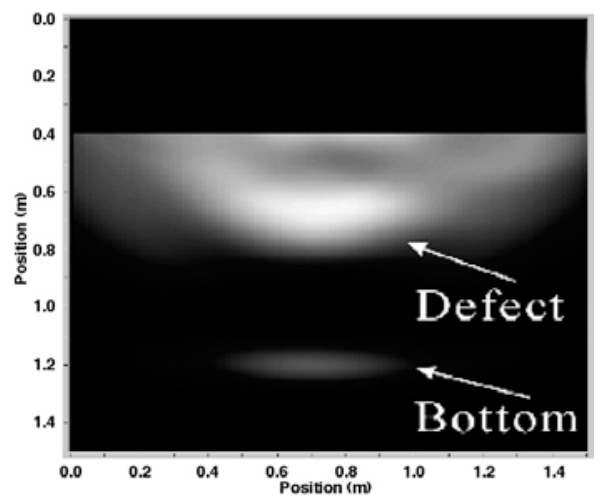

(b) SAFT processing result.

(a) B-scan displacement result.

Figure 5.63 Elastic-wave-based imaging results for block with rectangular void.

Source: J-H Tong and S-T Liao, "An Elastic-Wave-Based Imaging Method for Scanning the Defects inside the Structure," $12^{\text {th }}$ Asian-Pacific Conference on Non-Destructive Testing, Auckland, New Zealand, 5-10 November 2006 (http://www.ndt.net/article/apcndt2006/toc.htm).

\subsubsection{Large Concrete Block with Inclined Crack}

Ground-penetrating radar was investigated as a technique for detection of deep cracks in concrete (5.31). A large concrete block, $3 \times 3 \times 4 \mathrm{~m}^{3}$, was fabricated from ordinary Portland cement concrete and contained an inclined crack. The inclined crack was formed in the structure at a depth of $3.4 \mathrm{~m}$ by hydraulic fracture at a zone of 
intentional weakness created when the block was cast. The crack width could be adjusted by injecting water into the crack. Steel reinforcement (16-mm-diameter bars) was contained in the portion of the block above the inclined crack. Figure 5.64a presents a drawing of the block and Figure 5.64b presents the bloc with instrumentation.

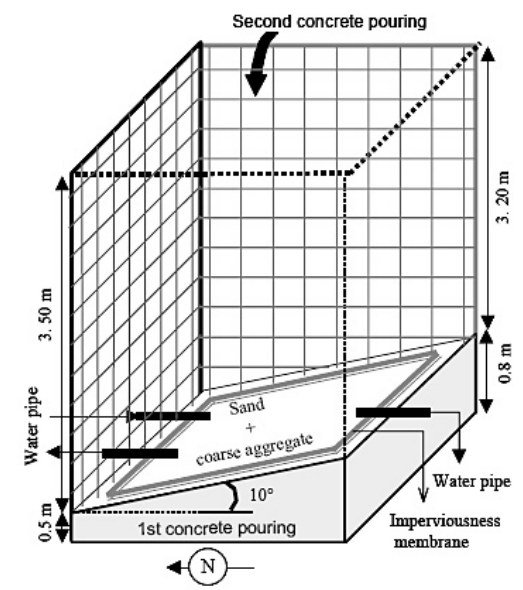

(a) Diagram of test block with precast crack.

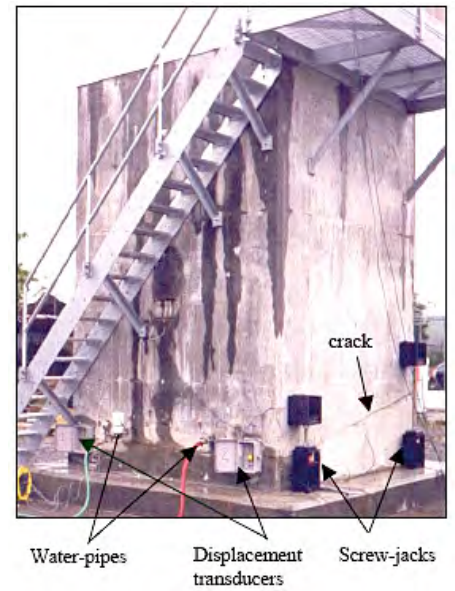

(b) Completed construction of block.

Figure 5.64 Block with precast crack for ground-penetrating radar study.

Source: J. Rhazi, O. Dous, and S. Kaveh, "Detection of Fractures in Concrete by GPR Technique," $16^{\text {th }}$ World Conference on NDT 2004, Montreal, Canada, August 30 - September 3, 2004 (http://www.ndt.net/abstract/wcndt2004/751.htm).

Ground-penetrating radar (400 MHz) tests were performed from the top of the concrete block for different crack widths and different crack conditions (e.g., air-filled and water-filled). Figure 5.65a presents results for a water- and an air-filled crack of $0.5 \mathrm{~mm}$ width. The reflection amplitude of the air-filled crack is negatively polarized whereas the reflection obtained in the case of the water-filled crack is polarized positively and lower in magnitude. Figure $5.65 \mathrm{~b}$ presents results for a crack width of $0.2 \mathrm{~mm}$. The signals were obtained for several different conditions: crack filled with air, water progressively filling crack, water progressively leaving the crack, and water filling the crack again. It was concluded from the study that ground-penetrating radar can detect deep cracks with large lateral dimensions in concrete.

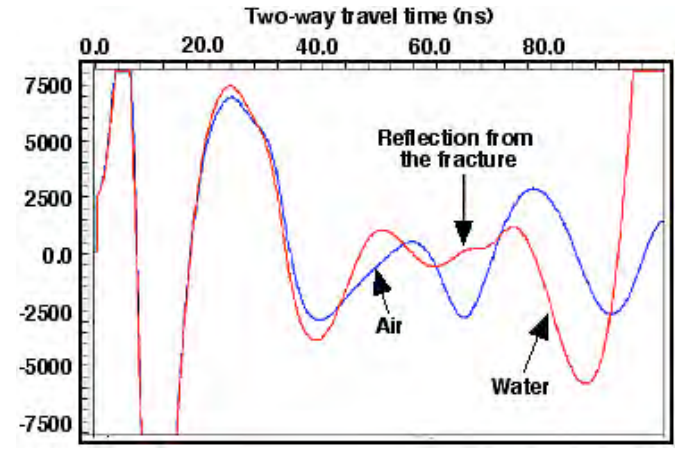

(a) Results for 0.5 -mm thick air- and water-filled crack in concrete.

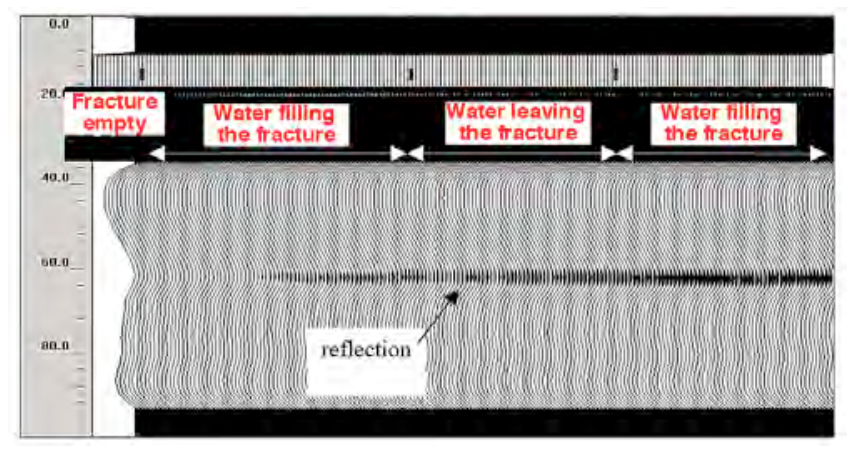

(b) Results for 2-mm-thick crack in concrete for different conditions.

Figure 5.65 Ground-penetrating radar results for deep crack in concrete.

Source: J. Rhazi, O. Dous, and S. Kaveh, "Detection of Fractures in Concrete by GPR Technique," $16^{\text {th }}$ World Conference on NDT 2004, Montreal, Canada, August 30 - September 3, 2004

(http://www.ndt.net/abstract/wcndt2004/751.htm). 


\subsubsection{Nuclear Power Plant Floor Slab}

Ground-penetrating radar was utilized to map the spatial location and depth of embedded steel reinforcement bars and conduits that existed within a $1.8 \times 3 \mathrm{~m}^{2}$ area prior to installation of a new crane hoist at a nuclear power plant (5.32). The work site was inside a five-story, cast-in-place, reinforced concrete structure adjacent to one of the reactors. The floor of interest consisted of a $350 \mathrm{~mm}$ thick suspended concrete slab containing \#4 and \#5 reinforcing bar meshes (30.5-mm center-to-center spacing) located in the upper and lower parts of the slab. The floor had a polyurethane surface coating and was located directly above two intersecting beams. Ground-penetrating radar scans were conducted over six scan grids covering an area of $2.4 \times 3.6 \mathrm{~m}^{2}$ as noted in Figure 5.66a. The slab bottom reflection and beam boundaries were visible in the ground-penetrating radar profiles as noted in Figure 5.66b. The processed data for the six grids is shown pieced together in Figure 5.67 for a depth slice from 75 to $100 \mathrm{~mm}$ below

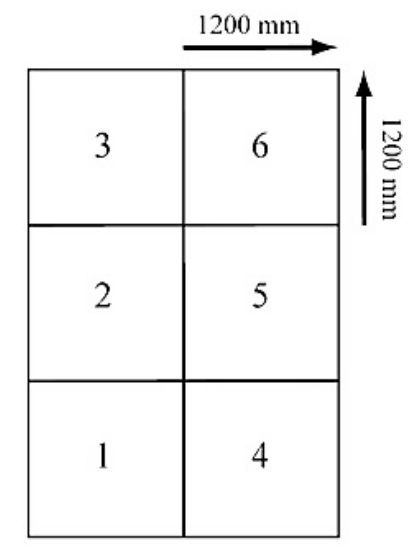

(a) Ground-penetrating radar grid used to survey floor slab.

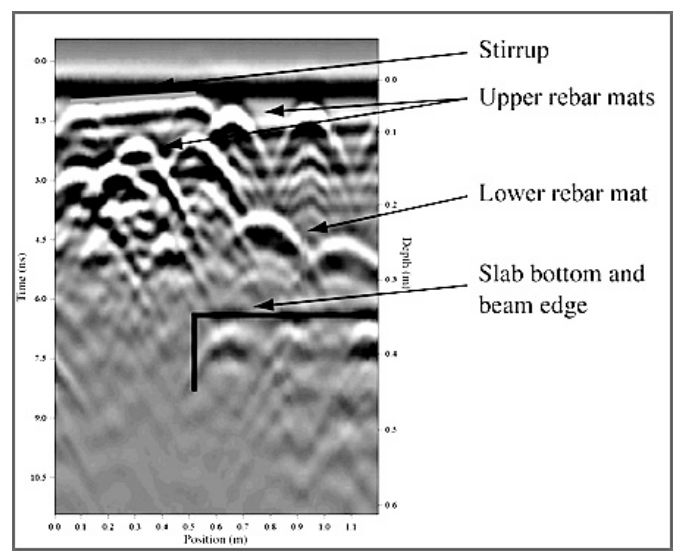

(b) Sample results for slab cross section.

Figure 5.66 Ground-penetrating radar results for floor slab.

Source: P. Giamou, "Ground Penetrating Radar Imaging of Concrete at a Nuclear Power Plant," Back to Basics, The American Society for Nondestructive Testing, Columbus, Ohio, December 2006 (http://asnt.org/publications/materialseval/basics/dec06basics/dec06basics.htm).

the concrete surface. The presence of stirrup cages is apparent in the figure. For reference, a photo of a typical reinforcement cage that had been utilized to fabricate the slab is also presented in Figure 5.67. A more detailed view

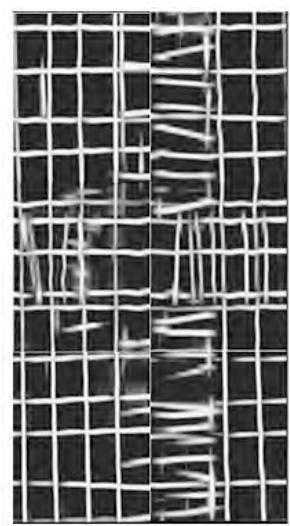

Radar result.

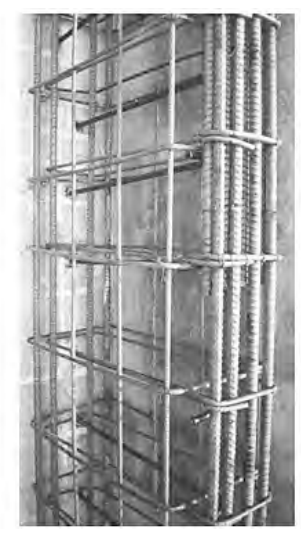

Actual rebar cage.

Figure 5.67 Comparison of ground-penetrating radar result with typical cage used in floor slab.

Source: P. Giamou, "Ground Penetrating Radar Imaging of Concrete at a Nuclear Power Plant," Back to Basics, The American Society for Nondestructive Testing, Columbus, Ohio, December 2006 (http://asnt.org/publications/materialseval/basics/dec06basics/dec06basics.htm). 
of the top right-hand grid showing a beam in the left half of the image is shown in Figure 5.68a. A deeper section shown in Figure 5.68b indicates a diagonal feature within the slab that was identified as an electrical cable conduit. It was noted that ground-penetrating radar was able to provide the desired results at the plant with minimal intrusion and disruption to the operation. Testing was completed and results provided within one day.

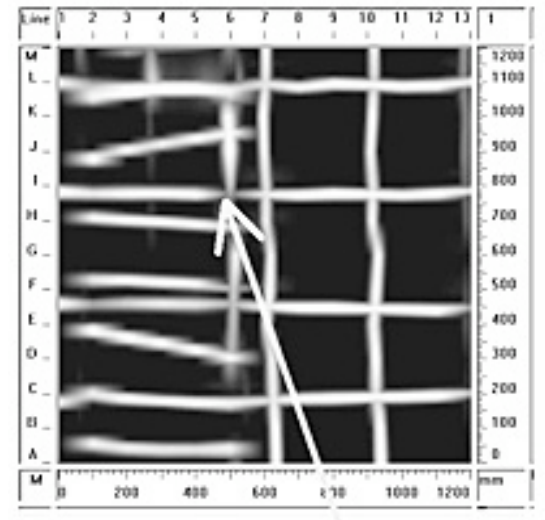

(a) Details of beam structure.

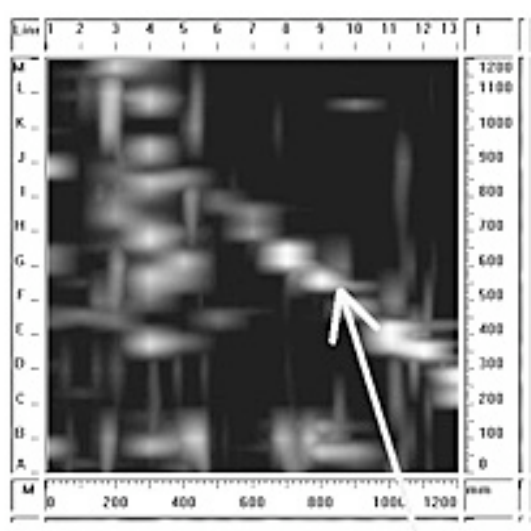

(b) Embedded electrical conduit.

Figure 5.68 More detailed view of radar results in top right grid in Figure 5.67.

Source: P. Giamou, "Ground Penetrating Radar Imaging of Concrete at a Nuclear Power Plant," Back to Basics, The American Society for Nondestructive Testing, Columbus, Ohio, December 2006 (http://asnt.org/publications/materialseval/basics/dec06basics/dec06basics.htm).

\subsubsection{Post-Tensioned Reinforced Concrete Bridge Beam}

Ultrasonic tomography involves measuring the time of flight of an ultrasonic pulse along many ray paths through a section of the component investigated. The data are then processed using tomographic software and the results provided as a contour plot of velocity across the section. This technique was utilized to investigate grouted tendon ducts of a post-tensioned reinforced concrete beam (5.33). A short beam $1.2 \times 0.75 \times 0.4 \mathrm{~m}^{3}$ was constructed that contained two 100-mm-diameter tendon ducts as shown in Figure 5.69.
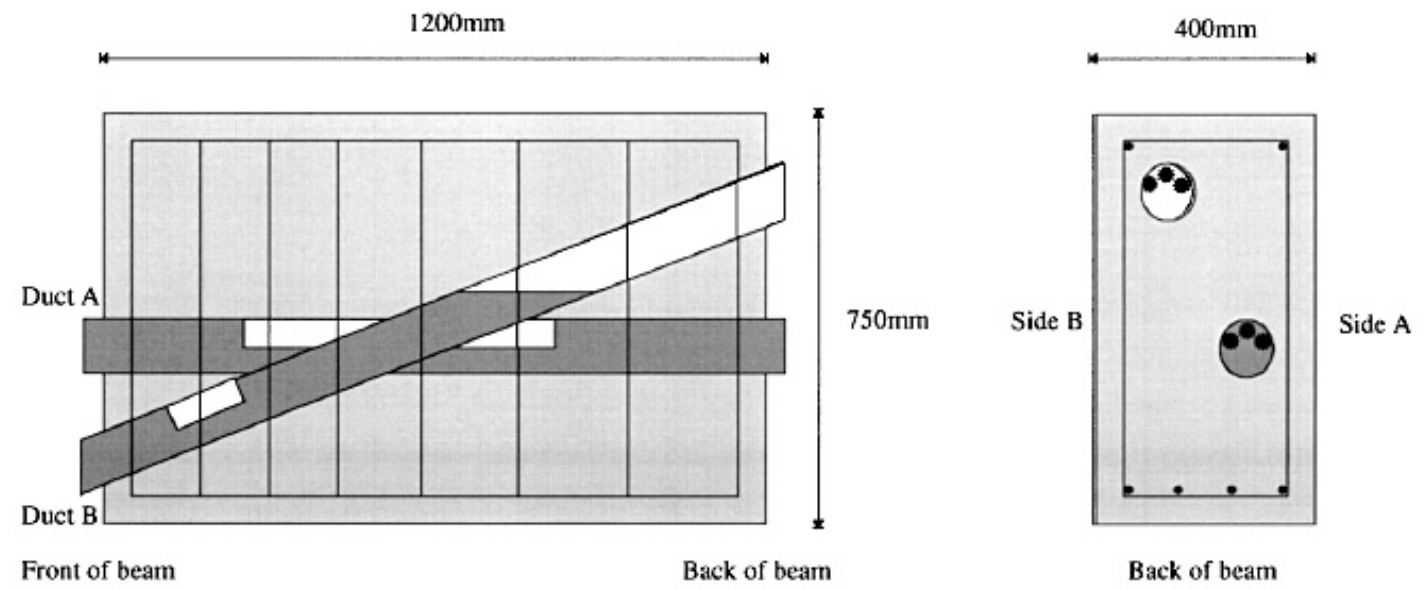

Figure 5.69 Bridge beam model with tendon duct defects.

Source: J. Martin, K.J. Broughton, A. Giannopolous, M.S.A. Hardy, and M.C. Forde, "Ultrasonic Tomography of Grouted Duct Post-Tensioned Reinforced Concrete Bridge Beams," NDT\&E International 34(2), pp. 107113, March 2001.

Tomographic surveys were conducted at positions of $0.4 \mathrm{~m}, 0.8 \mathrm{~m}$, and $0.9 \mathrm{~m}$ from the front end of the beam. The surveys were set up on the sides and top surface of the beam with the test points at spacings of $100 \mathrm{~mm}$. Results 
obtained at these positions are presented in Figure 5.70. In Figure 5.70a (position at $0.4 \mathrm{~m}$ from beam front end) a clear reduction in velocity at Duct A occurs indicating voiding. Duct B is not identifiable indicting there is no voiding in Duct B at this location. Areas of low velocity occurring in lower left- and right-hand corners of the figure are in the outer layer of pixels where results are unreliable due to a small number of ray paths. In Figure 5.70b (position at $0.8 \mathrm{~m}$ from beam front end) a low velocity area occurs in the lower part of the beam corresponding to poor quality concrete. Calculated velocity at the position of Duct B (slightly above center and to the right) is reduced indicting voiding in this duct. Velocity calculated at position of Duct A is similar to that of the surrounding concrete but lower velocity areas are visible below indicting possible voiding. In Figure 5.70c (position at $0.9 \mathrm{~m}$ from beam front end) velocity calculated at this position indicates probable voiding in Duct B and possible voiding in Duct A. Condition of concrete surrounding the ducts appears to be good at this position. Results at these three positions were determined to compare well with the beam model as constructed. Although time-of-flight tomography potentially provides a method for investigating post-tensioned concrete beams, it was noted that the method is time consuming. It was recommended that tomography be used in conjunction with simpler test methods (e.g., impact echo) that would be utilized initially to identify areas of interest for follow-on tomography studies.

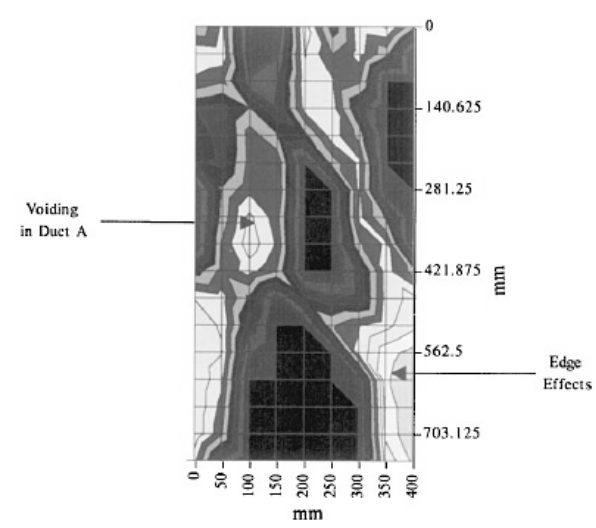

(a) Tomography result at position
$0.4 \mathrm{~m}$ from beam front end.

(a) Tomography result at position
$0.4 \mathrm{~m}$ from beam front end.

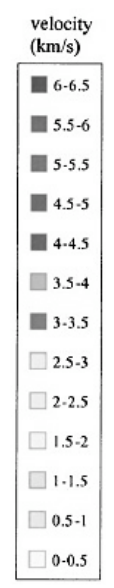

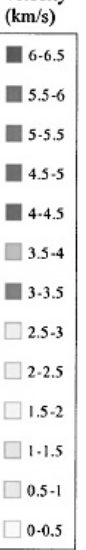
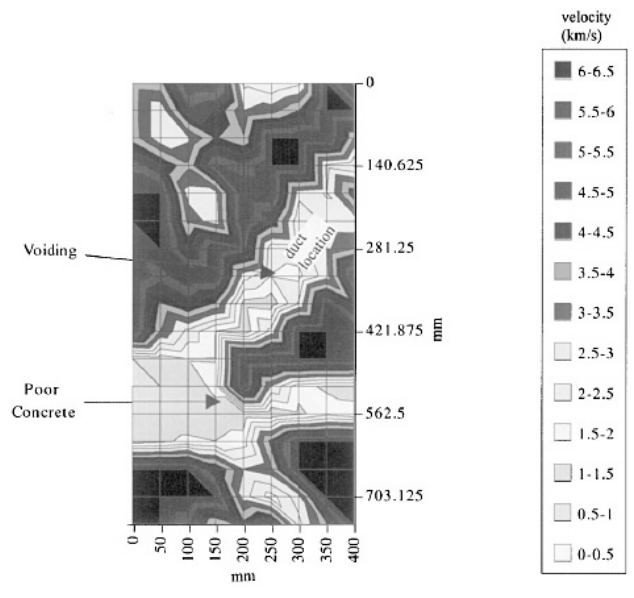

(b) Tomography result at position $0.8 \mathrm{~m}$ from beam front end.

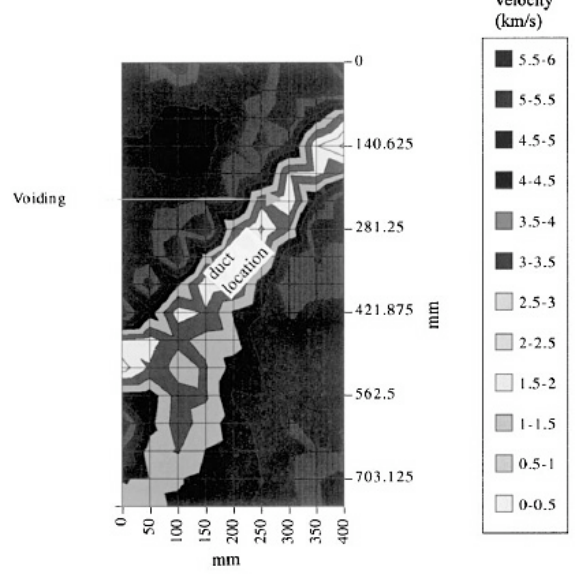

(c) Tomography result at position $0.9 \mathrm{~m}$ from beam front end.

Figure 5.70 Tomography results for bridge beam model.

Source: J. Martin, K.J. Broughton, A. Giannopolous, M.S.A. Hardy, and M.C. Forde, "Ultrasonic Tomography of Grouted Duct Post-Tensioned Reinforced Concrete Bridge Beams," NDT\&E International 34(2), pp. 107113, March 2001. 


\subsection{SUMMARY AND COMMENTARY}

Nondestructive evaluations of concrete structures are required for compliance testing, collection of specific data or parameters, condition assessments, and damage assessment. The performance of older structures can be poor due to a number of factors such as variability of concrete quality and other effects of poor workmanship, and inadequate supervision at the construction site. In addition, the condition of the concrete globally or through a thick section may have changed with time, and these conditions cannot always be predicted in an older structure (i.e., less is known about older structures). The quality of results produced by nondestructive evaluation methods is directly related to the quality of the concrete. Modern concretes are usually of higher quality so application of nondestructive testing in all likelihood will produce improved results relative to older concrete structures indicating that nondestructive evaluations will have increased use in the future (5.7).

Inspection of nuclear power plant concrete structures presents challenges different from conventional civil engineering structures in that wall thicknesses can be in excess of one meter; the structures often have increased steel reinforcement density with more complex detailing; there can be a number of penetrations or cast-in-place items present; and accessibility may be limited due to the presence of liners and other components, harsh environments, or the structures may be located below ground. Changes in the conditions of these structures may not be adequately described by what can be observed on the surface. Properties of the concrete can vary significantly with depth and as-built conditions (e.g., section thickness) can vary from the design value. Noninvasive techniques for characterization, inspection, and monitoring of these structures to provide additional assurances of their continued structural integrity are desirable (e.g., identification of honeycombed areas, voids adjacent to the liner, and embedded items; inspection of thick-section concrete). Consideration should be given in new nuclear power plant designs to providing improved accessibility of the concrete structures for application of nondestructive examination methods.

A workshop sponsored by the Committee on Safety of Nuclear Installations of the Nuclear Energy Agency was held to assess the status of nondestructive evaluation of nuclear power plant concrete structures and to identify development priorities $(5.1,5.2)$. Conclusions of this workshop were summarized previously in Section 3.5 and areas of high and medium benefit needs were identified in Table 5.1. Since the time of this workshop (1997), there have been a number of studies conducted related to the development of nondestructive evaluation methods for reinforced concrete structures that will lead to nondestructive evaluation playing an increasingly important role related to managing the aging of nuclear power plant safety-related concrete structures [e.g., determination of asbuilt (or current) structural features, detection of flaws, and characterization and quantification of flaws]. These studies have ranged from relatively simple mock-ups to evaluate the capability of a particular nondestructive evaluation method to determination of section thickness or locating internal voids to a sophisticated methodology combining nondestructive evaluation with finite-element methods for aging management of nuclear power plant containment structures.

Results presented in this chapter indicate that acoustic (e.g., ultrasonic pulse velocity, ultrasonic pulse echo, spectral analysis of surface waves, impact echo, and acoustic tomography), radar, and radiography techniques appear to have the greatest potential for application to reinforced concrete structures in nuclear power plants. Impact echo can provide information on elastic modulus, approximate strength and mechanical properties; determine section thickness; and locate cracks, larger voids, and honeycomb in structures with relatively simple geometry. Impact echo was able to detect empty tendon ducts, but had difficulty when the ducts were grouted, and was not as effective as ultrasonic pulse echo in detecting smaller voids. Ultrasonic pulse echo had application to detection of voids, steel reinforcement position and depth (maximum of two layers and $100 \mathrm{~mm}$ depth), tendon duct position and depth, voids in tendon ducts, and thickness determinations to about $1.2 \mathrm{~m}$ with no steel reinforcement (or very low reinforcement ratios) and to about $75 \mathrm{~cm}$ with relatively high reinforcement ratios. Spectral analysis of surface waves can indicate property variation with depth, damaged or deteriorated concrete, and the condition of the bond between concrete and liner. Radar was capable of indicating steel reinforcement position and depth (maximum of 3 layers and depth of 250-300 mm), resolving rebars at spacing $>100 \mathrm{~mm}$, indicating tendon duct position and depth (depths to $250 \mathrm{~mm}$ in areas of low rebar content having mesh size $>150 \mathrm{~mm}$ ), identifying voids in tendon ducts, and locating voids. Radar performance, however, was dependent on steel reinforcement presence (density, size, depth), concrete type and moisture content, cracking, antenna performance configuration, and processing tools and operating experience. For close spacings of steel reinforcement or tendon ducts, individual rebars and tendon ducts are hard to determine using radar. High energy computed radiography can locate, position, and size steel reinforcement and tendon ducts in presence of several layers of reinforcing steel and to depths up to about $1.4 \mathrm{~m}$. 
Radiography is also capable of locating ungrouted areas of tendon ducts and can determine liner voids or section loss. Additional information on applicability and capabilities of these methods was provided in Chapter 3.

Nondestructive evaluation methods have been successfully used for determining the properties of construction materials and in assessing the condition of built structures. Recent advances in areas such as signal conditioning and imaging concrete have resulted in significant improvements in the capability of these methods. Combinations of methods in which one method (e.g., stress wave) is used to rapidly detect and locate suspect areas followed by a second method (e.g., radar) to provide high quality images to permit assessment of the condition of the area in question has been shown to be an effective approach. New approaches such as the CONMOD Project (5.3,5.4) in which finite-element methods were combined with in situ nondestructive testing offers the potential of an improved approach to aging management of concrete structures. Improvements are still desirable, however, with respect to inspection of nuclear power plant reinforced concrete structures because of their complex geometries, existence of inclusions, restricted accessibility in certain locations, problems related to sensitivity to inhomogeneities in the concrete of the method utilized, and influence of the presence of moisture or steel reinforcement in particular. With the exception of information provided in Section 3.3 on inspection of concrete foundation elements, little information was identified with respect to inspection of nuclear power plant basemats that provide inspection challenges due to their thick cross sections and accessibility constraints.

\subsection{REFERENCES}

5.1 NEA Workshop on Development Priorities for NDE of Concrete Structures in Nuclear Plants (Risely, United Kingdom), NEA/CSNI/R(97)28, Nuclear Energy Agency, Committee on Safety of Nuclear Installations, Issy-les-Moulineaux, France, November 12, 1997.

5.2 Development Priorities for Non-Destructive Examination of Concrete Structures in Nuclear Plant, NEA/CSNI/R(98)6, Nuclear Energy Agency, Committee on Safety of Nuclear Installations, Issy-lesMoulineaux, France, November 2, 1998.

5.3 "Concrete Containment Management Using the Finite Element Technique Combined with In-Situ NonDestructive Testing of Conformity with Respect to Design and Construction Quality (CONMOD)," Fifth International Symposium on EU Research for Reactor Safety, Session 2.7 - Concrete Ageing, Luxembourg, November 10-13, 2003.

5.4 CONMOD - Main Report, Coordinated by Force Technology, Brøndby, Sweden, Contract No: FIKS-CT 2001-00204, European Union Research for Reactor Safety, Fifth Framework Program, (http://cordis.europa.eu/fp5-euratom/src/lib finalreports.htm).

5.5 O. Jovall, J-A. Larsson, P. Shaw, J-P. Touret, and G. Karlberg, "Concrete Containment Modeling and Management, Conmod," Transactions of the $17^{\text {th }}$ International Conference on Structural Mechanics in Reactor Technology, Paper H04-4, Prague, Czech Republic, 17-22 August 2003.

5.6 D. Youdan, "The Use of Acoustic Monitoring to Manage Concrete Structures in the Nuclear Industry," OECD-NEA Workshop - The Instrumentation and Monitoring of Concrete Structures, NEA/CSNI/R(2000)15, Nuclear Energy Agency, Committee on Safety of Nuclear Installations, Issy-lesMoulineaux, France, January 10, 2001.

5.7 Final Report: Non-Destructive Testing Methods for Integrity Determination of Concrete Structures, Version 1.1 SG, Nordic Industrial Fund, Oslo, Norway, May 5, 2004 (http://www.nordicinnovation.net/prosjekt.cfm?id=3-4415-82).

5.8 P. Shaw, J. Rasmussen, and T.K. Pedersen, A Practical Guide to Non-Destructive Examination of Concrete, Nordic Innovation Centre, Oslo, Norway, 2004.

5.9 P. Shaw, "A Study of NDE-Performance in the Condition Assessment of Reinforced Concrete Structures," Proceedings of the International RILEM Workshop on Life Prediction and Aging Management of Concrete Structures held in Cannes, France, Proceedings PRO 16, pp. 63-76, RILEM Publications, S.A.R.L., Cachan, France, 2000. 
5.10 A. Taffe, K. Borchart, and H. Wiggenhauser, "Specimen for the Improvement of NDT Methods - Design and Construction of a Large Concrete Slab for NDT Methods at BAM," International Symposium on NonDestructive Testing in Civil Engineering (NDT-CE-2003), Bundesanstalt für Materialforschung und prüfung, Berlin, Germany, 2003.

5.11 R. Beutel, H-W. Reinhardt, C.U. Grosse, A. Glaubitt, M. Krause, C. Maierhofer, D. Algernon, H. Wiggenhauser, and M. Schickert, "Performance Demonstration of Non-Destructive Testing Methods," European Conference on NDT, Paper Tu.3.2.2, 9 pp., Berlin, Germany, 25-29 September 2006.

5.12 M. Schickert, U. Tümmler, and L. Bühling, "Rapid Scanning Approaches for Ultrasonic imaging of Concrete," European Conference on NDT, Poster 20, 8 pp., Berlin, Germany, 25-29 September 2006.

5.13 A. Taffe, M. Krause, B. Milmann, and E. Niederleithinger, "Assessment of Foundation Slabs with USEcho in the Re-Use Process," Proceedings of International Conference on Concrete Repair, Rehabilitation, and Retrofitting (ICCRRR) held 21-23 November 2005 at University of Cape Town, South Africa, pp. 525530, 2006.

5.14 A. Taffe and H. Wiggenhauser, "Validation for Thickness Measurement in Civil Engineering with Ultrasonic Echo," European Conference on NDT, Paper Th.2.5.3, 8 pp., Berlin, Germany, 25-29 September 2006.

5.15 H. Wiggenhauser, M. Krause, and J. Krieger, "Tests and Assessments of NDT Methods for Concrete Bridges," Proceedings of $8^{\text {th }}$ International Conference on Structural Faults and Repair 99, Session - NDT of Bridges, London, United Kingdom, July 15-19, 1999.

5.16 M. Krause, F. Mielentz, B. Milmann, M. Müller, and V. Schmitz, "Imaging of Cracks and Honeycombing in Concrete Elements," Acoustical Imaging 27, pp. 129-137, Kluwe Academic Publishers, London, United Kingdom, 2004.

5.17 C. Maierhofer, H. Wiggenhauser, A. Brink, and M. Röllig, "Quantitative Numerical Analysis of Transient IR-Experiments on Buildings,” Infrared Physics \& Technology 46 (1-2), pp.173-180, December 2004.

5.18 C. Maierhofer, A. Brink, M. Röllig, and H. Wiggenhauser, "Detection of Shallow Voids in Concrete Structures with Impulse Thermography and Radar," NDT \& E International 36(4), pp. 257-263, June 2003.

5.19 C. Colla, G. Schneider, and H. Wiggenhauser, "Scanning Impact-Echo of Concrete Slab with Empty Ducts," Bundesanstalt für Materialforschung und -prüfung, Berlin, Germany, March 1, 2007. http://www.bam.de/de/kompetenzen/fachabteilungen/abteilung_8/fg82/fg82 medien/fg82 ie_scannend mi chelsrombach engl.pdf.

5.20 M. Krause. B. Milmann, M. Schickert, and K. Mayer, "Investigation of Tendon Ducts by Means of Ultrasonic Echo Methods: A Comparative Study," European Conference on NDT, Paper Tu.3.2.1, 12 pp., Berlin, Germany, 25-29 September 2006.

5.21 M. Krause, F. Mielentz, B. Milmann, D. Streicher, and W. Müller, "Ultrasonic Imaging of Concrete Elements: State of the Art Using 2D Synthetic Aperture," International Symposium on Non-Destructive Testing in Civil Engineering (NDT-CE-2003), Bundesanstalt für Materialforschung und -prüfung, Berlin, Germany, 2003.

5.22 O. Paris, C. Poidevin, J.M. Rambach, and C. Nahas, "Study of Phased Array Techniques for Concrete Inspection," European Conference on NDT, Paper Tu.3.2.3, 7 pp., Berlin, Germany, 25-29 September 2006.

5.23 O. Paris, Ph. Brédif, O. Roy, J.M. Rambach, and C. Nahas, "Study of Phased Array Techniques for Cracks Characterization in Concrete Structures," International Symposium on Non-Destructive Testing in Civil Engineering (NDT-CE-2003), Bundesanstalt für Materialforschung und -prüfung, Berlin, Germany, 2003. 
5.24 X. Dérobert, C. Aubagnac, and O. Abraham, "Comparison of NDT Techniques on a Post-Tensioned Beam Before Its Autopsy,” NDT \& E International 35(8), pp. 541-548, December 2002.

5.25 A. Kumar, B. Raj, P. Kalyanasundaram, T, Jayakumar, and M. Thavasimuthu, "Structural Integrity Assessment of a Pressurized Heavy Water Nuclear Reactor Using Impact Echo Technique," NDT \& E International 35(4), pp. 213-220, June 2002.

5.26 S.K. Woo and Y.C. Song, "Non-Destructive Testing Method for the Detection of the Internal Defects Inside Concrete," $10^{\text {th }}$ Asian-Pacific Conference on Non-Destructive Testing, Brisbane, Australia, 17-21 September 2001 (http://www.ndt.net/article/apcndt01/papers/1121/1121.htm).

5.27 D.S. Kim, H.W. Kim, W.S. Seo, K.C. Choi, and S.K. Woo, "Feasibility Study of the IE-SASW Method for Nondestructive Evaluation of Containment Building Structures in Nuclear Power Plants,' Nuclear Engineering and Design 219(2), pp. 97-110, February 2003.

5.28 M. Asano, T. Kamada, M. Kunieda, and K. Rokugo, "Impact Acoustics Methods for Defect Evaluation in Concrete," International Symposium on Non-Destructive Testing in Civil Engineering (NDT-CE-2003), Bundesanstalt für Materialforschung und -prüfung, Berlin, Germany, 2003.

5.29 T. Uomoto, "Utilization of NDI to Inspect Internal Defects in Reinforced Concrete Structures," International Symposium on Non-Destructive Testing in Civil Engineering (NDT-CE-2003), Bundesanstalt für Materialforschung und -prüfung, Berlin, Germany, 2003.

5.30 J-H Tong and S-T Liao, "An Elastic-Wave-Based Imaging Method for Scanning the Defects Inside the Structure," $12^{\text {th }}$ Asian-Pacific Conference on Non-Destructive Testing, Auckland, New Zealand, 5-10 November 2006 (http://www.ndt.net/article/apcndt2006/toc.htm).

5.31 J. Rhazi, O. Dous, and S. Kaveh, "Detection of Fractures in Concrete by GPR Technique," $16^{\text {th }}$ World Conference on NDT 2004, Montreal, Canada, August 30 - September 3, 2004 (http://www.ndt.net/abstract/wcndt2004/751.htm).

5.32 P. Giamou, "Ground Penetrating Radar Imaging of Concrete at a Nuclear Power Plant," Back to Basics, The American Society for Nondestructive Testing, Columbus, Ohio, December 2006 (http://asnt.org/publications/materialseval/basics/dec06basics/dec06basics.htm).

5.33 J. Martin, K.J. Broughton, A. Giannopolous, M.S.A. Hardy, and M.C. Forde, "Ultrasonic Tomography of Grouted Duct Post-Tensioned Reinforced Concrete Bridge Beams," NDT\&E International 34(2), pp. 107113, March 2001. 


\section{REVIEW OF APPLICATIONS OF NONDESTRUCTIVE EVALUATION (NDE) TO CONTAINMENT METALLIC PRESSURE BOUNDARIES}

\subsection{BACKGROUND}

Inspection of inaccessible portions of metallic pressure boundary components of nuclear power plant containments (e.g., fully embedded or inaccessible containment shell or liner portions, the sand pocket region in Mark I and II drywells, and portions of the shell obscured by obstacles such as platforms or floors) requires special attention. Embedded metallic portions of the containment pressure boundary may be subjected to corrosion resulting from ground water permeation through the concrete; a breakdown of the sealant at the concrete-containment shell interface that permits entry of corrosive fluids from spills, leakage, or condensation; or in areas adjacent to floors where the gap contains a filler material that can retain fluids.

Examples of some of the problems that have occurred at nuclear power plants include corrosion of the steel containment shell in the drywell sand cushion region, shell corrosion in ice condenser plants, corrosion of the torus of the steel containment shell, and concrete containment liner corrosion (see Section 2.6). In addition there have been a number of metallic pressure boundary corrosion incidents that have been identified in Europe (e.g., corrosion of the liner in several of the French $900 \mathrm{MW}$ (e) plants, metal containment corrosion in Germany, and corrosion of embedded containment metal liner in Sweden) (6.1-6.3). Corrosion incidences such as these may challenge the containment structural integrity and, if through-wall, can provide a leak path to the outside environment. Although no completely suitable techniques for inspection of inaccessible portions of containment pressure boundaries have been demonstrated to date, several techniques have been investigated (i.e., ultrasonics, electromagnetic acoustic transducers, half-cell potential measurements, magnetostrictive sensors, and multimode guide waves). Provided below are a summaries of several or these studies.

\subsection{REVIEW OF RESEARCH HAVING APPLICATION TO INSPECTION OF INACCESSIBLE PORTIONS OF METALLIC PRESSURE BOUNDARIES}

\subsubsection{Corrosion Damage of Containment Metallic Pressure Boundaries in Germany}

In Germany, an extensive evaluation was conducted to evaluate the feasibility of using ultrasonic methods to detect corrosion damage of the containments of Pressurized Water Reactors (PWRs) or liners of Boiling Water Reactors (BWRs) in areas that are inaccessible (i.e., embedded bottom portion of containments of PWRs, areas of containments of PWRs adjoining platforms, penetrations through the containments of PWRs, and steel liners of BWRs inside pressure-suppression chamber) (6.2). In order to establish suitable search units (favorable signal-tonoise ratio) for detection of metal containment corrosion, a calibration block with simulated corrosion was prepared. A sharp-edged and a cambered shallow pit were machined to a depth of $2.5 \mathrm{~mm}$ into a $39-\mathrm{mm}$-thick calibration block. Figure 6.1 presents information on sharp-edged Shallow Pit 1A and Figure 6.2 presents information on

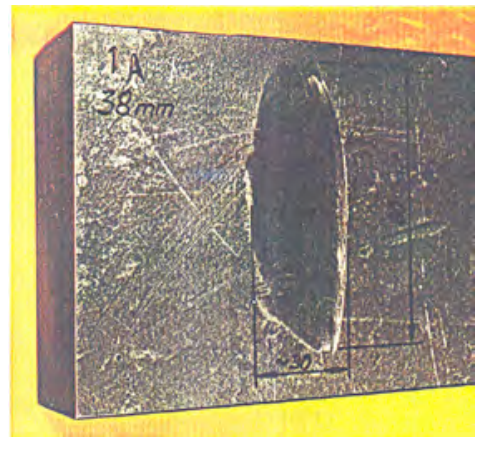

(a) Sharp-edged Shallow Pit 1A.

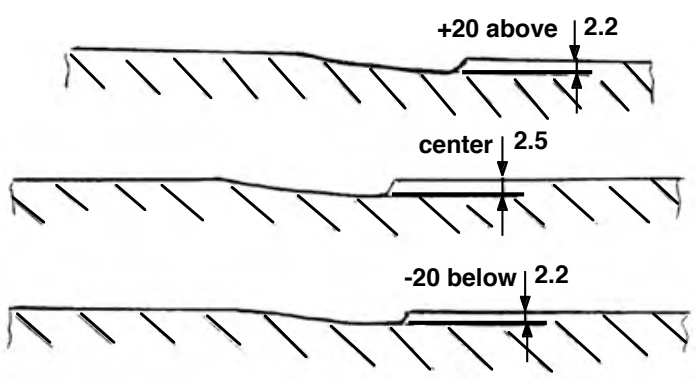

(b) Test specimen B.

Figure 6.1 Information on sharp-edged Shallow Pit 1A, calibration Block No.1, no corrosion.

Source: D.C. Pocock, J.C. Worthington, R. Oberpichler, H. Van Exel, D. Beukelmann, R. Huth, and B. Rose, LongTerm Performance of Structures Comprising Nuclear Power Plants, Report EUR 12758 EN, DirectorateGeneral Science, Research and Development, Commission of European Communities, Luxembourg, 1990. 


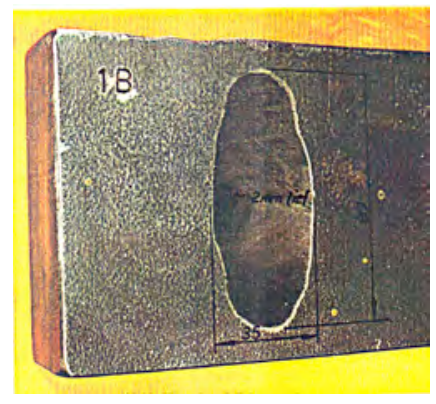

(a) Cambered Shallow Pit 1B.
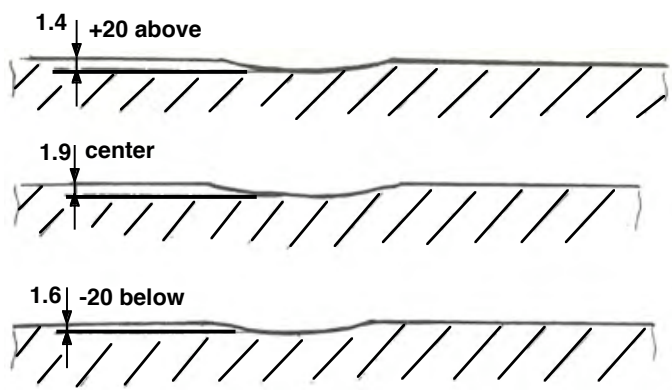

(b) Cross section of Shallow Pit $1 \mathrm{~B}$.

Figure 6.2 Information on cambered Shallow Pit 1B, calibration Block No.1, no corrosion.

Source: D.C. Pocock, J.C. Worthington, R. Oberpichler, H. Van Exel, D. Beukelmann, R. Huth, and B. Rose, LongTerm Performance of Structures Comprising Nuclear Power Plants, Report EUR 12758 EN, DirectorateGeneral Science, Research and Development, Commission of European Communities, Luxembourg, 1990.

cambered Shallow Pit 1B. The sharp-edged pit was used to qualify the search units considered. Corrosioninhibiting paint was applied to one surface of the block. Several angle beam search units were used to examine the calibration block $\left(45^{\circ}, 60^{\circ}, 70^{\circ}\right.$, and $\left.90^{\circ}\right)$. In setting up the qualification tests, experience had shown that locations of corrosion in containments can occur at distances to approximately $100 \mathrm{~mm}$ below the interface where the containment shell becomes embedded in concrete. This results in long beam paths with correspondingly large projection distances for the ultrasonic examinations. A pulse-echo unit was used in the tests with sensitivity adjusted based on signal-to-noise ratio (average method). Results obtained showed that the sharp-edged pit was detectable (signal-to-noise ratio $>12$, input angles from $45^{\circ}$ to $90^{\circ}$ ), but the rounded pit (input angles from $35^{\circ}$ to $80^{\circ}$ ) could not be detected. Supplemental testing was then performed on a PWR containment and corroded calibration blocks.

During repair to the containment of a PWR at a German nuclear power plant it was possible to perform ultrasonic examinations and to establish the extent to which such examinations were suitable for detecting corrosion damage. To facilitate detection of surface corrosion on the inside of the containment, which later became visible when the concrete was removed, angle beam search units were used to scan zones with different coupling conditions. When selecting search units for examination of containment corrosion several aspects were taken into account: (1) surface conditions of the calibration block and the containment differed, (2) the containment was coated internally and externally while the corrosion block was coated only with a corrosion-inhibiting paint, and (3) reflection characteristics of corrosion points in the containment differ from those of the sharp-edged or cambered shallow pits in the corrosion block. Supplemental examinations were carried out to characterize the corrosion and to qualify the testing technique. The tests involved coated surfaces and surfaces machined until they were bright metal. With the $45^{\circ}$ search unit it was found that the influence of the coating could be disregarded and locations of corrosion could be separated from the interference level of the detection zone $(\sim 6 \mathrm{~dB})$ in single to triple skips. For the $60^{\circ}$ and $70^{\circ}$ search units, because of the long paths and surface roughness of the component, the indications of corrosion were masked by interference. With coating present, signals from the $90^{\circ}$ search units were highly damped so wave propagation distance was inadequate. When the coating was removed by grinding, the noise level from surface roughness was too high to use the $90^{\circ}$ search units. With this as background, ultrasonic tests were performed from the inside and outside of the containment with varying beam paths (single to triple skip distances) using the $45^{\circ}$ search unit.

Measurements on the inside containment surface were performed at four locations. The locations included those with and without corrosion. Coupling conditions were such that the surface was either coated or bright metal (e.g., ground). Indications of corrosion pits were obtained from each of the locations where corrosion pits were present. For measurements from the outside of the containment, the coupling area was slightly smoothed and coated. Echo heights indicative of corrosion were obtained from the outside surface of the containment for only one of the four corrosion locations. Removal of the concrete adjacent to this area revealed corrosion that was about $100 \mathrm{~mm}$ below the interface. Wall thickness measurements were then performed on the containment at this location. The initial wall thickness at coated, non-corroded locations ranged from 31.2 to $31.4 \mathrm{~mm}$. The smallest measured wall 
thickness in the area of corrosion was $29.3 \mathrm{~mm}$ indicating an approximate wall thinning of $2 \mathrm{~mm}$, or a loss in thickness of $6.4 \%$. General corrosion was found to be difficult to detect.

Further examinations were carried out on calibration blocks with artificial corrosion induced. These examinations were performed to verify whether and under which test conditions corrosion could be safely detected with $45^{\circ}$ angle beam search units. The previous calibration block and another calibration block containing a 2-mm-deep pit, sharpedged on one side and flattened on the other, were artificially corroded for a period of seven months using $1 \% \mathrm{NaCl}$ solution at $20^{\circ} \mathrm{C}$ to produce corrosion pits up to $2.4-\mathrm{mm}$ deep. The corrosion pits were detectable in both calibration blocks with adequate signal-to-noise ratio.

The study concluded that corrosion pits could be adequately detected by ultrasonic testing with $45^{\circ}$ angle beam search units if the corroded surfaces were sufficiently pitted (e.g., $\geq 2.4-\mathrm{mm}$ deep). In this case sufficient sound intensity is transmitted back to the search unit as a result of adequate reflectivity. The ultrasonic wavelength is a measure of reflectivity and it must be on the order of magnitude of the extent of the corrosion pits. Signal-to-noise ratio should be on the order of $12 \mathrm{~dB}$ for detectability. Results of this study indicated that it was possible to detect well-developed corrosion pits (pit depth of same order of magnitude as ultrasonic wavelength) with $45^{\circ}$ angle beam $2 \mathrm{MHz}$ search units within a distance of up to $130 \mathrm{~mm}$ below the interface between the concrete and metal containment.

\subsubsection{EMAT Detection of Flaws in Plate Structure}

An electromagnetic acoustic transducer (EMAT) is a device that generates and detects ultrasonic waves in metal based on the Lorentz force which is a force that acts on a moving charge in a static magnetic field (6.4). The EMAT consists of a transmitter and receiver, both of which contain a permanent magnet or electromagnet and a coil, as noted in Figure 6.3. The transmitter coil is excited by high radio-frequency current to induce an eddy current into the surface of the metal examined. The eddy current interacts with the magnetic field generated by the transmitter coil to produce a Lorentz force that interacts with alternating current (supplied by the EMAT coil) and an externally supplied magnetic flux to generate guided plate waves in the metal (i.e., pulse-echo and through-transmission modes generate low frequency horizontal shear (SH) plate or Lamb waves). Detection of elastic waves is accomplished by the reverse process in which the wave in the presence of a static magnetic field gives rise to eddy currents in the metal that induces a voltage to the EMAT coil. EMATs have been applied to long-range inspections of tubes (6.5) and steel sheets (6.6). EMATs have advantages for detection of corrosion because: a couplant is not needed, the ultrasound is generated directly in the metal rather than in the transducer, the high-energy waves can travel relatively long distances parallel to the plate surface, the wave velocity is independent of plate thickness, and the ultrasound can be generated through a surface coating up to about 1.5-mm-thick. Disadvantages of EMATs are that their efficiency is low and thus the signal-to-noise ratio may be poor, and they lose sensitivity when the gap to the surface of the component inspected is increased.

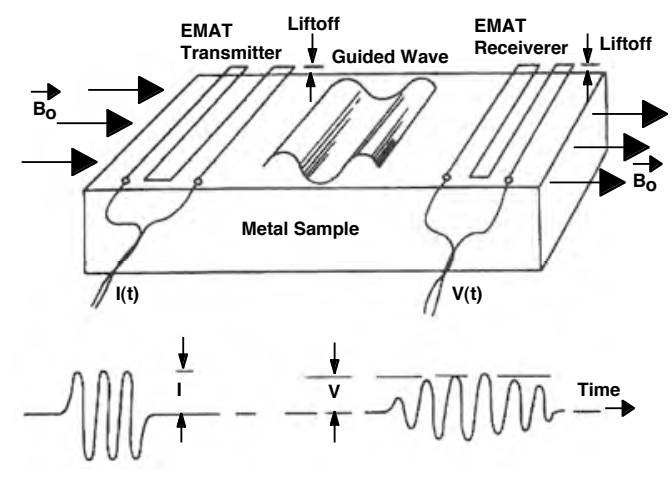

Figure 6.3 Common EMAT setup for guided waves.

Source: H. Kwun, Feasibility of Magnetostrictive Sensor Inspection of Containments, NUREG/CR-5724, U.S. Nuclear Regulatory Commission, Washington, D.C., March 1999.

The capability of adapting EMATs to detect corrosion in Mark I containment vessels and correlating EMAT signals with corrosion damage to make quantitative evaluations was evaluated in the laboratory (6.7). Since it had been 
shown that the $\mathrm{SH}_{0}$ mode had less attenuation than the $\mathrm{SH}_{1}$ mode, the $\mathrm{SH}_{0}$ mode was primarily used for the experiments. Simulated corrosion-like defects (12.7-mm wide by $101.6-\mathrm{mm}$ long by $11.4-\mathrm{mm}$ deep) were milled into a $2.1-\mathrm{m}$-wide by $4.9-\mathrm{m}$-long by $25.4-\mathrm{mm}$-thick plate at a distance of $0.6 \mathrm{~m}$ from one end. Figure $6.4 \mathrm{a}$ presents the general plate, defect, and EMAT layout that was used for most of the results obtained in the study. The EMAT launches a plate wave (primarily an $\mathrm{SH}_{0}$ mode) in both directions. The receiver EMAT detects the plate wave as it passes beneath the receiver (the "direct" signal). A portion of this signal is scattered back toward the receiver by the defect. The remaining signal is reflected from the end, scattered slightly by the defect and is detected by the receiver as an END 1 reflection. The plate wave launched in the opposite direction is reflected from END 2 and then detected by the receiver. Depending on the location of the receiver and transmitter, the END 1 reflection may be either before or after END 2 reflection. Figure $6.4 \mathrm{~b}$ presents a schematic of the arrangement used for the measurements. Figure 6.5 presents the digitized waveform taken with the receiver $0.9 \mathrm{~m}$ from the transmitter and
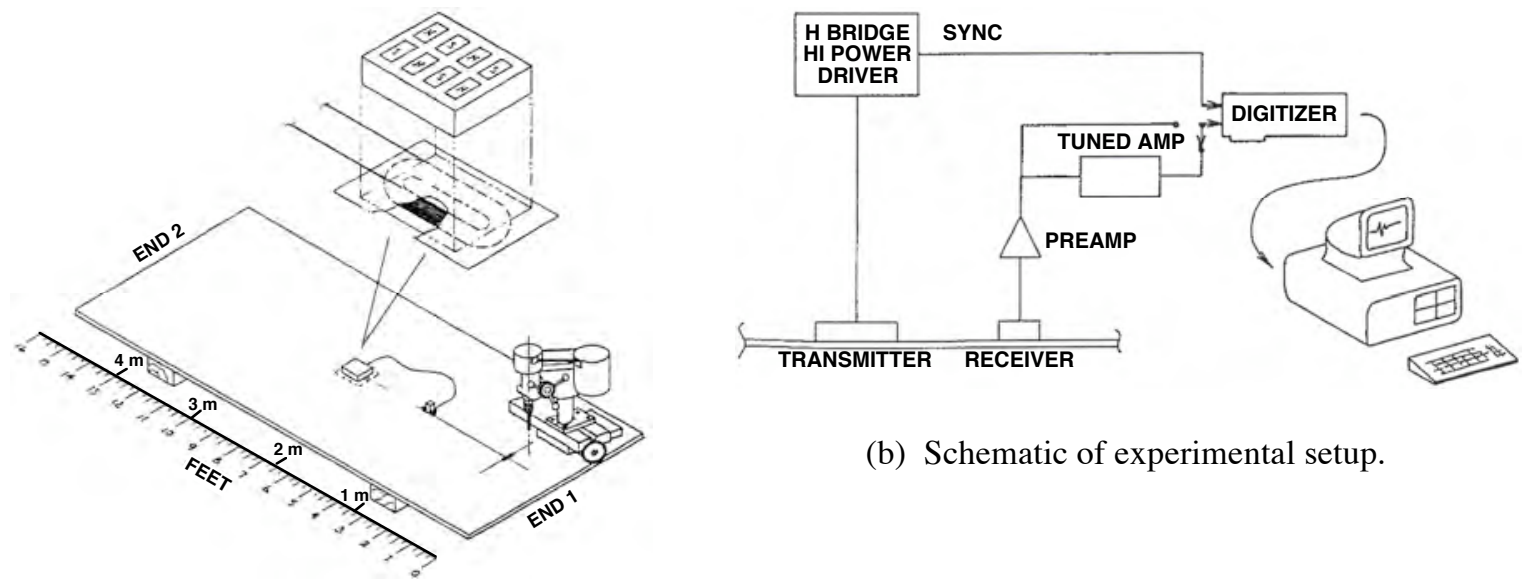

(b) Schematic of experimental setup.

(a) General plate, defect, and EMAT layout.

Figure 6.4 Plate and setup for EMAT defect experiment.

Source: B.W. Maxfield and A. Kuramoto, The Feasibility of Using Electromagnetic Acoustic Transducers to Detect Corrosion in Mark I Containment Vessels, EPRI NP-6090, Electric Power Research Institute Palo Alto, California, November 1988.

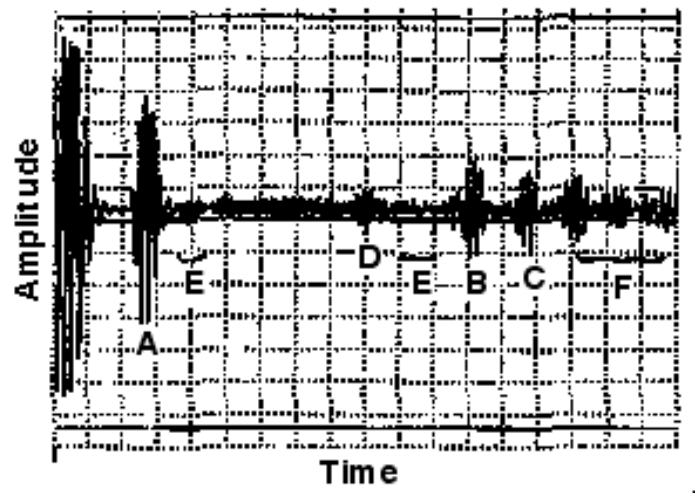

Figure 6.5 Typical amplitude-time waveform.

Source: B.W. Maxfield and A. Kuramoto, The Feasibility of Using Electromagnetic Acoustic Transducers to Detect Corrosion in Mark I Containment Vessels, EPRI NP-6090, Electric Power Research Institute Palo Alto, California, November 1988.

$2.1 \mathrm{~m}$ from END 2 using a tuned amplifier and averaging the signal 16 times. The signal labeled " $\mathrm{A}$ " is the direct propagation from the transmitter to the receiver located about $0.9 \mathrm{~m}$ from the transmitter. Signal "B" is the same waveform after traveling to END 1 and back to the receiver, an additional distance of $3.7 \mathrm{~m}$, while signal " $\mathrm{C}$ " is the 
corresponding reflection from END 2. Signal "D" is the scattering from a 12.7-mm wide by 101.6-mm long by 11.4-mm deep slot located on the plate centerline at a distance of $61 \mathrm{~cm}$ from END 1. Signals "E" are coherent background noise after the first arrival signal, much of which could be removed by spatial averaging or other synthetic aperture type of signal processing. Signal "F" is due to scattering of the transmitter side lobe and/or peripheral portions of the main lobe from the plate edge and end. If plate-to-plate welds were present, signals similar to "F" would be generated, but have much smaller amplitude. Signal processing techniques can be used to separate geometric scatterings such as "F" from those due to corrosion.

Experimental results show that SH waves scattered from planar slots (also for planar cracks and similar boundaries) produce signals that are measurable at substantial distances ( $3 \mathrm{~m}$ or more) from a small (two wavelength) scatterer that extends halfway through the plate. In the pulse-echo geometry, a flaw at least half-way through the plate thickness and two wavelengths long $(\sim 127 \mathrm{~mm})$ provided strong scattering signals that could be detected at distances to $4.6 \mathrm{~m}$. Rounding of the flaw caused the signal to become weaker and spread it more over a larger angle (i.e., scattered energy from planar slot was primarily $\mathrm{SH}_{0}$ mode while a semi-circular slot scattered a great deal of energy into other modes). Although the through-transmission mode was not as sensitive (lower relative detectability), it was felt that deep corrosion damage (i.e., $>75 \%$ of the plate thickness) could be detected at distances to $15 \mathrm{~m}$ or more, but defect sizing would be difficult. The significant amount of coherent elastic wave energy present in the plate indicated that discrimination of any type of scattering anomaly will be improved dramatically using synthetic aperture signal processing. No concrete was adjacent to the plate surfaces during these experiments.

\subsubsection{High Frequency Acoustic Imaging}

Exploratory analytical and experimental simulations have been conducted to investigate the feasibility of applying high-frequency acoustic imaging techniques to the detection and localization of thickness reductions in the metallic pressure boundaries of nuclear power plant containments $(6.8,6.9)$.

\subsubsection{Numerical Simulations}

The analytical study used an elastic layered-media code (OASES Code, Massachusetts Institute of Technology) to perform a series of numerical simulations to determine the fundamental two-dimensional propagation physics (6.10, 6.11). Results from the two-dimensional studies were used to address three-dimensional issues related to defect classification.

The range-dependent version of the OASES Code successfully modeled the steel containment and steel-lined concrete containment scenarios using the discrete notch approach. The two-dimensional numerical model used for the embedded steel containment scenario is presented in Figure 6.6. For the steel containment scenario, significant degradations $(>2 \mathrm{~mm})$ located below the concrete/air interface gave reasonable intrinsic backscatter levels $(-15 \mathrm{~dB})$ that were $10-15 \mathrm{~dB}$ above the expected noise level due to surface imperfections. Dependence of degradation depth was small, but measurable. The embedding concrete introduced large losses that would limit penetration ability.

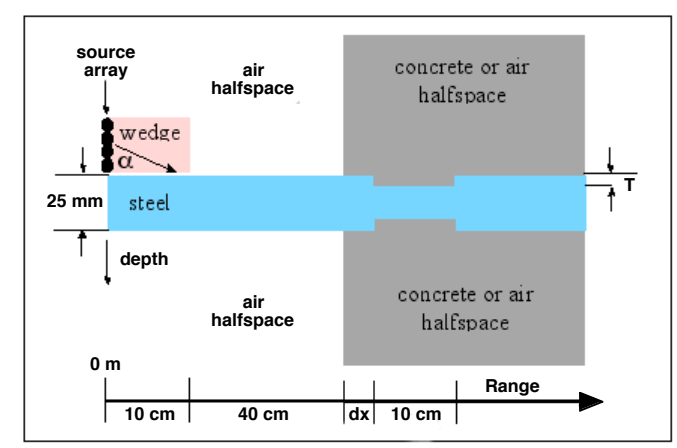

Figure 6.6 Range-dependent numerical simulation scenario for steel containment.

Source: J.E. Bondaryk, C.N. Corrado and V. Godino, Feasibility of High Frequency Acoustic Imaging for Inspection of Containments, NUREG/CR-6614, U. S. Nuclear Regulatory Commission, Washington, D.C., August 1998. 
Backscatter strength was not very sensitive to frequency or angle of the transducer $(<5 \mathrm{~dB})$ for the sharp-edge degradations examined. Results indicated that acoustic imaging technology can be applied to the steel containment scenario. For the steel-lined reinforced concrete containment scenario, the thin steel liner in conjunction with the concrete produced unacceptably high signal losses to concrete $(\sim 100 \mathrm{~dB})$. Application of acoustic imaging technology to this scenario seems unlikely. Available sensors at the time of this study could not be used in array configurations to interrogate a large area (global inspection) due to their intrinsic narrow beam pattern, which did not allow steering. This limited these sensors to spot detection and mapping scenarios, where degradation was already suspected; however, scannable sensor technology, such as used for medical ultrasound, should be capable of being developed.

\subsubsection{Experimental Simulations}

Based on the prior numerical simulations, the proposed solution was to propagate ultrasonic waves (either shear or compressional), whose wavelengths are a fraction of the plate thickness, from accessible regions of a free-standing steel containment vessel (or liner of reinforced concrete containments) laterally to detect degradation located below the air-concrete interface. Ideally, the reflected returns from material defects can be processed to generate an image of the degradation. Shear waves were used because for a given inspection frequency they have shorter wavelengths than compressional waves and therefore can resolve smaller defects. These refracted waves "skip" laterally away from the source through the structure and when the waves encounter discontinuities, acoustic reflections occur. This approach is typically used for weld inspection, however, it is not typically required to propagate over considerable distances or to propagate in constrained or embedded regions of the test structure, as required to do in order to demonstrate success in the proposed test scenarios. Moreover, the significance of the embedding concrete on propagation of ultrasonic waves in the steel and how well corrosive type degradations act as acoustic reflectors are unknown. The feasibility of employing the technique under the proposed scenario therefore centers on determining if a measurable and decipherable signal was returned from an area exhibiting degradation (e.g., wall thinning due to corrosion).

In an effort to not only provide a basis for improving the numerical models, but also to continue the feasibility study in a more practical forum, a series of controlled laboratory experiments were designed. The experiments attempt to limit conditions to two-dimensional scenarios where only degradation variations in the direction of the incident wave are considered, and flat plates can be used as propagating media. The physics side of the problem was addressed by investigating the energy lost from the interrogating signals into the surrounding concrete, as well as characterizing acoustic scatter arising from different defect geometries. Also of primary importance was the practical issue of determining the performance limits exhibited by a commercially available angle-beam inspection system.

\section{Testing equipment}

The testing equipment consisted of a pulser/receiver card, a high frequency analog-to-digital acquisition board (both of which were attached to a standard PC ISA bus), controlling software, piezoelement contact transducers, coupling wedges, and industrial grade ultrasonic gel couplant. The transducers had a 25 -mm-diameter circular radiating face that produced an estimated half-angle beam width of just over six degrees. The transducers were tuned to $0.5 \mathrm{MHz}$, which is a relatively low frequency for ultrasonic testing (shear wavelength in steel at $0.5 \mathrm{MHz}$ is about $6 \mathrm{~mm}$ ), but allows for additional penetration. The equipment could be utilized in either the through-transmission mode, where separate transducers act as source and receiver (bistatic), or the pulse-echo mode, in which a single transducer injects a wave and then passively listens for a return (monostatic). When operated in the through-transmission mode, the source and receiver transducers are attached to coupling wedges having the same angle. The coupling wedges are specified by the refracted shear-wave angle (measured from the surface normal) introduced into the test structure. All the wedge angles used $\left(45^{\circ}, 60^{\circ}\right.$, and $\left.70^{\circ}\right)$ were past the compressional wave critical angle for steel (i.e., compressional waves will not be excited in the steel plate). As the transducer does not generate a planar incident field, the energy was injected in all directions. Therefore, the main lobe of the incident sound field did not excite compressional waves in the steel test structure, but the side lobes below the main lobe may excite compressional waves.

The input-voltage waveform was a tone burst, with a signal length of 4 microseconds and a frequency of $0.5 \mathrm{MHz}$. The maximum input voltage that the pulser could generate was $300 \mathrm{~V}$. Because the transducers were uncalibrated, the relationship between input voltage and mechanical force was unknown. The acquisition board range was \pm 0.5 volts with a precision of 8 bits. The receiver gain ranged from $0-70 \mathrm{~dB}$. 


\section{$\underline{\text { Assessment of signal loss components }}$}

Figure 6.7a presents a schematic of the test setup used to study the signal levels returned from "artificial" degradations of various shapes. The artificial degradations were uniform cross-section slots, either rectangular, rounded, or "V" shaped, cut across the width of a 914-mm long by 203-mm wide by $25-\mathrm{mm}$ thick steel plate. Because side interactions were intentionally avoided, the degradations were rendered effectively two-dimensional. All of the degradations were 4- $\mathrm{mm}$ deep by $10-\mathrm{mm}$ wide. Monostatic returns were measured at several distances from each slot's leading edge. Figure $6.7 \mathrm{~b}$ shows a sample return signal from a rectangular slot. The reflected signal "level" was defined as the maximum value in the signal packet that was assumed by simple time gating procedures to have emanated from the slot.
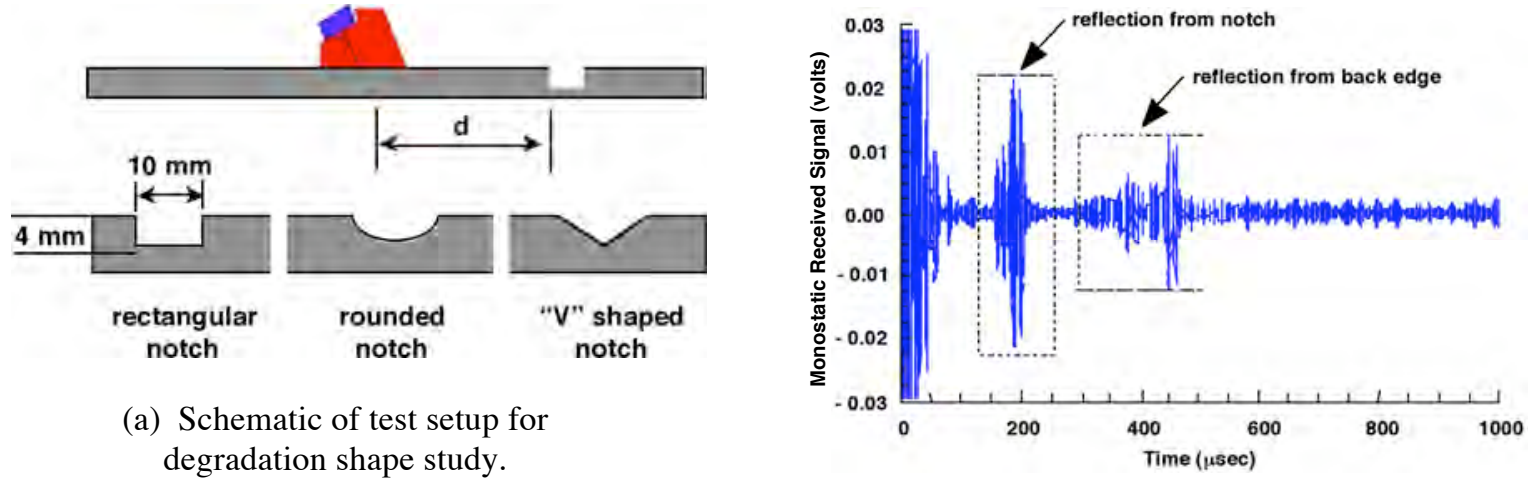

(a) Schematic of test setup for degradation shape study.

(b) Sample reflected return signal from rectangular notch.

Figure 6.7 Test setup and sample reflected signal for signal loss experiments.

Source: J. Rudzinsky, J. Bondaryk, and M. Conti, Feasibility of High Frequency Acoustic Imaging for Inspection of Containments: Phase II, ORNL/NRC/LTR-99/1, Lockheed Martin Energy Systems, Inc., Oak Ridge National Laboratory, Oak Ridge, Tennessee, July 1999.

Figure 6.8 presents reflected signal levels at several source locations relative to the slot geometry. For the $45^{\circ}$ coupling wedge, the returns from the rectangular slot were, averaged over source location, around $1 \mathrm{~dB}$ higher than those from the rounded slot and $4 \mathrm{~dB}$ higher than those from the "V" shaped slot. For the $70^{\circ}$ coupling wedge, the differences were 5 and $9 \mathrm{~dB}$, respectively. When an increase in received signal level was obtained at a position located a greater distance from the notch leading edge this was due to the location's proximity to a "hot" spot where the structural wave interacts with the plate surface. These results included the effects of geometric spreading, which were greater for the $45^{\circ}$ coupling wedge than for the $70^{\circ}$ wedge because the path to and from the slot was longer for the deeper angle.
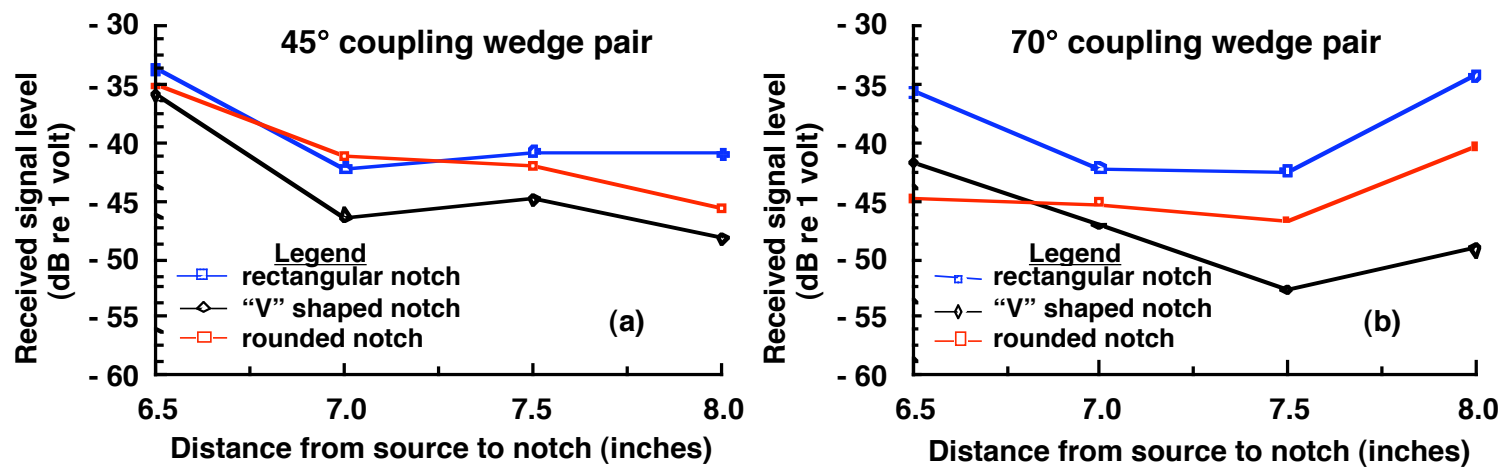

Figure 6.8 Results of degradation shape study.

Source: J. Rudzinsky, J. Bondaryk, and M. Conti, Feasibility of High Frequency Acoustic Imaging for Inspection of Containments: Phase II, ORNL/NRC/LTR-99/1, Lockheed Martin Energy Systems, Inc., Oak Ridge National Laboratory, Oak Ridge, Tennessee, July 1999. 
Reflected signal levels were also used to evaluate the effect of degradation depth. Figure 6.9 provides a sketch of the notches that were used in this study. All notches were rectangular in shape, 10-mm wide, and had notch depths of either 4,8 , or $12 \mathrm{~mm}$. Differences in reflected signals at several source locations relative to the notch for both a

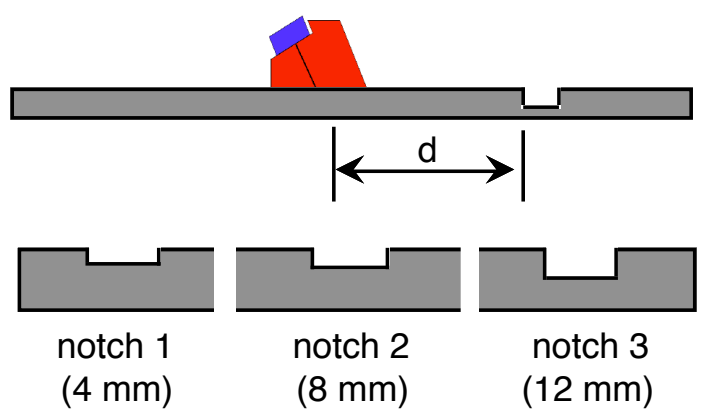

Figure 6.9 Test setup for degradation depth study.

Source: J. Rudzinsky, J. Bondaryk, and M. Conti, Feasibility of High Frequency Acoustic Imaging for Inspection of Containments: Phase II, ORNL/NRC/LTR-99/1, Lockheed Martin Energy Systems, Inc., Oak Ridge National Laboratory, Oak Ridge, Tennessee, July 1999.

$45^{\circ}$ and $70^{\circ}$ coupling wedge pair are presented in Figure 6.10. For the $45^{\circ}$ coupling pair, the returns from the 4-mmdeep notch were, averaged over source location, around $3 \mathrm{~dB}$ lower than those from the 8 -mm-deep notch and about $6 \mathrm{~dB}$ lower than those from the 12-mm-deep notch. This trend was as expected, as deeper notches project a greater area of acoustic impedance. The trend of results presented in Figure 6.10 for the reflected signal levels from the three different notches using a $70^{\circ}$ coupling wedge pair were not as expected. For some source-receiver separation distances the reflected returns from the shallowest notch were actually greater than those received from the deepest notch. The odd trend was qualitatively observed over a broad range of separation distances, eliminating skipping effects as a possible explanation. The explanation for these results may only be realized after incorporating advanced scattering theories, which was beyond the scope of this limited study.
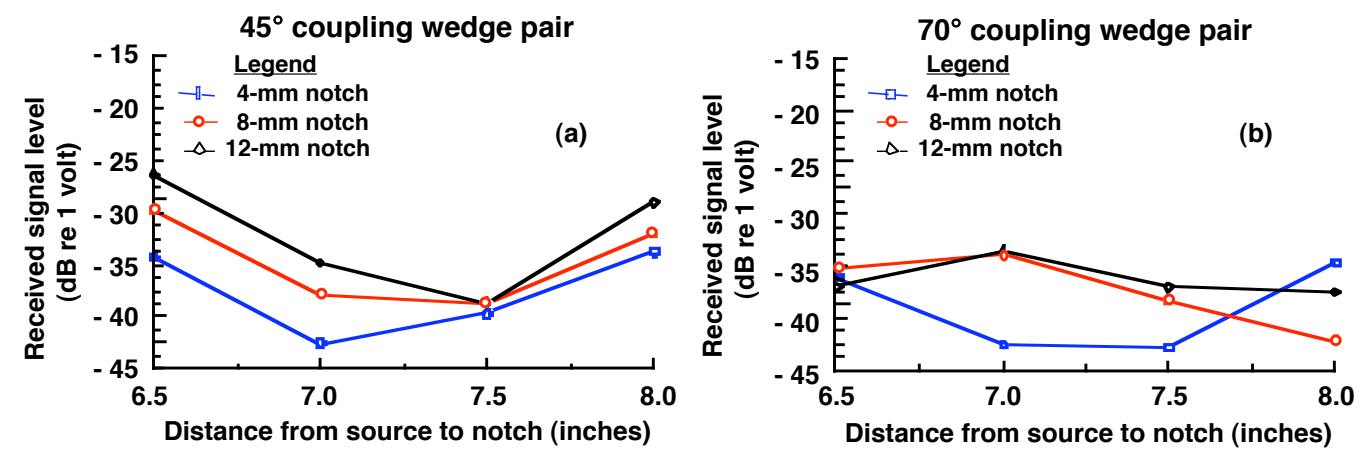

Figure 6.10 Results of degradation depth study.

Source: J. Rudzinsky, J. Bondaryk, and M. Conti, Feasibility of High Frequency Acoustic Imaging for Inspection of Containments: Phase II, ORNL/NRC/LTR-99/1, Lockheed Martin Energy Systems, Inc., Oak Ridge National Laboratory, Oak Ridge, Tennessee, July 1999.

\section{Concrete effects}

The final series of tests to assess the individual components of signal loss involved measuring the effect that concrete had on waves traveling in an embedded plate. To determine the effect that bond quality had on induced losses, one of the plates was wrapped with a single layer of 4-mil-thick plastic sheet prior to concrete casting to prevent bonding between the concrete and plate ("unbonded"). Two other plates were cast without the plastic sheet to permit bond development between the concrete and plates ("bonded"). 
Figure 6.11 presents a simplified schematic of the test setup for the concrete effects tests. The source transducer location, s, was varied from $6.3 \mathrm{~cm}$ to $11.4 \mathrm{~cm}$ in $1.27-\mathrm{cm}$ steps in order to sufficiently sample one half of a skip

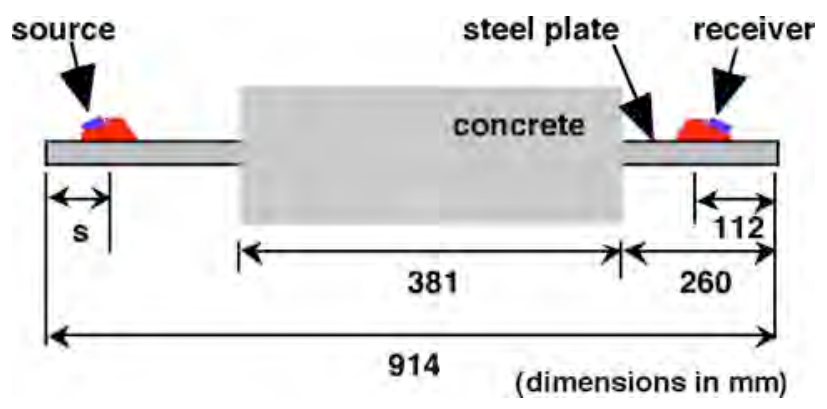

Figure 6.11 Test setup for concrete effects tests.

Source: J. Rudzinsky, J. Bondaryk, and M. Conti, Feasibility of High Frequency Acoustic Imaging for Inspection of Containments: Phase II, ORNL/NRC/LTR-99/1, Lockheed Martin Energy Systems, Inc., Oak Ridge National Laboratory, Oak Ridge, Tennessee, July 1999.

length for a $45^{\circ}$ coupling wedge. A receiving transducer maintained at a fixed position was used to monitor the signal that propagated through the plate. The received signal level was defined as the maximum value in the incident signal packet that arrived at the receiver. Figure 6.12 presents time histories of signals transmitted through a freestanding steel plate, an unbonded steel plate with concrete, and a bonded steel plate with concrete. The effect of plate unbonding was essentially to eliminate additional loses imposed by the embedding concrete. As noted in the figure, the character and overall level of the transmitted signal changed when the steel plate was bonded to the concrete (note change in scale for received signal axis for bonded steel plate with concrete).

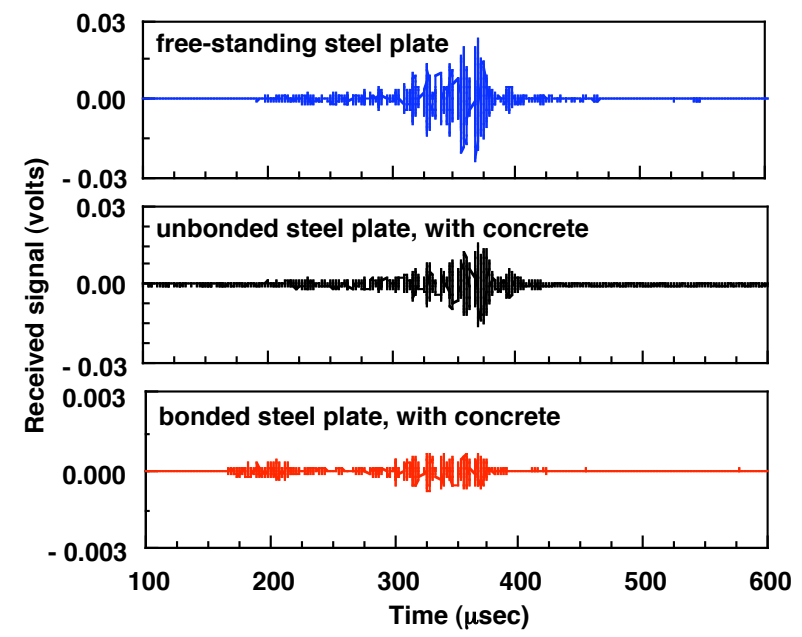

Figure 6.12 Time histories of signals transmitted through freestanding steel plate, unbonded steel plate with concrete, and bonded steel plate with concrete.

Source: J. Rudzinsky, J. Bondaryk, and M. Conti, Feasibility of High Frequency Acoustic Imaging for Inspection of Containments: Phase II, ORNL/NRC/LTR-99/1, Lockheed Martin Energy Systems, Inc., Oak Ridge National Laboratory, Oak Ridge, Tennessee, July 1999.

Figure 6.13a presents the maximum value in received signal level for the three freestanding plates prior to their embedment in concrete using an input source positioned at several locations. As expected, there was only minimal variation from plate to plate and the plastic wrap had no noticeable effect. Shown in Figure $6.13 \mathrm{~b}$ are results after embedding the midsections of the three plates in concrete. The two "bonded" plates display a significant loss in signal level (30 dB, or $1.6 \mathrm{~dB}$ per centimeter of two-way travel), while the "unbonded" plate signal level remained relatively high, incurring virtually no losses. Note that the results for the "bonded" plates are very similar, with the 
differences being attributable to a combination of measurement and concrete bond variations. These results showed that the interface, or bond, between the concrete and steel plays a critical role in determining the proportion of energy lost from waves traveling in the steel.
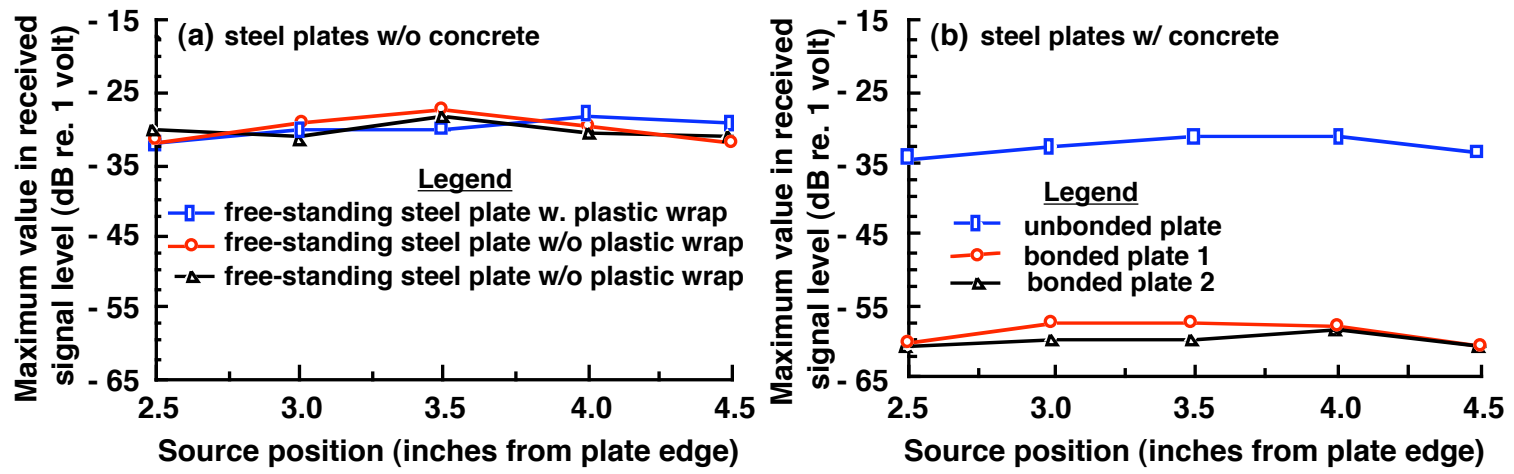

Fig. 6.13 Transmitted signal level: (a) free-standing steel plates and (b) steel plates embedded in concrete over part of their length.

Source: J. Rudzinsky, J. Bondaryk, and M. Conti, Feasibility of High Frequency Acoustic Imaging for Inspection of Containments: Phase II, ORNL/NRC/LTR-99/1, Lockheed Martin Energy Systems, Inc., Oak Ridge National Laboratory, Oak Ridge, Tennessee, July 1999.

Results of the concrete-effects tests indicate that characterizing degradation based on reflected returns from a defect may be difficult, even if its position can be determined. The propagation path plays a prominent role in determining the level of the returned signal. Path conditions cannot be well known without destructive testing. Also, the overall level of the reflected returns cannot be used (for the system and procedure employed here) to confidently characterize degradation located below the air/concrete interface.

\section{Conclusions from experimental simulations}

The experiments performed were designed to assess the performance of a commercially available fully integrated angle-beam inspection system, and to investigate the propagation physics that governs the use of angle-beam inspections. The measurement system displayed an input/output dynamic range of $125 \mathrm{~dB}$. Therefore, in the absence of competing signals, $105 \mathrm{~dB}$ of losses could be incurred while still maintaining a $20 \mathrm{~dB}$ signal-to-noise ratio. The mild steel plates used in the experiments propagated signals as if they were effectively free of surface imperfections, which would otherwise act as random scatterers. Under similar conditions, the surface generated noise baseline due to surface flaws should be minimal. Results obtained from rectangular, rounded, and "V" shaped notches provided a preliminary basis for estimating reflected signal levels from a vast array of two-dimensional degradations. Results for the steel plates embedded in concrete indicated that an additional $1.6 \mathrm{~dB}$ and $1.4 \mathrm{~dB}$ of signal loss was incurred for each centimeter of two-way signal travel when using $45^{\circ}$ and $70^{\circ}$ coupling wedges, respectively. Thus, waves directed at shallow angles were least affected by the concrete, regardless of coupling condition, and may be of more value for the inspection scenario of interest. Steel plates that were not bonded to concrete showed virtually no additional losses compared to free plate signal losses; however, if fluids were present at the interface between the concrete and steel plate, increased signal losses would occur. Results from the signalloss component experiments provided a basis for estimating the total loss induced on an incident signal for many scenarios (e.g., in the absence of competing signals, a 4-mm-deep rounded degradation located $30 \mathrm{~cm}$ below the air/concrete interface for the steel containment scenario should be detectable using a $70^{\circ}$ coupling wedge because $50 \mathrm{~dB}$ of signal-to-noise ratio remains after estimated losses of $73 \mathrm{~dB}$ ).

\subsubsection{Magnetostrictive Sensors}

Magnetostrictive sensors (MsS) are devices that launch guided waves and detect elastic waves in ferromagnetic materials electromagnetically to determine the location and severity of a defect based on timing and signal amplitude. The magnetostrictive force refers to the force that acts in ferromagnetic materials due to strains associated with magnetic domain motion (6.12). Figure 6.14 presents a schematic diagram of a MsS setup used for generation and detection of guided waves in a pipe. With MsS, the magnetostrictive force is produced directly in the 


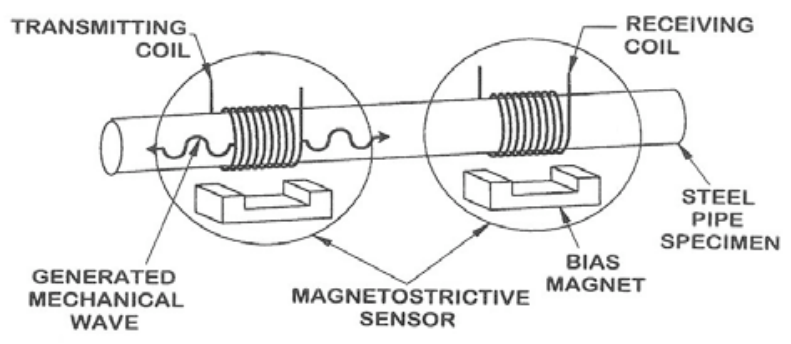

Figure 6.14 Schematic of magnetostrictive sensor setup for generation and detection of guided waves.

Source: H.Kwun, Feasibility of Magnetostrictive Sensor Inspection of Containments, NUREG/CR-5724, U. S. Nuclear Regulatory Commission, Washington, D. C., March 1999.

part under inspection by setting the magnetic domains in the material into a vibrational motion by applying alternating magnetic fields to the material. For piping, the magnetic fields are applied by supplying an alternating electric current to the MsS coil that encircles the pipe. This magnetostrictive force generates the guided waves. Detection of the guided waves is achieved by the reverse process where the guided waves cause domains to vibrate and, consequently, causes the magnetic induction of the material to change with time. The changing magnetic induction induces an electric voltage in the MsS coil. The magnetostrictive force is independent of the sign of the applied magnetic field and is in the direction of the applied field. Therefore, in the absence of a static bias magnetic field, the alternating magnetic field results in generation of guided waves of twice the frequency of the applied magnetic field (6.4). To produce a wave of the same frequency and to enhance the efficiency of the sensor (which is proportional to the magnetostriction coefficient), a static magnetic field is also applied to the material $(6.13,6.14)$. The technique is noncontact, couplant free, and requires minimum surface preparation. In addition, the technique has a sensing or inspection range from a single sensor location that can exceed several hundred meters on bare metals, the sensor can detect defects on the inside and outside diameters of pipe surfaces, and it can inspect structures whose surfaces are not directly accessible due to the presence of paint or insulation. For noncontact applications, the technique is limited to ferromagnetic materials. Its primary application has been to piping systems.

Two studies have been conducted to investigate the feasibility of applying magnetostrictive sensor technology to inspection of plate-type materials and evaluate its potential for detecting and locating thickness reductions in the containment metallic pressure boundary resulting from corrosion $(6.15,6.16)$.

\subsubsection{Feasibility Investigation}

The initial feasibility investigation involved both modeling and experimental studies.

\section{$\underline{\text { Modeling studies }}$}

Dispersion properties of Lamb waves, which refer to longitudinal guided waves in plates, were investigated theoretically using a general-purpose software package called DISPERSE (6.17,6.18). Using this software package, dispersion curves of Lamb waves were calculated for three different boundary conditions-free boundary, one side in contact with concrete, and both sides in contact with concrete. Table 6.1 presents the material property values used in the calculations. In the modeling studies the plate was assumed to be $12.7 \mathrm{~mm}$ thick, and the concrete was assumed to be infinitely thick and perfectly bonded to the plate.

Table 6.1 Material property values

\begin{tabular}{|l|c|c|}
\hline \multirow{2}{*}{ Property } & \multicolumn{2}{|c|}{ Material } \\
\cline { 2 - 3 } & Steel plate & Concrete \\
\hline \hline Density, $\mathrm{g} / \mathrm{cm}^{3}$ & 7.93 & 2.2 \\
\hline Compressional wave speed, $\mathrm{cm} / \mathrm{sec}$ & $5.96 \times 10^{5}$ & $4.30 \times 10^{5}$ \\
\hline Shear wave velocity, $\mathrm{cm} / \mathrm{sec}$ & $3.26 \times 10^{5}$ & $2.30 \times 10^{5}$ \\
\hline
\end{tabular}

Source: H.Kwun, Feasibility of Magnetostrictive Sensor Inspection of Containments, NUREG/CR-5724, U. S. Nuclear Regulatory Commission, Washington, D.C., March 1999. 
Figure 6.15 presents calculated dispersion curves of longitudinal guided waves for a plate that is free, backed by concrete on one side, and backed by concrete on both sides. The vertical axis represents the group velocity of the wave expressed in units of $\mathrm{mm} / \mu \mathrm{sec}$, where $1 \mathrm{~mm} / \mu \mathrm{sec}$ is equivalent to $10^{5} \mathrm{~cm} / \mathrm{sec}$. The horizontal axis represents the product of the wave frequency and the plate thickness expressed in units of MHz-mm. The use of the frequencythickness product in the horizontal axis normalizes the effects of plate thickness on the dispersion curves and makes the plots valid for plates of arbitrary thickness (e.g., the $1 \mathrm{MHz}-\mathrm{mm}$ point in the horizontal axis corresponds to $1 \mathrm{MHz}$ of frequency in a $1-\mathrm{mm}$-thick plate, or $100 \mathrm{kHz}$ of frequency in a $10-\mathrm{mm}$-thick plate). Curves indicated by S0, S1, and S2 are those for the first three symmetric (S) wave modes. Curves indicated by A0, A1, and A2 are those for the first three antisymmetric (A) wave modes. With respect to the median line of the plate thickness, the displacement of $\mathrm{S}$ wave modes has a symmetric distribution, whereas that of A wave modes has an antisymmetric distribution, as illustrated in Figure 6.16.
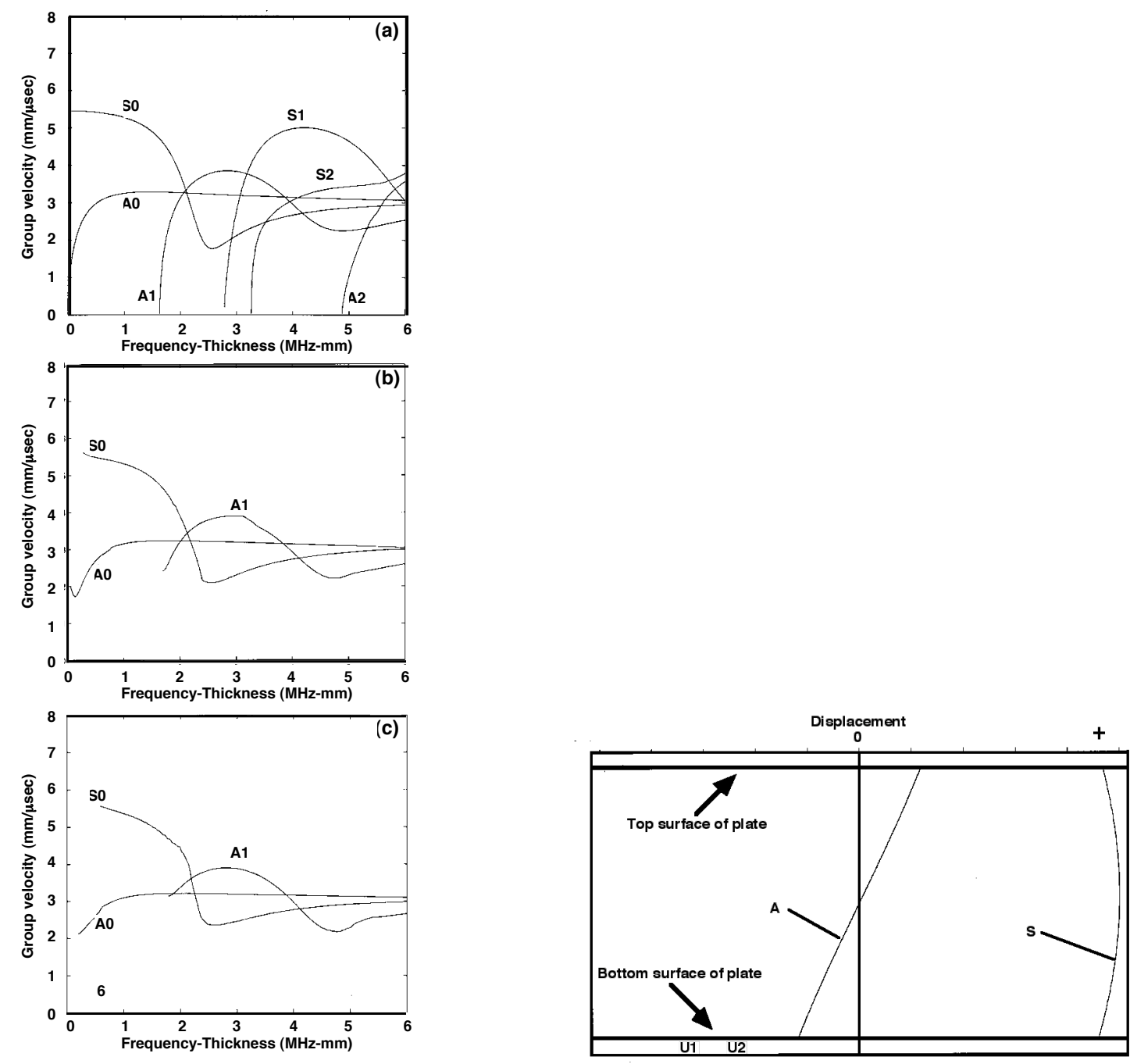

Figure 6.15 Calculated dispersion curves for longitudinal guided waves in a plate for three conditions:(a) plate is free, (b) plate is backed by

Figure 6.16 Displacements of antisymmetric (A) and symmetric (S) wave modes across plate thickness.

concrete on one side, (c) plate is backed by concrete on both sides.

Source: H.Kwun, Feasibility of Magnetostrictive Sensor Inspection of Containments, NUREG/CR-5724, U. S. Nuclear Regulatory Commission, Washington, D.C., March 1999.

For cases where the plate was backed on one or both sides by concrete, the DISPERSE program became somewhat unstable, so the calculations were performed for only S0, A0, and A1 modes. Comparing the plots in Figure 6.15 for 
the three plate conditions, the minimum velocity of the S0 mode increased from approximately $1.8 \mathrm{~mm} / \mu \mathrm{sec}$ in (a) to $2.05 \mathrm{~mm} / \mu \mathrm{sec}$ in (b), and then to $2.4 \mathrm{~mm} / \mu \mathrm{sec}$ in (c). Also, comparing the A0 mode velocities for the free plate and plates backed by concrete, there was only a slight decrease (i.e., no more than $0.3 \mathrm{~mm} / \mu \mathrm{sec}$ ) in the lowfrequency range (i.e., below $1 \mathrm{MHz}-\mathrm{mm}$ ). Overall, the effect of concrete on the group velocity appears to be relatively small.

In addition to dispersion curves, the DISPERSE program calculates wave attenuation. Results for a plate backed by concrete on one side and on both sides are shown in Figures 6.17(a) and 6.17(b), respectively. It was assumed that the attenuation in the plate material was negligible and, thus, the free plate had zero wave attenuation. The attenuation plots in Figure 6.17 therefore represent the energy loss into the surrounding concrete. In these plots, only A0 and S0 modes are shown. Attenuation of other modes was much higher and out of range of the plot. The plots show a large increase in attenuation when the concrete was placed on one side of a plate. As might be expected, the effect of concrete on attenuation increased by a factor of two or more when the concrete was placed on both sides of the plate. The plots also show that attenuation was significantly less for the A0 mode than for the S0 mode. Interestingly, the plots showed negligible attenuation for the A0 mode when the frequency-thickness was less than about $0.55 \mathrm{MHz}-\mathrm{mm}$. According to these results, the A0 mode would be better than the S0 mode for longrange inspection of plates backed by concrete on one or both sides. Particularly, if the frequency of the A0 mode was less than $0.55 \mathrm{MHz}-\mathrm{mm}$, no reduction in the inspection range due to concrete-induced attenuation is expected to occur (e.g., in a 12.7-mm-thick plate, this frequency corresponds to less than about $43 \mathrm{kHz}$ ).
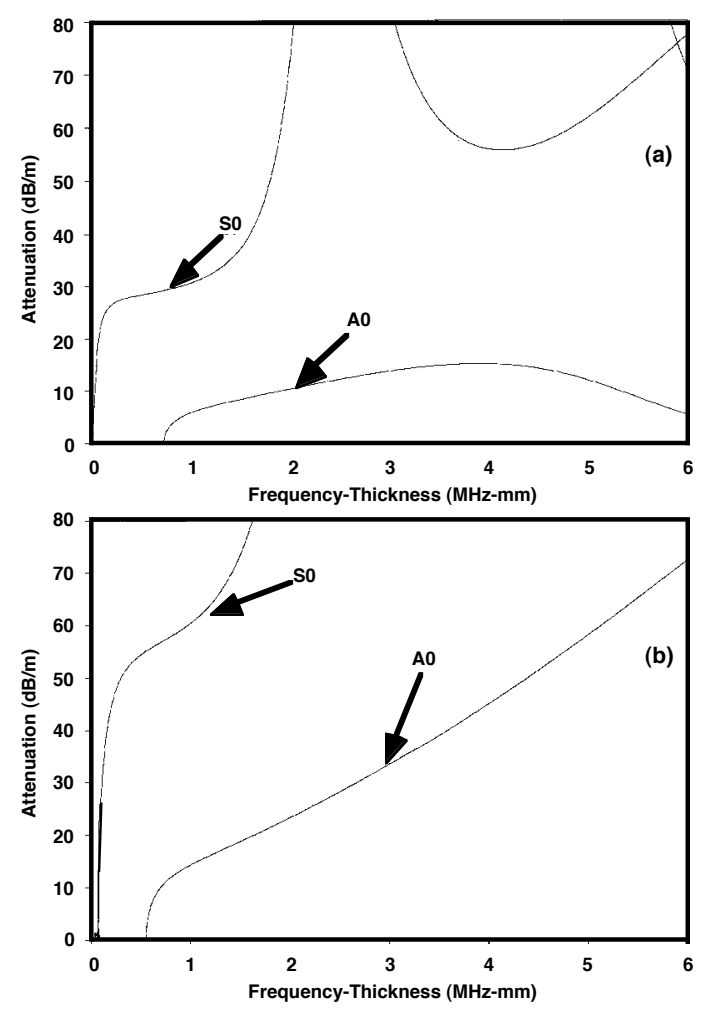

Figure 6.17 Calculated wave attenuation for: (a) plate backed by concrete on one side and (b) plate backed by concrete on both sides.

Source: H. Kwun, Feasibility of Magnetostrictive Sensor Inspection of Containments, NUREG/CR-5724, U. S. Nuclear Regulatory Commission, Washington, D.C., March 1999.

The guided wave loses its energy into the surrounding concrete by generating both shear and compressional waves at the plate and concrete interface that propagate away in the concrete medium. The propagation angle, $\theta$, of these waves is governed by Snell's law

$$
\theta=\sin ^{-1}\left(V_{c} / V_{p}\right)
$$


where $\mathrm{V}_{\mathrm{c}}$ is the velocity of a bulk (shear or compressional) wave in the concrete, and $\mathrm{V}_{\mathrm{p}}$ is the phase velocity of the guided wave in the plate. If $\mathrm{V}_{\mathrm{p}}$ is less than $\mathrm{V}_{\mathrm{c}}$, then $\theta$ would be imaginary. This means that the bulk wave in the concrete cannot be generated, and consequently the energy of the guided wave would not be leaked away and there would be no increase in guided-wave attenuation. Below $0.55 \mathrm{MHz}-\mathrm{mm}$, the phase velocity of the A0 mode was smaller than the velocity of the shear (and compressional) wave in concrete. This explains why the attenuation of the A0 mode was negligible in that frequency region, even if the plate was backed by concrete on both sides.

The validity of the DISPERSE program calculations for simple geometries such as pipes and plates has been well confirmed experimentally. Although its validity for complicated geometries such as a plate backed by concrete on both sides has yet to be confirmed, it appears possible to achieve long-range inspection under this scenario using a lowfrequency A0 wave mode.

\section{$\underline{\text { Experimental studies }}$}

For generation and detection of guided waves in plates the MsS design shown schematically in Figure 6.18 was used (6.19). The probe consisted of a stack of U-shaped cores (e.g., made of ferrite) and a coil wound on the core. When an alternating electric current was supplied to the probe, an alternating magnetic field was applied to the plate underneath in the widthwise direction. The applied magnetic field generated guided waves in the plate that propagated in the same direction. Guided wave detection was achieved by the reverse process in which the alternating magnetic induction of the plate caused by the guided waves was electromagnetically coupled to the core material and a voltage signal induced in the coil. In addition to the MsS probe, a device was added (i.e., permanent magnets) to apply the required static bias magnetic field to the plate.

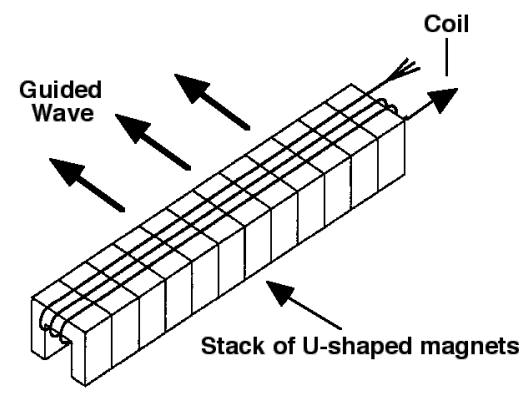

Figure 6.18 Schematic of a coil wound around a stack of U-shaped magnets.

Source: H. Kwun, Feasibility of Magnetostrictive Sensor Inspection of Containments, NUREG/CR-5724, U. S. Nuclear Regulatory Commission, Washington, D.C., March 1999.

The overall experimental setup is shown in Figure 6.19a. A carbon steel plate (ASTM A-36) approximately 6.35$\mathrm{mm}$-thick by $1.23-\mathrm{m}$-wide by $6.11-\mathrm{m}$ long placed on two wooden supports was used as the test article. Due to its weight, the plate arched somewhat toward the floor. The transmitting and receiving MsS probes were

approximately $30 \mathrm{~cm}$ long and $2.5 \mathrm{~cm}$ wide. The length of the probe was aligned parallel to the width of the plate so that the wave was launched in the lengthwise direction of the plate. Static magnetic fields were applied in the lengthwise direction of the plate using permanent magnetic circuits. Excitation and detection of guided waves were accomplished using an instrument called the "magnetostrictive sensor reflectometer (MsSR)" that had been developed for piping inspections. A photograph of the overall experimental arrangement is shown in Figure 6.19b.

Initial activities addressed the capability of the MsS to generate and detect guided waves. Both the pitch-catch and pulse-echo techniques were employed for data acquisition. For the pitch-catch technique the transmitting MsS probe was placed near one end of the plate and the receiving probe near the mid-length location of the plate. For the pulse-echo technique both probes were placed near one end of the plate (Figure 6.19). After investigating guidedwave generation and detection capability using the pitch-catch technique, the feasibility of detecting defects in the plate was investigated using the pulse-echo technique. For this purpose a notch was machined into the plate at a position corresponding to approximately $2 / 3$ the plate length (Figure $6.19 \mathrm{a}$ ). The notch was approximately $3-\mathrm{mm}$ 

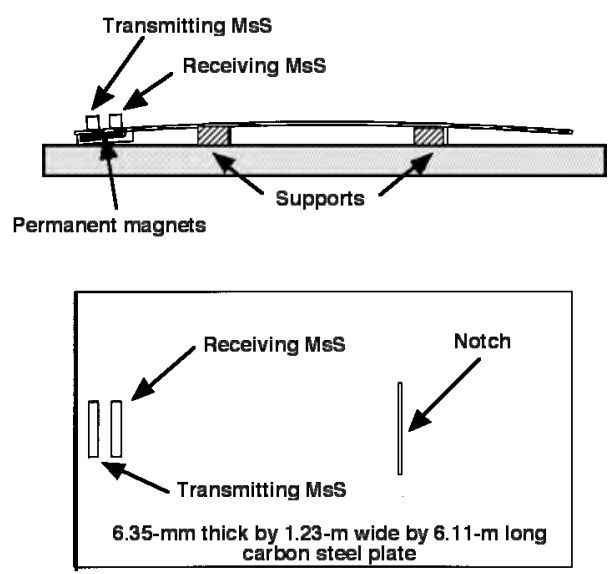

(a) Schematic of plate test article with setup for MsS probes.

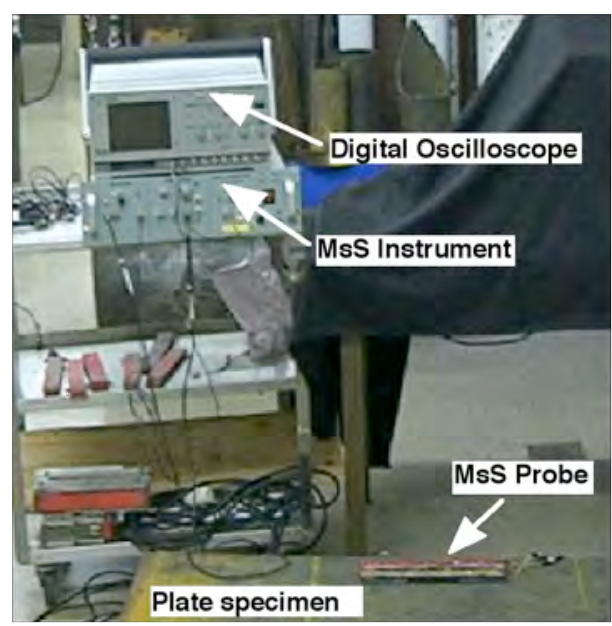

(b) Photograph of the overall experimental arrangement.

Figure 6.19 MsS test setup for monitoring plate specimen.

Source: H. Kwun, Feasibility of Magnetostrictive Sensor Inspection of Containments, NUREG/CR-5724, U. S. Nuclear Regulatory Commission, Washington, D.C., March 1999.

deep by 6-mm wide, and had a length that was changed from 10 to $30 \mathrm{~cm}$ in $10-\mathrm{cm}$ increments to evaluate the relationship between notch length and signal amplitude. A photograph of the $30-\mathrm{cm}$-long notch is shown in Figure 6.20.

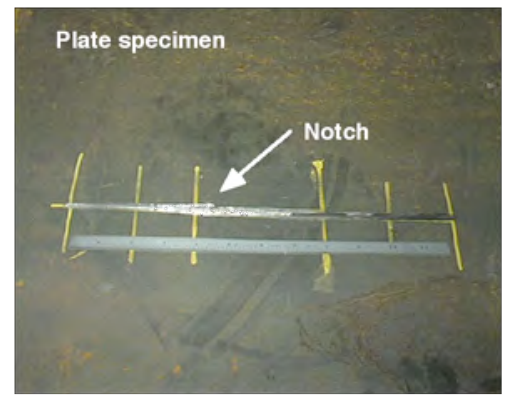

Figure 6.20 Photograph of the 30-cm-long notch in plate specimen.

Source: H. Kwun, Feasibility of Magnetostrictive Sensor Inspection of Containments, NUREG/CR-5724, U. S. Nuclear Regulatory Commission, Washington, D.C., March 1999.

The experimental studies addressed the generation and detection of guided waves in plates and the capability to detect defects in a plate. An example of data obtained from the plate sample using the pitch-catch technique is shown in Figure 6.21a. The data were taken with the transmitting and receiving probes placed at approximately $5 \mathrm{~cm}$ and 2.73 meters from one end of the plate, respectively. The transmitting probe was excited with a 3-cyclelong, $60 \mathrm{kHz}$ sinusoidal pulse. The detected signals after the initial pulse were relatively complex. To identify each of the detected signals by observing their dispersion characteristics (6.20), the short-time Fourier transform (STFT) was performed on the time-amplitude data in Figure 6.21a and the results are presented in Figure $6.21 \mathrm{~b}$. In this figure the logarithms of the absolute values of the STFT are shown as gray-scale images (the brighter the image, the larger the amplitude of the spectral component). The time evolution of each frequency component comprising the detected signals can be observed and used to study wave dispersion (6.20).

From the data in Figure 6.21b, the highest frequency component contained in the signals in Figure 6.21a was no more than about $120 \mathrm{kHz}$. Referring to the dispersion curves for a free plate given in Figure 6.15(a), the above frequency corresponds to about the $0.76 \mathrm{MHz}-\mathrm{mm}$ point in the frequency-thickness axis. Over that frequency range, 


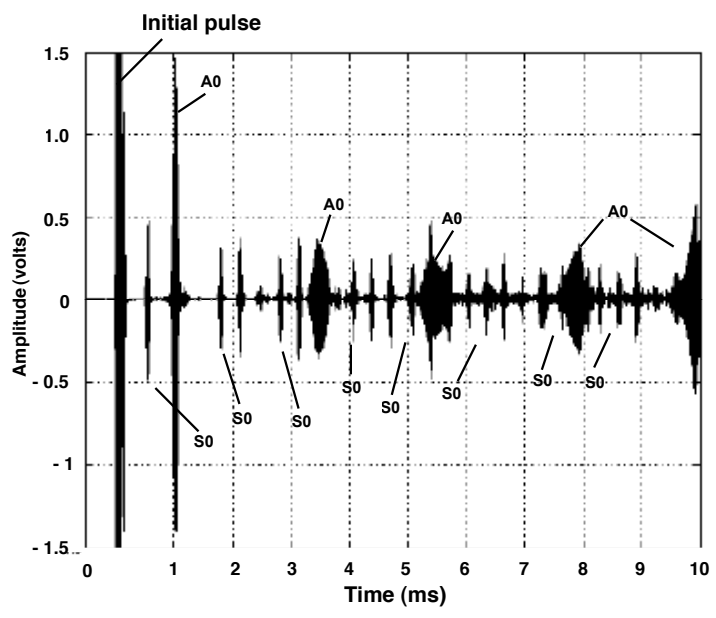

(a) MsS data from plate specimen using pitch-catch technique.

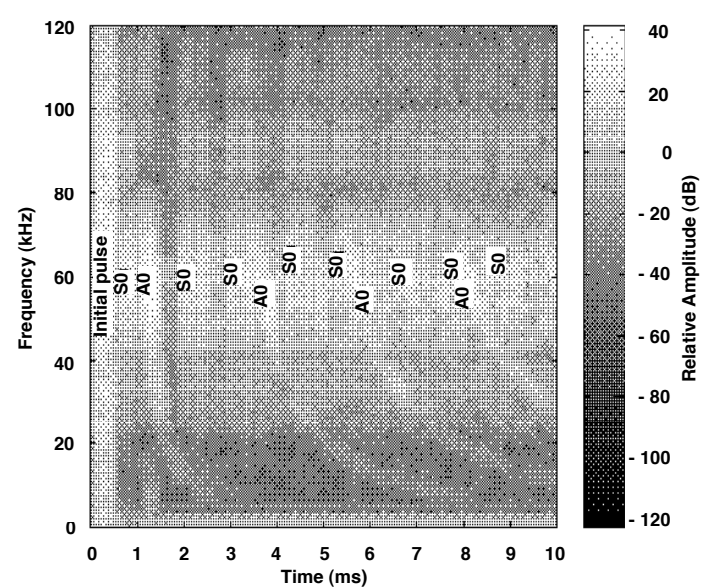

(b) (b) Time-frequency representation of data in (a) obtained by using short-time Fourier transform (STFT).

Figure 6.21 Example of data obtained from plate specimen.

Source: H. Kwun, Feasibility of Magnetostrictive Sensor Inspection of Containments, NUREG/CR-5724, U. S. Nuclear Regulatory Commission, Washington, D.C., March 1999.

there are only two possible longitudinal guided waves - the lowest order symmetric wave mode (S0) and the lowest order antisymmetric wave mode (A0). According to the dispersion curves in Figure 6.15(a), the group velocity of the S0 mode over that frequency range is approximately constant (e.g., $5.44 \times 10^{5} \mathrm{~cm} / \mathrm{sec}$ at $20 \mathrm{kHz}$,

$5.42 \times 10^{5} \mathrm{~cm} / \mathrm{sec}$ at $60 \mathrm{kHz}$, and $5.38 \times 10^{5} \mathrm{~cm} / \mathrm{sec}$ at $100 \mathrm{kHz}$ ), whereas that of the A0 mode increased rapidly with frequency (e.g., $1.98 \times 10^{5} \mathrm{~cm} / \mathrm{sec}$ at $20 \mathrm{kHz}, 2.81 \times 10^{5} \mathrm{~cm} / \mathrm{sec}$ at $60 \mathrm{kHz}$, and $3.10 \times 10^{5} \mathrm{~cm} / \mathrm{sec}$ at $100 \mathrm{kHz}$ ).

Based on the expected behavior of the S0 and A0 modes, the curved lines in Figure $6.21 \mathrm{~b}$ are easily identified as the A0 mode. They are curved to the right because the lower frequency components have a slower group velocity and thus arrive at the receiving MsS probe later in time than the higher frequency components. The second signal after the initial pulse in Figure 6.21a is then identified as the A0 mode that was detected when the wave reached the receiving probe while traveling toward the far end of the plate. The subsequent A0 mode signals are those that were detected after the wave was reflected from the far end of the plate sample and was traveling back and forth between the two ends. The pulse length of the A0 mode signals gets longer with time because of the dispersion. Using the first and third A0 mode signals in Figure $6.21 \mathrm{~b}$, the round-trip time of the wave was measured at $6.150 \mathrm{msec}$ at $20 \mathrm{kHz}$ and $4.305 \mathrm{msec}$ at $60 \mathrm{kHz}$. The corresponding group velocity is then $1.99 \times 10^{5} \mathrm{~cm} / \mathrm{sec}$ at $20 \mathrm{kHz}$ and $2.84 \mathrm{x}$ $10^{5} \mathrm{~cm} / \mathrm{sec}$ at $60 \mathrm{kHz}$, respectively, which agrees well with the calculated values given earlier.

The straight lines in Figure $6.21 \mathrm{~b}$ are identified as those produced by the $\mathrm{S} 0$ mode. The lines are straight because the S0 mode had an approximately constant velocity and thus was nearly dispersionless over the frequency range investigated. The signal after the initial pulse in Figure 6.21a was identified as the S0 mode, detected when the wave reached the receiving probe while traveling toward the far end of the plate. Excluding those identified as A0 signals, all subsequent signals in Figure 6.21a should therefore be S0 mode signals.

The data in Figure 6.21a show that both the $\mathrm{S} 0$ and the $\mathrm{A} 0$ wave modes can be generated and detected using the MsS probe. Since the first A0 signal is larger in amplitude than the first S0 signal, the probe design used in this experiment appears to be more effective in generating the $\mathrm{A} 0$ wave mode than the $\mathrm{S} 0$ wave mode. The tendency of the probe to simultaneously produce both modes was not a significant concern because the primary wave mode generated and detected could be controlled by applying a phased-array principle using multiple probes.

Before inducing a notch in the plate sample, data were acquired from one end of the test article using the pulse-echo technique while controlling the MsS probes to generate and detect either the S0 or the A0 wave mode. Mode control was achieved using a total of three MsS probes (one for transmitting and two for differential receiving) whose relative positions from each other and from the probe end of the plate sample were adjusted to maximize the signal amplitudes of the desired wave mode. Figure 6.22 presents the resulting data for the S0 mode and the A0 mode 
waves. The data in Figure 6.22(a) were obtained by exciting the transmitting MsS probe with a 5-cycle, $40-\mathrm{kHz}$ sinusoidal pulse. The data in Figure 6.22(b), on the other hand, were obtained by exciting the transmitting MsS probe with a 2-cycle, $20-\mathrm{kHz}$ sinusoidal pulse. The S0 mode data in Figure 6.22(a) show the secondary signals after each end-reflected signal. These secondary signals, produced by mode conversion at the lateral boundaries of the plate sampled together with the unsuppressed A0 mode signals, make the signal pattern complicated. For longrange inspection of a large welded-plate structure (e.g., nuclear power plant concrete containment liner) using the S0 mode wave, secondary signals produced from the welds may interfere with defect detection. Because of the modeconverted secondary signals and the presence of unsuppressed A0 mode signals, the attenuation of the S0 mode wave in the plate material was difficult to determine from the data in Figure 6.22(a). However, the apparent wave attenuation (which includes the loss due to beam divergence) may be determined by using the amplitudes of the first arriving signals of the end-reflected signals. The first arriving signals represent the waves that traveled along the straight path normal to the MsS probe. Secondary signals represent the waves that diverged from the straight path and, thus would be lost. Using the amplitudes of the first arriving signal of the first and second end-reflected signals, the apparent attenuation was determined to be approximately $0.33 \mathrm{~dB} / \mathrm{m}$.
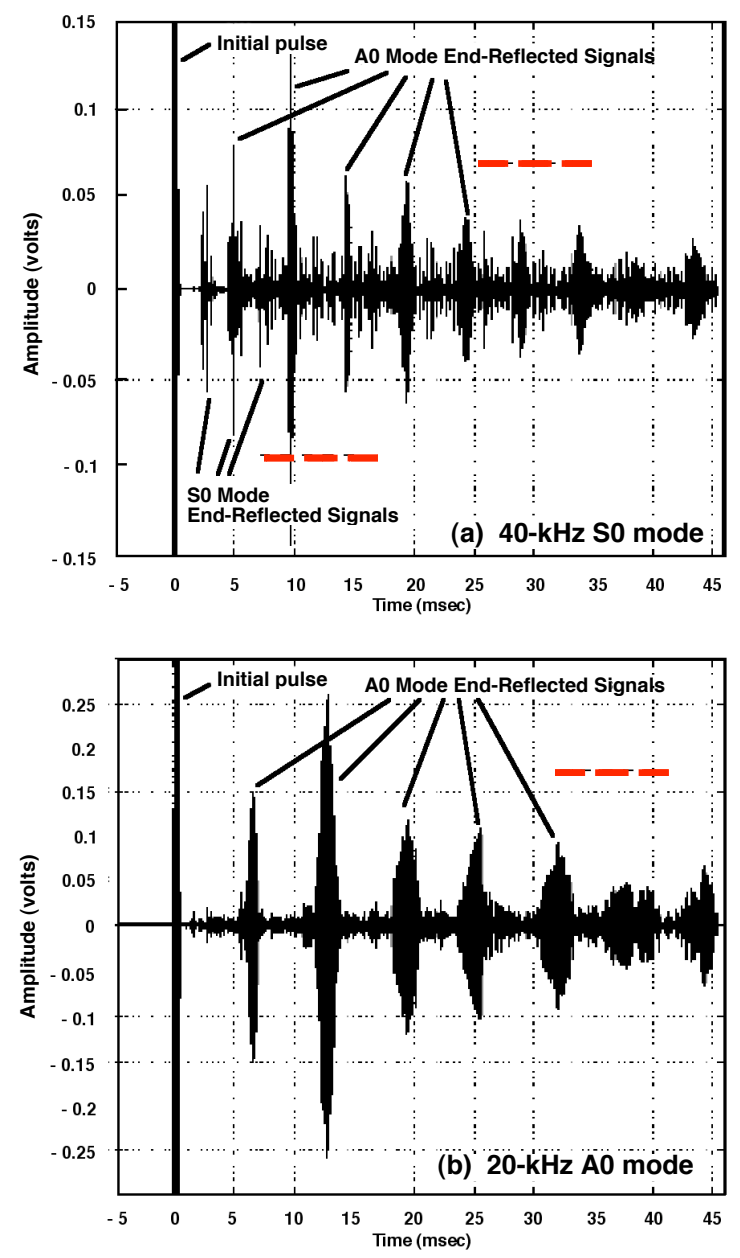

Figure 6.22 MsS data using pulse-echo mode for steel plate prior to introducing a defect

(Dotted lines indicate signals continue to occur).

Source: H. Kwun, Feasibility of Magnetostrictive Sensor Inspection of Containments, NUREG/CR-5724, U. S. Nuclear Regulatory Commission, Washington, D. C., March 1999.

The A0 mode data in Figure 6.22(b), unlike the data in Figure 6.22(a), show a relatively simple signal pattern. The data also exhibit low-amplitude S0 mode signals that were not completely suppressed. The unsuppressed S0 mode signals form most of the background noise signals. Due to the dispersion of the A0 mode, the pulse length of the A0 signals was elongated with time and it was observed that the second end-reflected signal was larger in amplitude than the first signal. The same behavior was also observed with the A0 mode signals in Figure 6.22(a). The cause 
of this erratic behavior was uncertain. Using the first and the third end-reflected signals, the attenuation coefficient of the $20-\mathrm{kHz}$ A0 wave was determined to be approximately $0.086 \mathrm{~dB} / \mathrm{m}$.

Operating the MsS probes to generate and detect one of the S0 and A0 mode waves, data were acquired after introducing a $10-\mathrm{cm}$-long notch at 4.06 meters from the probe end of the plate. This process was then repeated after increasing the notch length to $20 \mathrm{~cm}$ and then to $30 \mathrm{~cm}$. Notch depth was kept at approximately 50 percent of the plate thickness. Results are shown in Figure 6.23 for the $40-\mathrm{kHz}$ S0 mode wave and the 20-kHz A0 mode wave, respectively. In both cases, the signals from all three notches were observable, indicating that long-range guided-
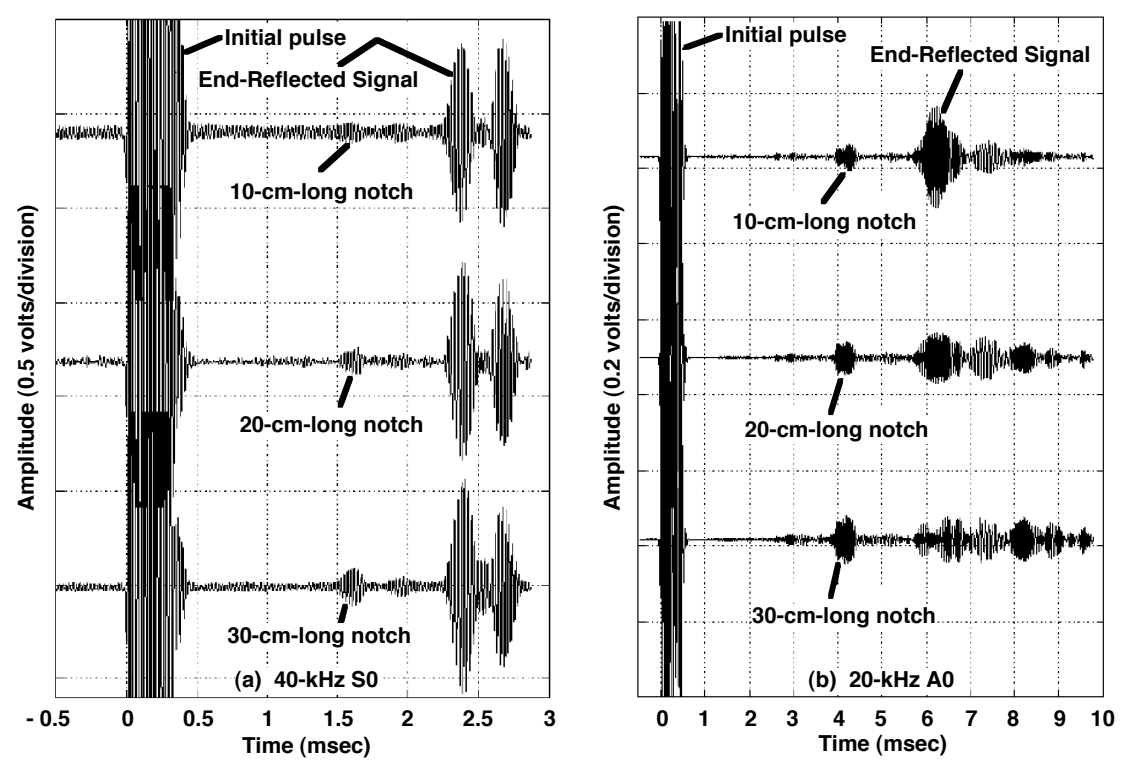

Figure 6.23 Examples of data obtained from plate specimen.

Source: H. Kwun, Feasibility of Magnetostrictive Sensor Inspection of Containments, NUREG/CR-5724, U. S. Nuclear Regulatory Commission, Washington, D. C., March 1999.

wave inspection of plates using the MsS technique was feasible. Figure 6.24 presents plots of defect signal amplitude versus the notch length. As in the case of guided-wave inspection of piping (6.23), the amplitudes of the defect signals increase approximately linearly with notch length, also indicating the feasibility of determining the severity of a defect from the defect signal. The amplitude of a signal from a reflector, such as a notch or corrosion, was proportional to the cross-sectional area of the defect (in the plane normal to the guided wave beam propagation) relative to the total beam width of the interrogating guided wave. Therefore, the product of both length and depth of a defect influenced the defect signal amplitude. Consequently, separate determination of both length and depth of a defect from a single data trace was not generally feasible. However, since the area of a given-size defect relative to the total beam width of the guided wave will vary with the mode and frequency of the guided wave employed for inspection, the signal amplitude from the same defect will also vary. The marked difference in the amplitude of the $30-\mathrm{cm}$-long notch relative to the end-reflected signal amplitude in Figures 6.23a and 6.23b, for example, confirms the variation of the defect signal with the guided wave mode and frequency used for detection (in this case, $40-\mathrm{kHz}$ $\mathrm{S} 0$ mode and $20-\mathrm{kHz}$ A0 mode). Taking advantage of this variation, it appeared feasible to separately determine both the depth and the length of a defect by combining two or more sets of data taken using different guided wave modes and frequency.

Assuming that the signal-to-noise ratio required for detection was $6 \mathrm{~dB}$ and that the defect signal amplitude was linearly proportional to the notch length, the minimum detectable length of a 50-percent wall notch was estimated using the data in Figure 6.24 and a simple linear interpolation. For example, assume that the defect was located approximately 4 meters from the MsS probe, as in the test setup used in this investigation. In order for a defect to be detectable, its signal amplitude was required to be at least twice (i.e., $6 \mathrm{~dB}$ ) that of the background noise level. Based on the background noise level and the notch signal amplitude plots in Figure 6.24, the minimum detectable length of a 50 percent through-wall notch was estimated to be about $10 \mathrm{~cm}$ for the $40-\mathrm{kHz}$ S0 wave and about $1.5 \mathrm{~cm}$ for the $20-\mathrm{kHz}$ A0 wave. If the defect was located at a distance of 15 meters from the MsS probe, the defect signal 

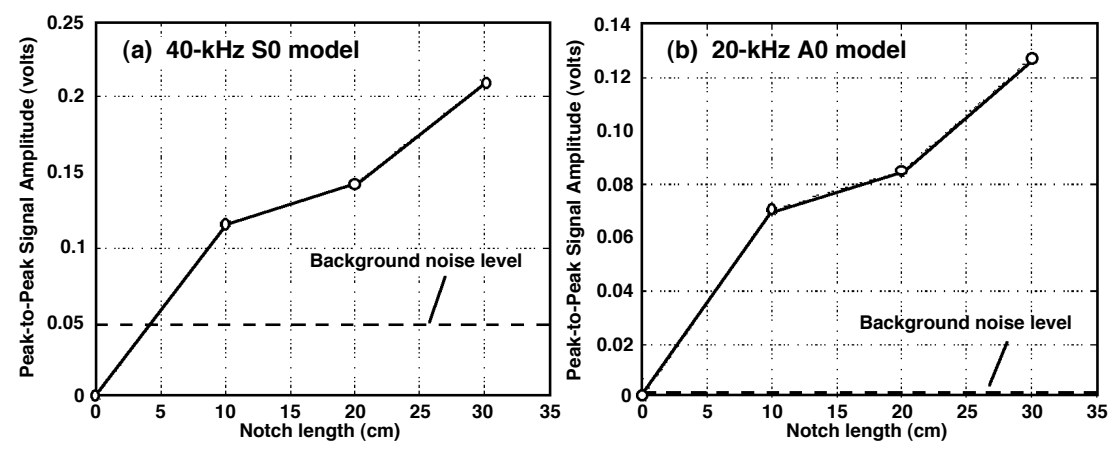

Figure 6.24 Plots of signal amplitude versus notch length.

Source: H. Kwun, Feasibility of Magnetostrictive Sensor Inspection of Containments, NUREG/CR-5724, U. S. Nuclear Regulatory Commission, Washington, D. C., March 1999.

amplitude would be further reduced by the wave attenuation over that distance, which was equal to $0.33 \mathrm{~dB} / \mathrm{m} \times 2 \times 15 \mathrm{~m}=10 \mathrm{~dB}$ for the $40-\mathrm{kHz}$ S0 wave and $0.086 \mathrm{~dB} / \mathrm{m} \times 2 \times 15 \mathrm{~m}=2.58 \mathrm{~dB}$ for the $20-\mathrm{kHz} \mathrm{A} 0$ wave. The minimum detectable notch length at the $15-\mathrm{m}$ distance was then about $4.4 \mathrm{~cm}$ for the $40-\mathrm{kHz} \mathrm{S} 0 \mathrm{wave}$ and about $1.8 \mathrm{~cm}$ for the $20 \mathrm{-kHz}$ A0 wave. Although the data in Figure 6.24 show that the A0 wave was much better than the S0 mode for defect detection, this may not be true since the background noise level can be reduced, particularly for the S0 mode, by improving the MsS probe. For the same cross-sectional area of defect, the signal amplitude from a corrosion pit was generally equal to or larger than the signal amplitude from a notch (6.23). Therefore, the results obtained with the $20-\mathrm{kHz}$ A0 wave suggest that a 50-percent through-wall, 1.8-cm-diameter corrosion pit located within a 15-meter distance could be detectable using the MsS technique.

Referring to the $40-\mathrm{kHz}$ S0 wave data in Figure 6.23a, there was also a secondary notch signal that was produced by mode conversion at the lateral boundaries of the plate sample. The presence of the notch did not seem to affect the end-reflected signal significantly; but it produced a noticeable reduction in the amplitude of the secondary endreflected signals, indicating that the notch reflects a substantial portion of the mode-converted SH wave while the wave traverses the plate.

The effect of the notch on the end-reflected signal of the $20-\mathrm{kHz}$ A0 wave data in Figure $6.23 \mathrm{~b}$ was dramatic as its peak-to-peak amplitude was reduced from approximately 0.27 volts with a 10 -cm-long notch to 0.12 volts with a $30-\mathrm{cm}-$ long notch. The influence of the notch on the end-reflected signal was understandable since the beam divergence angle of the A0 mode was relatively small. Therefore, when a notch becomes significantly long relative to the width of the outgoing beam, a significant portion of the outgoing beam is reflected from the notch, which substantially reduces the amount of beam reaching the far end of the plate.

Experimental results indicate that (1) guided waves have potential for performing global, long-range inspections of plates and plate-like structures such as the metallic pressure boundary of nuclear power plant containments, and (2) guided waves are expected to work well for inspection of plates backed by concrete on either one or both sides. For a given MsS probe size, the beam-divergence angle was significantly smaller for the A0 mode wave than the S0 mode wave. Because of the smaller beam divergence and associated benefits such as a higher spatial resolution, a smaller energy loss through beam spreading and less probability of extraneous signal generation from interaction with welded boundaries, the A0 mode wave would be better for use in plate inspection than the S0 mode wave. One disadvantage of good beam collimation of the A0 mode was that a large defect can shadow the area behind it and, as a result, may create a blind spot.

\subsubsection{Evaluation of Concrete Effects Investigation}

In order to determine possible limitations on the inspection capability of guided waves caused by the presence of concrete, the effects of concrete on guided wave attenuation was investigated (6.16). Two carbon steel (ASTM A36) plates, $1.22 \mathrm{~m} \mathrm{x} 6.10 \mathrm{~m} \times 6.35-\mathrm{cm}$, were used as test articles. One plate to investigate the effects of concrete on wave attenuation and the other to investigate long-range inspection capability. 


\section{Effects of Concrete on Guided-Wave Attenuation}

Lamb Wave Modes. To investigate the effects of concrete on guided waves tests were conducted with concrete on one side of the plate and with concrete on both sides of the plate. For a region covered with concrete on one side an approximately 102-cm-thick concrete layer was cast and cured on the topside of the plate that covered about half the plate length (i.e., $1.22 \mathrm{~m} \mathrm{x} 3.05 \mathrm{~m}$ ). For the region covered by concrete on both sides an approximately 152-mmthick layer was cast and cured that measured about $1.22 \mathrm{~m} \mathrm{x} 2.44 \mathrm{~m}$ covering $40 \%$ of the plate length. Figure 6.25 presents one of the plates with concrete on both sides and a drawing of the experimental setup. Single transmitting and receiving MsS probes were positioned along the plate width centerline at approximately the $1 / 4$ and $1 / 2$ plate length positions. The transmitting probe was excited using a pulse that consisted of two cycles of sinusoidal wave of a given frequency. The resulting guided wave signals propagating in the plate were detected using the receiving probe. Signals were analyzed using short-time Fourier transformation to observe the dispersion properties of the generated waves and to identify their modes.

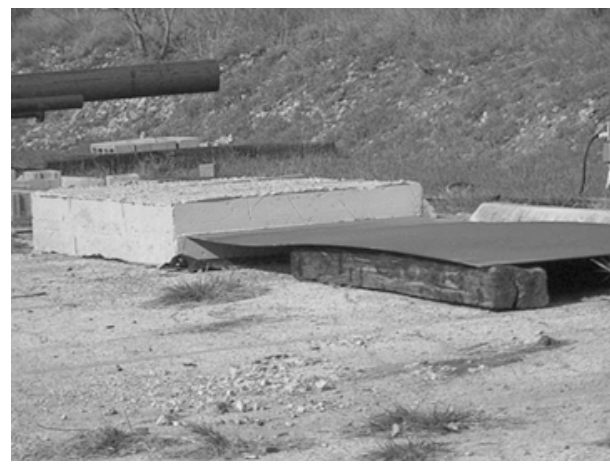

(a) Plate with concrete on both sides.

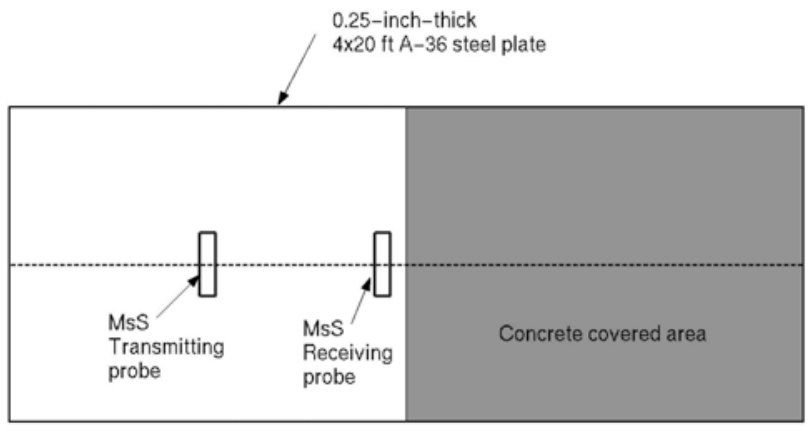

(b) Experimental arrangement used to investigate concrete effects on wave attenuation.

Figure 6.25 Concrete effects test arrangement.

Source: H. Kwun and S.Y. Kim, Experimental Validation of Concrete Effects on Guided Waves in Plates, EPRI Report 1000105, Electric Power Research Institute, Charlotte, North Carolina, 2000.

The first series of tests was conducted on the plates without concrete present. Figure 6.26 presents the A0 and S0 Lamb wave mode signals obtained using a $60-\mathrm{kHz}$ pulse. The superscripts are used to identify the travel path of each signal. As noted in the figure, the MsS probe produced both S0 and A0 wave modes because both modes exist over the same frequency range. Results show that the probe was more efficient in generating the A0 mode. Signals marked as " $\mathrm{m}$ " result from mode conversion of S0 waves at the plate lateral boundaries. The apparent peak
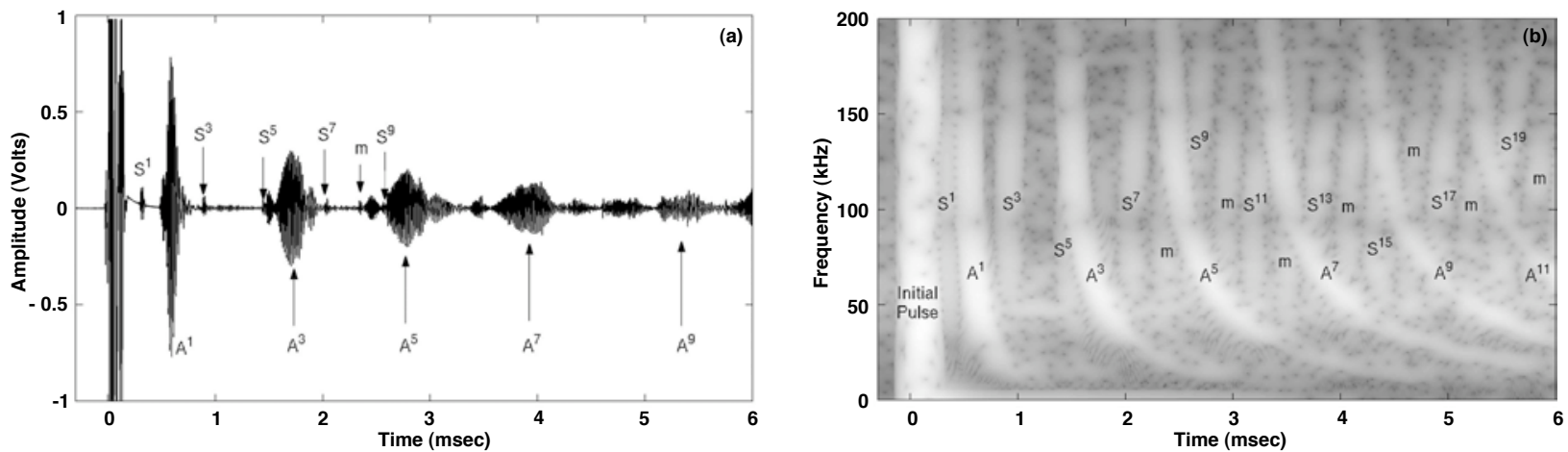

Figure 6.26 MsS data for 60-kHz A0 and S0 waves from bare plate: (a) detected signals and (b) spectrogram.

Source: H. Kwun and S.Y. Kim, Experimental Validation of Concrete Effects on Guided Waves in Plates, EPRI Report 1000105, Electric Power Research Institute, Charlotte, North Carolina, 2000. 
attenuation at $60-\mathrm{kHz}$ was determined to be about $0.97 \mathrm{~dB} / \mathrm{m}$ for the $\mathrm{S} 0$ and $1.62 \mathrm{~dB} / \mathrm{m}$ for the A0 wave. After covering the plate with concrete on one side (length of $3.05 \mathrm{~m}$ ), except for the first two signals that traveled in the section of the plate not containing concrete, there was an absence of subsequent signals. The absence of signals indicates that the concrete layer adjacent to the plate greatly increases the wave attenuation. Wave attenuation for the A0 mode was estimated as smaller than $5.2 \mathrm{~dB} / \mathrm{m}$ and greater than $5.0 \mathrm{~dB} / \mathrm{m}$ for the S0 mode. When the plate was covered on both sides with concrete the covered length was reduced to approximately $2.44 \mathrm{~m}$ (as opposed to $3.05 \mathrm{~m}$ for the one-sided tests) so that signals reflected from the concrete interface could be separated from those traveling in the concrete-covered area. The wave attenuation at $60-\mathrm{kHz}$ in the concrete-covered region was estimated to be about $5.2 \mathrm{~dB} / \mathrm{m}$ for the A0 mode and greater than $5.0 \mathrm{~dB} / \mathrm{m}$ for the $\mathrm{S} 0$ mode. The velocity of the $60-\mathrm{kHz}$ wave had slowed by $23 \%$ relative to the velocity obtained for the plate without concrete.

SH Wave Modes. Figure 6.27 presents the SH0 wave data (100-kHz pulse) obtained from the plate without concrete present. The apparent wave attenuation at $100-\mathrm{kHz}$ was approximately $0.96 \mathrm{~dB} / \mathrm{m}$.
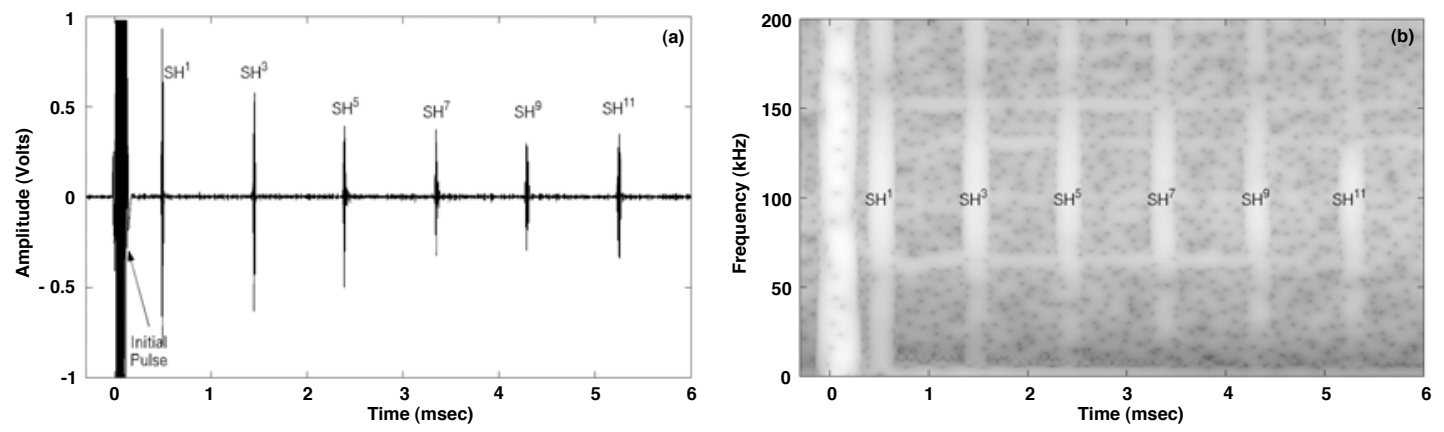

Figure 6.27 MsS data for 100-kHz SH0 wave from bare plate: (a) detected signals and (b) spectrogram.

Source: H. Kwun and S.Y. Kim, Experimental Validation of Concrete Effects on Guided Waves in Plates, EPRI Report 1000105, Electric Power Research Institute, Charlotte, North Carolina, 2000

Covering the plate with concrete on one side again resulted in an absence of signals except those that traveled in the section of the plate not covered by concrete. The attenuation in the concrete-covered region was estimated at $4.3 \mathrm{db} / \mathrm{m}$ compared to $0.96 \mathrm{~dB} / \mathrm{m}$ for the bare plate. The velocity of the $\mathrm{SH} 0$ wave in this region was $12 \%$ less than the value obtained for the bare plate.

Summary. The experimental results show that the presence of concrete has two effects on guided waves: (1) increased wave attenuation and (2) decreased wave velocity. These effects increase when the concrete backing is increased from one side to two sides. Long-range $(>3 \mathrm{~m})$ inspection of plates in the presence of concrete can not be achieved using guided waves except for the A0 mode at fairly low frequency (below about $25-\mathrm{kHz}$ ) where the concrete effects are less severe.

\section{Effects of Concrete on Long-Range Inspection}

The experimental arrangement used for evaluating the effects of concrete on long-range inspection capability of guided waves is presented in Figure 6.28a. Two pairs of MsS probes, one for transmitting and one for receiving, were positioned along the central axis of the plate at a distance $\mathrm{x}$ from the left end (E1) of the plate. A pulse of guided waves (phased-array principle) was launched toward the plate far end (E2). Signals were reflected back from a notch (102-mm long extending half-way through the plate thickness) placed in the plate at a distance of $1.55 \mathrm{~m}$ from E2. Results were obtained from the plate before and after notch placement as well as before and after concrete placement. Figure $6.28 \mathrm{~b}$ presents $22-\mathrm{kHz}$ A0 wave data obtained from the plate prior to concrete placement without and with the notch present $(\mathrm{x}=1.37 \mathrm{~m})$. Despite the presence of relatively high-amplitude extraneous noise in Figure $6.28 \mathrm{~b}$, the signal reflected from the notch $(\mathrm{N})$ approximately $3.2 \mathrm{~m}$ from the MsS probes was apparent. This demonstrated the capability of long-range $(>3 \mathrm{~m})$ detection. Additional results demonstrating the capability of long-range inspection were obtained at higher frequencies $(60-\mathrm{kHz}$ and $128-\mathrm{kHz})$. Also, some preliminary results were obtained in which simultaneous A0 and S0 waves were generated. As the reflection coefficients and amplitudes of mode-converted signals from a defect vary with defect geometry (e.g., defect depth), the relationship between the two could be used for defect characterization. 

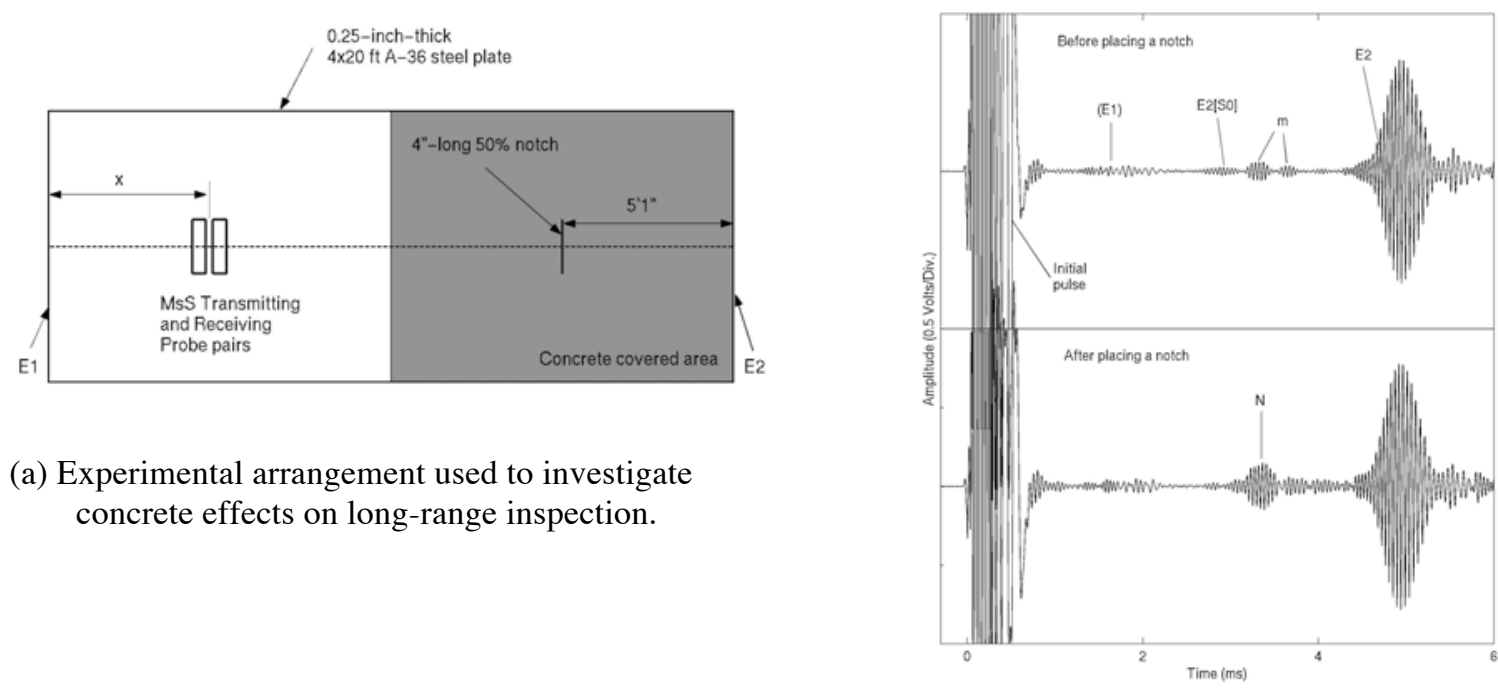

(b) $22-\mathrm{kHz} \mathrm{A} 0$ wave data from bare plate before and after the presence of a notch.

Figure 6.28 Long-range inspection test setup and example of results from bare plate.

Source: H. Kwun and S.Y. Kim, Experimental Validation of Concrete Effects on Guided Waves in Plates, EPRI Report 1000105, Electric Power Research Institute, Charlotte, North Carolina, 2000.

Figure 6.29 presents $22-\mathrm{kHz}$ A0 data obtained from the plate sample when it was bare, covered by concrete on one side, and covered by concrete on both sides. The data obtained from the plate with concrete-covered area exhibit a relatively large signal reflected from the concrete interface (CI) and a small E2 signal. The signal from the notch (N) was observable but exhibited a poor signal-to-noise ratio. When a $60-\mathrm{kHz}$ SH0 wave was utilized, the notch
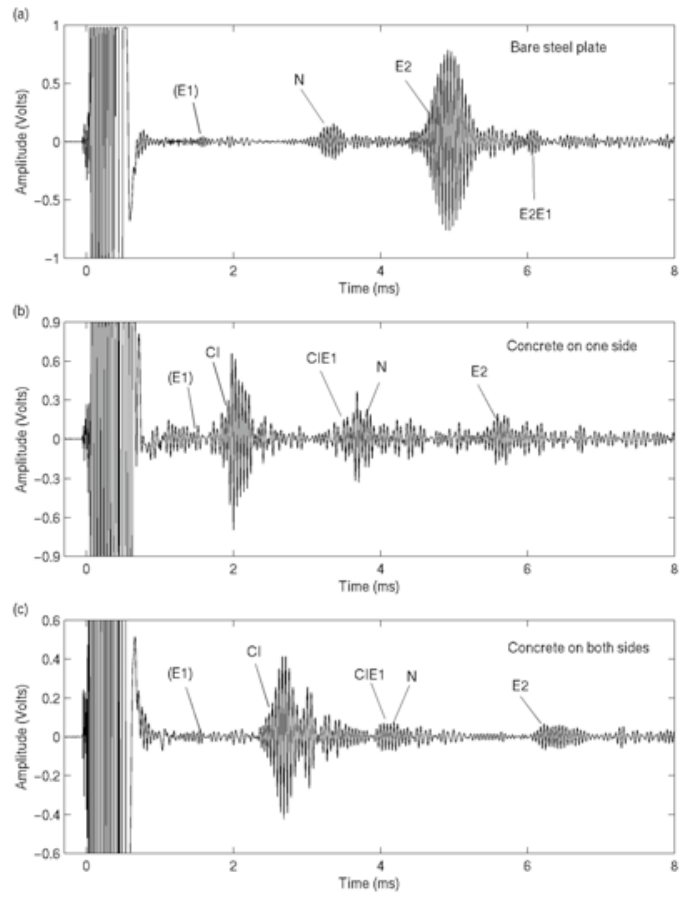

Figure $6.2922-\mathrm{kHz}$ A0 wave data with notch present for (a) bare plate, (b) concrete on one side of plate, and (c) concrete on both sides of plate.

Source: H. Kwun and S.Y. Kim, Experimental Validation of Concrete Effects on Guided Waves in Plates, EPRI Report 1000105, Electric Power Research Institute, Charlotte, North Carolina, 2000. 
signal was not detectable. The concrete adjacent to the plate severely limited the inspection range of SH0 waves. It was concluded that $\mathrm{S} 0$ waves as well as high frequency A0 waves have limited inspection capability in concretecovered areas.

In order to investigate the effect of bond between the concrete and steel plate a series of tests were conducted after the concrete on both sides of the plate had been debonded. Results obtained were similar to those that had been obtained from the bare plate (Figure 6.28b).

\section{Effects of Construction Features on Long-Range Inspection}

Two plate samples $1.22-\mathrm{m}$ wide by $6.1 \mathrm{-m}$ long were joined with full-penetration butt welds widthwise to form a $12.2-\mathrm{m}$-long specimen. A $4.88 \mathrm{-m}$ long section of the sample containing a $102-\mathrm{mm}$ long notch was covered with concrete blocks and the detectability of the notch across the weld examined. Afterwards a sealant (63.5-mm wide by $50.8-\mathrm{mm}$ high) was applied at the concrete interface and the tests repeated. Finally, in order to examine the effects of water located between the plate and concrete, the experiments were repeated while supplying water between the concrete blocks and plate. Figure 6.30a presents the welded plate sample with sealant applied and Figure $6.30 \mathrm{~b}$ the experimental setup and $128 \mathrm{-kHz}$ SH wave results. The results presented in Figure $6.30 \mathrm{~b}$ indicate that the presence of a weld, sealant at the concrete plate interface, or water between the plate and concrete do not significantly affect the long-range inspection capability or the characteristics of the notch signal.

After completion of the above tests the surface of an approximately 3.66-m-long section of the plate was sandblasted and an epoxy-based paint applied. When the probe was placed in the sandblasted and painted area the signal

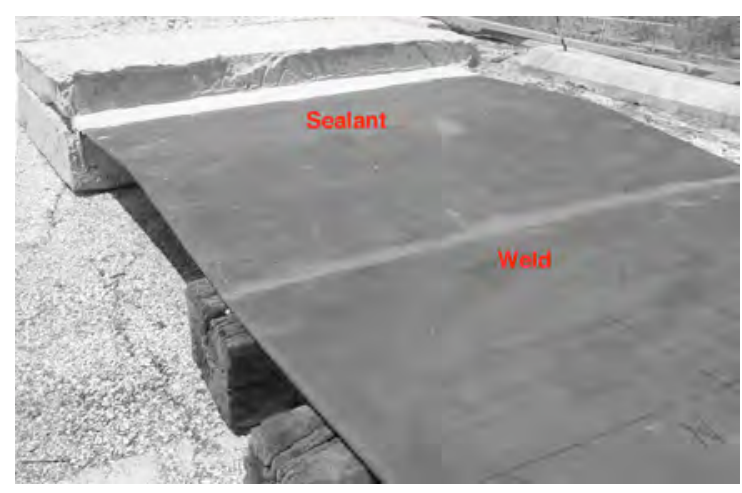

(a) Welded plate specimen.

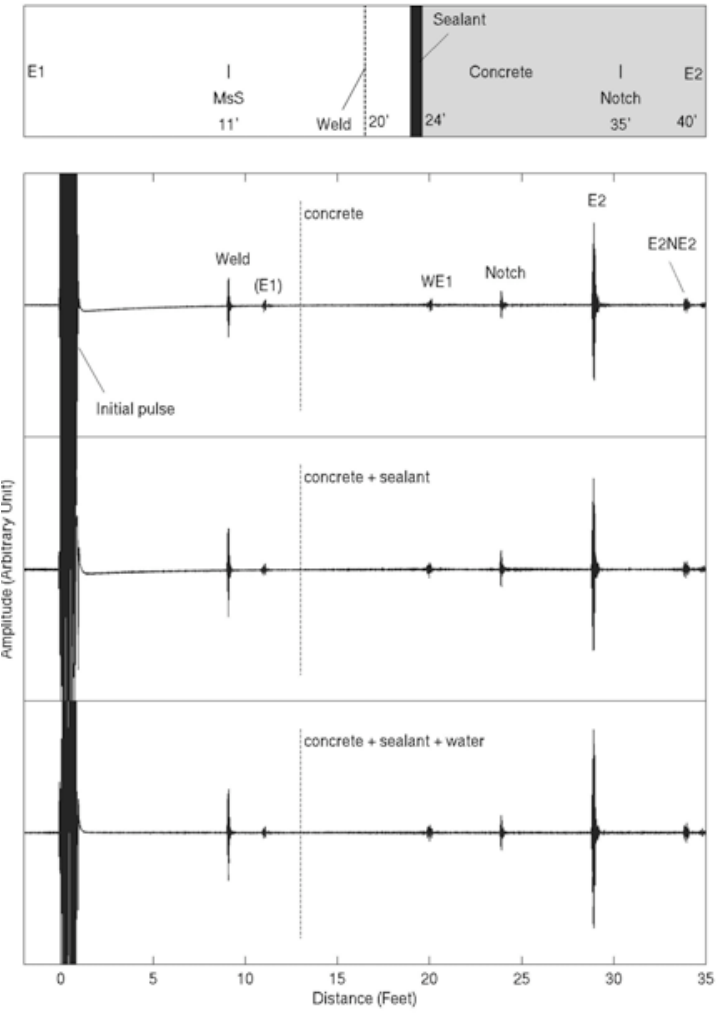

(b) Schematic diagram of experimental setup and $128-\mathrm{kHz}$ SH wave data obtained under different plate conditions.

Figure 6.30 Construction features test setup and results.

Source: H. Kwun and S.Y. Kim, Experimental Validation of Concrete Effects on Guided Waves in Plates, EPRI Report 1000105, Electric Power Research Institute, Charlotte, North Carolina, 2000. 
amplitudes were reduced significantly. The large reduction in signal amplitude was attributed to compressive residual stresses induced in the plate by the sandblasting operation that degraded the plate magnetostrictive properties and lowered the sensitivity of the MsS probe.

\section{Detectability of Section Loss Due to Corrosion}

Four circular simulated corrosion defects were placed into the plate in Figure 6.30a approximately $305 \mathrm{~mm}$ from the weld line as shown in Figure 6.31a. The defects were 76.2-mm diameter and had depths of either 25\%, 50\%, 75\%, or $100 \%$ the plate thickness. The experimental arrangement is shown in Figure $6.31 \mathrm{~b}$.

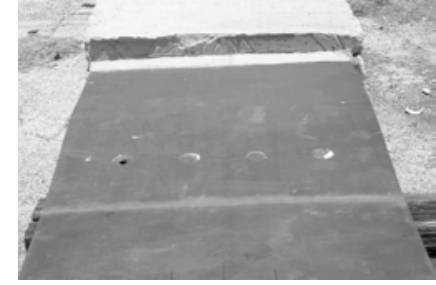

(a) Simulated corrosion defects plate specimen.

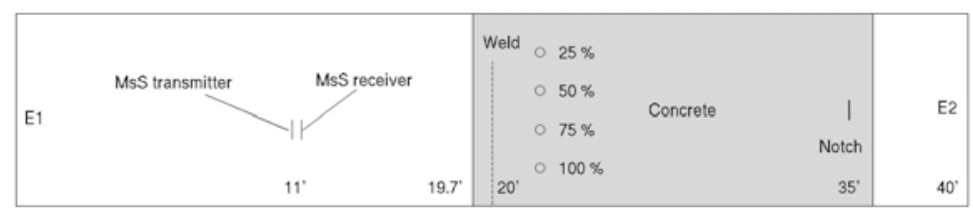

(b) Experimental arrangement and setup used for simulated corrosion defect study.

Figure 6.31 Details of simulated corrosion defects investigation.

Source: H. Kwun and S.Y. Kim, Experimental Validation of Concrete Effects on Guided Waves in Plates, EPRI Report 1000105, Electric Power Research Institute, Charlotte, North Carolina, 2000.

Figure 6.32 presents $128-\mathrm{kHz}$ SH wave data for the simulated corrosion defects plate study. The $75 \%$ and $100 \%$ corrosion depth defects produced readily detectable signals; however, the signals from the $50 \%$ defect depth were barely recognizable and the $25 \%$ defect depth signals were undetectable because of background noise. The semielliptical contour shape of the shallower defects evidently produced weaker wave reflections.

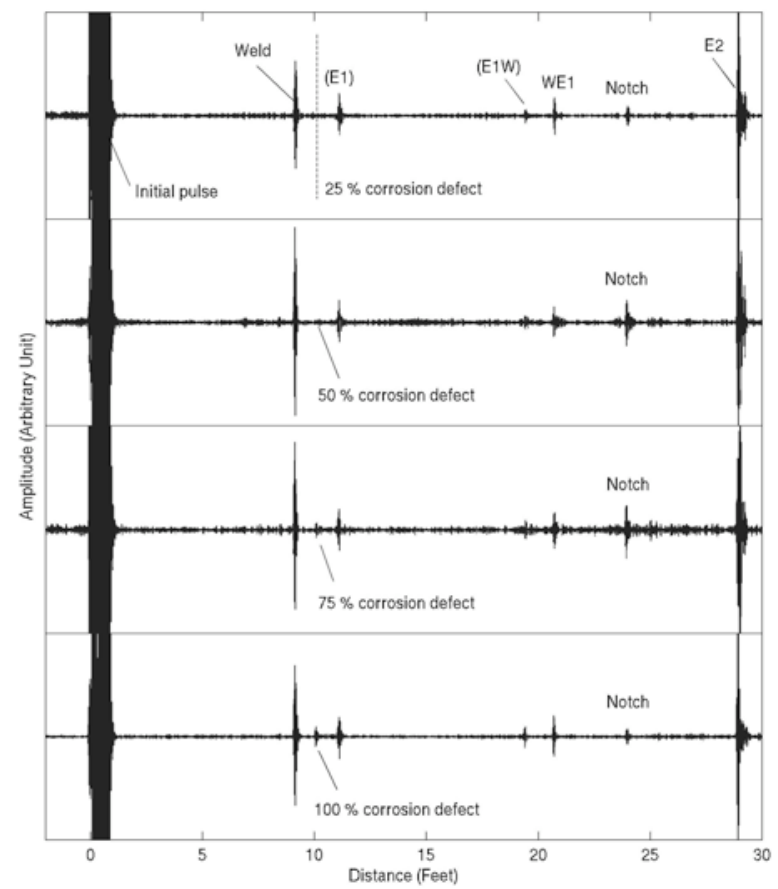

Figure 6.32 128-kHz SH wave data for simulated corrosion defect study.

Source: H. Kwun and S.Y. Kim, Experimental Validation of Concrete Effects on Guided Waves in Plates, EPRI Report 1000105, Electric Power Research Institute, Charlotte, North Carolina, 2000. 
Summary. When concrete is bonded to the plate surface the concrete increased the guided wave attenuation significantly to limit the long-range inspection capability; however, if the concrete is debonded from the plate it has no measurable affect on guided wave attenuation. Construction features such as welds, sealants, and paints did not have a significant affect on long-range inspection capability. Guided waves having an A0 wave mode at fairly low frequency (less than $25-\mathrm{kHz}$ ) can detect relatively large defects within a couple of meters from the interface. Notchtype defects having an abrupt thickness change and deep defects ( $>50 \%$ wall thickness) having a gradual contour profile were detectable using guided waves.

\subsubsection{Multimode Guided Wave Techniques}

The multimode guided wave technique is more sensitive than techniques which utilize shear waves (e.g., electromagnetic acoustic transducers), provides a global inspection technique for characterizing corrosion damage, follows the contour of the structure, can travel long distances (e.g., $100 \mathrm{~m}$ depending on frequency and mode characteristics), and can interrogate different regions or cross sections (i.e., depths) of the component inspected (6.24-6.31). The guided plate waves can be excited at one point on the structure, propagate over considerable distances, and be received at a remote point on the structure. Although this technique has been used with success to detect defects in piping materials, its applicability to plate-type materials has been a relatively recent development.

A preliminary investigation was conducted to investigate the feasibility of applying multimode guided waves to inspection of containment metallic pressure boundary materials $(6.32,6.33)$. The investigation involved theoretical and experimental studies as well as defect sizing.

\subsubsection{Theoretical and Experimental Investigations}

\section{Theoretical Background}

Figure 6.33 presents a coordinate system that could be used for $\mathrm{SH}$ wave propagation. For Lamb wave propagation, consider the particle velocity to be in the $\mathrm{x}_{1}-\mathrm{x}_{2}$ plane direction rather than in the $\mathrm{x}_{3}$ direction shown. Phase velocity and group velocity dispersion curves can be generated for each (6.34). A sample Lamb wave dispersion curve for a

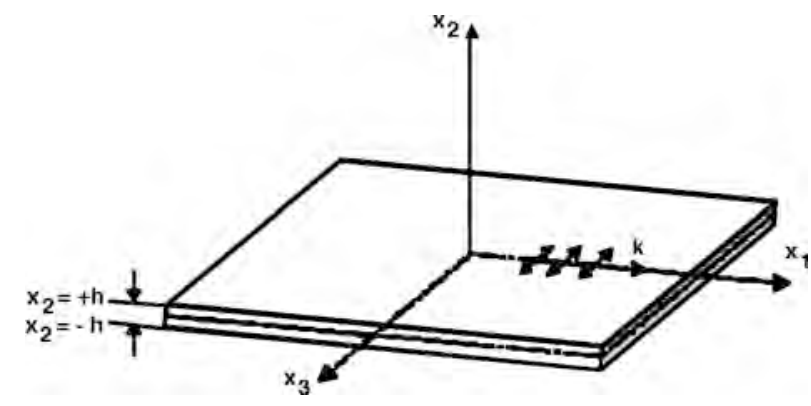

Figure 6.33 $\mathrm{SH}$ wave propagation where propagation is along $\mathrm{x}_{1}$ and particle displacements are along $\mathrm{x}_{2}$.

Source: J. Li and J.L. Rose, “Guided Wave Inspection of Containment Structures,” Materials Evaluation 59(6), pp. 783-787, June 2001.

steel plate is shown in Fig. 6.34a and an example of a SH phase velocity dispersion curve is illustrated in Fig. 6.34b. Note that some SH modes are dispersive, but for $\mathrm{n}=0$ the mode is non-dispersive. Wave structure is identical along a particular SH mode but changes drastically along a Lamb wave mode. When using guided waves to penetrate a steel plate embedded in concrete, it becomes necessary to consider wave structure at the surfaces of the plate and subsequent energy leakage into the concrete. Rather than study this phenomenon theoretically, a variety of different Lamb wave modes and SH mode situations were studied. It is know that phase velocity and frequency tuning would be useful in this Lamb wave case in order to modify wave structure and, hence, energy leakage into the concrete. For the $\mathrm{SH}$ case, only the $\mathrm{n}=0$ mode was considered, but excellent results were obtained.

At a frequency of $565-\mathrm{kHz}$, there are several modes propagating in a $25.4-\mathrm{mm}$-thick steel plate. Two modes were studied with emphasis on pseudo-surface (combined A0 and S0 modes) waves and the A3 mode. The wave structures of both modes are shown in Figure 6.35. Both Figures 6.35a and 6.35b show the in-plane and 


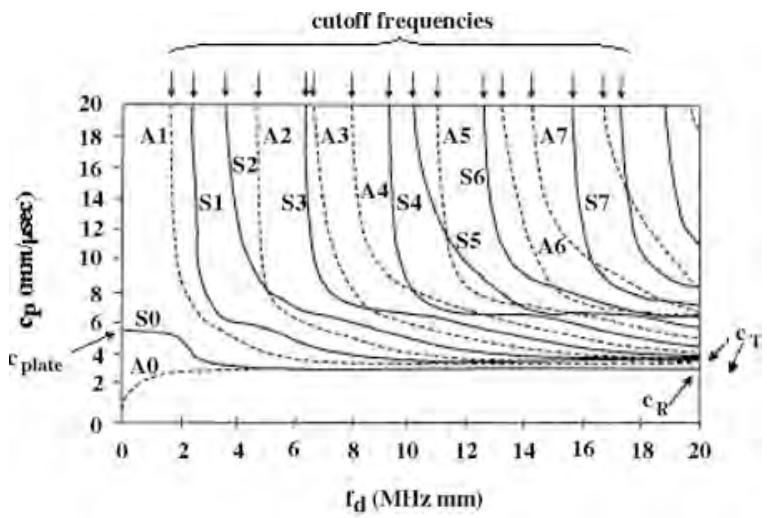

(a) Sample Lamb wave phase velocity dispersion curves.

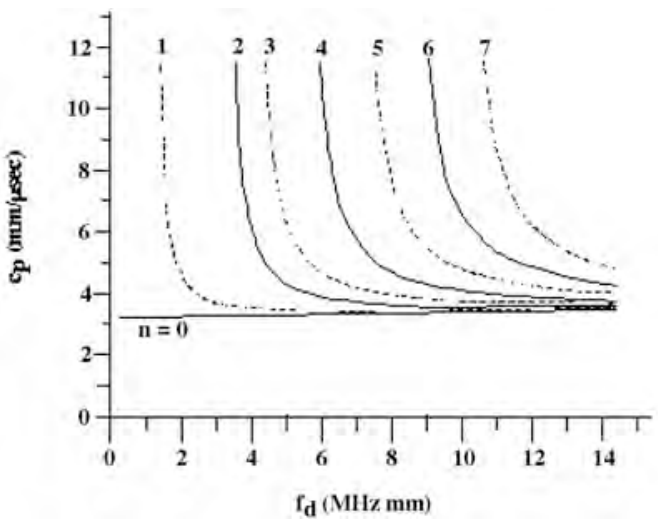

(b) Sample SH mode phase velocity dispersion curves: solid curves denote symmetric modes and dashed curves antisymmetric mode.

Figure 6.34 Simple dispersion curves for steel plate $\left(\mathrm{c}_{\mathrm{T}}=3.1 \mu \mathrm{m} / \mathrm{msec}\right)$.

Source: J. Li and J.L. Rose, “Guided Wave Inspection of Containment Structures,” Materials Evaluation 59(6), pp. 783787, June 2001.
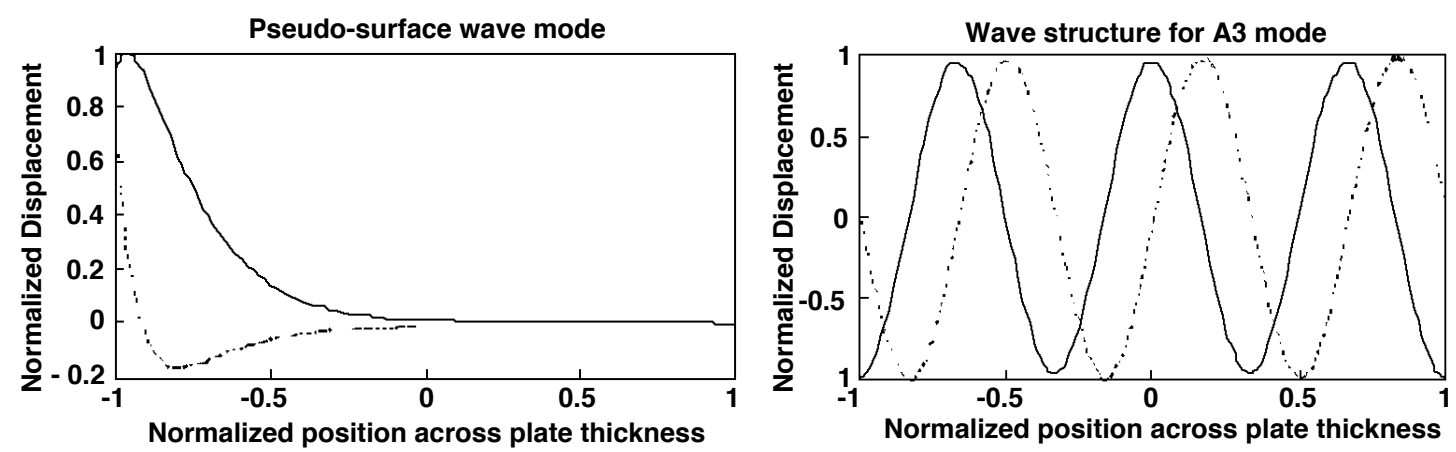

Figure 6.35 Wave structure for the pseudo-surface mode and A3 mode at frequency of $565 \mathrm{kHz}$.

(Plate thickness is $25.4 \mathrm{~mm}$. Solid line is out-of-plane displacement and dashed line is in-plane displacement).

Source: J. Li and J.L. Rose, "Guided Wave Inspection of Containment Structures," Materials Evaluation 59(6), pp. 783-787, June 2001.

out-of-plane displacements, each with a different distribution pattern. From Figure 6.35a, it can be seen that the energy focuses close to the plate boundary area on the same side of the transducer. Therefore, it can detect anomalies on one side only. In order to find anomalies close to the other side using the pseudo-surface mode, the transducer needs to be moved to the other side. Although more tedious for experimentation, this wave mode can determine which side the anomalies are close to, and thus provides more information about anomalies. Compared with pseudo-surface waves, A3 modes have the energy distribution across the entire plate thickness and can detect anomalies on the both sides of the plate.

\section{$\underline{\text { Experimental Studies }}$}

A limited experimental investigation has been conducted to demonstrate the feasibility of using the guided wave technique for identification and location of thickness reductions in the metallic pressure boundary of nuclear power plant containments. The test specimens are shown in Figure 6.36a, and include a free plate (no concrete) with two anomalies (Plate 1), a plate embedded in concrete with one anomaly (Plate 2), and a plate embedded in concrete but having no anomalies (Plate 3 ). All three plates are $25.4-\mathrm{mm}$ thick by $203-\mathrm{mm}$ wide by $914-\mathrm{mm}$ long. For practical purposes, the thickness of the concrete, when present, is large enough that it can be considered a "half space." The 
plate specimens provide a benchmark for studying various aspects of guided wave inspection, including sensitivity, transmission ability across anomalies, inspection reliability, and penetration ability.

SH waves. SH guided waves have particle displacements in the shear horizontal direction, which is perpendicular to the propagation direction. SH waves are sensitive to the transverse boundary conditions. Therefore, a transducer couplant for SH waves should be a highly viscous material such as honey. Although coupling requirements once limited applications of SH waves, advancements of electromagnetic acoustic transducers (EMATs) have resulted in $\mathrm{SH}$ waves once again receiving a lot of attention because of the couplant-free advantage of EMATs. Figure 6.36b presents a schematic of a typical EMAT application system and a picture of the EMAT's used in the experiments. The grid spacing of the EMAT's was $17.7 \mathrm{~mm}$, which determines the corresponding frequency for generating the non-dispersive SH wave mode (i.e., $200-250 \mathrm{kHz}$ ). The non-dispersive $\mathrm{SH}$ wave mode has the same phase velocity as the SH bulk wave velocity $(3200 \mathrm{~m} / \mathrm{s})$, and a uniform displacement distribution across the plate thickness.
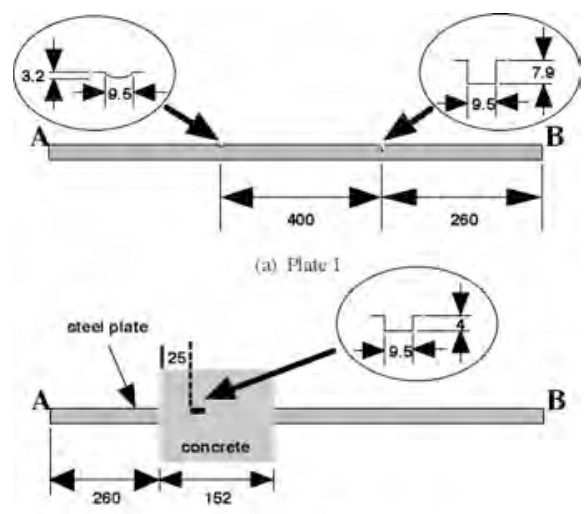

(b) Pate 2

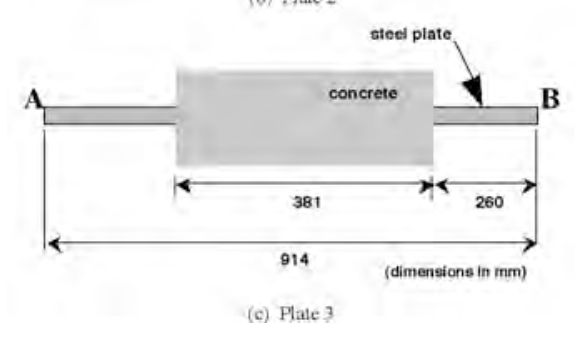

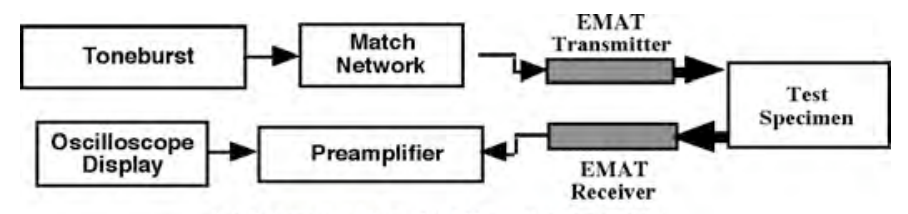

(a) Schematic of an EMAT application system.

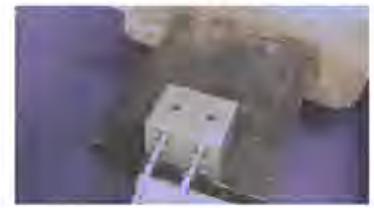

(b) An EMAT system for concrete inspection.

(b) Schematic of typical EMAT system and its application to embedded plate scenario.

(a) Schematics of plate specimens.

Figure 6.36 Plate specimens and schematic of typical EMAT system application.

Source: J. Li and J.L. Rose, "Guided Wave Inspection of Containment Structures," Materials Evaluation 59(6), pp. 783-787, June 2001.

The waveforms obtained from testing the three plate specimens are shown in Figure 6.37. Figure 6.37a presents the reflected echoes for the free plate with two anomalies (Plate 1) and shows that both anomalies can be detected by using the SH waves. Because the non-dispersive $\mathrm{SH}$ wave mode has a uniform particle displacement distribution, some energy can pass the first anomaly to be reflected by the second anomaly. The back wall echo (BWE) shows good penetration ability of the SH wave mode. Figure $6.37 \mathrm{~b}$ and $6.37 \mathrm{c}$ present the anomaly echoes for the plate containing an anomaly embedded in concrete (Plate 2). The echoes were obtained by putting the transducer at end A on the top and bottom surfaces of the plate, respectively. From Figure $6.37 \mathrm{~b}$ and $6.37 \mathrm{c}$ it can be seen that the SH guided waves have the same sensitivity to the anomaly whether the transducer is located on the top or bottom plate surface, even though the anomaly is just on the top surface. The signal when the transducer is placed at end B of Plate 2 is shown in Figure 6.37d. The signal for the plate specimen embedded in concrete but without an anomaly (Plate 3) is shown in Figure 6.37e and demonstrates insensitivity to the concrete edge and the plate-concrete interface. The strong back wall echo demonstrates the excellent penetration power of the SH guided waves across the steel-concrete interface. 


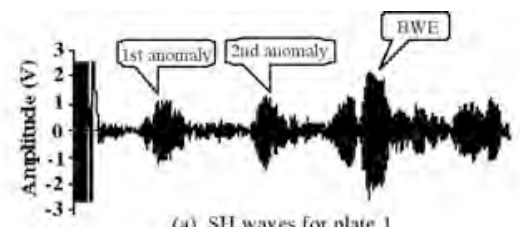

(a) SH waves for plate 1
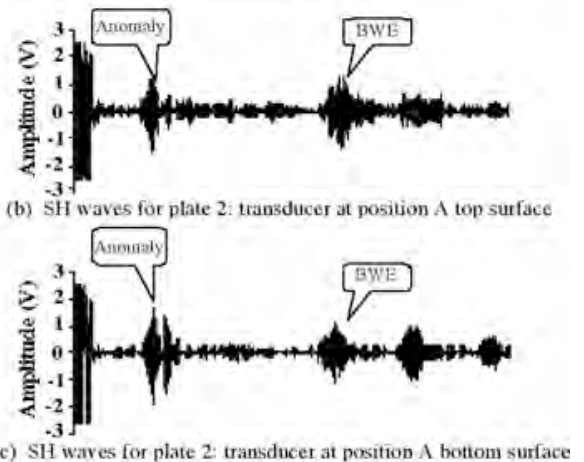

(c) SH wayes for plate 2: transducer at position A bottom surface
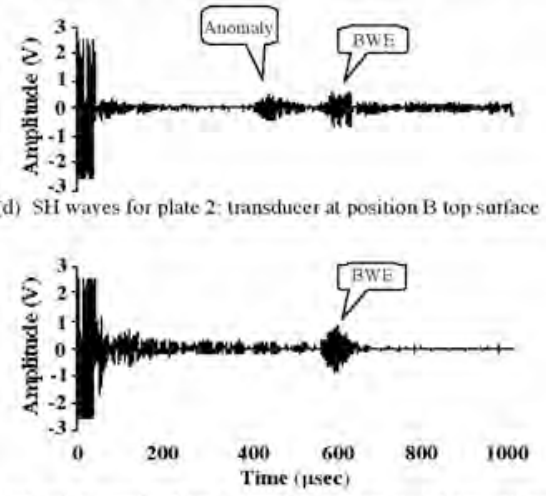

(c) SH waves for plate 3: transducer at position A top surface

Figure 6.37 SH guided wave experimental results with EMAT SH system.

(Frequency $=240 \mathrm{kHz}$, nondispersive $\mathrm{SH}$ wave mode).

Source: J. Li and J.L. Rose, "Guided Wave Inspection of Containment Structures," Materials Evaluation 59(6), pp. 783-787, June 2001.

Lamb waves. Unlike SH waves, Lamb waves have particle displacement distribution in both parallel and perpendicular directions to the propagation direction. Lamb waves are sensitive to both transverse and normal boundary conditions. Common couplants can be used for generating Lamb waves. The frequency and wedge angle determines the generated Lamb wave mode. Two wedge angles were considered at the frequency of $565 \mathrm{kHz}$. When the wedge was set to 62 degrees, it generated the A0 and S0 modes simultaneously, both having the same phase velocity $(3030 \mathrm{~m} / \mathrm{s})$ at the working frequency, which degenerates into pseudo-surface waves. As the pseudosurface wave has energy distribution close to the plate boundary, it is very sensitive to an anomaly close to the boundary. However, it is not sensitive to the anomalies on the other side of the plate. Figure 6.38a is the pulse-echo signal for the transducer placed at the opposite surface (bottom) to anomalies on the free plate (plate 1). It can be seen that both anomalies are ignored and only a back wall echo is received. If the transducer is placed on the same surface (top) as the anomalies, however, only the first anomaly echo can be received, as shown in Figure 6.38b, which means that most energy close to the plate boundary is reflected back by the first anomaly. This is a different case than occurred for the $\mathrm{SH}$ waves due to the uniform energy distribution feature of the SH wave mode.

In order to obtain a fairly uniform energy distribution across the plate thickness for Lamb waves, the wedge angle was changed to 38 degrees. Once again, the tone burst frequency was $565 \mathrm{kHz}$. The phase velocity and group velocity of the generated Lamb waves were $4385 \mathrm{~m} / \mathrm{s}$ and $2220 \mathrm{~m} / \mathrm{s}$, respectively. As a result, the A3 Lamb wave mode was generated (Figure 6.35b). Figures 6.39a and 6.39b present the pulse-echo signals for the free plate

(plate 1) with the transducer on the top and bottom surfaces, respectively. The signals shown in Figures 6.39a and $6.39 \mathrm{~b}$ indicate that by generating the A3 Lamb wave mode, the transducer can detect anomalies from either the top 


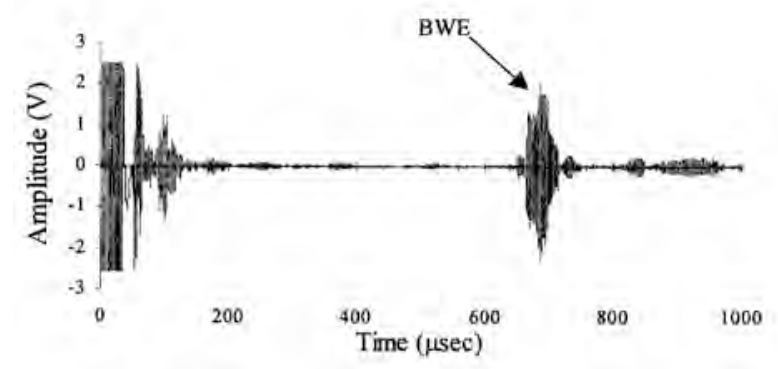

(a) Pulse echo signal Plate 1: transducer at position A bottom surface.

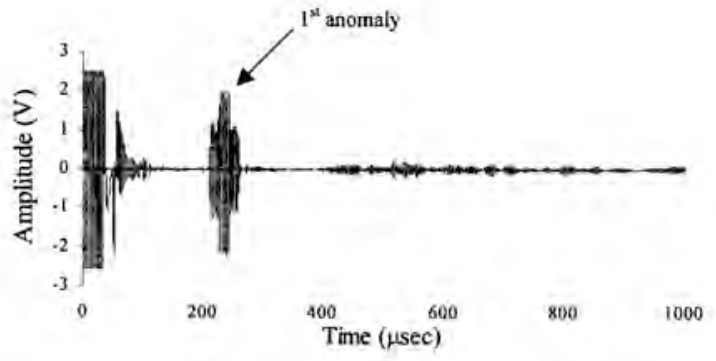

(b) Pulse echo signal Plate 1: transducer at position A top surface.

Figure 6.38 Pseudo-surface Lamb wave mode for plate inspections

$\left(\right.$ Frequency $=565 \mathrm{kHz}$, wedge angle $=62^{\circ}$ ).

Source: J. Li and J.L. Rose, “Guided Wave Inspection of Containment Structures,” Materials Evaluation 59(6), pp. 783-787, June 2001.

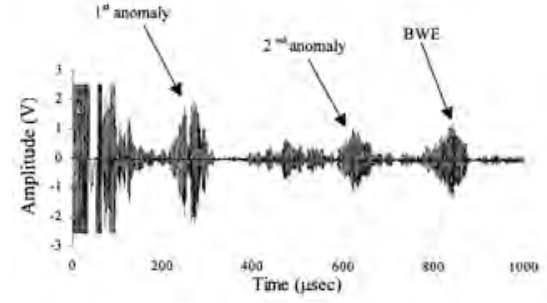

(a) Pulse echo signal for A3 Lamb wave mode: Plate 1 transducer at position A top surface.

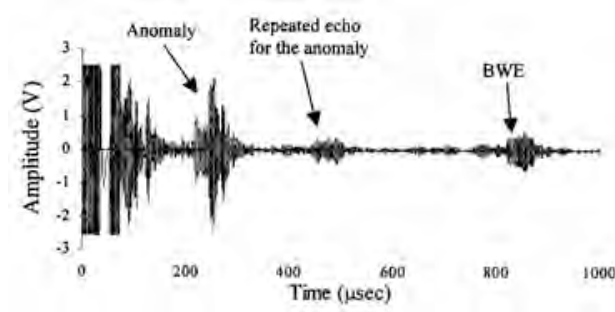

(c) Pulse echo signal for A3 Lamb wave mode: Plate 2 transducer at position A top surface.

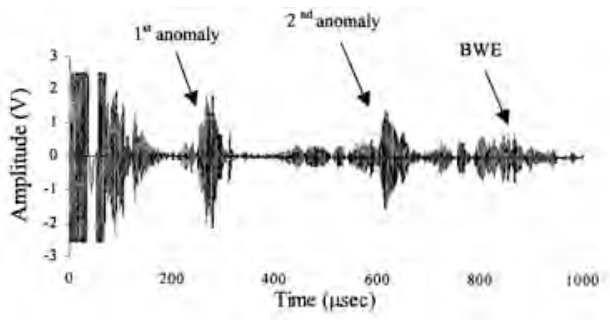

(b) Pulse echo signal for A3 Lamb wave mode: Plate 1 transducer at position A bottom surface.

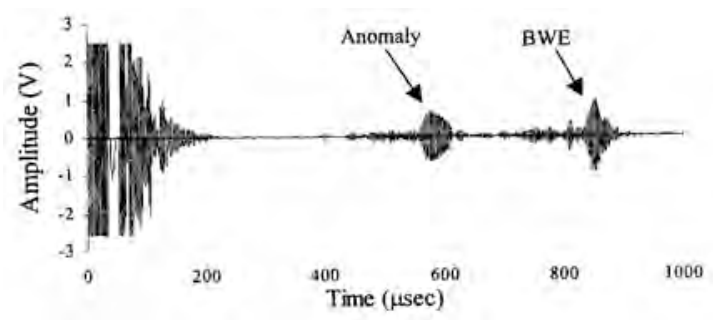

(d) Pulse echo signal for A3 Lamb wave mode: Plate 2 transducer at position B bottom surface.

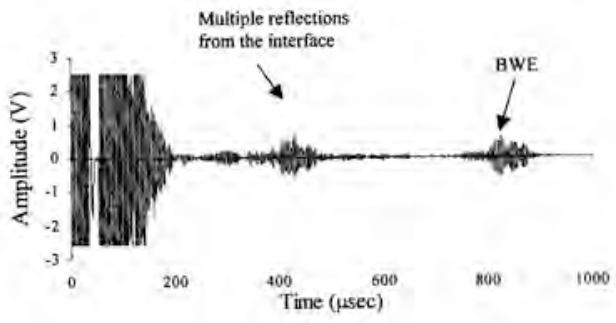

(e) Pulse echo signal for A3 Lamb wave mode:

Plate 3 transducer at position A top surface.

Figure 6.39 Pulse echo signal for A3 Lamb wave mode.

Source: J. Li and J.L. Rose, “Guided Wave Inspection of Containment Structures,” Materials Evaluation 59(6), pp. 783-787, June 2001. 
or bottom surfaces of the plate. The Lamb wave mode also shows a great sensitivity to anomalies. Figures 6.39c and $6.39 \mathrm{~d}$ provide the signals for the plate containing an anomaly embedded in concrete (plate 2 ) when the transducers were placed at ends A and B, respectively. Compared with SH waves, Lamb waves show a higher signal to noise ratio in Figures $6.39 \mathrm{c}$ and $6.39 \mathrm{~d}$. Figure 6.39e is the pulse-echo signal for the plate embedded in concrete without an anomaly (plate 3). Multiple echoes were received from the plate-concrete interface before the back wall echo, indicating a disadvantage of the Lamb wave mode. This problem could be overcome by setting a threshold for an anomaly call. Most anomalies of major concern would probably be more than $20 \%$ the plate thickness and reflect stronger echoes than those from the plate-concrete interface. Use of multi-mode Lamb wave signals can also be considered for an anomaly call.

Conclusions. Results indicate that both SH and Lamb wave modes can be used for the inspection of steel containment structures, with both being somewhat insensitive to the concrete boundary for specific velocity and frequency values. Strong benefits of the SH wave via an EMAT transducer were demonstrated with overall improved signal-to-noise ratio with practically no interference from the concrete interface and the non-contacting testing potential.

\subsubsection{Elements of Defect Sizing in a Wave Guide Using SH Guided Waves}

The Boundary Element Method (BEM) is being developed to study the interaction of various guided wave packets of energy with various corrosion boundaries in a structure (6.33). This study was carried out on elliptical-shaped scatterers with a variation in defect depth and length values as shown in Figure 6.40. This type of reflection could model items of interest such as corrosion boundaries and pitting. Corrosion and surface breaking defects, of course, will be more complex than the nice geometrical figures used in the BEM studies. The BEM program is being developed, though, to handle greater variations in the geometrical shaped reflectors compared to elliptical pitting. Frequency spectrums for the amplitudes of the scattered modes in both pulse-echo and through-transmission modes are considered. Characterization of the defect depth and length was implemented for some special situations based on features of the BEM results. For initial experiments, artificial corrosion and crack-type defects were fabricated with different depths and lengths in 10-mm-thick steel plates. Theoretical and experimental data on the scattering of SH waves were obtained, demonstrating potential for solving this difficult classification problem. The goal of the modeling effort was to establish guidelines so that the best modes and frequencies could be considered for impingement to provide the best chance of success in determining the defect shape and size characteristics. An electromagnetic-acoustic transducer (EMAT) technique for SH wave excitation was used.

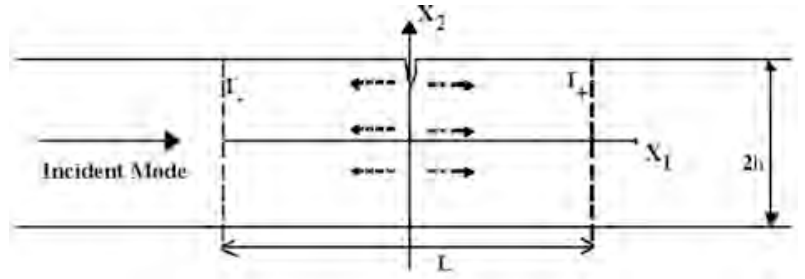

(a) Plane model, solid and dashed arrows show incident and scattering modes, respectively. Area between $\Gamma \pm$ lines is used for BEM modeling.

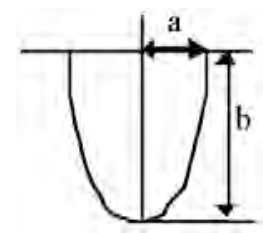

(b) Parameters for an elliptical-shaped flaw.

Figure 6.40 Boundary element method (BEM) wave scattering model.

Source: J.L. Rose, and X. Zhao, "Anomaly Throughwall Depth Measurement Potential with Shear Horizontal Guided Waves," Materials Evaluation 59(10), pp. 1234-1238, October 2001.

Ultrasonic guided waves were used extensively for defect and materials characterization; some theoretical and experimental results using BEM are available (6.34-6.38). The finite-element method (FEM) for the Lamb and SH wave scattering problem has been analyzed elsewhere (6.39-6.42). The electromagnetic acoustic transducer (EMAT) technique for SH wave excitation has also been described elsewhere (6.43).

\section{$\underline{\text { Problem Statement and Solution }}$}

The boundary value problem for the elastic isotropic plate presented in Figure 6.40 is considered. The incident time harmonic wave is propagating in the positive $X_{1}$ direction. The mode incident on the crack results in both reflected 
and transmitted waves of all orders of the propagation modes that could exist in the plate for a given frequency. The crack considered has an elliptical shape, with horizontal axis $2 \mathrm{a}$ and vertical axis $2 \mathrm{~b}$.

For any frequency, scattering from a crack generates a finite number of propagating and countable numbers of nonpropagating modes. For the SH modes the particle displacement vector has only an $\mathrm{X}_{3}$ component. Displacement and stress for the friction-free boundary conditions can be presented in a form (6.44):

\section{$\underline{\text { Displacement }}$}

$$
u_{3}^{n}\left(x_{1}, x_{2}, t\right)=U^{n}\left(x_{1}, x_{2}\right) e^{-i \omega t}=\left\{\begin{array}{cc}
B_{n} \cos \left(n \pi x_{2} / d\right) e^{i\left(k_{n} x_{1}-\omega t\right)} & \text { (symmetric modes) } \\
A_{n} \sin \left(n \pi x_{2} / d\right) e^{i\left(k_{n} x_{1}-\omega t\right)} & \text { (antisymmetric modes) }
\end{array}\right.
$$

\section{$\underline{\text { Stress }}$}

$$
\begin{aligned}
& \tau_{23}^{n}\left(x_{1}, x_{2}, t\right)=T_{23}^{n}\left(x_{1}, x_{2}\right) e^{-i \omega t}=\left\{\begin{array}{c}
-B_{n} \mu q_{n} \sin \left(n \pi x_{2} / d\right) e^{i\left(k_{n} x_{1}-\omega t\right)} \quad \text { (symmetric modes) } \\
A_{n} \mu q_{n} \cos \left(n \pi x_{2} / d\right) e^{i\left(k_{n} x_{1}-\omega t\right)} \quad \text { (antisymmetric modes) }
\end{array}\right. \\
& \tau_{13}^{n}\left(x_{1}, x_{2}, t\right)=T_{13}^{n}\left(x_{1}, x_{2}\right) e^{-i \omega t}=\left\{\begin{array}{c}
i k_{n} B_{n} \mu \cos \left(n \pi x_{2} / d\right) e^{i\left(k_{n} x_{1}-\omega t\right)} \quad \text { (symmetric modes) } \\
i k_{n} A_{n} \mu \sin \left(n \pi x_{2} / d\right) e^{i\left(k_{n} x_{1}-\omega t\right)} \quad \text { (antisymmetric modes) }
\end{array}\right. \\
& k_{n}^{2}=\left(\frac{\omega}{c_{T}}\right)^{2}-\left(\frac{\pi n}{d}\right)^{2} ; \ldots q_{n}^{2}=\left(\frac{\omega}{c_{T}}\right)^{2}-k_{n}^{2} \ldots(n=0,1,2, \ldots)
\end{aligned}
$$

where $A_{n}$ and $B_{n}$ are unknown coefficients and $d=2 h$. Note that the amplitudes of the SH modes (Eqn. 6.2) are independent of frequency and wave number. Hence wave structure of the SH mode does not vary along the entire dispersion curve. This is in contrast to Lamb wave behavior, where the wave field is a function of the position on the dispersion curve. The total displacement field is the superposition of the incident and scattered wave fields. The time dependent term $e^{-i \omega t}$ is omitted elsewhere.

$$
U\left(x_{1}, x_{2}\right)=A_{p}^{I N} U^{p}\left(x_{2}\right) e^{i k_{p} x_{1}}+\sum_{n=0}^{\infty} A_{n}^{ \pm} U^{n}\left(x_{2}\right) e^{ \pm i k_{n} x_{1}}
$$

where, $A_{p}^{I N}$ is the known amplitude of the incident $p_{\text {th }}$ mode, and $A_{n}^{ \pm}$denotes the unknown amplitudes of the scattered waves traveling in the positive and negative $\mathrm{x}_{1}$ directions respectively. $U^{n}\left(x_{2}\right)$ denotes the known amplitude of the $n_{\text {th }}$ mode for the traction free plate, and $k_{n}$ represents wave numbers of SH waves. The summation in Eqn. (6.4) is over all propagating and evanescent modes that can exist in a plate for a particular frequency of interest.

Far away from a defect only the amplitudes of the propagating modes are significant. This is expressed by keeping only the real roots, $k_{n}$, according to the phase velocity dispersion curves as shown in Figure 6.41. The solution of the problem can be obtained by coupling the BEM solution for the rectangular area and a far-scattered field on the boundaries $\Gamma_{ \pm}$(Figure 6.40a). This approach is effective for a rectangular area with a large enough length $\mathrm{L}$. Therefore the far-field displacement and stress on the boundaries $\Gamma_{ \pm}$can be expressed only by using propagating modes.

The boundary-value problem for modeling the rectangular area leads to the following boundary integral equation $(6.34,6.35)$.

$$
C(\xi) U(\xi)+\int_{\Gamma} \frac{\partial U^{*}(\xi, x)}{\partial n} U(x) d \Gamma(x)=\int_{\Gamma} U^{*}(\xi, x) \frac{\partial U(x)}{\partial n} d \Gamma(x)
$$

where $\Gamma$ is the total boundary of the modeling area, the value of $C(\xi)$ depends on the boundary smoothness and $\partial U / \partial n$ is the derivative of $U$ with respect to the outward normal to the boundary $\Gamma$. The terms $U(x)$ and 


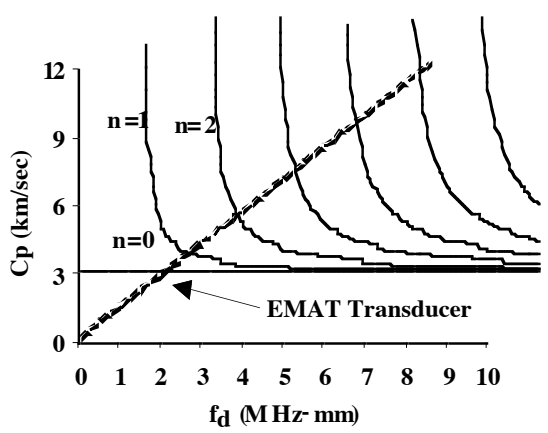

(a) Phase velocity dispersion curves

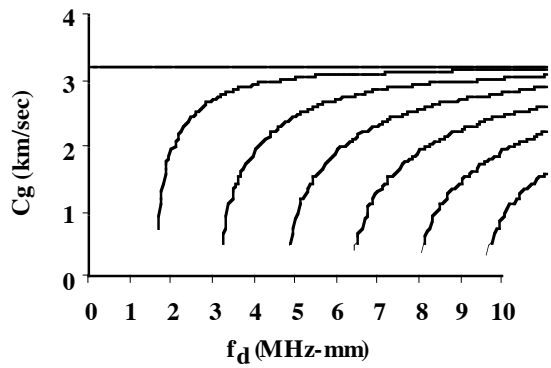

(b) Group velocity dispersion curves

Figure 6.41 SH phase and group velocity dispersion curves for 10-mm-thick steel plate..

Source: J.L. Rose, and X. Zhao, "Anomaly Throughwall Depth Measurement Potential with Shear Horizontal Guided Waves," Materials Evaluation 59(10), pp. 1234-1238, October 2001.

$\partial U(x) / \partial n$ are the boundary values of the displacements and tractions. $U^{*}(r)$ is the fundamental solutions in the frequency domain expressed through a Hankel function of the first kind (6.29)

$$
U^{*}(r)=\frac{i}{4} H_{0}^{1}\left(\frac{\omega}{c_{T}} r\right) .
$$

The procedure to obtain a numerical solution of Eqn. (6.5) by using coupling conditions on the boundaries $\Gamma_{ \pm}$and finding the reflection and transmission coefficients is discussed elsewhere $(6.34,6.35)$.

The results presented here are used for a sizing study of elliptical defects with $2 \mathrm{a}$ equal to $0.3,6.35$, and $12.7 \mathrm{~mm}$. Reflection and transmission coefficients versus frequency are shown in Figure 6.42 for an $\mathrm{n}=0$ incident mode, $\mathrm{n}=0$

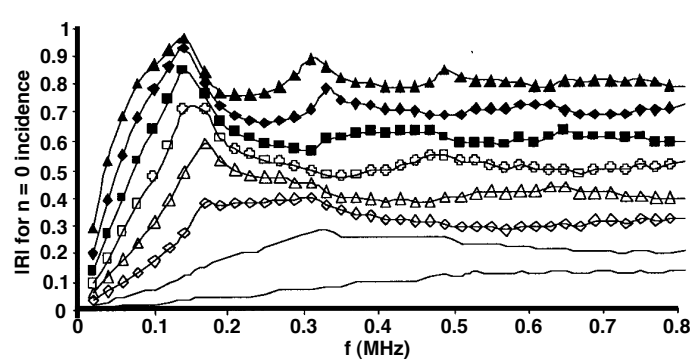

(a) Reflection coefficients

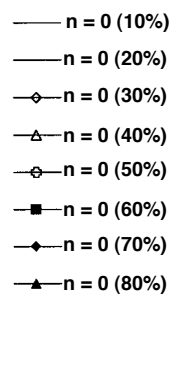

Figure 6.42 Reflection and transmission coefficients.

$(\mathrm{N}=0$ mode under $\mathrm{n}=0$ incident mode for 0.3 -mm elliptical notch width and 10 to 80 percent through-plate thickness depth.)

Source: J.L. Rose, and X. Zhao, "Anomaly Throughwall Depth Measurement Potential with Shear Horizontal Guided Waves," Materials Evaluation 59(10), pp. 1234-1238, October 2001.

reflected and transmitted mode from the $0.3 \mathrm{~mm}$ notch defect. There is an excellent monotonic change in amplitude versus percent through-wall depth for all frequencies. A sample result is shown in Figure 6.43 for $0.5 \mathrm{MHz}$.

Sample results are illustrated in Figures 6.44 and 6.45 for elliptical defect widths of 6.35 and $12.7 \mathrm{~mm}$, respectively. There is sometimes a monotonic change of amplitude with defect depth, but not at all frequencies.

Generally, many BEM computer runs could be conducted to seek a reflection characteristic such that there would be a monotonic increase with depth of a reflector. At this time, sizing is only possible if the reflector type is known. Therefore the focus will be on the 0.3 -mm-wide notch-type defect. Theoretical results were shown in Figures 6.42 and 6.43 with a monotonic change of amplitude with through-wall size. Future work should focus on both defect detection and quantification. BEM tools are now available to assist in this study. 


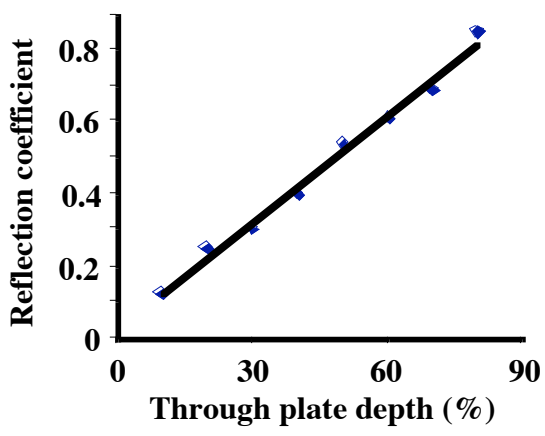

(a) Reflection

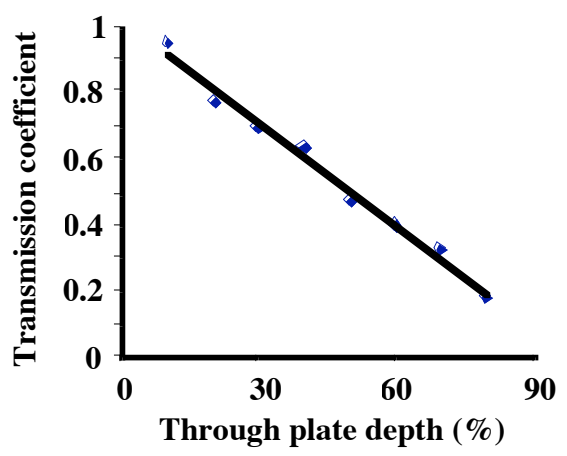

(b) Transmission

Figure 6.43 Reflection and transmission coefficients showing linear increase in amplitude with percent through-wall depth $(\mathrm{n}=0$ mode under $\mathrm{n}=0$ incident mode at frequency of $0.5 \mathrm{MHz})$.

Source: J.L. Rose, and X. Zhao, “Anomaly Throughwall Depth Measurement Potential with Shear Horizontal Guided Waves,” Materials Evaluation 59(10), pp. 1234-1238, October 2001.

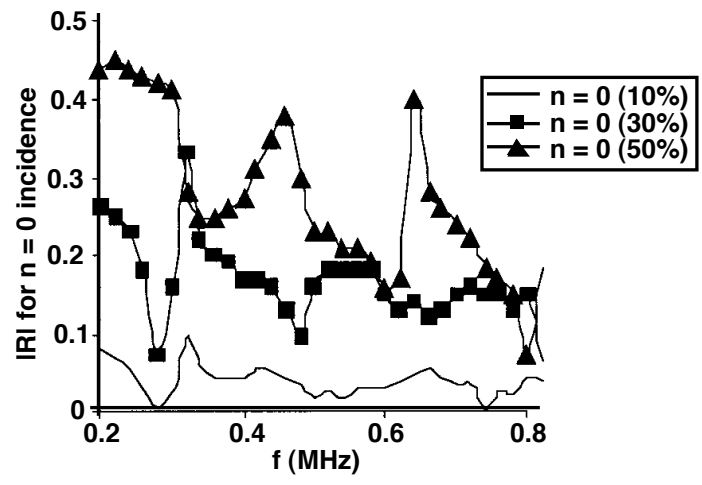

(a) Reflection

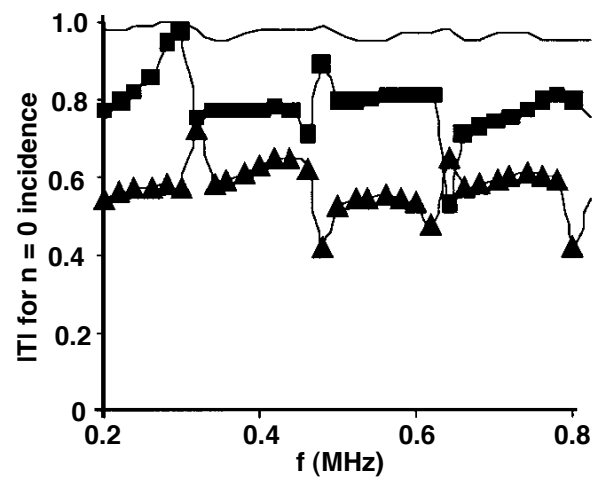

(b) Transmission

Figure 6.44 Reflection and transmission coefficients for 6.35-mm elliptical defect width and either 10,30, or 50 percent through-plate thickness depth $(\mathrm{n}=0$ mode under $\mathrm{n}=0$ incident mode.

Source: J.L. Rose, and X. Zhao, “Anomaly Throughwall Depth Measurement Potential with Shear Horizontal Guided Waves,” Materials Evaluation 59(10), pp. 1234-1238, October 2001.

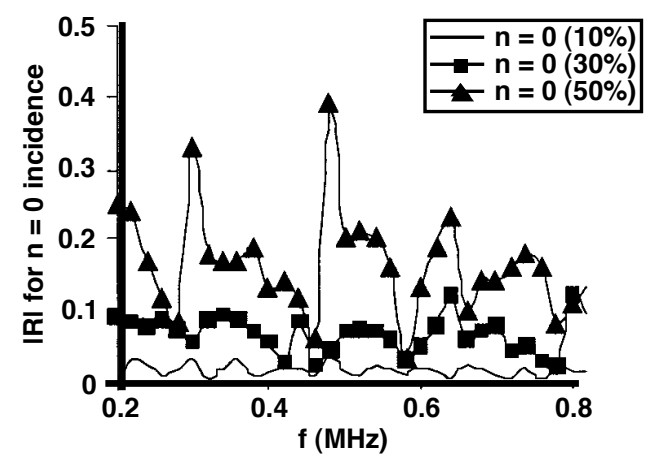

(a) Reflection

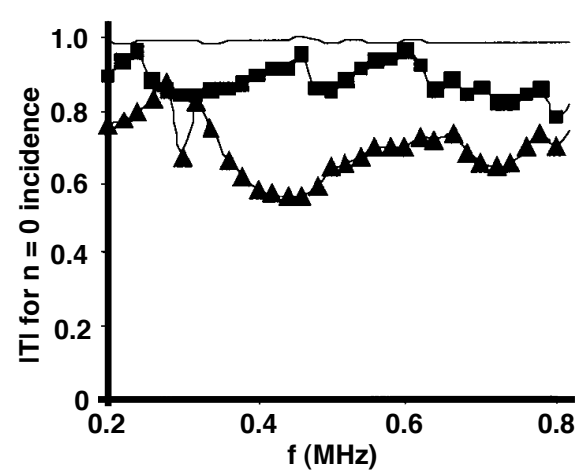

(b) Transmission

Figure 6.45 Reflection and transmission coefficients for 12.7-mm elliptical defect width and either 10,30 , or 50 percent through-plate thickness depth $(n=0$ mode under $n=0$ incident mode.

Source: J.L. Rose, and X. Zhao, "Anomaly Throughwall Depth Measurement Potential with Shear Horizontal Guided Waves,” Materials Evaluation 59(10), pp. 1234-1238, October 2001. 


\section{$\underline{\text { Experimental studies }}$}

Experiments were conducted on nine steel plates, each of which had either a groove or notch in one surface. The size of a defect was either $0.305-, 6.35-$, or $12.7-\mathrm{mm}$ wide with a depth equal to either $10 \%, 30 \%$ or $50 \%$ the through-plate thickness. Two electromagnetic SH wave transducers (SH EMATs) were used to generate and receive horizontal shear waves in the steel plate using a tone burst signal generator and oscilloscope system. Both throughtransmission and pulse-echo modes were used. On each plate a reference signal was obtained by separating the two EMATs $76.2 \mathrm{~mm}$. The non-defect signal amplitude was then recorded. For through transmission the two EMATs were $76.2 \mathrm{~mm}$ apart with each transducer $38.1 \mathrm{~mm}$ from the centerline of the defect (see Figure 6.46a). A

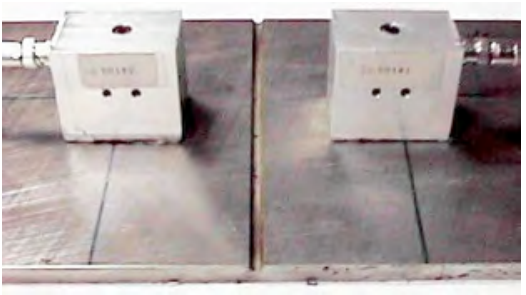

(a) Through transmission mode for defect sizing (EMATs are spaced $76.2 \mathrm{~mm}$ apart and $38.1 \mathrm{~mm}$ from center groove.

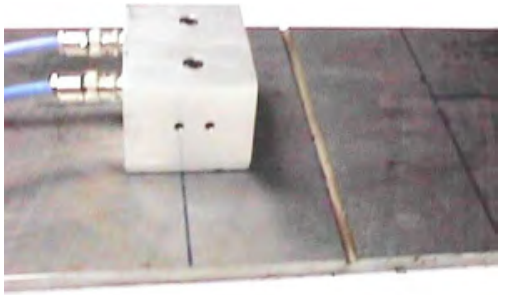

(b) Pulse echo mode (EMATs are spaced $38.1 \mathrm{~mm}$ from center groove).

Figure 6.46 Experimental setup.

Source: J. Li and J.L. Rose, “Guided Wave Inspection of Containment Structures," Materials Evaluation 59(6), pp. 783787, June 2001.

sample through-transmission signal is shown in Figure 6.47a. A sample pulse-echo waveform for the setup shown in Figure 6.46b is shown in Figure 6.47b. The envelope peak-to-peak value of the signal was measured

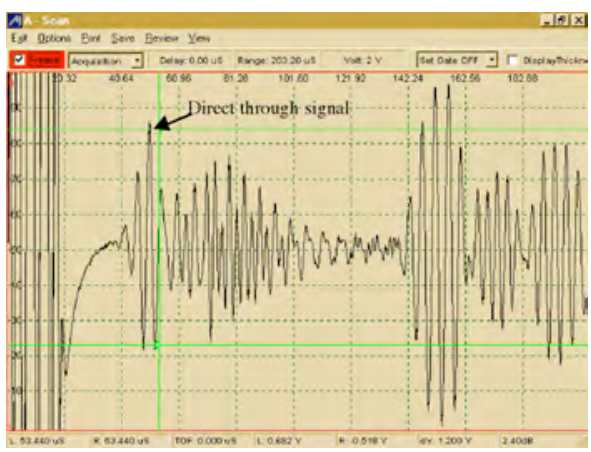

(a) $\mathrm{SH}$ wave of mode 0 , through transmission signal from a $0.305-\mathrm{mm}$ wide $10 \%$ through plate notch in a $10-\mathrm{mm}$ thick steel plate.

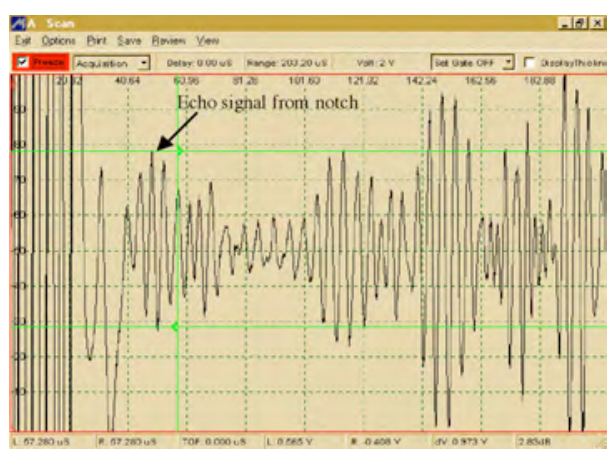

(b) SH wave of mode 0 , pulse echo signal from a $0.305-\mathrm{mm}$ wide $30 \%$ through plate notch in 10 -mm thick steel plate.

Figure 6.47 SH through transmission and pulse echo sample waveforms.

Source: J. Li and J.L. Rose, “Guided Wave Inspection of Containment Structures,” Materials Evaluation 59(6), pp. 783787, June 2001.

and the transmission coefficient calculated by dividing it by that of the reference signal. For the pulse-echo mode the two EMATs were placed side by side and on the same side of the defect to simulate the pulse-echo mode. They were located $38.1 \mathrm{~mm}$ away from the center of the defect. Similar calculations to above can provide the reflection coefficient. A through-transmission result is shown in Fig. 6.48. It can be seen that the trend of the curve for the theoretical and experimental results is consistent. Examining the $0.305-\mathrm{mm}$-wide notch, Figure 6.49 shows good agreement for both the through-transmission and pulse-echo modes. 


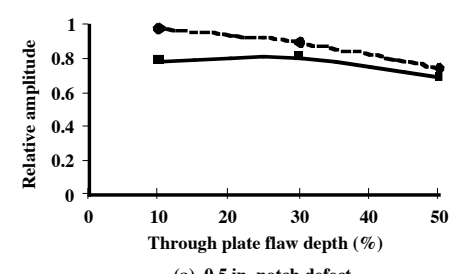

(a) 0.5 in. notch defect
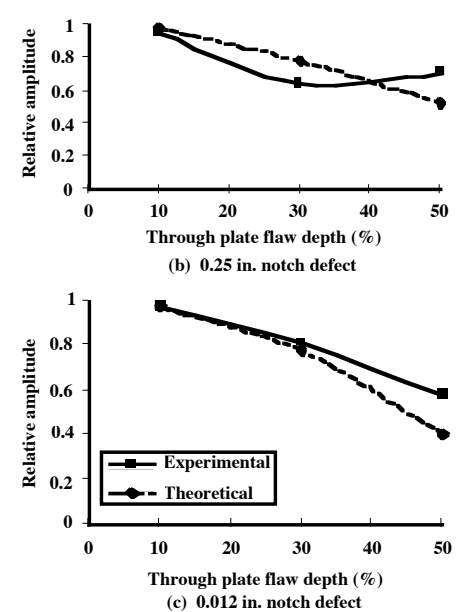

Figure 6.48 Theoretical and experimental relative amplitude results for (a) $12.7-\mathrm{mm}$, (b) $6.35-\mathrm{mm}$, and (c) $0.305-\mathrm{mm}$-wide notches of different depth in a $10-\mathrm{mm}$-thick plate (76.2-mm transducer separation, $205 \mathrm{kHz}, \mathrm{n}=0$ mode).

Source: J. Li and J.L. Rose, "Guided Wave Inspection of Containment Structures," Materials Evaluation 59(6), pp. 783787, June 2001.

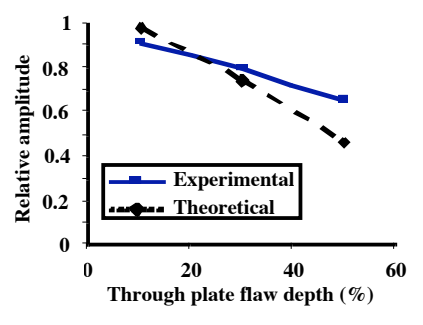

(a) Through transmission mode.

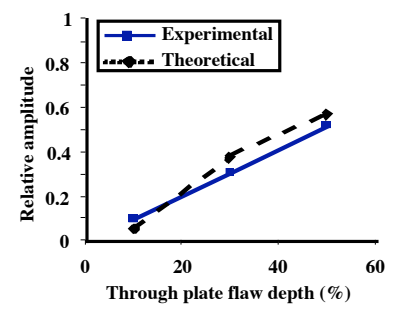

(b) Pulse echo mode.

Figure 6.49 Theoretical and experimental through transmission and pulse echo signal amplitude versus through-plate flaw depth for $0.305-\mathrm{mm}$-wide notch. ( $\mathrm{n}=0$ mode at $205 \mathrm{kHz}$ ).

Source: J. Li and J.L. Rose, “Guided Wave Inspection of Containment Structures,” Materials Evaluation 59(6), pp. 783787, June 2001.

\section{Conclusions}

Preliminary results show that defect quantification analysis can be carried out for SH guided wave impingement onto a defect in a wave guide. Both pulse-echo and through-transmission methods were considered. In particular, the possibility of a monotonic increase in amplitude change with size is noted. Potential advantages of shearhorizontal waves compared to "Lamb" type waves include less mode conversion, constant wave structure for a particular mode for all frequencies, and less sensitivity to boundary conditions because of the lateral particle velocity. Presented BEM results can be used to establish data acquisition and analysis guidelines for development of a test protocol and quantification algorithm development program. Besides modeling and BEM analysis, feature extraction possibilities could also be obtained from experimental or calibration standards using guidelines established in this study. 


\subsubsection{Ultrasonic Testing of Containment Liners Embedded in Concrete}

An experimental investigation was conducted to evaluate the ability of ultrasonic transducers to detect artificial defects in a mock-up of a containment section (6.45). The mock-up was fabricated of 38-mm-thick by $2-\mathrm{m}$-long by 1 -m-wide carbon steel plate. Artificial concave defects were placed into one side of the plate simulating corrosion having a diameter and depth of $200 \mathrm{~mm}$ and $19 \mathrm{~mm}$ or $100 \mathrm{~mm}$ and $9.5 \mathrm{~mm}$, respectively. The defects were located at a distance of $400 \mathrm{~mm}$ from one edge of the plate and a gap was provided between the defect and plate. The defects had a rough surface. The top and bottom surfaces of the plate were covered with 200-mm-thick layers of concrete in order to simulate liners embedded in concrete. Figure 6.50 presents a drawing of the test article.

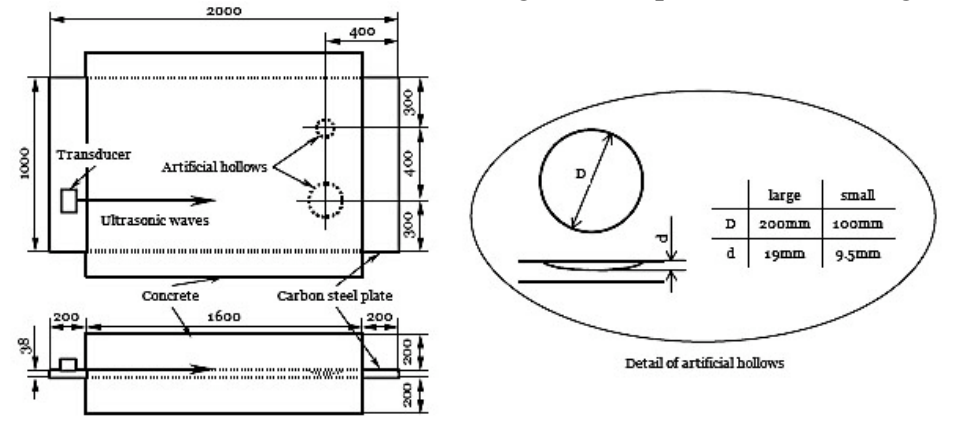

Figure 6.50 Drawing of containment liner mock-up.

Source: H. Ishida, Y. Kurozumi, and Y. Kaneshima, "Development of Ultrasonic Testing Technique to Inspect Containment Liners Embedded in Concrete on Nuclear Power Plants," Paper 249, $16^{\text {th }}$ World Conference on NDT 2004, Montreal, Canada, August 30 - September 3, 2004.

The transducers were installed on the plate where it extended from the concrete as shown in Figure 6.50. Surface shear horizontal $(\mathrm{SH})$ waves with low frequencies $(0.3,0.5$, or $0.7 \mathrm{MHz})$ were used in the study as well as a conventional ultrasonic flaw detector. Initial tests were conducted with the plate not covered on both sides with concrete. Results for positions representing no defect, small defect, and large defect obtained from the $0.5 \mathrm{MHz}$ transducer are presented in Figure 6.51. The plate end and defects were detectable as noted in the figure. The

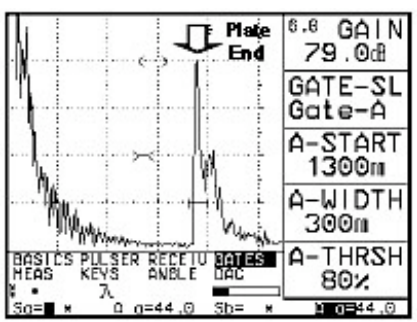

(a) Position without defect.

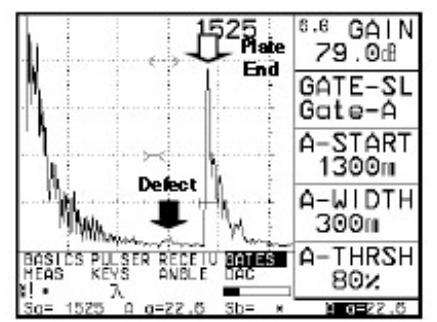

(b) Position with small defect.

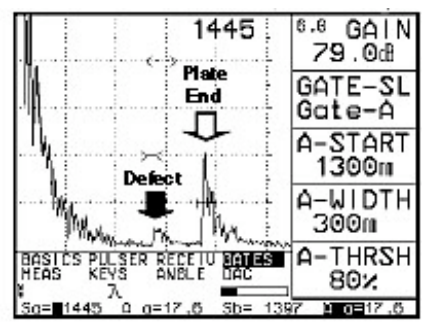

(c) Position with large defect.

Figure 6.51 Results for mock-up not covered with concrete $-0.5-\mathrm{kHz}$ transducer.

Source: H. Ishida, Y. Kurozumi, and Y. Kaneshima, "Development of Ultrasonic Testing Technique to Inspect Containment Liners Embedded in Concrete on Nuclear Power Plants," Paper 249, $16^{\text {th }}$ World Conference on NDT 2004, Montreal, Canada, August 30 - September 3, 2004.

plate was then covered with concrete on both surfaces and the tests repeated. Addition of the concrete resulted in the plate end being barely detectable and the defects not being detected using a $0.5-\mathrm{kHz}$ transducer. These results demonstrated the significant effect of concrete on wave transmission.

New transducers were then fabricated having three active elements arranged in a line and simultaneously driven by a low frequency ultrasonic pulsar/receiver having a 0.08 - to 6-MHz frequency band (-3dB). Results for the plate covered on both sides with concrete obtained using a $0.5-\mathrm{MHz}$ transducer with $70-$ to $250-\mathrm{kHz}$ band pass filter are presented in Figure 6.52. The plate end and defects were detectable as noted in the figure. Thus, it was concluded that defects such as corrosion on liners embedded in concrete are detectable at distances to $1.5 \mathrm{~m}$. 


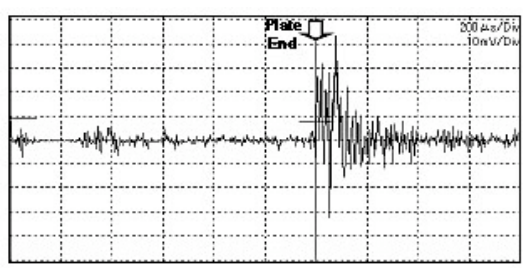

(a) Position without defect.

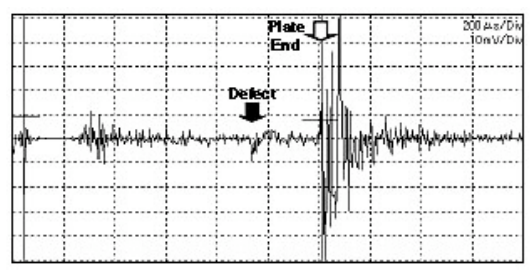

(b) Position with small defect.

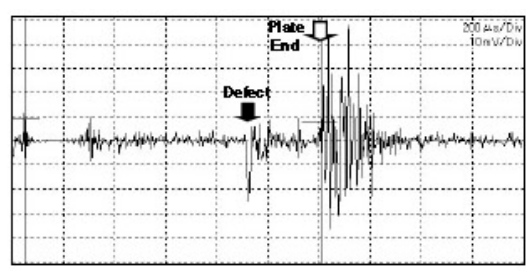

(c) Position with large defect.

Figure 6.52 Results for mock-up covered with concrete - three element, $0.5-\mathrm{kHz}$ transducer.

Source: H. Ishida, Y. Kurozumi, and Y. Kaneshima, "Development of Ultrasonic Testing Technique to Inspect Containment Liners Embedded in Concrete on Nuclear Power Plants," Paper 249, $16^{\text {th }}$ World Conference on NDT 2004, Montreal, Canada, August 30 - September 3, 2004.

\subsubsection{Electrochemical Technique Detection of Liner Corrosion}

Nondestructive electrochemical techniques (see Section 3.2 for a description of techniques utilized) were applied to liners at two nuclear power plants (LinerA and Liner B) (6.46). Measurements were made directly over the concrete slab above the liner plate. The concrete slab, which varied in thickness above the embedded liner, (i.e., 0.5 to $0.8 \mathrm{~m}$ ) had two carbon steel meshes consisting of 20 - $\mathrm{mm}$-diameter steel bars spaced at $30 \mathrm{~cm}$ center-to-center. All metal components (i.e., rebars and liner) were connected to a ground. A compressible 10-mm-thick material with seals was placed at all joints between the slab and containment wall as noted in Figure 6.53a. The pH was determined at 12 locations in Liner A and electrochemical measurements were made at 8 locations in Liner A and 6 locations in

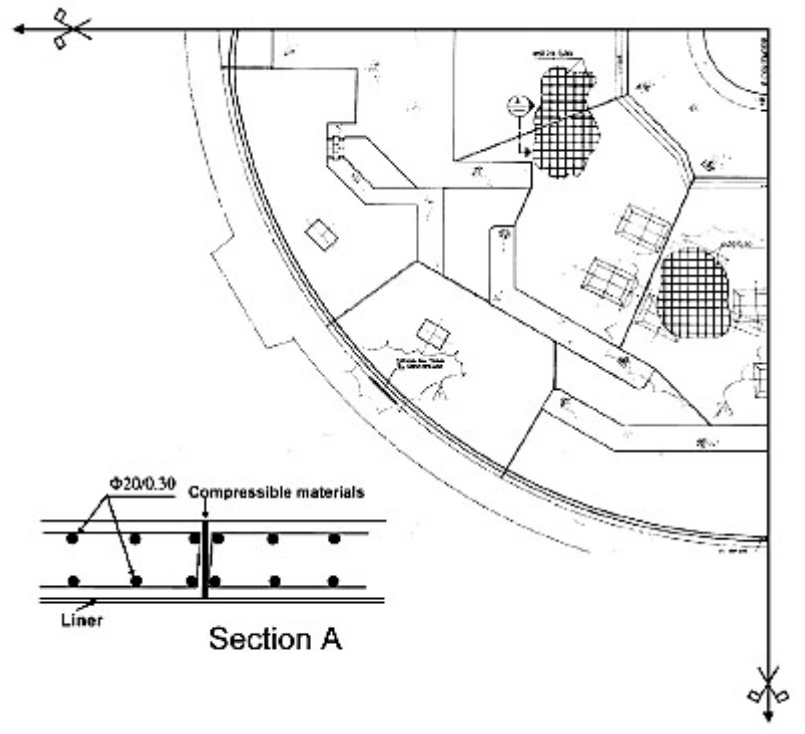

(a) Slab configuration.

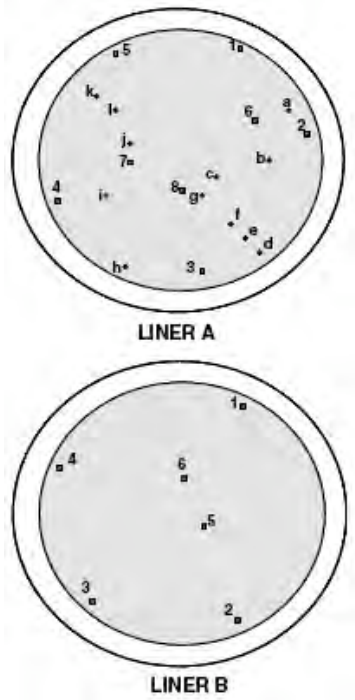

(b) Measurement locations (letters $=\mathrm{pH}$ points and numbers $=$ electrochemical points).

Figure 6.53 Drawing of nuclear power plant slab configuration and identification of measurement locations.

Source: I. Martínez, A. Castillo, and C. Andrade, "Non-Destructive Electrochemical Techniques Applied to the Corrosion Evaluation of the Liner Structures in Nuclear Power Plants," Journal of Nuclear Materials, 11 p., 2007 (In Press).

Liner B as noted in Figure 6.53b. Electrochemical parameters measured in the study were: corrosion potential $\left(\mathrm{E}_{\text {corr }}\right)$, corrosion rate $\left(\mathrm{I}_{\text {corr }}\right)$, concrete resistivity $(\rho)$, and passivity verification (PVT). Corrosion potential measurements were made to locate areas where metal embedded in concrete had become depassivated and thus potentially able to corrode. Corrosion rate measurements provided information on the corrosion intensity or corrosion level. Resistivity measurements were made to indicate the risk of corrosion. Passivity verification relates to the state of passivity of a metallic component embedded in concrete (i.e., qualitative determination of whether the 
metal is well protected, moderately protected, or unprotected).

The $\mathrm{pH}$ of water samples taken from different points under the slab of Liner A were all alkaline and ranged from 7.5 - 12.7. Corrosion potential results for Liner A ranged from -250 to $-350 \mathrm{mV}$ which fell in the range where corrosion risk was uncertain. Corrosion potential results for Liner B indicated that the corrosion risk was low and when measurements were made where paint was over the concrete surface the results were slightly more negative than when paint was not present. Concrete resistivity measurements in the slab over Liner A indicated that the concrete was moist when the measurements were obtained. Concrete resistivity measurements in the slab over Liner B also indicated that the concrete was moist and increased in the presence of paint on the concrete surface. Corrosion rate measurements are summarized in Figure 6.54a for Liner A and indicate one measurement area (area 1) that had a moderate corrosion rate. Results from the passive verification technique, only applied to Liner B, are provided in Figure $6.54 \mathrm{~b}$ and indicate that none of the six areas evaluated had high corrosion activity. Figure 6.55 a presents corrosion rate versus corrosion potential results for each of the 14 measurement points over Liners A and B. Corrosion criteria provided in ASTM C 876 (6.47) are shown with dotted lines in the figure. Some points show $\mathrm{I}_{\text {corr }}$ values $<0.1 \mu \mathrm{A} / \mathrm{cm}^{2}$ while the $\mathrm{E}_{\text {corr }}$ is more cathodic than $-250 \mathrm{mV}$ indicating that $\mathrm{E}_{\text {corr }}$ is not a suitable parameter to distinguish between activity and passivity (i.e., only $\mathrm{I}_{\text {corr }}$ provides a quantitative

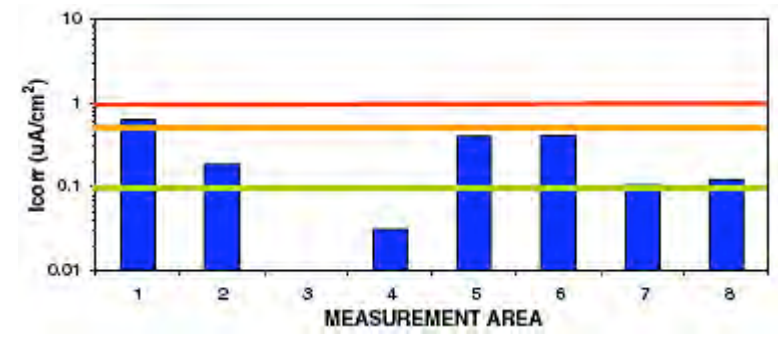

(a) Corrosion rate measurements: Liner $\mathrm{A}$ (No paint present on concrete).

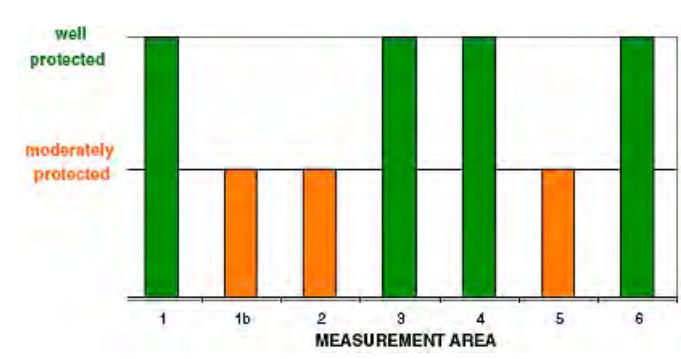

(b) Passive verification results: Liner B.

Figure 6.54 Corrosion rate and PVT measurements. (No paint present on concrete).

Source: I. Martínez, A. Castillo, and C. Andrade, "Non-Destructive Electrochemical Techniques Applied to the Corrosion Evaluation of the Liner Structures in Nuclear Power Plants," Journal of Nuclear Materials, 11 p., 2007 (In Press).

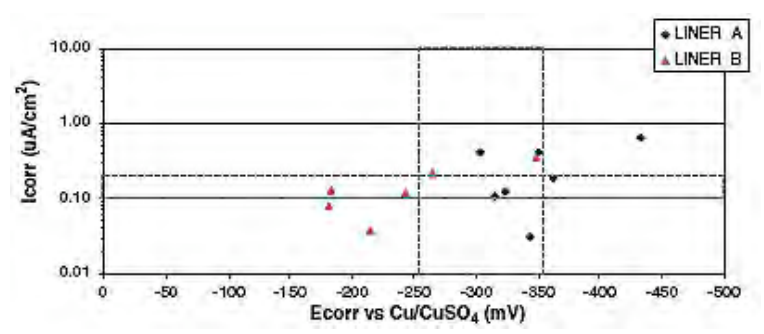

(a) Corrosion rate versus corrosion potential.

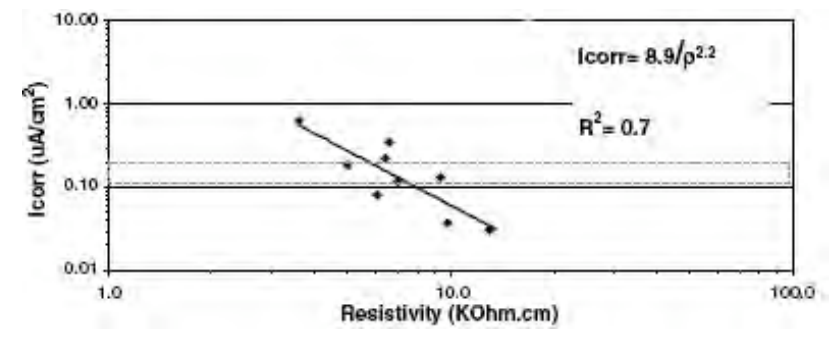

(b) Corrosion rate versus concrete resistivity.

Figure 6.55 Corrosion rate versus corrosion potential and concrete resistivity.

Source: I. Martínez, A. Castillo, and C. Andrade, "Non-Destructive Electrochemical Techniques Applied to the Corrosion Evaluation of the Liner Structures in Nuclear Power Plants," Journal of Nuclear Materials, 11 p., 2007 (In Press).

indication). In the presence of active corrosion the resistivity of concrete is one of the most influential material parameters relative to corrosion intensity as it provides information on the moisture condition of the concrete. A comparison between corrosion rate and concrete resistivity is presented in Figure $6.55 \mathrm{~b}$. The plot indicates that the threshold in corrosion current $\left(0.1 \mu \mathrm{A} / \mathrm{cm}^{2}\right)$ corresponds to a resistivity value of about $9-10 \mathrm{k} \cdot \Omega . \mathrm{cm}^{2}$, however, this value was determined for the corrosion current threshold for a steel bar embedded in concrete that may be different 
from the threshold for a steel plate embedded in concrete. It was concluded in this study that $\mathrm{pH}$ measurements of the water indicate that metal in contact with the electrolyte could be at risk, the resistivity of the concrete indicates that it was relatively wet for both liners thus providing a potential corrosion risk, calculations from corrosion rate measurements estimate metal loss at about $66 \mu \mathrm{m} /$ year which would not lead to a loss of liner integrity during its expected service life, and nondestructive electrochemical techniques appear to be an appropriate tool for evaluation of corrosion of metal liners embedded in concrete.

\subsubsection{Concrete-Filled Pipes with Internal Voids and Inclusions}

Four different mortar-filled steel pipes, containing different degrees of separation, and one hollow steel pipe were inspected (6.48). The length of the pipes was $914.4 \mathrm{~mm}$ and the outer and inner diameters were 22.36 and $19.26 \mathrm{~mm}$, respectively. The four different degrees of separation were $0,25,50$, and $75 \%$ of the pipe length as shown in Figure 6.56a. The separations were artificially fabricated by placing 7.9-mm-diameter wooden bars into the pipes and then extracting them six hours after casting the mortar. The experimental setup is shown in

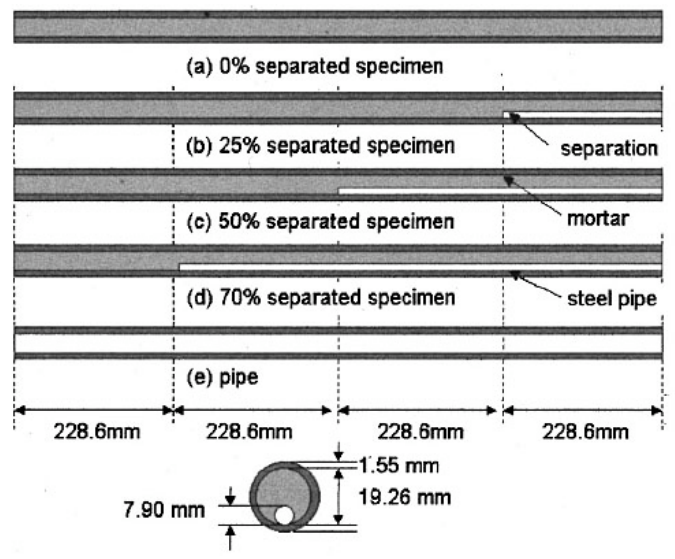

(a) Geometries of test articles.

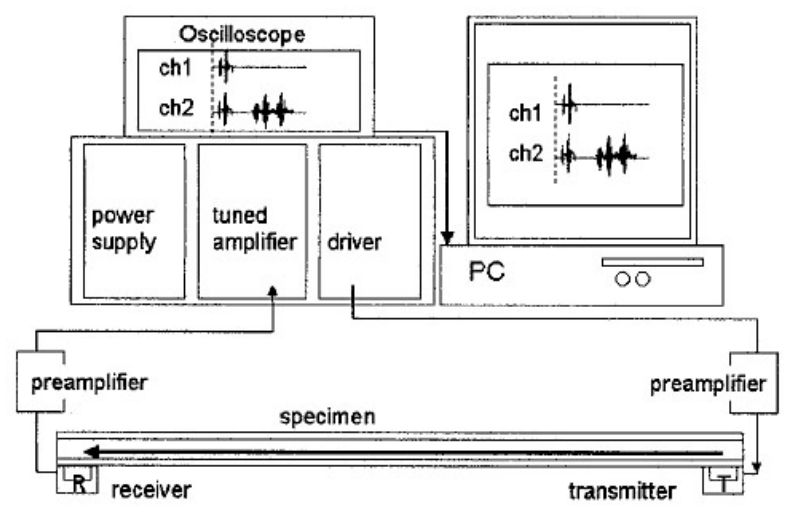

(b) Experimental setup.

Figure 6.56 Mortar-filled pipes with voids details.

Source: W-B Na and T. Kundu, "EMAT-Based Inspection of Concrete-Filled Pipes for Internal Voids and Inclusions," Journal of Pressure Vessel Technology 124, pp. 265-272, American Society of Mechanical Engineers, New York, New York, 2002.

Figure 6.56b. Test results for the hollow steel pipe are presented in Figure 6.57. Time-history results for: (a) voidfree, (b) $25 \%$ void length, (c) 50\% void length, and (d) $75 \%$ void length are presented in Figure 6.58. For the

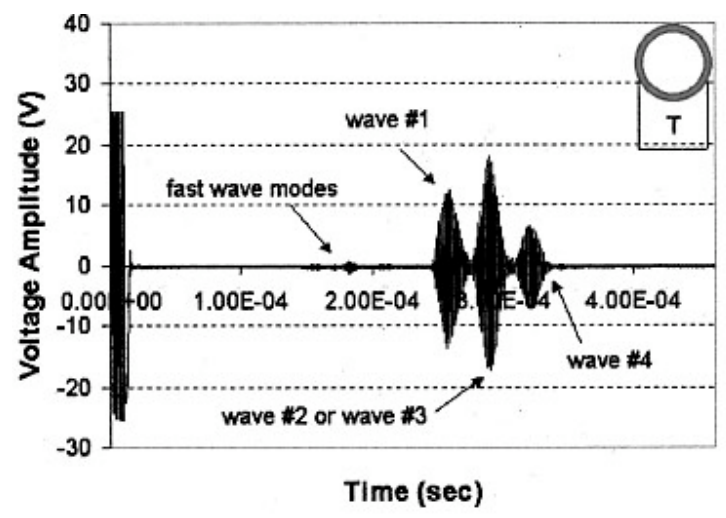

Figure 6.57 Voltage amplitude history for hollow steel pipe.

Source: W-B Na and T. Kundu, "EMAT-Based Inspection of Concrete-Filled Pipes for Internal Voids and Inclusions," Journal of Pressure Vessel Technology 124, pp. 265-272, American Society of Mechanical Engineers, New York, New York, 2002. 
delaminated specimens the void was located at the top portion of the pipe cross section. These curves show that the larger voids provided smaller received signal amplitudes indicating that the degree of void or separation can be estimated from the received signal amplitude. Comparing the results of Figure 6.58 with Figure 6.57 shows that the amplitudes of the time-history curves are much larger for the pipe without mortar indicating that the presence of mortar reduces the signal strength. Results obtained when the voids were located at the bottom of the pipe indicated that the location of the void affects the strength of the signal obtained with the wave amplitudes reduced when the void locations are aligned with the EMATs. The affect of inclusions was evaluated by reinserting the wooden bars initially used to form the voids and repeating the tests. For inclusions located at either the top or bottom of the pipe the presence of the wooden bar resulted in a slight elevation of wave amplitudes relative to the void results. It was concluded from the results that an EMAT-based guided wave inspection technique can distinguish between voids of different lengths and voids from inclusions; and the received signal was sensitive to the location of voids and inclusions relative to the EMAT position.
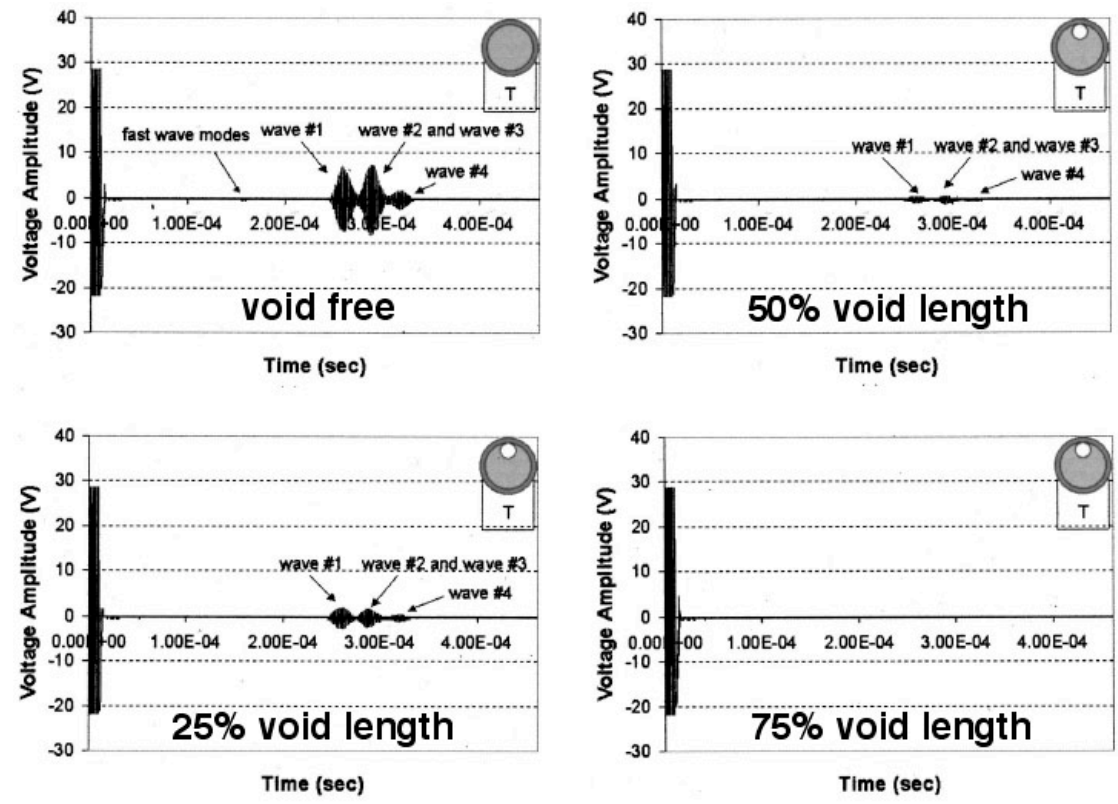

Figure 6.58 Voltage amplitude history for mortar-filled pipe with or without voids.

Source: W-B Na and T. Kundu, "EMAT-Based Inspection of Concrete-Filled Pipes for Internal Voids and Inclusions," Journal of Pressure Vessel Technology 124, pp. 265-272, American Society of Mechanical Engineers, New York, New York, 2002.

\subsubsection{Holes in Steel Plate Embedded in Concrete}

An experiment was conducted to investigate the sensitivity of radiography in detecting holes and reduced section thickness of a steel plate embedded in concrete (6.49). Figure 6.59 presents the test article that consisted of an

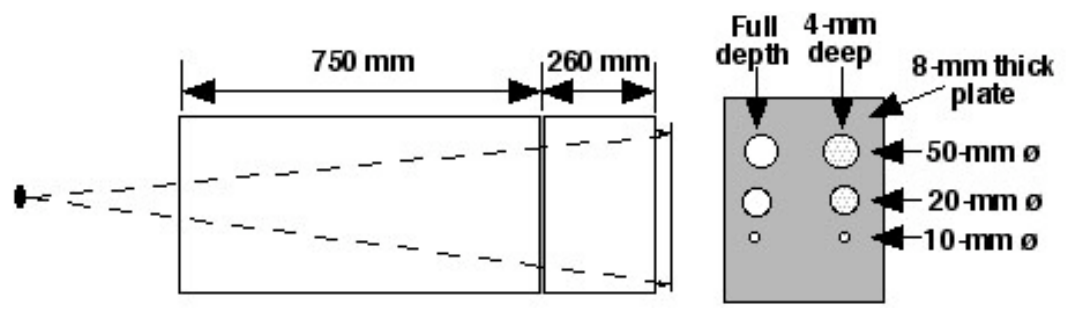

Figure 6.59 Plate with defects used in radiography study.

Source: A Practical Guide to Non-Destructive Examination of Concrete, Nordic Innovation Center Report, Force Technology, Helsingborg, Sweden, 2004. 
8-mm-thick steel plate containing circular holes that was sandwiched between 750-mm-thick and 260-mm-thick concrete blocks. The test article was radiographed using digital imaging plates and a Betatron that produces pulsed radiation with a peak energy of $7.5 \mathrm{MeV}$. The Betatron consisted of an accelerator head, a power supply unit, and a control panel. Figure 6.60 presents a radiographic image of the blocks. The three holes that completely penetrated the steel plate were clearly visible although the $10-\mathrm{mm}$-diameter hole was not as visible as the other two holes. The reduction in density across the center of the image was due to the presence of a horizontal rebar. The three holes that penetrated only half the plate thickness were not as clear as the holes that completely penetrated the plate. The two larger holes were visible, however, the smallest hole was not visible. Results indicate that radiography can locate holes in a steel plate embedded in concrete at distances up to at least $750 \mathrm{~mm}$.

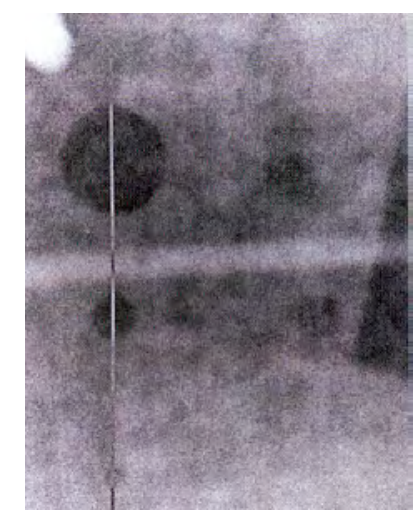

Figure 6.60 Radiographic image of plate with holes shown in Figure 6.59.

Source: A Practical Guide to Non-Destructive Examination of Concrete, Nordic Innovation Center Report, Force Technology, Helsingborg, Sweden, 2004.

\subsection{SUMMARY AND COMMENTARY}

Inspection of inaccessible portions of metallic pressure boundary components of nuclear power plant containments (e.g., fully embedded or inaccessible containment shell or liner portions, the sand pocket region in Mark I and II drywells, and portions of the shell obscured by obstacles such as platforms or floors) requires special attention. These areas may be subjected to corrosion resulting from ground water permeation through the concrete; a breakdown of the sealant at the concrete-containment shell interface that permits entry of corrosive fluids from spills, leakage, or condensation; or corrosion may occur in areas adjacent to floors where the gap contains a filler material that can retain fluids. Corrosion, should it occur, may challenge the containment structural integrity and, if through-wall, can provide a leak path to the outside environment. At present nondestructive evaluation techniques for use in determining the condition of the containment pressure boundary are time-consuming and costly because they tend to examine only a small area at a time. A nondestructive technique is required that can be used remotely to examine inaccessible regions of the containment metallic pressure boundary. Such a technique ideally should also be capable of performing global inspections so that determination of the overall condition of the containment metallic pressure boundary can be achieved in a cost- and performance-effective manner.

The performance of a commercially available fully integrated angle-beam inspection system has been evaluated through both numerical and experimental studies. The numerical studies indicated that for the embedded steel-lined concrete containment scenario, the thin steel liner with concrete backing combine to give unacceptably high signal loss to the concrete for small degradations close to the interface. However, for the embedded steel containment scenario, significant degradations (i.e., $2 \mathrm{~mm}$ ) below the concrete-air interface give a reasonable intrinsic backscatter level that is sufficiently above the expected noise level to be detectable. Experimental results using 25-mm-thick steel plates show that notches contained in the plates were detectable using high-frequency acoustic-imaging technology. When the plates were embedded in concrete, the concrete caused additional signal loss, but defects such as a 4-mm-deep rounded degradation located up to $30 \mathrm{~cm}$ below the air-concrete interface should be detectable. The losses to the concrete were strongly dependent on the coupling conditions between the steel and concrete, and ultrasonic waves directed at shallow angles were least affected by the concrete, regardless of coupling condition. Tests conducted at a nuclear power plant in Germany indicate that angle-beam inspection systems were able to detect pitting corrosion within $130 \mathrm{~mm}$ of the steel containment-concrete interface. 
Conventional ultrasonic inspection techniques generate ultrasonic beams that tend to spread out as the beam is reflected from the component boundaries to limit the technique's inspection resolution. Also, mode conversion occurs where both longitudinal and shear waves are present after reflections from component boundaries to potentially influence the signal-to-noise ratio and make the defect echoes difficult to interpret. Furthermore, multiple echoes can be received from the plate-concrete interface and, unless the correct combination of frequency and wedge-input angle is selected, only the first of a series of defects will be detected, or defects may not be detectable at all from the opposite surface of a plate containing a surface defect. Lower frequency methods appear to be best for inspection of plates bounded by concrete because of reduced attenuation, but sensitivity to defects and defect resolution are reduced relative to higher frequency methods. Horizontal shear and Lamb wave modes can be used for inspection of steel containment structures, both somewhat insensitive to the concrete boundary for specific velocity and frequency values. Therefore, techniques utilizing guided waves (e.g., magnetostrictive sensors, electromagnetic acoustic transducers, and multimode guided wave methods) that interrogate the specimen cross section (i.e., provide energy distribution across component cross section) appear to provide the greatest potential to address the topic of interest.

Magnetostrictive sensor-generated guided waves that had been used for inspection of long lengths of piping and tubing have been successfully adapted for application to guided wave inspection of plate-type materials. Modeling studies suggest that a low frequency A 0 wave mode is best suited for inspection of containment boundaries backed on one or both sides by concrete. Experimental results demonstrated that the magnetostrictive sensor technique can generate and detect guided waves in plates and detect a defect over a long range, including defects contained in areas difficult to access because of equipment or attachments. The amplitude of signals reflected from notches machined in a steel plate was affected by the product of defect length and depth in the plate normal to the guided wave beam propagation. When concrete is bonded to the plate surface the concrete increased the guided wave attenuation significantly to limit the long-range inspection capability; however, if the concrete is debonded from the plate it has no measurable affect on guided wave attenuation. Construction features such as welds, sealants, and paints did not have a significant affect on long-range inspection capability. Guided waves (A0 wave mode) at fairly low frequency $(<25-\mathrm{kHz})$ can detect relatively large defects within a couple of meters from the concrete-steel plate interface. Notch-type defects having abrupt thickness change and deep defects ( $>50 \%$ wall thickness) having a gradual contour profile were detectable using guided waves.

Strong benefits of the horizontal wave mode via an electromagnetic acoustic transducer were demonstrated with overall improved signal-to-noise ratio, practically no interference from the concrete interface, and the non-contact testing potential. Although preliminary, results show that defect quantification analysis can be carried out for horizontal shear guided wave impingement onto a defect in a wave guide. Both pulse-echo and throughtransmission methods were considered. Results indicate that both SH and Lamb wave modes can be used for the inspection of steel containment structures, with both being somewhat insensitive to the concrete boundary for specific velocity and frequency values. Potential advantages of horizontal shear waves compared to "Lamb" type waves include less mode conversion, constant wave structure for a particular mode for all frequencies, and less sensitivity to boundary conditions because of the lateral particle velocity. Strong benefits of the SH wave via an EMAT transducer were demonstrated with overall improved signal-to-noise ratio with practically no interference from the concrete interface and the non-contacting testing potential. In particular, the possibility of a monotonic increase in amplitude change with defect size was noted. The Boundary Element Method (BEM) can be used to establish data acquisition and analysis guidelines for development of a test protocol and quantification algorithm development program. Besides modeling and BEM analysis, feature extraction possibilities could also be obtained from experiment or calibration standards using guidelines established.

In addition to the above, a number of investigations were identified that have application to inspection of metallic pressure boundaries to detect areas of reduced section. Low-frequency shear horizontal waves were able to detect through-thickness and half-depth simulated corrosion defects in a plate embedded in concrete. Electrochemical techniques typically used to assess corrosion of steel reinforcement in reinforced concrete structures were applied to assess likelihood of corrosion of liners embedded in concrete at two nuclear power plants. Results indicate that electrochemical techniques appear to be an appropriate tool for evaluation of metal liners embedded in concrete. EMATs were successfully applied to detection of internal voids and inclusions in steel pipes filled with mortar. Finally, radiography was capable of locating holes in a steel plate embedded in concrete at distances up to $750 \mathrm{~mm}$. 


\subsection{REFERENCES}

6.1 Report of the Task Group Reviewing National and International Activities in the Area of Ageing of Nuclear Power Plant Concrete Structures, OCDE/GD(96)31, Committee on the Safety of Nuclear Installations, OECD Nuclear Energy Agency, Issy-les-Moulineaux, France, 1996.

6.2 D.C. Pocock, J.C. Worthington, R. Oberpichler, H. Van Exel, D. Beukelmann, R. Huth, and B. Rose, LongTerm Performance of Structures Comprising Nuclear Power Plants, Report EUR 12758 EN, DirectorateGeneral Science, Research and Development, Commission of European Communities, Luxembourg, 1990.

6.3 B. Wegemar, “Corrosion Failure of a BWR Embedded Reactor Containment Liner," Journal de Physique IV 136(1), pp. 257-262, November 2006.

6.4 J. Krautkramer and H. Krautkramer, Ultrasonic Testing of Materials, Chapter 8, $4^{\text {th }}$ Ed., Springer Verlag, New York, New York, 1990.

6.5 W. Mohr and P. Holler, "On Inspection of Thin-Walled Tubes for Transverse and Longitudinal Flaws by Guided Ultrasonic Waves," Institute of Electrical and Electronics Engineers Transactions on Sonics and Ultrasonics SU-23, pp. 369-374, New York, New York, 1976.

6.6 W.M. Latham, P.J. Latimer, and E.T. MacLauchlan, "EMAT-Generated Lamb Waves for Volumetric Inspection of Strip Steel," Process Control and Sensors for Manufacturing, Editors R.H. Boss and D.M. Pepper, Proceedings of Society of Photographic Instrumentation Engineers 3399, pp. 139-150, Bellingham, Washington, 1998.

6.7 B.W. Maxfield and A. Kuramoto, The Feasibility of Using Electromagnetic Acoustic Transducers to Detect Corrosion in Mark I Containment Vessels, EPRI NP-6090, Electric Power Research Institute Palo Alto, California, November 1988.

6.8 J.E. Bondaryk, C.N. Corrado and V. Godino, Feasibility of High Frequency Acoustic Imaging for Inspection of Containments, NUREG/CR-6614, U. S. Nuclear Regulatory Commission, Washington, D.C., August 1998.

6.9 J. Rudzinsky, J. Bondaryk, and M. Conti, Feasibility of High Frequency Acoustic Imaging for Inspection of Containments: Phase II, ORNL/NRC/LTR-99/1, Lockheed Martin Energy Systems, Inc., Oak Ridge National Laboratory, Oak Ridge, Tennessee, July 1999.

6.10 H. Schmidt, SAFARI: Seismo-Acoustic Fast-Field Algorithm for Range Independent Environments, User's Guide, SACLANT ASW Research Centre I-19100 La Spezia, Italy, May 1987.

6.11 H. Schmidt, OASES User Guide and Reference Manual, Version 2.1, Massachusetts Institute of Technology, Cambridge, Massachusetts, 1997.

6.12 C. Kittel, "Physical Theory of Ferromagnetic Domains," Rev. Modern Phys 21, pp. 541-583, 1949.

6.13 H. Kwun and K.A. Bartels, "Magnetostrictive Sensor Technology and Its Applications," Ultrasonics 36, pp. 171-178, 1998.

6.14 R.C. Williams, "Theory of Magnetostrictive Delay Lines for Pulse and Continuous Wave Transmission," IEEE Trans. on Ultrasonics Engineering UE-7, pp. 16-38, New York, New York, 1959.

6.15 H. Kwun, Feasibility of Magnetostrictive Sensor Inspection of Containments, NUREG/CR-5724 (ORNL/SUB/98-SZ272V), U. S. Nuclear Regulatory Commission, Washington, D. C., March 1999.

6.16 H. Kwun and S.Y. Kim, Experimental Validation of Concrete Effects on Guided Waves in Plates, EPRI Report 1000105, Electric Power Research Institute, Charlotte, North Carolina, 2000. 
6.17 B. Pavlakovic, M. Lowe, D. Alleyne, and P. Cawley, "DISPERSE: A General-Purpose Program for Creating Dispersion Curves," Review of Progress in Quantitative Nondestructive Evaluation 16, (Edited by D. O. Thompson and D. E. Chimenti), Plenum Press, New York, New York, pp. 185-192, 1997.

6.18 B. Pavlakovic and Lowe, DISPERSE User's Manual, Version 1.0, Imperial College, University of London, London, England, 1997.

6.19 Development of Magnetostrictive Sensor for Plate Inspection (ongoing), Southwest Research Institute Project 17-9077, Southwest Research Institute, San Antonio, Texas.

6.20 H. Kwun and B.A. Bartels, "Experimental Observation of Elastic-Wave Dispersion in Bounded Solids of Various Configurations," J. Acoust. Soc. Am. 99, pp. 962-96, 1996.

6.21 J. Krautkramer and H. Krautkramer, Ultrasonic Testing of Materials, Chapter 16, Section 2, $4^{\text {th }}$ Ed., Springer Verlag, New York, New York, 1990.

6.22 C. Kittel, "Physical Theory of Ferromagnetic Domains," Rev. Modern Physics 21, pp. 541-583, 1949.

6.23 H. Kwun and C. Dynes, "Long-Range Guided-Wave Inspection of Pipe Using the Magnetostrictive Sensor Technology-Feasibility of Defect Characterization," Nondestructive Evaluation of Utilities and Pipelines II, Edited by W. G. Reuter, SPIE Vol. 3398, pp. 28-34, Bellingham, WA., 1998.

6.24 Y. Cho and J.L. Rose, "Guided Waves in a Water Loaded Hollow Cylinder," Nondestructive Testing \& Evaluation 12, pp. 323-339, 1996.

6.25 J.L. Rose, D. Jiao, and J. Spanner, Jr., "Ultrasonic Guided Wave NDE for Piping,” Materials Evaluation 54(11), pp. 1310-1313, November 1996.

6.26 M.J. Quarry and J.L. Rose, "Multimode Guided Wave Inspection of Piping Using Comb Transducers," Materials Evaluation 57(10), pp. 1089-1090, October 1999.

6.27 D.N. Alleyne and P. Cawley, "Long Range Propagation of Lamb Wave in Chemical Plant Pipework," Materials Evaluation 45(4), pp. 504-508, April 1997.

6.28 H. Kwun, and K.A. Bartels, "Experimental Observation of Elastic-Wave Dispersion in Bounded Solids of Various Configurations," J. Acoustical Society of America 99(2), pp. 962-968, February 1996.

6.29 D.N. Alleyne and P. Cawley, "The Interaction of Lamb Waves With Defects," IEEE Transactions on Ultrasonics, Ferro Electrics, and Frequency Control 39(3), pp. 381-397, 1992.

6.30 D.N. Alleyne and P. Cawley, "The Long-Range Detection of Corrosion in Pipes Using Lamb Waves," Review of Progress in Quantitative NDE, Plenum Press, New York, NY, pp. 2075-2080, 1995.

6.31 J.L. Rose, S.P. Pelts, and M.J. Quarry, “A Comb Transducer Model for Guided Wave NDE,” Ultrasonics 36, Elsevier Publishers, New York, NY, pp. 163-169, 1998.

6.32 J. Li and J.L. Rose, "Guided Wave Inspection of Containment Structures," Materials Evaluation 59(6), pp. 783-787, June 2001.

6.33 J.L. Rose, and X. Zhao, "Anomaly Throughwall Depth Measurement Potential with Shear Horizontal Guided Waves," Materials Evaluation 59(10), pp. 1234-1238, October 2001.

6.34 J.L Rose, Ultrasonic Waves in Solid Media, Cambridge University Press, New York, NY, 1999.

6.35 Y. Cho and J.L. Rose, "A Boundary Element Solution for a Mode Conversion Study on the Edge Reflection of Lamb Waves.” J. Acoustical Society of America 99(4), pp. 2097-2109, 1996.

6.36 J.L. Rose, S.P. Pelts, and Y. Cho, "Modeling of Flaw Size Potential," Journal of Nondestructive Evaluation 19(2), pp. 55-66, June 2000. 
6.37 S.P. Pelts, J.P. Cysyk, and J.L. Rose, "The Boundary Element Method for Flaw Classifications in Wave Guides," Review of Progress in Quantitative Nondestructive Evaluation 16A pp. 137-144, 1996.

6.38 Y. Cho, D.D. Hongerholt, and J.L. Rose, "Lamb Wave Scattering Analysis for Reflector Characterization," IEEE Transactions on Ultrasonics, Ferroelectrics, and Frequency Control 44(1), pp. 44-52, 1997.

6.39 Z Abduljabbar, S.K. Datta, and A.H. Shah, "Diffraction of Horizontally Polarized Shear Waves by Normal Edge Cracks in a Plate," J. Applied Physics 54(2), pp. 461-472, 1983.

6.40 S.K. Datta, Y. Al-Nassar, and A.H. Shah, "Lamb Wave Scattering by a Surface Breaking Crack in a Plate," Review of Progress in Quantitative Nondestructive Evaluation 10, pp. 97-104, 1991.

6.41 M. Koshiba, S. Karakida, and M. Suzuki, "Finite-Element Analysis of Lamb Wave Scattering in an Elastic Plate Waveguide," IEEE Trans. Sonics Ultrasonics, SU-31, pp. 18-25, 1984.

6.42 M. Koshiba, K. Hasegawa, and M. Suzuki, "Finite-Element Solution of Horizontally Polarized Shear Wave Scattering in an Elastic Plate," IEEE Trans. Ultrasonics, Ferro Electrics, and Frequency Control 34(4), pp. 461-466, 1987.

6.43 C.M. Fortunko, R.B. King, and M.J. Tan, "Nondestructive Evaluation of Planar Defects in Plates Using Low Frequency Shear Horizontal Waves," J. Applied Physics 53, pp. 3450-3458, 1982.

6.44 S. Kobayashi, "Chapter 4, Elastodynamics," Boundary Element Methods in Mechanics, North-Holland Publishers, Amsterdam, The Netherlands, pp.192-255, 1987.

6.45 H. Ishida, Y. Kurozumi, and Y. Kaneshima, "Development of Ultrasonic Testing Technique to Inspect Containment Liners Embedded in Concrete on Nuclear Power Plants," Paper 249, $16^{\text {th }}$ World Conference on NDT 2004, Montreal, Canada, August 30 - September 3, 2004.

6.46 I. Martínez, A. Castillo, and C. Andrade, "Non-Destructive Electrochemical Techniques Applied to the Corrosion Evaluation of the Liner Structures in Nuclear Power Plants," Journal of Nuclear Materials, 373(1-3), pp. 226-236, February 2007.

6.47 "Standard Test Method for Half-Cell Potentials of Uncoated Reinforcing Steel in Concrete," ASTM C 87691, Annual Book of ASTM Standards, American Society for Testing and Materials, West Conshohocken, Pennsylvania, 2004.

6.48 W-B Na and T. Kundu, "EMAT-Based Inspection of Concrete-Filled Pipes for Internal Voids and Inclusions," Journal of Pressure Vessel Technology 124, pp. 265-272, American Society of Mechanical Engineers, New York, New York, 2002.

6.49 A Practical Guide to Non-Destructive Examination of Concrete, Nordic Innovation Center Report, Force Technology, Helsingborg, Sweden, 2004. 


\section{SUMMARY AND CONCLUSIONS}

\subsection{SUMMARY}

The objectives of this limited study were to provide an overview of the methods that are available for inspection of nuclear power plant reinforced concrete and metallic structures, and to provide an assessment of the status of methods that address inspection of thick, heavily-reinforced concrete and inaccessible areas of the containment metallic pressure boundary. In meeting these objectives a general description of nuclear power plant safety-related structures was provided as well as identification of potential degradation factors, testing and inspection requirements, and operating experience; methods for inspection of nuclear power plant reinforced concrete structures and containment metallic pressure boundaries were identified and described; and applications of nondestructive evaluation methods specifically related to inspection of thick-section reinforced concrete structures and inaccessible portions of containment metallic pressure boundaries were summarized.

\subsection{CONCLUSIONS}

Safety-related nuclear power plant structures are designed to withstand loadings from a number of low-probability external and internal events. Loads occurring during normal plant operation therefore generally are not significant enough to cause appreciable degradation. Overall the performance of these structures has been very good; however, there have been isolated incidences that if not remedied could eventually degrade the structural margins. Many of the instances related to degradation occurred early in life and have been corrected. As these structures age, incidences of degradation are likely to increase, primarily due to environmental effects.

Operating experience has demonstrated that periodic inspection, maintenance, and repair are essential elements of an overall aging management program to maintain an acceptable level of reliability over the service life of a nuclear power plant containment, or in fact, of any structural system. Knowledge gained from conduct of an in-service condition assessment can serve as a baseline for evaluating the safety significance of any degradation that may be present, and defining subsequent in-service inspection programs and maintenance strategies. Effective in-service inspection, maintenance, and repair programs provide an effective approach to management of aging and maintaining adequate structural margins.

Effective in-service condition assessment of the safety-related structures requires knowledge of the expected type of degradation, where it can be expected to occur, and application of appropriate methods for detecting and characterizing the degradation. The ASME Code documents the conditions that must be monitored, the inspection techniques adequate to observe those conditions, the frequency of the inspections, and the acceptance criteria that the results of the inspections must meet in order to assure the integrity of the safety-related structures. The USNRC has incorporated the ASME Code into the regulations in 10 CFR 50.55a. Overall the testing and inspection requirements for these structures have been effective in identifying and addressing potential problem areas in a timely manner. Operating experience, however, indicates that there are two areas with respect to inspection of safety-related structures where additional criteria (or methods) are desirable - inspection of thick, heavily-reinforced concrete structures and inaccessible areas of the containment metallic pressure boundary.

Testing of concrete is conducted to determine in situ strength, provide information on the relative quality and local integrity, evaluate durability, and identify causes of deterioration. Nondestructive evaluation methods are capable of performing measurements both on laboratory specimens as well as on objects in situ. The ability to make in situ measurements of concrete materials is important because characteristics of the hardened concrete impacted by factors such as thermal history, presence of moisture, and consolidation in place can be included. Inspection of concrete structures is becoming increasingly important as the structures age and incidences of degradation are likely to increase. Nondestructive evaluation methods thus are valuable tools to evaluate the current condition of a structure and for conduct of periodic inspections to monitor the extent of deterioration that has resulted from service conditions.

Inspection of nuclear power plant reinforced concrete structures presents challenges different from conventional civil engineering structures in that wall thicknesses can be in excess of one meter; the structures often have increased steel reinforcement density with more complex detailing; there can be a number of penetrations or cast-inplace items present; and accessibility may be limited due to the presence of liners and other components, harsh environments, or the structures may be located below ground. Inspection techniques to image concrete also face challenges due to the composite nature of the concrete materials. Grain size distribution can be highly variable and the properties of the constituent materials vary greatly making it difficult to obtain accurate images. Moisture 
variations affect test method performance as the speed and penetration of methods such as acoustic and electromagnetic pulses are strongly dependent on this factor. Methods related to an assessment of many of the in situ properties of concrete typically provide an indication of the concrete property through an indirect manner in that they measure a characteristic that is then related to the property in question (e.g., correlation relations). Therefore the accuracy of property measurements based on nondestructive evaluation methods depends on: the relationship between the desired property and the quantity actually measured by the nondestructive evaluation method, how insensitive the indirect measurement is to factors that do not affect the property in question, and the precision of the nondestructive evaluation measurement. Correlation curves are most effective when developed from nondestructive and destructive tests conducted in tandem on the structue in question; however, destructive tests may not be an option for many nuclear power plant structures. Successful application of nondestructive evaluation methods requires an understanding of their operating principles as well as their inherent limitations.

Information presented in this report indicates that there have been a number of successful applications of nondestructive evaluation methods to reinforced concrete structures. However, applications specifically related to nuclear power plant reinforced concrete structures are somewhat limited. Improvements in noninvasive techniques for characterization, inspection, and monitoring of concrete structures to provide additional assurances of their continued structural integrity are desirable (e.g., identification of honeycombed areas, voids adjacent to the liner, delaminated areas, and embedded items). Methods that can be used to inspect thick-section, heavily-reinforced concrete sections and basemats without the requirement for removal of material are of particular interest. Fabrication of a test article(s) representing a nuclear power plant condition of interest (e.g., basemat or other location having increased section and reinforcement density) could be a consideration. The test article(s) could be part of an international standard test program to advance and quantify the capabilities and knowledge of nondestructive evaluation methods with respect to conditions representative of nuclear power plant structures as well as contribute to the development of guidance or standards. Examples of conditions that could be incorporated into the test article include: simulated voids of various size and depth in the concrete and adjacent to a liner; honeycomb regions; areas of unbond between the steel reinforcement and concrete as well as the liner and concrete; and cracks and delaminated areas of various size, orientation, and depth. With potential use of grouted tendons in some of the new reactor designs, grouted tendons with locations of incomplete grouting or failed tendon wires or strands could be included in the test article to provide additional information and data for improved inspection of nuclear power plant grouted tendon systems.

Inspection of inaccessible portions of metallic pressure boundary components of nuclear power plant containments (e.g., fully embedded or inaccessible containment shell or liner portions, the sand pocket region in Mark I and II drywells, and portions of the shell obscured by obstacles such as platforms or floors) also is an item of interest. Embedded metal portions of the containment pressure boundary may be subjected to corrosion resulting from groundwater permeation through the concrete; a breakdown of the sealant at the concrete-containment shell interface that permits entry of corrosive fluids from spills, leakage, or condensation; or in areas adjacent to floors where the gap contains a filler material that can retain fluids. Corrosion, should it occur, may challenge the containment structural integrity and, if through-wall, can provide a leak path to the outside environment.

Current assessments of the inaccessible portions of the containment metallic pressure boundary primarily utilize visual inspections (e.g., examination of the moisture barrier at the junction where the containment shell or liner becomes embedded and the concrete to ensure that it is free of penetrating cracks that potentially provide a pathway for water seepage to the surface of the containment metallic pressure boundary). Suspect areas that exhibit flaws or evidence of degradation require supplemental evaluation. Often a supplemental evaluation may require excavation of material to provide access for examination and assessment. At present nondestructive evaluation techniques for use in determining the condition of the containment pressure boundary are time-consuming and costly because they tend to examine only a small area at a time. A method(s) that can be used to inspect the containment metallic pressure boundary to identify any loss of section that has occurred without the requirement for removal of material is desirable.

Results summarized in this report related to inspection of inaccessible portions on containment metallic pressure boundaries were generally from limited studies investigating nondestructive evaluation methods for detection of areas of plate structures (with or without concrete present) having reduced section. Results utilizing guided wave methods for detection of reduced sections of metallic pressure boundary components were sufficiently encouraging that guided wave techniques should be investigated in more detail. A series of laboratory experiments (e.g., round robin evaluation) could be conducted to evaluate candidate systems under more prototypical conditions. Specimens would be fabricated and tested that evaluate effects such as flaw geometry (e.g., notch, flat-bottom holes, and thinned areas), size (e.g., width, length, and depth), orientation, and location relative to the plate-concrete interface; 
three-dimensional effects (e.g., plate curvature); structural discontinuities (e.g., welds, anchor, or studs); and the presence of concrete as well as the quality of the bond between the concrete and steel. As a part of these investigations instrumentation systems could be optimized to control wave direction and mode, establish operable plate thicknesses, inspection range, and defect detectability data generated (e.g., probability of defect detection curves). Signal processing could be investigated as a method to discriminate between defects of potential significance and other scatterers (e.g., welds, concrete voids, and anchor studs). In addition to being able to detect defects, work could be done on sizing and classifying the severity of a particular defect. Activities could address development of a system that can perform global inspections through use of transducer arrays. Once these experiments have been completed, the most promising technique could be evaluated under representative field conditions and optimized to provide global inspection capability. An associated activity could be conducted to further evaluate the capabilities of electrochemical methods to detect and quantify corrosion activity in steel liner plate embedded in concrete.

Finally, as it has been several years since the Committee on the Safety of Nuclear Installations of the Nuclear Energy Agency has addressed the subject of nondestructive evaluation of nuclear power plant structures, it would be worthwhile to revisit this topic in the form of a workshop as there have been a number of advancements in areas such as signal conditioning and imaging. This organization would also be a likely forum for the organization, fabrication, testing, and analysis of a test article(s) to advance nondestructive evaluation technique capabilities with respect to thick-section, heavily-reinforced concrete structures, basemats, and inaccessible areas of containment metallic pressure boundaries. 
